\title{
Hypoxia Selective DNA Alkylating Analogs of Tirapazamine and Ap-Derived DNA Interstrand Cross-Links
}

\begin{tabular}{c} 
A Dissertation \\
presented to \\
the Faculty of the Graduate School \\
University of Missouri \\
In Partial Fulfillment \\
of the Requirements for the Degree \\
Kevin Matthew Johnson \\
Doctor of Philosophy \\
buly 2014 \\
\hline
\end{tabular}


The undersigned, appointed by the dean of the Graduate School, have examined the dissertation entitled

\section{HYPOXIA SELECTIVE DNA ALKYLATING ANALOGS OF TIRAPAZAMINE AND AP-DERIVED DNA INTERSTRAND CROSS-LINKS}

presented by Kevin Johnson, a candidate for the degree of doctor of philosophy of Chemistry, and hereby certify that, in their opinion, it is worthy of acceptance.

Professor Kent Gates

Professor Michael Harmata

Professor Paul Sharp

Professor Thomas Quinn 


\section{AKNOWLEDGEMENTS}

I would first and foremost like to thank Dr. Kent Gates for the opportunity to work in his lab. For his continued guidance and support throughout my graduate degree. I can never be grateful enough for everything he has done and all he has taught me. Learning how to be a good scientist and effectively communicate my work to other people will be valuable skills for my post-graduate career.

I would like to thank my fellow chemistry graduate students at MIZZOU, especially those in the Gates lab for all their help and support. They provided a social and enjoyable work place for me to earn my graduate degree. I hope to stay in contact with as many people as possible after leaving the University of Missouri.

Finally I would like to thank my friends and family for all their love and support throughout my life. I especially will always be grateful for everything my parents have done, and will continue to do for me in the future. It is comforting knowing that I can always rely on them for help if needed. They definitely were crucial in relieving a lot of the stress and financial burden through my schooling typically associated involved in graduate and undergraduate degrees. I would not have gotten this far without them. 


\section{TABLE OF CONTENTS}

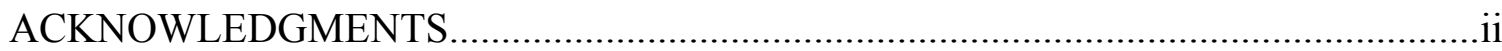

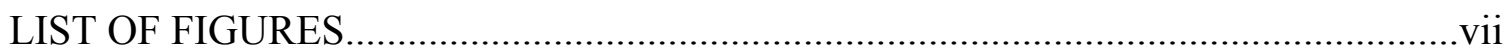

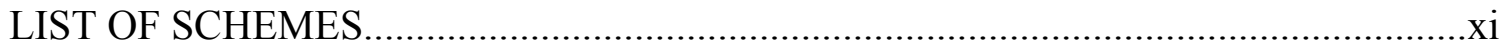

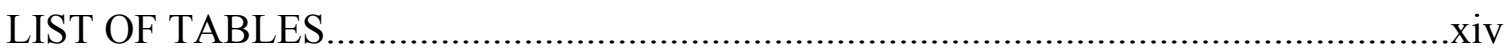

\section{Chapter 1. Tirapazamine and Preparation of Benzotriazine Analogs}

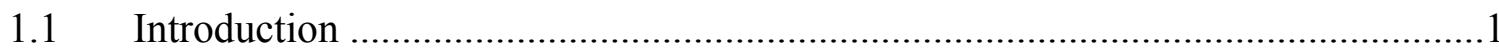

1.2 Preparation of Various Substituted Benzotriazine Analogs ...................................

1.3 Fluorescence Properties of Substituted Benzotriazine Analogs ...........................16

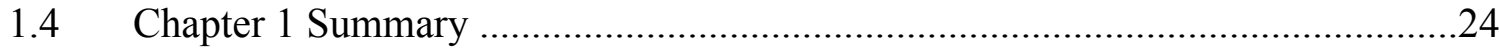

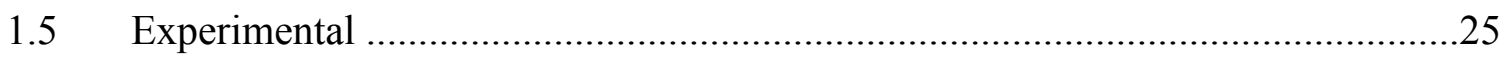

1.6 NMR Spectra for Compound Characterization .................................................55

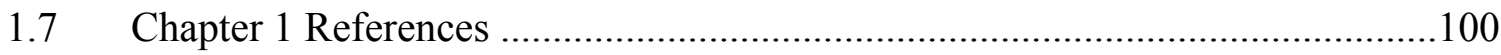

\section{Chapter 2. Hypoxia Selective DNA Alkylating Analogs of Tirapazamine}

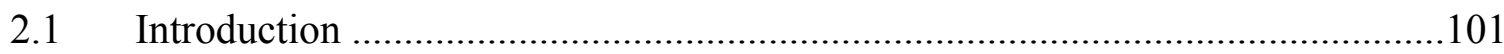

2.2 Preparation of Tirapazamine Mustards ...........................................................105

2.3 Rates of Hydrolysis Measured by ${ }^{1}$ HNMR for Benzotriazine N-Mustards .........107

2.4 Preparation and Hydrolysis Rate Measurements of Quinone

Methide Analogs

$2.5 \quad$ Hypoxia-Selective, In Vitro Metabolic Conversion of $\mathbf{3 8}$ to $\mathbf{3 6} \ldots \ldots \ldots \ldots \ldots \ldots \ldots \ldots \ldots . . .116$

2.6 Assessment of Hydrolysis Products of Benzotriazine N-Mustards ....................119 
2.7 Measurement of the Electron-Withdrawing Power of the Benzotriazine

Ring Systems

2.8 DNA Alkylation of Benzotriazine 1-Oxide N-Mustard ......................................125

2.9 DNA "Cross-Linking" of Benzotriazine 1-Oxide N-Mustard .............................131

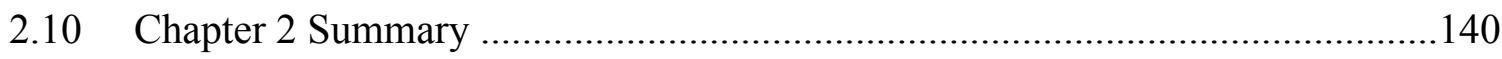

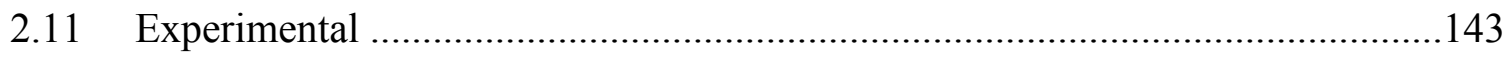

2.12 NMR Spectra for Compound Characterization ……….....................................165

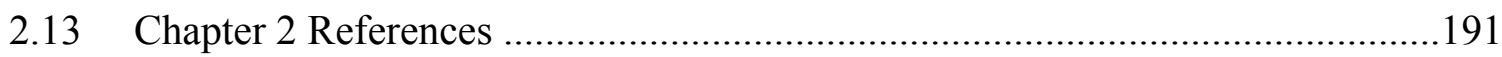

Chapter 3. DNA Interstrand Cross-Links Between an Abasic Site and the Opposing Guanine Residue of 5'-CAP Sequences in Duplex DNA

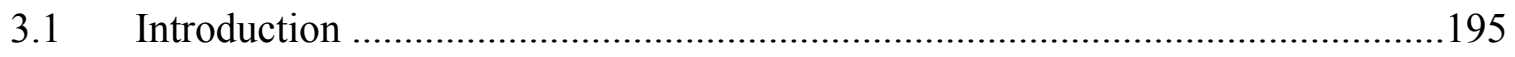

3.2 dG-Ap DNA Interstrand Cross-Links Trapped By Reductive Amination ...........197

3.3 MALDI Mass Spectrometric Analysis of Reduced Cross-Link ……..................207

3.4 Cross-Linking of Ap-Containing DNA in Neutral Aqueous Solution .................208

3.5 Formation and Stability of the Native Unreduced dG-Ap Cross-Link ...............210

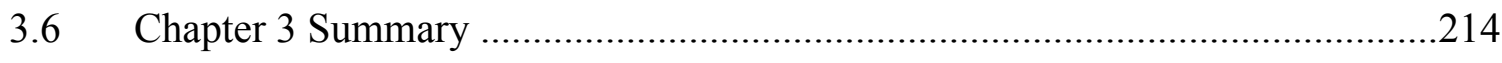

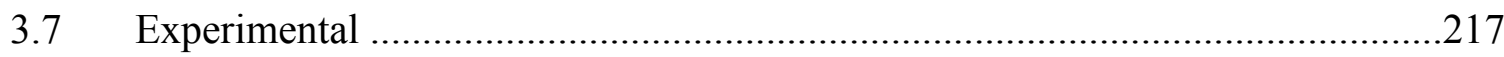

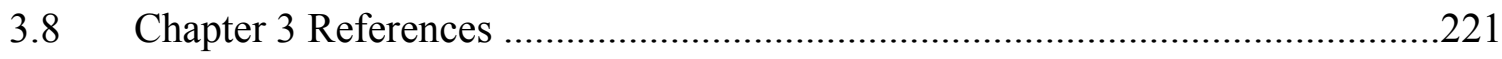

\section{Chapter 4. Ap-Derived DNA Interstrand Cross-Links are Sequence Dependent}

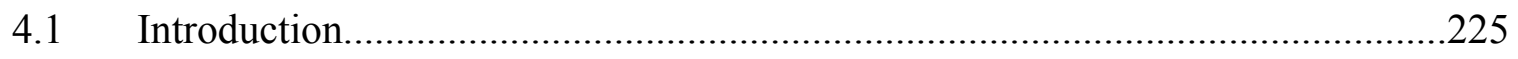


4.2 Structure of Ap-Derived DNA Interstrand Cross-Link Changes Depending on the Sequence .226

4.3 Formation and Stability of the High Yielding dA-Ap ........................................232

4.4 Sequence Effects of Ap-Derived DNA Interstrand Cross-Links .........................241

4.5 Native dA-Ap and Reduced dG-Ap Cross-Links Stall Polymerase $\Phi 29$...........246

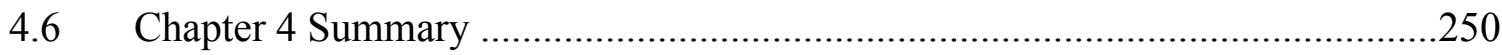

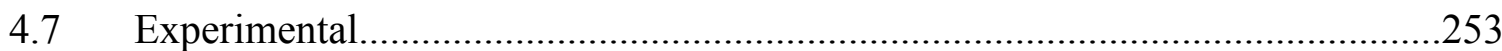

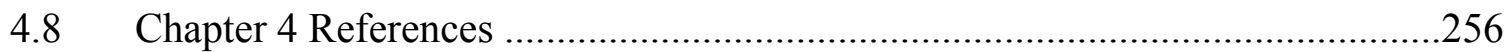

Chapter 5. DNA Interstrand Cross-Links Derived From Single Strand Breaks in the DNA Duplex

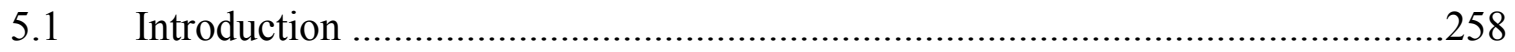

5.2 Generating Low Molecular Weight Cross-Links with Endonuclease III ...........262

5.3 Structure Elucidation of the EndoIII-Generated Cross-Links by Hydroxyl Radical Footprinting and Gel Shift Assay ....................................................268

5.4 Mass S0ectrometric Analysis of Low Molecular Weight Cross-Links Generated by Endonuclease III 273

5.5 Generating Low Molecular Weight Cross-Links with Spermine 277

5.6 Site of Attachment for Cross-Links Generated by Spermine

Treated Ap-DNA 281

5.7 Mass Spectrometric Analysis of Low Molecular Weight Cross-Link

Generated by Spermine .284

5.8 Chapter 5 Summary .286 
Hypoxia Selective DNA Alkylating Analogs of Tirapazamine and Ap-Derived DNA Interstrand Cross-Links

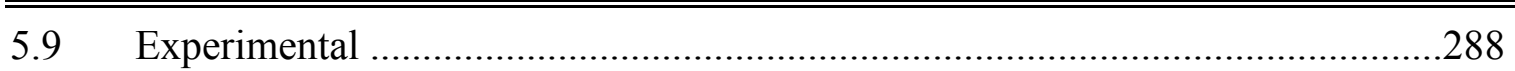

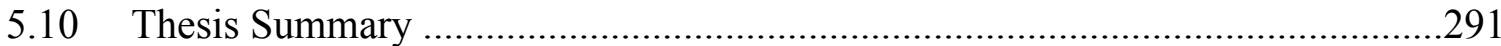

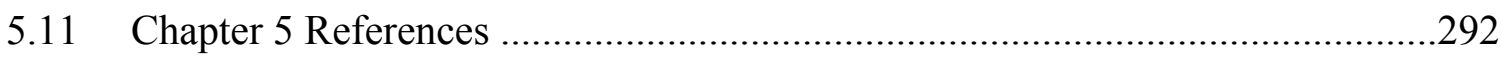

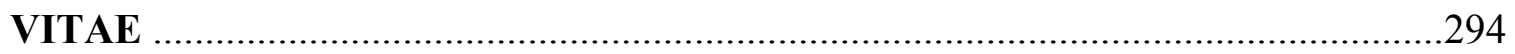




\section{LIST OF FIGURES}

\section{CHAPTER 1}

Figure 1 3-Amino-1,2,4-Benzotriazine 1,4-Di-N-Oxide Map ......................4

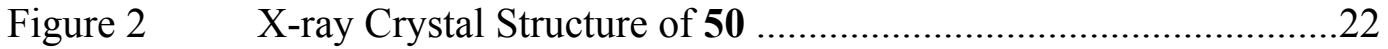

\section{CHAPTER 2}

Figure 1 Rates of Decay for Compounds $\mathbf{5 4}, \mathbf{5 5}, \mathbf{5 6}$, and $\mathbf{5 7}$

Measured by ${ }^{1} \mathrm{HMR}$ 108

Figure 2 HPLC Chromatograms Showing In Vitro Metabolic

Reduction of $\mathbf{3 8}$ and $\mathbf{1}$

Figure 3 HPLC Chromatograms Showing the Hydrolysis of 56 and 57...120

Figure $4 \quad \mathrm{pK}_{\mathrm{a}}$ Determination for $\mathbf{8 0}$

Figure $5 \quad \mathrm{pK}_{\mathrm{a}}$ Determination for $\mathbf{3 1}$ and $\mathbf{3 2}$

Figure $6 \mathrm{pH}$-Dependent Changes in the Absorbance Spectra of 4 and 1 ..125

Figure 7 DNA Alkylation by $\mathbf{5 6}$ in Duplex A and B 128

Figure 8 Sequence Preference of N7-Guanine Alkylation by

Mechlorethamine 130

Figure 9 Molecular Modeling of 56 Interaction with a 5 -GT Base Pair ..131

Figure 10 DNA Cross-Linking by 56, 86, and 87 in Duplex $\mathbf{C}$

Figure 11 DNA Cross-Linking by 56, 86, and 87 in Duplexes C-E .135

Figure 12 Identification of Abasic-Site-Derived Cross-Link .140

\section{CHAPTER 3}

Figure 1 Interstrand Cross-Link Formation in Duplexes B-E 
Figure 2 Time Course for the Formation of Cross-Linked Duplex B

Under Conditions of Reductive Amination ...............................203

Figure 3 Hydroxyl Radical Footprinting of Duplex F Formed

Under Conditions of Reductive Amination ................................204

Figure 4 Molecular Modeling of a 5 '-CAp Base Paired Sequence ...........205

Figure 5 Inosine Substitution for Guanine in Duplex B ………...............206

Figure 6 MALDI-MS of the dG Cross-Linked Duplex B Formed

Under Conditions of Reductive Amination ...............................207

Figure 7 Interstrand Cross-Link Formation in Duplexes B Under

Neutral Non-Reductive Conditions ..........................................209

Figure 8 Gel Shift Assay of Reduced and Unreduced Cross-Linked

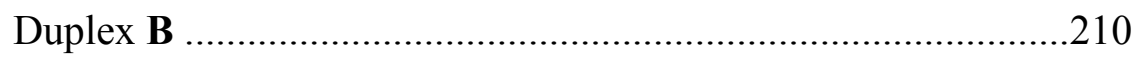

Figure 9 Time Course for the Formation of Cross-Linked Duplex B

Under Neutral Non-Reductive Conditions .................................211

Figure 10 Stability and Effect of Various Formation Conditions

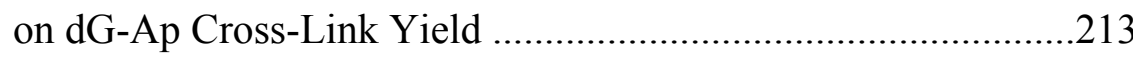

\section{CHAPTER 4}

Figure 1 Interstrand Cross-Link Formation in Duplexes $\mathbf{B}, \mathbf{H}, \mathbf{I}$, and $\mathbf{J}$

Under Neutral Non-Reductive Conditions ................................227

Figure 2 Molecular Models of Ap-Containing DNA Duplexes ................229

Figure 3 Molecular Model of a 5 -CApT Base Paired DNA Sequence ....229

Figure $4 \quad$ Hydroxyl Radical Footprinting of Duplex K ..............................231

Figure 5 Time Course for the Formation of Cross-Linked Duplex I ........233 
Figure 6 Interstrand Cross-Link Formation in Duplex $\mathbf{L}$

Figure 7 Interstrand Cross-Link Formation in Duplex $\mathbf{M}$ .235

Figure 8 Stability of Cross-Linked Duplex $\mathbf{I}$

Figure 9 Effect of Cross-Link Yield of Duplex I in the Presence of Various Additives .238

Figure 10 Gel Shift Assay of Reduced and Unreduced

Cross-Linked Duplexes B and I .240

Figure 11 Nanospray QTOF MS of Cross-Linked Duplex I-2

Figure 12 Hydroxyl Radical Footprinting of Duplex JJ .245

Figure 13 List of DNA Sequences Used for $\Phi 29$ Polymerase

Extension Reactions .247

Figure 14 Ф29 Polymerase Extension Reactions of the Native dA-Ap and Reduced dG-Ap Cross-Links .248

\section{CHAPTER 5}

Figure 1 LMW Cross-Link Formation in Duplex N By Treatment of EndoIII .264

Figure 2 LMW Cross-Link Formation in Duplex $\mathbf{O}$ By Treatment of EndoIII .265

Figure 3 Time Course of Formation and Decay for the LMW

Cross-Link of Duplex $\mathbf{O}$ .266

Figure 4 Hydroxyl Radical Footprinting for the LMW Cross-Link of Duplex $\mathbf{O}$ Generated by EndoIII .269 
Figure 5 Thiol Induced Gel Shift Assay of EndoIII Generated

LMW Cross-Link in Duplex $\mathbf{N}$

.271

Figure 6 Nanospray QTOF MS of EndoIII Generated LMW

Cross-Link of Duplex $\mathbf{N}$

Figure 7 Nanospray QTOF MS of EndoIII Generated LMW

Cross-Link of Duplex $\mathbf{N}$ in the presence of thiol

Figure 8 LMW Cross-Link Formation in Duplexes $\mathbf{N}$ and $\mathbf{O}$ By

Treatment of Spermine

Figure 9 Hydroxyl Radical Footprinting for the LMW Cross-Link

of Duplex $\mathbf{O}$ Generated by Spermine

Figure 10 Hydroxyl Radical Footprinting for the LMW Cross-Link

of Duplex R Generated by Spermine

Figure 11 Nanospray QTOF MS of Spermine Generated LMW

Cross-Link of Duplex $\mathbf{N}$ 


\section{LIST OF SCHEMES}

\section{CHAPTER 1}

Scheme $1 \quad$ Bioreduction of Tirapazamine .......................................................

Scheme 2 Summary of Reactions for Benzotriazine Analogs ..........................5

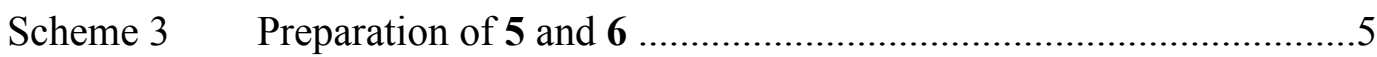

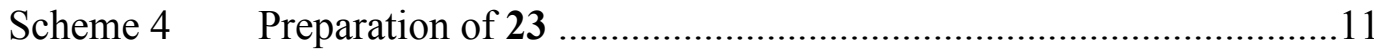

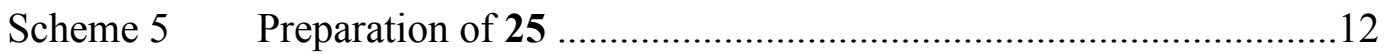

Scheme 6 Preparation of 28, 30, and 33, and attempted $\mathbf{3 5} \ldots \ldots \ldots \ldots \ldots \ldots \ldots \ldots \ldots . . . .13$

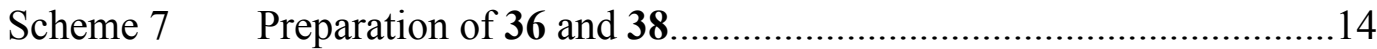

Scheme $8 \quad$ Preparation of 39 and attempted 41 .........................................15

Scheme 9 Deoxygenation of Pyridine N-Oxide by Ethanol ...........................16

Scheme $10 \quad$ Calculated excited state structures of 1 and 4 ............................19

Scheme 11 Preparation of 43 ................................................................20

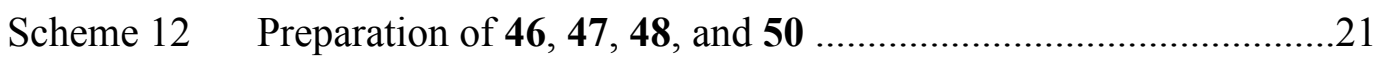

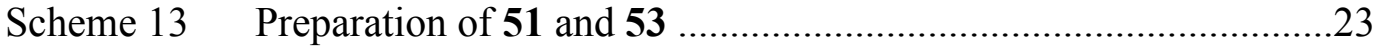

\section{CHAPTER 2}

Scheme 1 DNA Alkylating Mechanism of Nitrogen Mustards ....................102

Scheme 2 Bioactivation of Aryl Nitrogen Mustards ...................................103

Scheme 3 Bioactivation of Tirapazamine N-Mustard Analogs ....................104

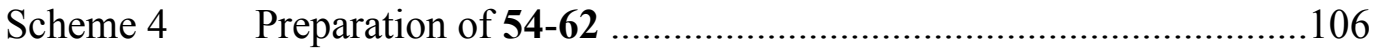

Scheme $5 \quad$ Proposed Mechanism of formation for 58 ................................107

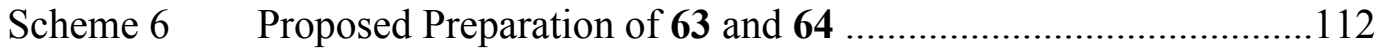

Scheme $7 \quad$ Preparation of 65-68 ………………….................................111 
Scheme 8 Bioreductive activation of Mytomycin C

Scheme 9 Bioactivation of Tirapazamine Quinone Methide Analogs ........114

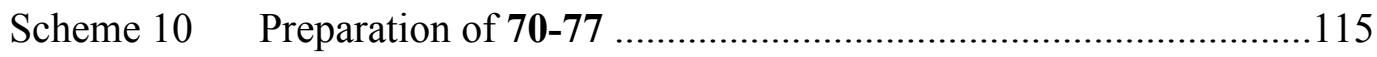

Scheme 11 Products Generated by the Hydrolyis of $56 \ldots \ldots \ldots \ldots \ldots \ldots \ldots \ldots \ldots \ldots \ldots . . .121$

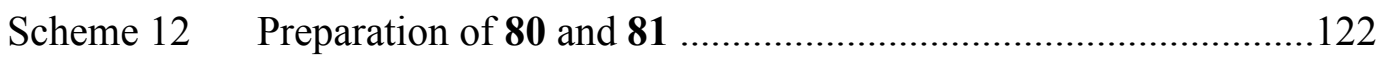

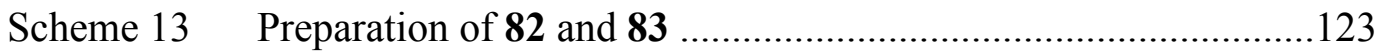

Scheme 14 Mechanism of N7-Guanine Alkylating and Depurination ..........126

Scheme 15 Generation of Abasic-Sites by Depurination and UDG …..........137

Scheme 16 Mechanistic Route to All Possible Products Resulting

From N-Mustard Alkylated 5'GNC Sequences ..........................138

\section{CHAPTER 3}

Scheme 1 Generation of Abasic-Sites in DNA

Scheme 2 Imine Formation and DNA Cross-Linking by Acrolein

Scheme 3 Mechanistic Overview of Reaction Involving the Ap-Site in

Experiments Described ........................................................198

\section{CHAPTER 4}

Scheme 1 Mechanism of Formation for dA-Ap Cross-Link 251

\section{CHAPTER 5}

Scheme 1 Mechanistic Overview of Reaction Involving the $\alpha, \beta$-eliminated

Ap-Site in Experiments Described .259

Scheme 2 Generation of Oxidized Ap-sites .260

Scheme 3 Generation of Cross-Links Formed by $\alpha, \beta$-eliminated C4-Oxidized Ap-Sites .260 
Hypoxia Selective DNA Alkylating Analogs of Tirapazamine and Ap-Derived DNA Interstrand Cross-Links

Scheme 4 Experimental Design for Generating LMW Cross-Links

Scheme 5 Overview of LMW Cross-Link Structures .....

.274

Scheme 6 LMW Cross-Linking in DNA Duplexes with Different

Melting Temperatures .278

Scheme 7 Proposed Structures for the Attachment of Deoxyadenine with $\alpha, \beta$-Unsaturated Ap Sites Generated by Spermine .287 


\section{LIST OF TABLES}

\section{CHAPTER 1}

Table 1 Comparison of Buchwald-Hartwig Coupling vs Substitution

Reactions of 3-Amino-Substituted 3-Amino-1,2,4-Benzotriazine

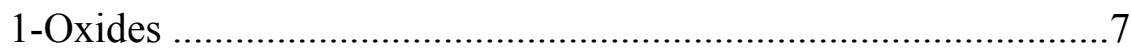

Table 2 Confirmation of Pd Catalysis .....................................................

Table 3 Preparation of 1,2,4-benzotriazine 1-Oxide Analogs by Suzuki

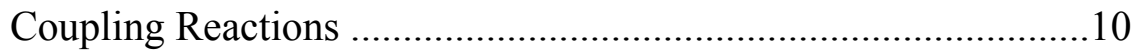

Table 4 Spectroscopic Data for Substituted Benzotriazine Analogs ..........19

\section{CHAPTER 2}

Table 1 Summary of Rates of Hydrolysis for Sulfonate N-Mustards ......109

Table 2 Methide Analog Rates of Hydrolysis ...........................................115

\section{CHAPTER 4}

Table 1 Survey of Various dA-Ap Cross-Linking DNA Sequences .......243

Table 2 Survey of Various dG-Ap Cross-Linking DNA Sequences .......244

\section{CHAPTER 5}

Table $1 \quad$ Sequence Dependent Formation of LMW Cross-Links

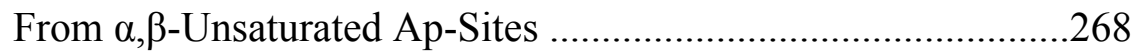

Table 2 pH Dependent Formation of LMW Cross-Links

From $\alpha, \beta$-Unsaturated Ap-Sites ...............................................2279 


\section{ABSTRACT}

Tirapazamine (3-amino-1,2,4-benzotriazine 1,4-dioxide, TPZ) is a heterocyclic di- $N$-oxide that can be selectively reduced enzymatically in oxygen-poor (hypoxic) cells commonly associated with solid tumors. This reduction yields a non-toxic mono- $N$-oxide metabolite resulting from deoxygenation that we were interested in functionalizing. We prepared various structural TPZ analogs to expand the library of benzotriazine containing compounds in hopes of finding structural changes promising for use clinically. We looked at changing the structure of TPZ and its 1-oxide metabolite at various positions of the benzotriazine core. We found interesting fluorescence properties of TPZ and its 1oxide metabolite that could be exploited for use as a hypoxia selective fluorescence probe. We also report how metabolic deoxygenation of tirapazamine would result in electronic changes useful for activation of various DNA-alkylating substituents. We designed TPZ analogs containing nitrogen mustards or quinone methide derivatives that would be selectively activated upon reduction in hypoxic cells. We examined rates of reactivity and physical properties of these new compounds to test their viability as hypoxia selective DNA alkylating agents. The results provided evidence that the 1,2,4benzotiazine 1,4-dioxide unit can serve as an oxygen-sensing prodrug platform for the selective activation of external substituents in hypoxic cells.

We observed that DNA alkylating agents like $\mathrm{N}$-mustards, designed to form DNA cross-links at 5 -GNC sequences, also form cross-links not previously associated with the class of compounds. These new cross-links are described to result from depurination of deoxyguanine residues to form an abasic site (Ap). We have previously reported the ability of Ap-sites to cross-link with an opposing deoxyadenine residue. Ap-sites are 
commonly generated by DNA alkylating agents, and are one of the most common DNA

lesions that occur in cells. This intriguing result is directly related to the other work presented in this document, involving the reaction between an Ap-site in DNA and various nucleobases on the opposing strand of the DNA double helix. Here we summarize the work included in our previous reports of Ap-site cross-links formed with deoxyguanine or deoxyadenine residues, along with new and unpublished experiments. 


\section{Chapter 1. Tirapazamine as a Fluorescent Probe for Cellular}

\section{Hypoxia}

\subsection{Introduction}

Cellular hypoxia may enable selective treatment of tumor cells. ${ }^{1-2}$ Several prodrugs currently in clinical trials have been designed to take advantage of this phenomenon in order to selectively treat tumors. ${ }^{3}$ These drugs contain structures such as nitro groups, quinones, and N-oxides, ${ }^{4-6}$ and undergo $1 \mathrm{e}^{-}$enzymatic reduction to yield an $\mathrm{O}_{2}$-sensitive radical. The initial 1-e reduction is reversed in healthy-normoxic cells by a process known as "redox cycling." ${ }^{7}$ Alternatively, under low oxygen concentration (hypoxia), the radical species can fragment or undergo further reduction. ${ }^{3}$ This oxygen sensitivity provides the selectivity towards hypoxic cells. It should be noted that some pro-drugs are metabolized by $2 \mathrm{e}^{-}$reductases through a non-oxygen sensitive process. And while $2 \mathrm{e}^{-}$reduction may not be inhibited by molecular oxygen, it can still be useful against tumors over-expressing these enzymes. ${ }^{3}$ 


\section{Scheme 1}

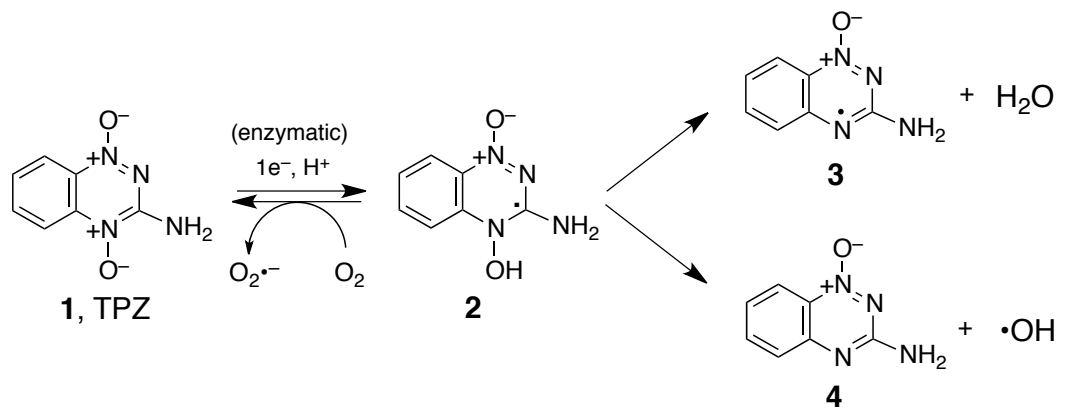

Our group has been particularly interested in tirapazamine (TPZ, 1), one of the first pro-drugs used as a treatment against hypoxic tumor cells. Its IUPAC name is 3amino-1,2,4-benzotriazine 1,4-dioxide. This drug showed promising anti-tumor selectivity and even advanced to Phase III clinical trials. ${ }^{6} \mathrm{TPZ}$ is metabolized through an oxygen sensitive $1 \mathrm{e}^{-}$reduction to generate free radical 2 . This then fragments to form a DNA-damaging radical. Two mechanisms have been proposed for this process (Scheme 1). One involves formation of a triazinyl radical 3 that causes DNA damage, ${ }^{8}$ although evidence leading to hydroxyl radical $(\bullet \mathrm{OH})$ generation instead has been described. ${ }^{9}$ After fragmentation, the unreactive benzotriazine $1-\mathrm{N}$-oxide metabolite 4 is left as a byproduct. While TPZ (1) has shown to have high reactivity towards DNA after $1 \mathrm{e}^{-}$reduction, it showed only limited effectiveness in clinical trials. In fact it was often used in combination with other treatments. ${ }^{6,10}$ And while TPZ has high selectivity toward "moderate" hypoxia $\left(\mathrm{K}_{\mathrm{O} 2} \approx 1 \mathrm{uM}=\right.$ inhibition by oxygen, $\left.\mathrm{K}_{\mathrm{i}}\right){ }^{3,11}$ its limited efficacy is theorized to be partly due to its low tissue penetration of hypoxic tumors ${ }^{12}$ as well as failure to stratify patients based upon the hypoxic character of their tumors. ${ }^{13}$ Some other pro-drugs require more extreme hypoxic conditions than TPZ $\left(\mathrm{K}_{\mathrm{O} 2} \sim 0.1 \mathrm{uM}\right)$, consequently these compounds require higher tissue penetration to be reduced enzymatically. ${ }^{3}$ While TPZ has not earned approval by the FDA, it has sparked interest in 
many researchers to develop new benzotriazine 1,4-dioxide analogues for enhanced tumor cell killing properties. ${ }^{14-16}$

Synthesis of TPZ analogs will be required for second-generation drugs in this family, or for use as molecular tools to detect hypoxia and bioreductive enzymes in biological samples. While there have been successful efforts to synthesize analogues of improved cellular permeability, ${ }^{13,}{ }^{15}$ our lab focused on a different goal. TPZ (1) has fluorescent properties which could be exploited for use as a probe for hypoxia or enzymes involved in drug activation. When TPZ (1) is reduced to its 1-oxide metabolite (4), a bright green fluorescence (513 nm in $\mathrm{pH} 7$ buffered water, $478 \mathrm{nM}$ in acetonitrile) can be observed upon excitation. ${ }^{17-18}$ The parent drug TPZ is not fluorescent under the same conditions. This significant change in fluorescent properties sparked our interest towards using TPZ for detecting hypoxia in cell samples and as a fluorescent substrate for bioreductive enzymes. While typically fluorescent probes for bio-imaging typically emit at higher wavelengths $(650-800 \mathrm{~nm}){ }^{19}$ probes which fluoresce at lower wavelengths $(500-550 \mathrm{~nm})$ have been useful for cellular imaging. ${ }^{20-23}$ Additionally, probes with quantum yields much higher than the mono- $N$-oxide metabolite of TPZ (compound 4, $\sim 0.12$ in acetonitrile) typically are used. ${ }^{18}$ Our goal in this study is to test a variety of structurally diverse benzotriazine analogues to see if particular structural changes would lead to promising compounds of higher quantum yield for use as fluorescent probes for detecting hypoxia and bioreductive enzymes in cell samples. 


\section{Figure 1}

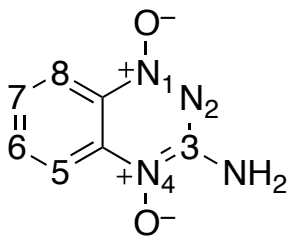

Figure 1. 3-Amino-1,2,4-benzotriazine 1,4-di-N-oxide map.

\subsection{Preparation of Various Substituted Benzotriazine Analogs}

Chapter 1 primarily focuses on the preparation of benzotriazine analogues with substituents in different locations on the ring system (Scheme 2). Not only did we synthesize analogs with the goal of finding compounds with improved fluorescence properties, but we also prepared analogs that could be functionalized for other purposes as well (Chapter 2). The first analogs prepared involved various Pd-catalyzed reactions, particularly C-C bond forming Suzuki-Miyaura couplings and C-N bond forming Buchwald-Hartwig couplings. To our knowledge there has been no previous report of using Pd-catalyzed reactions to couple amines or aryl boronic acids to a halide-containing benzotriazine core (Scheme 2). We chose to synthesize various substituted benzotriazines at the 3-position (Figure 1). Literature reports of 3-chlorobenzotriazine (5) has been previously described, ${ }^{24}$ and this would be useful for Pd-coupling reactions to achieve a wide variety of products. 


\section{Scheme 2}

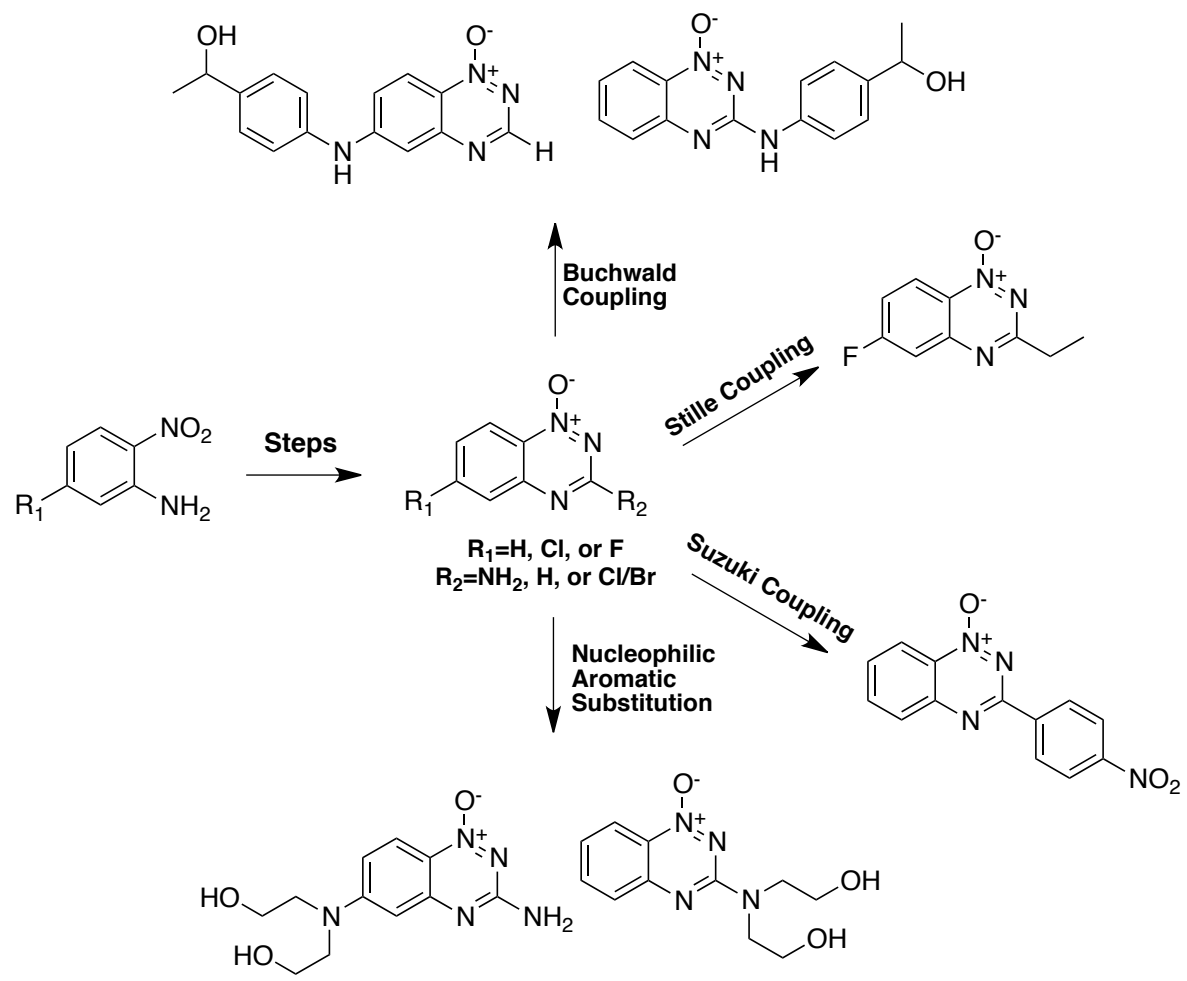

\section{Scheme 3}

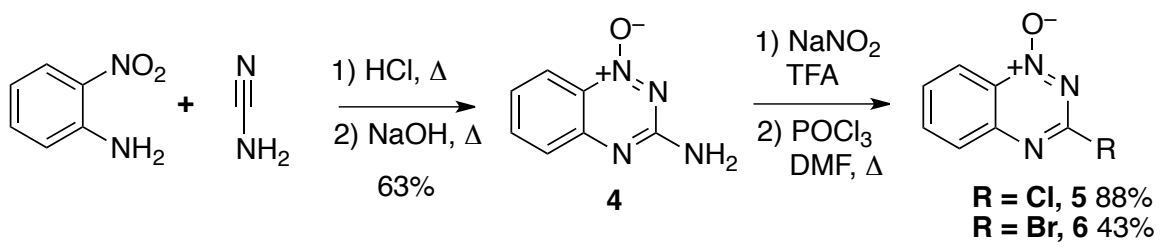


Starting with compound 4, prepared using a method adapted from Fuchs et $a l^{25}$ compound 5 was synthesized as in Boyd et al (Scheme 3). ${ }^{24}$ First, hydroxylation of the $\mathrm{NH}_{2}$ group in 4 via diazaonium ion intermediate was done with sodium nitrite in trifluoroacetic acid followed by hydrolysis. The dried precipitate was then chlorinated with Vilsmeier reagent in neat $\mathrm{POCl}_{3}$ with a catalytic amount of DMF. In a similar reaction, $\mathrm{POBr}_{3}$ is used to prepare the 3-bromo derivative (6) for use in $\mathrm{Pd}$ coupling reactions. Aryl halides in hand, various amines were coupled with compounds $\mathbf{5}$ and $\mathbf{6}$ (3-Cl and 3-Br) to yield products 7-15 (Table 1). The reactions were done in toluene under reflux conditions with a catalytic amount of $\mathrm{Pd}(\mathrm{OAc})_{2}$ and SPhos ligand with $\mathrm{K}_{3} \mathrm{PO}_{4}$ (4 equiv.) for $24 \mathrm{~h}$. The products were purified by column chromatography and the resulting yields are summarized in Table 1. The Buchwald coupling yields seemed to be influenced by sterics and nucleophilicity. Not all the reactions shown were complete within the $24 \mathrm{~h}$ reaction time. Several reactions could potentially provide higher yields if allowed to react further. 
Table 1. Comparison of Buchwald-Hartwig Coupling vs Substitution Reactions of 3-Amino-Substituted-1,2,4-Benzotriazine 1-Oxides
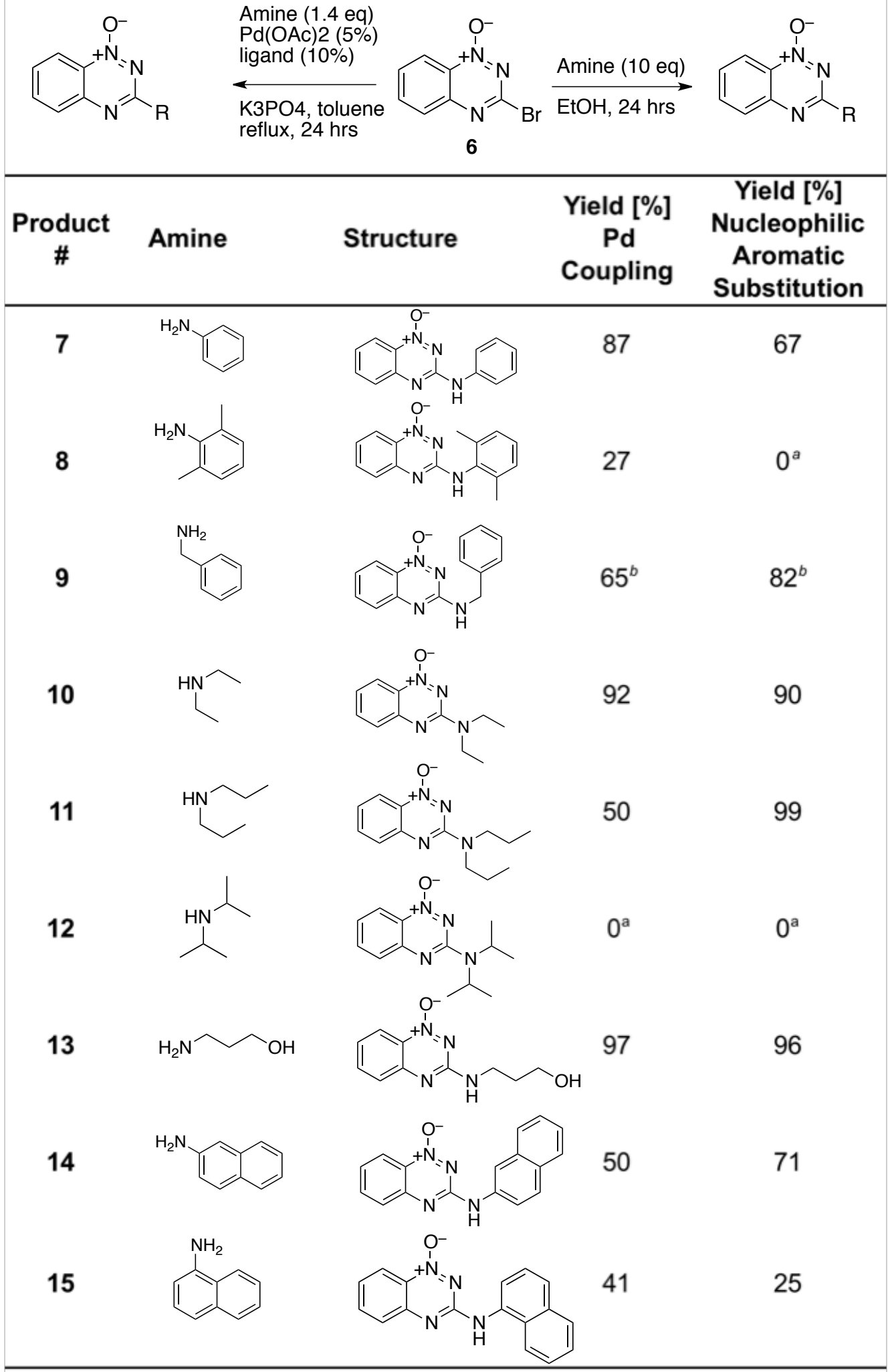

${ }^{a}$ no isolated product, ${ }^{b}$ using $\mathbf{5}$ instead 
We wanted to show that the halide-substituted benzotriazines are indeed viable substrates for Pd coupling reactions. We synthesized compounds $\mathbf{7}$ and $\mathbf{8}$ under Pdcoupling conditions at varying temperature, both with and without the Pd-catalyst (Table 2, structures provided in Table 1). The results show that in the presence of catalyst, product yield was significantly higher (Table 2). Higher temperatures gave marginally higher yields in both reactions as well. Stoichiometric amounts of benzylamine yielded product in the absence of catalyst, suggesting that the 3-position is highly electrophilic toward nucleophilic aromatic substitution. We prepared compounds 7-15 via nucleophilic aromatic substitution as well and compared these results to the Pd-coupling reactions (Table 1).

Table 2. Presence of Pd-Catalyst Increased Reaction Yield for Benzotriazine Pd-Coupilng Reactions

\begin{tabular}{|l|l|r|}
\hline Amine & Pd & No Pd \\
\hline Aniline (7) & & \\
\hline 20 degrees & $21 \%$ & $0 \%$ \\
\hline 55 degrees & $27 \%$ & $5 \%$ \\
\hline Benzylamine (9) & & \\
\hline 20 degrees & $74 \%$ & $34 \%$ \\
\hline 50 degrees & $87 \%$ & $67 \%$ \\
\hline
\end{tabular}

Nucleophilic aromatic substitution reactions at the 3-position under mild conditions using excess amine have already been reported. ${ }^{26}$ All Pd-catalyzed products (7-15) were additionally synthesized by a nucleophilic aromatic substitution reaction in ethanol with excess amine at room temperature to see if similar trends in product yields were obtained (Table 1). The results show that reaction yields again varied depending on the amine nucleophilicity, but not all products were obtained with this method (compound 8). While nucleophilic aromatic substitution would provide selective product 
generation, Pd coupling reactions could still be a powerful tool for preparing certain 3amino-substituted benzotriazines. Products requiring less nucleophilic amines, use of stoichiometric equivalents because of low supply, or removal of excess starting materials during workup make a Pd catalyzed reaction more desirable. Overall our results support a mixed mechanism of Pd-coupling and nucleophilic aromatic substitution occurring in our reactions.

We felt it useful to explore other Pd-coupling reactions for use in generating other TPZ analogs. In addition to $\mathrm{C}-\mathrm{N}$ bond coupling reactions, $\mathrm{C}-\mathrm{C}$ bond coupling reactions were explored (Table 3). Using Suzuki conditions, analogs 16-18 were prepared where we coupled aryl boronic acids to 3 -halide containing 5 or $\mathbf{6}$. Both electron rich and electron poor boronic acids were utilized, each requiring differing reaction times. Under Suzuki conditions with a toluene/water solvent system, C-C coupling was inefficient in presence of an unprotected $-\mathrm{NH}_{2}$ substitutent. Reaction of $p$-aminophenyl boronic acid gave compound 7 as the major product. This means that either the Buchwald coupling or competing nucleophilic aromatic substitution reactions (or some combination) must have been favored over $\mathrm{C}-\mathrm{C}$ coupling, resulting in $\mathrm{C}-\mathrm{N}$ bond formation followed by protodeboronation to yield the 3-N-substituted $7 .{ }^{27}$ Using an $N$-Boc-protected amine as in as in compound $\mathbf{1 6}$ was required to prevent unwanted $\mathrm{C}-\mathrm{N}$ coupling reactions from occurring. $p$-Cyanophenyl boronic acid provided compound $\mathbf{1 7}$ in relatively low yield. Lower product yield can be attributed to the cyano substituent generating an electron poor carbon resulting in a slower coupling reaction, though slightly different reaction conditions were used as well (see Experimental). Performing these Suzuki coupling reactions in round bottom flasks under reflux in $\mathrm{N}_{2}$ generally seemed to provide non- 
quantitative yields (presented in Ujjal Sarkar's Thesis ${ }^{17}$ and unpublished observations), independent of the reaction time. This must be due to oxidation of the palladium catalyst or phosphine ligand during the reaction, resulting from inadequate reaction setup leading to contamination by $\mathrm{O}_{2}$. We observed similar results for the synthesis of compound $\mathbf{1 8}$, but performing the coupling reaction in a sealed tube for a longer period of time $(96 \mathrm{~h})$ substantially increased the reaction yield of this product $(93 \%)$ when compared to previous methods $(31 \%)$.

Table 3. Preparation of 1,2,4-benzotriazine 1-Oxide

Analogs by Suzuki Coupling Reactions

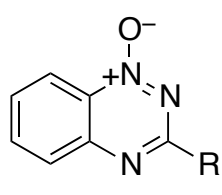

Aryl-B $(\mathrm{OH})_{2}(1.4 \mathrm{eq})$

Pd Catalyst (5\%)

Base

$\mathrm{R}=\mathrm{Cl}, 5$

Solven

reflux, $24 \mathrm{hrs}$

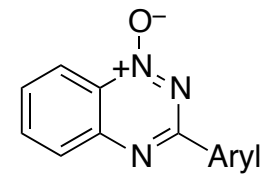

$\mathrm{R}=\mathrm{Br}, 6$

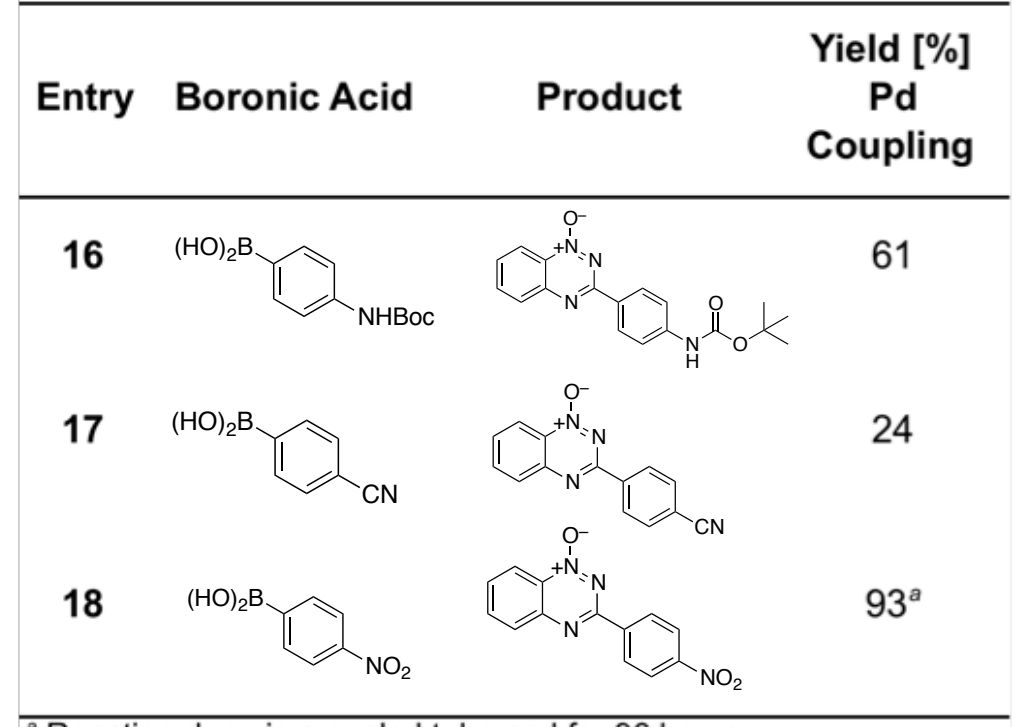

${ }^{a}$ Reaction done in a sealed tube and for 96 hours

The Stille coupling reaction has been utilized for installation of an ethyl group onto the 3-position of the benzotriazine system in the presence of various substituents at the 6- and 7-position (Figure 1) ${ }^{28}$ Pchalek et al reported the synthesis for a TPZ analogue 
currently in clinical trials as a hypoxia selective tumor drug with improved cellular resilience for increased tumor cytotoxicity. A series of papers concluded that analogues containing 3-aminoalkylamino substituents are prone to faster unwanted metabolism rates, and that electron-donating substituents in the 6-position helped counteract this increased rate of metabolism of the benzotriazine di- $N$-oxide system. ${ }^{13,15}$ Therefore, synthesizing analogues with varying substituents on the benzo ring (Figure 1) could be a useful tactic.

We set out to synthesize various diethanolamine (DEA) substituted TPZ analogues initially using the 6-fluoro-3-ethyl benzotriazine (21) as a scaffold for incorporating this diol-containing amine. Oxidation of 21 with $m$-CPBA followed by nucleophilic aromatic substitution with diethanolamine in acetonitrile gave $\mathbf{2 3}$ with room temperature (Scheme 4). The resulting compound gave a benzotriazine of increased polarity (and water solubility), and resembled an aromatic nitrogen-mustard (see Chapter 2).

\section{Scheme 4}

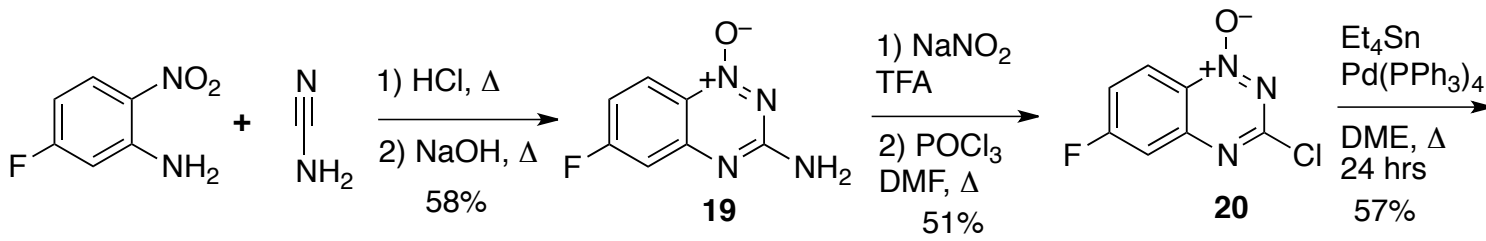

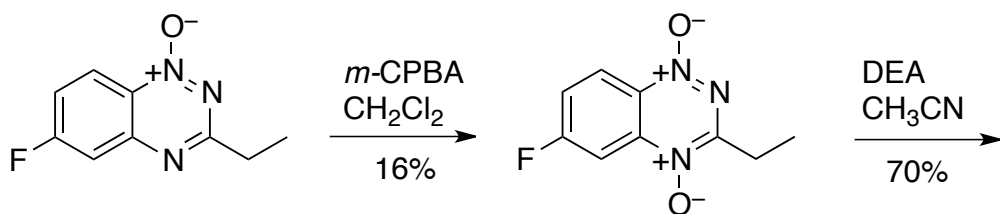

21

22<smiles></smiles>

23

We prepared other analogues containing this polar dialkylamino substituent.

Using conditions listed before, we prepared compound 25 (Scheme 5A) containing the 
diethanolamine substituent at the 3-position instead. Diethanolamine was easily substituted onto compound 5 to give 24, but isolation of 25 after $N$-oxidation was unsuccessful. This observation has been described before by earlier group members, where $N$-oxidation of the benzotriazine system containing a 3-dialkylamine deaminated yielding the 3-OH containing 26 (Scheme 5B). ${ }^{17}$ Additionally, benzotriazine N-oxidation of $\mathbf{5}$ does not proceed easily (Scheme 5). ${ }^{29}$ Thus we did not pursue preparation of 25 any further.

\section{Scheme 5}

A.

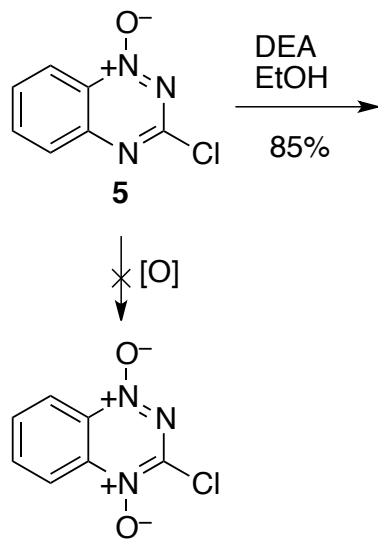<smiles></smiles><smiles>C1C[GeH2][Al]1</smiles><smiles>[O-][n+]1nc(N(CCO)CCO)[n+]([O-])c2ccccc21</smiles>

25
B.

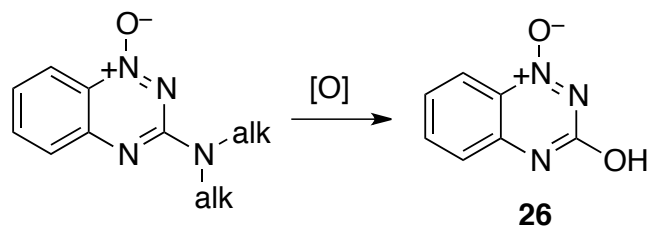

We continued functionalizing the benzo ring with amine substituents, specifically at the 6- and 7-positions (Figure 1, Scheme 6). Using fluorine-containing benzotriazines (19 and 31), we synthesized 27 and 32 by radical deamination with tert-butyl nitrite in DMF both in $50 \%$ yield as reported by from Boyd et al. ${ }^{24}$ Removing the $-\mathrm{NH}_{2}$ group from the benzotriazine core (Figure 1, 3-position) results in a more electron deficient ring system, allowing for easy nucleophilic aromatic substitution of the fluorine atoms on the benzotriazine ring. Nucleophilic aromatic substitution of $\mathbf{2 7}$ with diethanolamine at room 
temperature in acetonitrile at room temperature provided 28 in $81 \%$ yield. The reaction of 7-fluoro benzotriazine 32 with diethanolamine in acetonitrile gave an isolated yield of $66 \%$, but heat was required to get the reaction to proceed in a comparable amount of time as with 6-fluoro 28. The observed reaction conditions requiring higher temperatures indicates that the 6-position is much more electrophilic than the 7-position on the 1,2,4benzotriazine 1-oxide ring system (Scheme 6).

\section{Scheme 6}

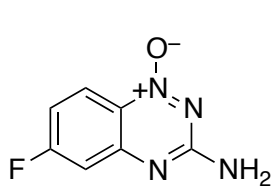

19

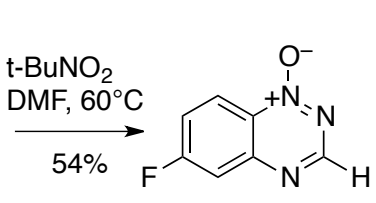

27
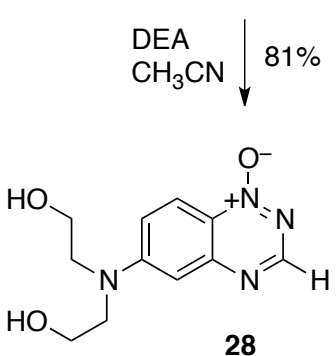

28

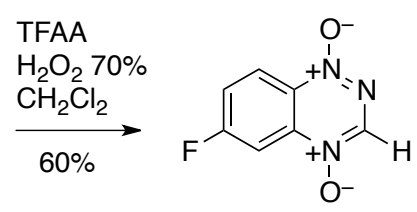

29

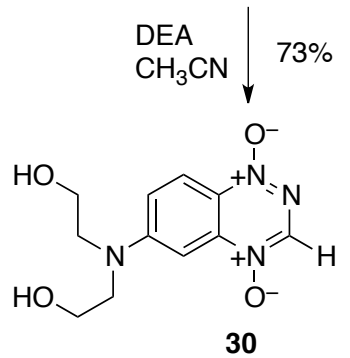

30
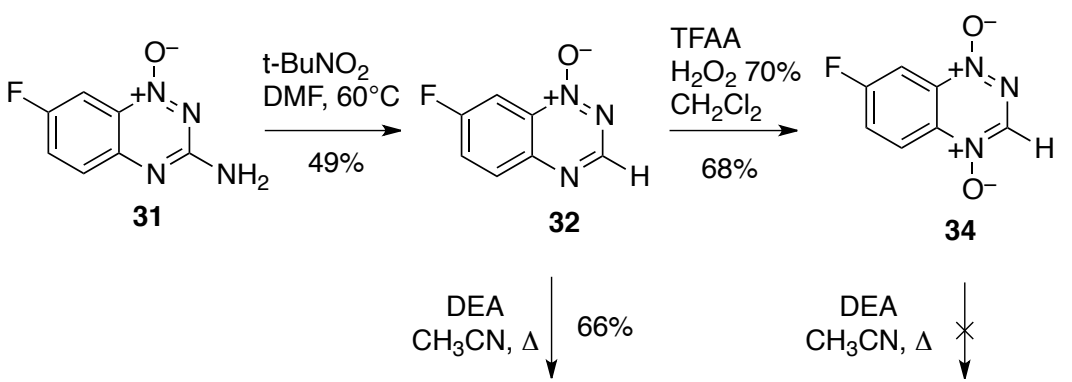<smiles>[O-][n+]1nccc2ncc(N(CCO)CCO)cc21</smiles>

33<smiles></smiles>

35 


\section{Scheme 7}

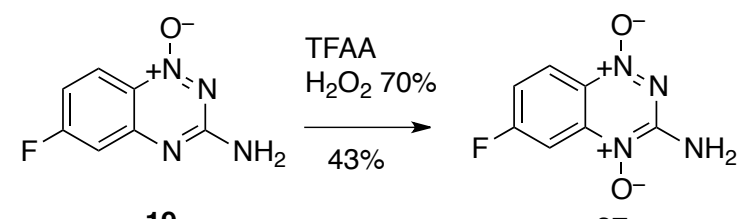

19

37
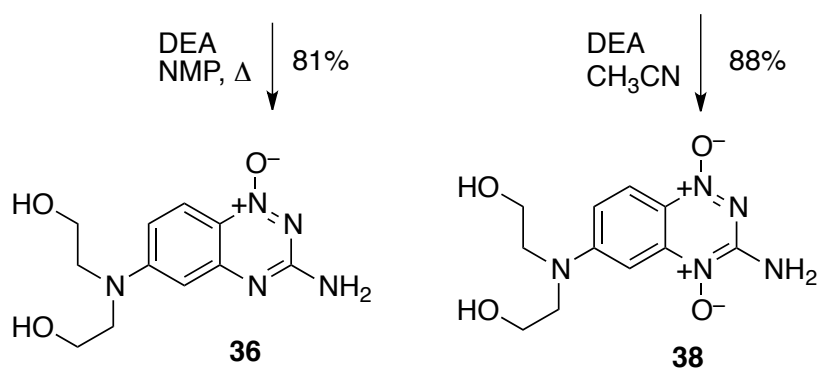

Using the same reaction conditions for the 3-amine containing 6-fluoro or 7fluoro benzotriazines 19 and 31, respectively, did not yield 36 and 39 efficiently. The reactions would not go to completion, even in the presence of heat. We found it necessary to use a much more polar solvent than previously required in addition to heat to facilitate these reactions. $\mathrm{N}$-methylpyrrolidinone (NMP) was selected and upon heating $\left(100{ }^{\circ} \mathrm{C}\right)$ of $\mathbf{1 9}$ with excess diethanolamine (DEA), the reaction afforded $\mathbf{3 6}$ in high yield as a suspension isolated by filtration (Scheme 7).

Utilizing these same vigorous reaction conditions was not suitable for preparation of compound 39. The reaction did not go to completion and poor solubility of both starting material and product prevented the isolation of $\mathbf{3 9}$ (Scheme 8). It seems that the 6-position is a significantly more electrophilic site than at the 7-position, as seen by the difference in reaction conditions to obtain complete substitution at each position (Scheme 6). In fact, experimental evidence shows that the presence of the di- $N$-oxide selectively assists in the nucleophilic substitution of 6-fluoro over 7-fluoro benzotriazines. ${ }^{30}$ These 
observations would be explained by a less electrophilic carbon at position 7 of the benzotriazine system, similar to the relationship between para- and meta-positions on a substituted benzene ring.

\section{Scheme 8}
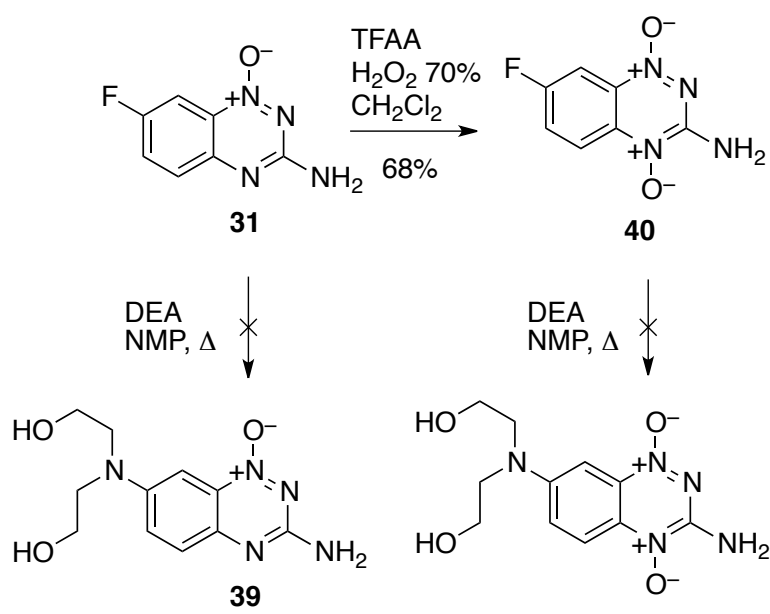

41

Adapting previously reported methods, fluoro-containing di- $N$-oxides 29, 34, 37, and 40 were prepared via oxidation of the 1-oxide benzotriazine precursors $(\mathbf{1 9 , 2 7 , 3 1}$, and 32) with trifluoroperacetic acid generated in situ. ${ }^{28,}{ }^{30}$ Using similar reaction conditions listed before (Scheme 6), diethanolamine was substituted onto the benzoring (displacing fluorine) to yield products $\mathbf{3 0}$ and $\mathbf{3 8}$ cleanly as 1,4-di- $N$-oxide counterparts to compounds 28 and 36 (Schemes 6 and 7). Neither NMP nor heat was required to prepare 38, as supported by literature ${ }^{30}$ suggesting that the 6-position (Figure 1) of the benzotriazine core is more electrophilic upon oxidation to the 4-N-oxide. This relationship was not seen for substitution at the 7-position, as nucleophilic substitution of 34 and 40 with diethanolamine did not yield 35 or 41 cleanly, thus were not isolated nor characterized (Scheme 6 and 8). (The implications of these observations are discussed in Chapter 2) Additionally, it was observed that dexoxygenation of compound $\mathbf{3 4}$ was 
occuring during the attempted synthesis of $\mathbf{3 5}$ (Scheme 8 and 9). It has been shown that $N$-oxides can be deoxygenated when heated in the presence of alcohols under basic conditions (Scheme 9). ${ }^{31}$

\section{Scheme 9}

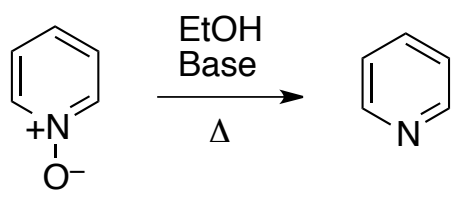

\subsection{Fluorescence Properties of Substituted Benzotriazine Analogues}

We were interested in comparing absorbance and emission wavelengths of all new compounds with that of the parent mono- $N$-oxide compound 4. We additionally performed calculations for molar absorptivity $(\varepsilon)$, quantum yield $(\Phi)$ of fluorescence, and brightness $(\varepsilon \times \Phi)$. With molecules in hand, selected benzotriazine analogues were tested for fluorescence and Table 4 summarizes the results. Absorbance and fluorescence measurements were taken in acetonitrile $(20 \mathrm{uM})$ because the quantum yield of compound 4 (0.12) has previously been determined (in acetonitrile).$^{18}$. Additionally, aqueous environments commonly quench fluorescence measurements.

$$
\begin{gathered}
A=\varepsilon b c \\
\Phi=\Phi_{\mathrm{R}} \frac{A_{R}}{A} \frac{I}{I_{R}}\left(\frac{n}{n_{R}}\right)^{2} \quad \text { Eq. } 2
\end{gathered}
$$

Molar absorptivity coefficients were calculated using Beer's law (Equation 1). Fluorescence quantum yields were estimated using Equation 2. Using compound 4 as a fluorescent standard with known quantum yield $\left(\Phi_{\mathrm{R}}\right)$, the measured absorbance $(A)$ at a 
given excitation wavelength and the integration of the fluorescent peak $(I)$ resulting from emission can provide a quantum yield useful for comparison. ${ }^{32}$ The refractive index $(n)$ is only needed when using different solvents for comparison. This equation was used to estimate measurements for quantum yield $(\Phi)$ and brightness ( $\varepsilon \times \Phi)$ of select compounds that showed promising fluorescence properties (Table 4).

For the 3-substituted analogs, only compound $\mathbf{9}$ and $\mathbf{1 1}$ displayed any significant fluorescent properties. Both produced weak fluorescence in acetonitrile, but interestingly compound 9 was fluorescent in the low polarity solvent dichloromethane $(\Phi=0.070)$. We are unsure why such weak fluorescent properties are seen for analogs containing groups at the exocyclic $-\mathrm{NH}_{2}$ group. It is possible that intramolecular quenching is occuring, ${ }^{33-34}$ as seen by compound 9 when in polar solvents (unpublished observations).

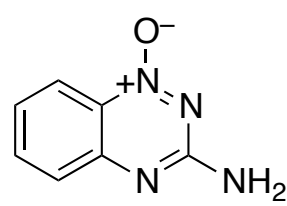

4<smiles>COc1ccc2nc(N)n[n+]([O-])c2c1</smiles>

42

The 7-substituted compounds (33 and 31) showed promising fluorescence. The addition of the exocyclic secondary amine at the 6- or 7-position resulted in a significant change in absorbance and fluorescence properties, particularly the 7-position (33). In addition to a longer fluorescence wavelength $(565 \mathrm{~nm})$ compared to the compound 4 (478 $\mathrm{nm})$, compound $\mathbf{3 3}$ is a stronger chromophore resulting in "brighter" fluorescence as well. Compound 31 containing the 7-fluoro atom produced the brightest fluorescence listed in Table 4. The emission wavelength of $\mathbf{3 1}(485 \mathrm{~nm})$ was similar to that of the parent compound 4 but its quantum yielding $(\Phi)$ was estimated to be almost twice as large (0.21). These results indicate that substituents (EDG and EWG) placed at the 7-position 
of the benzotriazine core would be useful for producing interesting fluorescent properties for these compounds.

Table 4. Spectroscopic Data for Substituted Benzotriazine Analogs

\begin{tabular}{cccccc}
\hline Compound \# & $\boldsymbol{\Lambda}_{\text {abs }}$ & $\boldsymbol{\varepsilon}$ & $\boldsymbol{\Lambda}_{\mathrm{em}}$ & $\boldsymbol{\Phi}$ & $\begin{array}{c}\text { Brightness } \\
(\boldsymbol{\varepsilon} \mathbf{X} \boldsymbol{\Phi})\end{array}$ \\
\hline $\mathbf{4}$ & 405 & 3868 & 478 & $0.12^{\mathrm{a}, \mathrm{b}}$ & 460 \\
$\mathbf{4 2}$ & $413^{\mathrm{a}}$ & $5395^{\mathrm{a}}$ & $500^{\mathrm{a}}$ & $0.18^{\mathrm{a}}$ & $971^{\mathrm{a}}$ \\
$\mathbf{9}$ & 421 & 4700 & $507^{\mathrm{c}}$ & 0.070 & 330 \\
$\mathbf{1 1}$ & 447 & 3900 & 550 & 0.005 & 20 \\
$\mathbf{2 3}$ & 464 & 9600 & 558 & 0.007 & 70 \\
$\mathbf{2 8}$ & 437 & 1100 & 552 & 0.010 & 10 \\
$\mathbf{3 0}$ & 398 & 16000 & 558 & 0.006 & 96 \\
$\mathbf{3 3}$ & 465 & 17000 & 565 & 0.072 & 1200 \\
$\mathbf{3 6}$ & 412 & 16000 & 540 & 0.013 & 210 \\
$\mathbf{3 8}$ & 472 & 1600 & 569 & 0.007 & 11 \\
$\mathbf{3 1}$ & 413 & 6300 & 485 & 0.210 & 1350 \\
$\mathbf{4 3 B}$ & 456 & 4400 & 589 & 0.081 & 358 \\
$\mathbf{4 3}$ & 466 & 5400 & 588 & 0.212 & 1150 \\
$\mathbf{4 6}$ & 413 & 4800 & none & - & - \\
$\mathbf{4 7}$ & 375 & 2300 & 603 & 0.026 & 59 \\
$\mathbf{4 8}$ & 423 & 5500 & 466 & 0.210 & 1150 \\
$\mathbf{5 0}$ & 416 & 13000 & 468 & 0.019 & 270 \\
$\mathbf{5 1}$ & 407 & 3200 & 608 & $<0.001$ & $<3$ \\
$\mathbf{5 3}$ & 406 & 4900 & 495 & 0.170 & 831 \\
\hline $\mathbf{5}$ & 400 & & &
\end{tabular}

${ }^{\mathrm{a}}$ From Thesis of Ujjal Sarkar

${ }^{\mathrm{b}}$ From Shi et al

${ }^{\mathrm{c}}$ Measurements taken in $\mathrm{CH}_{2} \mathrm{Cl}_{2}$

Previous work in our group has shown that compound 42, containing an electron donating -OMe group at the 7-position produces bright fluorescence with approximately $50 \%$ increase in quantum yield (0.18) when compared to $4(0.12)$, the major TPZ metabolite. ${ }^{17-18}$ Fluorophores generally require a "push-pull" system for brilliant fluorescence. The electron withdrawing $1-N$-oxide moiety is in conjugation with the 7- 
OMe substituent, similar to $\mathbf{3 3}$, and possibly acts as an electron withdrawing "group" for charge transfer. Excitation of TPZ (1) was reported to result in formation of an oxaziridinium intermediate (Scheme 10 ) by the 4 - $N$-oxide. ${ }^{18}$ This cyclization was hypothesized to be the cause of fluorescence quenching in TPZ. ${ }^{18}$ Cyclization of the $1-N$ oxide was reported to be much less favorable, preventing any rapid quenching in compound 4 resulting in longer fluorescence lifetime than the 1,4-dioxide. ${ }^{18}$

\section{Scheme 10}

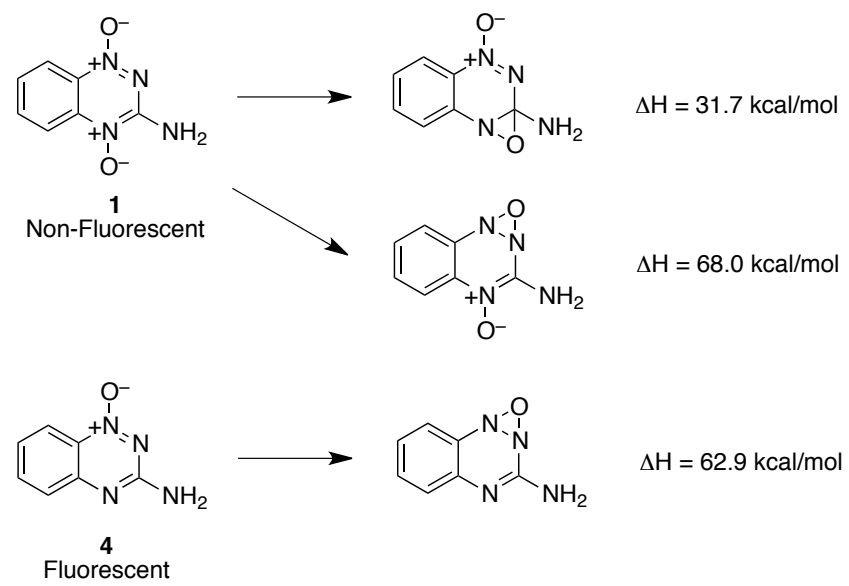

To see if using a different electron-donating substituent would have a similar effect, a morpholine substituent was attached to the 7-position (43). It was discussed before that 7-fluoro benzotriazine (31) is not a useful electrophile for nucleophilic aromatic substitution reactions. So we took a different approach utilizing Pd-coupling reaction to attach a morpholino group at the 7-position using 7-chloro containing 44 (Scheme 11). Synthesis was carried out starting with Boc protection of 7-Cl containing 44 with di-tert-butyl dicarbonate to provide 45 ready for Pd-catalyzed Buchwald coupling with morpholine. Boc protection of the 3-amino group helped solubilize the starting materials and products for purification (as well as lowering electron density of the $-\mathrm{NH}_{2}$ ). Subsequent deprotection with TFA in $\mathrm{CH}_{2} \mathrm{Cl}_{2}$ yielded 43. This product was 
obtained in low yield, as multiple products were obtained during the Pd-coupling reaction. All starting material (45) underwent a single- or double-Boc-deprotection during the reaction under these conditions. The mono-deprotected, morpholino coupled product (43A) was used for final isolation of product 43 after acid deprotection. Additionally, 43B was isolated from the reaction mixture as well. The fluorescence properties of these compounds are discussed below.

\section{Scheme 11}
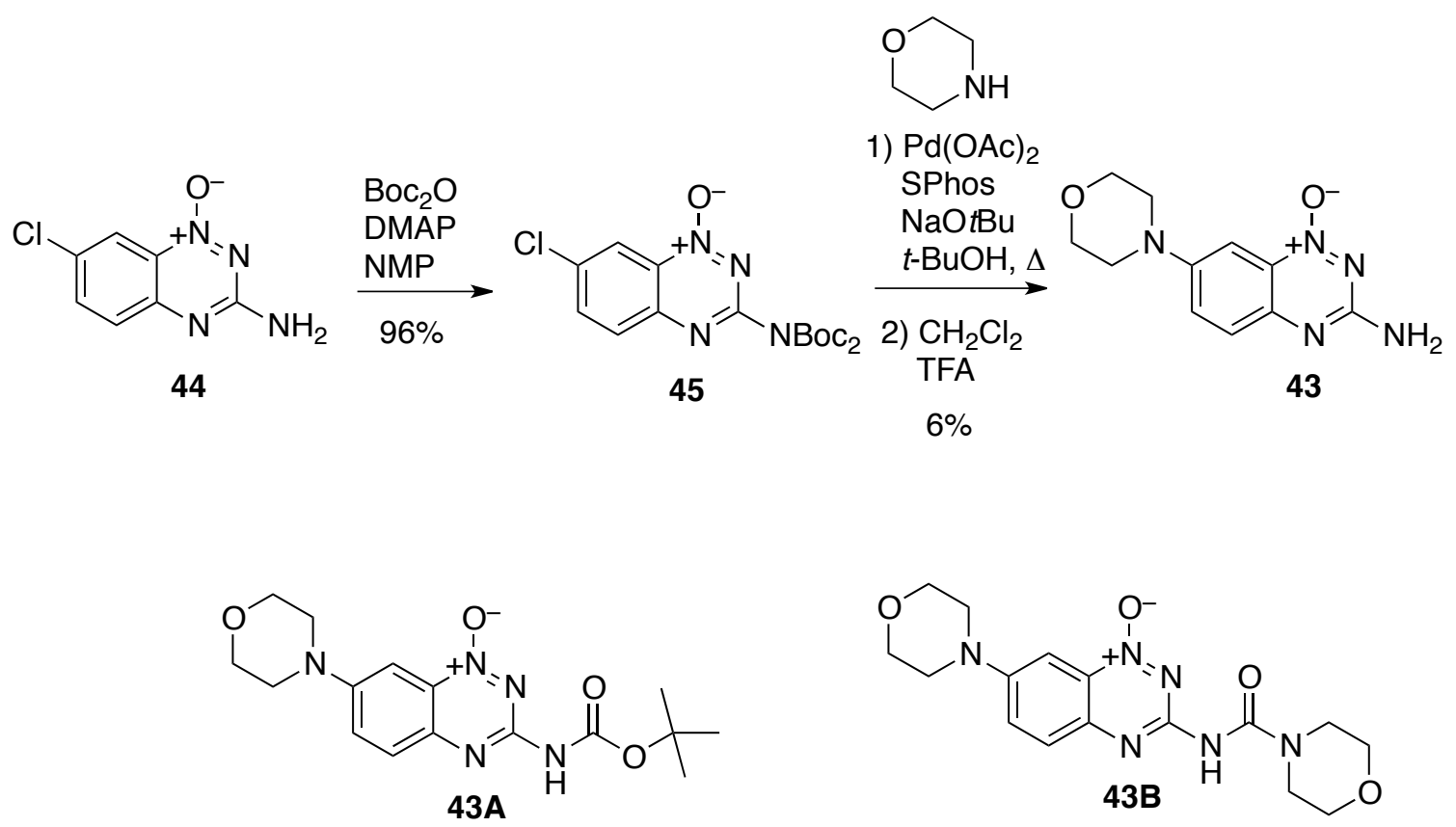

Currently, the parent drug TPZ would not be a useful fluorescent probe for bioimaging as fluorescence at longer wavelengths $(650-800 \mathrm{~nm})$ are typically more advantageous. ${ }^{19}$ Red and near IR wavelengths reduce photo damage to samples, have higher tissue penetration, and minimizes background fluorescence from biomolecules. Consequently, we wanted to test if increasing the aromatic conjugation by using naphthotriazine ring systems would significantly alter the fluorescence properties for this class of compounds. We set out to prepare compounds 46, 47, and 48. All three 
compounds were synthesized using cyanamide condensation conditions as before with the respective amino-nitronaphthalenes (Scheme 12). 2-amino-3-nitronaphthalene was commercially available whereas 2-aminonitronaphthalene and 1-amino-2nitronaphthalene were prepared as previously reported. ${ }^{35-36}$ All naphthotriazines were synthesized in low yields, attributed to lower solubility in aqueous acid and base. Early attempts to synthesize 46 proved difficult, as utilizing a previously reported synthesis forming 49 followed by unselective oxidation did not yield the 1-oxide product of interest (Scheme $12, \mathbf{5 0}) .{ }^{37}$ A crystal structure was obtained to confirm that $N$-oxidation occurred at the position 2 endocyclic nitrogen of the triazine ring (Figure 2), thus this route was not pursued further.

\section{Scheme 12}
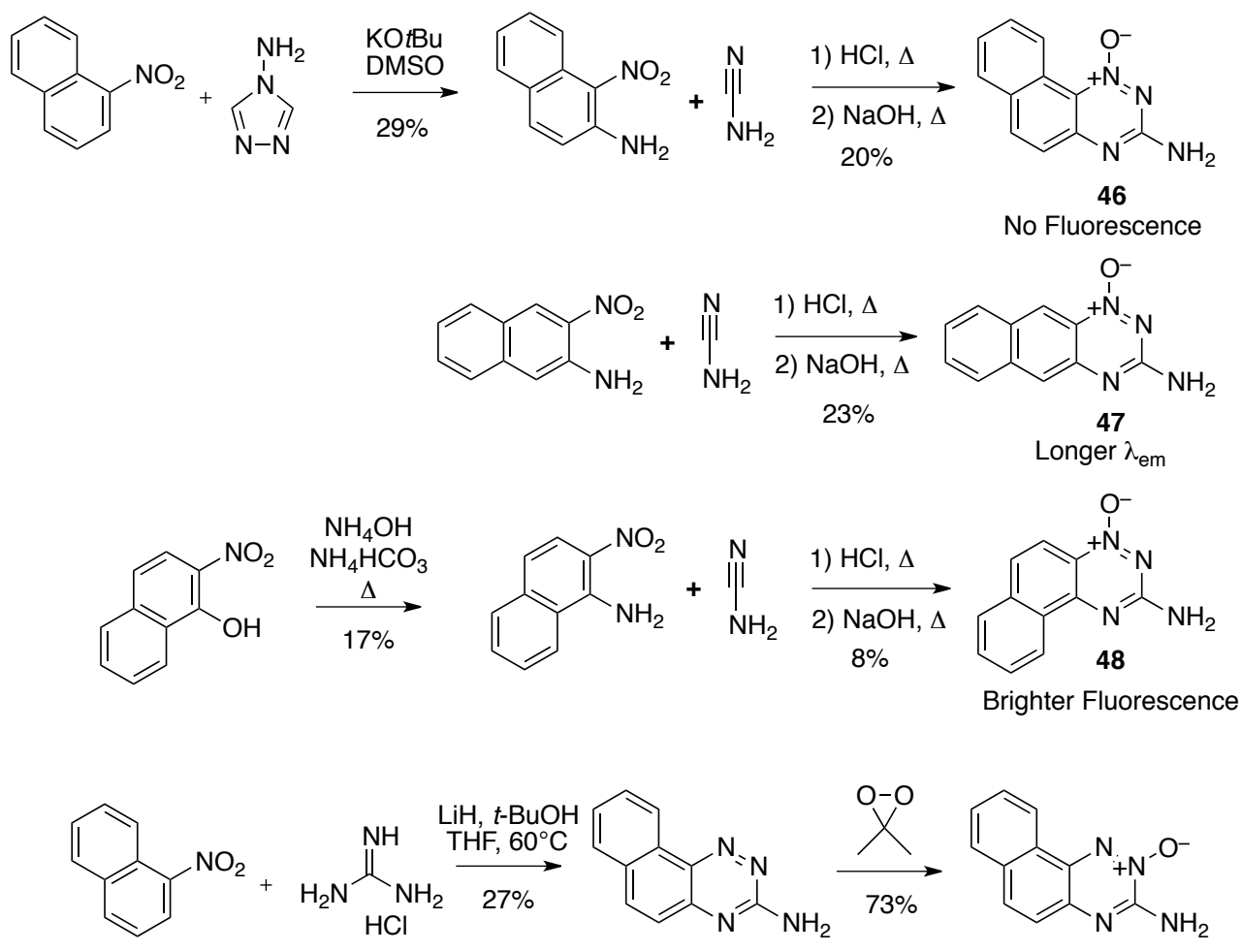

49 


\section{Figure 2}

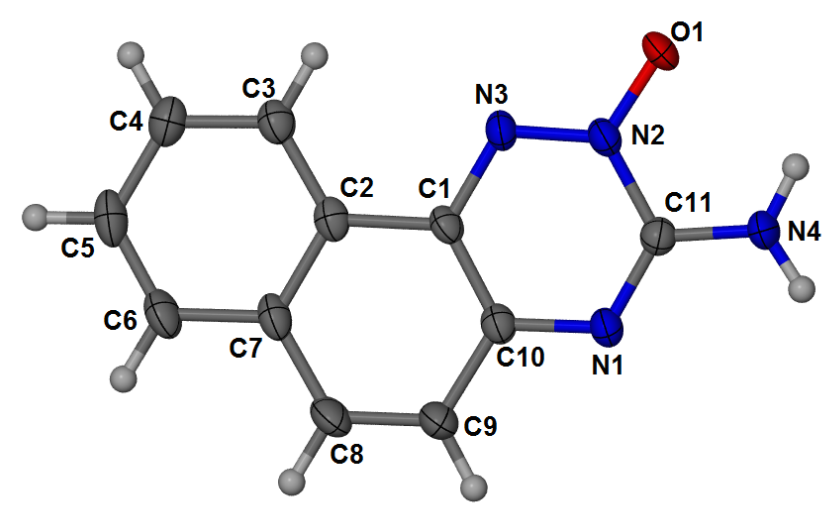

Figure 2. X-ray crystal structure of compound $\mathbf{5 0 .}$

We also prepared molecules designed with a goal of changing conjugation in the ring by using different substituents on the benzotriazine core (Scheme 13). Compound $\mathbf{5 1}$ was prepared by acid deprotection of $\mathbf{1 6}$ (see below). This molecule was predicted to extend the conjugation of the exocyclic $-\mathrm{NH}_{2}$ group with the triazine ring system by addition of a phenyl group. Compound $\mathbf{5 3}$ was prepared to see if putting an electron withdrawing group in the 7-position would create a new push-pull system. Placing an ester in the 7-position allows one to draw a resonance structure and delocalize the lone pair of the $-\mathrm{NH}_{2}$ group onto the carbonyl oxygen (Scheme 13). We predicted this would implement a new conjugated system, potentially altering the fluorescence properties of the benzotriazine ring system. Compound $\mathbf{5 3}$ was synthesized in two steps. The first reaction involved nucleophilic aromatic substitution of free guanidine base with 3-fluoro4-nitrobenzoic acid followed by ring closure using potassium tert-butoxide to provide $\mathbf{5 2}$. 
The second reaction involved esterification of the resulting carboxylic acid containing benzotriazine yielded $\mathbf{5 3}$ cleanly.

\section{Scheme 13}
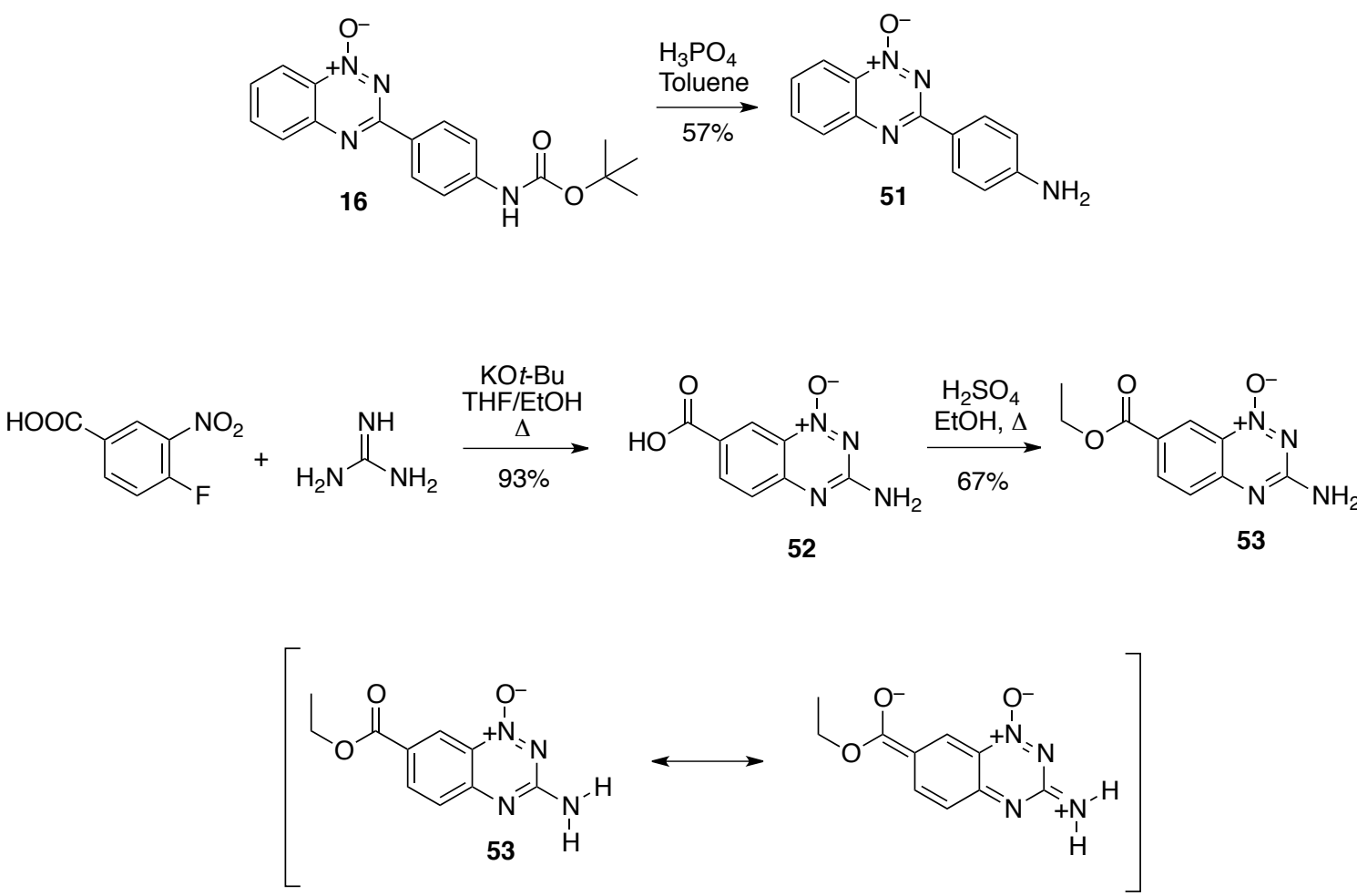

Absorbance and fluorescence spectra for these benzo-substituted benzotriazine 1oxide analogues were taken and are listed in Table 1 . Compound 43, containing the 7morpholino group, was estimated to have almost two-fold increase in quantum yield (0.21) when compared to 4 (0.12), similar to the bright green fluorescent 7-OMe analog (42) previously described. ${ }^{17}$ Upon excitation, 43 fluoresced at much longer wavelengths (598 nm) as well, suggesting this could be a good candidate for development of a hypoxia selective fluorescent probe.

The naphthotriazine $N$-oxide compounds 46, 47, 48, and 50 displayed very diverse fluorescent properties. Compound $\mathbf{4 8}$ provided the brightest fluorescence, with the highest quantum yield (0.21) of the naphthalene derived triazines. Only compound 
47 showed fluorescence of longer wavelength $(603 \mathrm{~nm})$, but it also gave lower quantum yield (0.026). Compound 46 produced no measureable fluorescence, though its $2-\mathrm{N}-$ oxide isomer 51 surprisingly produced blue fluorescence $(468 \mathrm{~nm})$, meaning lower wavelength with respect to 4 .

Compound 51 containing the phenyl "bridge" between the exocyclic $-\mathrm{NH}_{2}$ and the triazine core resulted in the expected longer wavelength fluorescence, though with a significant loss in quantum yield. Compound $\mathbf{5 3}$ on the other hand, only observed a minor increase in fluorescence wavelength $(495 \mathrm{~nm})$ with about a $50 \%$ increase in quantum yield. Similar observations have been seen for 6- and 7-fluoro compounds 19 and 31, suggesting the "through-conjugation" effect may not be a contributor of the fluorescence for this compound.

\subsection{Chapter 1 Summary}

Here we presented the synthesis of a variety of 1,2,4-benzotriazine $\mathrm{N}$-oxide precursors potentially for use as fluorescent probes to detect hypoxia and bioreductive enzymes in biological samples. The synthetic techniques combined here will be useful to generate many more TPZ analogs with different structural characteristics. We utilized Pd-coupling reactions to attach substituents at various positions on the benzotriazine core. Yields varied widely, but we feel this would still be a useful technique for preparation of benzotriazine analogs. Nucleophilic aromatic substitution reactions expanded the possibilities for utilizing the different positions on the benzotriazine ring system.

We explored how fluorescence properties of compound 4 (Scheme 1) changed when making substitutions at various positions of the benzotriazine core. While the 1- 
oxide metabolite 4 of TPZ (1) is fluorescent, longer fluorescence wavelengths and quantum yields are needed for biological imaging. ${ }^{19}$ Extending conjugation did indeed produce longer fluorescence wavelengths, though typically the quantum yield decreased as well (47 and 51). Similar to earlier experiments in the lab, substitution of a morpholine group onto the 7-position produced a fluorophore with superior quantum yield or brightness (43 and 33). We were surprised to observe a significant red-shift in fluorescence associated with compound $\mathbf{4 3}$, along with the increased brightness. While substitutions at the 6-position provided red-shifted fluorescence as well, they were not as bright (36 and 28).

These results will guide future work towards the first report of using the benzotriazine core as a useful tool to detect hypoxia and bioreductive enzymes in cell samples. We will calculate quantitative data of fluorescent properties for all potential 1$\mathrm{N}$-oxide candidates, and their corresponding 1,4-dioxides to check for switchable fluorescence.

\subsection{Experimental}

Synthesis of 3-amino-1,2,4-benzotriazine 1-oxide (4): Compound 4 was prepared as in Ujjal Sarkar's thesis. ${ }^{17}$ 2-nitroaniline $(4.8 \mathrm{~g}, 35 \mathrm{mmol})$ and cyanamide $(3 \mathrm{~g}, 70 \mathrm{mmol})$ were heated together at $100{ }^{\circ} \mathrm{C}$ for 10 minutes until a melt is achieved. The mixture was cooled slightly and $\mathrm{HCl}(25 \mathrm{~mL}$, conc.) was added dropwise while stirring over a 30 minute period. (CAUTION: A violent exothermic reaction may occur during or after $\mathrm{HCl}$ addition). After addition of acid was complete the mixture was heated to $100^{\circ} \mathrm{C}$ for $20 \mathrm{~min}$ and then cooled to room temperature with continued stirring. $\mathrm{NaOH}(12 \mathrm{~mL}, 16$ 
M) was added and the mixture stirred vigorously at $100^{\circ} \mathrm{C}$ for $2 \mathrm{~h}$. The orange precipitate was collected by vacuum filtration, washed thoroughly with $25 \%$ hexane in ethyl acetate and dried in the oven overnight. The bright yellow powder was obtained in $93 \%$ yield: ${ }^{1} \mathrm{H}$ NMR $\left(300 \mathrm{MHz}, \mathrm{DMSO}-d_{6}\right) \delta 8.12(\mathrm{ddd}, J=8.6,1.2,0.27 \mathrm{~Hz}, 1 \mathrm{H}), 7.75(\mathrm{ddd}, J=$ 8.4, 6.9, $1.4 \mathrm{~Hz}, 1 \mathrm{H}), 7.53(\mathrm{dd}, J=8.5,0.7 \mathrm{~Hz}, 1 \mathrm{H}), 7.36-7.31$ (comp, $3 \mathrm{H}) ;{ }^{13} \mathrm{C} \mathrm{NMR}$ (75 MHz, DMSO- $\left.d_{6}\right) \delta 160.3,148.8,135.7,129.9,125.9,124.7,119.9$.

Synthesis of 3-amino-1,2,4-benzotriazine 1,4-dioxide (1): Compound 4 (411 mg, 2.5 mmol) was dissolved in trifluoroacetic acid $(7.7 \mathrm{~mL})$ with stirring while $\mathrm{H}_{2} \mathrm{O}_{2}(6.1 \mathrm{~mL}$ of $70 \%$ solution) was added dropwise. The reaction was allowed to stir for $10 \mathrm{~min}$ and heated to $50{ }^{\circ} \mathrm{C}$ overnight protected from light. The reaction was cooled to room temperature and poured into $\mathrm{H}_{2} \mathrm{O}(100 \mathrm{~mL})$. The resulting yellow solution was neutralized by slow addition of solid $\mathrm{NaHCO}_{3}$ with vigorous stirring. The solution became deep red and a red powder precipitated. The precipitate was collected by vacuum filtration, washed thoroughly with water and diethyl ether, and dried in a dessicator to give 1 in $40 \%$ yield: ${ }^{1} \mathrm{H}$ NMR (500 MHz, DMSO- $\left.d_{6}\right) \delta 8.20(\mathrm{~d}, J=8.7 \mathrm{~Hz}, 1 \mathrm{H}), 8.13(\mathrm{~d}$, $J=8.6 \mathrm{~Hz}, 1 \mathrm{H}$ ), 8.02 (bs, $2 \mathrm{H}$ ), 7.93 (appt, $J=8.1,7.5 \mathrm{~Hz}, 1 \mathrm{H}$ ), 7.53 (appt, $J=8.1,7.6$ $\mathrm{Hz}, 1 \mathrm{H}) ;{ }^{13} \mathrm{C}$ NMR $\left(125 \mathrm{MHz}\right.$, DMSO- $\left.d_{6}\right) \delta 151.9,138.8,135.7,130.9,127.1,121.5$, 117.4 .

Synthesis of 3-chloro-1,2,4-benzotriazine 1-oxide (5): A procedure from Boyd et al was followed for preparation of compound $\mathbf{5 .}^{24}$ Compound 4 (1.3 g, $\left.7.2 \mathrm{mmol}\right)$ was dissolved in trifluoroacetic acid $(8 \mathrm{~mL})$ and then cooled to $0{ }^{\circ} \mathrm{C}$. Sodium nitrite $(1 \mathrm{~g}, 2$ 
equiv) was added slowly, keeping the temperature of the solution $<5{ }^{\circ} \mathrm{C}$. The resulting solution was stirred at room temperature for $2 \mathrm{~h}$ before being poured into an ice/water slurry $(80 \mathrm{~mL})$ and stirred for $30 \mathrm{~min}$. The resulting precipitate was collected by vacuum filtration, washed with cold water $(20 \mathrm{~mL})$, and dired in the oven overnight. In a $\mathrm{N}_{2}$ purged 2-neck roundbottom flask with reflux condenser, the dried solid (1.12 $\mathrm{g}, 7 \mathrm{mmol})$, phosphorus (V) oxychloride (5 mL, 12-13 equiv), and dimethylformamide (60 $\mu \mathrm{L})$ were added. The mixture was heated at $105{ }^{\circ} \mathrm{C}$ under an $\mathrm{N}_{2}$ atmosphere for $1 \mathrm{~h}$. The reaction was immediately poured onto crushed ice $(100 \mathrm{~mL})$ and stirred for $30 \mathrm{~min}$. The resulting suspension was extracted with $\mathrm{CH}_{2} \mathrm{Cl}_{2}(100 \mathrm{~mL})$ and organic fraction separated, dried with anhydrous $\mathrm{Na}_{2} \mathrm{SO}_{4}$ and solvent removed by rotary evaporation. Purification by column chromatography with silica gel with $\mathrm{CH}_{2} \mathrm{Cl}_{2}$ afforded 5 as a colorless solid in $88 \%$ overall yield after 2 steps. Characterization by NMR (in DMSO- $d_{6}$ ) compared with lit. reports confirmed identity: ${ }^{1} \mathrm{H}$ NMR $\left(500 \mathrm{MHz}, \mathrm{CDCl}_{3}\right) \delta 8.41(\mathrm{~d}, J=8.6 \mathrm{~Hz}, 1 \mathrm{H})$, 8.00-7.99 (m, $2 \mathrm{H}), 7.77$ (ddd, $J=8.6,7.1,1.4 \mathrm{~Hz}, 1 \mathrm{H}) .{ }^{13} \mathrm{C}$ NMR $\left(125 \mathrm{MHz}, \mathrm{CDCl}_{3}\right) \delta$ $157.1,147.4,136.9,133.9,131.1,128.6,120.4$.

Synthesis of 3-bromo-1,2,4-benzotriazine 1-oxide (6): Compound 6 was prepared using a method similar to 5. Compound $4(1.3 \mathrm{~g}, 7.2 \mathrm{mmol})$ was dissolved in trifluoroacetic acid $(8 \mathrm{~mL})$ and then cooled to $0{ }^{\circ} \mathrm{C}$. Sodium nitrite $(1 \mathrm{~g}, 2$ equiv) was added slowly, keeping the temperature of the solution $<5{ }^{\circ} \mathrm{C}$. The resulting solution was stirred at room temperature for $2 \mathrm{~h}$ before being poured into an ice/water slurry $(80 \mathrm{~mL})$ and stirred for $30 \mathrm{~min}$. The resulting precipitate was collected by vacuum filtration, washed with cold water $(20 \mathrm{~mL})$, and dired in the oven overnight. In a $\mathrm{N}_{2}$-purged 2-neck 
roundbottom flask with reflux condenser, the dried solid (423 $\mathrm{mg}, 2.6 \mathrm{mmol})$ and solid phosphorus (V) oxybromide ( $5 \mathrm{~mL}, 12-13$ equiv) were added. The mixture was heated at $105{ }^{\circ} \mathrm{C}$ under an $\mathrm{N}_{2}$ atmosphere for $30 \mathrm{~min}$. The reaction was immediately poured into an ice-water slurry $(25 \mathrm{~mL})$ and stirred for $30 \mathrm{~min}$. The resulting suspension was extracted with $\mathrm{CH}_{2} \mathrm{Cl}_{2}(4 \times 15 \mathrm{~mL})$. The combined organic fractions were washed with saturated sodium bicarbonate, saturated brine, and dried with anhydrous $\mathrm{Na}_{2} \mathrm{SO}_{4}$. The

solvent was then removed by rotary evaporation. Purification by column chromatography with silica gel with $\mathrm{CH}_{2} \mathrm{Cl}_{2}$ afforded $\mathbf{6}$ as a colorless solid in $43 \%$ overall yield after 2 steps: ${ }^{1} \mathrm{H}$ NMR $\left(300 \mathrm{MHz}, \mathrm{CDCl}_{3}\right) \delta 8.41(\mathrm{~d}, J=8.7 \mathrm{~Hz}, 1 \mathrm{H}), 8.01-7.99$ (comp, $2 \mathrm{H}$ ), 7.78 (ddd, $J=8.5,4.8,3.6 \mathrm{~Hz}, 1 \mathrm{H}) ;{ }^{13} \mathrm{C} \mathrm{NMR}\left(75 \mathrm{MHz}, \mathrm{CDCl}_{3}\right) \delta 147.9$, 147.4, 136.7, 131.0, 128.4, 120.3; HRMS (ESI) $\mathrm{m} / \mathrm{z}$ calc for $\mathrm{C}_{7} \mathrm{H}_{4} \mathrm{~N}_{3} \mathrm{ONaBr}\left(\mathrm{M}+\mathrm{Na}^{+}\right)$ 247.9435, found 247.9439.

Representative Procedure for Coupling of 3-Halo-1,2,4-benzotriazine 1-Oxides with Amines: 3-N-phenylamino-1,2,4-benzotriazine 1-oxide (7). Toluene (4 mL) was degassed by bubbling nitrogen through the solvent for $10 \mathrm{~min}$ in a round bottom flask. To this container compound 6 (28.5mg, $0.16 \mathrm{mmol}), \mathrm{K}_{3} \mathrm{PO}_{4}(150 \mathrm{mg}, 4 \mathrm{eq}), \mathrm{Pd}(\mathrm{OAc})_{2}(5$ mol\%), SPhos ligand (10\%), and Anilne (13 $\mu \mathrm{L}, 1.4 \mathrm{eq})$ were added and the mixture was stirred at $55{ }^{\circ} \mathrm{C}$ for 24 hours. The reaction was cooled to room temperature, water added $(10 \mathrm{~mL})$, and extracted 3 times with dichloromethane $(10 \mathrm{~mL})$. The organic layers were collected, combined, and dried with anhydrous $\mathrm{Na}_{2} \mathrm{SO}_{4}$. The solvent was evaporated and the crude product was purified by column chromatography on silica gel with $\mathrm{CH}_{2} \mathrm{Cl}_{2}$ to obtain a yield of $27 \%$ of an orange solid. Using the same conditions at $20{ }^{\circ} \mathrm{C}$ gave a $21 \%$ 
yield. Without palladium catalyst yields were $0 \%$ at $20{ }^{\circ} \mathrm{C}$ and $5 \%$ at $55^{\circ} \mathrm{C}:{ }^{1} \mathrm{H} \mathrm{NMR}{ }^{1} \mathrm{H}$ NMR (300 MHz, DMSO-d $\left.)_{6}\right) \delta 10.245(1 \mathrm{H}, \mathrm{s}), 8.225$ (1H, dd, $\left.8.5 \mathrm{~Hz}, 1.0 \mathrm{~Hz}\right), 7.906-$ $7.855(3 \mathrm{H}, \mathrm{m}), 7.746(1 \mathrm{H}, \mathrm{dd}, 8.4 \mathrm{~Hz}, 0.8 \mathrm{~Hz}), 7.472(1 \mathrm{H}, \mathrm{t}, 7.8 \mathrm{~Hz}), 7.36(2 \mathrm{H}, \mathrm{t}, 7.9 \mathrm{~Hz})$, $7.054(1 \mathrm{H}, \mathrm{t}, 7.4 \mathrm{~Hz}) ;{ }^{13} \mathrm{C}$ NMR $\left(300 \mathrm{MHz}, \mathrm{DMSO}-d_{6}\right) \delta 156.83,148.04,139.76,131.43$, 129.12, 127.07, 126.41, 123.05, 120.29, 119.85; HRMS (ESI) m/z calculated for $\mathrm{C}_{13} \mathrm{H}_{10} \mathrm{~N}_{4} \mathrm{O}\left(\mathrm{M}+\mathrm{H}^{+}\right)$239.0927, found 239.0915

\section{Representative Procedure for Coupling of 3-Halo-1,2,4-benzotriazine 1-Oxides with}

Amines: 3-N-benzylamino-1,2,4-benzotriazine 1-oxide (9). Toluene (4 mL) was degassed by bubbling nitrogen through the solvent for $10 \mathrm{~min}$ in a round bottom flask. To this container 3 compound 5 (58.3mg, $0.33 \mathrm{mmol}), \mathrm{K}_{3} \mathrm{PO}_{4}(300 \mathrm{mg}, 4 \mathrm{eq}), \mathrm{Pd}(\mathrm{OAc})_{2}$ (5 mg, 5\% eq), SPhos ligand (15 mg, 10\%), and benzylamine (50uL, 1.4 eq) were added and the mixture was stirred at $50{ }^{\circ} \mathrm{C}$ for 24 hours. The reaction was cooled to room temperature, water added $(10 \mathrm{~mL})$, and extracted 3 times with dichloromethane $(10 \mathrm{~mL})$. The organic layers were collected, combined, and dried with anhydrous $\mathrm{Na}_{2} \mathrm{SO}_{4}$. The solvent was evaporated and the crude product was purified by column chromatography on silica gel with $\mathrm{CH}_{2} \mathrm{Cl}_{2}$ to obtain compound 9 as a yellow solid in $87 \%$. Using the same conditions at $20{ }^{\circ} \mathrm{C}$ gave a $74 \%$ yield. Without the palladium catalyst yields of $34 \%$ at $20{ }^{\circ} \mathrm{C}$ and $67 \%$ at $55^{\circ} \mathrm{C}$ were obtained: ${ }^{1} \mathrm{H}$ NMR (500 MHz, DMSO- $\left.d_{6}\right) \delta 8.442$ $(1 \mathrm{H}, \mathrm{s}), 8.138(1 \mathrm{H}, \mathrm{d}, 8.6 \mathrm{~Hz}), 7.770(1 \mathrm{H}, \mathrm{t}, 7.7 \mathrm{~Hz}), 7.559(1 \mathrm{H}, \mathrm{t}, 8.4 \mathrm{~Hz}), 7.386-7.304$ $(6 \mathrm{H}, \mathrm{m}), 7.233(1 \mathrm{H}, \mathrm{t}, 7.3 \mathrm{~Hz}), 4.592(2 \mathrm{H}, \mathrm{d}, 5.5) ;{ }^{13} \mathrm{C}$ NMR (500 MHz, DMSO- $\left.d_{6}\right) \delta$ $159.36,139.54,136.15,130.61,128.78,128.65,127.56,127.18,126.48,125.09,120.29$, 44.16; HRMS (ESI) m/z calculated for $\mathrm{C}_{14} \mathrm{H}_{12} \mathrm{~N}_{4} \mathrm{O}\left(\mathrm{M}+\mathrm{H}^{+}\right)$253.1084, found 253.1097. 


\section{General Buchwald Coupling at 3 position $(\operatorname{Method} A)$ :}

Toluene $(4 \mathrm{~mL})$ was degassed by bubbling nitrogen through the solvent for $10 \mathrm{~min}$ in a round bottom flask attached to a reflux condenser with $\mathrm{N}_{2}$. To this container compound 6 $(0.3 \mathrm{mmol}), \mathrm{K}_{3} \mathrm{PO}_{4}(150 \mathrm{mg}, 4 \mathrm{eq}), \mathrm{Pd}\left(\mathrm{PPh}_{3}\right)_{4}(5 \mathrm{~mol} \%)$ and the amine $(1.4 \mathrm{eq})$ were added and the mixture was stirred at $100{ }^{\circ} \mathrm{C}$ for 24 hours. The reaction was cooled to room temperature, water added $(10 \mathrm{~mL})$, and extracted 3 times with dichloromethane (10 $\mathrm{mL}$ ). The organic layers were collected, combined, and dried with anhydrous $\mathrm{Na}_{2} \mathrm{SO}_{4}$. The solvent was evaporated and the crude product was purified by column chromatography on silica gel with $\mathrm{CH}_{2} \mathrm{Cl}_{2}$.

\section{General Nucleophilic Aromatic Substitution at 3-position (Method B):}

To a solution of compound $6(0.16 \mathrm{mmol})$ in $\mathrm{EtOH}(2 \mathrm{~mL})$, the amine $(1.4 \mathrm{eq})$ is added and the mixture was stirred at room temperature for 24 hours. The resulting mixture was dissolved in $\mathrm{CH}_{2} \mathrm{Cl}_{2}(10 \mathrm{~mL})$ and water added $(10 \mathrm{~mL})$. The organic layer was collected, and dried with anhydrous $\mathrm{Na}_{2} \mathrm{SO}_{4}$. The solvent was evaporated and the crude product was purified by column chromatography on silica gel with $\mathrm{CH}_{2} \mathrm{Cl}_{2}$

Synthesis of 3-N-phenylamino-1,2,4-benzotriazine 1-oxide (7): Method A gave compound 7 as an orange solid in $87 \%$ yield and method B in $67 \%$ yield.

Synthesis of 3-N-phenylamino-1,2,4-benzotriazine 1-oxide (9): Method A gave compound 9 as an orange solid in $65 \%$ yield and method B in $82 \%$ yield. 


\section{Synthesis of 3-(2,6-dimethylphenylamino)-1,2,4-benzotriazine 1-oxide (8):}

Method A gave compound $\mathbf{8}$ as a yellow solid in $27 \%$ yield and method B afforded no product: ${ }^{1} \mathrm{H}$ NMR $\left(500 \mathrm{MHz}, \mathrm{CDCl}_{3}\right) \delta 8.292(1 \mathrm{H}, \mathrm{d}, 8.7 \mathrm{~Hz}), 7.688(1 \mathrm{H}, \mathrm{t}, 7.6 \mathrm{~Hz})$, $7.575(1 \mathrm{H}, \mathrm{d}, 8.0 \mathrm{~Hz}), 7.337$ (1H, t, 7.8), 7.207-7.148 (3H, m), 7.207-7.148 (1H, s), 2.294 $(6 \mathrm{H}, \mathrm{s}) ;{ }^{13} \mathrm{C} \mathrm{NMR}\left(500 \mathrm{MHz}, \mathrm{CDCl}_{3}\right) \delta 149.23,136.66,135.98,134.32,131.69,128.81$, 127.94, 125.93, 120.79, 106.06, 19.07; HRMS (ESI) m/z calculated for $\mathrm{C}_{15} \mathrm{H}_{14} \mathrm{~N}_{4} \mathrm{O}$ $(\mathrm{M}+\mathrm{H})$ 267.1240, found 267.1231

\section{Synthesis of 3-(diethylamino)-1,2,4-benzotriazine 1-oxide (10):}

Method A gave compound $\mathbf{1 0}$ as an orange solid in $92 \%$ yield and method B in $90 \%$ yield: ${ }^{1} \mathrm{H}$ NMR $\left(500 \mathrm{MHz}, \mathrm{CDCl}_{3}\right) \delta 8.120(1 \mathrm{H}, \mathrm{d}, 8.6 \mathrm{~Hz}), 7.769(1 \mathrm{H}, \mathrm{t}, 7.3 \mathrm{~Hz}), 7.571$ $(1 \mathrm{H}, \mathrm{d}, 8.5 \mathrm{~Hz}), 7.321(1 \mathrm{H}, \mathrm{t}, 7.7 \mathrm{~Hz}), 3.620(4 \mathrm{H}, \mathrm{q}, 9.8 \mathrm{~Hz}), 1.178(6 \mathrm{H}, \mathrm{t}, 7.0 \mathrm{~Hz}) ;{ }^{13} \mathrm{C}$ NMR $\left(500 \mathrm{MHz}, \mathrm{CDCl}_{3}\right) \delta 157.70,149.01,136.15,129.51,126.52,124.96,120.24$; HRMS (ESI) m/z calculated for $\mathrm{C}_{11} \mathrm{H}_{14} \mathrm{~N}_{4} \mathrm{O}(\mathrm{M}+\mathrm{H})$ 219.1240, found 219.1236

\section{Synthesis of 3-dipropylamino-1,2,4-benzotriazine 1-oxide (11):}

Method A gave compound 11 as a thick orange oil in 50\% yield and method B in $99 \%$ yield: ${ }^{1} \mathrm{H}$ NMR $\left(500 \mathrm{MHz}, \mathrm{CDCl}_{3}\right) \delta 8.150(1 \mathrm{H}, \mathrm{d}, 8.6 \mathrm{~Hz}), 7.552(1 \mathrm{H}, \mathrm{t}, 7.7 \mathrm{~Hz}), 7.463$ $(1 \mathrm{H}, \mathrm{d}, 8.5 \mathrm{~Hz}), 7.123(1 \mathrm{H}, \mathrm{t}, 7.7 \mathrm{~Hz}), 3.511(4 \mathrm{H}, \mathrm{t}, 7.6 \mathrm{~Hz}), 1.659-1.584(4 \mathrm{H}, \mathrm{m}), 0.897$ $(6 \mathrm{H}, \mathrm{t}, 7.5 \mathrm{~Hz}) ;{ }^{13} \mathrm{C} \mathrm{NMR}\left(500 \mathrm{MHz}, \mathrm{CDCl}_{3}\right) \delta 158.49,149.46,135.24,129.77,126.63$, 124.18, 120.54, 49.74, 20.98, 11.45; HRMS (ESI) m/z calculated for $\mathrm{C}_{10} \mathrm{H}_{18} \mathrm{~N}_{4} \mathrm{O}(\mathrm{M}+\mathrm{H})$ $247.155,0$ found 247.1550 
Synthesis of 3-(3'-hydroxypropylamino)-1,2,4-benzotriazine 1-oxide (13): Method A

gave the compoundn 13 as a bright yellow solid in 97\% yield and method B in 96\% yield: ${ }^{1} \mathrm{H}$ NMR (500 MHz, DMSO-d $) \delta 8.127(1 \mathrm{H}, \mathrm{d}, 8.6 \mathrm{~Hz}), 7.874(1 \mathrm{H}, \mathrm{bs}), 7.772(1 \mathrm{H}$, t, $7.7 \mathrm{~Hz}), 7.566(1 \mathrm{H}, \mathrm{d}, 8.3 \mathrm{~Hz}), 7.323(1 \mathrm{H}, \mathrm{t}, 7.8 \mathrm{~Hz}), 4.494(1 \mathrm{H}, \mathrm{t}, 5.2 \mathrm{~Hz}), 3.500(2 \mathrm{H}$, m), $3.394(2 \mathrm{H}, \mathrm{bm}), 1.739(2 \mathrm{H}, \mathrm{m}) ;{ }^{13} \mathrm{C}$ NMR (500 MHz, DMSO-d $) \delta 158.96,135.72$, 130.03, 126.02, 124.43, 119.94, 58.51, 38.02, 31.78; HRMS (ESI) m/z calculated for $\mathrm{C}_{10} \mathrm{H}_{12} \mathrm{~N}_{4} \mathrm{O}_{2}(\mathrm{M}+\mathrm{H}) 221.1033$, found 221.1042

\section{Synthesis of 3-(2`-naphthylamino)-1,2,4-benzotriazine 1-oxide (14):}

Method A gave compound 14 as a red solid in 50\% yield and method B in $71 \%$ yield. ${ }^{1} \mathrm{H}$ NMR (500 MHz, DMSO-d $) \delta 10.492(1 \mathrm{H}, \mathrm{s}), 8.647(1 \mathrm{H}, \mathrm{s}), 8.260(1 \mathrm{H}, \mathrm{d}, 8.5 \mathrm{~Hz})$, 7.944-7.808 (6H, m), $7.505(2 \mathrm{H}, \mathrm{m}), 7.405(1 \mathrm{H}, \mathrm{t}, 7.5 \mathrm{~Hz}) ;{ }^{13} \mathrm{C}$ NMR (500 MHz, DMSO$\left.d_{6}\right) \delta 156.77,147.96,137.37,136.40,133.95,131.50,129.79,128.62,127.83,127.65$, 127.21, 126.78, 126.55, 124.73, 120.93, 120.25, 115.23; HRMS (ESI) m/z calculated for $\mathrm{C}_{17} \mathrm{H}_{12} \mathrm{~N}_{4} \mathrm{O}(\mathrm{M}+\mathrm{H}) 289.1084$, found 289.1093

\section{Synthesis of 3-(1`-naphthylamino)-1,2,4-benzotriazine 1-oxide (15):}

Method A gave compound $\mathbf{1 5}$ as a red solid in $41 \%$ yield and method B in $25 \%$ yield: ${ }^{1} \mathrm{H}$ NMR $\left(500 \mathrm{MHz}, \mathrm{DMSO}-d_{6}\right) \delta 10.087(1 \mathrm{H}, \mathrm{s}), 8.209(1 \mathrm{H}, \mathrm{d}, 8.7 \mathrm{~Hz}), 8.106(1 \mathrm{H}, \mathrm{d}, 7.8$ Hz), 7.979 (1H, d, $8.0 \mathrm{~Hz}), 7.849$ (1H, d, $8.3 \mathrm{~Hz}), 7.819-7.764(2 \mathrm{H}, \mathrm{m}), 7.586-7.502(4 \mathrm{H}$, m), $7.429(1 \mathrm{H}, \mathrm{t}, 7.8 \mathrm{~Hz}) ;{ }^{13} \mathrm{C}$ NMR (500 MHz, DMSO-d $) \delta 158.56,148.14,135.94$, $133.98,133.96,130.86,129.06,128.13,126.44,126.14,126.00,125.84,125.73125 .69$, 
123.24, 122.81, 119.92; HRMS (ESI) m/z calculated for $\mathrm{C}_{17} \mathrm{H}_{12} \mathrm{~N}_{4} \mathrm{O}(\mathrm{M}+\mathrm{H})$ 289.1084, found 289.1093

Synthesis of 3-(4-N-Boc-aminophenyl)-1,2,4-benzotriazine 1-oxide (16): Toluene (7 $\mathrm{mL})$ and water $(2.5 \mathrm{~mL})$ were degassed by bubbling nitrogen through the solvents for 10 min in a round bottom flask. To this container 3-chloro-1,2,4-benzotriazine 1-oxide (5, 109.2mg, $0.6 \mathrm{mmol}), \mathrm{K}_{3} \mathrm{PO}_{4}(150 \mathrm{mg}, 4 \mathrm{eq}), \mathrm{Pd}(\mathrm{OAc})_{2}(5 \mathrm{~mol} \%)$, SPhos ligand (10\%), and 4 -aminophenyl boronic acid (185 mg, $1.4 \mathrm{eq}$ ) were added and the mixture was stirred at $100{ }^{\circ} \mathrm{C}$ for 18 hours. The reaction was cooled to room temperature, water added $(10 \mathrm{~mL})$, and extracted with dichloromethane $(3 \times 10 \mathrm{~mL})$. The organic layers were collected, combined, and dried with anhydrous $\mathrm{Na}_{2} \mathrm{SO}_{4}$. The solvent was evaporated and the crude product was purified by column chromatography on silica gel with $0-0.5 \%$ $\mathrm{MeOH}$ in $\mathrm{CH}_{2} \mathrm{Cl}_{2}$ to obtain compound 16 as a pale yellow solid with a yield of $61 \%$. ${ }^{1} \mathrm{H}$ NMR (500 MHz, DMSO-d 6 ) $\delta 9.779(1 \mathrm{H}, \mathrm{s}), 8.389(1 \mathrm{H} \mathrm{d}, 8.6 \mathrm{~Hz}), 8.299(2 \mathrm{H}, \mathrm{d}, 8.8 \mathrm{~Hz})$, 8.104-8.055 (2H, m), $7.806(1 \mathrm{H}, \mathrm{t}, 7.3 \mathrm{~Hz}), 7.681(2 \mathrm{H}, \mathrm{d}, 8.8 \mathrm{~Hz}) ;{ }^{13} \mathrm{C}$ NMR $(500 \mathrm{MHz}$, DMSO- $\left.d_{6}\right) \delta 159.62,152.94,147.57,143.53,136.61,133.37,130.72,129.14,127.60$ 120.20, 118.27, 80.01, 28.43; HRMS (ESI) $\mathrm{m} / \mathrm{z}$ calculated for $\mathrm{C}_{18} \mathrm{H}_{18} \mathrm{~N}_{4} \mathrm{O}_{3}\left(\mathrm{M}+\mathrm{H}^{+}\right)$ 339.1452 , found 339.1465 .

Synthesis of 3-(4-cyanophenyl)-1,2,4-benzotriazine 1-oxide (17): Acetonitrile (1.5 $\mathrm{mL})$, aqueous $\mathrm{Na}_{2} \mathrm{CO}_{3}(1.5 \mathrm{~mL}, 0.4 \mathrm{M})$, 3-bromo-1,2,4-benzotriazine 1-oxide $(6,69 \mathrm{mg}$, $0.3 \mathrm{mmol}$ ), and 4-cyanophenylboronic acid (48 $\mathrm{mg}, 1.1$ equiv) were added to a roundbottom flask and degassed by bubbling nitrogen through the solvent for $10 \mathrm{~min}$. To 
this container $\mathrm{Pd}(\mathrm{PPh})_{4}(17 \mathrm{mg}, 5 \mathrm{~mol} \%)$ was added and the mixture was stirred at $95{ }^{\circ} \mathrm{C}$ for 43 hours. The reaction was cooled to room temperature, water added $(10 \mathrm{~mL})$, and extracted with dichloromethane $(3 \times 10 \mathrm{~mL})$. The organic layers were collected, combined, and dried with anhydrous $\mathrm{Na}_{2} \mathrm{SO}_{4}$. The solvent was evaporated and the crude product was purified by column chromatography on silica gel with $\mathrm{CH}_{2} \mathrm{Cl}_{2}$ to obtain compound 17 as a pale yellow solid in 20\% yield. Crude NMR's supplied were compared with previously characterized product showing the reaction was successful: NMR (300 $\left.\mathrm{MHz}, \mathrm{CDCl}_{3}\right) \delta 8.65(\mathrm{~m}, J=8.7,1.9 \mathrm{~Hz}, 2 \mathrm{H}), 8.52(\mathrm{~d}, J=8.7,0.9 \mathrm{~Hz}, 1 \mathrm{H}), 8.13(\mathrm{dd}, J$ $=8.5,0.8 \mathrm{~Hz}, 1 \mathrm{H}), 8.01(\mathrm{ddd}, J=8.4,7.0,1.4 \mathrm{~Hz}, 1 \mathrm{H}), 7.84(\mathrm{~m}, J=8.7,1.9 \mathrm{~Hz}, 2 \mathrm{H})$, $7.78(\mathrm{ddd}, J=8.7,7.0,1.3 \mathrm{~Hz}, 1 \mathrm{H}) ;{ }^{13} \mathrm{C} \mathrm{NMR}\left(75 \mathrm{MHz}, \mathrm{CDCl}_{3}\right) \delta 147.4,136.0,132.5$ 131.0, 129.5, 128.9, 120.3, 114.2; HRMS (ESI) m/z calc for $\mathrm{C}_{14} \mathrm{H}_{9} \mathrm{~N}_{4} \mathrm{O}\left(\mathrm{M}+\mathrm{Na}^{+}\right)$ 271.0596, found 271.0604.

Synthesis of 3-(4-nitrophenyl)-1,2,4-benzotriazine 1-oxide (18): Toluene (10 mL), water (2.5 mL), 3-bromo-1,2,4-benzotriazine 1-oxide (6, $504 \mathrm{mg}, 2.5 \mathrm{mmol}), 4$ cyanophenylboronic acid (504 mg, 1.4 equiv), $\mathrm{K}_{3} \mathrm{PO}_{4}$ (500 mg, 1.2 equiv), $\mathrm{Pd}(\mathrm{OAc})_{2}(25$ $\mathrm{mg}, 5 \%$ equiv), and SPhos (100 mg, 10\% equiv) were added to a seal tube and degassed by bubbling nitrogen through the solution for 15 minutes. Then the reaction was sealed and was stirred at $105{ }^{\circ} \mathrm{C}$ for $96 \mathrm{~h}$. The reaction was cooled to room temperature, water added $(50 \mathrm{~mL})$, and extracted with dichloromethane $(3 \times 50 \mathrm{~mL})$. The organic layers were collected, combined, and dried with anhydrous $\mathrm{Na}_{2} \mathrm{SO}_{4}$. The solvent was evaporated and the crude product was purified by column chromatography on silica gel with $75 \% \mathrm{CH}_{2} \mathrm{Cl}_{2}$ in hexane to obtain a pale yellow solid in $93 \%$ yield: ${ }^{1} \mathrm{H}$ NMR $\left(500 \mathrm{MHz}\right.$, DMSO- $\left.d_{6}\right) \delta$ 
$8.73(\mathrm{~d}, J=8.9 \mathrm{~Hz}, 2 \mathrm{H}), 8.53(\mathrm{~d}, J=8.5,1 \mathrm{H}), 8.39(\mathrm{~d}, J=8.9 \mathrm{~Hz}, 2 \mathrm{H}), 8.16(\mathrm{~d}, J=8.5$,

$1 \mathrm{H}), 8.02$ (appt, $J=7.2,7.1 \mathrm{~Hz}, 1 \mathrm{H}), 7.80$ (appt, $J=7.4,7.3 \mathrm{~Hz}, 1 \mathrm{H}) ;{ }^{13} \mathrm{C} \mathrm{NMR}(125$

MHz, DMSO-d $\left.d_{6}\right) \delta 158.5,149.8,147.4,139.7,136.0,131.1,129.5,129.3,123.8,120.3$;

HRMS (ESI) m/z calc for $\mathrm{C}_{13} \mathrm{H}_{9} \mathrm{~N}_{4} \mathrm{O}_{3}\left(\mathrm{M}+\mathrm{H}^{+}\right)$269.0675, found 269.0671.

Synthesis of 3-amino-6-fluoro-1,2,4-benzotriazine 1-oxide (19): Compound 19 was prepared using a procedure adopted from Hay, M.P. et al. $)^{30}$ 5-fluoro-2-nitroaniline (5 g, $32 \mathrm{mmol})$ and cyanamide $(10 \mathrm{~g}, 240 \mathrm{mmol})$ were heated together at $100{ }^{\circ} \mathrm{C}$ for 15 minutes to combine the solids. The mixture was cooled slightly and $\mathrm{HCl}$ (25 mL, conc.) was added drop wise while stirring over 30-min. (CAUTION: A violent exothermic reaction may occur during or after $\mathrm{HCl}$ addition). After addition of acid was complete stirring was continued for an additional $10 \mathrm{~min}$, adding more cyanamide to help stir if needed. The mixture was heated to $100{ }^{\circ} \mathrm{C}$ for $2 \mathrm{~h}$ and cooled to room temperature with continued stirring. $\mathrm{NaOH}(50 \mathrm{~mL}, 7.5 \mathrm{M})$ was added and the mixture stirred vigorously at $100{ }^{\circ} \mathrm{C}$ for $30 \mathrm{~min}$. The orange suspension was cooled to room temperature, poured into $500 \mathrm{~mL} \mathrm{H} \mathrm{H}_{2} \mathrm{O}$, and filtered under vacuum. The precipitate was washed thoroughly with water and diethyl ether and then dried in the oven at $70{ }^{\circ} \mathrm{C}$ overnight. Compound 19 was obtained in $70 \%$ yield as a bright yellow powder. ${ }^{1} \mathrm{H}$ NMR $\left(500 \mathrm{MHz}, \mathrm{DMSO}-d_{6}\right) \delta$ $8.21(\mathrm{dd}, J=10,6 \mathrm{~Hz}, 1 \mathrm{H}), 7.50(\mathrm{bs} 2 \mathrm{H}), 7.30(\mathrm{dd}, J=10,2.6 \mathrm{~Hz}, 1 \mathrm{H}), 7.21(\mathrm{~m}, 1 \mathrm{H}) ;{ }^{13} \mathrm{C}$ NMR (125 MHz, DMSO-d $)_{6} \delta 166.1(\mathrm{~d}, J=254 \mathrm{~Hz}), 160.8,150.7(\mathrm{~d}, J=16 \mathrm{~Hz}), 127.5$, $123.4(\mathrm{~d}, J=12 \mathrm{~Hz}), 114.2(\mathrm{~d}, J=26 \mathrm{~Hz}), 109.6(\mathrm{~d}, J=23 \mathrm{~Hz}) ;$ HRMS (ESI) m/z calculated for $\mathrm{C}_{7} \mathrm{H}_{5} \mathrm{FN}_{4} \mathrm{O}\left(\mathrm{M}+\mathrm{H}^{+}\right)$181.0520, found 181.0521 . 
Synthesis of 3-chloro-6-fluoro-1,2,4-benzotriazine 1-oxide (20): Compound 19 (1.3 g,

$7.2 \mathrm{mmol})$ was dissolved in trifluoroacetic acid $(8 \mathrm{~mL})$ and then cooled to $0{ }^{\circ} \mathrm{C}$. Sodium

nitrite ( $1 \mathrm{~g}, 2$ equiv) was added slowly, keeping the temperature of the solution $<5{ }^{\circ} \mathrm{C}$.

The resulting solution was stirred at room temperature for $2 \mathrm{~h}$ before being poured into an ice/water slurry $(80 \mathrm{~mL})$ and stirred for $30 \mathrm{~min}$. The resulting precipitate was collected by vacuum filtration, washed with cold water $(20 \mathrm{~mL})$, and dried in an oven at $70{ }^{\circ} \mathrm{C}$ overnight. In a $\mathrm{N}_{2}$-purged 2-neck roundbottom flask with reflux condenser, the dried solid (730 mg, $4 \mathrm{mmol}$ ), phosphorus (V) oxychloride (5 mL, 12-13 equiv), and dimethylformamide $(60 \mu \mathrm{L})$ were added. The mixture was heated at $105{ }^{\circ} \mathrm{C}$ under an $\mathrm{N}_{2}$ atmosphere for $1 \mathrm{~h}$. The reaction was immediately poured onto crushed ice $(100 \mathrm{~mL})$ and stirred for $30 \mathrm{~min}$. The resulting suspension was extracted with $\mathrm{CH}_{2} \mathrm{Cl}_{2}(100 \mathrm{~mL})$ and organic fraction separated, dried with anhydrous $\mathrm{Na}_{2} \mathrm{SO}_{4}$ and solvent removed by rotary evaporation. Purification by column chromatography with silica gel with $\mathrm{CH}_{2} \mathrm{Cl}_{2}$ afforded 20 as a colorless solid in 55\% overall yield after 2 steps: ${ }^{1} \mathrm{H}$ NMR $(500 \mathrm{MHz}$, DMSO- $\left.d_{6}\right) \delta 8.50(\mathrm{dd}, J=9.5,5.5 \mathrm{~Hz}, 1 \mathrm{H}), 7.98(\mathrm{dd}, J=9.1,2.6 \mathrm{~Hz}, 2 \mathrm{H}), 7.81$ (ddd, $J$ $=9.3,8.5,2.7 \mathrm{~Hz}, 1 \mathrm{H}) ;{ }^{13} \mathrm{C} \mathrm{NMR}\left(125 \mathrm{MHz}, \mathrm{DMSO}-d_{6}\right) \delta 166.8(\mathrm{~d}, J=258 \mathrm{~Hz}), 156.9$, $149.4(\mathrm{~d}, J=16 \mathrm{~Hz}), 132.0,123.9(\mathrm{~d}, J=11 \mathrm{~Hz}), 121.7(\mathrm{~d}, J=27 \mathrm{~Hz}), 112.8(\mathrm{~d}, J=24$ $\mathrm{Hz}$ ); HRMS (ESI) m/z calculated for $\mathrm{C}_{7} \mathrm{H}_{3} \mathrm{ClFN}_{3} \mathrm{O}$ 198.9949, found 198.9950 .

Synthesis of 3-ethyl-6-fluoro-1,2,4-benzotriazine 1-oxide (21): To a $\mathrm{N}_{2}$ purged 2-neck round-bottom flask with reflux condenser, compound 20 (555 $\mathrm{mg}, 2.8 \mathrm{mmol})$, tetraethyltin ( $667 \mu \mathrm{L}, 1.2$ equiv), and dimethoxyethane $(10 \mathrm{~mL})$ were added. The mixture was degassed by bubbling nitrogen through the solution and then $\mathrm{Pd}\left(\mathrm{PPh}_{3}\right)_{4}(162 \mathrm{mg}, 5 \%$ 
equiv) was added. The solution was refluxed for $24 \mathrm{~h}$. The solvent was evaporated and dark solid taken up in $\mathrm{CH}_{2} \mathrm{Cl}_{2}(15 \mathrm{~mL})$ and sat'd $\mathrm{KF}$ (aq, $\left.10 \mathrm{~mL}\right)$ and the mixture was stirred vigorously for $30 \mathrm{~min}$. THe biphasic mixture was passed through a pad of celite. The filtrate was washed with $\mathrm{CH}_{2} \mathrm{Cl}_{2}$ and organic phase collected. Purification by column chromatography with silica gel with $\mathrm{CH}_{2} \mathrm{Cl}_{2}$ to give 21 in $28 \%$ yield with $55 \%$ recovery of 20: ${ }^{1} \mathrm{H}$ NMR $\left(500 \mathrm{MHz}, \mathrm{DMSO}-d_{6}\right) \delta 8.46(\mathrm{dd}, J=9.5,5.6 \mathrm{~Hz}, 1 \mathrm{H}), 7.90$ (dd, $J=9.3,2.7 \mathrm{~Hz}, 1 \mathrm{H}), 7.73$ (ddd, $J=9.4,8.5,2.7 \mathrm{~Hz}, 1 \mathrm{H}), 2.96$ (q, $J=7.56 \mathrm{~Hz}, 4 \mathrm{H})$, $1.34(\mathrm{t}, J=7.6 \mathrm{~Hz}, 3 \mathrm{H}) ;{ }^{13} \mathrm{C}$ NMR $\left(125 \mathrm{MHz}, \mathrm{DMSO}-d_{6}\right) \delta 168.3,165.8(\mathrm{~d}, J=256 \mathrm{~Hz})$, $149.0(\mathrm{~d}, J=15 \mathrm{~Hz}), 130.5,123.3(\mathrm{~d}, J=11 \mathrm{~Hz}), 120.4(\mathrm{~d}, J=27 \mathrm{~Hz}), 112.5(\mathrm{~d}, J=23$ $\mathrm{Hz}), 29.9,11.7$; HRMS (ESI) $\mathrm{m} / \mathrm{z}$ calculated for $\mathrm{C}_{9} \mathrm{H}_{9} \mathrm{FN}_{3} \mathrm{O}\left(\mathrm{M}+\mathrm{H}^{+}\right)$194.0724, found 194.0729.

Synthesis of 3-ethyl-6-fluoro-1,2,4-benzotriazine 1,4-dioxide (22): Compound 22 (490 $\mathrm{mg}, 2.5 \mathrm{mmol})$ was dissolved in $\mathrm{CH}_{2} \mathrm{Cl}_{2}(10 \mathrm{~mL})$ and MCPBA (1.3 g, 2.3 equiv) was added. The mixture was stirred at room temperature for $24 \mathrm{~h}$ before an additional portion of MCPBA was added and the solution stirred an additional 3 days. Water $(100 \mathrm{~mL})$ was then added and stirred with $\mathrm{NaHCO}_{3}(1.5 \mathrm{~g})$ overnight. The organic layer was separated, dried with anhydrous $\mathrm{Na}_{2} \mathrm{SO}_{4}$, and then purified by column chromatography on silica gel with $0-0.5 \% \mathrm{MeOH}$ in $\mathrm{CH}_{2} \mathrm{Cl}_{2}$. Compound 22 was obtained in $16 \%$ yield as a yellow solid: ${ }^{1} \mathrm{H}$ NMR $\left(500 \mathrm{MHz}, \mathrm{CDCl}_{3}\right) \delta 8.53(\mathrm{dd}, J=9.5,4.9 \mathrm{~Hz}, 1 \mathrm{H}), 8.17(\mathrm{dd}, J=8.2,2.6$ $\mathrm{Hz}, 2 \mathrm{H}), 7.57$ (ddd, $J=9.5,7.5,2.7 \mathrm{~Hz}, 1 \mathrm{H}), 3.21$ (q, $J=7.5 \mathrm{~Hz}, 2 \mathrm{H}), 1.44$ (t, $J=7.5$ $\mathrm{Hz}, 3 \mathrm{H}) ;{ }^{13} \mathrm{C} \mathrm{NMR}\left(125 \mathrm{MHz}, \mathrm{CDCl}_{3}\right) \delta 166.10(\mathrm{~d}, J=253.90 \mathrm{~Hz}), 160.83,150.72(\mathrm{~d}, J$ 
$=15.55 \mathrm{~Hz}), 127.45,123.35(\mathrm{~d}, J=11.69 \mathrm{~Hz}), 114.20(\mathrm{~d}, J=26.61 \mathrm{~Hz}), 109.6(\mathrm{~d}, J=$ $22.63 \mathrm{~Hz})$.

\section{Synthesis of 6-diethanolamino-3-ethyl-1,2,4-benzotriazine 1,4-dioxide (23):}

Compound 22 ( $86 \mathrm{mg}, 0.4 \mathrm{mmol}$ ), and Diethanolamine (102 mg, 2 equiv) were dissovled in acetonitrile $(10 \mathrm{~mL})$ and water $(0.5 \mathrm{~mL})$ and the reaction was stirred for 3 days or until completed. The solvent was removed by rotary evaporation and purification by column chromatography on silica gel with $0-5 \% \mathrm{MeOH}$ in $\mathrm{CH}_{2} \mathrm{Cl}_{2}$. Compound 23 was obtained as an orange solid in $70 \%$ yield: mp $210-212{ }^{\circ} \mathrm{C} \mathrm{dec} ;{ }^{1} \mathrm{H}$ NMR $\left(500 \mathrm{MHz}\right.$, DMSO- $\left.d_{6}\right) \delta$ $8.08(\mathrm{~d}, J=9.8 \mathrm{~Hz}, 1 \mathrm{H}), 7.52(\mathrm{dd}, J=9.9,2.8 \mathrm{~Hz}, 1 \mathrm{H}), 7.19(\mathrm{~d}, J=2.8 \mathrm{~Hz}, 1 \mathrm{H}), 4.94$ (t, $J=5.0 \mathrm{~Hz}, 2 \mathrm{H}), 3.66(\mathrm{comp}, 8 \mathrm{H}), 2.98(\mathrm{q}, J=7.4,2 \mathrm{H}), 1.25(\mathrm{t}, J=7.5 \mathrm{~Hz}, 3 \mathrm{H}) ;{ }^{13} \mathrm{C}$ NMR (125 MHz, DMSO- $\left.d_{6}\right) \delta 155.2,153.4,140.7,125.9,122.3,120.2,92.8,57.8,53.3$, 23.44, 9.2; HRMS (ESI) $\mathrm{m} / \mathrm{z}$ calculated for $\mathrm{C}_{13} \mathrm{H}_{19} \mathrm{~N}_{4} \mathrm{O}_{4}\left(\mathrm{M}+\mathrm{H}^{+}\right)$295.1401, found 295.1404.

Synthesis of 3-diethanolamino-1,2,4-benzotriazine 1-oxide (24): Compound 5 (102 $\mathrm{mg}, 0.5 \mathrm{mmol})$ was dissolved in ethanol $(2 \mathrm{~mL})$ and diethanolamine (580 $\mathrm{mg}, 10$ equiv) was added. The mixture was stirred at room temperature for $48 \mathrm{~h}$. The solution was diluted with water $(10 \mathrm{~mL})$ and extracted with $\mathrm{CH}_{2} \mathrm{Cl}_{2}(6 \mathrm{x} 10 \mathrm{~mL})$. The combined organic fractions were washed with brine, dried with anhydrous $\mathrm{Na}_{2} \mathrm{SO}_{4}$, and solvent removed by rotary evaporation. Purification by column chromatography on silica gel with $0-1 \% \mathrm{MeOH}$ in $\mathrm{CH}_{2} \mathrm{Cl}_{2}$ gave compound 24 as a bright orange solid in $85 \%$ yield: mp 205-210 ${ }^{\circ} \mathrm{C} \mathrm{dec} ;{ }^{1} \mathrm{H}$ NMR (500 MHz, DMSO- $\left.d_{6}\right) \delta 8.36(\mathrm{~d}, J=7.9 \mathrm{~Hz}, 1 \mathrm{H}), 7.79$ 
(ddd, $J=8.4,7.0,1.3 \mathrm{~Hz}, 2 \mathrm{H}$ ), 7.58 (d, $J=8.5 \mathrm{~Hz}, 1 \mathrm{H}$ ), 7.45 (ddd, $J=8.4,6.9,1.1,1$

H), $4.81(\mathrm{t}, J=5.4 \mathrm{~Hz}, 2 \mathrm{H}), 3.72(\mathrm{bs}, 4 \mathrm{H}), 3.65$ (bs, $4 \mathrm{H}) ;{ }^{13} \mathrm{C}$ NMR $(125 \mathrm{MHz}$, DMSO-

$\left.d_{6}\right) \delta 158.4,148.8,136.3,129.6,126.5,125.2,120.2,58.7,51.2 ;$ HRMS (ESI) m/z calculated for $\mathrm{C}_{11} \mathrm{H}_{5} \mathrm{~N}_{4} \mathrm{O}_{3}\left(\mathrm{M}+\mathrm{H}^{+}\right)$251.1139, found 251.1142.

Synthesis of 6-fluoro-1,2,4-benzotriazine 1-oxide (27). Using the general procedure of Boyd et al. ${ }^{24} 19$ (930 mg, $5 \mathrm{mmol}$ ) was dissolved in anhydrous DMF (50 mL) and the mixture degassed by bubbling argon through the solution for $30 \mathrm{~min}$. To this mixture $t$ butyl nitrite (3.5 mL, 5 equiv, 90\%) was added by syringe and the mixture heated in a 60 ${ }^{\circ} \mathrm{C}$ oil bath for $2 \mathrm{~h}$ under an atmosphere of argon gas. The reaction was cooled and the solvent removed under vacuum. The resulting dark residue was taken up in ethyl acetate $(300 \mathrm{~mL})$ and mixed with brine $(150 \mathrm{~mL})$ and stirred vigorously. The phases were allowed to separate and the organic layer was washed with brine $(2 \times 150 \mathrm{~mL})$, dried over anhydrous sodium sulfate, and solvent removed by rotary evaporation. Column chromatography on silica gel eluted with a gradient of $0-10 \%$ ethyl acetate in $\mathrm{CH}_{2} \mathrm{Cl}_{2}$ gave 27 in 50\% yield: mp $127-129{ }^{\circ} \mathrm{C}$; ${ }^{1} \mathrm{H}$ NMR $\left(500 \mathrm{MHz}, \mathrm{DMSO}-d_{6}\right) \delta 9.19(\mathrm{~s}, 1 \mathrm{H})$, $8.50(\mathrm{dd}, J=9.6,5.52 \mathrm{~Hz}, 1 \mathrm{H}), 7.99(\mathrm{dd}, J=9.1,2.7 \mathrm{~Hz}, 1 \mathrm{H}), 7.82(\mathrm{~m}, 1 \mathrm{H}) ;{ }^{13} \mathrm{C} \mathrm{NMR}$ (125 MHz, DMSO- $\left.d_{6}\right) \delta 166.1(\mathrm{~d}, J=257), 155.5,149.3(\mathrm{~d}, J=15 \mathrm{~Hz}), 133.1,123.8(\mathrm{~d}$, $J=11 \mathrm{~Hz}), 121.8(\mathrm{~d}, J=27 \mathrm{~Hz}), 113.3(\mathrm{~d}, J=23 \mathrm{~Hz})$; HRMS (ESI) m/z calculated for $\mathrm{C}_{7} \mathrm{H}_{4} \mathrm{FN}_{3} \mathrm{O}\left(\mathrm{M}+\mathrm{H}^{+}\right)$166.0411, found 166.0417.

Synthesis of 6-diethanolamino-1,2,4-benzotriazine 1-oxide (28): Compound 20 (361 $\mathrm{mg}, 2.2 \mathrm{mmol}$ ) and diethanolamine (500 $\mathrm{mg}, 2.5$ equiv) were dissolved in acetonitrile (7 
$\mathrm{mL}$ ) and the mixture heated in an $80{ }^{\circ} \mathrm{C}$ oil bath overnight. The reaction mixture was cooled and solvent removed under reduced pressure by rotary evaptoration. The resulting solid was suspended in ethanol $(10 \mathrm{~mL})$ and briefly heated to $80{ }^{\circ} \mathrm{C}$ with stirring then cooled to $0{ }^{\circ} \mathrm{C}$ and the resulting precipitate collected by vacuum filtration. The orange solid was washed with cold ethanol and diethyl ether and dried in an oven overnight at 70 ${ }^{\circ} \mathrm{C}$. Compound 28 was obtained in $81 \%$ yield: ${ }^{1} \mathrm{H}$ NMR $\left(500 \mathrm{MHz}, \mathrm{DMSO}-d_{6}\right) \delta 8.77$ $(\mathrm{s}, 1 \mathrm{H}), 8.11(\mathrm{~d}, J=9.8,1 \mathrm{H}), 7.50(\mathrm{dd}, J=9.8,2.7 \mathrm{~Hz}, 1 \mathrm{H}), 6.89(\mathrm{~d}, J=2.7,1 \mathrm{H}), 4.89$ $(\mathrm{t}, J=4.9 \mathrm{~Hz}, 2 \mathrm{H}), 3.64(\mathrm{bs}, 8 \mathrm{H}) ;{ }^{13} \mathrm{C}$ NMR (500 MHz, DMSO- $\left.d_{6}\right) \delta 154.9,154.0$, 149.6, 127.0, 121.0, 120.9, 102.3, 58.3, 53.5; HRMS (ESI) $\mathrm{m} / \mathrm{z}$ calculated for $\mathrm{C}_{11} \mathrm{H}_{14} \mathrm{~N}_{4} \mathrm{O}_{3}\left(\mathrm{M}+\mathrm{H}^{+}\right)$251.2612, found 251.1138.

Synthesis of 6-fluoro-1,2,4-benzotriainze 1,4-dioxide (29): A procedure adapted from Pchalek and Hay was followed. ${ }^{28}$ Trifluoroacetic anhydride $(600 \mu \mathrm{L})$ and $\mathrm{CH}_{2} \mathrm{Cl}_{2}(3 \mathrm{~mL})$ were mixed with stirring in an ice bath and $70 \% \mathrm{H}_{2} \mathrm{O}_{2}(210 \mu \mathrm{L})$ was added dropwise. The mixture was stirred for $10 \mathrm{~min}$ and then allowed to warm to room temperature. This solution was cooled in an ice bath and and slowly added to an ice cold solution of 27 (71 $\mathrm{mg}, 0.43 \mathrm{mmol})$ in $\mathrm{CH}_{2} \mathrm{Cl}_{2}(3 \mathrm{~mL})$. The reaction was stirred in an ice bath for $4 \mathrm{~h}$ before being diluted with cold $\mathrm{NH}_{4} \mathrm{OH}(4 \mathrm{~mL}, 1 \mathrm{M})$, shaken well, and the organic layer was separated. The aqueous layer was washed $2 \mathrm{x} \mathrm{CH}_{2} \mathrm{Cl}_{2}$. The combined organic fractions were dried over anhydrous sodium sulfate and column chromatography on silica gel eluted with $1 \% \mathrm{MeOH}$ in $\mathrm{CH}_{2} \mathrm{Cl}_{2}$ gave 29 in $71 \%$ yield: ${ }^{1} \mathrm{H}$ NMR (500 MHz, DMSO- $d_{6}$ ) $\delta 9.36(\mathrm{~s}, 1 \mathrm{H}), 8.48(\mathrm{dd}, J=9.5,5.0 \mathrm{~Hz}, 1 \mathrm{H}), 8.13(\mathrm{dd}, J=8.5,2.7 \mathrm{~Hz}, 2 \mathrm{H}), 7.92$ (ddd, $J=9.5,8.2,2.8 \mathrm{~Hz}, 1 \mathrm{H}) ;{ }^{13} \mathrm{C} \mathrm{NMR}\left(125 \mathrm{MHz}, \mathrm{DMSO}-d_{6}\right) \delta 165.8(\mathrm{~d}, J=258 \mathrm{~Hz})$, 
$143.2,141.7(\mathrm{~d}, J=12 \mathrm{~Hz}), 133.2,125.6(\mathrm{~d}, J=11 \mathrm{~Hz}), 122.8(\mathrm{~d}, J=26 \mathrm{~Hz}), 105.0(\mathrm{~d}, J$

$=18 \mathrm{~Hz}) ; \operatorname{HRMS}(E S I) \mathrm{m} / \mathrm{z}$ calculated for $\mathrm{C}_{7} \mathrm{H}_{5} \mathrm{FN}_{3} \mathrm{O}_{2}\left(\mathrm{M}+\mathrm{H}^{+}\right)$182.0360, found 182.0364

Synthesis 6-diethanolamino-1,2,4-benzotriazine 1,4-dioxide (30): Compound 27 (47 $\mathrm{mg} \mathrm{mg}, 0.26 \mathrm{mmol})$ was dissolved in a mixture acetonitrile $(4 \mathrm{~mL})$, water $(1 \mathrm{~mL})$, and diethanolamine (65 g, 2.4 equiv). The suspension was stirred at $75{ }^{\circ} \mathrm{C}$ overnight protected from light. The solvent was removed by rotary evaporation, the orange residue resuspended in ethanol, briefly heated with stirring and slowly cooled to $0{ }^{\circ} \mathrm{C}$. The resulting precipitate was collected by vacuum filtration and dried under vacuum to give 30 as a dark-red powder in 73\% yield: ${ }^{1} \mathrm{H}$ NMR $\left(500 \mathrm{MHz}, \mathrm{DMSO}-d_{6}\right) \delta 9.05(\mathrm{~s}, 1 \mathrm{H})$, $8.09(\mathrm{~d}, J=9.8 \mathrm{~Hz}, 1 \mathrm{H}), 7.58(\mathrm{dd}, J=9.8,2.6 \mathrm{~Hz}, 1 \mathrm{H}), 7.16(\mathrm{~d}, J=2.6 \mathrm{~Hz}, 1 \mathrm{H}), 4.94$ $(\mathrm{t}, J=4.9 \mathrm{~Hz}, 1 \mathrm{H}), 3.66(\mathrm{comp}, 8 \mathrm{H}) ;{ }^{13} \mathrm{C}$ NMR (125 MHz, DMSO-d $\left.d_{6}\right) \delta 153.3,142.0$, $140.8,126.5,122.4,121.0,93.0,57.7,53.3 ; \mathrm{HRMS}(\mathrm{ESI}) \mathrm{m} / \mathrm{z}$ calculated for $\mathrm{C}_{11} \mathrm{H}_{5} \mathrm{~N}_{4} \mathrm{O}_{4}$ $\left(\mathrm{M}+\mathrm{H}^{+}\right)$267.1088, found 267.1088.

Synthesis of 3-amino-7-fluoro-1,2,4-benzotriazine 1-oxide (31): （adopted from Hay, M.P. et al.) 4-fluoro-2-nitroaniline (5 g, $32 \mathrm{mmol})$ and cyanamide (11 g, $26 \mathrm{mmol})$ were heated together at $100^{\circ} \mathrm{C}$ for 15 minutes until a melt is achieved. The mixture was cooled slightly and $\mathrm{HCl}(20 \mathrm{~mL}$, conc.) was added dropwise while stirring over a 30-minute period. (CAUTION: A violent exothermic reaction may occur during or after $\mathrm{HCl}$ addition). After addition of acid was complete stirring was continued for an additional 10 minutes. The mixture was heated to $100^{\circ} \mathrm{C}$ for 3 hours and cooled to room temperature 
with continued stirring. $\mathrm{NaOH}(80 \mathrm{~mL}, 4 \mathrm{M})$ was added and the mixture stirred vigorously at $100^{\circ} \mathrm{C}$ for $2 \mathrm{~h}$. The orange suspension was cooled to room temperature, poured into water $(500 \mathrm{~mL})$ and vacuum filtered. The precipitate was washed thoroughly with $\mathrm{H}_{2} \mathrm{O}$ and $\mathrm{Et}_{2} \mathrm{O}$ and dried in the oven overnight. The yellow powder was obtained in 91\% yield. ${ }^{1} \mathrm{H}$ NMR (500 MHz, DMSO- $\left.d_{6}\right) \delta 7.89(\mathrm{dd}, J=8.6,2.9 \mathrm{~Hz}, 1 \mathrm{H}), 7.75(\mathrm{~m}$, $1 \mathrm{H}), 7.62(\mathrm{dd}, J=9.3,5.2 \mathrm{~Hz}, 1 \mathrm{H}), 7.35(\mathrm{bs}, 2 \mathrm{H}) ;{ }^{13} \mathrm{C}$ NMR $\left(125 \mathrm{MHz}, \mathrm{DMSO}-d_{6}\right) \delta$ $160.5,158.4(\mathrm{~d}, J=246 \mathrm{~Hz}), 146.6,129.8(\mathrm{~d}, J=11 \mathrm{~Hz}), 128.8(\mathrm{~d}, J=9 \mathrm{~Hz}), 126.1(\mathrm{~d}, J$ $=26 \mathrm{~Hz}), 105.0(\mathrm{~d}, J=27 \mathrm{~Hz})$; HRMS (ESI) $\mathrm{m} / \mathrm{z}$ calculated for $\mathrm{C}_{7} \mathrm{H}_{5} \mathrm{FN}_{4} \mathrm{O}\left(\mathrm{M}+\mathrm{H}^{+}\right)$ 181.1465 , found 181.0521 .

Synthesis of 7-fluoro-1,2,4-benzotriazine 1-oxide (32). Using the general procedure of Boyd et al. ${ }^{24} 31$ (930 mg, $5 \mathrm{mmol}$ ) was dissolved in anhydrous DMF (50 mL) and the mixture degassed by bubbling argon through the solution for $30 \mathrm{~min}$. To this mixture $t$ butyl nitrite (3.5 mL, 5 equiv, 90\%) was added by syringe and the mixture heated in a 60 ${ }^{\circ} \mathrm{C}$ oil bath for $2 \mathrm{~h}$ under an atmosphere of argon gas. The reaction was cooled and the solvent removed under vacuum. The resulting dark residue was taken up in ethyl acetate $(300 \mathrm{~mL})$ and mixed with brine $(150 \mathrm{~mL})$ and stirred vigorously. The phases were allowed to separate and the organic layer was washed with brine $(2 \times 150 \mathrm{~mL})$, dried over anhydrous sodium sulfate, and solvent removed by rotary evaporation. Column chromatography on silica gel eluted with a gradient of $0-10 \%$ ethyl acetate in $\mathrm{CH}_{2} \mathrm{Cl}_{2}$ gave 32 in 50\% yield: mp $160-162{ }^{\circ} \mathrm{C} ;{ }^{1} \mathrm{H}$ NMR $\left(500 \mathrm{MHz}, \mathrm{DMSO}-d_{6}\right) \delta 9.20(\mathrm{~s}, 1 \mathrm{H})$, $8.24(\mathrm{dd}, J=9.3,5.3 \mathrm{~Hz}, 1 \mathrm{H}), 8.202(\mathrm{dd}, J=8.4,2.8 \mathrm{~Hz}, 1 \mathrm{H}), 8.083(\mathrm{~m}, 1 \mathrm{H}) ;{ }^{13} \mathrm{C}$ NMR $\left(125 \mathrm{MHz}, \mathrm{DMSO}-d_{6}\right) \delta 162.6(\mathrm{~d}, J=254 \mathrm{~Hz}), 154.0(\mathrm{~d}, J=3 \mathrm{~Hz}), 144.9,136.0,132.5$ 

(d, $J=9 \mathrm{~Hz}), 126.7$ (d, $J=26 \mathrm{~Hz}), 105.2$ (d, $J=29 \mathrm{~Hz})$; HRMS (ESI) m/z calculated for $\mathrm{C}_{7} \mathrm{H}_{4} \mathrm{FN}{ }_{3} \mathrm{O}\left(\mathrm{M}+\mathrm{H}^{+}\right)$166.0411, found 166.0419.

Synthesis of 7-diethanolamino-1,2,4-benzotriazine 1-oxide (33): Compound 20 (361 $\mathrm{mg}, 2.2 \mathrm{mmol}$ ) and diethanolamine (500 mg, 2.5 equiv) were dissolved in acetonitrile (7 $\mathrm{mL}$ ) and the mixture heated in an $80{ }^{\circ} \mathrm{C}$ oil for 4 days. The reaction mixture was cooled and solvent removed under reduced pressure by rotary evaptoration. The resulting solid was suspended in ethanol $(10 \mathrm{~mL})$ and briefly heated to $80{ }^{\circ} \mathrm{C}$ with stirring then cooled to $0{ }^{\circ} \mathrm{C}$ and the resulting precipitate collected by vacuum filtration. The orange solid was washed with cold ethanol and diethyl ether and dried in an oven overnight at $70{ }^{\circ} \mathrm{C}$. Compound 32 was obtained in $66 \%$ yield. ${ }^{1} \mathrm{H}$ NMR $\left(500 \mathrm{MHz}, \mathrm{DMSO}-d_{6}\right) \delta 8.77(\mathrm{~s}, 1$ H), $7.86(\mathrm{~d}, J=9.5,1 \mathrm{H}), 7.79(\mathrm{dd}, J=9.5,2.9 \mathrm{~Hz}, 1 \mathrm{H}), 7.22(\mathrm{~d}, J=2.8,1 \mathrm{H}), 4.89(\mathrm{t}, J$ $=4.7 \mathrm{~Hz}, 2 \mathrm{H}), 3.63(\mathrm{bs}, 8 \mathrm{H}) ;{ }^{13} \mathrm{C}$ NMR $\left(125 \mathrm{MHz}, \mathrm{DMSO}-d_{6}\right) \delta 150.4,149.1,140.2$, 136.0, 129.3, 125.3, 93.1, 57.8, 53.1; HRMS (ESI) $\mathrm{m} / \mathrm{z}$ calculated for $\mathrm{C}_{11} \mathrm{H}_{14} \mathrm{~N}_{4} \mathrm{O}_{3}$ $\left(\mathrm{M}+\mathrm{H}^{+}\right)$251.2612, found 251.1144.

Synthesis of 7-fluoro-1,2,4-benzotriazine 1,4-dioxide (34): A procedure adapted from Pchalek and Hay was followed. ${ }^{28}$ Trifluoroacetic anhydride $(600 \mu \mathrm{L})$ and $\mathrm{CH}_{2} \mathrm{Cl}_{2}(3 \mathrm{~mL})$ were mixed with stirring in an ice bath and $70 \% \mathrm{H}_{2} \mathrm{O}_{2}(210 \mu \mathrm{L})$ was added dropwise. The mixture was stirred for $10 \mathrm{~min}$ and then allowed to warm to room temperature. This solution was cooled in an ice bath and and slowly added to an ice cold solution of 32 (75 $\mathrm{mg}, 0.43 \mathrm{mmol})$ in $\mathrm{CH}_{2} \mathrm{Cl}_{2}(3 \mathrm{~mL})$. The reaction was stirred in an ice bath for $4 \mathrm{~h}$ before being diluted with cold $\mathrm{NH}_{4} \mathrm{OH}(4 \mathrm{~mL}, 1 \mathrm{M})$, shaken well, and the organic layer was 
separated. The aqueous layer was washed $2 \mathrm{x} \mathrm{CH}_{2} \mathrm{Cl}_{2}$. The combined organic fractions were dried over anhydrous sodium sulfate and column chromatography on silica gel eluted with $1 \% \mathrm{MeOH}$ in $\mathrm{CH}_{2} \mathrm{Cl}_{2}$ gave 34 in $61 \%$ yield: ${ }^{1} \mathrm{H}$ NMR (500 MHz, DMSO- $d_{6}$ ) $\delta 9.33(\mathrm{~s}, 1 \mathrm{H}), 8.43$ (dd, $J=9.5,5.1 \mathrm{~Hz}, 1 \mathrm{H}), 8.20$ (dd, $J=8.5,2.6 \mathrm{~Hz}, 2 \mathrm{H}), 8.06$ (ddd, $J=9.4,8.2,2.7 \mathrm{~Hz}, 1 \mathrm{H}) ;{ }^{13} \mathrm{C}$ NMR $\left(125 \mathrm{MHz}, \mathrm{DMSO}-d_{6}\right) \delta 163.2(\mathrm{~d}, J=255 \mathrm{~Hz})$, 142.0, 137.3, $136.3(\mathrm{~d}, J=11 \mathrm{~Hz}), 125.1(\mathrm{~d}, J=26 \mathrm{~Hz}), 122.6(\mathrm{~d}, J=10 \mathrm{~Hz}), 106.5(\mathrm{~d}, J$ $=28 \mathrm{~Hz})$; HRMS (ESI) $\mathrm{m} / \mathrm{z}$ calculated for $\mathrm{C}_{7} \mathrm{H}_{5} \mathrm{FN}_{3} \mathrm{O}_{2}\left(\mathrm{M}+\mathrm{H}^{+}\right)$182.0360, found 182.0363 .

\section{Synthesis of 3-amino-6-(bis(2-hydroxyethyl)amino)-1,2,4-benzotriazine 1-oxide (36):}

Compound 19 (1.97 g, $11 \mathrm{mmol})$ and diethanolamine $(5.75 \mathrm{~g}, 5$ eq.) were suspended in 1methyl-2-pyrrolidinone $(18 \mathrm{~mL})$ and heated at $100{ }^{\circ} \mathrm{C}$ for $18 \mathrm{~h}$. The resulting orange suspension was cooled to room temperature, triturated with cold ethanol $(40 \mathrm{~mL})$ and collected by vacuum filtration. The solid was washed with dichloromethane and dried in an oven overnight at $70{ }^{\circ} \mathrm{C}$ to give 36 as an orange powder in $94 \%$ yield. For further purification the solid was suspended in ethanol, briefly heated with stirring, cooled, and collected by vacuum filtration. ${ }^{1} \mathrm{H}$ NMR $\left(500 \mathrm{MHz}, \mathrm{DMSO}-d_{6}\right) \delta 7.88(\mathrm{~d}, J=9.7 \mathrm{~Hz}, 1$ H), 6.99 (dd, $J=9.7,2.4 \mathrm{~Hz}, 2 \mathrm{H}), 6.83(\mathrm{bs}, 2 \mathrm{H}), 6.41$ (d, $J=2.3,1 \mathrm{H}), 4.85$ (t, $J=5.2$ $\mathrm{Hz}, 2 \mathrm{H}), 3.60-3.56(\mathrm{~m}, 8 \mathrm{H}) ;{ }^{13} \mathrm{C} \mathrm{NMR}\left(125 \mathrm{MHz}, \mathrm{DMSO}-d_{6}\right) \delta 160.6,153.3,150.8$, 122.0, 120.9, 114.4, 99.7, 58.0, 53.2; HRMS (ESI) $\mathrm{m} / \mathrm{z}$ calculated for $\mathrm{C}_{11} \mathrm{H}_{15} \mathrm{~N}_{5} \mathrm{O}_{3}$ $\left(\mathrm{M}+\mathrm{H}^{+}\right)$266.1248, found 266.1252. 
Preparation of 3-amino-6-fluoro-1,2,4-benzotriazine 1,4-oxide (37): Compound 19 $(0.59 \mathrm{~g}, 3.3 \mathrm{mmol})$ was dissolved in trifluoroacetic acid $(10 \mathrm{~mL})$ with stirring while $\mathrm{H}_{2} \mathrm{O}_{2}$ ( $8 \mathrm{~mL}$ of $70 \%$ solution) was added dropwise. The reaction was allowed to stir for $10 \mathrm{~min}$ and heated to $50{ }^{\circ} \mathrm{C}$ for $7 \mathrm{~d}$ protected from light. The reaction was cooled to room temperature and poured into $\mathrm{H}_{2} \mathrm{O}(100 \mathrm{~mL})$. The resulting yellow solution was neutralized by slow addition of solid $\mathrm{NaHCO}_{3}$ with vigorous stirring. The solution became deep red and a red powder precipitated. The precipitate was collected by vacuum filtration, washed thoroughly with water and diethyl ether, and dried in a dessicator to give 37 in $43 \%$ yield. ${ }^{1} \mathrm{H}$ NMR (500 MHz, DMSO- $\left.d_{6}\right) \delta 8.29(\mathrm{dd}, J=9.6,5.2 \mathrm{~Hz}, 1 \mathrm{H})$, $8.20(\mathrm{bs}, 2 \mathrm{H}), 7.83(\mathrm{dd}, J=9.2,2.7 \mathrm{~Hz}, 1 \mathrm{H}), 7.45(\mathrm{~m}, 1 \mathrm{H}) ;{ }^{13} \mathrm{C}$ NMR $(125 \mathrm{MHz}$ DMSO-d $d_{6} \delta 165.9(\mathrm{~d}, J=256), 151.9,139.9(\mathrm{~d}, J=13), 128.2,125.2(\mathrm{~d}, J=11), 116.5$ $(\mathrm{d}, J=27), 102.0(\mathrm{~d}, J=129)$; HRMS (ESI) $\mathrm{m} / \mathrm{z}$ calculated for $\mathrm{C}_{7} \mathrm{H}_{5} \mathrm{FN}_{4} \mathrm{O}_{2}\left(\mathrm{M}+\mathrm{H}^{+}\right)$ 197.0469, found 197.0477.

\section{Synthesis of 3-amino-6-(bis(2-hydroxyethyl)amino)-1,2,4-benzotriazine 1,4-oxide}

(38). Compound $37(240 \mathrm{mg}, 1.3 \mathrm{mmol})$ was suspended in a mixture acetonitrile (35 $\mathrm{mL})$, water $(1 \mathrm{~mL})$, and diethanolamine $(1.4 \mathrm{~g}, 10 \mathrm{eq})$. The suspension was stirred at room temperature for $2 \mathrm{~d}$ protected from light. The solvent was removed by rotary evaporation, the orange residue resuspended in cold ethanol, and the solid collected by vacuum filtration. The solid was washed with cold ethanol followed by diethyl ether and dried in an oven overnight at $70{ }^{\circ} \mathrm{C}$ to give 38 as an orange powder in $73 \%$ yield. ${ }^{1} \mathrm{H}$ NMR (500 MHz, DMSO-d $) \delta 7.94(\mathrm{~d}, J=9.8 \mathrm{~Hz}, 1 \mathrm{H}), 7.71$ (bs, $2 \mathrm{H}), 7.20$ (dd, $J=9.9$, $2.7 \mathrm{~Hz}, 1 \mathrm{H}), 6.96(\mathrm{~d}, J=2.7,1 \mathrm{H}), 4.93(\mathrm{t}, J=5.1 \mathrm{~Hz}, 2 \mathrm{H}), 3.64(\mathrm{bs}, 8 \mathrm{H}) ;{ }^{13} \mathrm{C} \mathrm{NMR}$ 
$\left(125 \mathrm{MHz}, \mathrm{DMSO}-d_{6}\right) \delta 153.7,151.8,140.1,123.0,122.8,116.5,91.2,58.2,53.7$;

HRMS (ESI) $\mathrm{m} / \mathrm{z}$ calculated for $\mathrm{C}_{11} \mathrm{H}_{15} \mathrm{~N}_{5} \mathrm{O}_{4}\left(\mathrm{M}+\mathrm{H}^{+}\right)$282.1197, found 282.1201 .

Synthesis 3-amino-7-fluoro-1,2,4-benzotriazine 1,4-dioxide (40): Compound 31 (500 mg, $2.8 \mathrm{mmol})$ was dissolved in trifluoroacetic acid $(6 \mathrm{~mL})$ with stirring while $\mathrm{H}_{2} \mathrm{O}_{2}(4$ $\mathrm{mL}$ of $70 \%$ solution) was added dropwise. The reaction was allowed to stir for $10 \mathrm{~min}$ and heated to $50{ }^{\circ} \mathrm{C}$ for $7 \mathrm{~d}$ protected from light. The reaction was cooled to room temperature and poured into $\mathrm{H}_{2} \mathrm{O}(100 \mathrm{~mL})$. The resulting yellow solution was neutralized by slow addition of solid $\mathrm{NaHCO}_{3}$ with vigorous stirring. The solution became deep red and a red powder precipitated. The precipitate was collected by vacuum filtration, washed thoroughly with water and diethyl ether, and dried in a dessicator to give 40 in $47 \%$ yield as a yellow solid. ${ }^{1} \mathrm{H}$ NMR (500 MHz, DMSO- $\left.d_{6}\right) \delta 8.20$ (dd, $J=$ 9.5, 5.1 Hz, $1 \mathrm{H}$ ), 8.03 (bs $2 \mathrm{H}), 7.98$ (dd, $J=8.7,2.6 \mathrm{~Hz}, 1 \mathrm{H}), 7.88$ (ddd, $J=9.3,8.3$, $2.7 \mathrm{~Hz}, 1 \mathrm{H}) ;{ }^{13} \mathrm{C}$ NMR $\left(125 \mathrm{MHz}, \mathrm{DMSO}-d_{6}\right) \delta 160.0(\mathrm{~d}, J=249), 151.7,136.5,131.2$ (d, $J=11), 125.6(\mathrm{~d}, J=27), 120.6(\mathrm{~d}, J=9), 106.3(\mathrm{~d}, J=28) ;$ HRMS $(\mathrm{ESI}) \mathrm{m} / \mathrm{z}$ calculated for $\mathrm{C}_{7} \mathrm{H}_{5} \mathrm{FN}_{4} \mathrm{O}_{2}\left(\mathrm{M}+\mathrm{H}^{+}\right)$197.1459, found 197.0472.

Synthesis 7-chloro-1,2,4-benzotriazine 1-oxide (44): Compound 44 was prepared using a procedure adopted from Hay, M.P. et al. $)^{30}$ 4-chloro-2-nitroaniline (5.6 g, 33 mmol) and cyanamide $(15 \mathrm{~g}, 360 \mathrm{mmol})$ were heated together at $100{ }^{\circ} \mathrm{C}$ for 15 minutes to combine the solids. The mixture was cooled slightly and $\mathrm{HCl}(20 \mathrm{~mL}$, conc.) was added drop wise while stirring over 30-min. (CAUTION: A violent exothermic reaction may occur during or after $\mathrm{HCl}$ addition). After addition of acid was complete stirring was 
continued for an additional $10 \mathrm{~min}$, adding more cyanamide to help stir if needed. The mixture was heated to $100{ }^{\circ} \mathrm{C}$ for $3 \mathrm{~h}$ and cooled to room temperature with continued stirring. $\mathrm{NaOH}(100 \mathrm{~mL}, 8 \mathrm{M})$ was added and the mixture stirred vigorously at $100{ }^{\circ} \mathrm{C}$ for $2 \mathrm{~h}$. The orange suspension was cooled to room temperature, poured into $400 \mathrm{~mL}$ water, and filtered under vacuum. The precipitate was washed thoroughly with water and diethyl ether and then dried in the oven at $70{ }^{\circ} \mathrm{C}$ overnight. Compound 44 was obtained in $73 \%$ yield as a yellow powder: ${ }^{1} \mathrm{H}$ NMR $\left(500 \mathrm{MHz}, \mathrm{DMSO}-d_{6}\right) \delta 8.13(\mathrm{~d}, J=2.3 \mathrm{~Hz}, 1$ H), $7.80(\mathrm{dd}, J=9.0,2.41 \mathrm{H}), 7.55(\mathrm{~d}, J=9.0 \mathrm{~Hz}, 1 \mathrm{H}), 7.48(\mathrm{bs}, 2 \mathrm{H}) ;{ }^{13} \mathrm{C} \mathrm{NMR}(125$ MHz, DMSO- $\left.d_{6}\right) \delta 160.4,147.7,136.0,130.0,128.3,128.0,118.9 ;$ HRMS (ESI) m/z calculated for $\mathrm{C}_{7} \mathrm{H}_{6} \mathrm{ClN}_{4} \mathrm{O}\left(\mathrm{M}+\mathrm{H}^{+}\right)$197.0225, found 197.0232.

\section{Synthesis 7-chloro-3-N,N-Bis(Boc-amino)-1,2,4-benzotriazine 1-oxide (45):}

Compound 44 (679 mg, $3.5 \mathrm{mmol})$ and 4-dimethylaminopyridine (21 $\mathrm{mg}, 5 \%$ equiv) were suspended in $\mathrm{N}$-methylpyrrolidone $(3.5 \mathrm{~mL})$ and di-tert-butyl dicarbonate $(1.67 \mathrm{~g}$ (2.2 equiv) was added. The mixture was stirred under an atmosphere of nitrogen at room temperature for $4 \mathrm{~h}$. The resulting solution was diluted with tetrahydrofuran $(20 \mathrm{~mL})$ and precipitated by slow addition of water $(200 \mathrm{~mL})$. The precipitate was collected by vacuum filtration, washed with water, and dried under vacuum. Compound $\mathbf{4 5}$ was collected as a colorless solid in 96\% yield: ${ }^{1} \mathrm{H}$ NMR $\left(500 \mathrm{MHz}, \mathrm{CDCl}_{3}\right) \delta 8.47(\mathrm{~d}, J=2.2$ $\mathrm{Hz}, 1 \mathrm{H}), 8.0(\mathrm{~d}, J=8.9 \mathrm{~Hz}, 1 \mathrm{H}),, 7.91(\mathrm{dd}, J=9.0,2.2 \mathrm{~Hz}, 1 \mathrm{H}), 1.46(\mathrm{~s}, 1 \mathrm{H}) ;{ }^{13} \mathrm{C}$ NMR $\left(125 \mathrm{MHz}, \mathrm{CDCl}_{3}\right) \delta 155.4,149.9,146.0,137.5,137.3,130.6,119.8,84.7,28.0$; HRMS (ESI) m/z calculated for $\mathrm{C}_{17} \mathrm{H}_{22} \mathrm{ClN}_{4} \mathrm{O}_{5}\left(\mathrm{M}+\mathrm{H}^{+}\right)$397.1273, found 397.1278. 
Synthesis 3-amino-7-morpholino-1,2,4-benzotriazine 1-oxide (43): Compound 45

(120 mg, $0.3 \mathrm{mmol})$, tert-butanol $(10 \mathrm{~mL})$, sodium tert-butoxide (87 $\mathrm{mg}, 2.5$ equiv), $\mathrm{Pd}(\mathrm{OAc})_{2}(3.4 \mathrm{mg}, 5 \%$ equiv), and $\mathrm{SPhos}(12.3 \mathrm{mg}, 10 \%$ equiv) were degassed inside a seal tube by bubbling $\mathrm{N}_{2}$ through the mixture for $20 \mathrm{~min}$. Morpholine (65 $\mu \mathrm{L}, 2.5$ equiv) was added and the reaction vessel sealed. The reaction was heated to $100{ }^{\circ} \mathrm{C}$ for $18 \mathrm{~h}$ before an additional portion of morpholine, $\mathrm{Pd}(\mathrm{OAc})_{2}$, and SPhos were added and the reaction continued heating at $100{ }^{\circ} \mathrm{C}$ for $24 \mathrm{~h}$. Water $(30 \mathrm{~mL})$ was added and the reaction was extracted with ethylacetate $(3 \times 30 \mathrm{~mL})$, organic fractions combined and dried over anhydrous $\mathrm{Na}_{2} \mathrm{SO}_{4}$. (significant amount of product lost in aqueous layer). Purification by column chromatography on silica gel with $0-2 \% \mathrm{MeOH}$ in $\mathrm{CH}_{2} \mathrm{Cl}_{2}$ yielded two products, $43 \mathrm{~A}$ and $\mathbf{4 3 B}$ in $9 \%$ and $16 \%$ yield respectively. Compound 43A (6.8 $\mathrm{mg})$ was dissolved in $\mathrm{CH}_{2} \mathrm{Cl}_{2}(2 \mathrm{~mL})$ and then trifluoroacetic acid $(200 \mu \mathrm{L})$ was added. The mixture was stirred at room temperature for $1.5 \mathrm{~h}$ and then neutralized by slowly addition of saturated sodium bicarbonate solution $(6 \mathrm{~mL})$. The mixture was vacuum filtered and dark red solid collected and dried under vacuum to yield 43 in $65 \%$ yield $(6 \%$ yield after two steps): ${ }^{1} \mathrm{H}$ NMR (500 MHz, DMSO- $\left.d_{6}\right) \delta 7.75(\mathrm{dd}, J=9.0,2.8 \mathrm{~Hz}, 1 \mathrm{H}), 7.47(\mathrm{~d}, J=$ $9.4 \mathrm{~Hz}, 1 \mathrm{H}), 7.29(\mathrm{~d}, J=2.7 \mathrm{~Hz}, 1 \mathrm{H}), 6.97(\mathrm{bs}, 2 \mathrm{H}), 3.76(\mathrm{t}, J=4.7 \mathrm{~Hz}, 4 \mathrm{H}), 3.12$, (t, $J$ $=4.8 \mathrm{~Hz}, 4 \mathrm{H}) ;{ }^{13} \mathrm{C}$ NMR $\left(125 \mathrm{MHz}, \mathrm{DMSO}-d_{6}\right) \delta 159.2,148.3,144.1,130.1,128.0$, 126.6, 99.4, 65.9, 48.1; HRMS (ESI) $\mathrm{m} / \mathrm{z}$ calculated for $\mathrm{C}_{11} \mathrm{H}_{14} \mathrm{~N}_{5} \mathrm{O}_{2}\left(\mathrm{M}+\mathrm{H}^{+}\right)$248.1142, found 248.1146 .

Synthesis of 3-aminonaphtho[2,1-e][1,2,4]triazine 1-oxide (46): Compound 46 was synthesized from 1-nitro-2-naphthylamine prepared as in Hodgson and Kilner. ${ }^{35}$ 1-nitro- 
2-naphthylamine (356 mg, $1.9 \mathrm{mmol})$ and cyanamide (1 g, $24 \mathrm{mmol})$ were mixed together by heating to $100{ }^{\circ} \mathrm{C}$ with stirring for $15 \mathrm{~min}$. The mixture was cooled to room temperature and then $\mathrm{HCl}(2.5 \mathrm{~mL}$, conc) was added and the reaction was stirred at 100 ${ }^{\circ} \mathrm{C}$ for $2 \mathrm{~h}$. The reaction was cooled to room temperature and then $\mathrm{NaOH}(10 \mathrm{~mL}, 16 \mathrm{M})$ was added. The reaction was heated again at $100{ }^{\circ} \mathrm{C}$ for $3 \mathrm{~h}$ before being cooled to room temperature and diluted with water $(25 \mathrm{~mL})$. The precipitate was collected by vacuum filtration and washed thoroughly with water and $25 \%$ ethyl acetate in hexane. After drying in an dessicator overnight, compound $\mathbf{4 6}$ was obtained as a yellow solid in $20 \%$ yield: ${ }^{1} \mathrm{H}$ NMR $\left(500 \mathrm{MHz}, \mathrm{DMSO}-d_{6}\right) \delta 9.70(\mathrm{~d}, J=8.5,1 \mathrm{H}), 8.21,(\mathrm{~d}, J=9.1,1 \mathrm{H})$, $8.204(\mathrm{~d}, J=7.7 \mathrm{~Hz}, 1 \mathrm{H}), 7.80$ (appt, $J=8.3,7.3,2 \mathrm{H}), 7.70$ (appt, $J=7.5,7.3 \mathrm{~Hz}, 1 \mathrm{H}$ ), $7.48(\mathrm{~d}, J=9.0,1 \mathrm{H}), 7.40(\mathrm{bs}, 2 \mathrm{H}) ;{ }^{13} \mathrm{C}$ NMR $\left(125 \mathrm{MHz}, \mathrm{DMSO}-d_{6}\right) \delta 161.5,153.4$ $138.4,130.9,130.1,129.7,128.0,125.2,125.1,125.1,124.9 ;$ HRMS (ESI) m/z calculated for $\mathrm{C}_{11} \mathrm{H}_{9} \mathrm{~N}_{4} \mathrm{O}\left(\mathrm{M}+\mathrm{H}^{+}\right)$213.0771, found 213.0776.

\section{Synthesis 3-aminonaphtho[2,3-e][1,2,4]triazine 1-oxide $\quad(47): \quad 3-n i t r o-2-$} naphthylamine (3.5 $\mathrm{mg}, 0.5 \mathrm{mmol})$ and cyanamide $(240 \mathrm{mg}, 2.1 \mathrm{mmol})$ was added to a round bottom flask and heated to $100{ }^{\circ} \mathrm{C}$ with stirring to melt together. The reaction was cooled to room temperature and then $\mathrm{HCl}(520 \mu \mathrm{L}$, conc $)$ was added and then the mixture was heated to $100{ }^{\circ} \mathrm{C}$ for $30 \mathrm{~min}$. The reaction was cooled to room temperature and then $\mathrm{NaOH}(1 \mathrm{~mL}, 8 \mathrm{M})$ was added. The reaction was stirred at $100{ }^{\circ} \mathrm{C}$ for $2 \mathrm{~h}$, then cooled to room temperature and water $(8 \mathrm{~mL})$ added. The resulting suspended solid was collected by centrifugation and washed with water and $25 \%$ ethyl acetate in hexane then dried under vacuum. Compound 47 was collected as a dark purple solid in $23 \%$ yield: ${ }^{1} \mathrm{H}$ 
NMR (500 MHz, DMSO-d $)_{6} \delta 8.91(\mathrm{~s}, 1 \mathrm{H}), 8.15(\mathrm{~d}, J=8.4 \mathrm{~Hz}, 1 \mathrm{H}), 8.06(\mathrm{~s}, 1 \mathrm{H}), 7.99$,

(d, $J=8.5 \mathrm{~Hz}, 1 \mathrm{H}), 7.60$ (appt, $J=7.3,6.9 \mathrm{~Hz}, 1 \mathrm{H}), 7.48$ (appt, $J=7.2,6.9 \mathrm{~Hz}, 1 \mathrm{H}$ ), 7.38 (bs $2 \mathrm{H}$ ); ${ }^{13} \mathrm{C}$ NMR (125 MHz, DMSO- $\left.d_{6}\right) \delta 158.3,143.1,137.2,129.6,129.4$, 129.3, 129.2, 127.1, 125.8, 121.8, 120.0; HRMS (ESI) $\mathrm{m} / \mathrm{z}$ calculated for $\mathrm{C}_{11} \mathrm{H}_{9} \mathrm{~N}_{4} \mathrm{O}$ $\left(\mathrm{M}+\mathrm{H}^{+}\right)$213.0771, found 213.0771.

Synthesis 3-aminonaphtho[1,2-e][1,2,4]triazine 1-oxide (48): Compound 48 was synthesized from 2-nitronaphthylamine prepared as in Katritzky and Laurenzo. ${ }^{36} 2$ nitronaphthylamine (812 $\mathrm{mg}, 4.3 \mathrm{mmol})$ and cyanamide $(2 \mathrm{~g}, 48 \mathrm{mmol})$ were mixed together by stirring at $100{ }^{\circ} \mathrm{C}$ for 15 minutes. The mixture was cooled to room temperature and $\mathrm{HCl}\left(5 \mathrm{ml}\right.$, conc) was added. The reaction was heated to $100{ }^{\circ} \mathrm{C}$ with stirring for $2 \mathrm{~h}$. After cooling to room temperature, $\mathrm{NaOH}(50 \mathrm{~mL}, 7.5 \mathrm{M})$ was added and the reaction stirred at $100{ }^{\circ} \mathrm{C}$ for $2 \mathrm{~h}$. When complete the mixture was diluted with water $(100 \mathrm{~mL})$ and vacuum filtered. The precipitate was washed thoroughly with water and diethyl ether. Purification was done by column chromatography on silica gel with $10 \%$ acetone in $\mathrm{CH}_{2} \mathrm{Cl}_{2}$ to give compound 48 as a yellow solid in $8 \%$ yield: ${ }^{1} \mathrm{H}$ NMR (500 MHz, DMSO-d $)_{6} \delta 8.83(\mathrm{~d}, J=8.2 \mathrm{~Hz}, 1 \mathrm{H}), 8.02,(\mathrm{~d}, J=3.4 \mathrm{~Hz}, 1 \mathrm{H}), 8.00(\mathrm{~s}, 1 \mathrm{H})$, 7.84 (appt, $J=8.0 \mathrm{~Hz}, 2 \mathrm{H}), 7.76$ (appt, $J=7.2,0.9 \mathrm{~Hz}, 1 \mathrm{H}), 7.71(\mathrm{~d}, J=9.4 \mathrm{~Hz}, 1 \mathrm{H})$, 7.52 (bs, $2 \mathrm{H}) ;{ }^{13} \mathrm{C}$ NMR (125 MHz, DMSO- $\left.d_{6}\right) \delta 161.2,149.4,135.3,131.1,128.4$, 128.0, 127.6, 126.6, 124.4, 124.7, 116.0; HRMS (ESI) $\mathrm{m} / \mathrm{z}$ calculated for $\mathrm{C}_{11} \mathrm{H}_{9} \mathrm{~N}_{4} \mathrm{O}$ $\left(\mathrm{M}+\mathrm{H}^{+}\right)$213.0771, found 213.0776. 
Synthesis 3-aminonaphtho[2,1-e][1,2,4]triazine 2-oxide (50): Compound 50 was synthesized via oxidation of $\mathbf{4 9}$ (prepared as reported in Suzuki and Kawakami. ${ }^{37}$ ) with dimethyldioxirane (prepared as in Murray and Singh) ${ }^{38}$ Compound 49 (20 mg, $0.1 \mathrm{mmol}$ ) was dissolved in acetone $(6 \mathrm{~mL})$ and dimethyldioxirane $(4 \mathrm{x} 1 \mathrm{~mL})$ was added over $2 \mathrm{~d}$ until most of the starting material has reacted. The solvent was removed by rotary evaporation and purification by column chromatography on silica gel with $4 \%$ acetone in $\mathrm{CH}_{2} \mathrm{Cl}_{2}$ gave compound 50 in $73 \%$ yield: ${ }^{1} \mathrm{H}$ NMR $\left(500 \mathrm{MHz}, \mathrm{DMSO}-d_{6}\right) \delta 8.63(\mathrm{~d}, J=$ $8.2 \mathrm{~Hz}, 1 \mathrm{H}), 8.26$ (bs $2 \mathrm{H}), 8.07$ (d, $J=9.0 \mathrm{~Hz}, 1 \mathrm{H}), 8.02$ (d, $J=7.9 \mathrm{~Hz}, 1 \mathrm{H}), 7.75$ (appt, $J=7.9,7.3 \mathrm{~Hz}, 1 \mathrm{H}), 7.68$ (appt, $J=7.8,7.1 \mathrm{~Hz}, 1 \mathrm{H}), 7.54(\mathrm{~d}, J=9.0 \mathrm{~Hz}, 1 \mathrm{H})$; ${ }^{13} \mathrm{C}$ NMR (125 MHz, DMSO-d $) \delta 150.4,133.9,132.6,132.1,131.2,128.8,128.5,127.8$, 127.2, 123.5, 121.8; An crystal structure was obtained by vapor diffusion with ethyl acetate and hexane and analyzed by Xray Diffraction (Figure 2).

Synthesis 3-(4-aminophenyl)-1,2,4-benzotriazine 1-oxide (51): Compound 16 (118 $\mathrm{mg}, 0.3 \mathrm{mmol})$ was dissolved in toluene $(5 \mathrm{~mL})$ and $\mathrm{H}_{3} \mathrm{PO}_{4}(0.25 \mathrm{~mL}, 85 \%, 5$ equiv) was added. The mixture was stirred vigorously at room temperature for $24 \mathrm{~h}$. At the end of the reaction water $(10 \mathrm{~mL})$ was added and the mixture was extracted with ethyl acetate (5x $10 \mathrm{~mL}$ ). The organic fractions were combined, dried with $\mathrm{Na}_{2} \mathrm{SO}_{4}$ and solvent removed by rotary evaporation. Purification by column chromatography with $10-50 \%$ ethyl acetate in hexane afforded $\mathbf{5 1}$ in $57 \%$ yield as a red solid: ${ }^{1} \mathrm{H}$ NMR $(500 \mathrm{MHz}$, DMSO- $\left.d_{6}\right) \delta 8.32(\mathrm{~d}, J=8.56 \mathrm{~Hz}, 1 \mathrm{H}), 8.10(\mathrm{~d}, J=8.7 \mathrm{~Hz}, 2 \mathrm{H}), 8.02-7.97(\operatorname{comp}, 2 \mathrm{H})$, 7.70 (ddd, $J=8.4,6.5,1.7 \mathrm{~Hz}, 1 \mathrm{H}), 6.69(\mathrm{~d}, J=8.7 \mathrm{~Hz}, 2 \mathrm{H}), 5.98(\mathrm{~s}, 2 \mathrm{H}) ;{ }^{13} \mathrm{C}$ NMR $\left(125 \mathrm{MHz}, \mathrm{DMSO}-d_{6}\right) \delta 160.4,153.2,147.8,136.4,132.8,130.0,129.6,128.8,120.6$, 
120.2, 113.8; HRMS (ESI) $\mathrm{m} / \mathrm{z}$ calculated for $\mathrm{C}_{13} \mathrm{H}_{13} \mathrm{~N}_{4} \mathrm{O}\left(\mathrm{M}+\mathrm{H}^{+}\right)$239.0927, found 239.0933 .

Synthesis of 3-amino-7-carboxy-1,2,4-benzotriazine 1-oxide (52): Compound 52 was prepared using a modified method of Suzuki and Kawakami. ${ }^{39} \mathrm{NaOH}$ (508 mg, equiv) was dissolved in hot ethanol (30 mL), guanidine hydrochloride (1.2 g, 10 equiv) added, and the resulting mixture stirred for $20 \mathrm{~min}$. The reaction was cooled to room temperature and filtered to remove the white precipitate. To the filtrate THF $(20 \mathrm{~mL})$ and 4-fluoro-3-nitrobenzoic acid (226 $\mathrm{mg}, 1.2 \mathrm{mmol})$ were added and the resulting heterogeneous mixture refluxed for $4 \mathrm{~h}$. Potassium tert-butoxide (153 mg, 10 equiv) were added and the mixture stirred at reflux for an additional $2 \mathrm{~h}$. After the reaction was complete, the THF was decanted off and water $(60 \mathrm{~mL})$ added with vigorous stirring. Acidification with $\mathrm{HCl}(1 \mathrm{M})$ resulted in precipitation of a yellow solid that was collected by vacuum filtration and washed with dilute $\mathrm{HCl}$, followed by minimal amounts of water and diethyl ether. The solid was then dried in an oven overnight at $70{ }^{\circ} \mathrm{C}$ to give $\mathbf{5 2}$ in 93\% yield: ${ }^{1} \mathrm{H}$ NMR (500 MHz, DMSO- $\left.d_{6}\right) \delta 13.33(\mathrm{bs}, 1 \mathrm{H}), 8.62(\mathrm{~d}, J=1.7 \mathrm{~Hz}, 1 \mathrm{H})$, $8.17(\mathrm{dd}, J=8.8,1.7 \mathrm{~Hz}, 1 \mathrm{H}), 7.69(\mathrm{~s}, 2 \mathrm{H})$, and $7.56(\mathrm{~d}, J=8.8 \mathrm{~Hz}, 1 \mathrm{H}) ;{ }^{13} \mathrm{C} \mathrm{NMR}$ $\left(125 \mathrm{MHz}, \mathrm{DMSO}-d_{6}\right) \delta 165.9,161.1,151.1,134.8,129.5,126.2,126.0,122.1$; HRMS (ESI) $\mathrm{m} / \mathrm{z}$ calculated for $\mathrm{C}_{8} \mathrm{H}_{6} \mathrm{~N}_{4} \mathrm{O}_{3}\left(\mathrm{M}+\mathrm{H}^{+}\right)$207.0513, found 207.0518.

Synthesis 3-amino-7-ethylester-1,2,4-benzotriazine 1-oxide (53): Compound 52 was suspended in ethanol $(5 \mathrm{~mL})$ and $\mathrm{H}_{2} \mathrm{SO}_{4}(0.5 \mathrm{~mL}$, conc $)$ and the mixture was refluxed for $6 \mathrm{~h}$. After completion, the reaction was diluted with ethyl acetate $(50 \mathrm{~mL})$ and washed 
with water $(3 \times 50 \mathrm{~mL})$, saturated sodium bicarbonate $(3 \times 50 \mathrm{~mL})$, and brine $(50 \mathrm{~mL})$.

The organic fraction was dried over anhydrous $\mathrm{Na}_{2} \mathrm{SO}_{4}$ and solvent removed by rotary evaporation. Compound 53 was obtained as a dark red solid in 67\% yield: ${ }^{1} \mathrm{H}$ NMR (500 MHz, DMSO-d $\left.d_{6}\right) \delta 8.62(\mathrm{~d}, J=1.8 \mathrm{~Hz}, 1 \mathrm{H}), 8.17(\mathrm{dd}, J=8.8,2.0 \mathrm{~Hz}, 1 \mathrm{H}), 7.74(\mathrm{bs}$, 2H), $7.57(\mathrm{~d}, J=8.9 \mathrm{~Hz}, 1 \mathrm{H}), 4.35(\mathrm{q}, J=7.1 \mathrm{~Hz}, 2 \mathrm{H}), 1.35(\mathrm{t}, J=7.1 \mathrm{~Hz}, 3 \mathrm{H}) ;{ }^{13} \mathrm{C}$ NMR $\left(125 \mathrm{MHz}, \mathrm{DMSO}-d_{6}\right) \delta 164.4,161.1,151.3,124.4,129.5,126.4,124.9,122.0$, 61.3, 14.1; HRMS (ESI) $\mathrm{m} / \mathrm{z}$ calculated for $\mathrm{C}_{10} \mathrm{H}_{10} \mathrm{~N}_{4} \mathrm{O}_{3}\left(\mathrm{M}+\mathrm{H}^{+}\right)$235.0826, found 235.0828 .

\section{Crystal Structure 1}

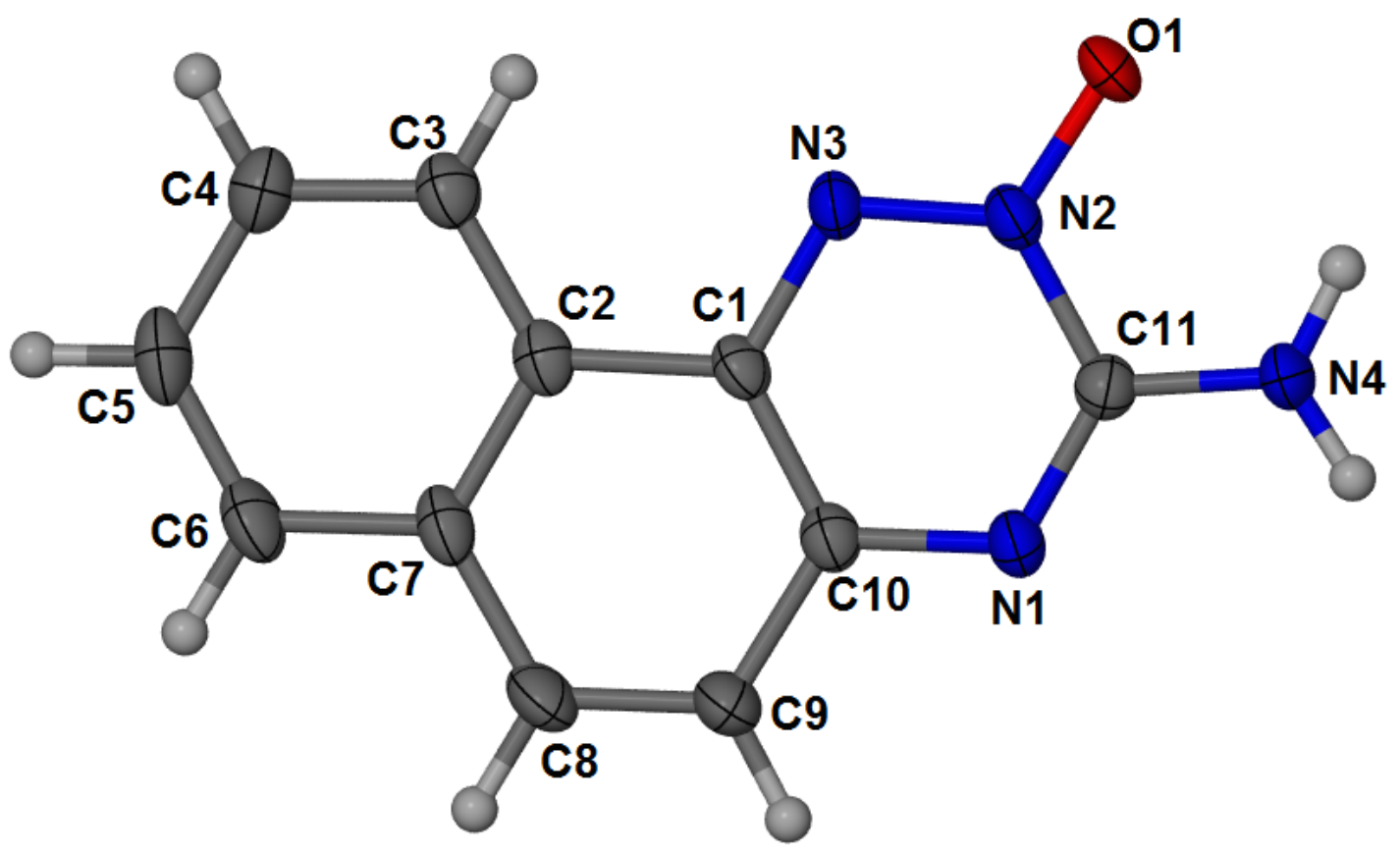


Crystallographic Data

Emperical formula

Formula weight

Temperature, $(\mathrm{K})$

W. length, $(\AA)$

Crystal system

Space group

$\mathrm{a},(\AA)$

b, $(\AA)$

$\mathrm{c},(\AA)$

$\alpha,(\operatorname{deg})$

$\beta,(\operatorname{deg})$

$\gamma,(\operatorname{deg})$

Volume, $\left(\AA^{3)}\right.$

$\mathrm{Z} /$ calculated density $\left(\mathrm{Mg} / \mathrm{m}^{3}\right)$

Absorption coefficient $\left(\mathrm{mm}^{-1}\right)$

Crystal size (mm)

Reflections collected/unique

Data/restraints/parameters

GOF

$\mathrm{R}$ indices (all data)

\section{Crystal Structure 1}

C11 H8 N4 O1

212.21

173(2)

0.71073

Triclinic

P -1

6.943(6)

7.699(7)

9.097(8)

$72.560(11)$

$87.991(11)$

$87.212(11)$

463.2(7)

$2 / 1.522$

0.105

$0.25 \times 0.15 \times 0.05$

$5306 / 2065[\mathrm{R}(\mathrm{int})=0.0434]$

2065 / 0 / 145

0.981

$\mathrm{R} 1=0.0582, \mathrm{wR} 2=0.1476$ 


\subsection{NMR Spectra for Compound Characterization}

${ }^{1}$ HNMR
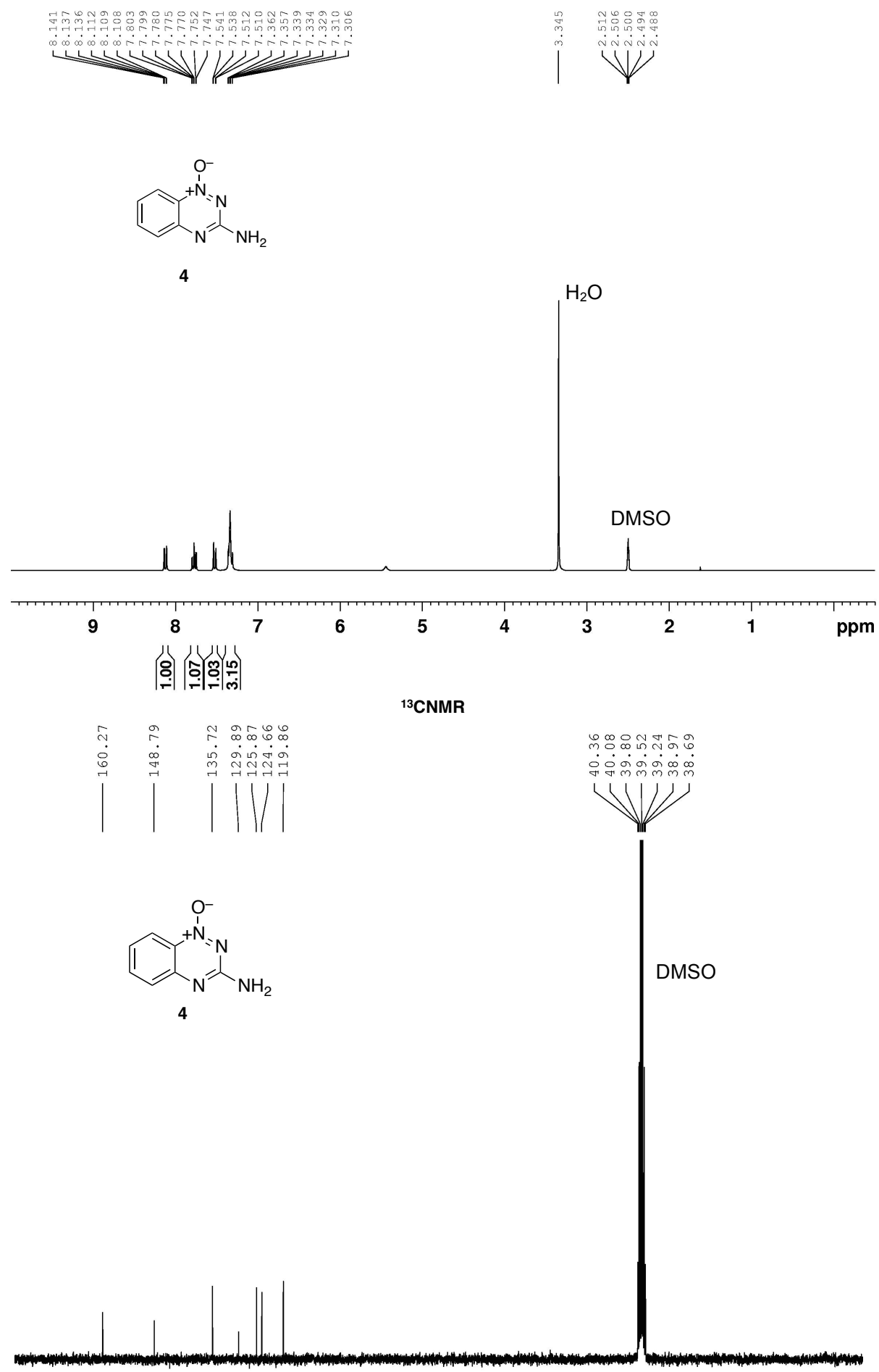

\begin{tabular}{llllllllllllllllll}
170 & 160 & 150 & 140 & 130 & 120 & 110 & 100 & 90 & 80 & 70 & 60 & 50 & 40 & 30 & 20 & 10 & 0 \\
\hline
\end{tabular} 
${ }^{1}$ HNMR
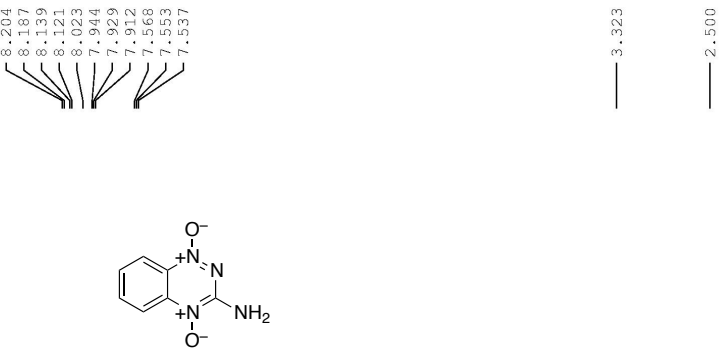

1
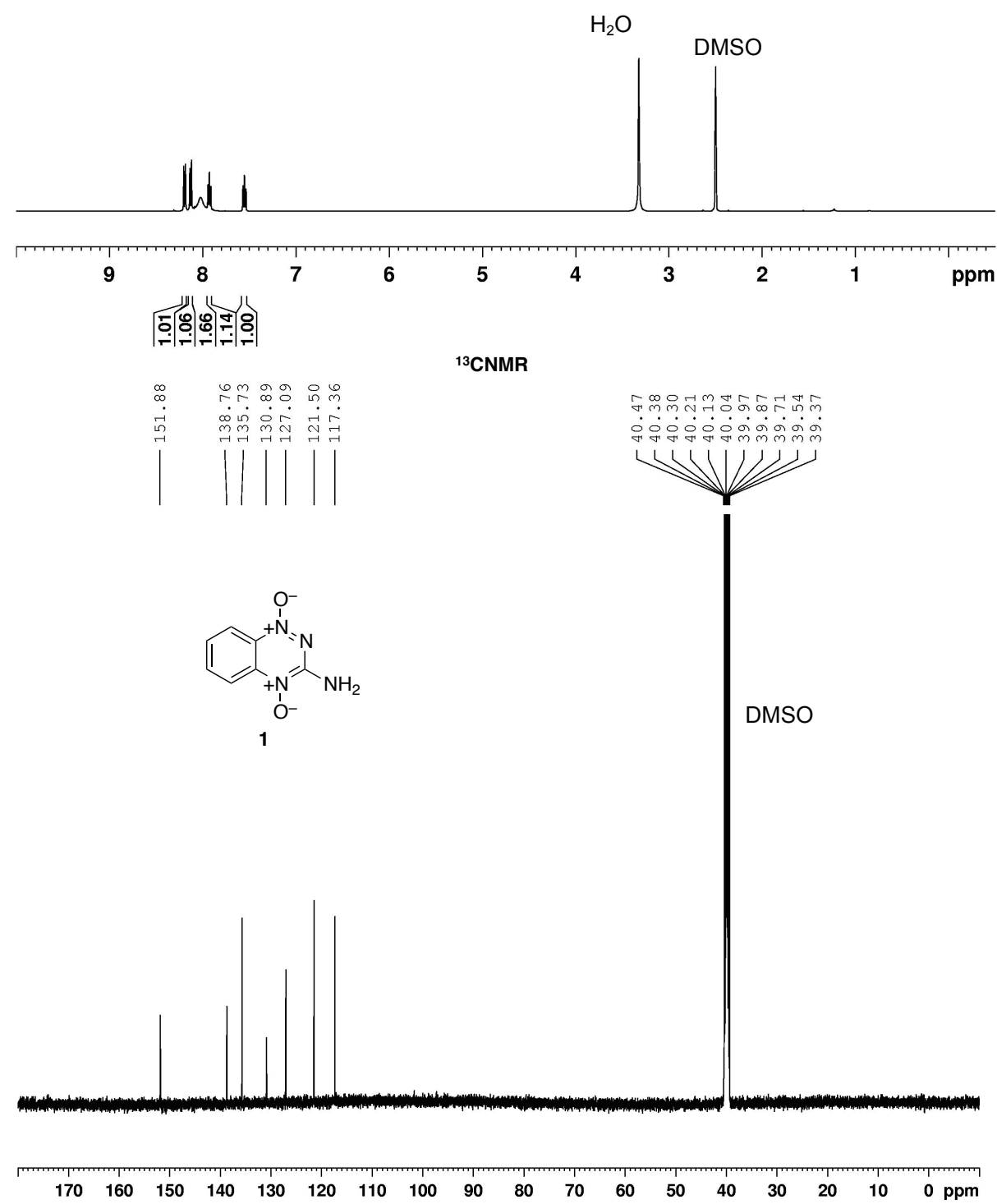


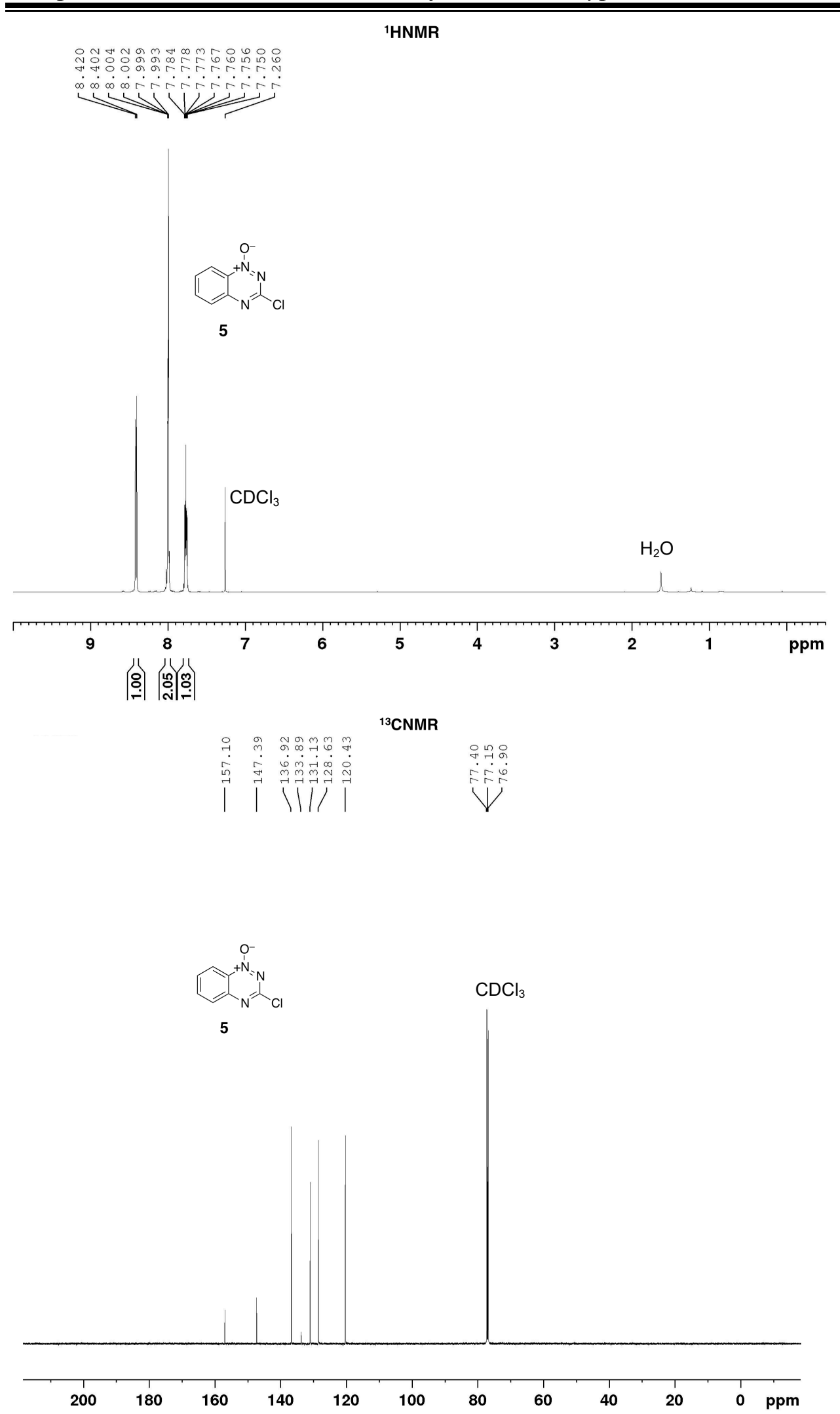




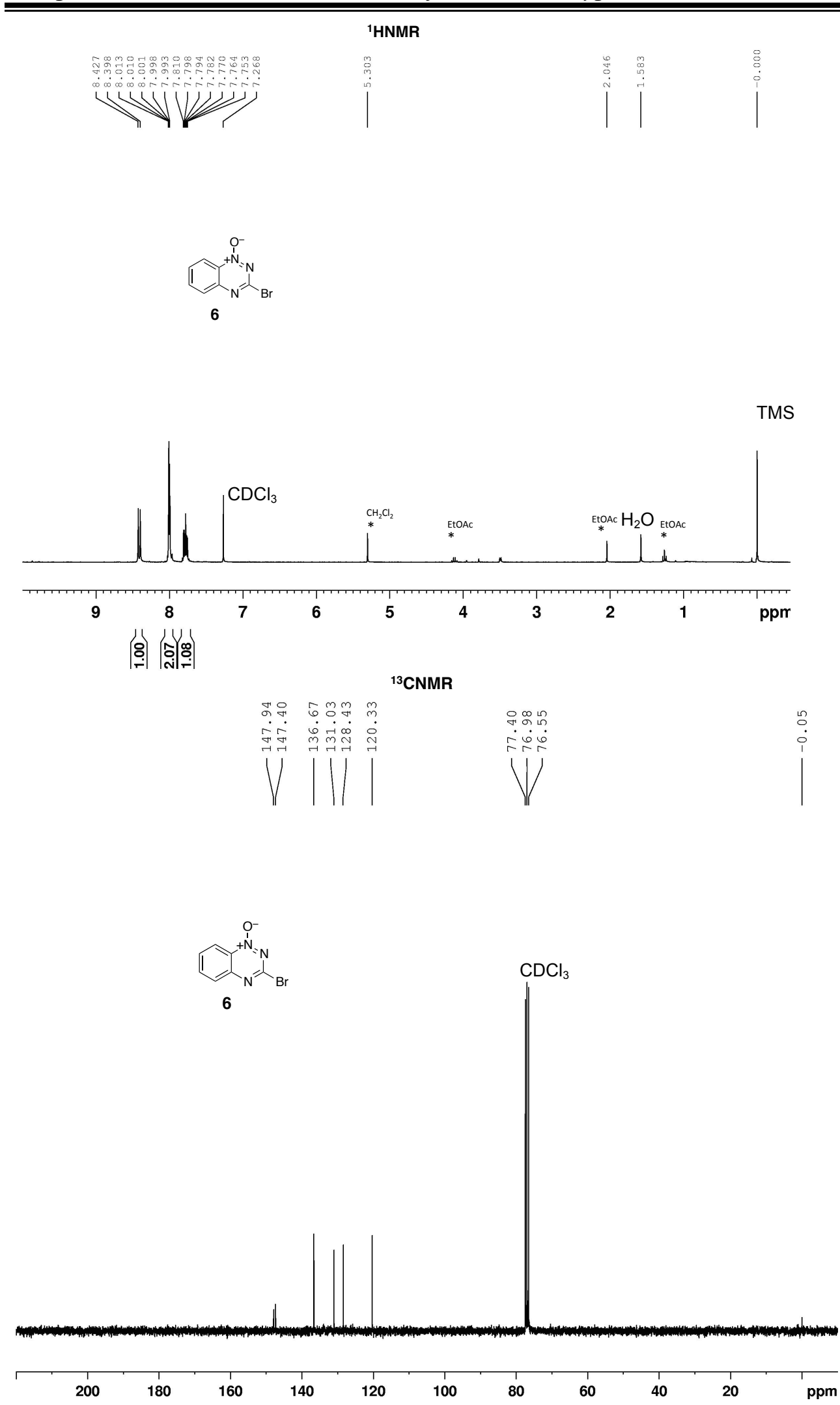


${ }^{1} \mathrm{HNMR}$
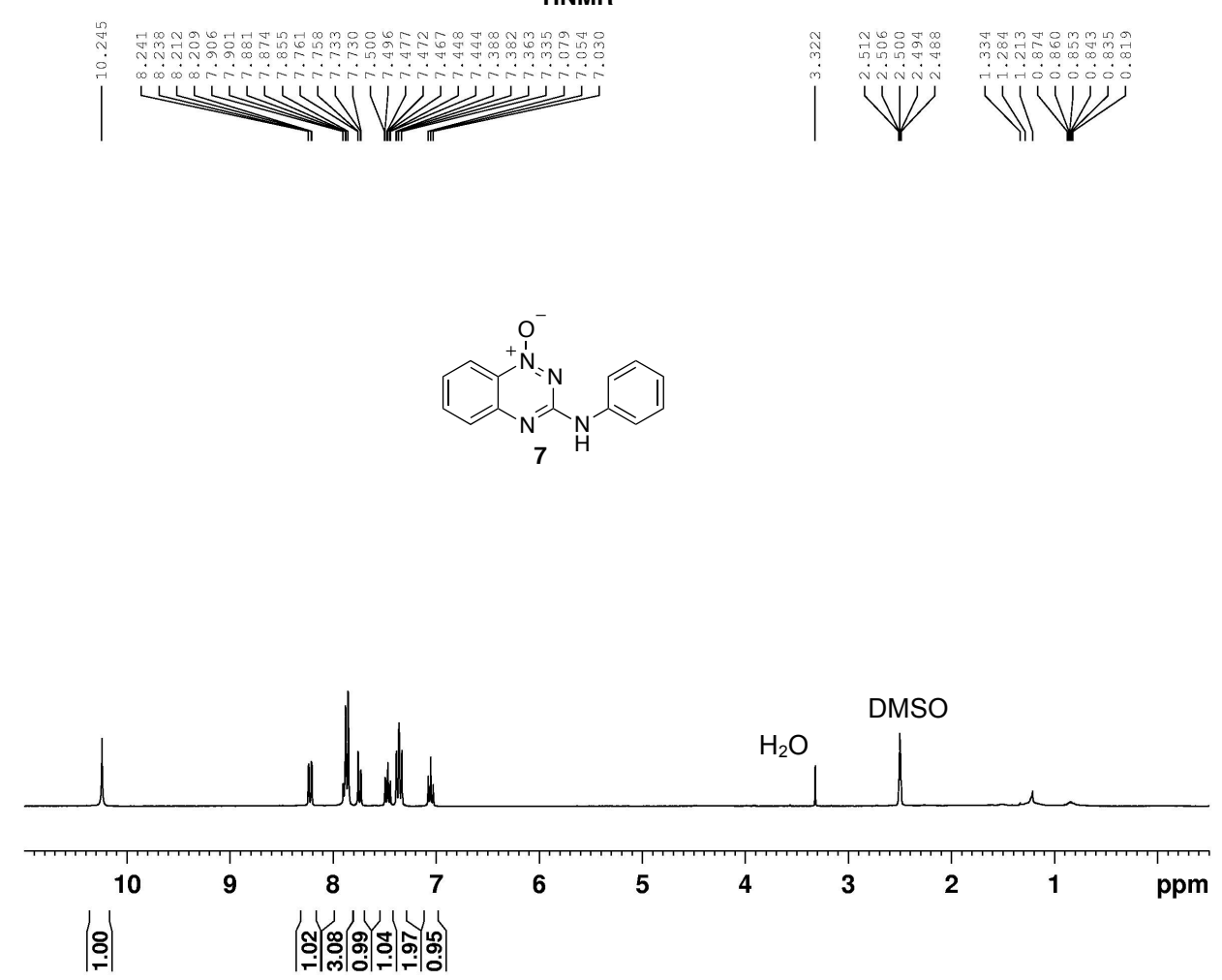

${ }^{13}$ CNMR
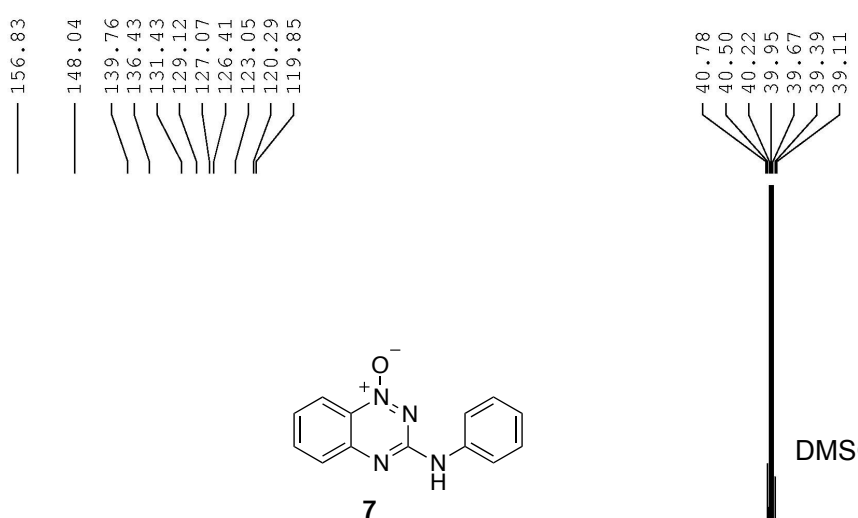

DMSO

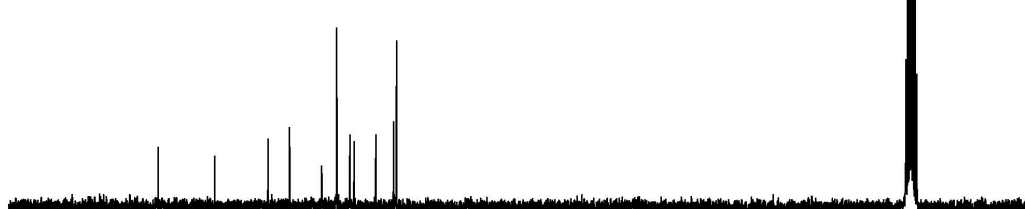

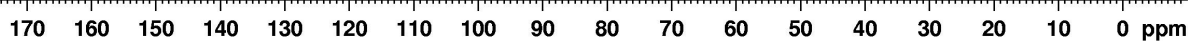


${ }^{1}$ HNMR
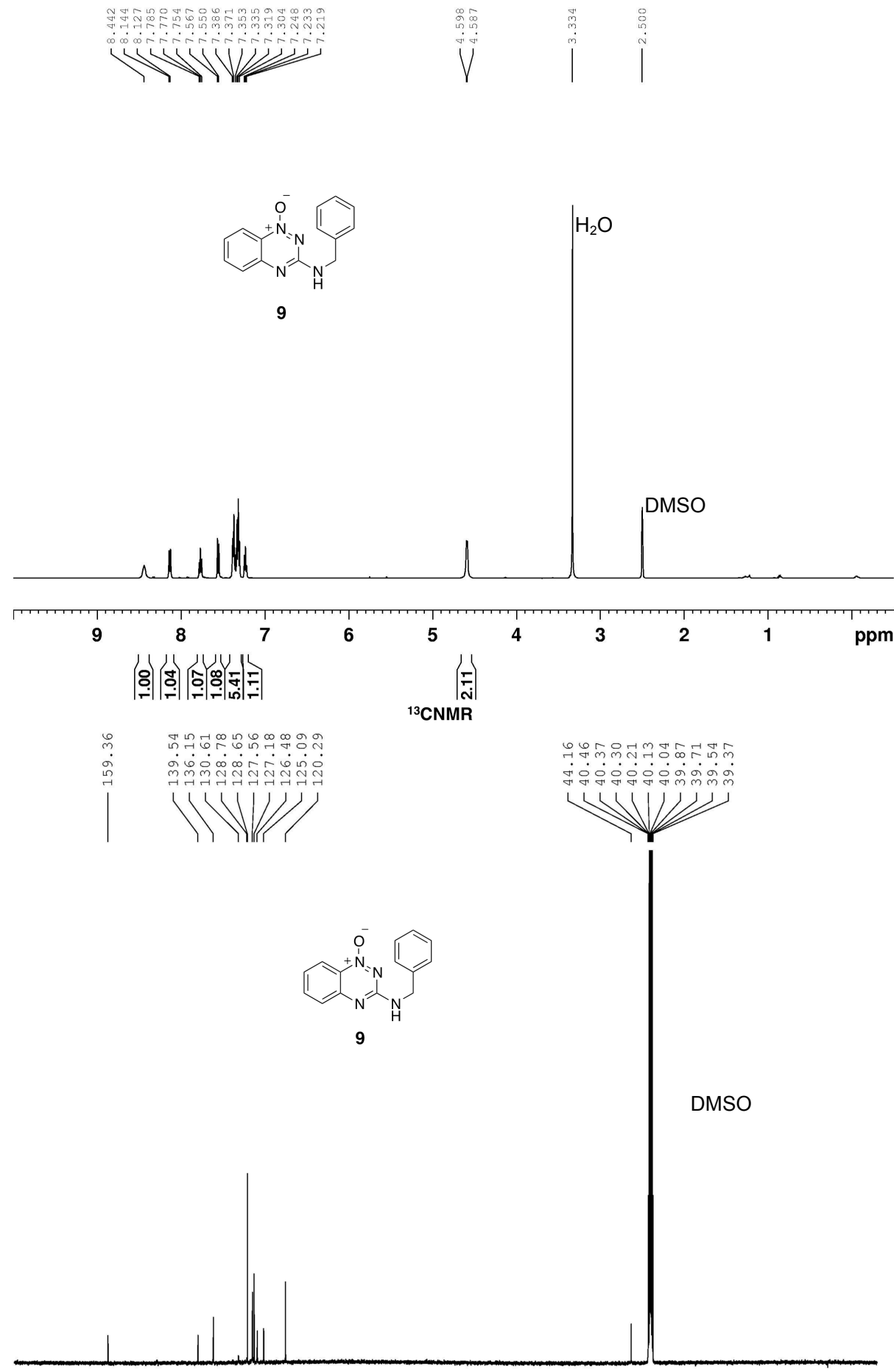

$\begin{array}{llllllllllllllllll}170 & 160 & 150 & 140 & 130 & 120 & 110 & 100 & 90 & 80 & 70 & 60 & 50 & 40 & 30 & 20 & 10 & 0\end{array}$ 
${ }^{1} \mathrm{HNMR}$

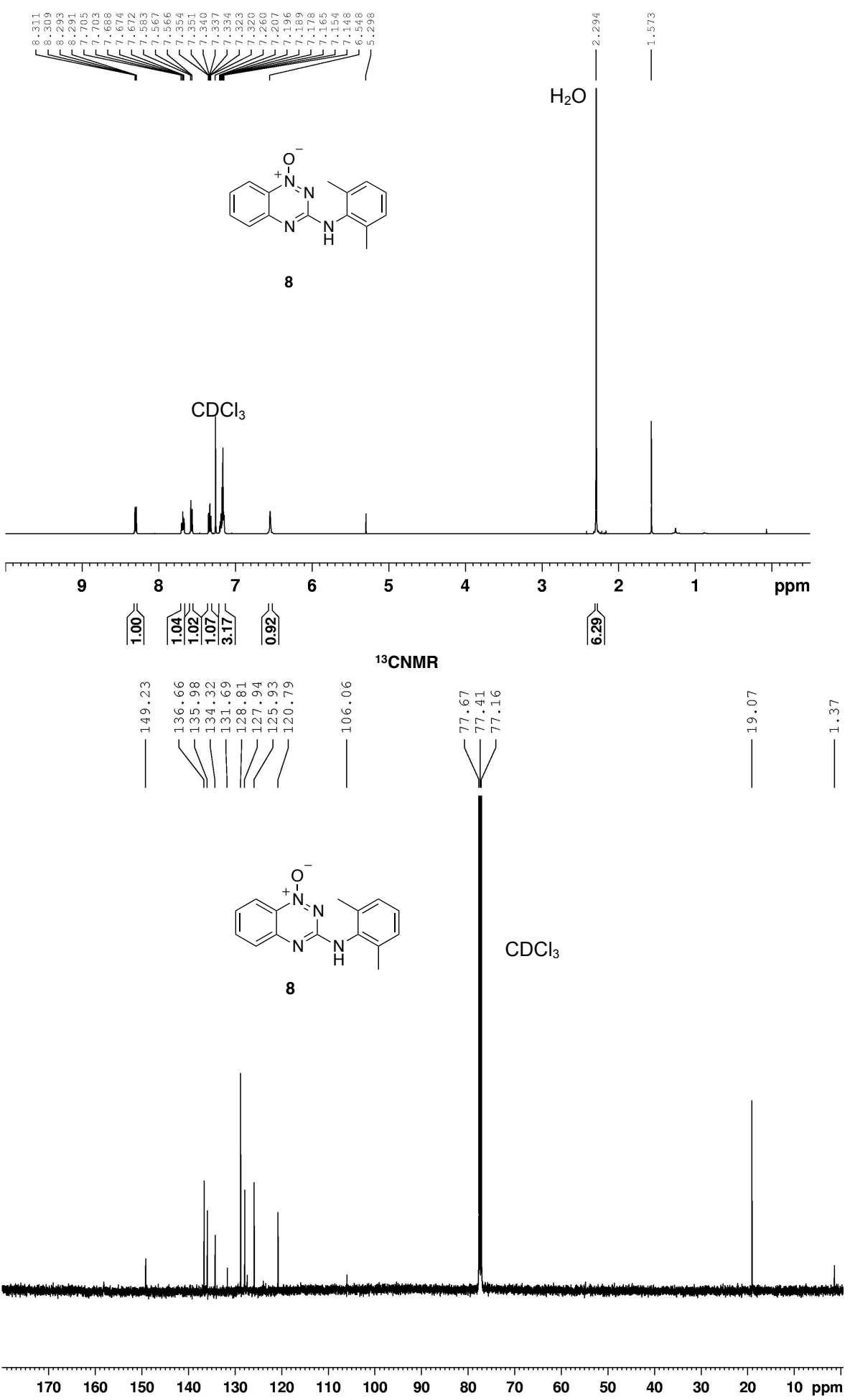



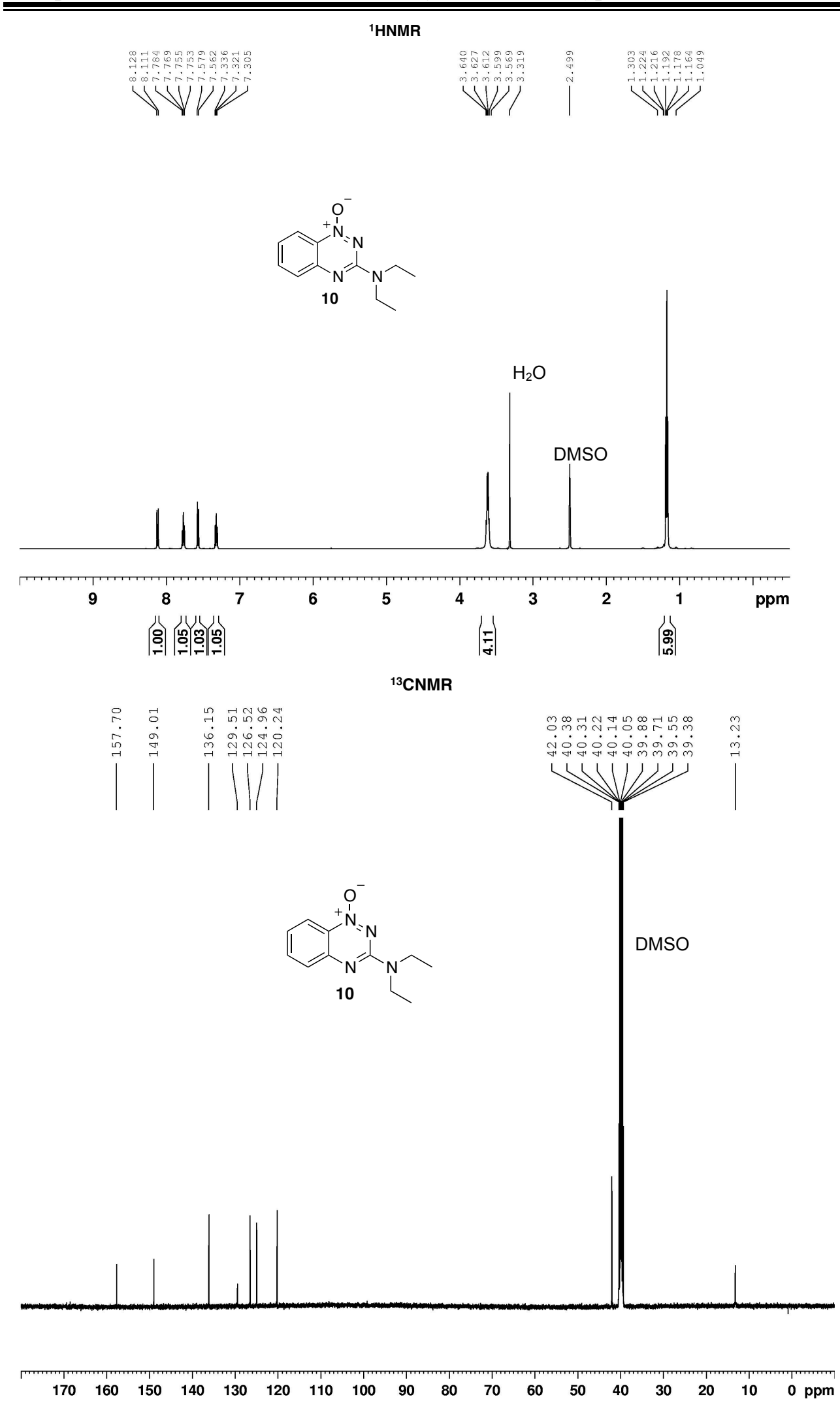
${ }^{1}$ HNMR

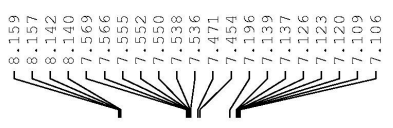

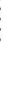
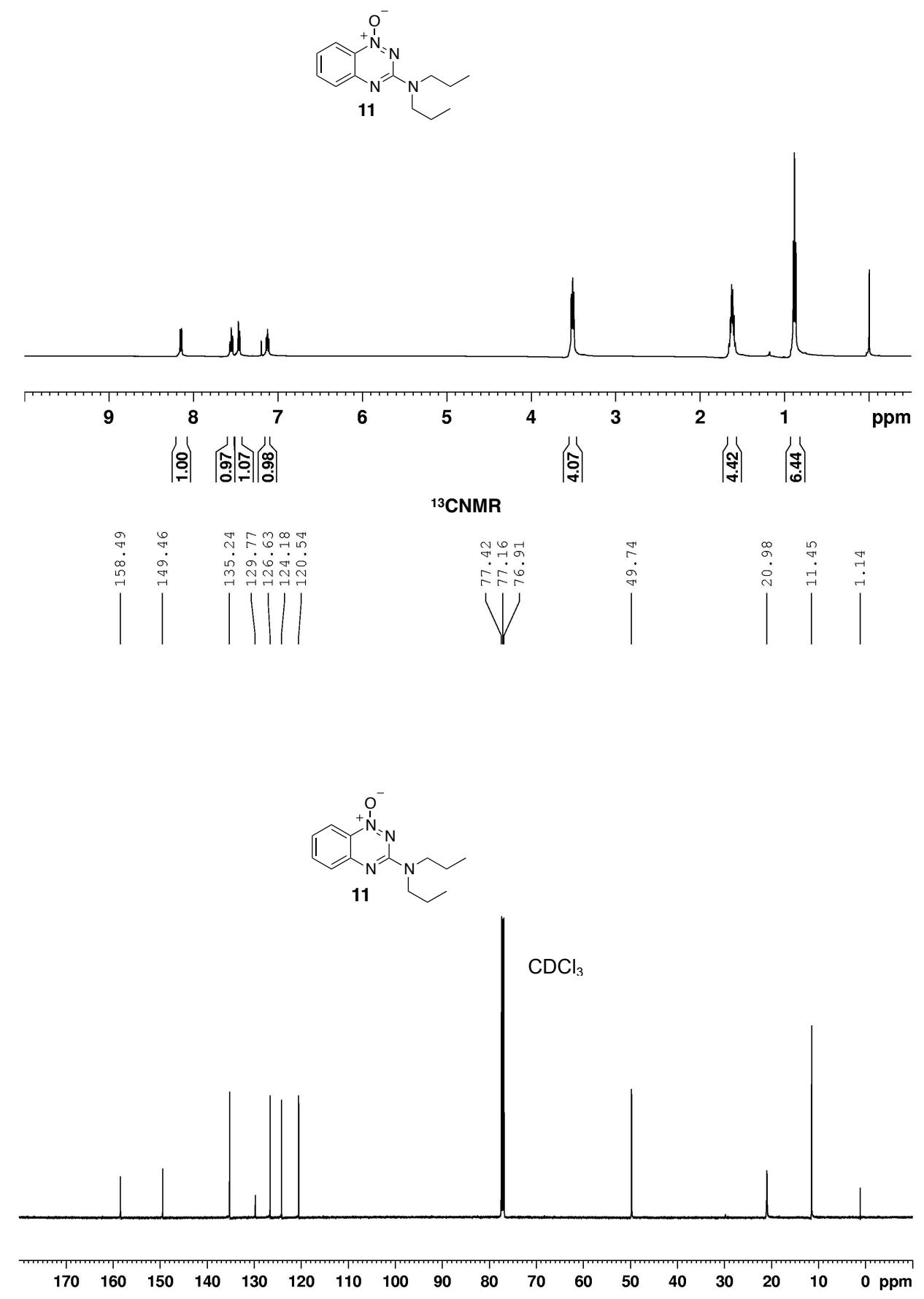
${ }^{1}$ HNMR
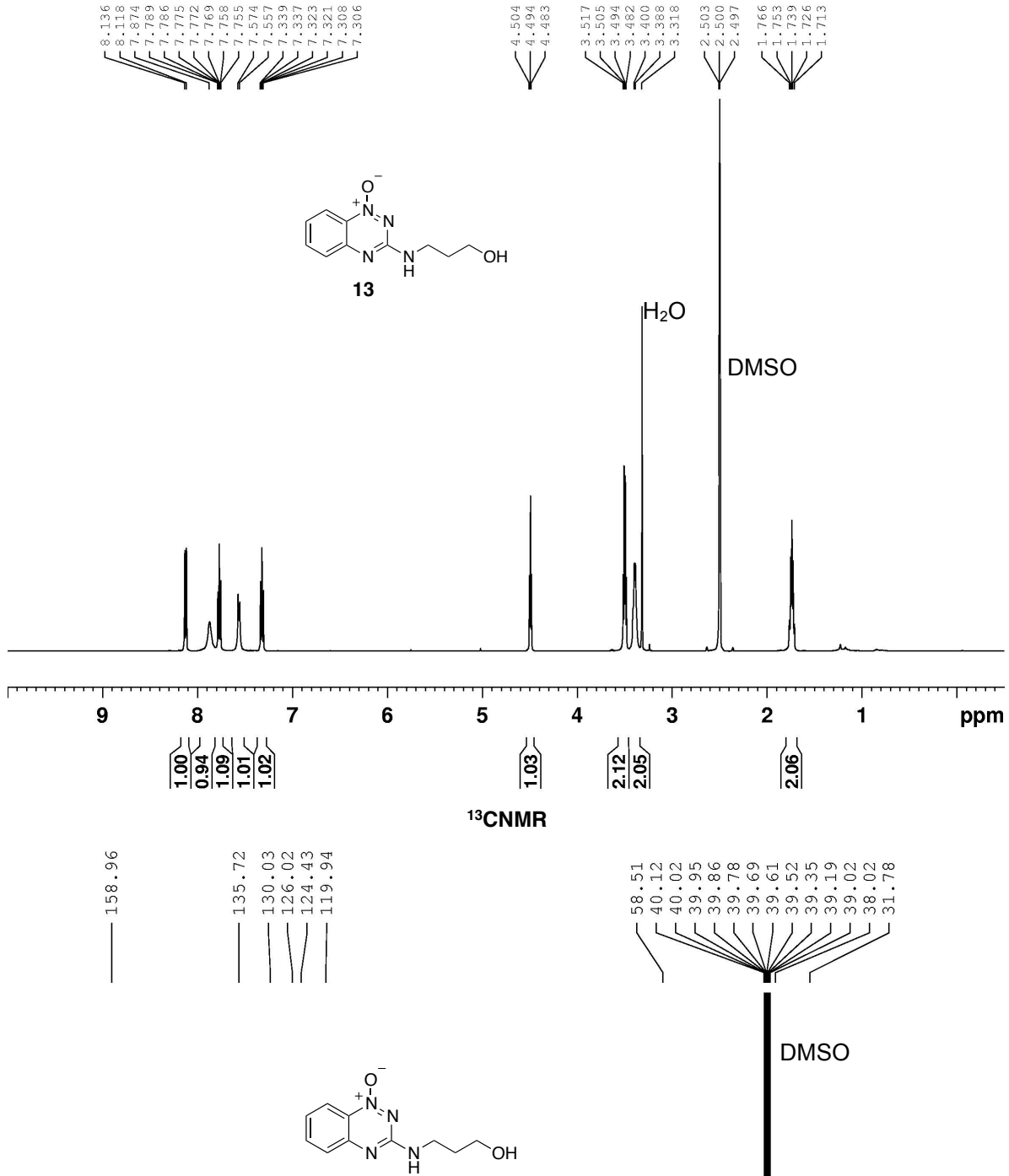

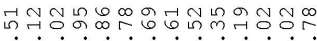

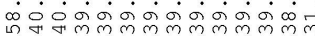

$\dot{m} \dot{0} \dot{0}$

11

13

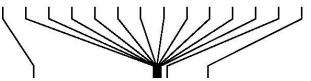

DMSO

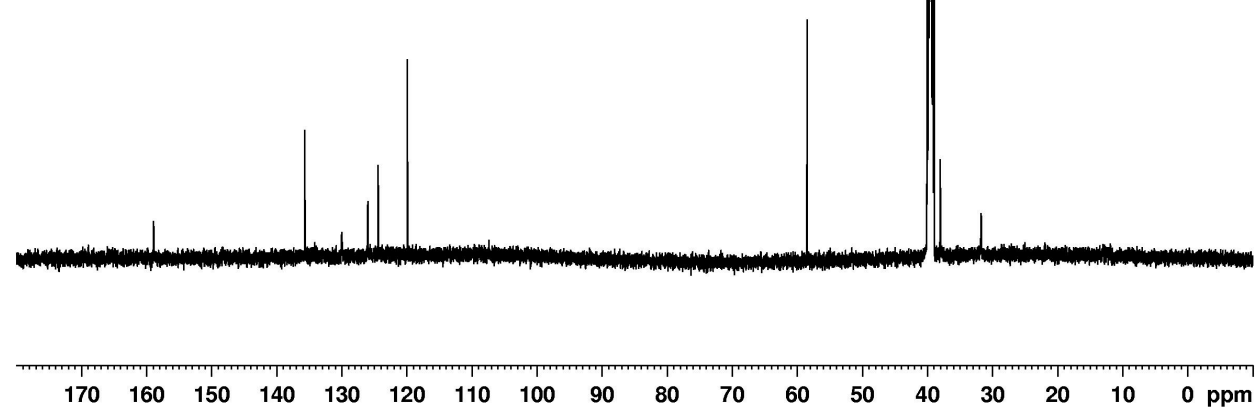


1HNMR
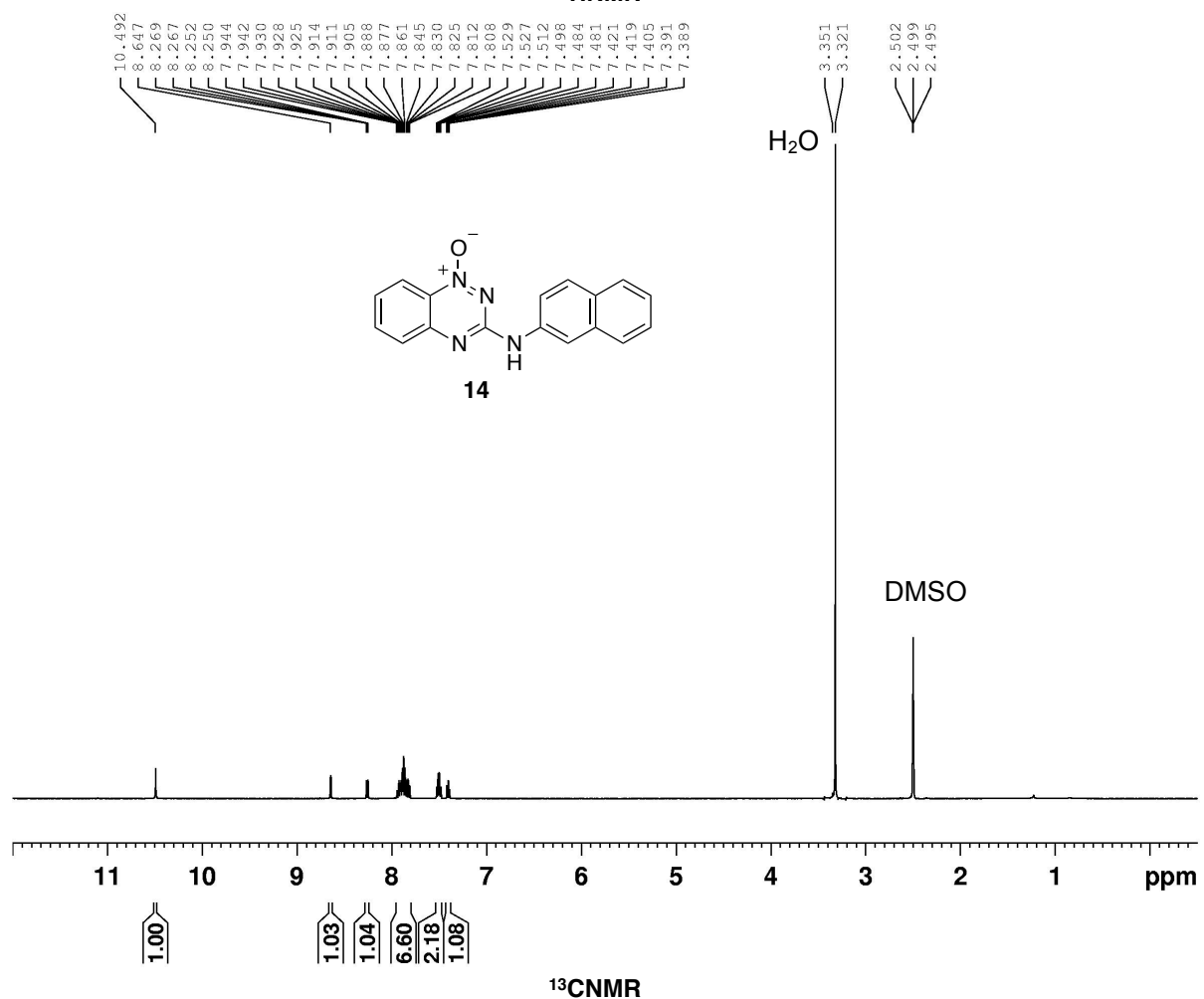

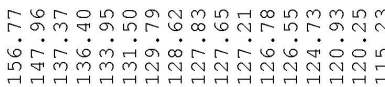

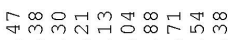

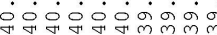

13
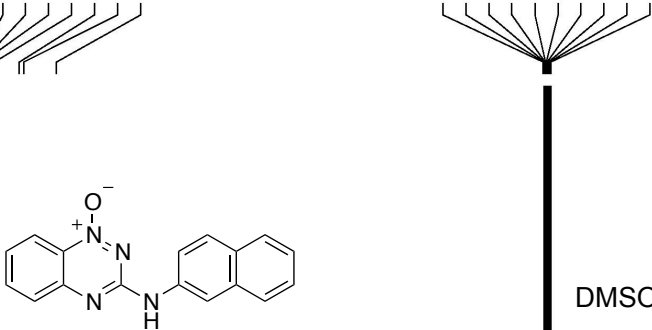

14

DMSO
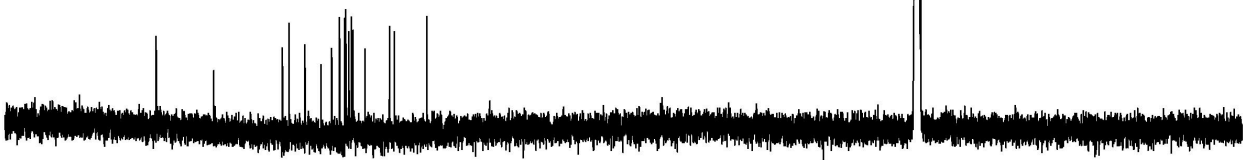

$\begin{array}{llllllllllllllllll}170 & 160 & 150 & 140 & 130 & 120 & 110 & 100 & 90 & 80 & 70 & 60 & 50 & 40 & 30 & 20 & 10 & 0\end{array}$ 
1HNMR
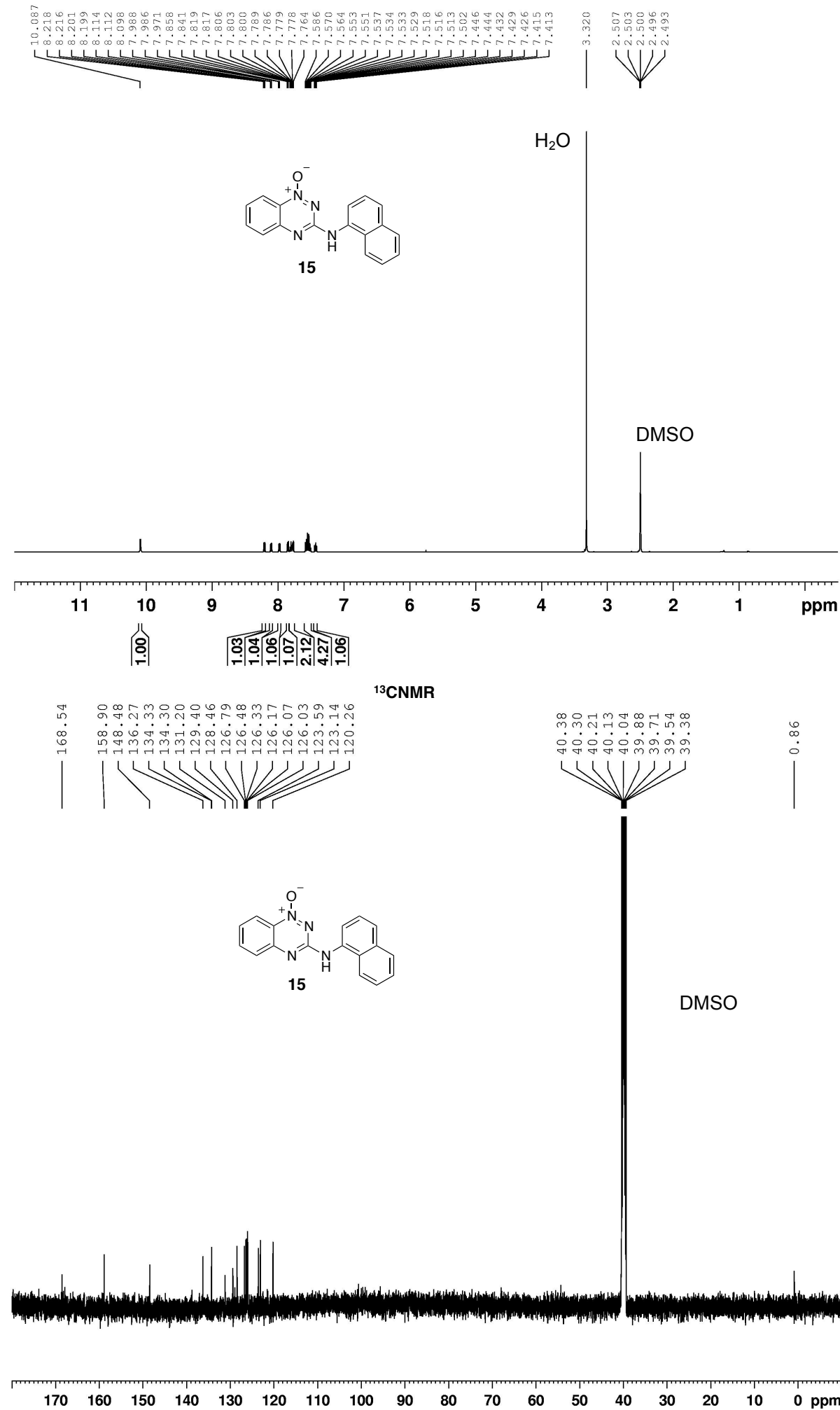

$\mathrm{H}_{2} \mathrm{O}$ 

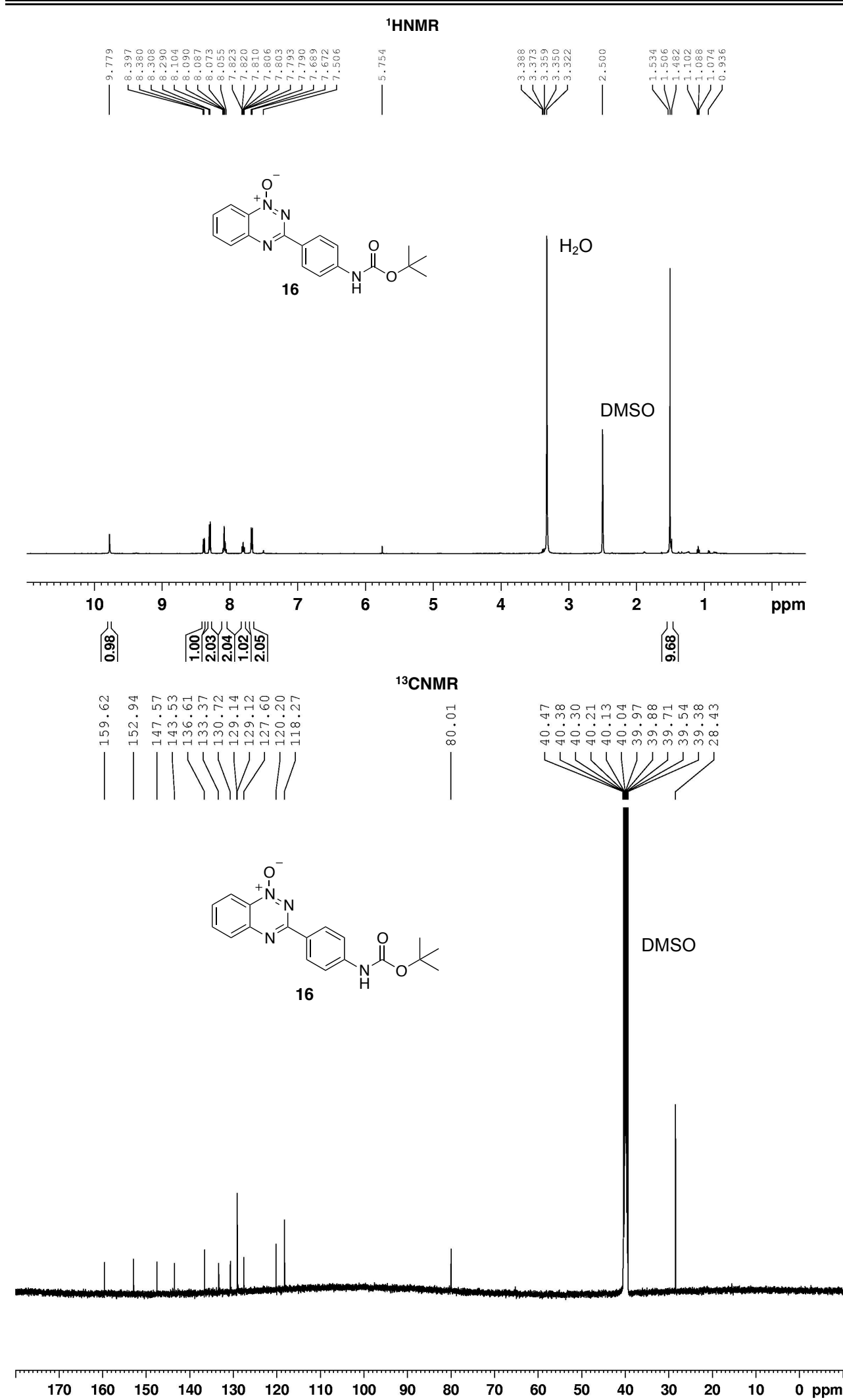
${ }^{1}$ HNMR
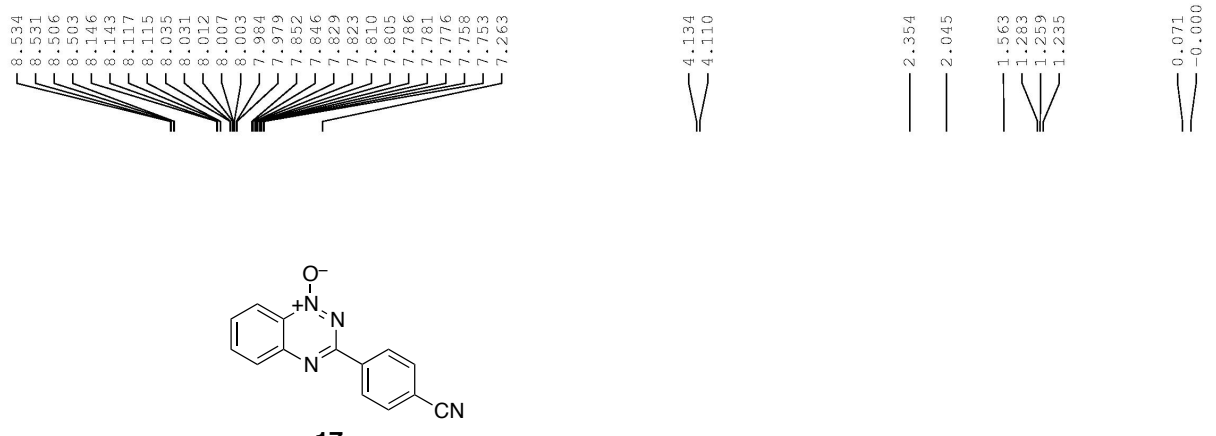

17

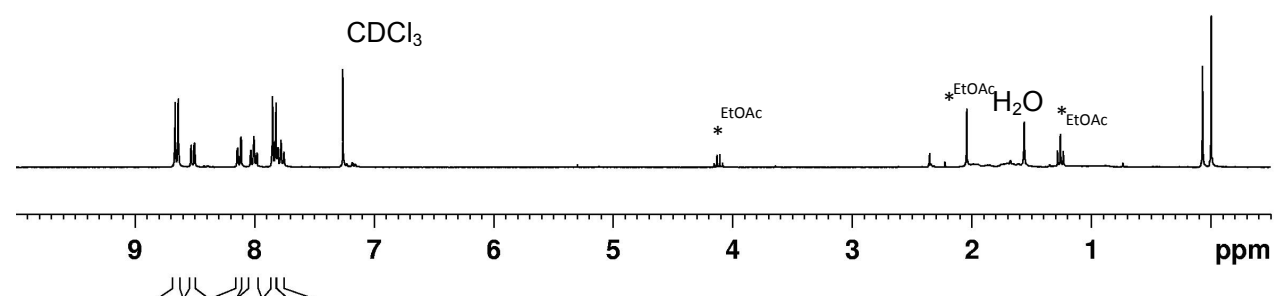

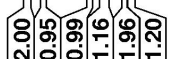

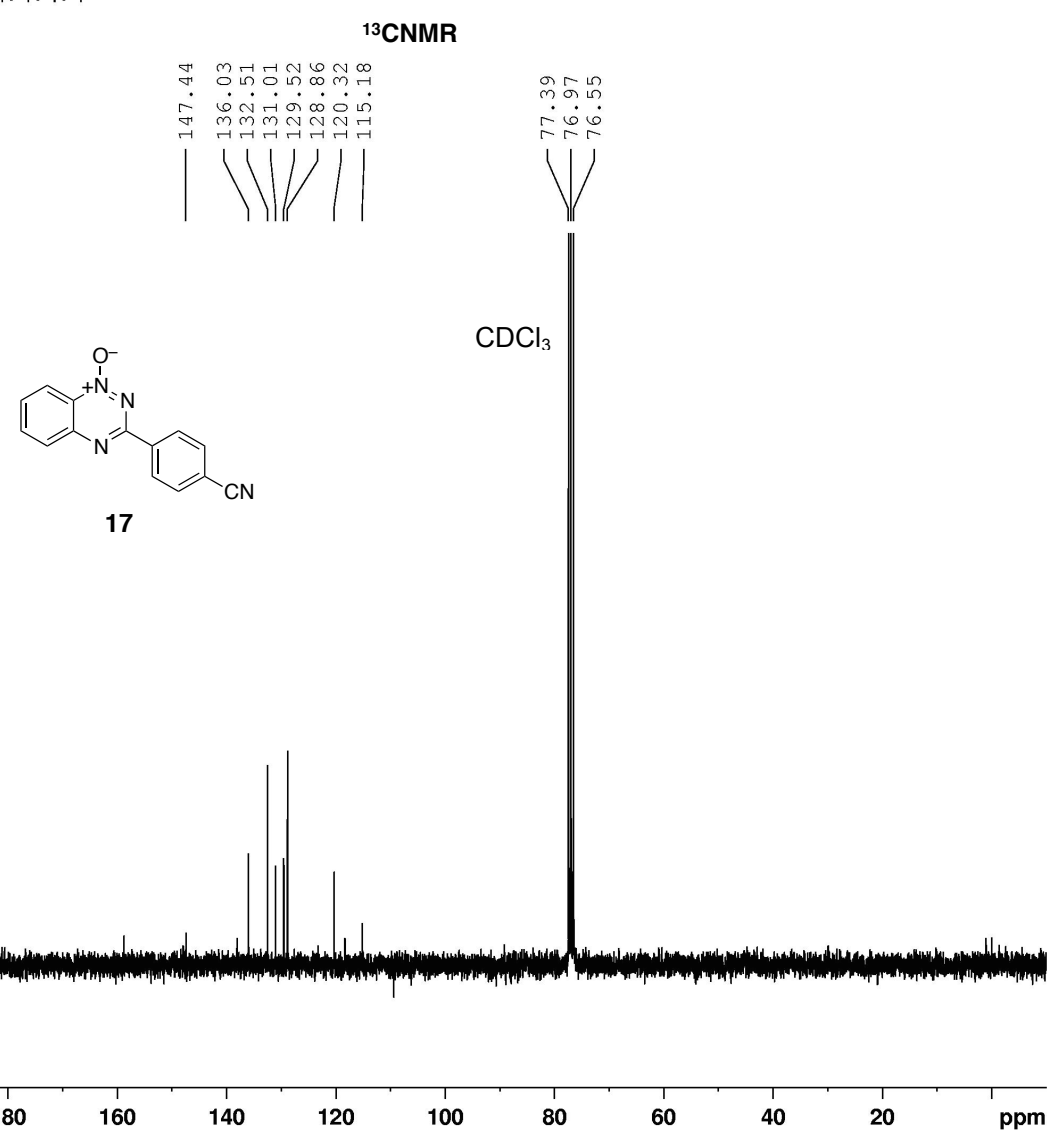


${ }^{1}$ HNMR
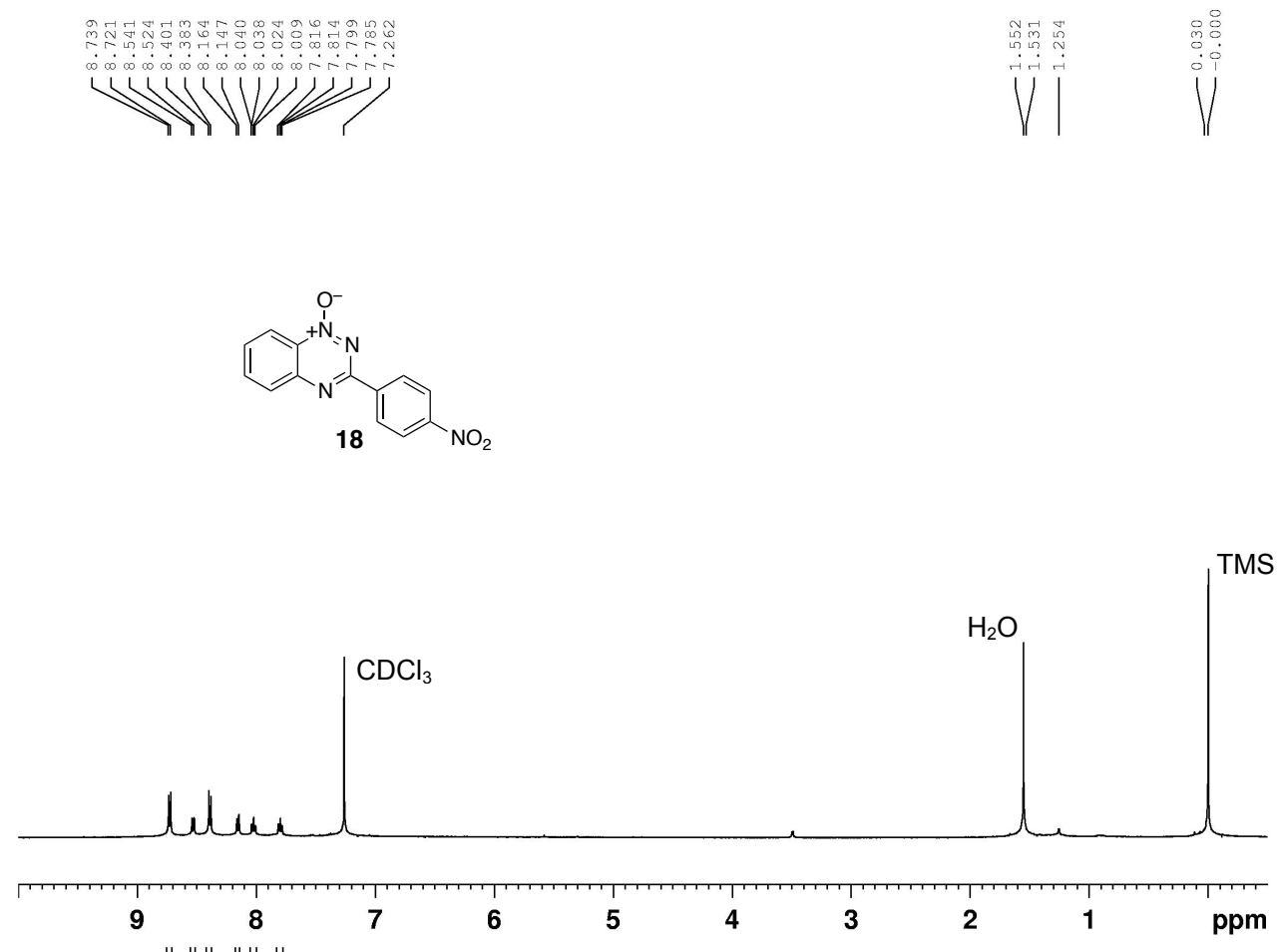

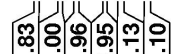

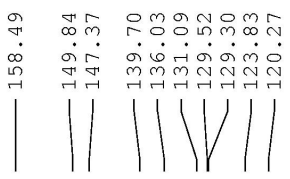

${ }^{13}$ CNMR

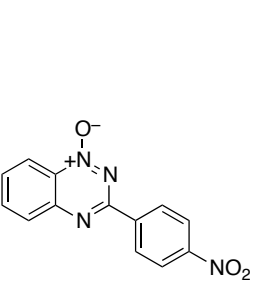

누요용

두용

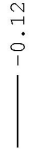

18

$\mathrm{CDCl}_{3}$

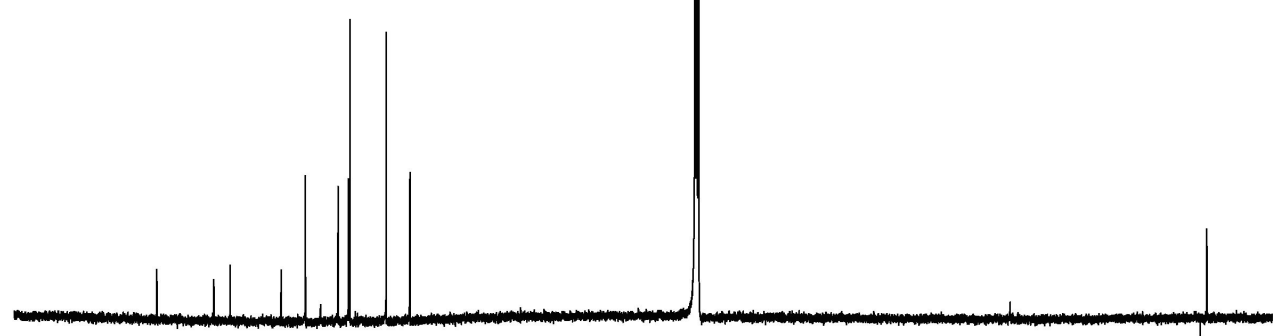

$\begin{array}{llllllllllllllllll}170 & 160 & 150 & 140 & 130 & 120 & 110 & 100 & 90 & 80 & 70 & 60 & 50 & 40 & 30 & 20 & 10 & 0\end{array}$ 
1HNMR
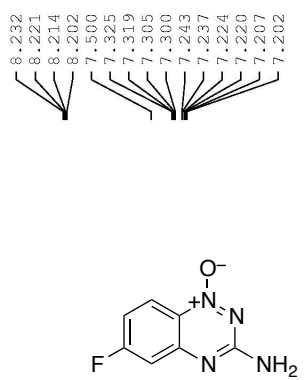

19

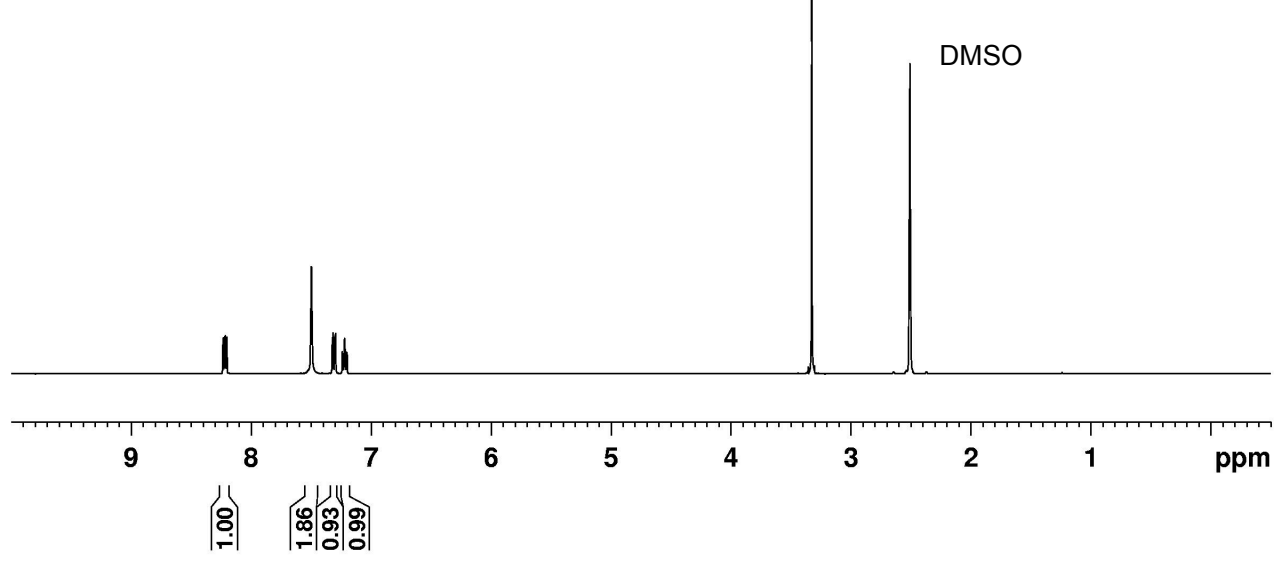

${ }^{13}$ CNMR
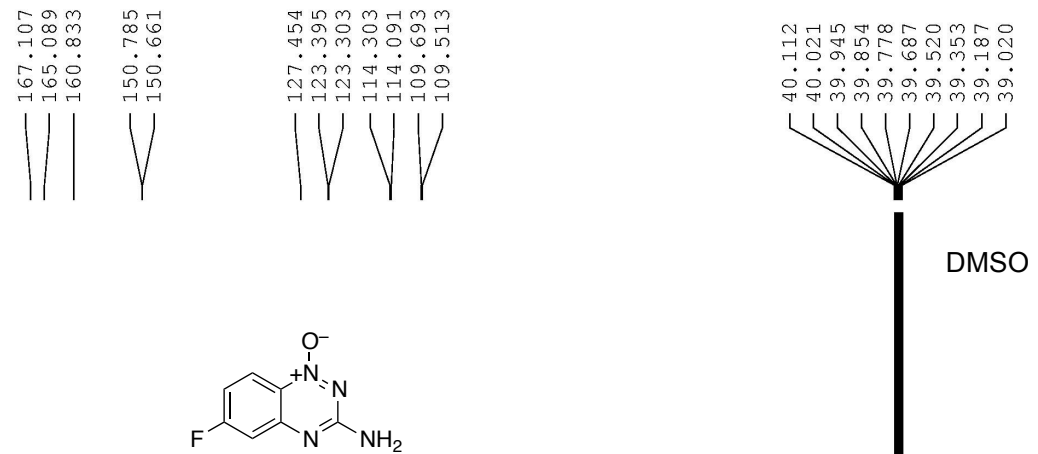

19

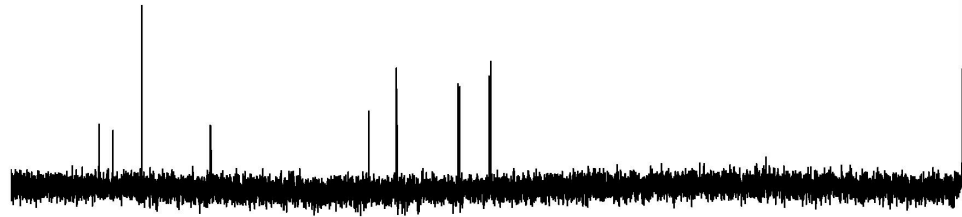

MSO

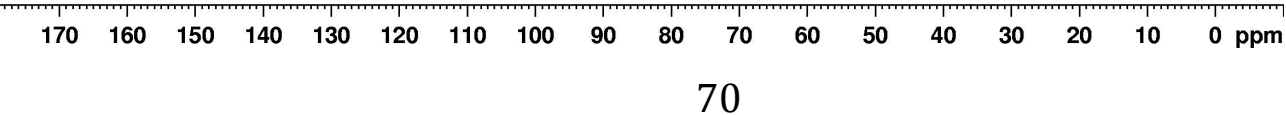


${ }^{1}$ HNMR

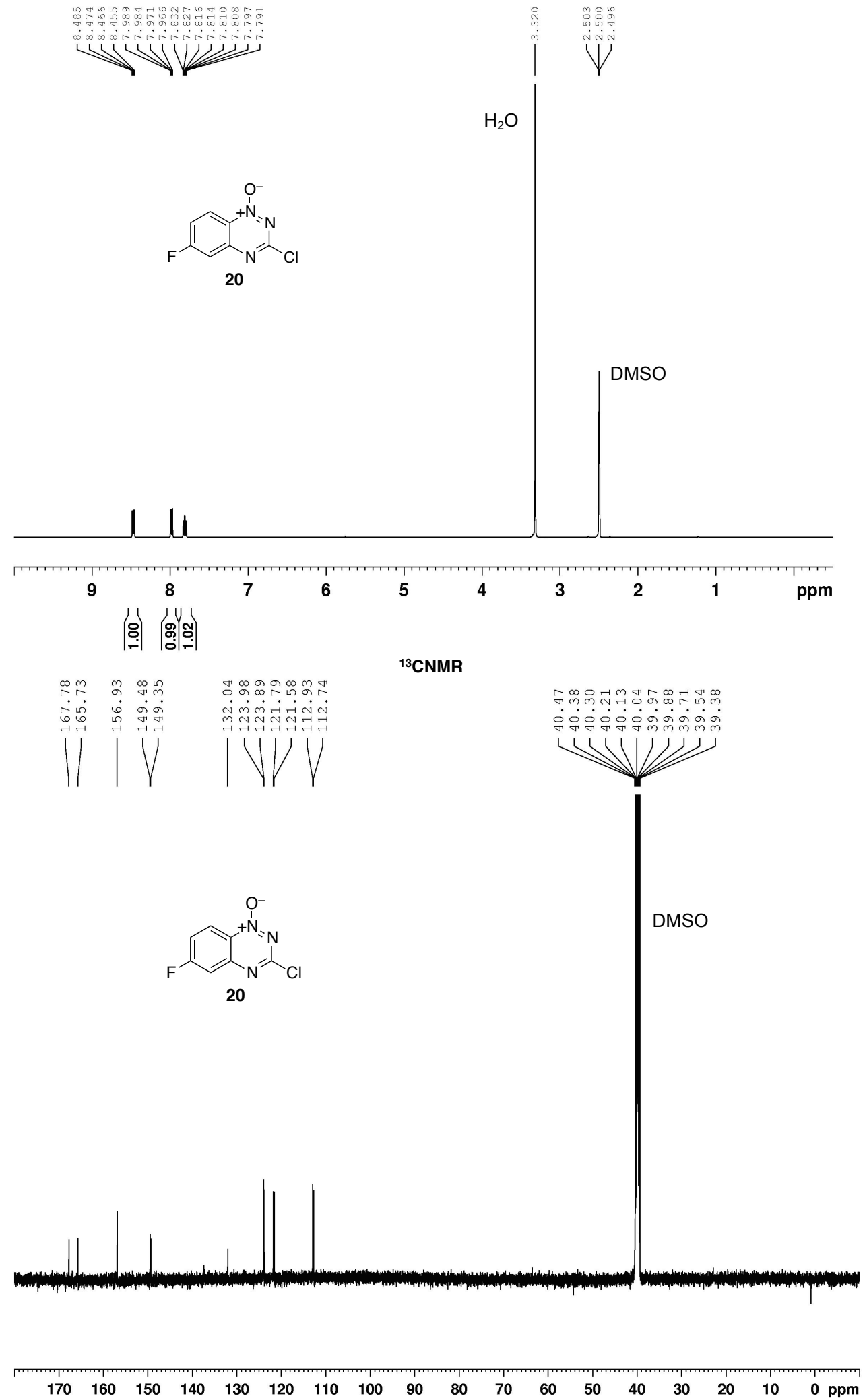


${ }^{1}$ HNMR

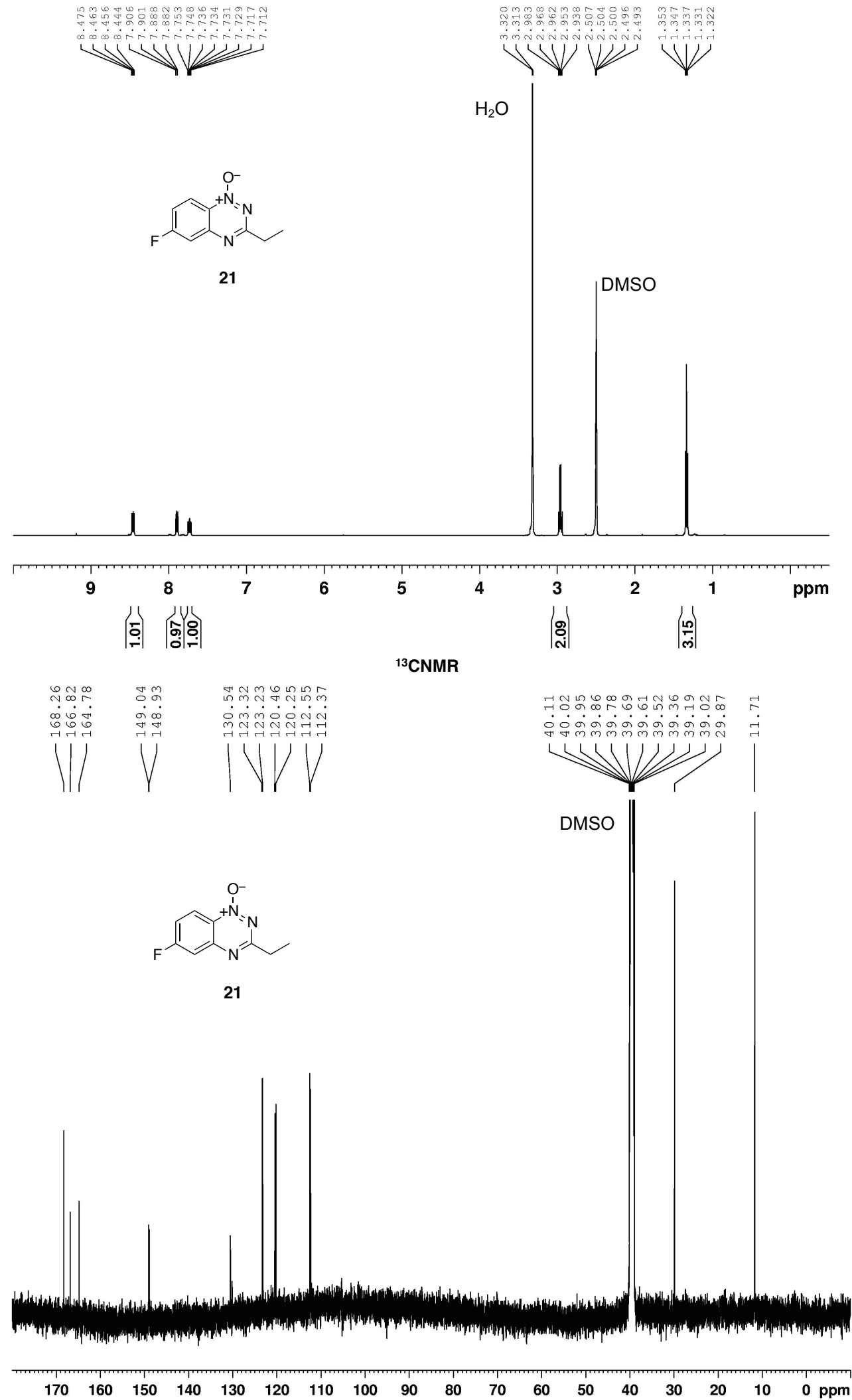


${ }^{1}$ HNMR
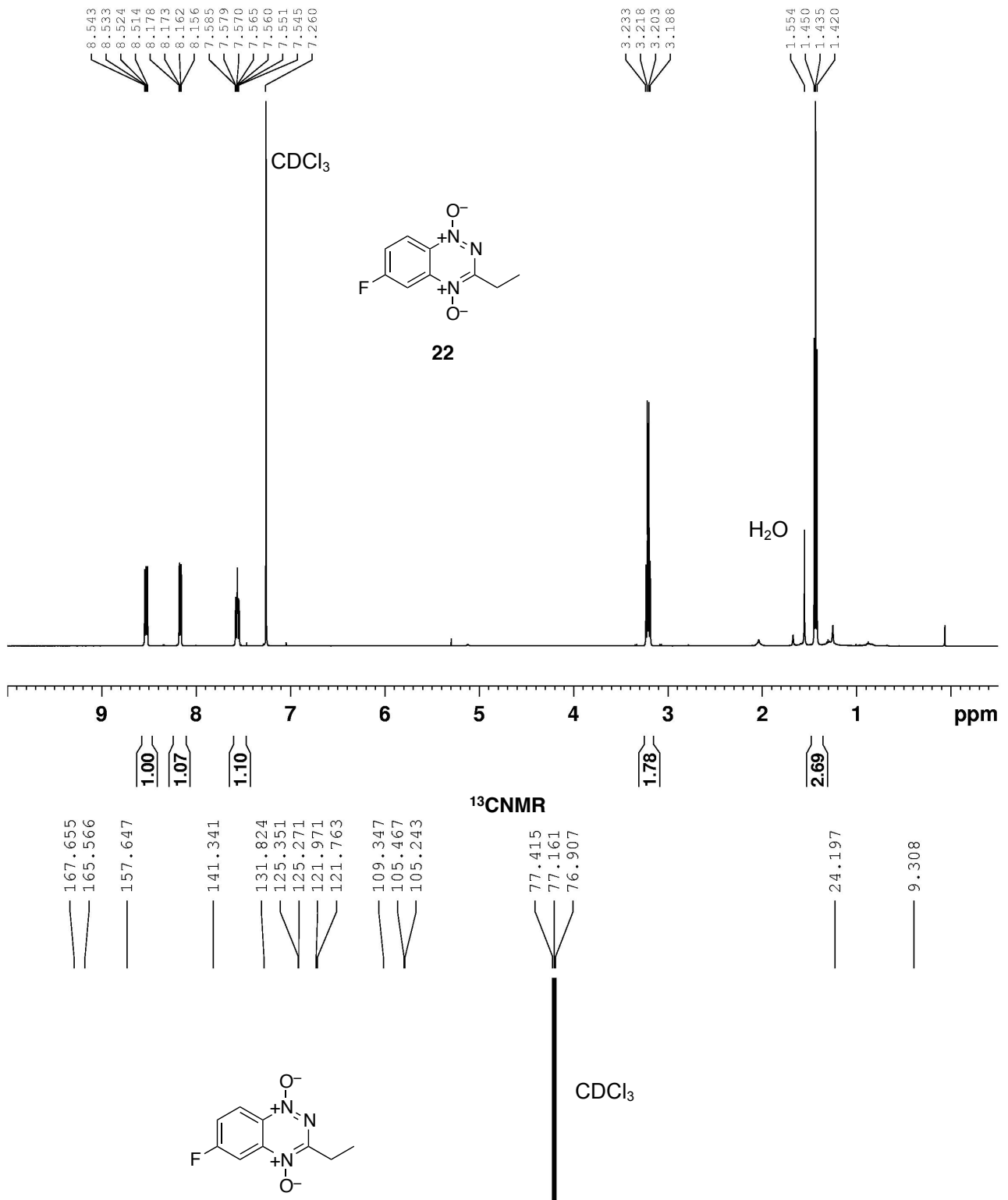

$\mathrm{CDCl}_{3}$

22
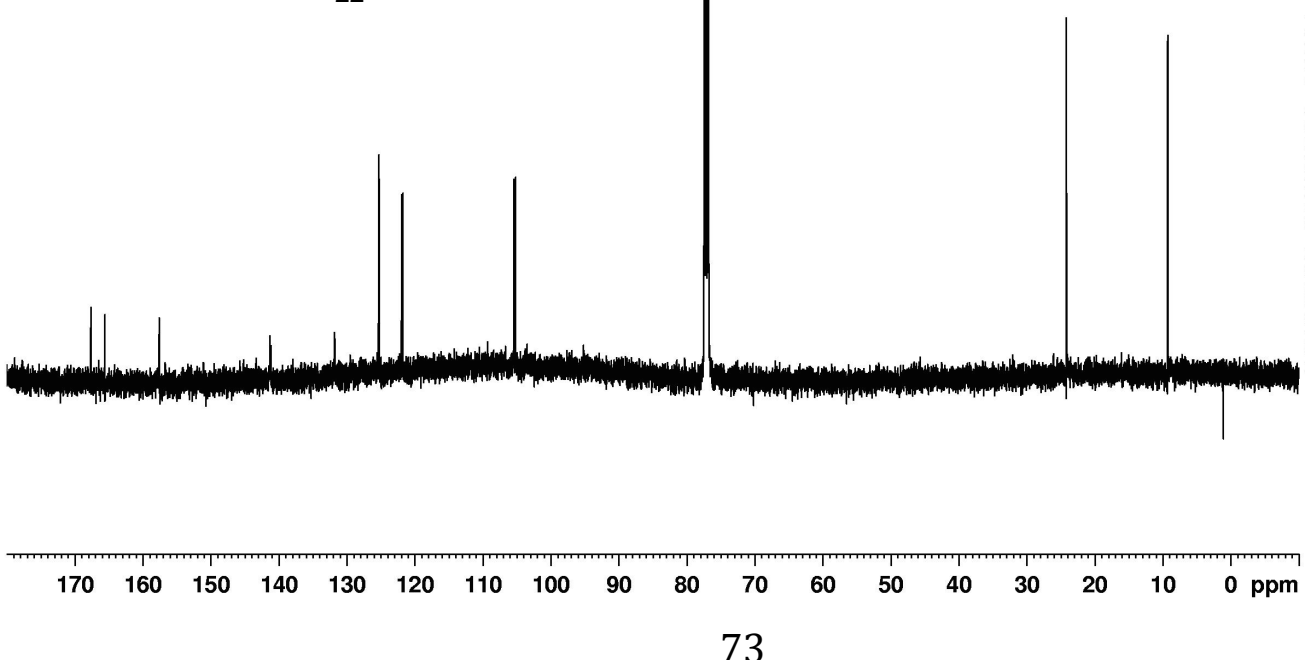


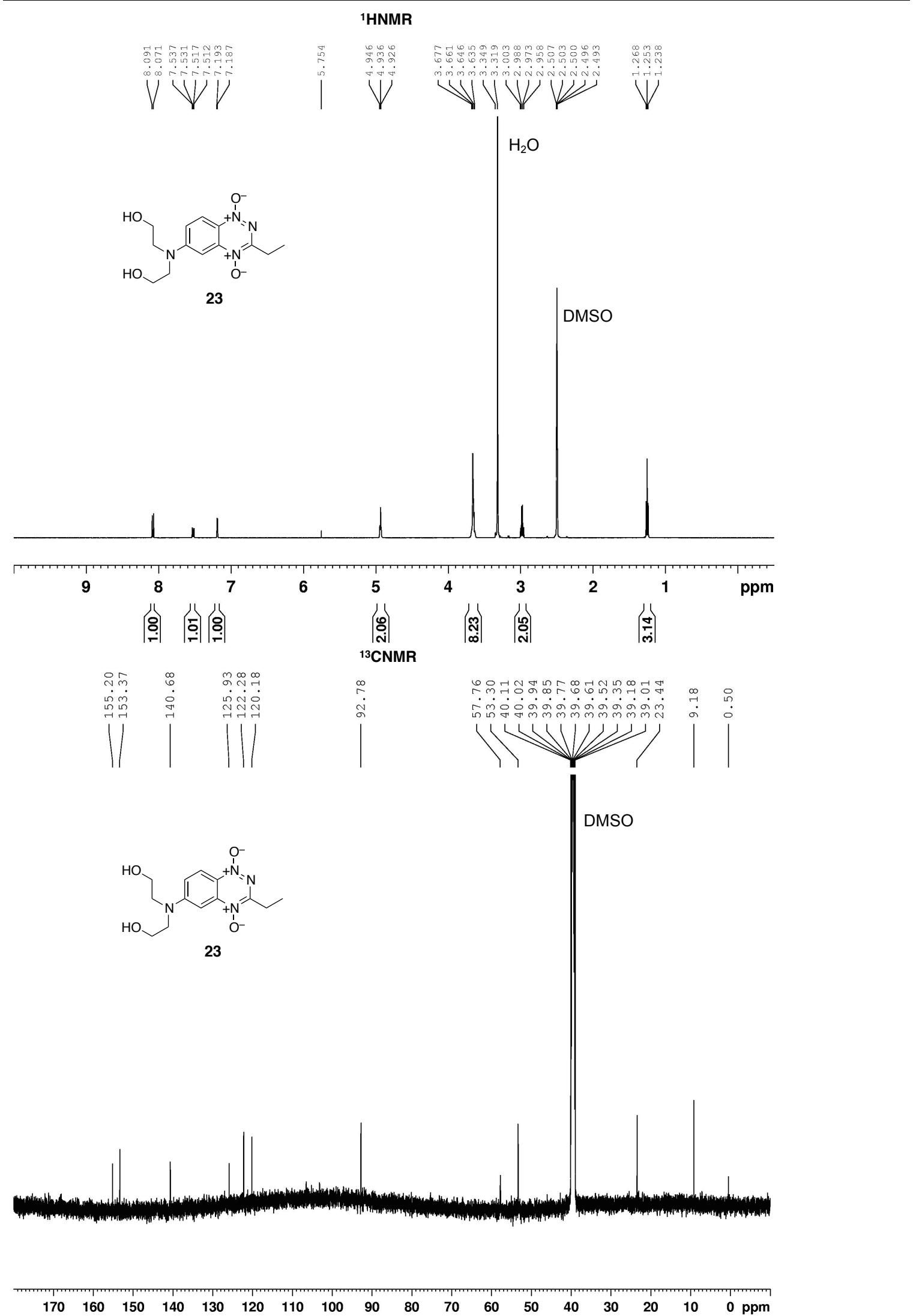


1HNMR
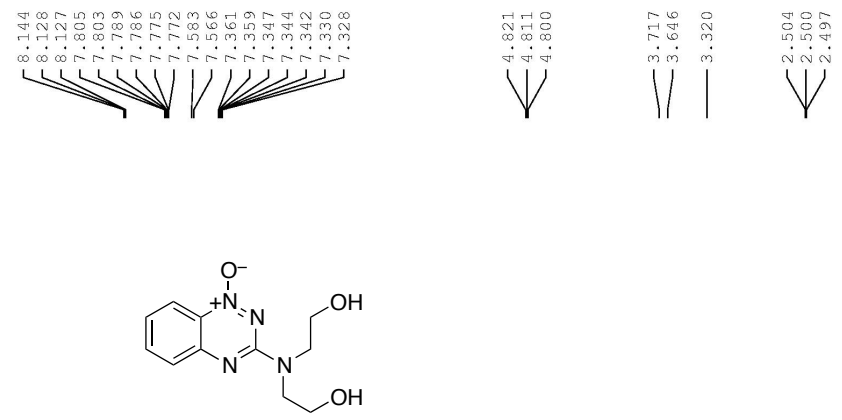

24
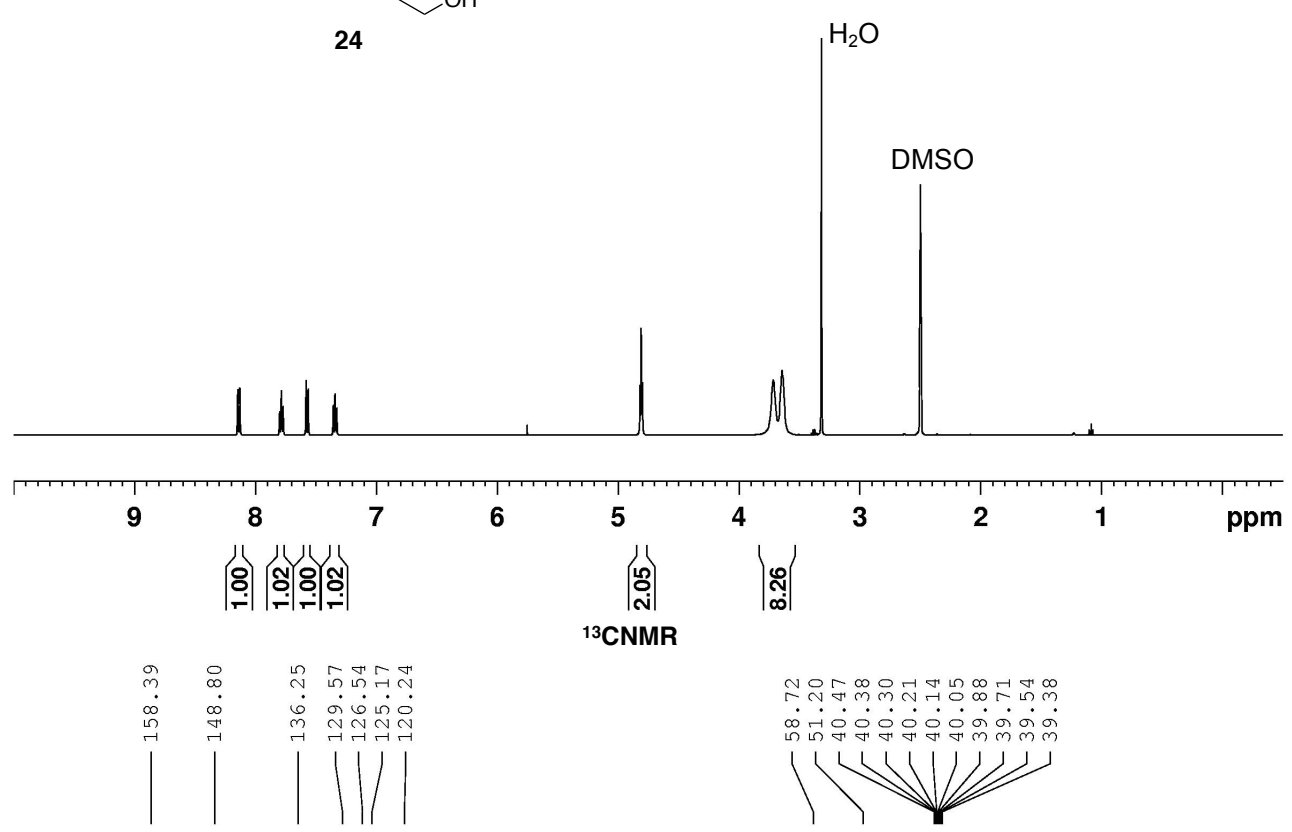

${ }^{13}$ CNMR

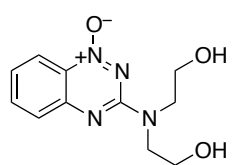

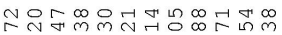

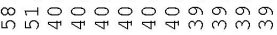

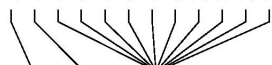

24

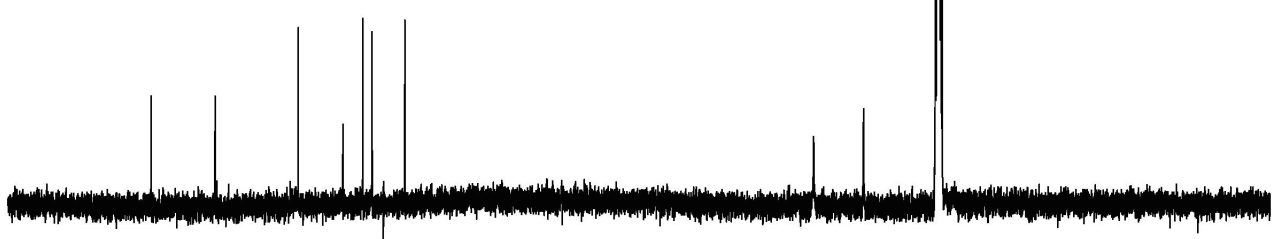

$\begin{array}{lllllllllllllllllll}170 & 160 & 150 & 140 & 130 & 120 & 110 & 100 & 90 & 80 & 70 & 60 & 50 & 40 & 30 & 20 & 10 & 0 & \text { ppm }\end{array}$ 
1HNMR

0
0

$\underbrace{\infty}_{1} \operatorname{los}^{\infty} \cos ^{\circ}$
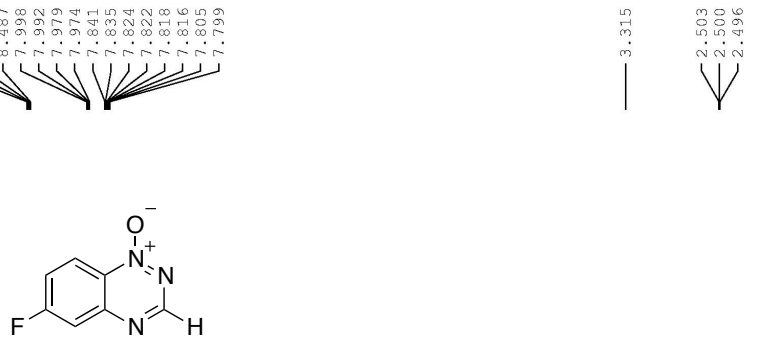

27

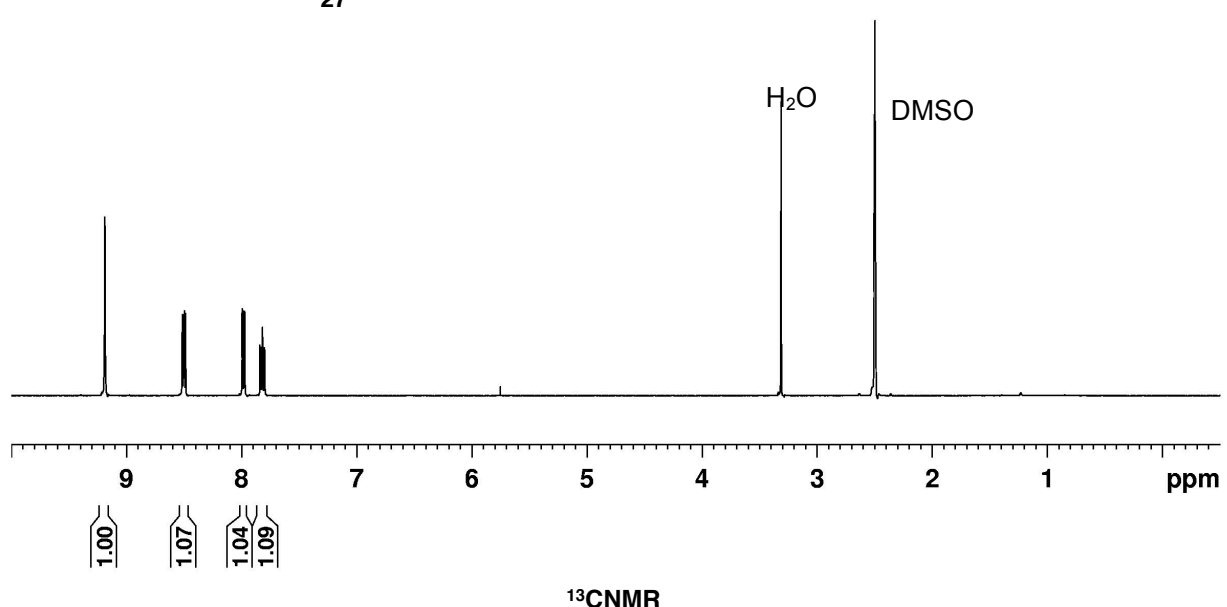

${ }^{13}$ CNMR
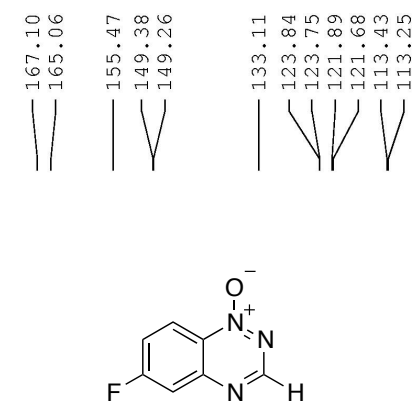

27

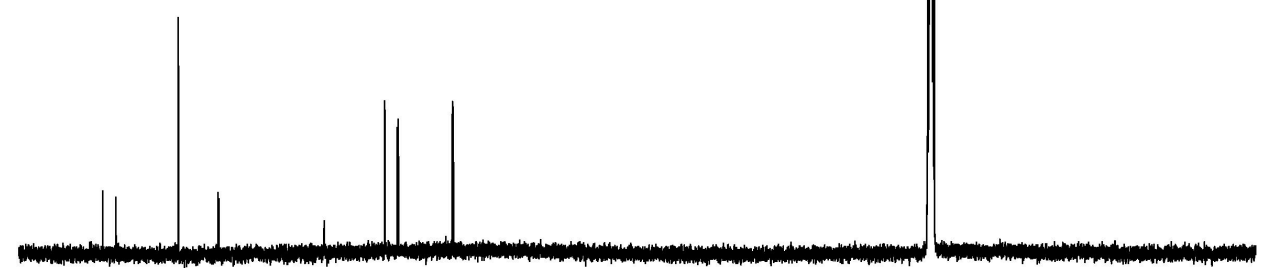

$\begin{array}{lllllllllllllllllll}170 & 160 & 150 & 140 & 130 & 120 & 110 & 100 & 90 & 80 & 70 & 60 & 50 & 40 & 30 & 20 & 10 & 0 & \mathrm{ppm}\end{array}$ 
${ }^{1}$ HNMR
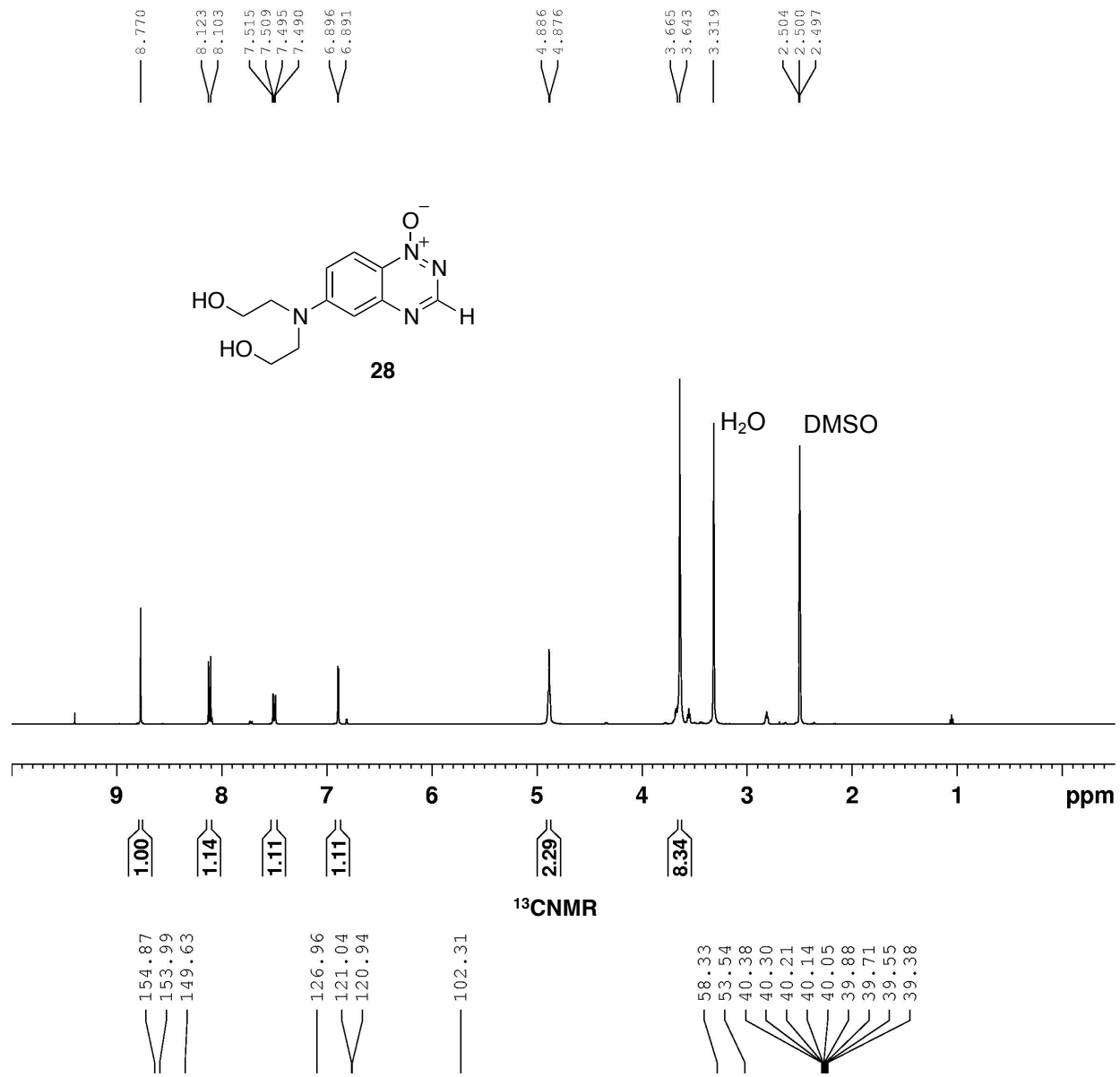

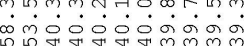

$11+1 / 4$

DMSO<smiles>[O-]c1[nH+]cnc2cc(N(CCO)CCO)ccc12</smiles>

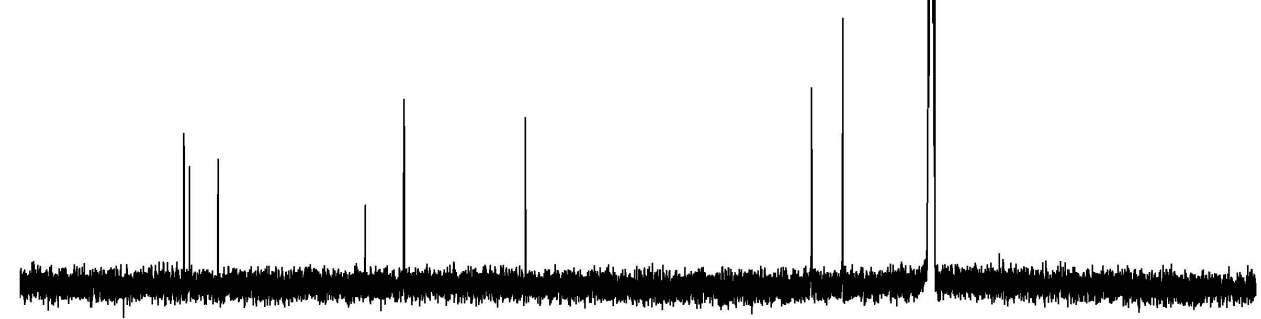

$\begin{array}{llllllllllllllllll}170 & 160 & 150 & 140 & 130 & 120 & 110 & 100 & 90 & 80 & 70 & 60 & 50 & 40 & 30 & 20 & 10 & 0\end{array}$ 
${ }^{1}$ HNMR
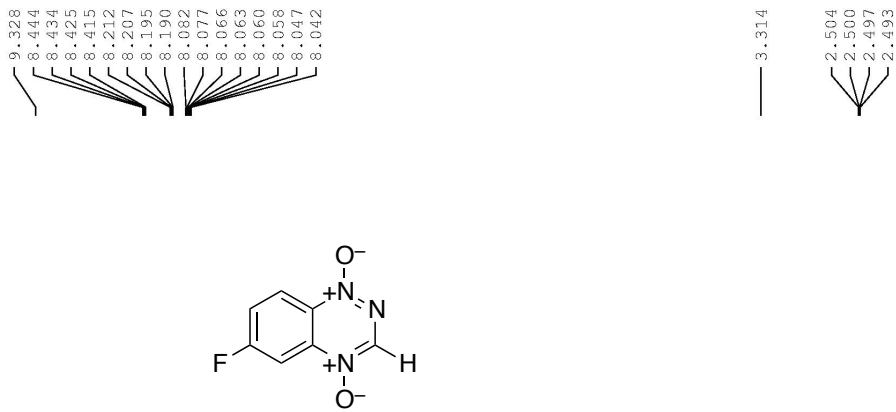

29

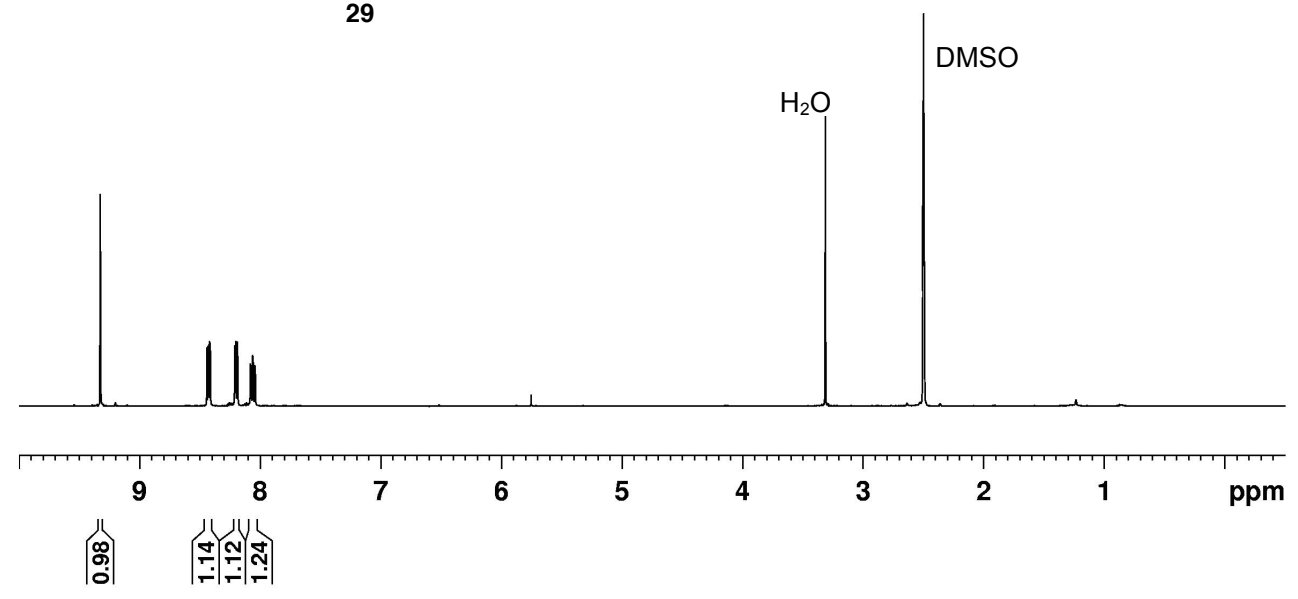

${ }^{13}$ CNMR
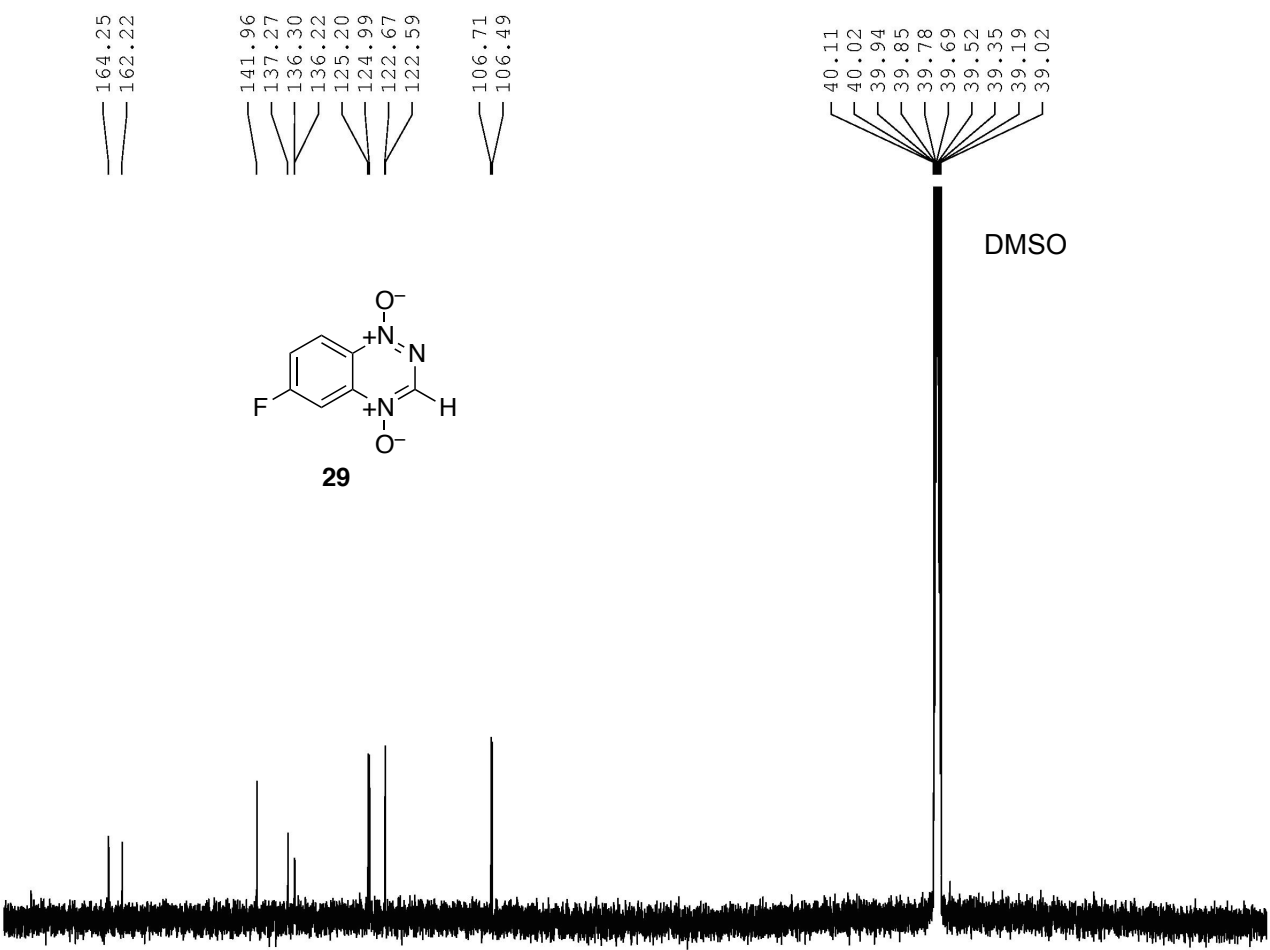

29

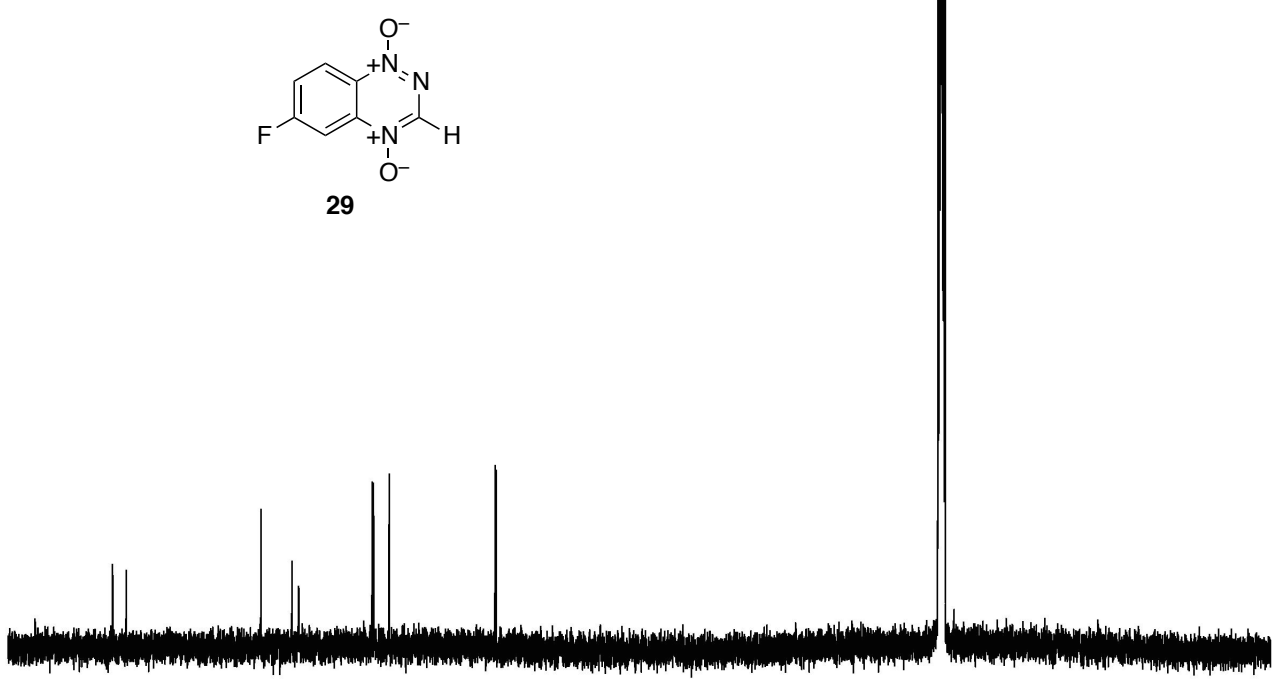

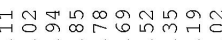

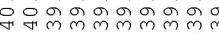

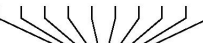

DMSO

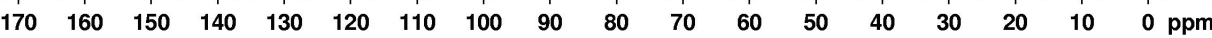




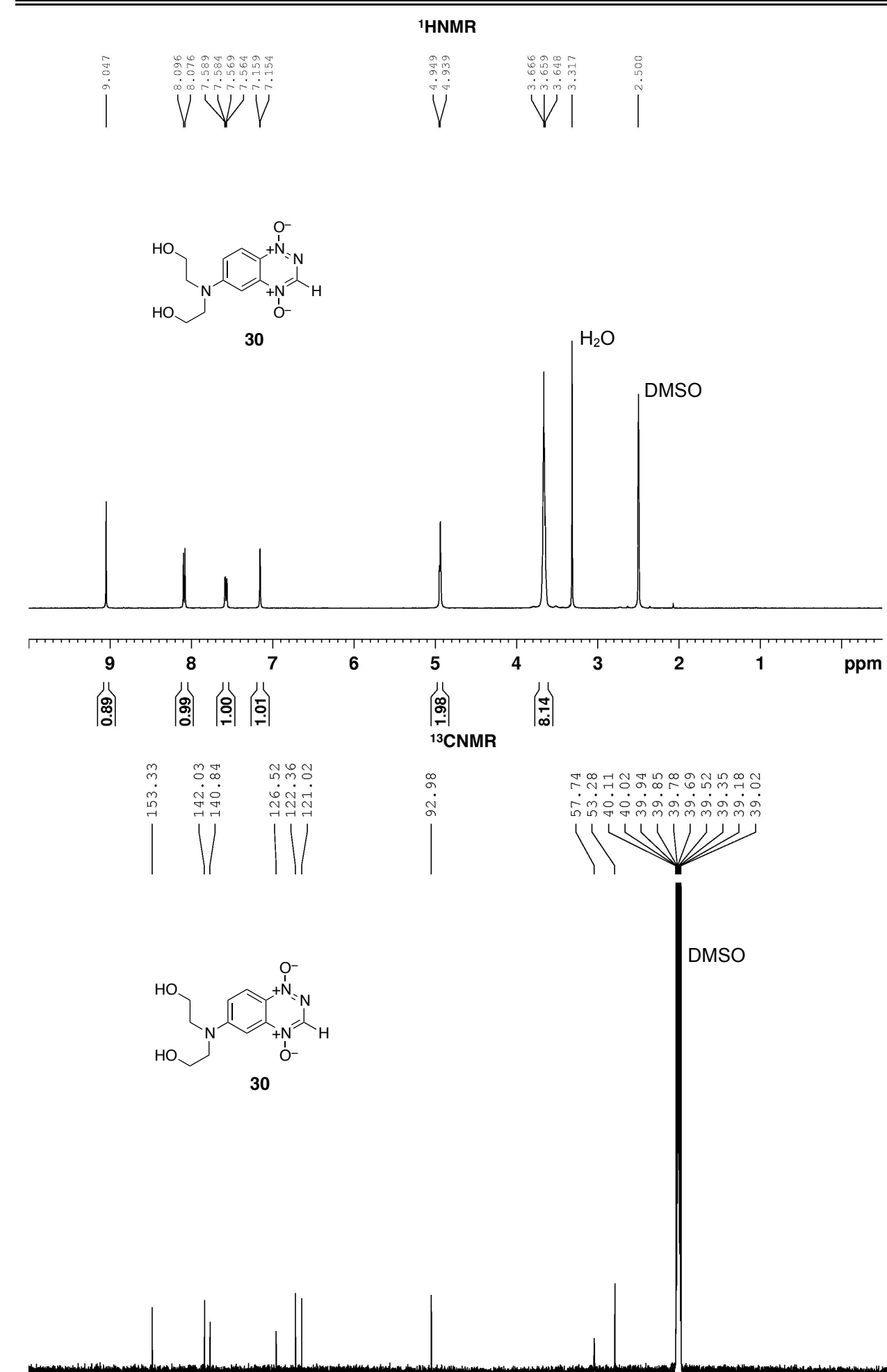

30

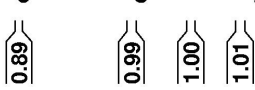

\section{m}


1HNMR
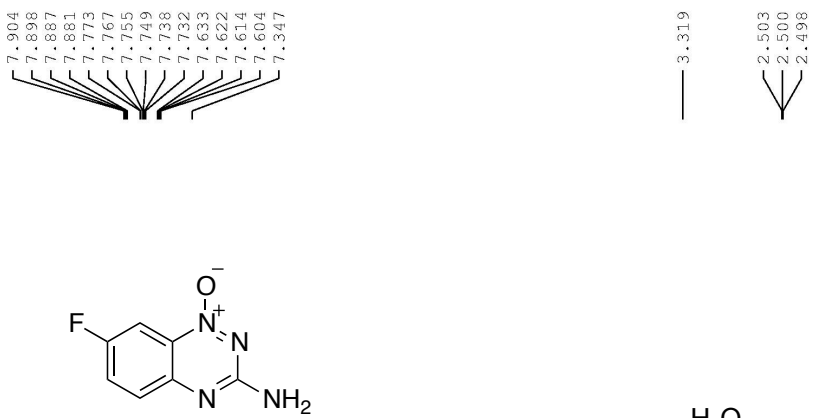

31

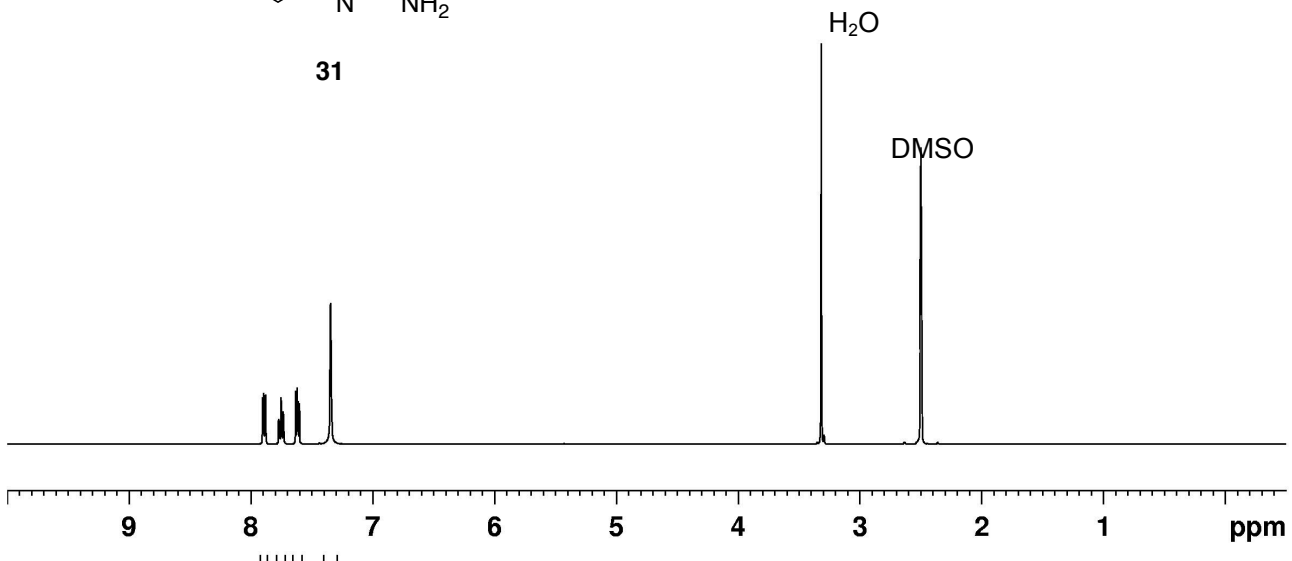

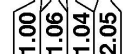

${ }^{13}$ CNMR
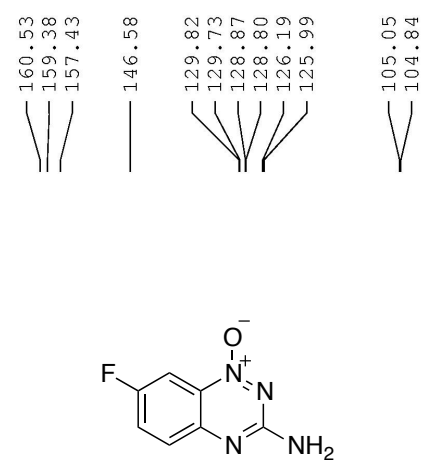

DMSO

31
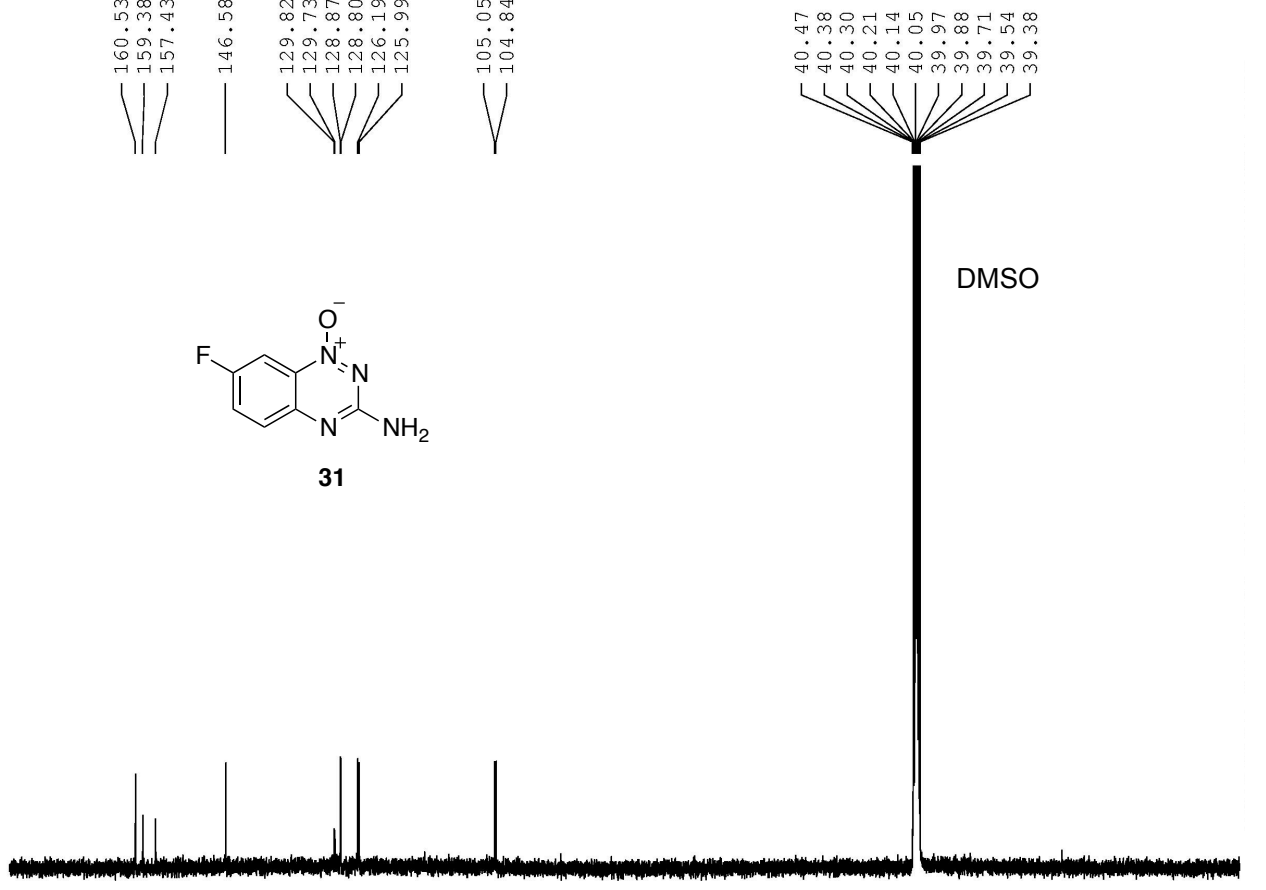

$\begin{array}{lllllllllllllllllll}170 & 160 & 150 & 140 & 130 & 120 & 110 & 100 & 90 & 80 & 70 & 60 & 50 & 40 & 30 & 20 & 10 & 0 & \mathrm{ppm}\end{array}$ 
${ }^{1}$ HNMR

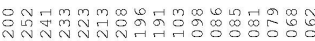

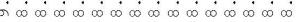

12
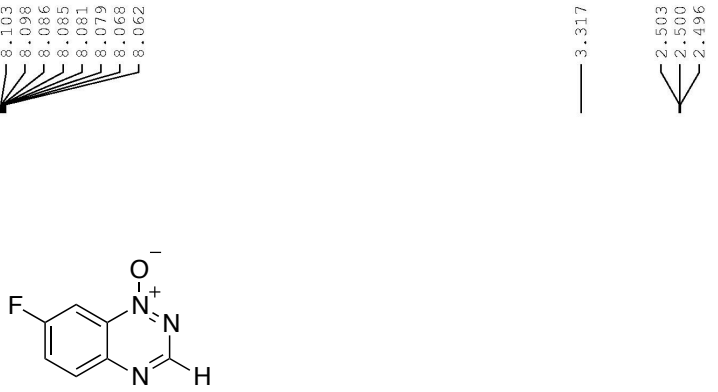

32

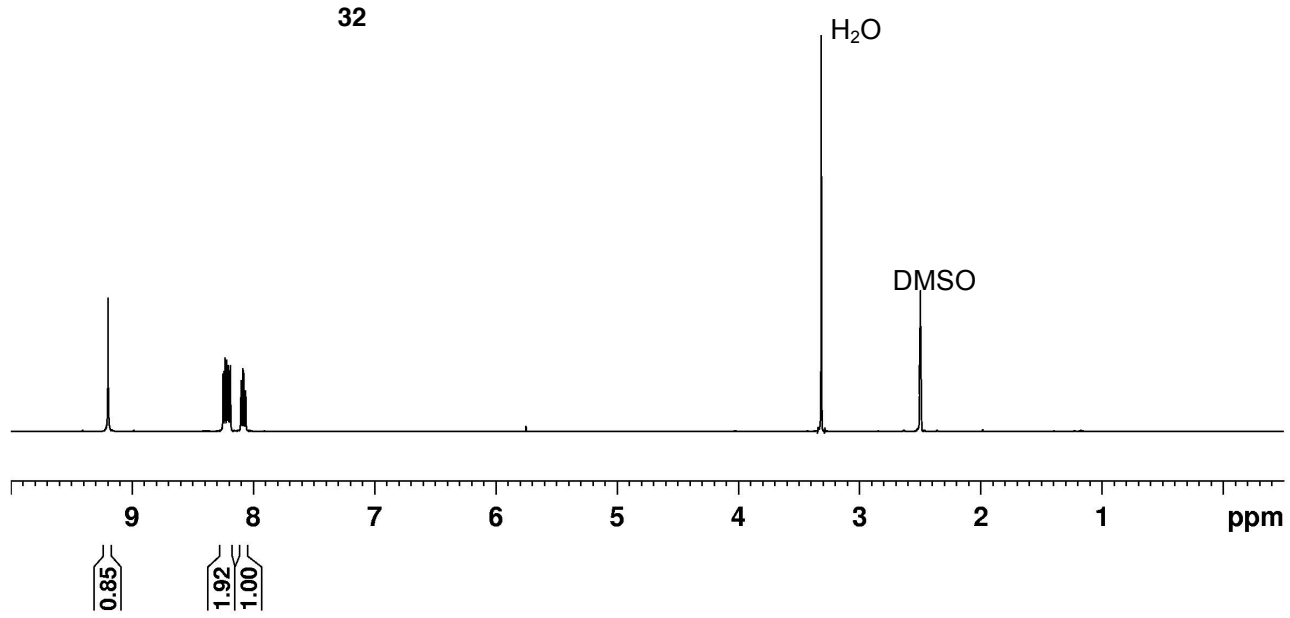

${ }^{13}$ CNMR
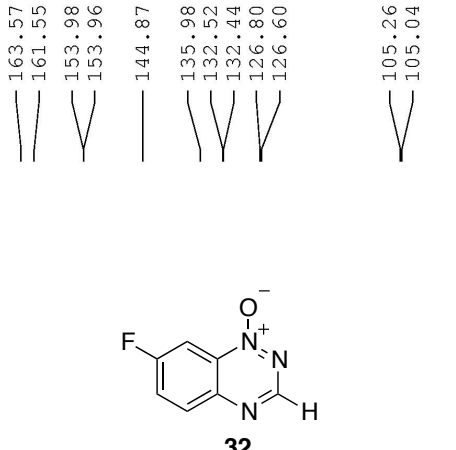

DMSO

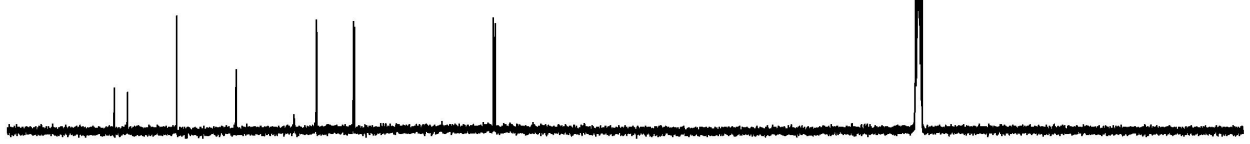

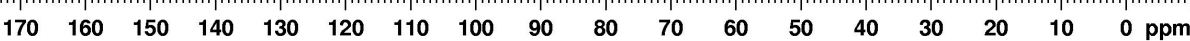



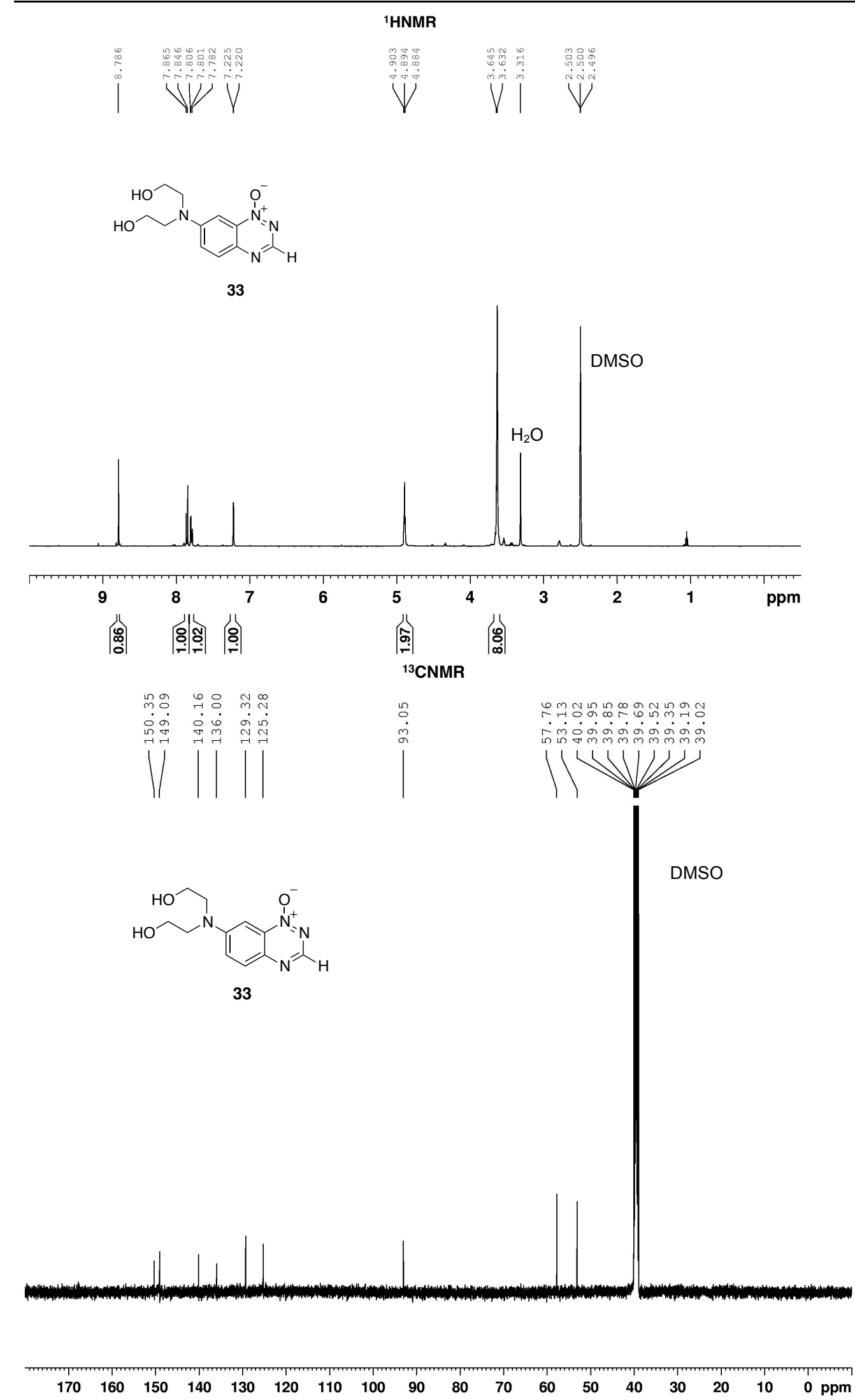
${ }^{1}$ HNMR
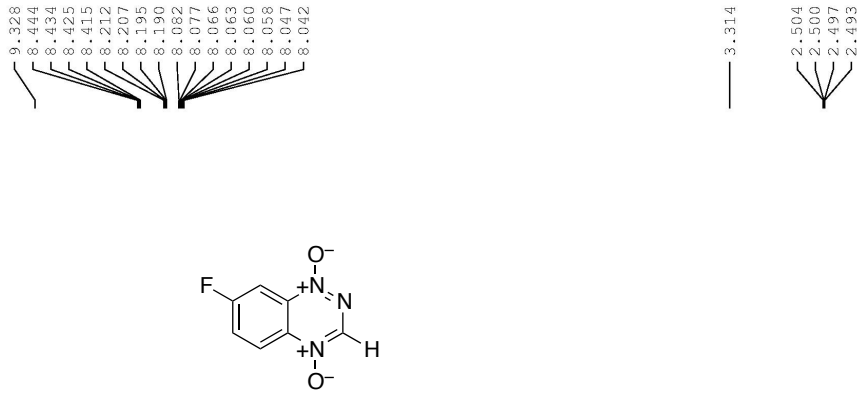

34

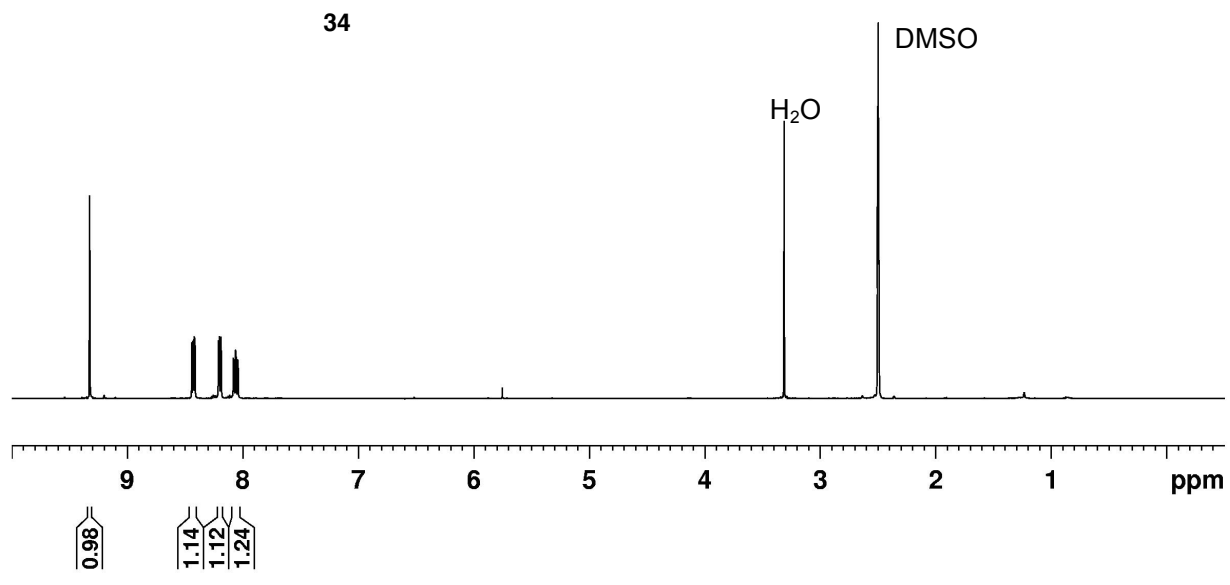

${ }^{13}$ CNMR
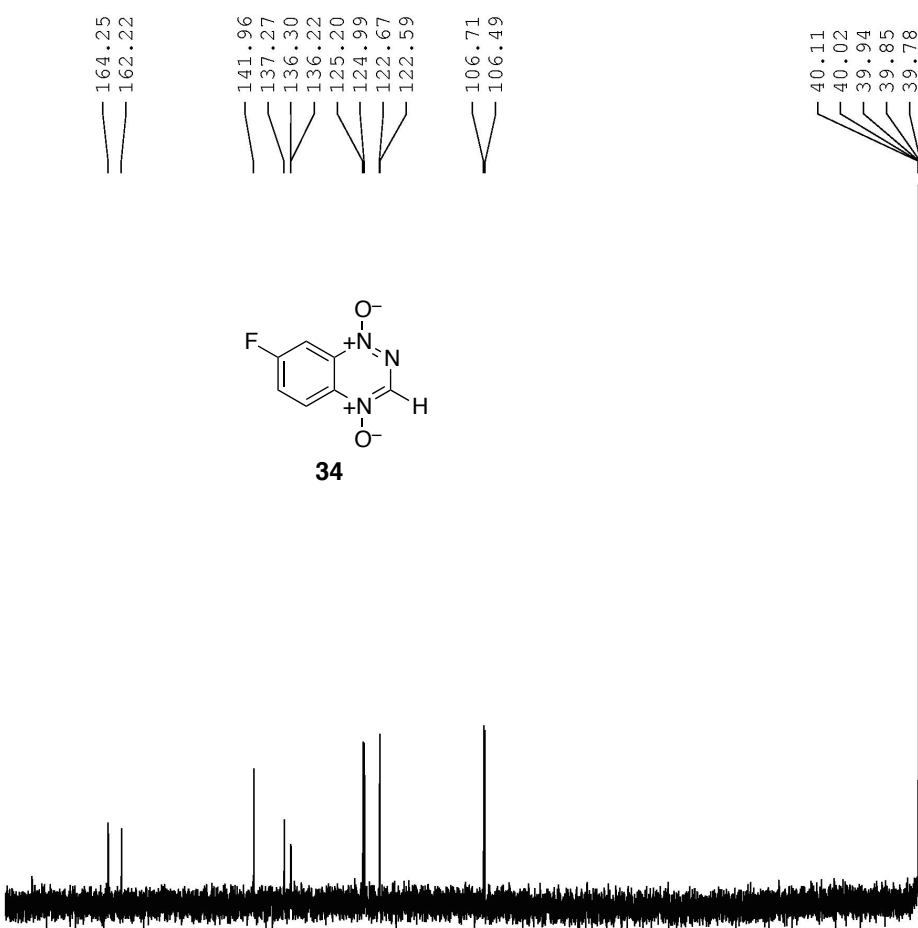

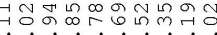

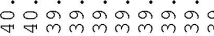

34 


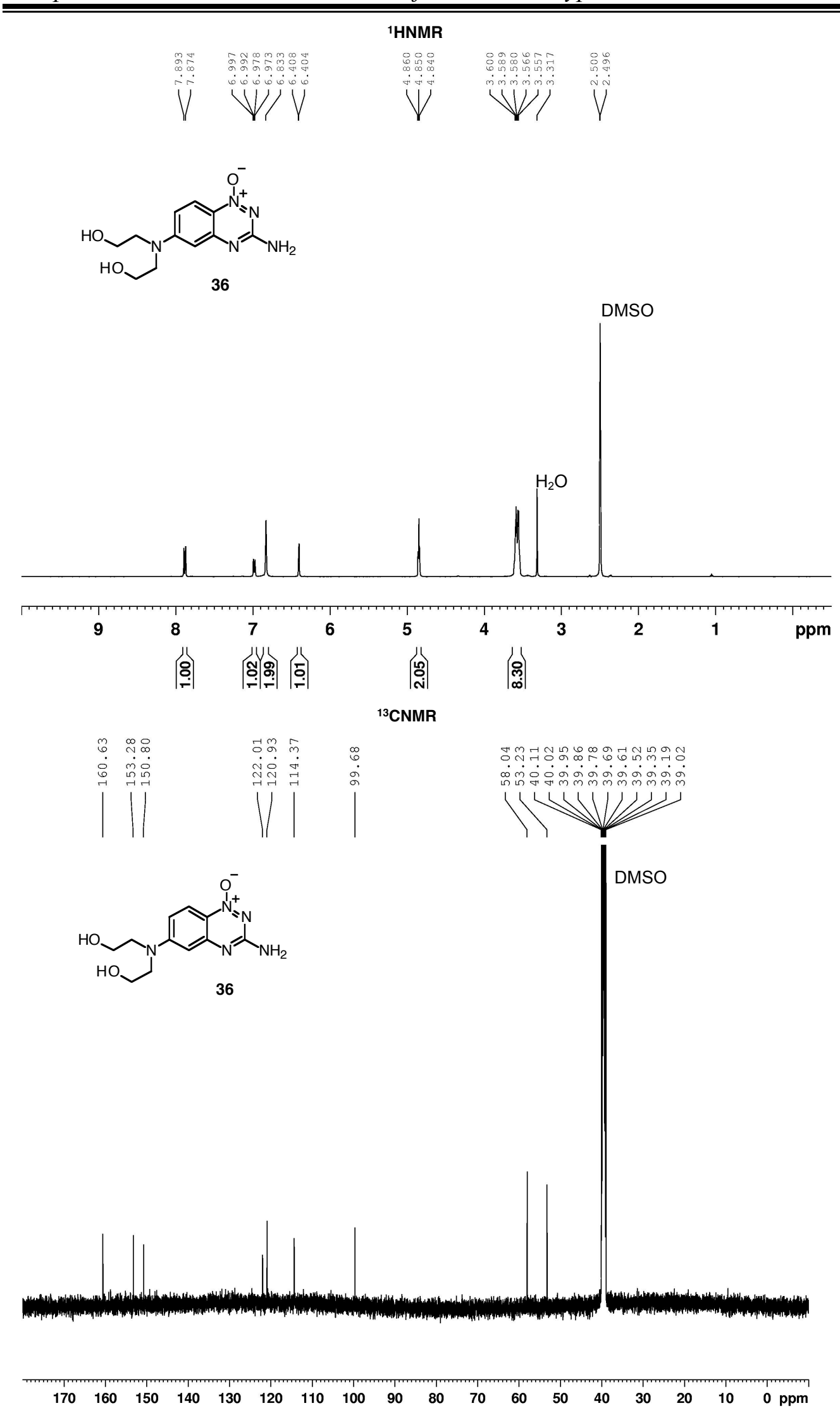




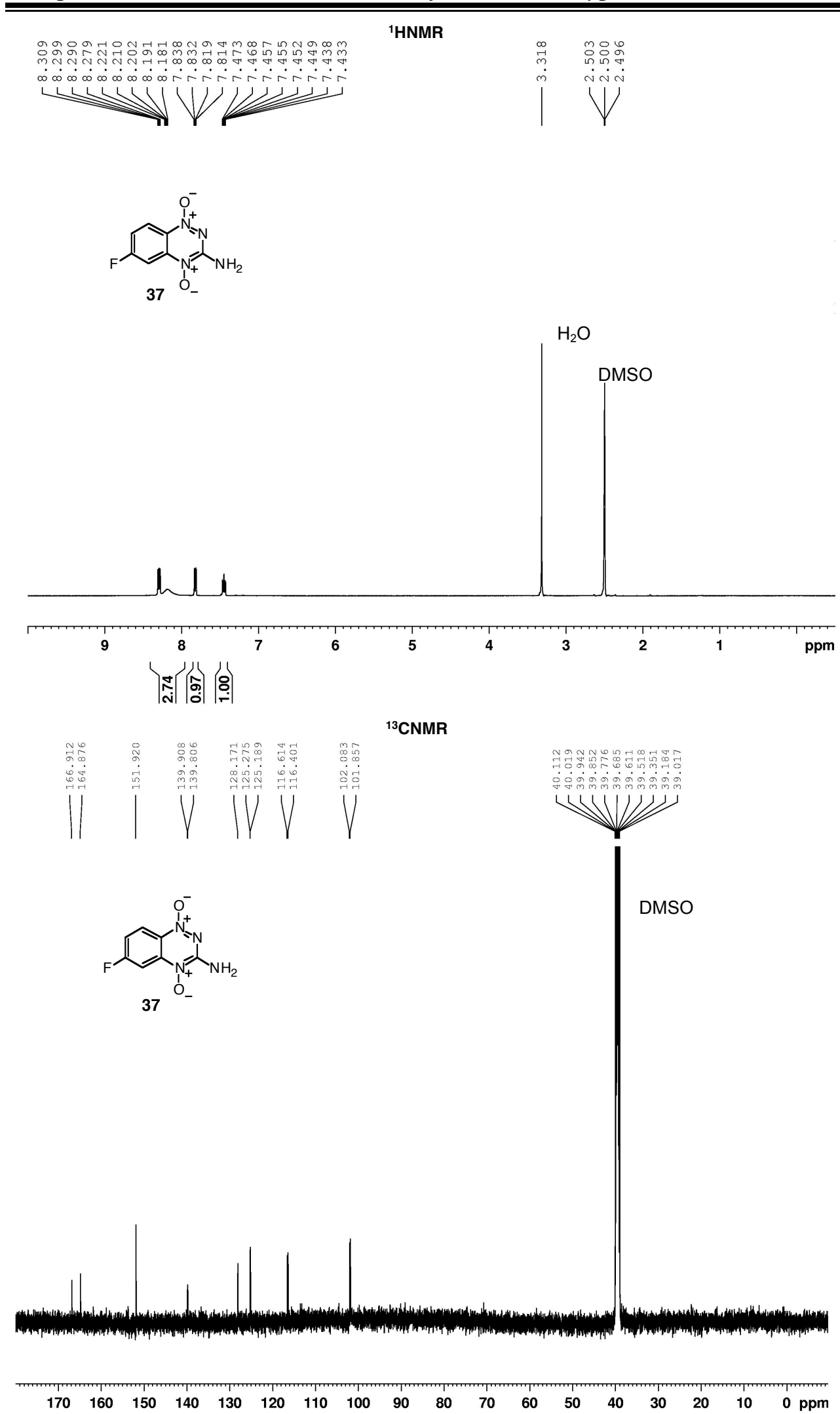




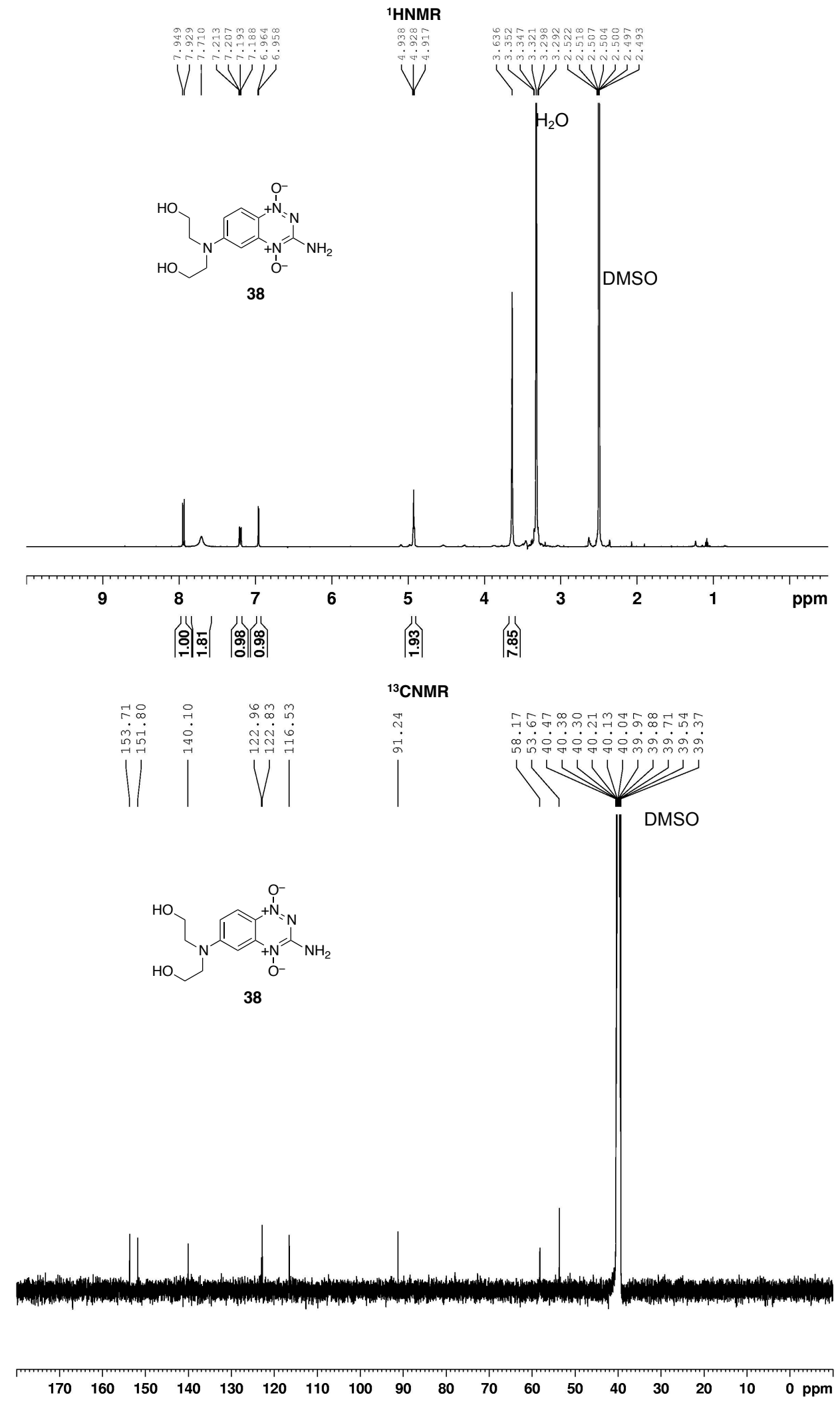


${ }^{1}$ HNMR
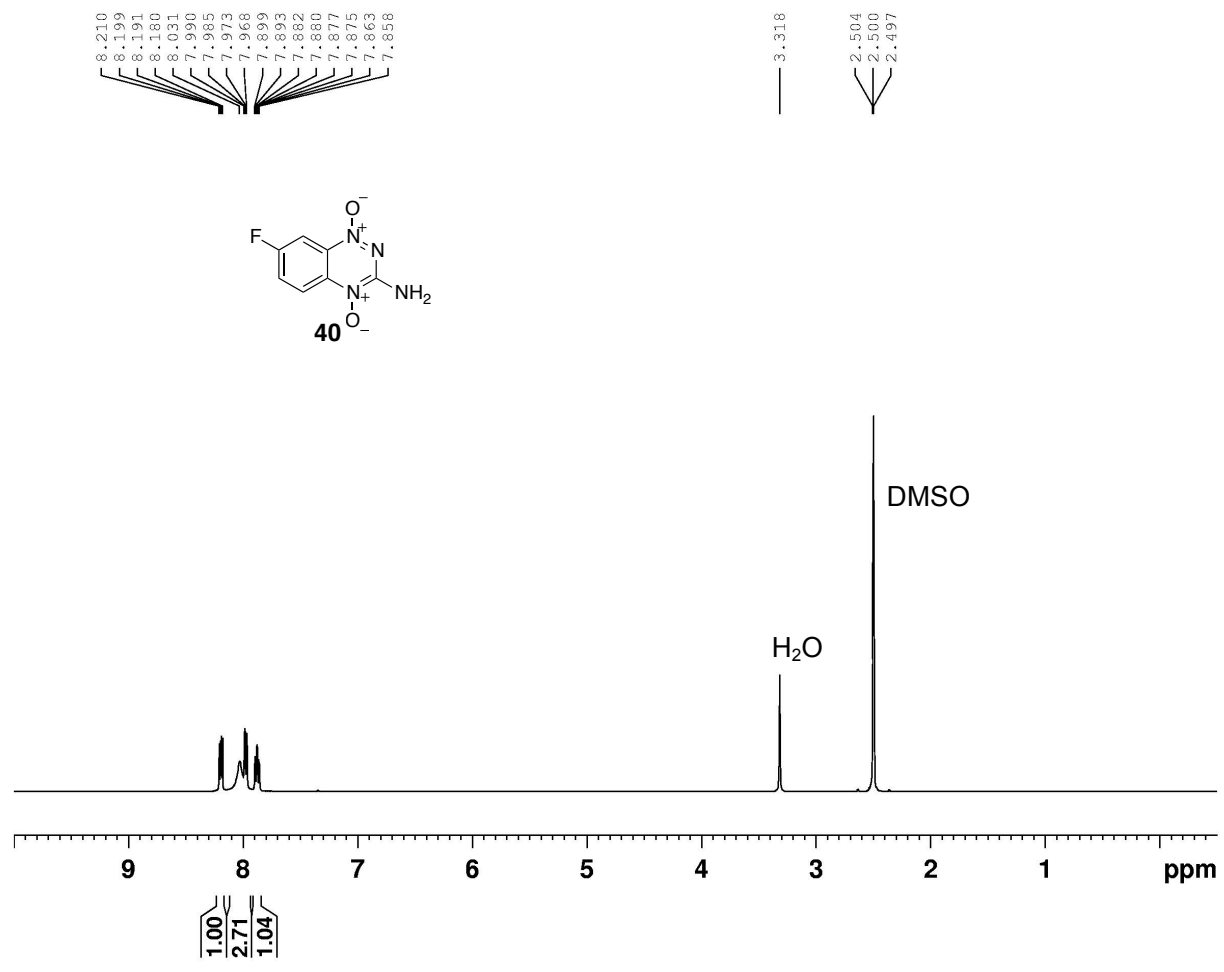

${ }^{13}$ CNMR
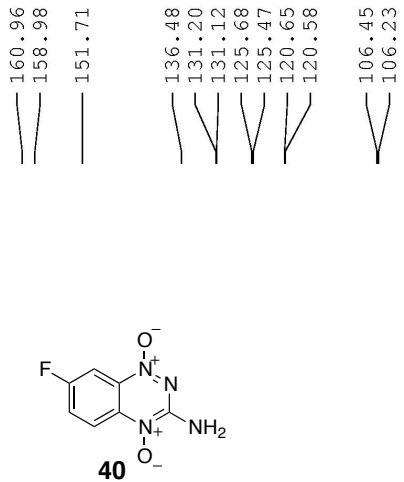

DMSO
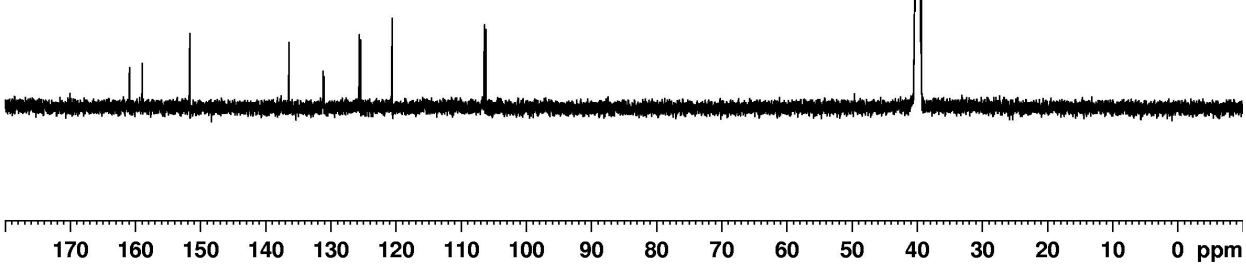
${ }^{1}$ HNMR
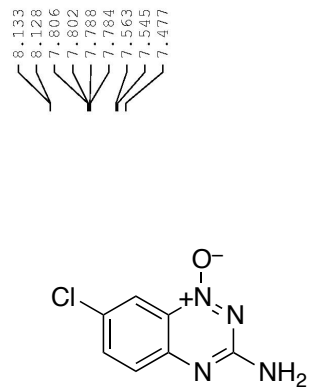

44
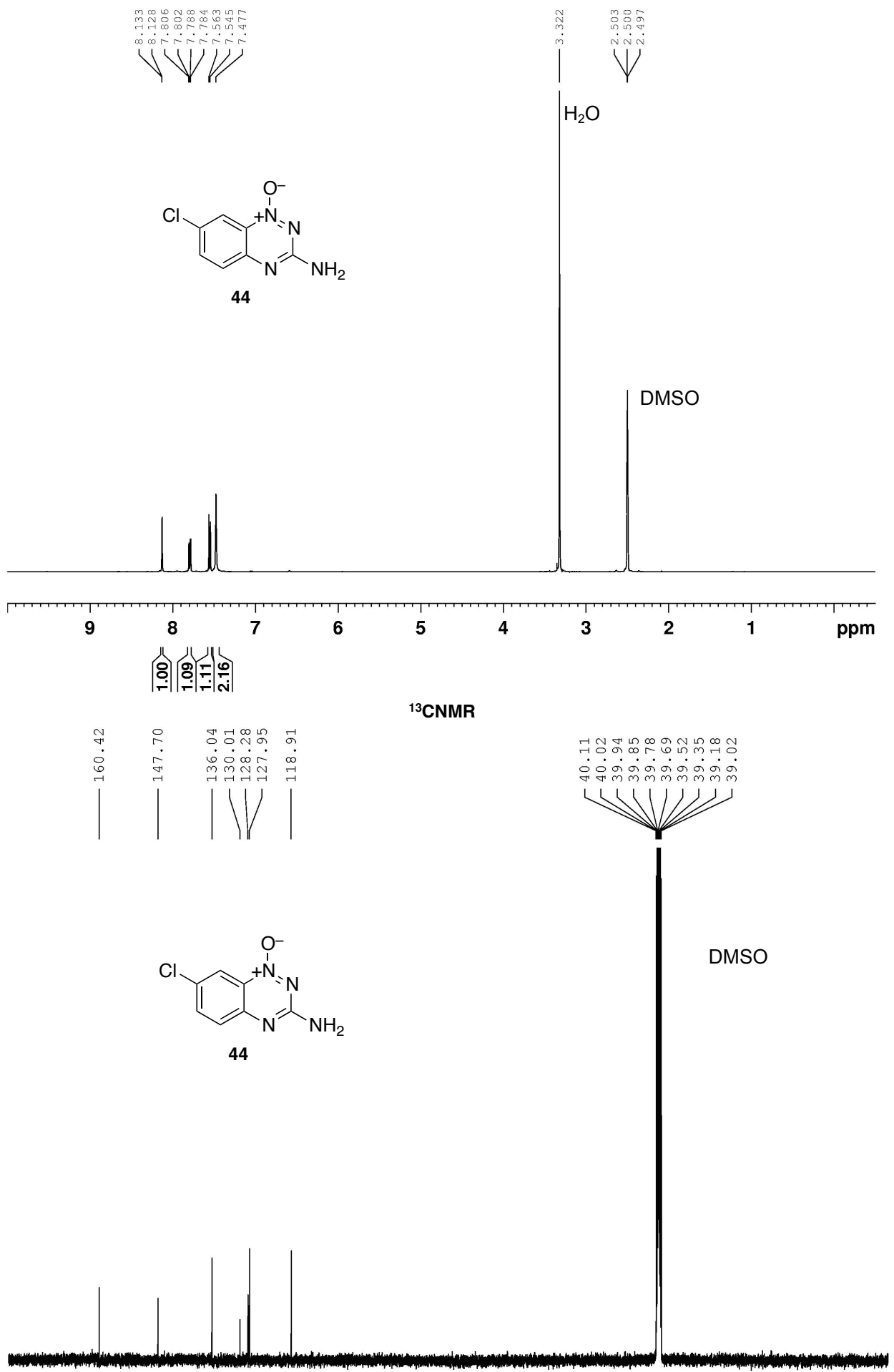

$\begin{array}{lllllllllllllllllll}170 & 160 & 150 & 140 & 130 & 120 & 110 & 100 & 90 & 80 & 70 & 60 & 50 & 40 & 30 & 20 & 10 & 0 & \mathrm{ppm}\end{array}$ 
${ }^{1}$ HNMR
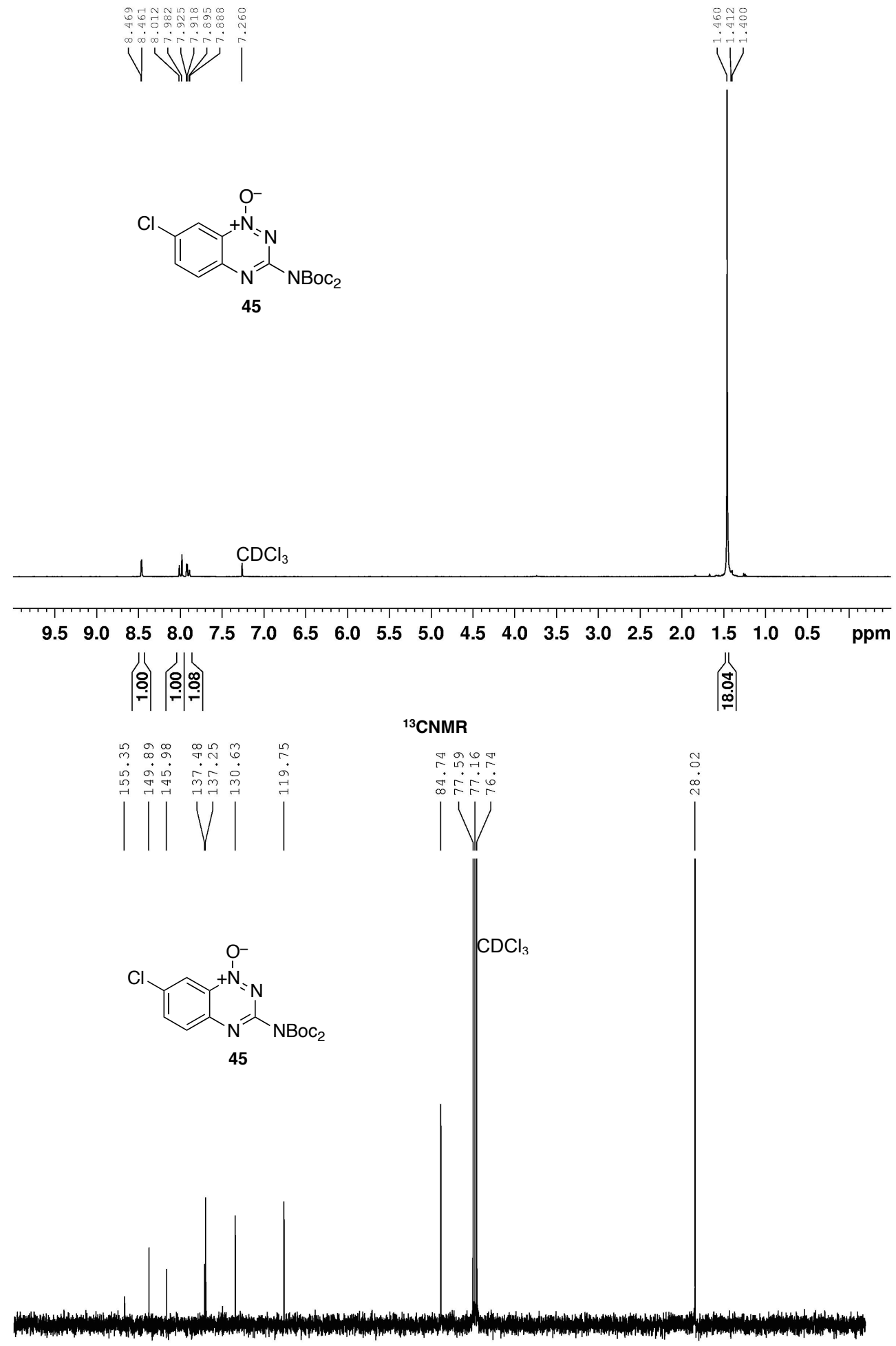

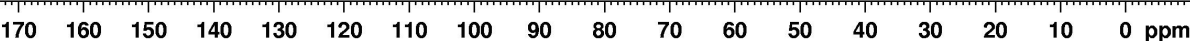


${ }^{1}$ HNMR
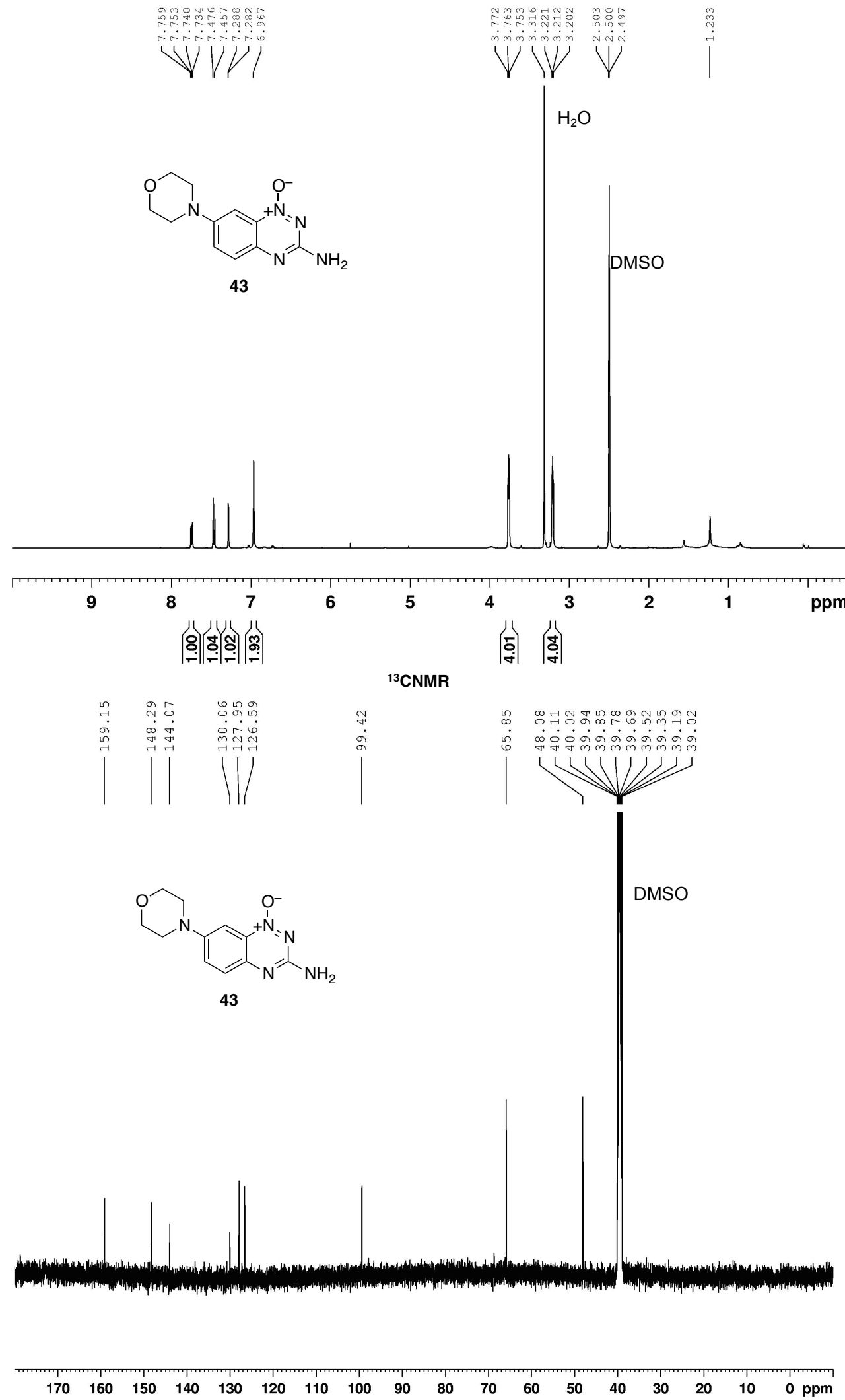
1HNMR
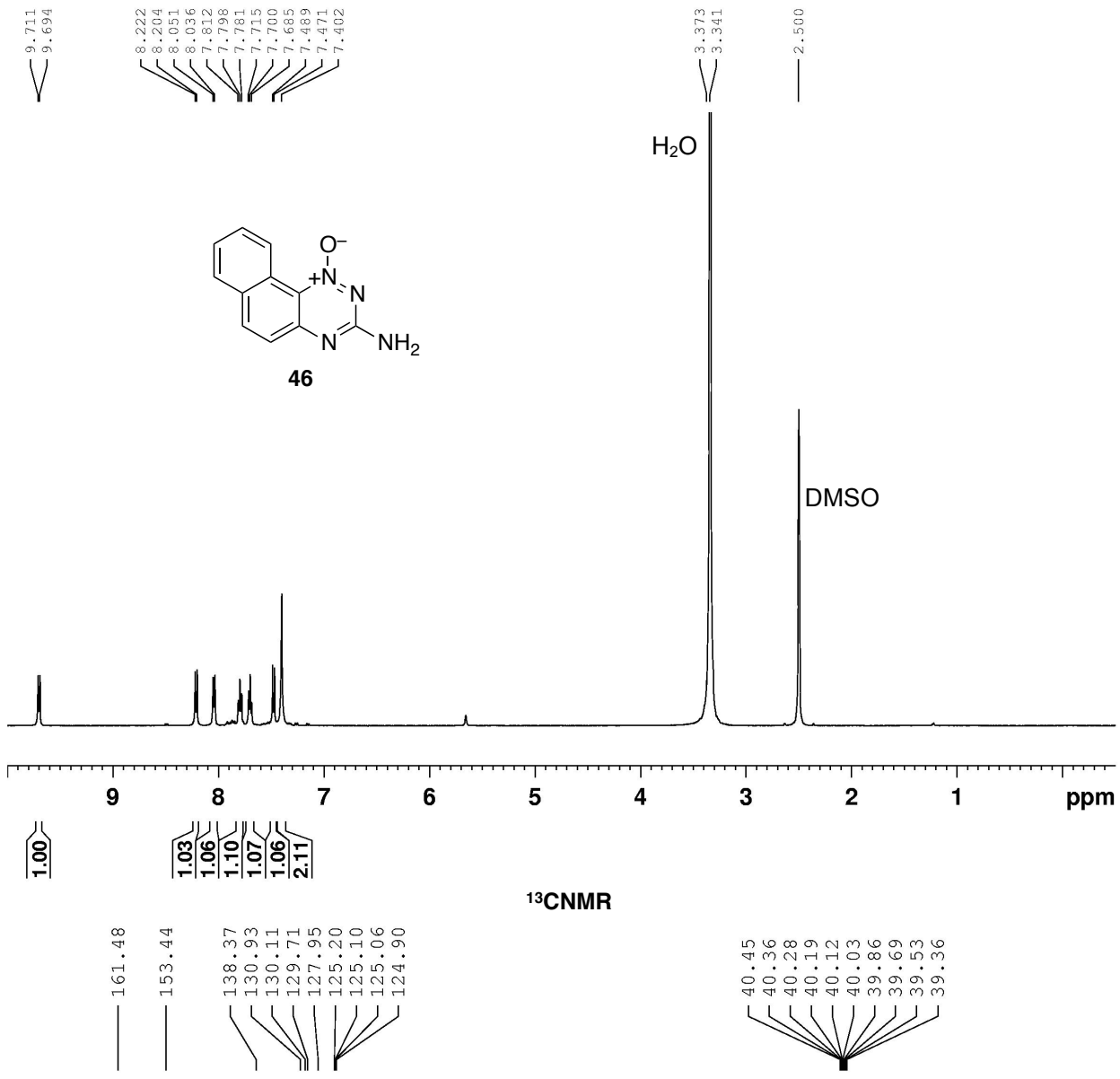

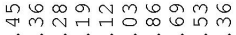

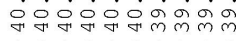

WW

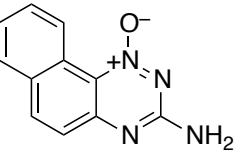

DMSO

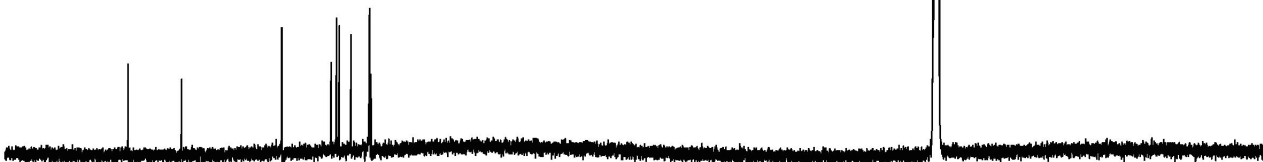




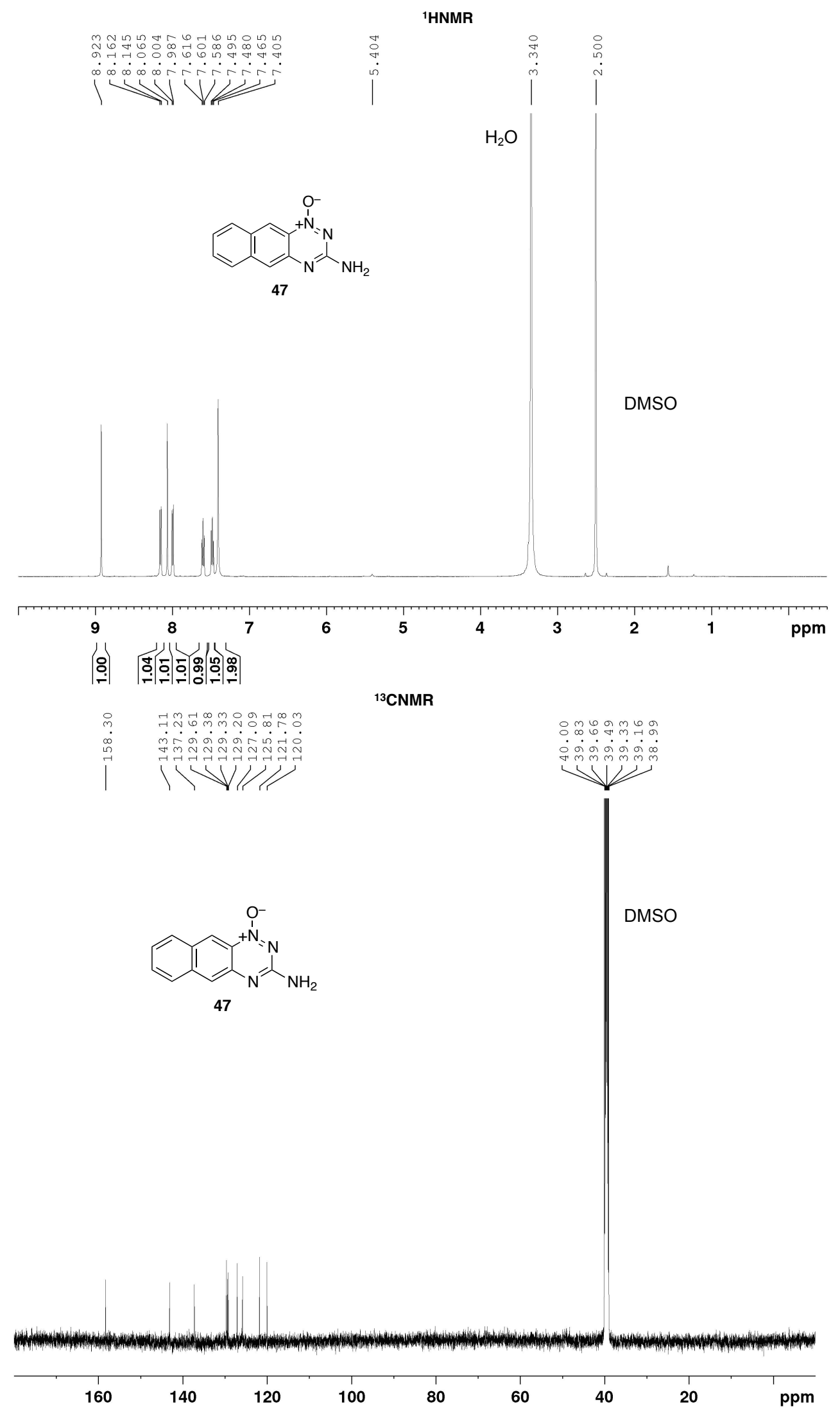


1HNMR
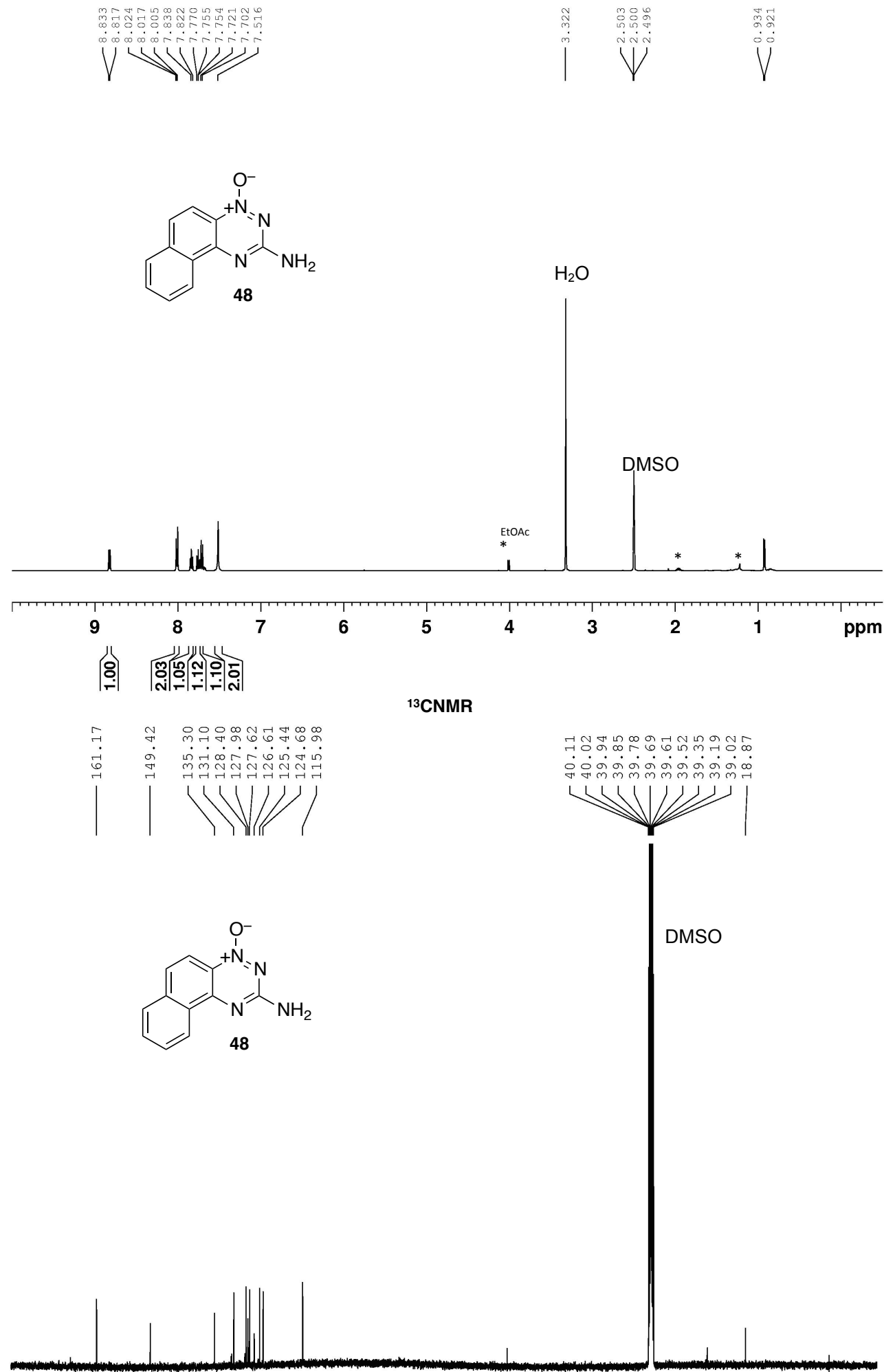

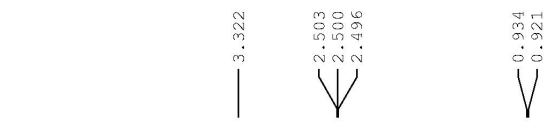

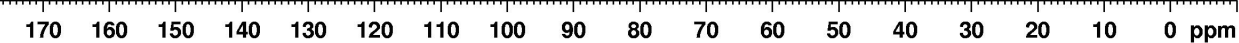


${ }^{1}$ HNMR
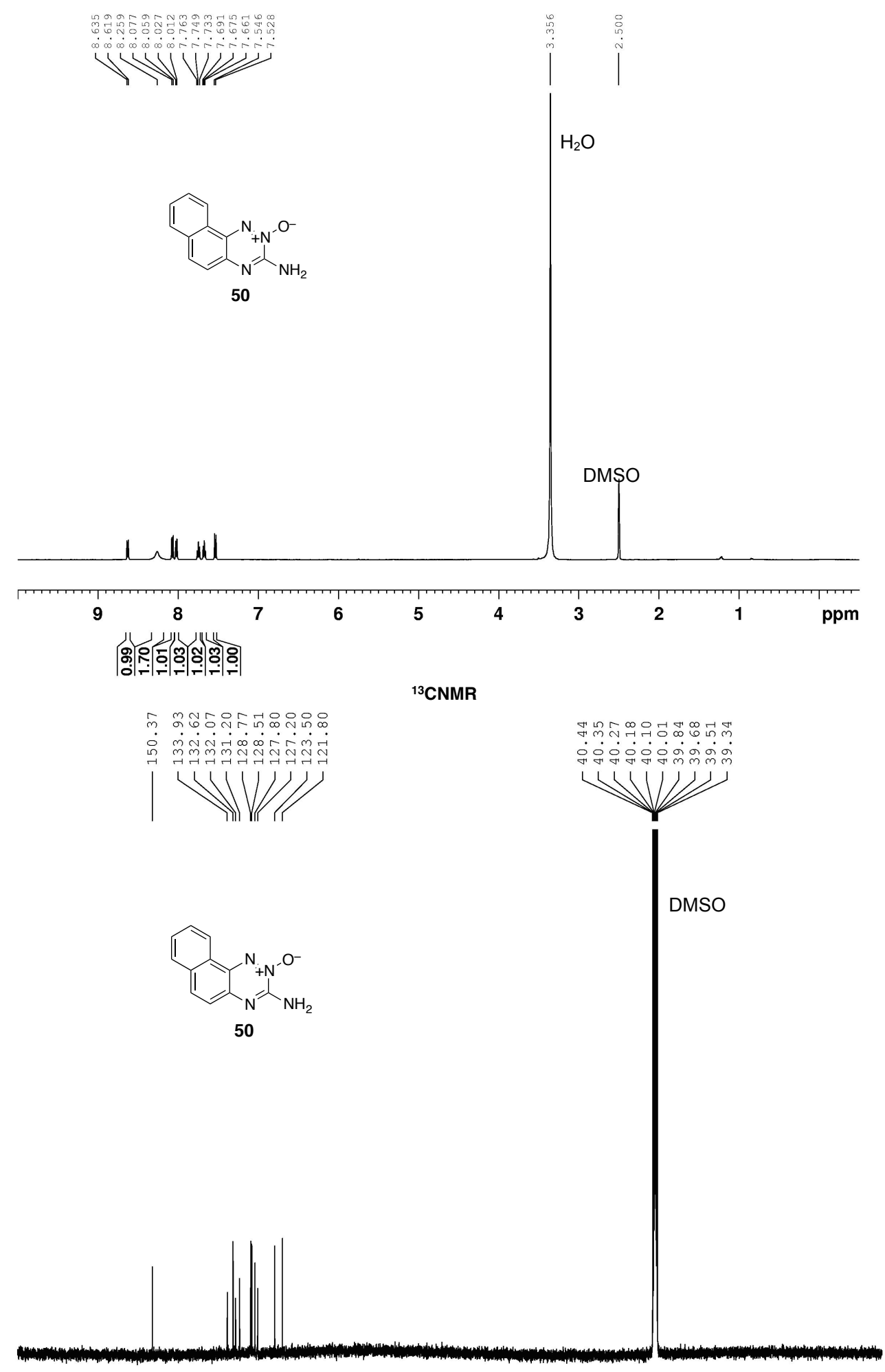

$\mathrm{H}_{2} \mathrm{O}$

$\begin{array}{llllllllllllllllll}170 & 160 & 150 & 140 & 130 & 120 & 110 & 100 & 90 & 80 & 70 & 60 & 50 & 40 & 30 & 20 & 10 & 0\end{array}$ 
1HNMR

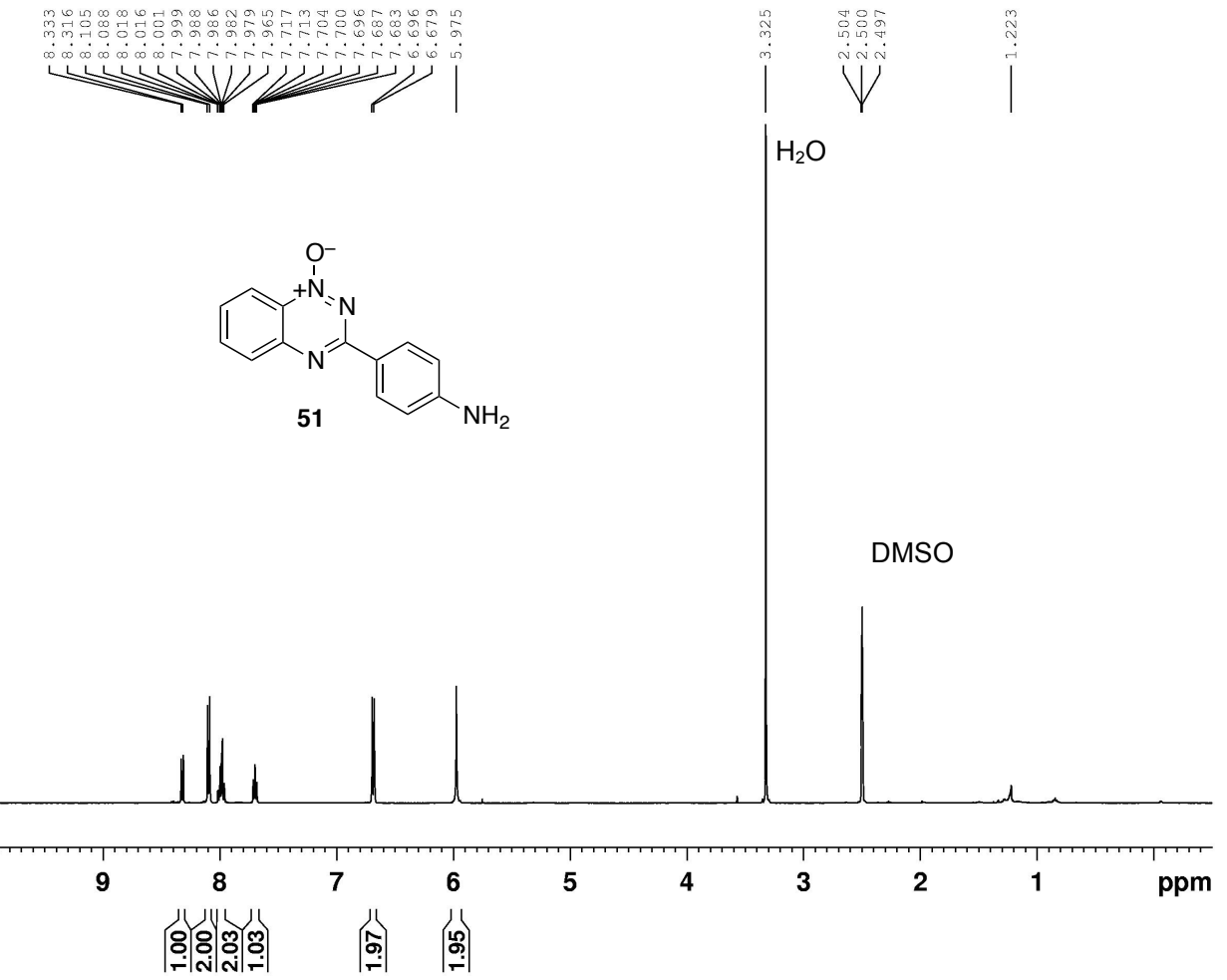

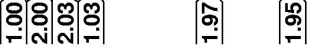

${ }^{13}$ CNMR
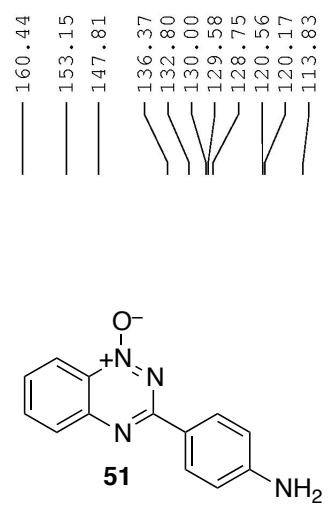

DMSO
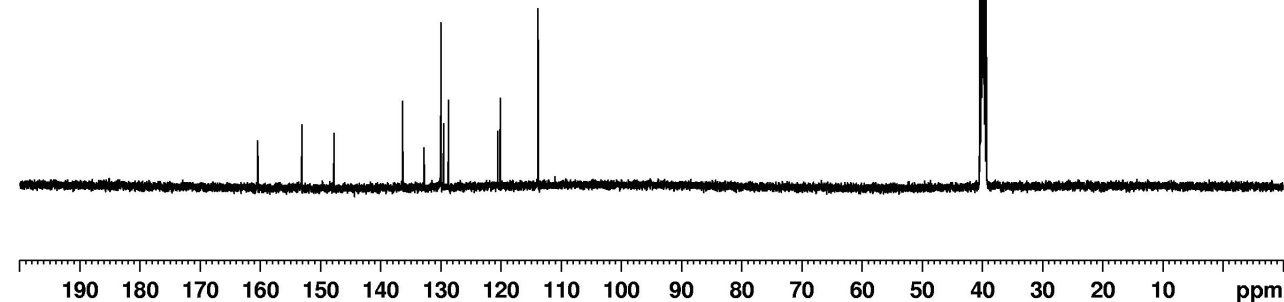
1HNMR<smiles>Nc1nc2ccc(C(=O)O)cc2[n+]([O-])n1</smiles>

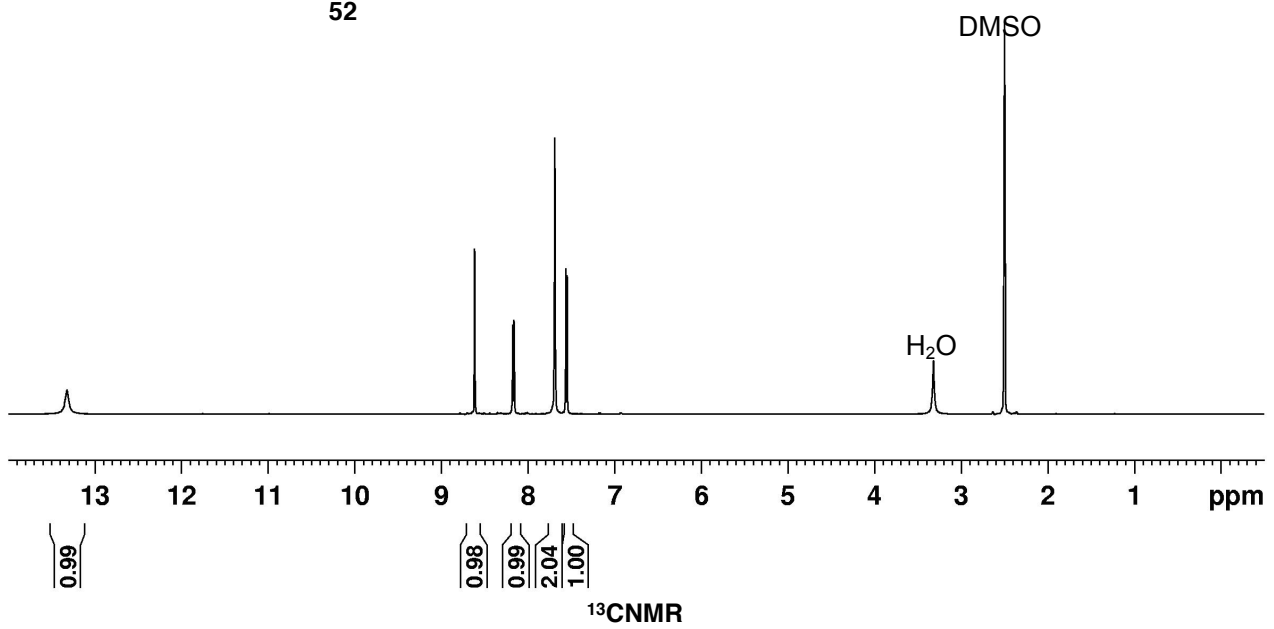<smiles>Nc1nc2ccc(C(=O)O)cc2[n+]([O-])n1</smiles>

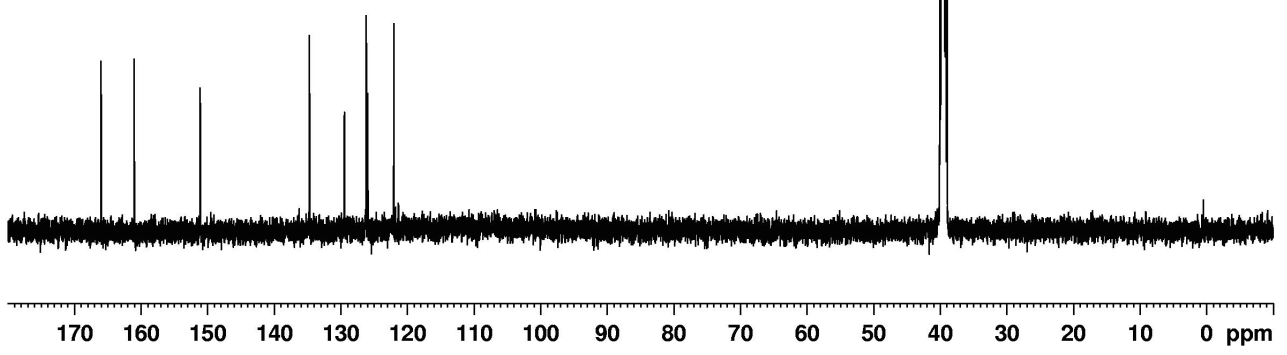




$$
\text { orimonat }
$$

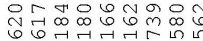

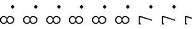

YWI

W

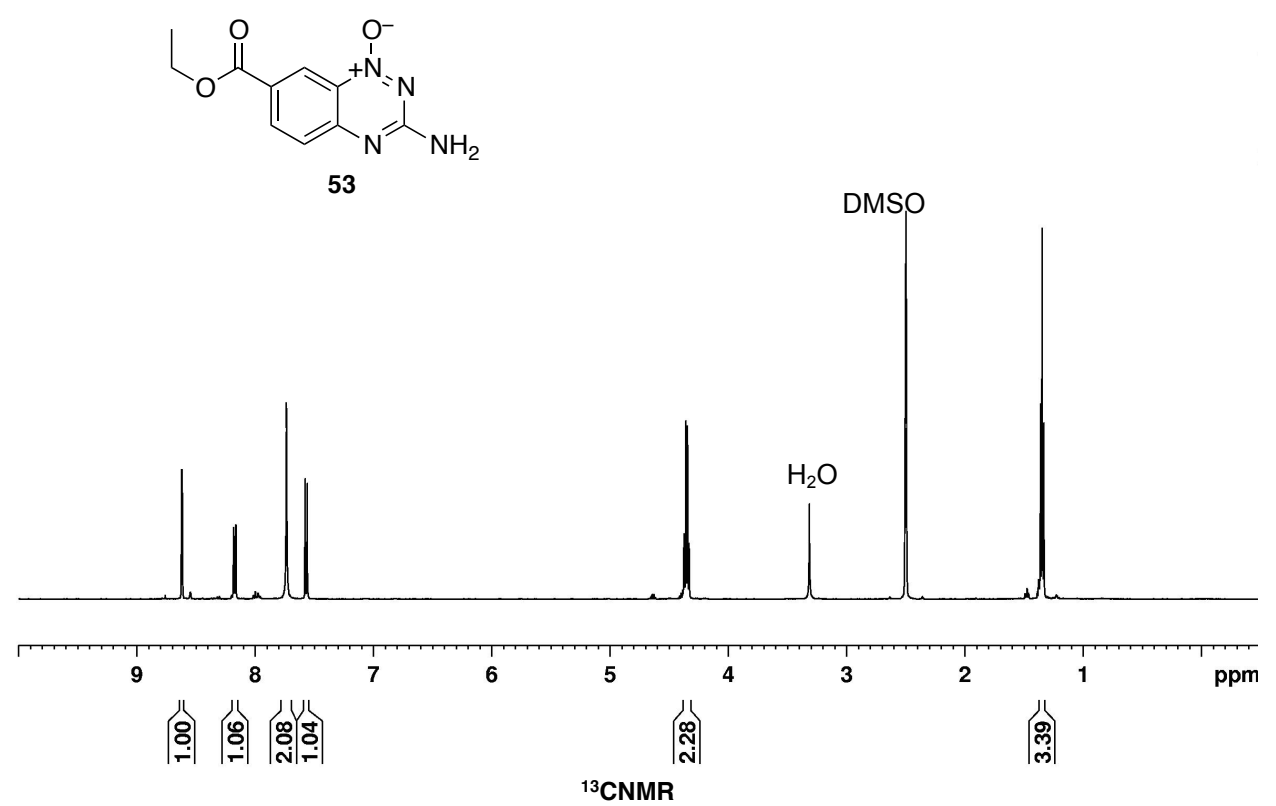

53
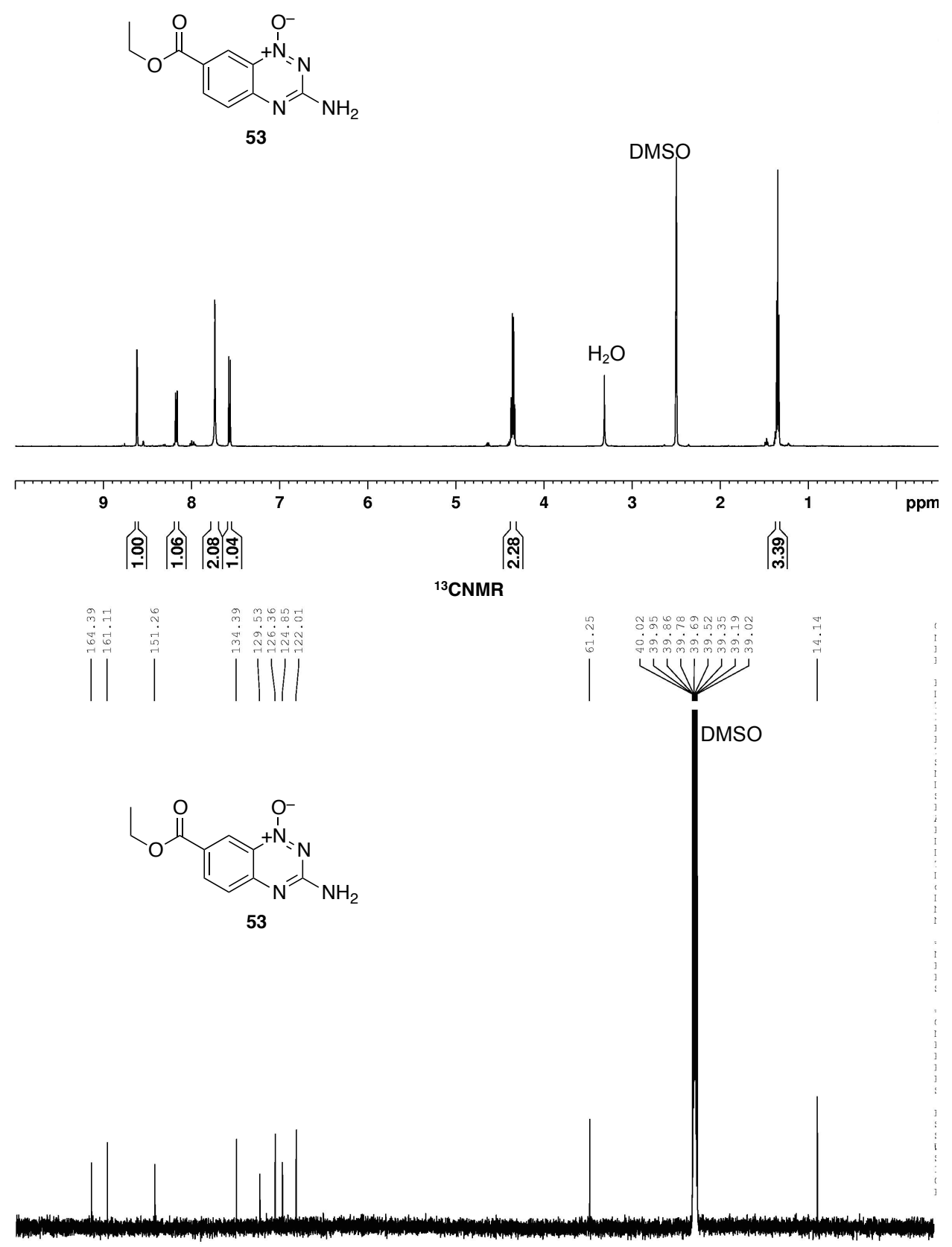

53

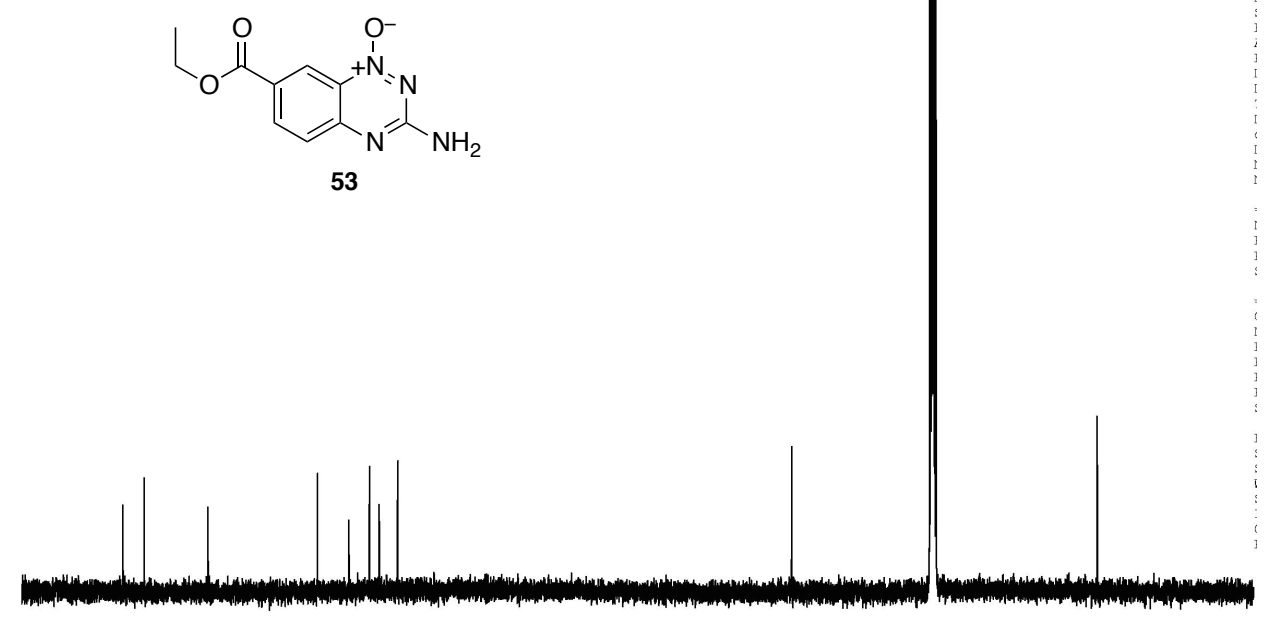

DMSO
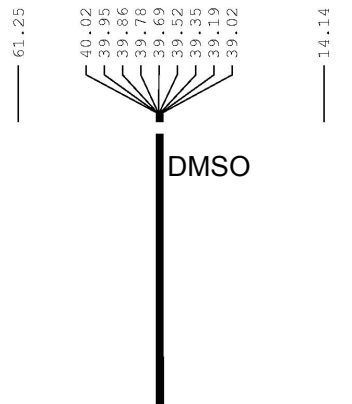

$\begin{array}{llllllllllllllllll}170 & 160 & 150 & 140 & 130 & 120 & 110 & 100 & 90 & 80 & 70 & 60 & 50 & 40 & 30 & 20 & 10 & 0\end{array}$ 


\section{References}

1. Palmer, B. D.; Wilson, W. R.; Atwell, G. J.; Schultz, D.; Xu, X. Z.; Denny, W. A. J. Med. Chem. 1994, 37 (14), 2175-2184.

2. Chen, Y.; Hu, L. Med Res Rev 2009, 29 (1), 29-64.

3. Wilson, W. R.; Hay, M. P. Nat Rev Cancer 2011, 11 (6), 393-410.

4. Fan, Y.-H.; Gold, B. J. Am. Chem. Soc. 1999, 121 (51), 11942-11946.

5. $\quad$ Atwell, G. J.; Yang, S.; Pruijn, F. B.; Pullen, S. M.; Hogg, A.; Patterson, A. V.; Wilson, W. R.; Denny, W. A. J. Med. Chem. 2007, 50 (6), 1197-212.

6. Brown, J. M. Br J Cancer 1993, 67 (6), 1163-70.

7. Mason, R. P.; Holtzman, J. L. Biochem. Biophys. Res. Commun. 1975, 67 (4), 1267-74.

8. $\quad$ Shinde, S. S.; Hay, M. P.; Patterson, A. V.; Denny, W. A.; Anderson, R. F. J. Am. Chem. Soc. 2009, 131 (40), 14220-1.

9. $\quad$ Chowdhury, G.; Junnotula, V.; Daniels, J. S.; Greenberg, M. M.; Gates, K. S. J. Am. Chem. Soc. 2007, 129 (42), 12870-7.

10. Reddy, S. B.; Williamson, S. K. Expert Opin Investig Drugs 2009, 18 (1), 77-87.

11. hicks, K. O. S., B.G.; Prujin, F. B.; and Wilson, W.R. Radiat. Res. 2004, 161 (6), 656-666.

12. Hicks, K. O.; Pruijn, F. B.; Secomb, T. W.; Hay, M. P.; Hsu, R.; Brown, J. M.; Denny, W. A.; Dewhirst, M. W.; Wilson, W. R. J Natl Cancer Inst 2006, 98 (16), 111828.

13. Hicks, K. O.; Siim, B. G.; Jaiswal, J. K.; Pruijn, F. B.; Fraser, A. M.; Patel, R.; Hogg, A.; Liyanage, H. D.; Dorie, M. J.; Brown, J. M.; Denny, W. A.; Hay, M. P.; Wilson, W. R. Clin Cancer Res 2010, 16 (20), 4946-57.

14. Pruijn, F. B.; Sturman, J. R.; Liyanage, H. D.; Hicks, K. O.; Hay, M. P.; Wilson, W. R. J. Med. Chem. 2005, 48 (4), 1079-87.

15. Hay, M. P.; Hicks, K. O.; Pchalek, K.; Lee, H. H.; Blaser, A.; Pruijn, F. B.; Anderson, R. F.; Shinde, S. S.; Wilson, W. R.; Denny, W. A. J. Med. Chem. 2008, 51 (21), 6853-65.

16. Xia, Q.; Zhang, L.; Zhang, J.; Sheng, R.; Yang, B.; He, Q.; Hu, Y. Eur. J. Med. Chem. 2011, 46 (3), 919-26.

17. Sarkar, U. PhD. Dissertation. University of Missouri, December 2009. 
18. Shi, X.; Poole, J. S.; Emenike, I.; Burdzinski, G.; Platz, M. S. J. Phys. Chem. A 2005, 109 (8), 1491-6.

19. Yuan, L.; Lin, W.; Zheng, K.; He, L.; Huang, W. Chem. Soc. Rev. 2013, 42 (2), 622-61.

20. Albers, A. E.; Okreglak, V. S.; Chang, C. J. J. Am. Chem. Soc. 2006, 128 (30), 9640-9641.

21. Hettiarachchi, S. U.; Prasai, B.; McCarley, R. L. J. Am. Chem. Soc. 2014, 136 (21), 7575-7578.

22. Miller, E. W.; Albers, A. E.; Pralle, A.; Isacoff, E. Y.; Chang, C. J. J. Am. Chem. Soc. 2005, 127 (47), 16652-16659.

23. Srikun, D.; Albers, A. E.; Nam, C. I.; Iavarone, A. T.; Chang, C. J. J. Am. Chem. Soc. 2010, 132 (12), 4455-4465.

24. Boyd, M.; Hay, M. P.; Boyd, P. D. Magn. Reson. Chem. 2006, 44 (10), 948-54.

25. Fuchs, T.; Chowdhury, G.; Barnes, C. L.; Gates, K. S. J. Org. Chem. 2001, 66 (1), 107-114.

26. Jiang, F.; Yang, B.; Fan, L.; He, Q.; Hu, Y. Bioorg. Med. Chem. Lett. 2006, 16 (16), 4209-13.

27. Kuivila, H. G.; Reuwer Jr, J. F.; Mangravite, J. A. Can. J. Chem. 1963, 41 (12), 3081-3090.

28. Pchalek, K.; Hay, M. P. J. Org. Chem. 2006, 71 (17), 6530-5.

29. Gatenyo, J.; Johnson, K.; Rajapakse, A.; Gates, K. S.; Rozen, S. Tetrahedron 2012, 68 (43), 8942-8944.

30. Hay, M. P.; Gamage, S. A.; Kovacs, M. S.; Pruijn, F. B.; Anderson, R. F.; Patterson, A. V.; Wilson, W. R.; Brown, J. M.; Denny, W. A. J. Med. Chem. 2003, 46 (1), 169-82.

31. Bjorsvik, H. R.; Gambarotti, C.; Jensen, V. R.; Gonzalez, R. R. J. Org. Chem. 2005, 70 (8), 3218-24.

32. Poole, J. S.; Hadad, C. M.; Platz, M. S.; Fredin, Z. P.; Pickard, L.; Levya Guerrero, E.; Kessler, M.; Chowdhury, G.; Kotandeniya, D.; Gates, K. S. Photochem. Photobiol. 2007, 75 (4), 339-345.

33. Marmé, N.; Knemeyer, J.-P.; Sauer, M.; Wolfrum, J. Bioconjugate Chem. 2003, 14 (6), 1133-1139. 
34. Giasson, R.; Lee, E. J.; Zhao, X.; Wrighton, M. S. J. Phys. Chem. 1993, 97 (11), 2596-2601.

35. Hodgson, H. H.; Kilner, E. J. Chem. Soc. 1926, 129 (0), 7.

36. Katritzky, A. R.; Laurenzo, K. S. J. Org. Chem. 1988, 53 (17), 3978-3982.

37. Suzuki, H.; Kawakami, T. J. Org. Chem. 1999, 64 (9), 3361-3363.

38. Murray, R. W. a. S., M. Org. Synth. 1997, 74, 91.

39. Suzuki, H.; Kawakami, T. Synthesis 1997, 1997 (08), 855-857. 


\section{Chapter 2. Hypoxia Selective DNA Alkylating Analogs of}

\section{Tirapazamine}

\subsection{Introduction}

As previously described, TPZ is a hypoxia selective prodrug with interesting anti-

tumor properties. ${ }^{1-2}$ It contains a triazine ring system with two N-oxide species. This triazine di- $N$-oxide core is a complex structure that undergoes redox cycling during drug metabolism. ${ }^{3}$ TPZ is enzymatically reduced to form a protonated radical anion species (2, Chapter 1, Scheme 1) thought to fragment producing a hydroxyl radical $(\bullet \mathrm{OH})$ and the reduced benzotriazine 1 -oxide 3 (Chapter 1 , Scheme 1 ). ${ }^{2}$ The $\bullet \mathrm{OH}$ species is the active drug metabolite that is thought to cause DNA damage via single- and double-strand breaks. $^{2,4-5}$ These are deleterious types of DNA damage that result in cell death.

In the presence of aerobic amounts of oxygen $(>10 \mu \mathrm{M})$, the protonated radical anion is back-oxidized to give TPZ, producing superoxide $\left(\bullet^{\mathrm{O}_{2}}{ }^{-}\right)$in the process. ${ }^{3,6}$ As termed earlier, this "Redox Cycling" is the basis for all hypoxia selective and 101 
bioreductively activated prodrugs. ${ }^{7-8}$ Nitro and $N$-oxide containing compounds can be bioreductively metabolized in the absence of oxygen $(<1 \mu \mathrm{M})$ by cytochrome $\mathrm{P} 450$ reductase. ${ }^{6-7,9-12}$ This oxygen sensitivity is what gives TPZ and other similar prodrugs their selective hypoxic cytotoxicity. The oxygen concentrations in normal healthy cells inhibit the bioreduction by oxidizing any radicals that form. Under low oxygen concentrations, as seen in tumor tissue, the oxygen concentration is not high enough to sufficiently block radical generation, allowing fragmentation and $\bullet \mathrm{OH}$ generation to occur. This process also produces 4 as unreactive, wasted material. This oxygen sensitive process results in a huge loss of mass with respect to the reactive metabolite, - $\mathrm{OH}$. We hope to develop analogues that make use of the unreactive benzotriazine 1oxide core (4) in order to increase the overall effective cytotoxicity of the pro-drug. We synthesized molecules potentially activated after $1 \mathrm{e}^{-}$reduction under hypoxic conditions by grafting nitrogen mustard substituents on the benzo-ring (Scheme 2).

\section{Scheme 1}

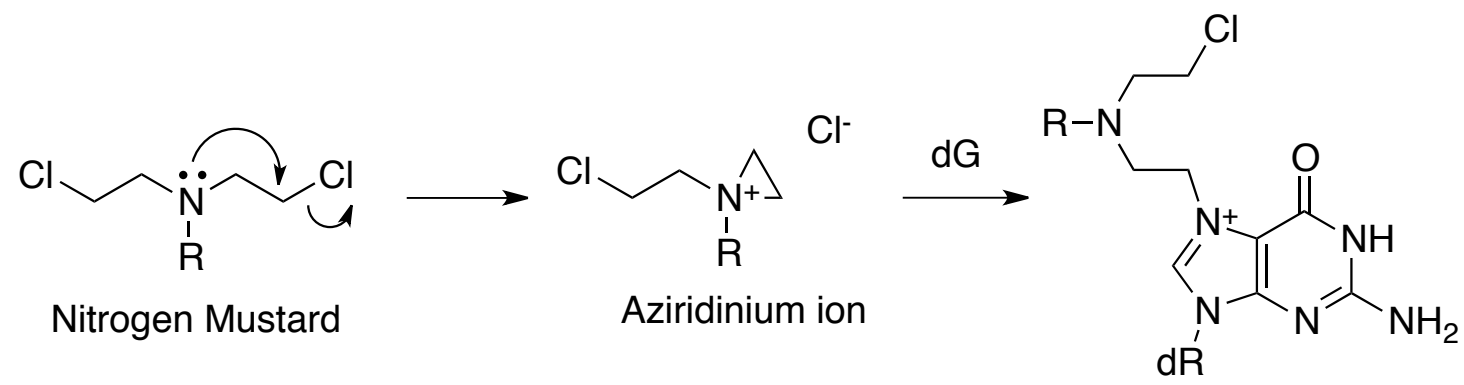

Many pro-drugs that incorporate $N$-mustards possess increased hypoxia-selective cell killing properties. They are notorious for causing DNA interstrand cross-links by alkylating $\mathrm{dG}$ in $5^{-}$-GNC sequences, ${ }^{13-14}$ and have been repeatedly used for designing new anticancer agents $(\mathbf{5 4}, \mathbf{5 5}, \mathbf{5 6}$, and $\mathbf{5 7}){ }^{10,15-20}$ Nitrogen mustards alkylate at the N-7 position of deoxyguanosine via aziridinium ion intermediate (Scheme 1). ${ }^{13,20}$ It is 
believed that aziridinium ion formation is the rate-determining step in $N$-mustard alkylation and hydrolysis. ${ }^{20}$ This requires the nitrogen lone pair to be "active" for nucleophilic attack, but in turn can be controlled by electron-withdrawing groups in an aromatic system. ${ }^{18}$ The benzotriazine ring in TPZ (1) contains two electron withdrawing $\mathrm{N}$-oxides. ${ }^{21}$ Upon reduction to its mono-N-oxide metabolite (4), the electronic structure of the benzotriazine ring changes. We theorized we could modulate $N$-mustard activity when grafted onto the TPZ core. It has been shown that anchimeric assistance in nucleophilic displacement reactions involving nucleophiles either in or attached to aryl rings can be highly sensitive to substituent effects (Scheme 2). ${ }^{22-24}$

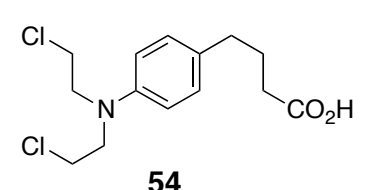

54

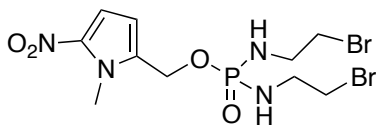

56
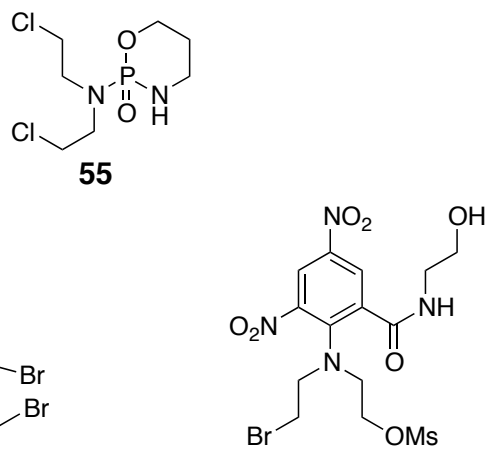

57

\section{Scheme 2}

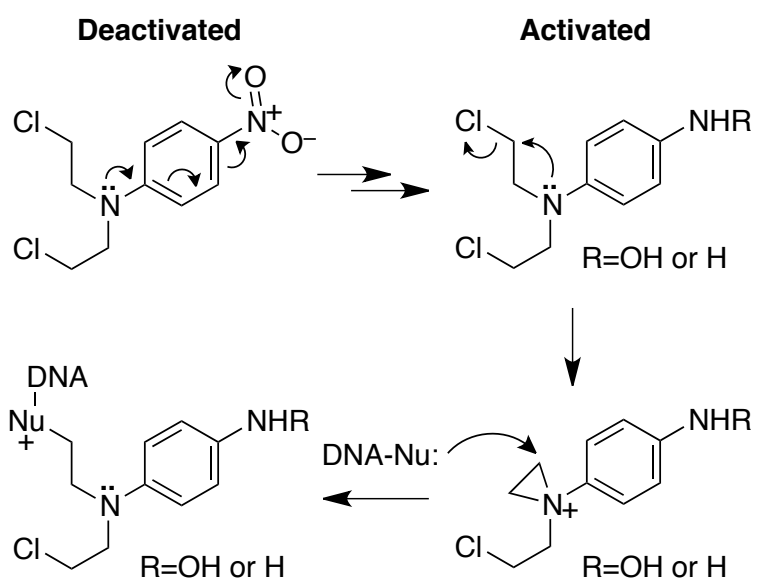


Aromatic compounds with strong electron-withdrawing substituents like $-\mathrm{NO}_{2}$ groups cause electron deficiencies in the ring. This in turn reduces the electron density of the nitrogen lone pair on an aromatic nitrogen-mustard substituent and inhibiting aziridinium ion formation. Reduction of the $-\mathrm{NO}_{2}$ will change the electronic distribution of the ring, resulting in a more nucleophilic nitrogen lone pair for faster aziridinium generation. Scheme 3 describes how an electron donating substituent at position 6 (Chapter 1, Figure 1) will show inductive effects with N-4. The N-4-oxide is an electronwithdrawing group capable of deactivating $N$-mustard substituents at the 6-position (Scheme 3). When reduced, the $N$-mustards are activated and will alkylate DNA faster via aziridinium ion formation. (Scheme 3) This change in reactivity would result in selective DNA-alkylation under hypoxic conditions in cells, introducing a new class of oxygen sensors. Changes in the electronic properties of molecules have widely been used to "switch on" the reactivity of functional groups. ${ }^{11}$ This reports the first use of these benzotriazine structures to modulate alkylating potential of nitrogen mustards. Here we describe TPZ analogues in which the mono-N-oxide metabolite is no longer an inert compound, but an activated species after bioreduction of the parent 1,4-di-N-oxide.

\section{Scheme 3}

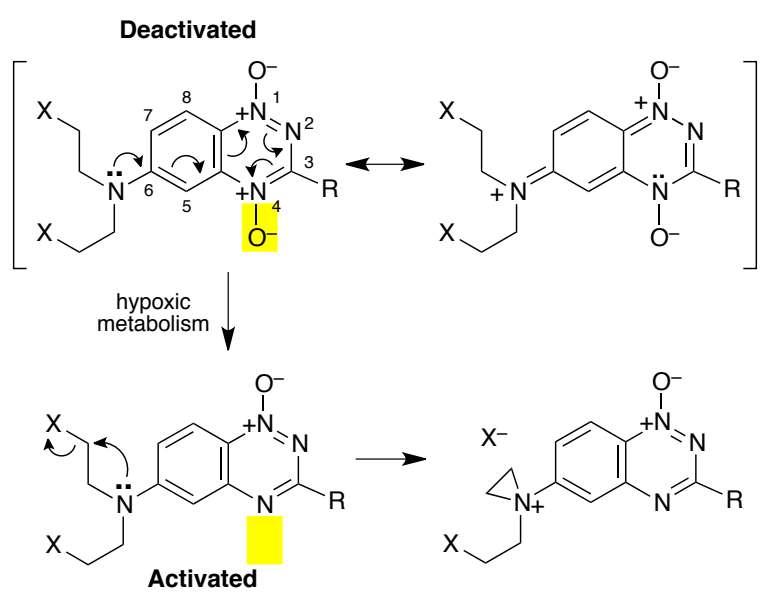




\subsection{Preparation of Tirapazamine mustards}

The synthesis of benzotriazine mustards is summarized in Scheme 4 using compounds presented in Chapter 1. The first route explored involved sulfonation of the diol containing 1-oxide 36 and 1,4-dioxide 38, which were prepared by aromatic substitution of fluorine containing benzotriazines with diethanolamine (Chapter 1). It is interesting to note the remarkable difference in electrophilicity at the 6-F position between compounds 19 and 31 (Chapter 1) to obtain diol-containing 36 and 38 . The substantial difference in reaction conditions required for synthesis provided first evidence that the 4- $\mathrm{N}$-oxide core would serve as an effective electron-withdrawing group for deactivation of nitrogen mustards at the 6-position (Figures 1 and 2).

1-Oxide mustards 54 and $\mathbf{5 6}$ can be prepared from 36 using their respective sulfonyl chlorides (Scheme 4). Synthesis of the corresponding 1,4-dioxides (55 and 57) was challenging, as sulfonation in the presence of a nucleophilic $4-N$-oxide ${ }^{21}$ produced side reactions giving a mixture of products by TLC. One major product (58) isolated by column chromatography was a compound possibly from a nucleophilic aromatic deoxygenation reaction (proposed mechanism in Scheme 5) ${ }^{21}$ A crystal structure of this product was obtained to confirm its identity (Experimental section, crystal structure 1). Other products obtained could possibly result from sulfonation of the 3-amino group, explaining the less polar products seen on TLC. This hypothesis is supported by previous

work in the Gates group. ${ }^{25}$ Acetylation of the 3 -amino group of the benzotriazine ring is facilitated in the presence of the $4-N$-oxide. ${ }^{25}$ We conclude sulfonation would significantly occur at the 4- $\mathrm{N}$-oxide. For these reasons, the "deactivated" 1,4-dioxide $\mathrm{N}$ - 
mustards 55 and 57 were prepared instead by $N$-oxidation of the 1-oxides (54 and 56)

with Oxone or $m$ CPBA in low yield.

\section{Scheme 4}
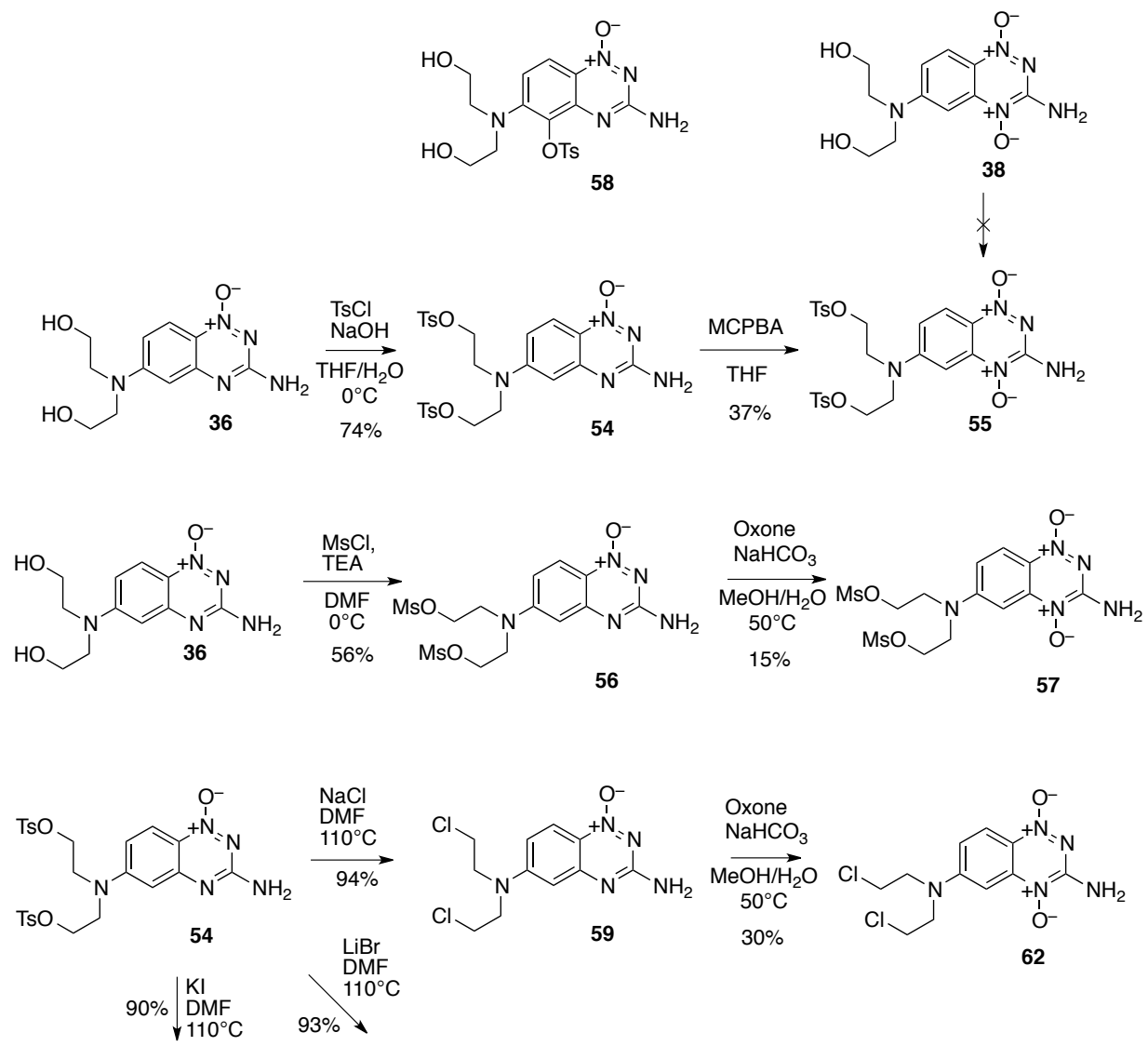

(1)

$30 \%$

62
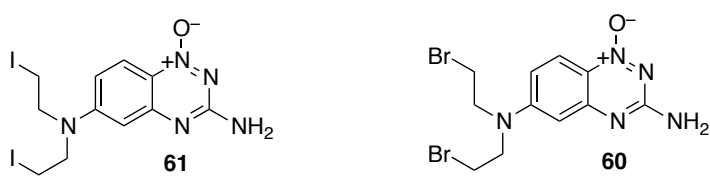

We also prepared - $\mathrm{Cl}$, $-\mathrm{Br}$, and -I containing benzotriazine $N$-mustards as well (Scheme 4). They were prepared by nucleophilic substitution of compound $\mathbf{5 4}$ with the corresponding halide salt in DMF with heat to yield 59, 60, and 61. Chlorine mustard 59 was oxidized to 62 with $m$ CPBA to afford the "deactivated" halide mustard as well. 


\section{Scheme 5}

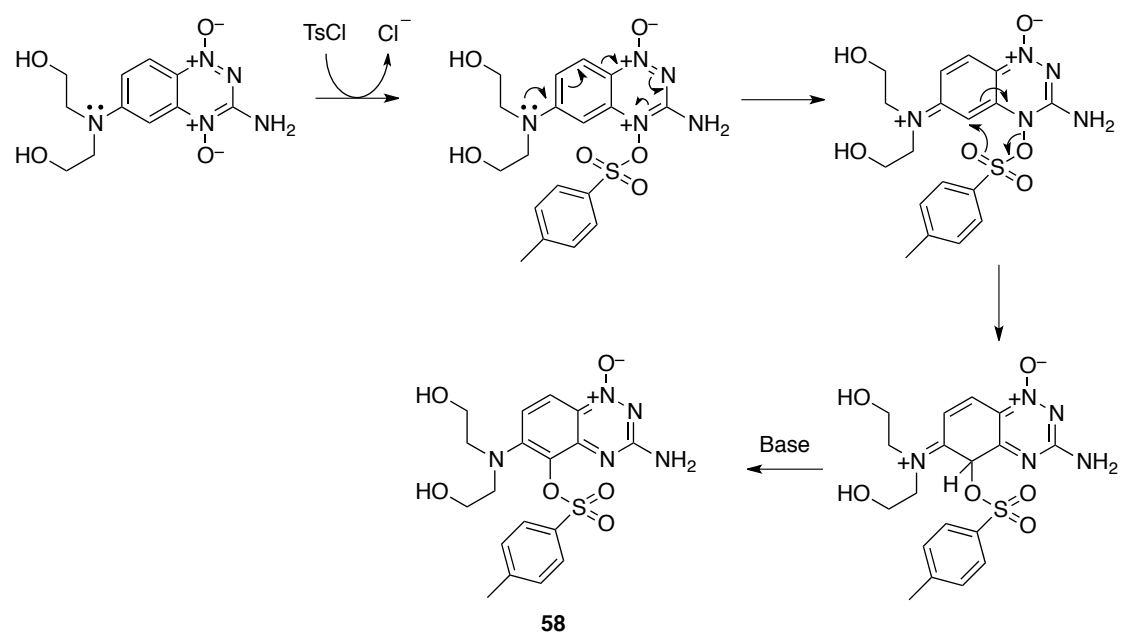

Scheme 5. Proposed reaction mechanism of formation for compound $\mathbf{5 8 .}$

\subsection{Rate of Hydrolysis Measured by NMR for Benzotriazine N-mustards}

To show that the 1,4-dioxide analogs $(\mathbf{5 5}, \mathbf{5 7}$, and $\mathbf{6 2})$ contained "deactivated" Nmustards, and their corresponding 1-oxide analogs $(\mathbf{5 4}, \mathbf{5 6}$, and 59) were "active", we monitored rates of hydrolysis by ${ }^{1} \mathrm{H}$ NMR. The reactivities of all $N$-mustards $(\sim 1 \mathrm{mM})$ were measured as time-course experiments under pseudo-1st-order reaction conditions inside NMR tubes as solutions of $50 \% \mathrm{CD}_{3} \mathrm{CN}$ in $\mathrm{D}_{2} \mathrm{O}$ heated to $50{ }^{\circ} \mathrm{C}$. At each timepoint, the reactions were cooled quickly to room temperature and a ${ }^{1} \mathrm{H}$ NMR spectrum was taken. Disodium maleate $(5 \mathrm{mM})$ was used as an internal standard for all ${ }^{1} \mathrm{HNMR}$ spectra. Integration of methyl or methylene peaks was monitored over time in order to calculate $N$-mustard rate of hydrolysis. Figure 1 shows the deactivation of compounds $\mathbf{5 4}, \mathbf{5 5}, \mathbf{5 6}$, and 57 as a time-course, including rates of reaction calculated using least squares fitting of experimental data converted to half-lives in days. The dimesyl mustard 
56 showed an approximate 5-fold increase in reactivity while the ditosyl mustard 54 showed about a 3-fold increase when compared their 1,4-dioxides $\mathbf{5 7}$ and 55, respectively (Table 1). These results confirm our initial hypothesis that the 4- $\mathrm{N}$-oxide effectively deactivates the nucleophilicity of the 6-position $N$-mustard nitrogen of the benzotriazine core.

\section{Figure 1}

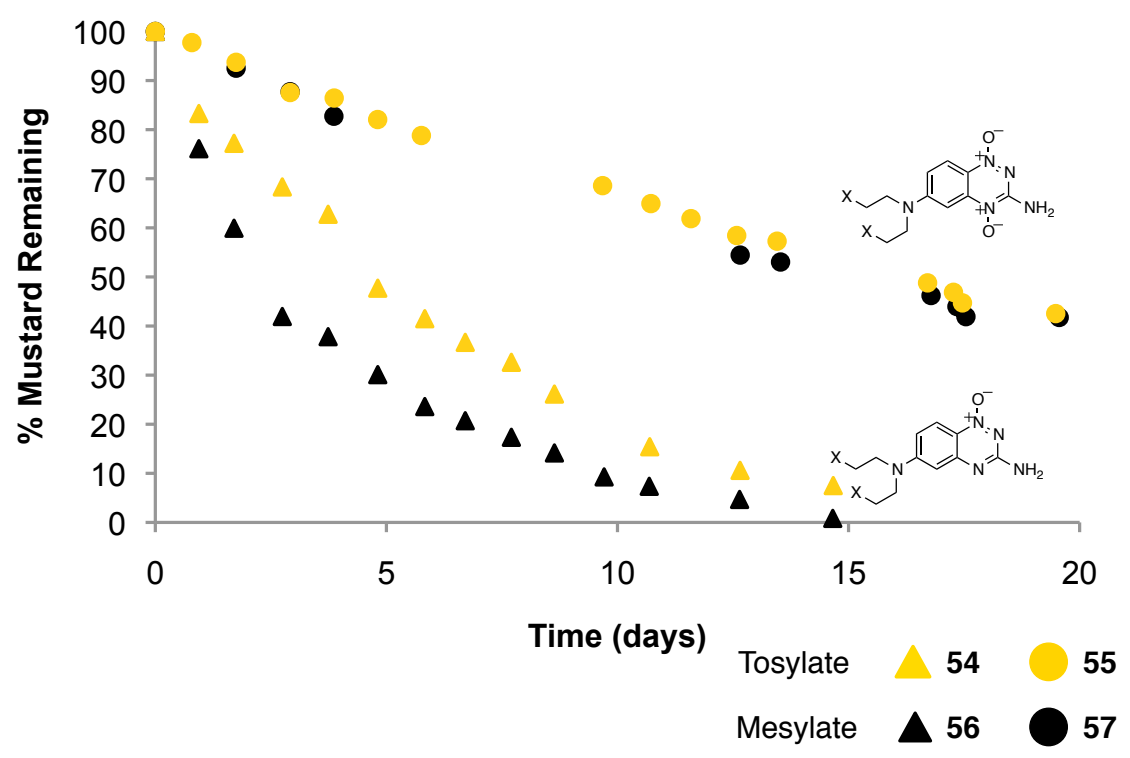

Figure 1. Rate of decay for compounds $\mathbf{5 4}, \mathbf{5 5}, \mathbf{5 6}$, and $\mathbf{5 7}$ in 1:1 acetonitrile- $d_{6} / \mathrm{D}_{2} \mathrm{O}$ measured by ${ }^{1} \mathrm{H}-\mathrm{NMR}$ in at $50{ }^{\circ} \mathrm{C}$. Compounds $\mathbf{5 4}$ and $\mathbf{5 6}$ were monitored for 2 weeks and compounds $\mathbf{5 5}$ and $\mathbf{5 7}$ were monitored for 2 months.

As mentioned before, this decrease in reactivity is attributed to a decrease in the electron density on the $N$-mustard nitrogen, resulting from the electronic interaction with the 4- $\mathrm{N}$-oxide. It is interesting to note that mesylate mustards $\mathbf{5 6}$ and $\mathbf{5 7}$ reacted faster than tosylate mustards $\mathbf{5 4}$ and $\mathbf{5 5}$, as literature precedents support that tosylates are slightly better leaving groups than mesylates. ${ }^{26-27}$ We theorized that the more hydrophobic tosylate leaving group was having hydrophobic interactions with the benzoring as depicted by a crystal structure obtained (Experimental, crystal structure 2). It is 
possible the hydrophobic interaction slows aziridinium ion formation, but this hypothesis was not tested further.

Table 1. Summary of Rates of Hydrolysis for Sulfonate N-Mustards<smiles>[R]c1nc2cc([R6])c([R])cc2[n+]([O-])n1</smiles>

1-oxide<smiles>[R]c1n[n+]([O-])c2cc([R])c([R6])cc2[nH+]1</smiles>

O_

1,4-dioxide

\begin{tabular}{cccccc} 
Compound & $\mathbf{R}_{\mathbf{1}}$ & $\mathbf{R}_{\mathbf{2}}$ & $\mathbf{R}_{\mathbf{3}}$ & Oxidation & $\boldsymbol{t}_{1 / 2}(\mathbf{d})$ \\
$\mathbf{5 4}$ & $-\mathrm{NH}_{2}$ & $-\mathrm{N}\left(\mathrm{CH}_{2} \mathrm{CH}_{2} \mathrm{OTs}\right)_{2}$ & $-\mathrm{H}$ & 1-oxide & $5.46 \pm 0.06$ \\
$\mathbf{5 5}$ & $-\mathrm{NH}_{2}$ & $-\mathrm{N}\left(\mathrm{CH}_{2} \mathrm{CH}_{2} \mathrm{OTs}\right)_{2}$ & $-\mathrm{H}$ & 1,4-dioxide & $15.4 \pm 0.7$ \\
\hline $\mathbf{5 6}$ & $-\mathrm{NH}_{2}$ & $-\mathrm{N}\left(\mathrm{CH}_{2} \mathrm{CH}_{2} \mathrm{OMs}\right)_{2}$ & $-\mathrm{H}$ & 1-oxide & $2.68 \pm 0.62$ \\
$\mathbf{5 7}$ & $-\mathrm{NH}_{2}$ & $-\mathrm{N}\left(\mathrm{CH}_{2} \mathrm{CH}_{2} \mathrm{OMs}\right)_{2}$ & $-\mathrm{H}$ & 1,4-dioxide & $15.4 \pm 0.7$ \\
\hline $\mathbf{6 5}$ & $-\mathrm{H}$ & $-\mathrm{N}\left(\mathrm{CH}_{2} \mathrm{CH}_{2} \mathrm{OTs}\right)_{2}$ & $-\mathrm{H}$ & 1-oxide & $13.9 \pm 1.1$ \\
$\mathbf{6 6}$ & $-\mathrm{H}$ & $-\mathrm{N}\left(\mathrm{CH}_{2} \mathrm{CH}_{2} \mathrm{OTs}\right)_{2}$ & $-\mathrm{H}$ & 1,4-dioxide & $12.6 \pm 1.4$ \\
\hline $\mathbf{6 7}$ & $-\mathrm{H}$ & $-\mathrm{H}$ & $-\mathrm{N}\left(\mathrm{CH}_{2} \mathrm{CH}_{2} \mathrm{OTs}\right)_{2}$ & 1-oxide & $6.48 \pm 0.79$ \\
$\mathbf{6 8}$ & $-\mathrm{H}$ & $-\mathrm{H}$ & $-\mathrm{N}\left(\mathrm{CH}_{2} \mathrm{CH}_{2} \mathrm{OTs}\right)_{2}$ & 1,4-dioxide & $6.54 \pm 0.06$
\end{tabular}

Hydrolysis Conditions: $50 \%$ acetonitrile- $\mathrm{D}_{3}$ in $\mathrm{D}_{2} \mathrm{O}$ at $50{ }^{\circ} \mathrm{C}$

We observed slightly slower hydrolysis rates for $\mathbf{6 0}$, and $\mathbf{6 1}$, and significantly slower rates with chlorine mustards 59 and 62 . Chloride mustard 59 ("activated") gave a calculated half-life of 51 days showing 85\% remaining SM after 10 days, whereas 62 (the di-oxide "deactivated" mustard) showed no noticeable reaction occurring. While typically chlorines are used for $\mathrm{N}$-mustard activity, we chose to only study the sulfonate mustards further for their higher reactivity. The sulfonate mustards also improved solubility over the halide mustards. The hydrolysis conditions discussed were chosen to allow for comparison of reactivity for molecules of differing solubility at concentrations needed for sufficient signal detection. The $50 \%$ organic conditions slowed the reaction rates enough 
for easy measurement by ${ }^{1} \mathrm{H}$ NMR. It should be noted that the reactivity of sulfur mustards can significantly change with increasing water concentrations. ${ }^{28}$ Consequently, accurate biological hydrolysis rates cannot be inferred from these results. But we have shown proof of concept for the controlled deactivation of a $\mathrm{N}$-mustard substituted at the 6-position in the presence of the 4- $\mathrm{N}$-oxide (Scheme 3).

\section{Scheme 6}
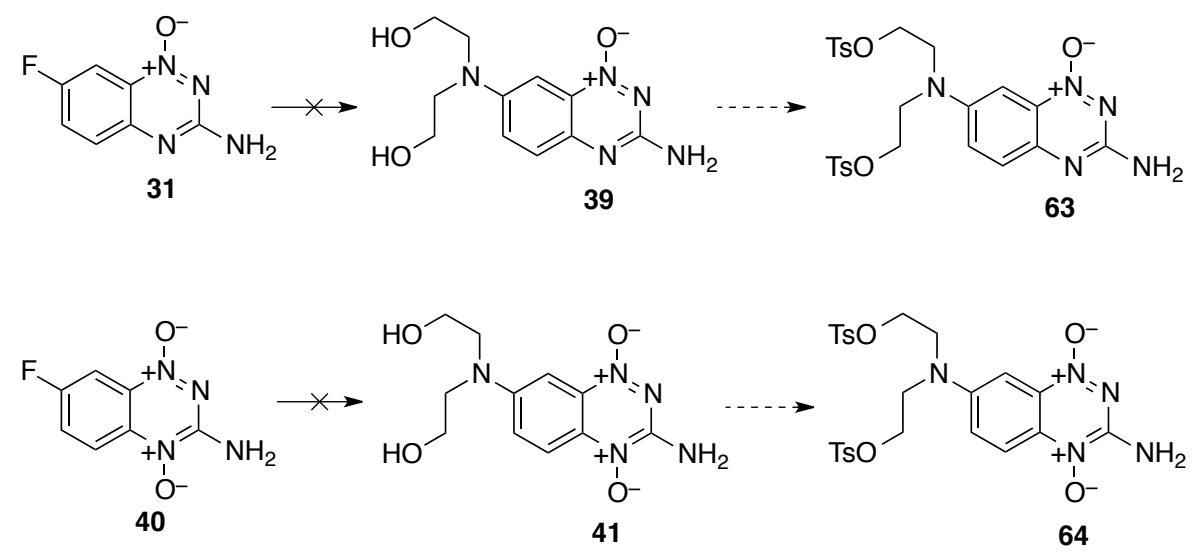

We were also interested to see if placing the nitrogen mustard moiety in other positions would observe the same deactivation. To do this, we looked to synthesize compounds containing the N-mustard moiety on the 7-position (compounds 63 and $\mathbf{6 4}$, Scheme 6) and compare the change in reactivity with that of compounds $\mathbf{5 4}$ and $\mathbf{5 5}$. The goal was to use structure 39, but we discussed in Chapter 1 how the reaction of $\mathbf{3 1}$ with diethanolamine gave little product and could not be efficiently isolated. This is interesting because compound $\mathbf{3 6}$ was prepared cleanly. Similarly compound $\mathbf{4 0}$ could not be efficiently aminated, whereas $\mathbf{3 7}$ was aminated quite easily (Chapter 1). This lower inherent electrophilicity of position 7 (Chapter 1, Figure 1) allows us to infer that compounds 63 and 64 would contain more nucleophilic N-mustard nitrogens than their 6- 
position counterparts $\mathbf{5 4}$ and 55. In terms of $N$-mustard activity this equates to faster rates of reaction. At the time other attempts were made towards synthesis of structure 39, utilizing Pd catalyzed reactions in particular but because of insolubility, the products observed in these reactions could not be isolated or characterized.

Instead we sought to use structures that did not contain the exocyclic $-\mathrm{NH}_{2}$ in order to reduce electron density of the aromatic system. In Chapter 1 we prepared fluorocontaining benzotriazines missing the exocyclic $-\mathrm{NH}_{2}$ (compounds 27 and 32), which were aminated with diethanolamine under mild conditions to give compounds $\mathbf{2 8}$ and $\mathbf{3 3}$. As described in chapter 1, we did this by deamination with tert-butyl nitrite in DMF to form desamino fluoro-containing derivatives $\mathbf{2 7}$ and $\mathbf{3 2}$ following a procedure in Boyd et $a l .{ }^{29}$ Nucleophilic aromatic substitution with diethanolamine provided the diol containing N-mustard scaffolds. Deamination at the 3-position made positions 6 and 7 (containing fluorine atoms) more susceptible towards substitution reactions. A significant increase in organic solubility was also observed allowing more versatility in solvent choice. Compounds 27 and 32 were sulfonated with tosyl chloride to give N-mustards 65 and 67 with tosyl chloride (Scheme 7). The 1,4-dioxide mustards 66 and 68 were obtained by Noxidation in low yield.

\section{Scheme 7}
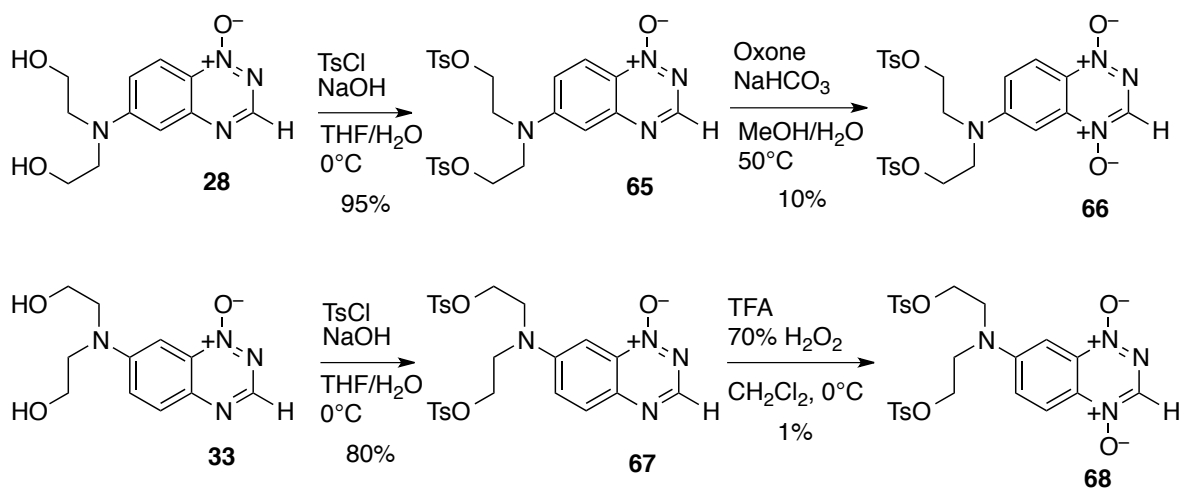
These low oxidation yields result from removing the electron donating $-\mathrm{NH}_{2}$ at the 3-position. This caused the endocyclic 4-nitrogen to become less nucleophilic towards $\mathrm{N}$-oxidation. This is even more noticeable with oxidation of 67 to 68 . As predicted before, the electron withdrawing effects of the 4- $\mathrm{N}$-oxide would not have significant affects on a $\mathrm{N}$-mustard in the 7-position. It holds that the 7-position would not provide any electron donating effects to assist the $\mathrm{N}$-oxidation at the 4- $\mathrm{N}$-position. After preparation of these new synthetic targets, their rates of hydrolysis were measured by ${ }^{1} \mathrm{H}$ NMR like before (Table 1).

As predicted, no significant difference in reactivity was observed for compounds 67 and 68. Confirming that the 7-position is not appreciably deactivated by the presence of a 4-N-oxide (Figure 2). It is interesting to note that $\mathbf{6 5}$ did not result in a significanly faster rate of hydrolysis than the dioxide $\mathbf{6 6}$, and both were still much less reactive than the 7-position mustards 67 and 68 . For the 6-position analogs lacking the 3-amino group (65 and 66), we also did not observe a significant difference in reactivity. The 3-amino group must serve to mitigate some of the strong electron-withdrawing interactions of the benzotriazine ring. Furthermore, compounds $\mathbf{6 5}$ and $\mathbf{6 6}$ have hydrolysis rates resembling that of $\mathbf{5 5}$ and $\mathbf{5 7}$. The 4-N-oxide group must exert such a strong electron-withdrawing (deactivating) effect on the mustard unit in the 6-position thereby preventing the participation of this nitrogen's lone pair in aziridinium ion formation altogether. The combination of these results suggests a tunable reactivity of substituents located at the 6position on the TPZ core. 


\subsection{Preparation and Hydrolysis Rate Measurements of Quinone Methide Analogs}

These results showing proof of concept sparked interest towards investigating if other substituents with DNA alkylating potential could be modulated. Quinone methides are highly reactive intermediates that have been utilized both in synthetic and medicinal chemistry. For example, mytomycin $\mathrm{C}(\mathbf{6 9})$, is a DNA cross-linking agent that is bioreductively activated in cells (Scheme 8). ${ }^{30}$ Enzymatic reduction initiates a series of reactions, which involve a set of quinone methide-like chemistry to alkylate DNA via conjugate addition (Scheme 8). We set out to incorporate quinone methide-like structures onto the benzotriazine core.

\section{Scheme 8}

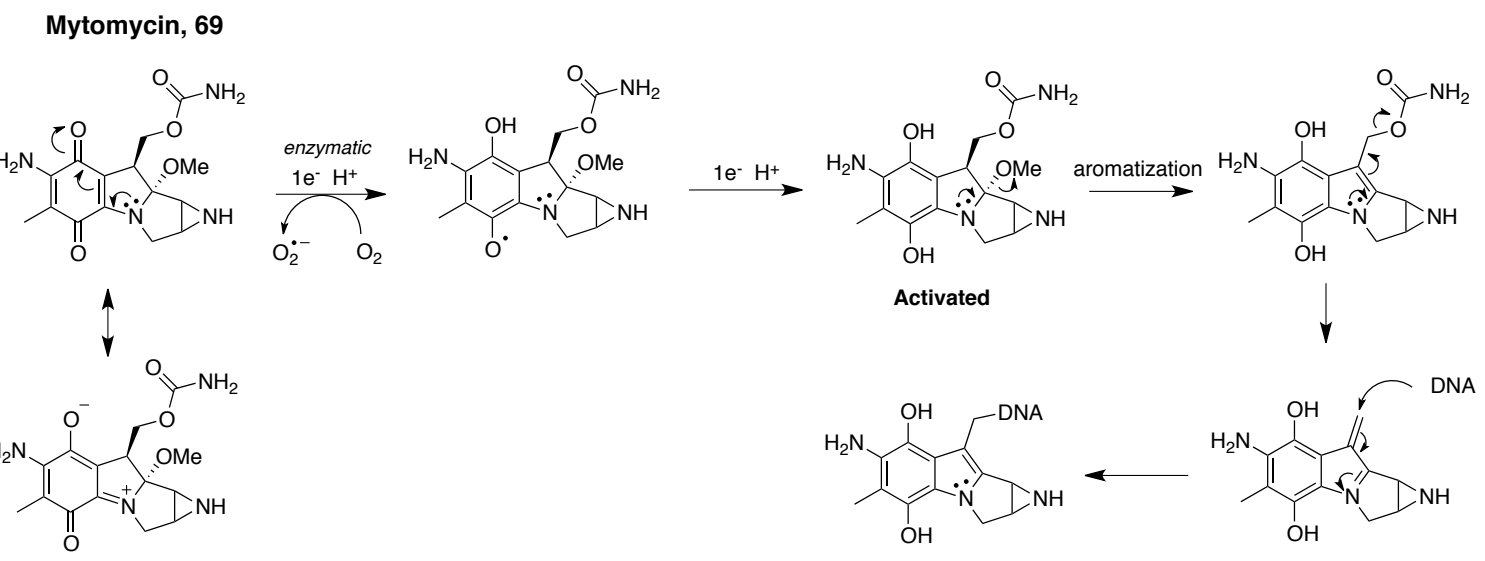




\section{Scheme 9}

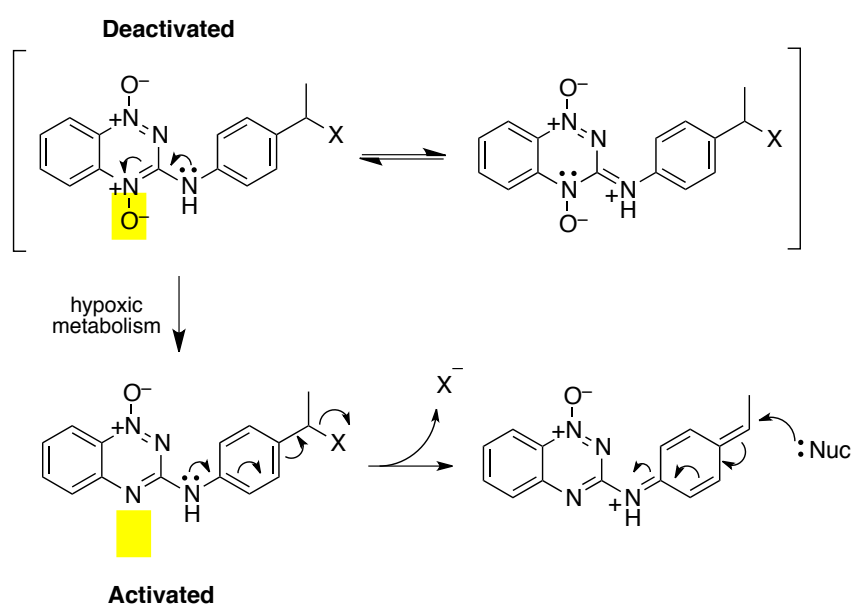

Our goal was to utilize an exocyclic aromatic amine with a benzyl substituent to generate a quinone methide-like enamine structure shown in Scheme 9. We theorize this would act similar to actual quinone methides, performing Michael Addition reactions. We prepared two sets of compounds including the mono- and di- $N$-oxide analogues, one substituted at the 3-position $\mathbf{7 1}$ and $\mathbf{7 2}$ and another substituted at the 6-position $\mathbf{7 6}$ and $\mathbf{7 7 .}$

The preparation is described in Scheme 10. Compound 73 was prepared by condensation of cyanamide with the corresponding nitroaniline. Deamination with tertbutyl nitrite provided 74. With compounds 5 and 74, we utilized Buchwald coupling presented in Chapter 1 to prepare the benzyl alcohol derivatives $\mathbf{7 0}$ and $\mathbf{7 5}$. Acetylation of the benzyl alcohol yielded "activated" compounds 71 and 76. Subsequent oxidation with $m$ CPBA gave "deactivated" analogues 72 and 77 in low yield. 


\section{Scheme 10}<smiles>[O-][n+]1nc(Cl)nc2ccccc21</smiles>

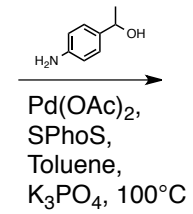<smiles>CC(O)c1ccc(Nc2nc3ccccc3[n+]([O-])n2)cc1</smiles><smiles></smiles>

72<smiles>CC(=O)OC(C)c1ccc(Nc2nc3ccccc3[n+]([O-])n2)cc1</smiles><smiles></smiles>

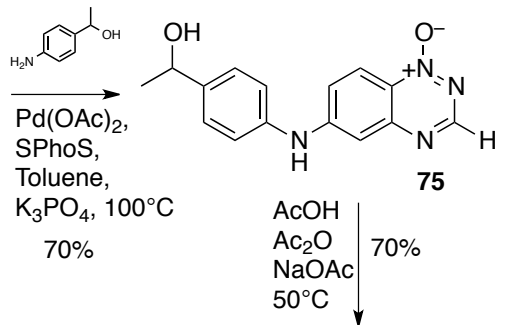<smiles>CC(=O)OC(C)c1ccc(Nc2ccc3c(c2)[n+]([O-])c(C)n[n+]3[O-])cc1</smiles><smiles>CC(C)OC(=O)OC(C)c1ccc(Nc2ccc3c(c2)nc([O+])n[n+]3[O-])cc1</smiles>

Table 2. Methide Analog Rates of Hydrolysis

\begin{tabular}{ccc} 
Compound & Oxidation & $\boldsymbol{t}_{1 / 2}(\mathrm{~d})$ \\
$\mathbf{7 1}$ & 1-oxide & 1.26 \\
$\mathbf{7 2}$ & 1,4-dioxide & 1.73 \\
\hline $\mathbf{7 6}$ & 1-oxide & 0.41 \\
$\mathbf{7 7}$ & 1,4-dioxide & 0.97 \\
\hline
\end{tabular}

Hydrolysis Conditions: $50 \%$ acetonitrile- $\mathrm{D}_{3}$ in $\mathrm{D}_{2} \mathrm{O}$ at $50{ }^{\circ} \mathrm{C}$ Half-lives are given as the average of two runs 
The rates of reaction were measured as before using ${ }^{1} \mathrm{H} N M R$ in $50 \% \mathrm{D}_{3}$-ACN in $\mathrm{D}_{2} \mathrm{O}$ solutions at $50^{\circ} \mathrm{C}$. The calculated half-lives are listed in Table 2. In summary, the reaction rates of all compounds are significantly faster compared to the $\mathrm{N}$-mustard analogues, with calculated half-lives of 1.26 days for compound 71 and 0.41 days for compound 76. Both reacted more than 2-fold faster than the dimesylate mustard 56. We also observe deactivation of quinone methide analogues in the presence of the 4- $\mathrm{N}$-oxide (72 and 77). Although the degree of deactivation is not as striking as with the $N$-mustard analogues, we see about a 50\% decrease in hydrolysis rate for compounds $\mathbf{7 1}$ and $\mathbf{7 2}$ and a two-fold decrease for compounds $\mathbf{7 6}$ and $\mathbf{7 7 .}$. Most likely the small change in reactivity results from only partial contribution of the amine to the benzyl carbocation formation. This suggests that significant benzyl carbocation formation occurred without assistance of the amine. Presumably using poorer leaving groups like $-\mathrm{OCH}_{3}$ could be used to tailor the change in reactivity at the expense of slower reaction rates. Overall these results further support the use of the benzotriazine core to modulate the reactivity of exocyclic substituents at not only the 6-position, but the 3-position as well (Chapter 1, Figure 1).

\subsection{Hypoxia-Selective, In Vitro Metabolic Conversion of 38 to 36}

Successful deployment of the activated mustard 56 requires hypoxia-selective enzymatic reduction of the dioxide 57. Thus, it was important to demonstrate that the dialkylamine substituent at the 6-position of tirapazamine did not prevent bioreductive, deoxygenative metabolism of the 1,2,4-benzotriazine 1,4-dioxide core. We performed enzymatic assays with the NADPH:cytochrome P450 reductase (POR) as the bioreductive enzyme for this test, as it is thought to be responsible for bioactivation of 
TPZ (1). ${ }^{6,}{ }^{12,}{ }^{31-33}$ Conditions similar to literature precedent were utilized for this experiment. $^{2}$ To avoid complex product analysis by the mesylate containing N-mustards, we decided to utilize the diol containing $N$-mustard $\mathbf{3 8}$ for this experiment. Compound 38 was incubated under anaerobic conditions in aqueous sodium phosphate $(25 \mathrm{mM}, \mathrm{pH}$ 7) degassed with argon in the presence of NADPH $(500 \mathrm{mM})$ and POR $(1 \mathrm{U} / \mathrm{mL})$ for $24 \mathrm{~h}$ at room temperature protected from light. Integration of peaks absorbing at $420 \mathrm{nM}$ were used to estimate a percent reduction of $\sim 16 \% 36$ relative to unreduced 38 remaining (Figure 2A). A control was run using the same buffer system but under aerobic conditions. In the presence of oxygen, no generation of $\mathbf{3 6}$ was observed (Figure 2B). When the anaerobic conditions were repeated using TPZ (1) for comparison, approximately $47 \%$ reduction was obtained (Figure 2C). The 6-diethanolamine substituted TPZ analogue $\mathbf{3 8}$ showed lower efficiency towards reduction when compared to its predecessor $\mathbf{1}$. This was to be expected, as literature reports that TPZ analogues containing an $\mathrm{e}^{-}$donating group at the 6-position, like in compound 38, have lower reduction potentials (more negative) ${ }^{34}$ Nonetheless, the results provide evidence that $\mathbf{3 8}$ can undergo hypoxia-selective metabolism in a manner similar to the parent compound Tirapazamine. 


\section{Figure 2}

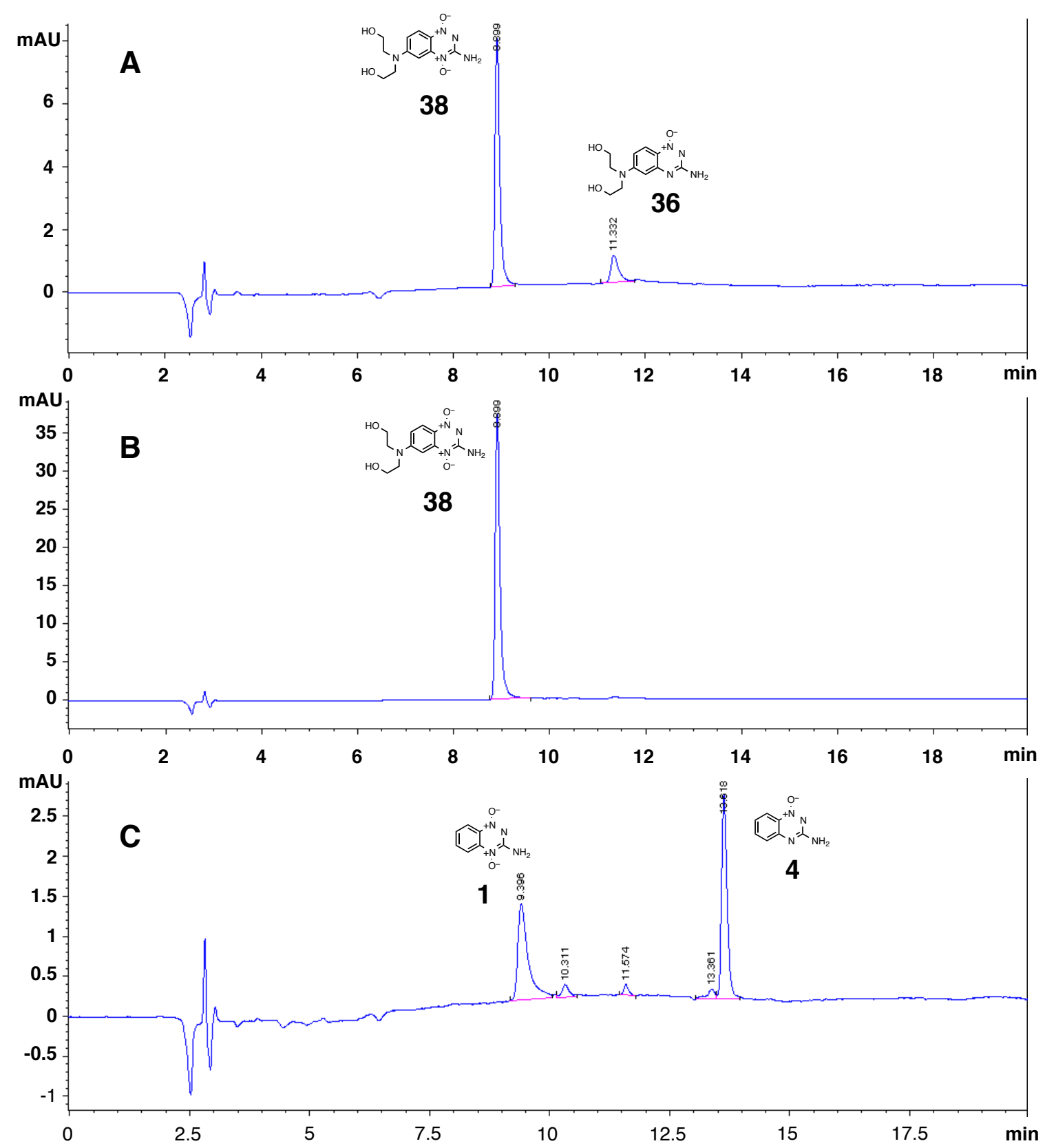

Figure 2. HPLC chromatogram showing the in vitro metabolic conversion of $\mathbf{3 8}$ to 36 and 1 to 4 by cytochrome P450:NADPH reductase under anaerobic conditions: (A) Reduction of $\mathbf{3 8}$ under anaerobic conditions, (B) same but under aerobic conditions, and (C) reduction of $\mathbf{1}$ under anaerobic conditions. 


\subsection{Assessment of Hydrolysis Products of Benzotriazine N-Mustards}

We felt it necessary to confirm the identity of $N$-mustard hydrolysis products formed. Compounds $\mathbf{5 6}$ and $\mathbf{5 7}$ were selected for their higher reactivity and superior aqueous solubility. Hydrolysis reactions were monitored by HPLC in buffered aqueous solution. The $N$-mustards $(250 \mu \mathrm{M}, 2.5 \% \mathrm{DMF})$ were heated to $50{ }^{\circ} \mathrm{C}$ in sodium phosphate buffer (25 mM, pH 7) in $\mathrm{H}_{2} \mathrm{O}$ over 24 hours. HPLC chromatograms monitoring integrated absorbance values at $280 \mathrm{nM}$ were taken at various time intervals to determine the rate of disappearance. Using linear regression, we determined half-lives for 56 and 57 to be $12 \pm 0.5 \mathrm{~h}$ and $96 \pm 21 \mathrm{~h}$, respectively, under aforementioned conditions (Figure 2). As expected, the hydrolysis rates of $\mathbf{5 6}$ and $\mathbf{5 7}$ were substantially faster under these conditions than when compared to the $50: 50 \mathrm{CD}_{3} \mathrm{CN}-\mathrm{D}_{2} \mathrm{O}$ mixture employed in the NMR experiments. ${ }^{35}$ Here the "activated" mono- $N$-oxide metabolite $\mathbf{5 6}$ reacted approximately seven times faster than the parent dioxide 57. Comparison with authentic synthetic standards revealed that the major products generated in the decomposition of 57 were the diol 36 and the morpholino 79, both presumably formed via the half-mustard 78 (Scheme 11). This was also observed with ${ }^{1} \mathrm{H}$ NMR, and is consistent with reported aryl $N$-mustard hydrolysis products. ${ }^{36}$ The two products were estimated to be about a 2:1 ratio of morpholino (79) and diol (36) for the hydrolysis of 1oxide mustard 56. Under the same conditions $\mathbf{5 7}$ did not show significant formation of analogous hydrolysis products, consistent with the deactivation of $N$-mustard activity. 


\section{Figure 3}
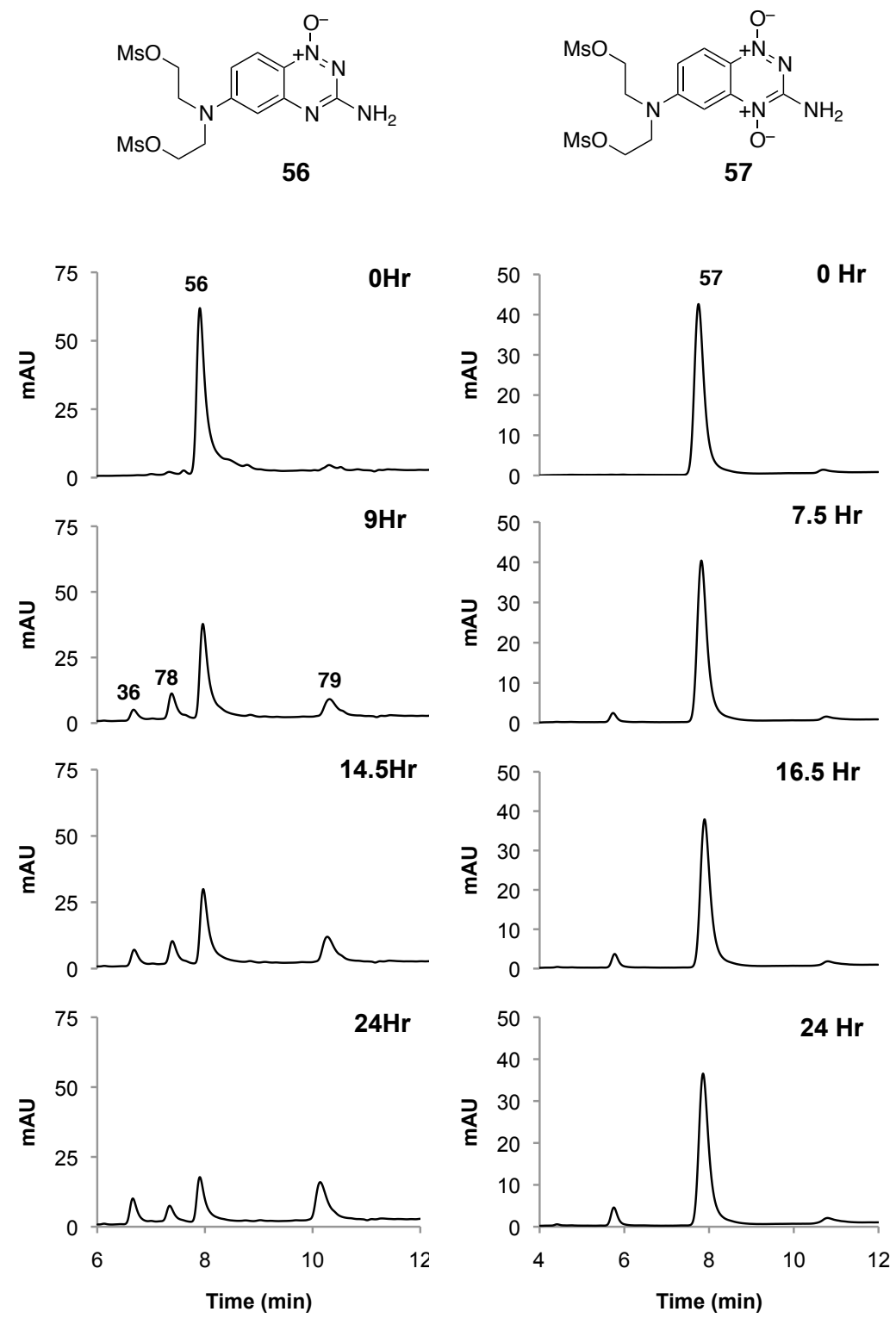

Figure 3. Representative HPLC chromatograms showing the hydrolysis of compounds 56 (left) and 57 (right) $(250 \mu \mathrm{M})$ in sodium phosphate buffer $(25 \mathrm{mM}, \mathrm{pH} 7)$ containing $\operatorname{DMF}(2.5 \% \mathrm{v} / \mathrm{v})$ at $50{ }^{\circ} \mathrm{C}$. Compounds were detected by their absorbance at $280 \mathrm{~nm}$. The disappearance of compound $\mathbf{5 6}$ and appearance of hydrolysis products $\mathbf{3 6}$ and $\mathbf{7 8}$ over a $24 \mathrm{~h}$ time period is shown on the left. The disappearance of compound 57 over a $24 \mathrm{~h}$ time period is shown on the right. 


\section{Scheme 11}

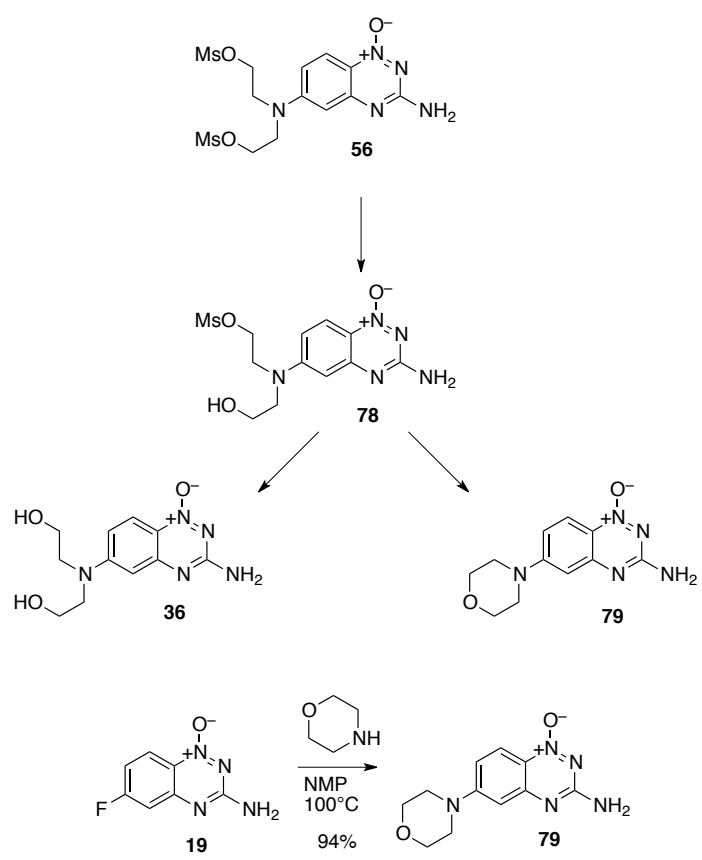

\subsection{Measurement of the Electron-Withdrawing Power of the Benzotriazine Ring} Systems.

We felt it would be useful to quantitatively measure the electron-withdrawing power of the triazine ring systems in $\mathbf{5 6}$ and $\mathbf{5 7}$. Electronic effects exerted by various substituents on an aromatic ring typically are measured using Hammett sigma $(\sigma)$ constants. ${ }^{37}$ Hammett $\sigma$ values are determined by measuring the affect of the substituent on the acidity of a carboxylic acid group (Scheme 12) on the aromatic ring system, where $\sigma_{\text {substituent }}=\log \left(\mathrm{K}_{\mathrm{a}(\text { substituted benzoic acid) }} / \mathrm{K}_{\mathrm{a}(\text { benzoic acid })}\right)$. Therefore, we prepared the carboxylic acid derivatives 80 and $\mathbf{8 1}$ via reaction of guanidine with 3-fluoro-4-nitrobenzoic acid under basic conditions, as shown in Scheme $12 .{ }^{38}$ We measured the acidity of $\mathbf{8 0}$ by monitoring the changes in its UV-vis spectra as a function of $\mathrm{pH}$ (Figure 4). From the 
measured $\mathrm{pK}_{\mathrm{a}}$ of 2.9 we were able to calculate a $\sigma$ value of 1.3 for the mono- $N$-oxide $\mathbf{8 0}$.

The establishes the 1,2,4-triazine-1-oxide ring as a strongly electron-withdrawing substituent comparable to a $p$-sulfonyl cyanide group $\left(-\mathrm{SO}_{2} \mathrm{CN}\right){ }^{37}$ Unfortunately, we were not able to accurately measure the $\mathrm{pK}_{\mathrm{a}}$ for the di-N-oxide $\mathbf{8 1}$ but a similar titration allowed us to estimate a $\mathrm{pK}_{\mathrm{a}}$ between 1.5 and 2.0. The UV-vis spectral changes for $\mathbf{8 1}$ associated with protonation of the carboxylic acid group were obscured by another process, perhaps involving protonation of the oxygen in the 4-oxide group.

\section{Scheme 12}

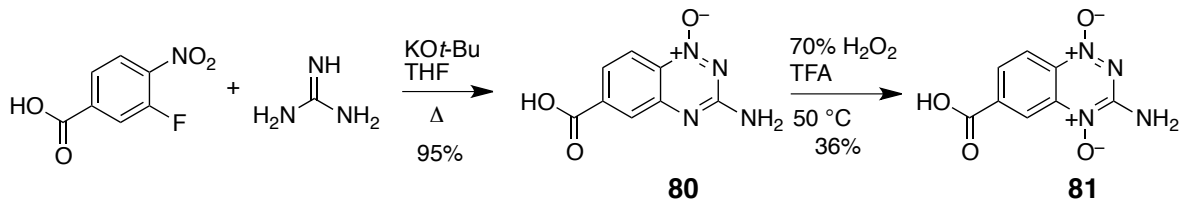

Figure 4
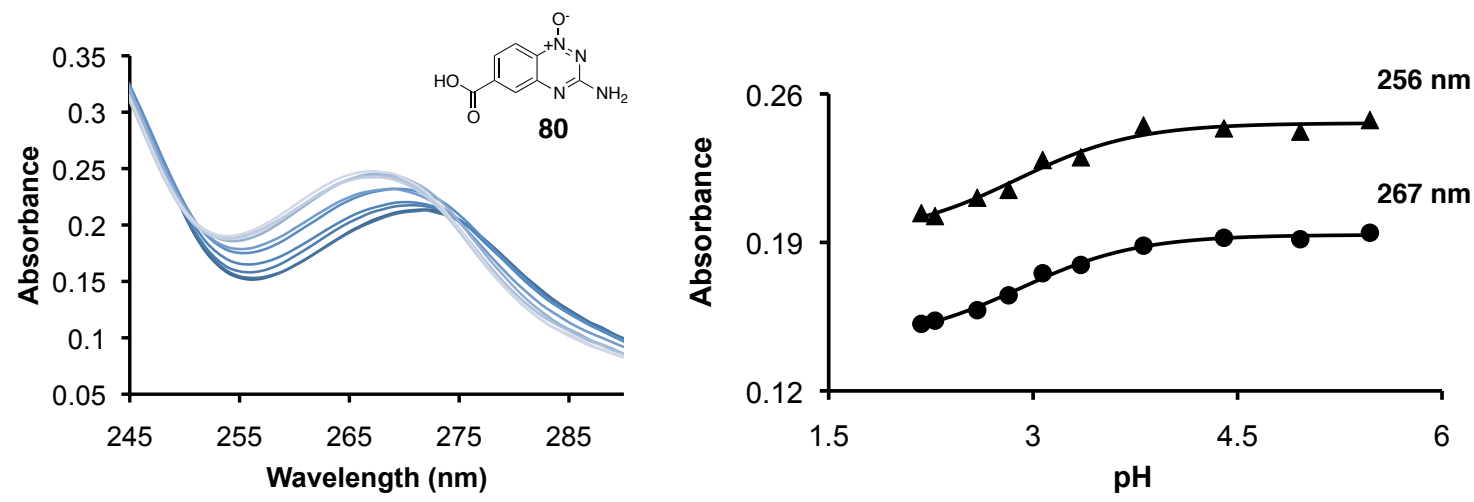

Figure 4. $\mathrm{pK}_{\mathrm{a}}$ determination for 80. Absorbance spectra (left) and titration curves (right) with least squares fitting for compound $\mathbf{8 0}$ from $\mathrm{pH}$ 2.18-5.47.

Electronic properties of substituents can also be measured using a $\sigma^{-}$parameter that is obtained by measuring the effect of substituents on the acidity of phenol ${ }^{37,39}$ While the $\sigma^{-}$parameter is probably less relevant than $\sigma$ to the aziridinium ion-forming reactions 
that are the subject of this work, ${ }^{40}$ we felt this measurement would nonetheless provide a useful evaluation of the electronic properties of the triazine mono-oxide and dioxide ring systems. Therefore, we synthesized the phenol derivatives $\mathbf{8 2}$ and $\mathbf{8 3}$ by hydrolysis of the corresponding fluoro compounds 19 and $\mathbf{3 8}$ respectively (Scheme $13^{41}$ We then measured the acidity of these compounds by monitoring the changes in their UV-vis spectra as a function of $\mathrm{pH}$ (Figure 5). The $\mathrm{pK}_{\mathrm{a}}$ of $\mathbf{8 2}$ was found to be 6.3 and that of $\mathbf{8 3}$ was 5.3. The $\mathrm{pK}_{\mathrm{a}}$ measurements allowed us to calculate $\sigma^{-}$values of 1.81 for the $1,2,4-$ triazine 1-oxide "substituent" in $\mathbf{8 2}$ and 2.31 for the 1,2,4-triazine 1,4-dioxide "substituent" in 83. These values indicate that both the triazine mono- $N$-oxide and the di$\mathrm{N}$-oxide rings are strongly electron withdrawing. By way of comparison, the sulfonyl perfluoropropane group $\left(-\mathrm{SO}_{2}\left(\mathrm{CF}_{2}\right)_{2} \mathrm{CF}_{3}\right)$ has a $\sigma^{-}$value of 1.75 and the diazonium group $\left(-\mathrm{N}_{2}{ }^{+}\right)$has a $\sigma^{-}$value of $3.43 .^{37}$ Importantly, there is a substantial difference $(0.5)$ between the $\sigma^{-}$values between the 1,2,4-triazine 1-oxide and 1,2,4-triazine 1,4-dioxide substituents in $\mathbf{8 2}$ and $\mathbf{8 3}$. This is similar to the difference between $\sigma^{-}$values of the nitro group (1.27) and the acetyl group (0.84). ${ }^{37}$

\section{Scheme 13}

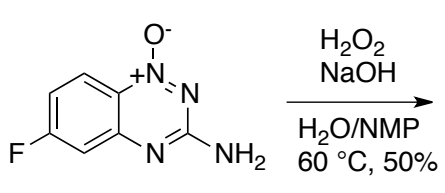

19

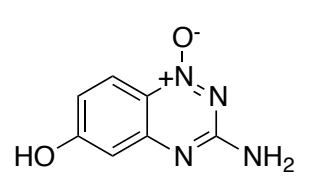

82

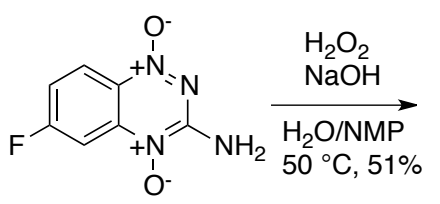

37<smiles>Nc1nn([O-])c2ccc(O)cc2[n+]1=O</smiles>

83 


\section{Figure 5}
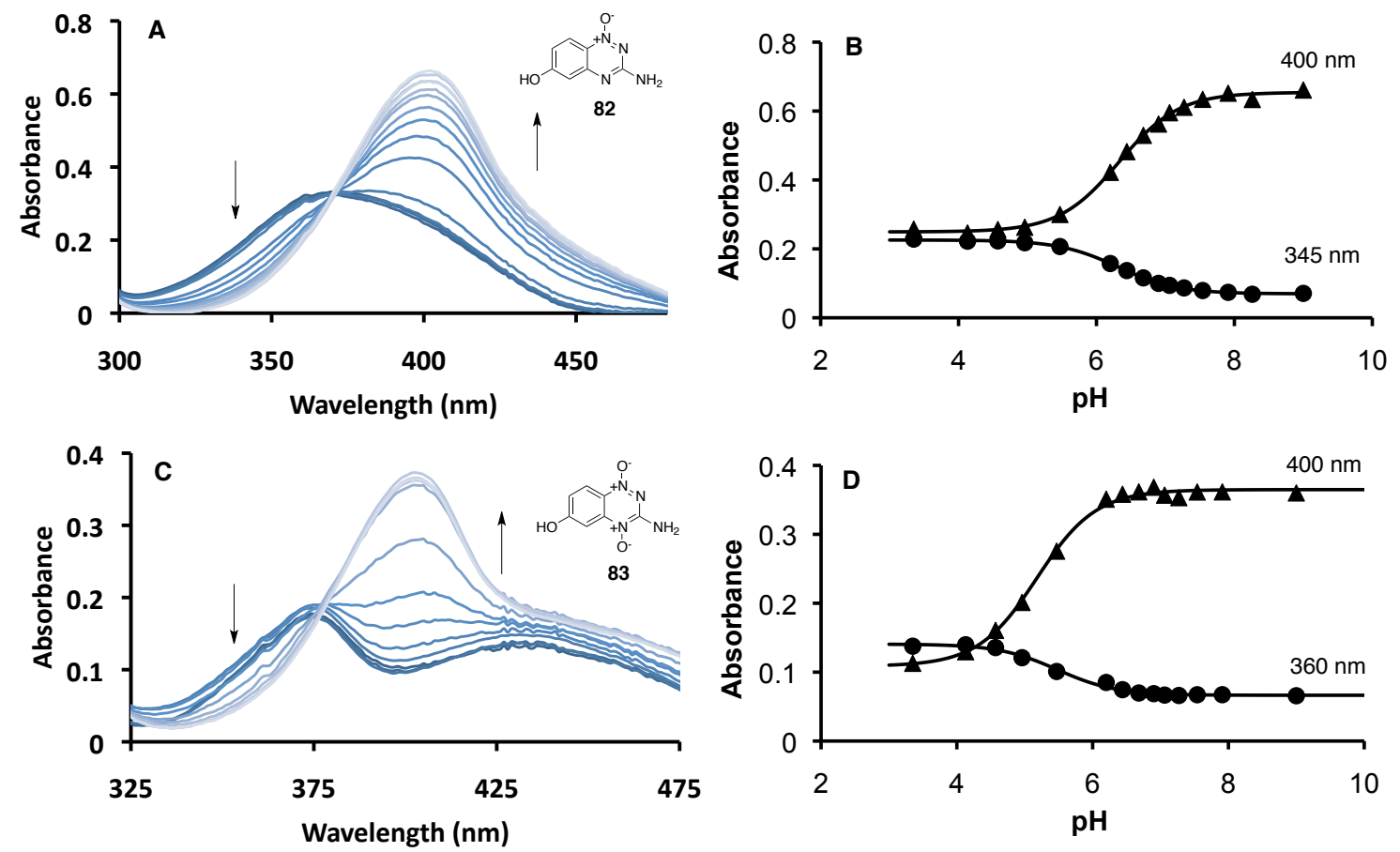

Figure 5. $\mathrm{pK}_{\mathrm{a}}$ determination for compounds 31 and 32. UV/Vis spectra of compounds $82(\mathrm{~A})$ and $\mathbf{8 3}(\mathrm{C})$ from $\mathrm{pH} 3.4 \rightarrow 9.0(\mathbf{8 2})$ and $\mathrm{pH} 2.4 \rightarrow 9.0(\mathbf{8 3})$. Titration curves with least squares fitting of compounds 82 (B) and $\mathbf{8 3}$ (D) from $\mathrm{pH}$ 3.35-9.00.

To confirm that $\mathrm{pK}_{\mathrm{a}}$ values measured reflected protonation of the 6-COOH or 6$\mathrm{OH}$ substituents in compounds 80, 82, and 83, $\mathrm{pH}$-absorbance measurements were performed with $\mathbf{4}$ and $\mathbf{1}$ to show that these control compounds displayed no significant changes in absorbance within the $\mathrm{pH}$ regions of interest (Figure 6). We suspect the changes in absorbance of compounds 1 and $4(\mathrm{pH}<2)$ result from protonation of the exocyclic $-\mathrm{NH}_{2}$ or of an $\mathrm{N}$-oxide moiety. Overall, the results confirm the notion that transformation of the 1,4-di- $N$-oxide to the $1-N$-oxide causes a substantial change in the electron-withdrawing power of the triazine "substituent", evident by the difference in the Hammett $\sigma$ (and $\sigma^{-}$) values of the 1-N-oxide and 1,4-di- $N$-oxide structures. 


\section{Figure 6}
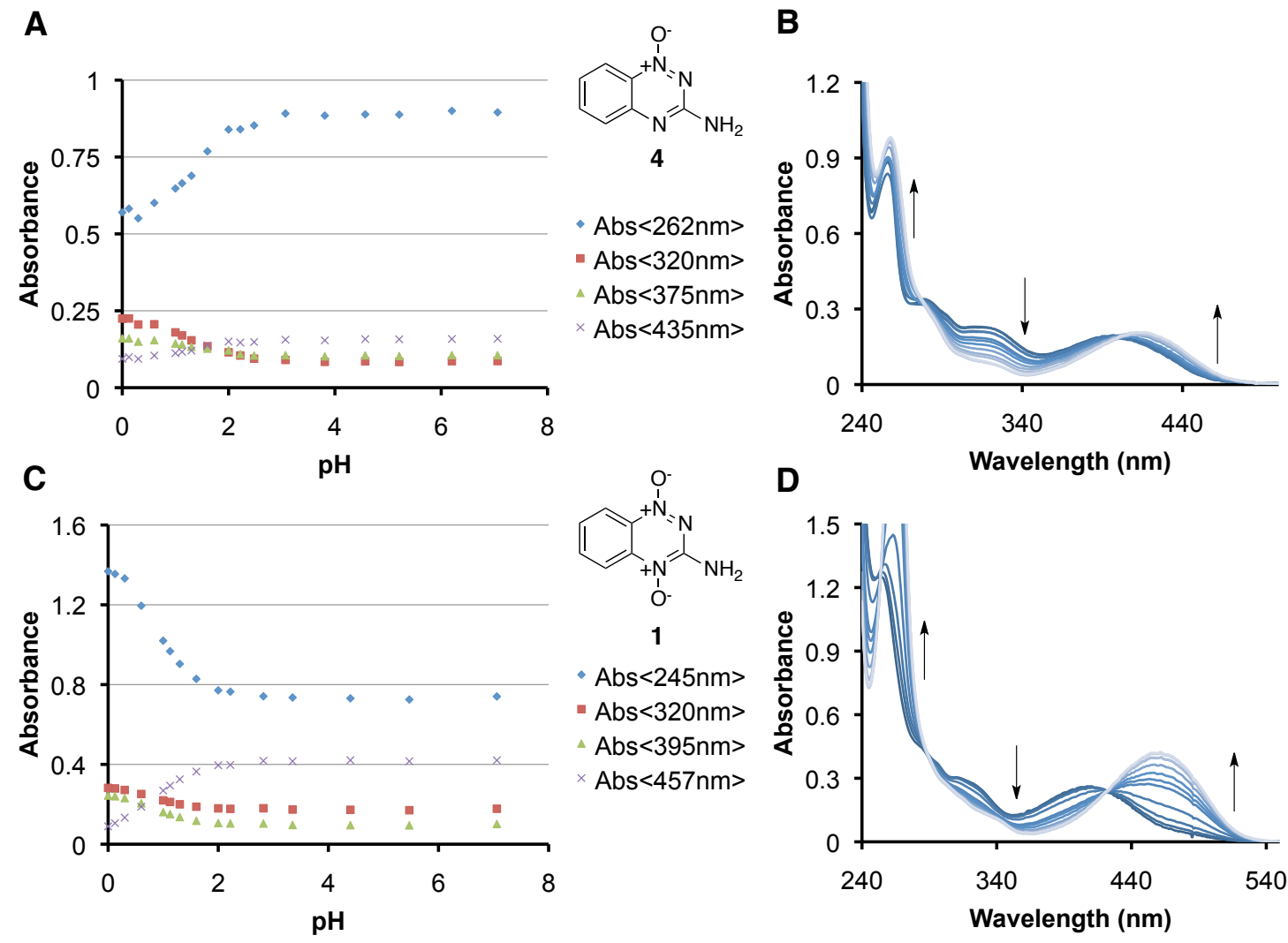

Figure 6. pH-Dependent changes in the absorbance spectra of compounds $\mathbf{4}$ and $\mathbf{1}$. The results show that the changes in the $\mathrm{pH}$-dependent absorbance spectra $(\mathrm{pH}>2)$ for $\mathbf{8 0}$, $\mathbf{8 2}$, and $\mathbf{8 3}$ are likely associated with protonation and deprotonation of the carboxylate and phenol groups.

\subsection{DNA Alkylation of Benzotriazine 1-Oxde N-mustard}

To confirm selective DNA alkylation by our 1-oxide benzotriazine nitrogen mustards, we used the dimesylate mustard (56) in our in vitro experiments for its superior water solubility over other mustards synthesized. We incubated our compounds in the presence of ${ }^{32} \mathrm{P}$-labeled oligonucleotide DNA duplexes and used $20 \%$ denaturing polyacrylamide gel electrophoresis (PAGE) to analyze reaction products resulting from alkylation of DNA bases. It is known that the N-7 of deoxyguanosine (dG) (Scheme 14) 
is the preferential site for DNA alkylation. In fact this property is used for MaxamGilbert G-selective DNA sequencing reactions. ${ }^{42}$ Alkylation (and protonation) of Gresidues at N-7 destabilizes the glycosidic bond, resulting in depurination. ${ }^{43}$ This reaction results in hydrolysis of the DNA base from the sugar-phosphate backbone, leaving you with what is termed an apurinic (Ap) site. (Scheme 14, 84) Ap sites are common DNA lesions, and can undergo $\alpha, \beta$-elimination reactions resulting in DNA single strand breaks (Ap*, 85) as they equilibrate between a closed ring hemiacetal and open chain aldehyde form (Scheme 14). ${ }^{43-45}$ We catalyzed this reaction via Schiff base formation with a hot piperidine treatment $\left(1 \mathrm{M}, 95{ }^{\circ} \mathrm{C}, 30 \mathrm{~min}\right)$ to quantitate the extent of DNA alkylation measure by DNA cleavage. In our experiments, any bands that move faster than the unreacted ${ }^{32} \mathrm{P}$-labeled single-strand oligonucleotides in the gel correspond to cleavage products resulting from DNA alkylation and depurination.

\section{Scheme 14}

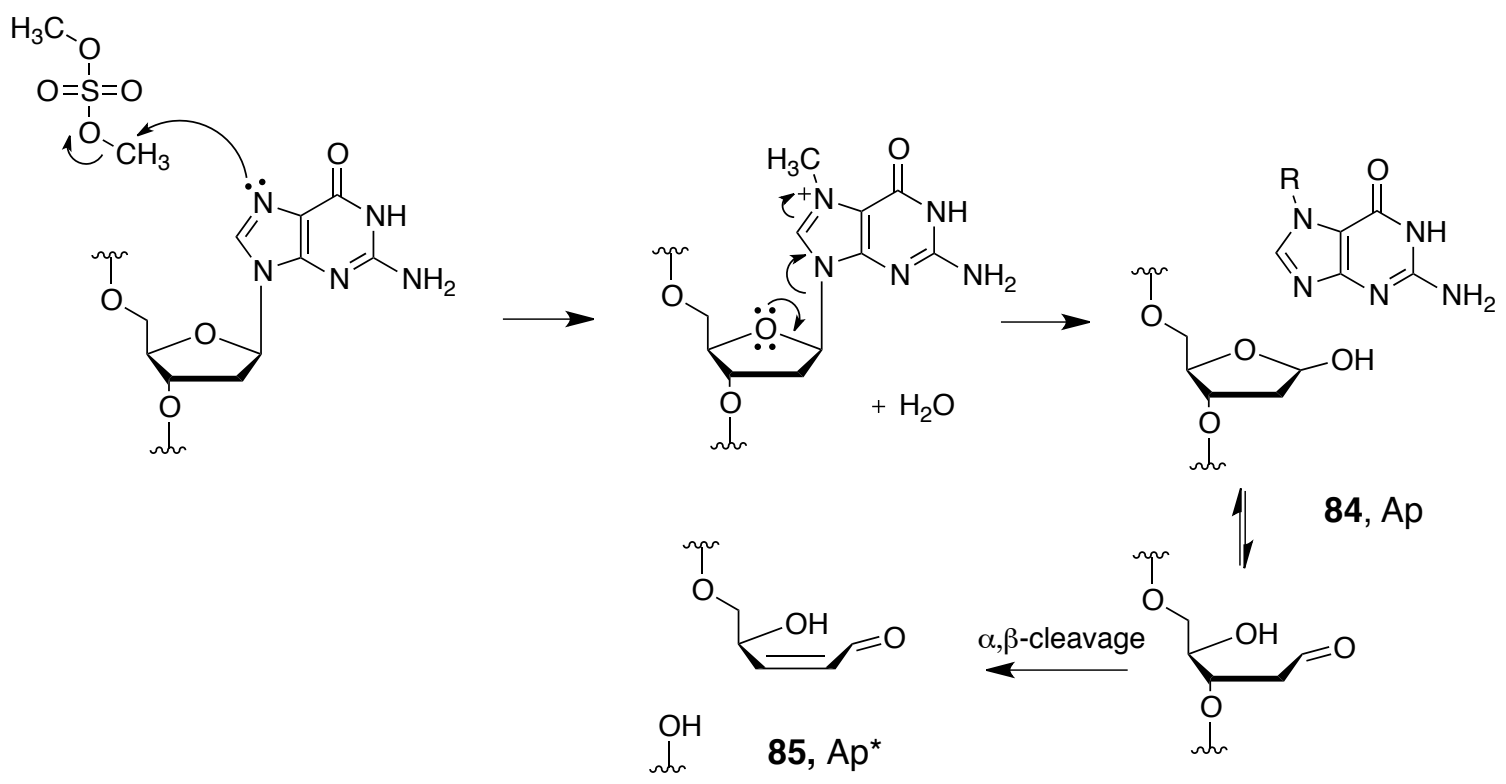

We radioactively labeled a palindromic sequence at the $5^{`}$-end to afford duplex $\mathbf{A}$. We incubated duplex $\mathbf{A}$ in the presence of synthesized $N$-mustards (Figure 7). 
Compounds 36 (lane 2) and 57 (lane 3) are used as controls serving as "dead" or

"deactivated" $N$-mustards, for which one would not expect aziridinium ion formation.

Compound 36 contains poor leaving groups to be used as an effective alkylating agent, and compound 57 contains the deactivating 4-N-oxide function. We also incubated duplex $\mathbf{A}$ with a clinically used nitrogen mustard, chlorambucil. ${ }^{46}$ Chlorambucil is an aromatic N-mustard (86, lane 5) approved by the FDA to treat chronic lymphatic leukemia. Incubations were done for $3 \mathrm{~d}$ to allow for adequate alkylation at $37{ }^{\circ} \mathrm{C}$ in HEPES buffer $(50 \mathrm{mM}, \mathrm{pH} 7)$ and $\mathrm{NaCl}(100 \mathrm{mM})$ with an $N$-mustard $(1 \mathrm{mM}, 10 \%$ DMF). After ethanol precipitation to remove excess salts and reagents, the DNA was further treated with piperidine $(1 \mathrm{M})$ with heat to generate cleavage products resulting from DNA alkylation. The reaction mixtures were analyzed by 20\% PAGE, shown in Figure 7. It should be noted that there are two possible G-alkylation sites in duplex $\mathbf{A}$, marked by bands generated from Maxam-Gilbert G-sequencing (Figure 7, lane 6). 


\section{Figure 7}

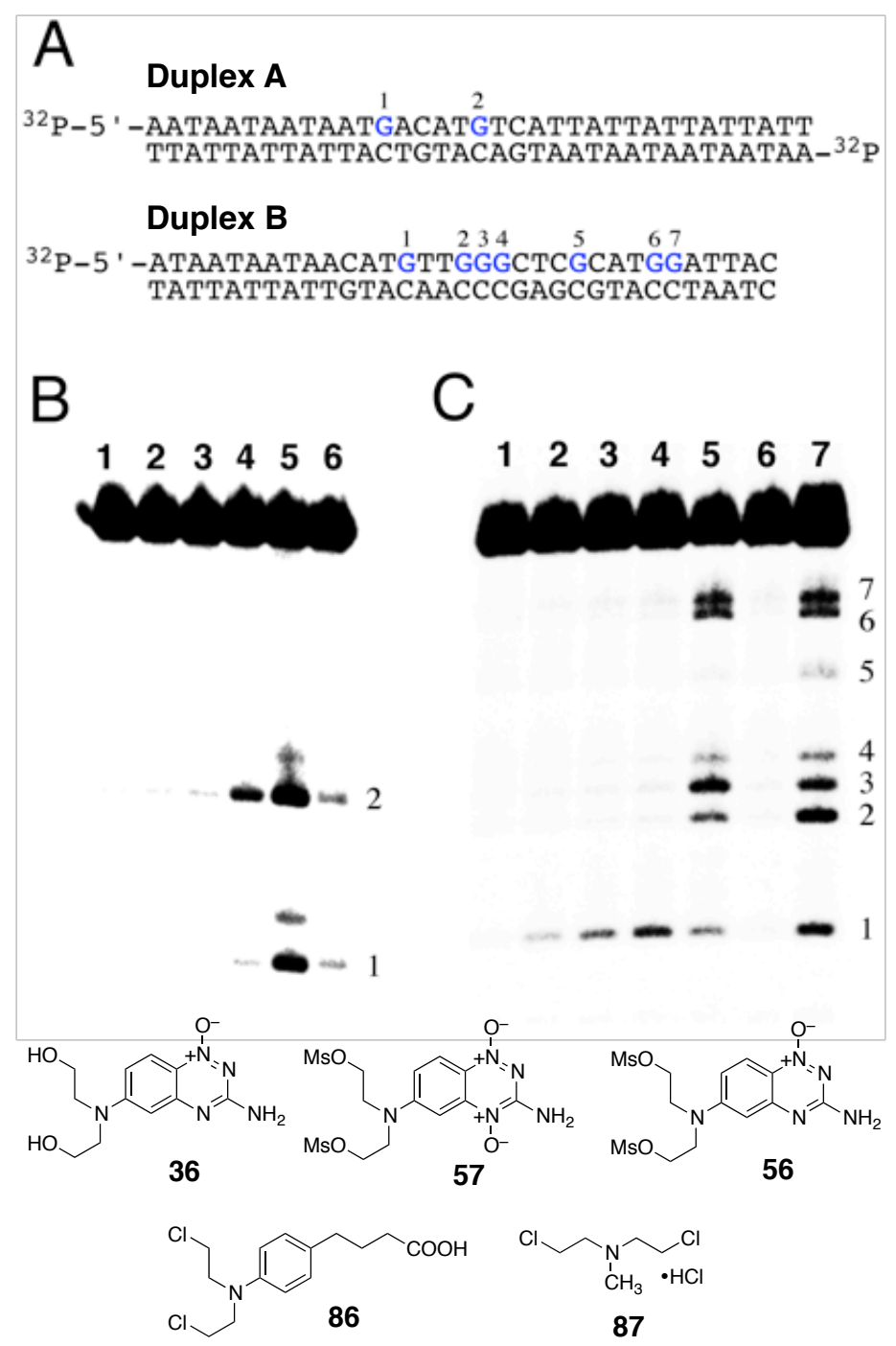

Figure 7. DNA alkylation by 56. $20 \%$ denaturing polyacrylamide gels of ${ }^{32} \mathrm{P}$ labeled Duplex DNA treated with piperidine after incubation in the presence (or absence) of the indicated N-mustard. Conditions: HEPES buffer $(50 \mathrm{mM}, \mathrm{pH} 7), \mathrm{NaCl}(100 \mathrm{mM}), \mathrm{N}-$ mustard (1 mM unless specified otherwise), 10\% DMF, $37{ }^{\circ} \mathrm{C}$ for 3 days followed by piperidine cleavage $\left(1 \mathrm{M}, 95^{\circ} \mathrm{C} 30 \mathrm{~min}\right)$. Panel A: duplexes $\mathbf{A}$ and $\mathbf{B}$ used to test for DNA alkylation of N-mustards. Panel B: Lane 1: duplex A (no mustard), Lane 2: duplex A with 36, Lane 3: duplex A with 57, Lane 4: duplex A with 56, Lane 5: duplex A with 86, Lane 6: G-sequencing of duplex A. Panel C: Lane 1: duplex B (no mustard), Lanes 2-4: duplex B with 56 at $0.25,0.5$, and $1 \mathrm{mM}$ concentrations, Lane 5: duplex B with 87 (0.25 $\mathrm{mM})$, Lane 6: duplex B with $\mathbf{8 6}(0.25 \mathrm{mM})$, and Lane 7: G-sequencing of duplex B. 
DNA cleavage is seen in varying amounts for DNA incubated with compounds 56 and 86 (lanes 4 and 5), and importantly no significant cleavage above background is seen for duplex $\mathbf{A}$ incubated in control lanes 1,2, and 3. While 56 with 86 observed comparable amounts of DNA alkylation, it is interesting to note the unequal distribution of G-alkylation seen between $\mathbf{G}_{1}$ and $\mathbf{G}_{\mathbf{2}}$ (Figure 7B, duplex $\mathbf{A}$ ). This observation could result from selective alkylation of each dG-residue, most likely resulting from nearest neighbor effects of DNA sequences. Kohn et al has shown previously that DNA alkylation of mechlorethamine (87) correlates with electrostatic potentials of guanines with different nearest neighboring bases. ${ }^{47}$ Mechlorethamine is a potent DNA alkylating and cross-linking agent no longer used in clinic because of its potent unselective reactivity. Kohn's ranking is listed in Figure 8: where higher electrostatic potential correlates with higher propensity for DNA alkylation by $\mathbf{8 7}$. It is important to note that this correlation is only observed for mechlorethamine (87). To probe if this correlation applies to the benzotriazine mustard, we designed a sequence that contained several of these 5 -NGN local sequences (Figure 7, duplex B). We incubated benzotriazine mustard 56 at different concentrations as well as 86 and 87 with duplex $\mathbf{B}$ and analyzed the reaction products as before. While mechlorethamine (87) seems to follow the ranking described in Kohn et al, it seems chlorambucil (86) and the mesylate-containing benzotriazine 56 did not. ${ }^{47}$ Interestingly, the dimesyl benzotriazine mustard (56) shows preferential alkylation at 5-GT sequences, a sequence on the low end of the alkylation site ranking. In fact, $\mathbf{G}_{\mathbf{2}}$ in duplex $\mathbf{A}$ (Figure 7) fulfills that 5'-TGT sequence context and actually alkylates significantly more than the $5^{`}$-TGA sequence at $\mathbf{G}_{\mathbf{1}}$ (which ranks higher on Kohn's list, Figure 8$){ }^{47}$ 


\section{Figure 8}

$\mathrm{CGC}<\mathrm{AGC}<\mathrm{TGC}<\mathrm{CGT}<\mathrm{TGT}=\mathrm{AGT}<\mathrm{AGA}=\mathrm{TGA}<\mathrm{CGA}<\mathrm{GGC}<\mathrm{CGG}<\mathrm{GGT}<\mathrm{AGG}=\mathrm{TGG}<\mathrm{GGA}<\mathrm{GGG}$

Figure 8. Sequence preference of N-7 guanine alkylation by Mechlorethamine (87) with 5 -CGC having the lowest alkylating potential and 5 '-GGG having the highest.

This unique preference for 5-'TGA for the compounds tested is striking, and could possibly be explained simply by the difference in mustard structure between $\mathbf{5 6}$ and 87. It is possible that mesylate mustards alkylate differently than chloride mustards, but Kohn et al describe how the molecular structure of $N$-mustards could influence preferential alkylation on DNA. ${ }^{47}$ Potentially a similar interaction could be exhibited by the compound 56, where the benzotriazine ring system is interacting with the duplex through a Hoogstein base pair interaction. We modeled this hypothesis with PyMOL by placing a chemdraw structure of compound 56 containing the aziridinium ion near a $5{ }^{`}$ GT duplex developed from PDB file 4OKL obtained from the online RCSB Protein Database (Figure 9). From this we can clearly see the possibility for hydrogen bonding interaction between the exocyclic $-\mathrm{NH}_{2}$ and $\mathrm{N}-4$ of compound 56 with the $\mathrm{N}-7$ and exocyclic $\mathrm{N}-6-\mathrm{NH}_{2}$ of the adenine residue. It places the aziridinium ring close to the $\mathrm{N}-7$ of the guanine residue in the 5'-GT sequence shown, supporting our observations of the preferential alkylation of $5{ }^{`}$-GT sequences by compound $\mathbf{5 6}$. 


\section{Figure 9}

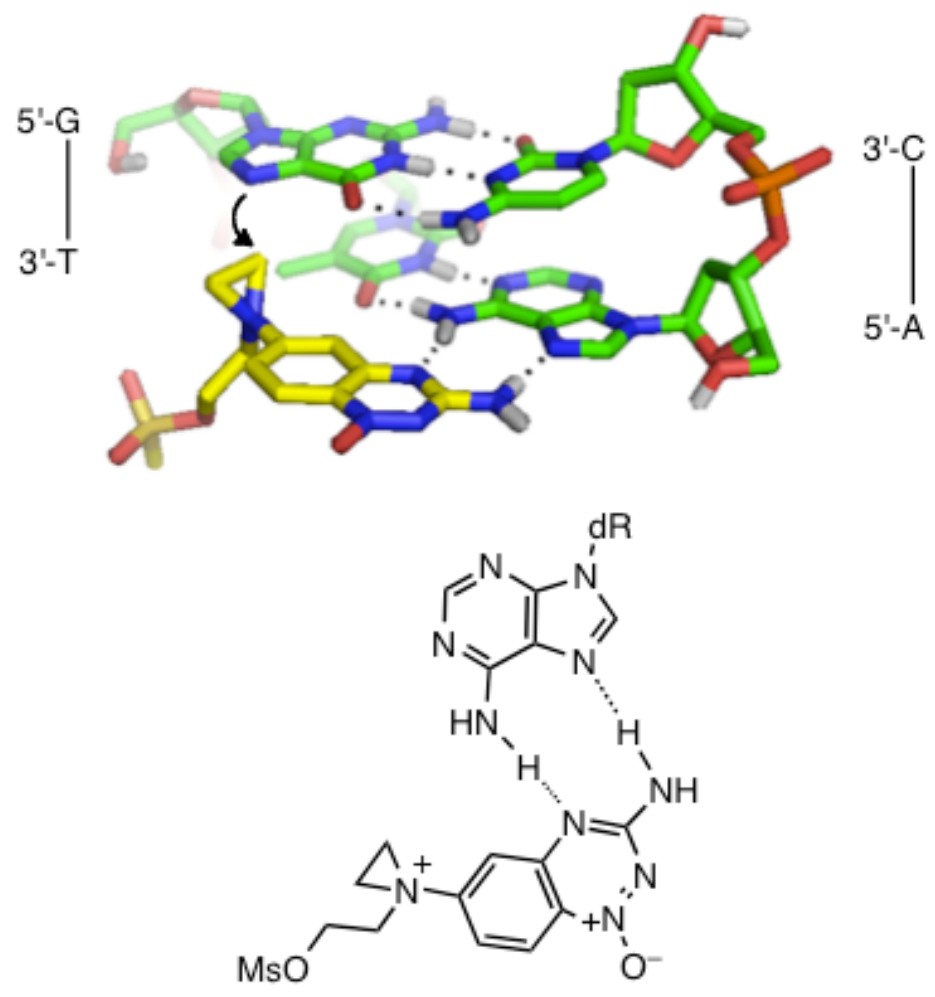

Figure 9. Molecular modeling generated with PyMOL displaying a Hoogstein base pairing of 56 with deoxyadenine, placing the $N$-mustard in close proximity with the N-7 guanine.

\subsection{DNA "Cross-Linking" of Benzotriazine 1-Oxde N-Mustard}

We were interested in testing the DNA cross-linking capabilities of our synthesized mustard 56. It is known that alkyl nitrogen mustards (87) generate DNA interstrand cross-links at $5^{-}$-GNC sequences. ${ }^{48}$ This is thought to occur first by alkylation at a single dG-residue, causing a destabilization of the DNA duplex possibly from the positive charge placed on the N-7 of guanine (Scheme 14) resulting in a bend of the duplex toward the major groove. ${ }^{13-14,48}$ This change in the duplex allows for adequate 
"reach" of the mustard to the second guanine residue and is well characterized for mechlorethamine 85 .

To test the potential for DNA cross-linking capabilities, compound $\mathbf{5 6}$ was incubated with ${ }^{32} \mathrm{P}$ labeled oligonucleotide DNA duplexes that contained a $5{ }^{`}$-GNC central sequence (Figure 10A, Duplex C). Duplex $\mathbf{C}$ was treated with the 1-oxide (56), 1,4-dioxide (57) mustards and diol 36 (0.25-1mM, 10\% DMF) in HEPES buffer (50 mM $\mathrm{pH}$ 7) and $\mathrm{NaCl}(100 \mathrm{mM})$ at $37{ }^{\circ} \mathrm{C}$ for up to $3 \mathrm{~d}$. After ethanol precipitation and suspension in formamide buffer the reaction mixtures were analyzed with $20 \%$ denaturing PAGE (Figure 10B). A slower moving band was only seen for compound 56 (lane 3) for all concentrations tested. This observation suggests a covalent attachment has been made between the two strands of the DNA duplex, as oligonucleotide strands not covalently bound would dissociate under denaturing PAGE conditions. Moreover, the absence of slow moving band with respect to full length single-strand DNA (lane 1) was not seen for compound $\mathbf{3 6}$ (lane 2) or $\mathbf{5 7}$ (lane 4), consistent with the observations seen in earlier experiments (Figure 7B). Finally, a faster moving band was seen for compound 56 without piperidine treatment, indicative of DNA alkylation followed by depurination (84) and spontaneous cleavage (85) as described before. Incubation of duplex $\mathbf{C}$ under matching conditions with mechlorethamine (87) and chlorambucil (86) showed a similar slow moving band for both compounds in comparable crosslink yields $(\sim 1-2 \%$ yield) (Figure 10C, lanes 4 and 5$)$. This further confirms that the slow moving band seen in the gel is due to cross-linking of the two DNA strands. 


\section{Figure 10}

\section{A Duplex C}

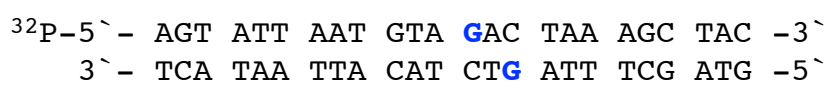

B $\quad \begin{array}{llll}1 & 2 & 3 & 4\end{array}$
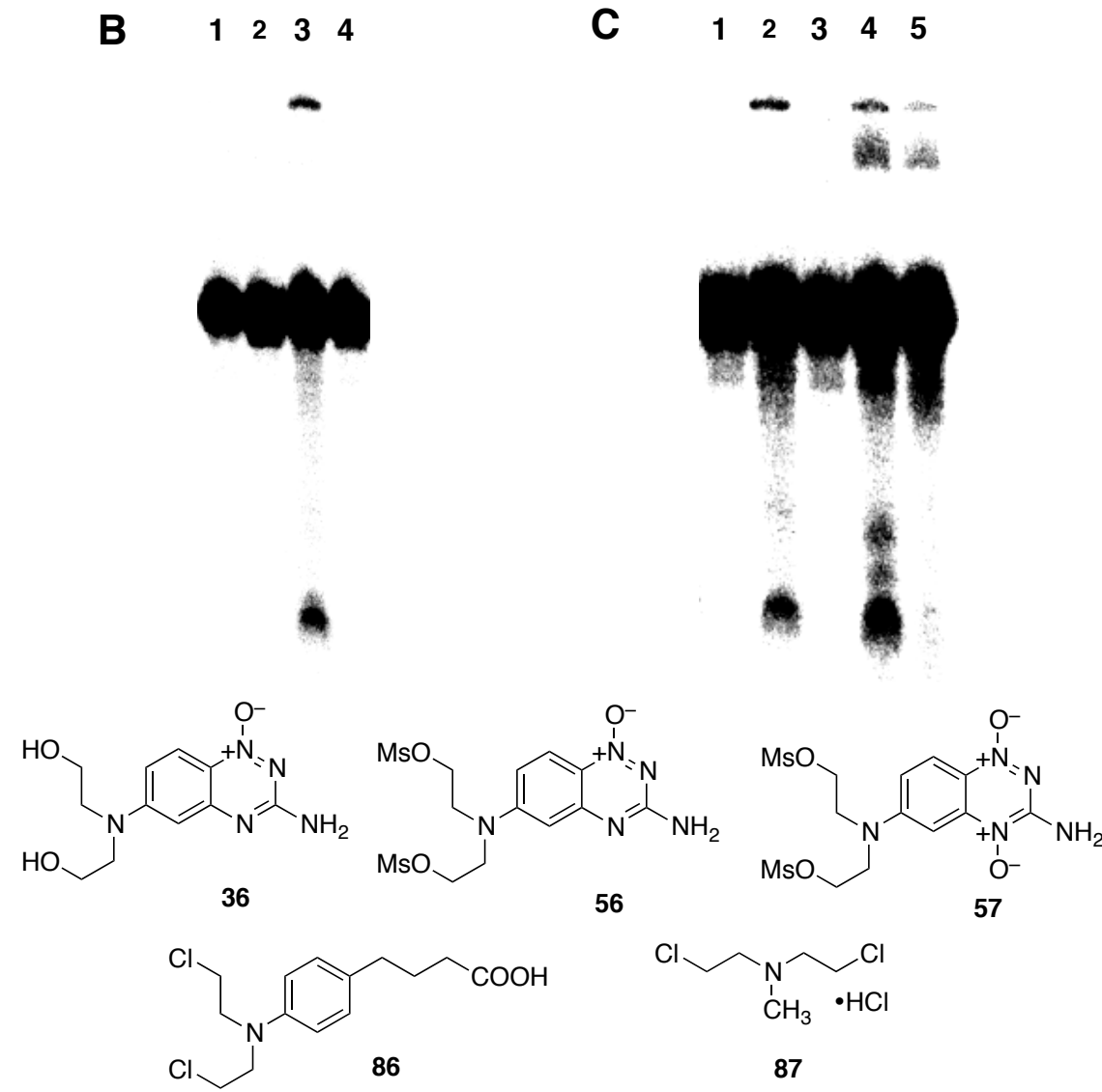<smiles>CN(CCCl)CCCl</smiles>

87

Figure 10. DNA cross-linking by 56, 86, and 87. $20 \%$ denaturing polyacrylamide gels of ${ }^{32} \mathrm{P}$ labeled duplex $\mathrm{C}$ incubated in the presence (or absence) of the indicated $\mathrm{N}$ mustard. Conditions: HEPES buffer (50 mM, pH 7), NaCl (100 mM), N-mustard (1 mM unless specified otherwise), $10 \% \mathrm{DMF}, 37^{\circ} \mathrm{C}$ for 3 days. Panel A: $32 \mathrm{P}$ labeled duplexes C used for DNA cross-link formation. Panel B: Lane 1: control (no mustard), Lane 2: 36, Lane 3: 56, Lane 4: 57. Panel C: Lane 1: control (no mustard), Lanes 2: 56, Lane 3: 57, Lane 4: 87, and Lane 5: 86.

During the experiments we would often see a smeared band of lower intensity traveling between the cross-linked duplex and full-length single-strand DNA. So we set out to characterize the cross-linked products. Using duplex $\mathbf{C}$ as a template, we made 
single base-pair changes in order to effectively remove either guanine from the 5 -GNC sequence. Thus $5{ }^{3}{ }^{32} \mathrm{P}$-labeled duplexes $\mathbf{D}$ and $\mathbf{E}$ were prepared (Figure 11). Using conditions described before, we incubated $N$-mustards with all three duplexes and analyzed by PAGE. The slow moving band was seen for all duplexes incubated with $\mathbf{5 6}$ (Figure 11, Lanes 3, 5, and 7). This result is not consistent with previously described $\mathrm{N}$ mustard cross-linking. ${ }^{48}$ Removing either $\mathrm{dG}$ from the $5^{`}$-GNC base paired sequence should prevent DNA cross-linking resulting from alkylation of dG-residues on opposing strands of a duplex. This means that the slow moving band seen in Figure 10 was not caused by traditional $\mathrm{N}$-mustard cross-linking between two $\mathrm{dG}$ residues. 


\section{Figure 11}

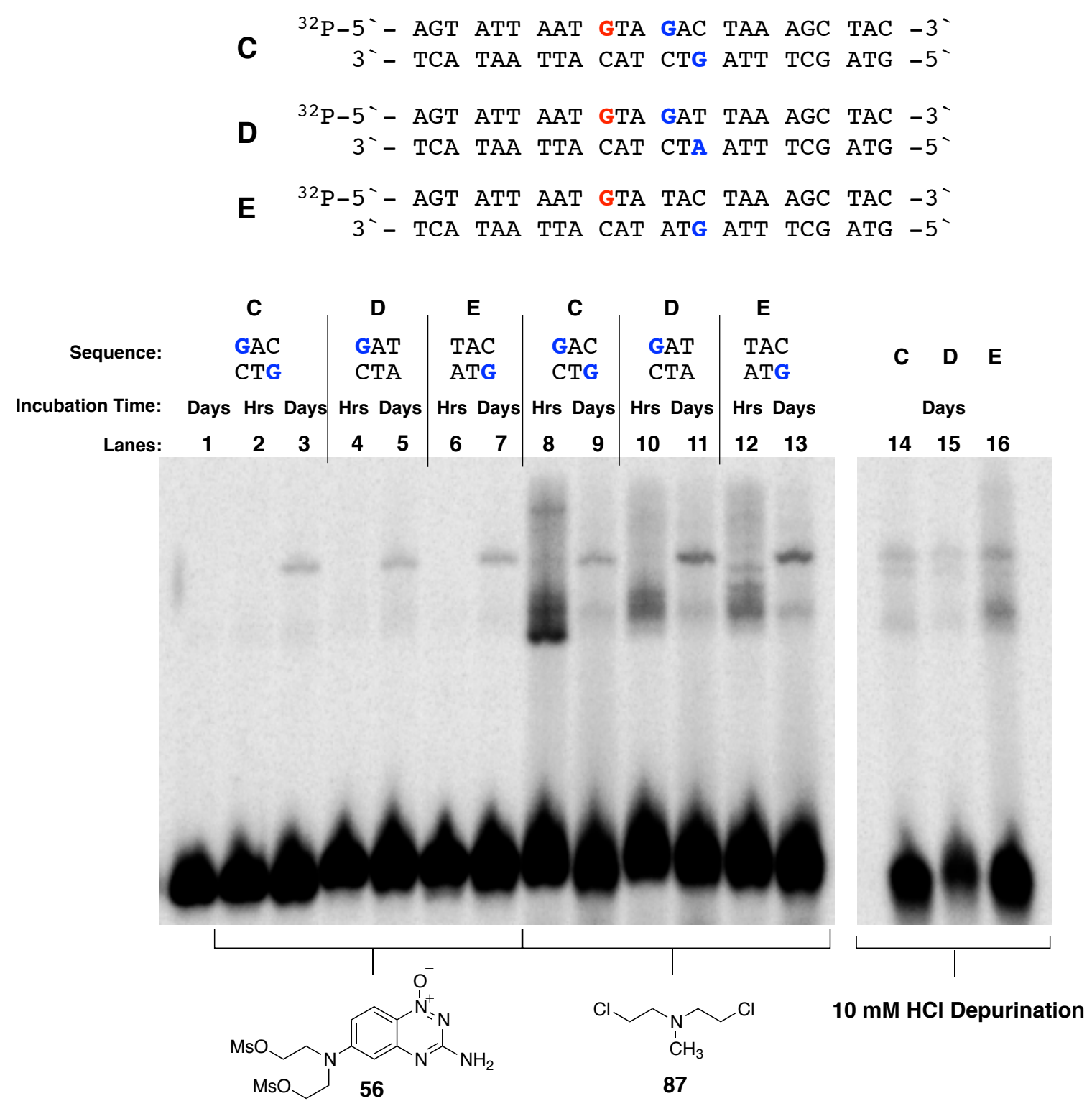

Figure 11. DNA cross-linking by 56 (lanes 2-7) and 87 (lanes 8-13) in duplexes C-E. $20 \%$ denaturing polyacrylamide gels of ${ }^{32} \mathrm{P}$ labeled duplexes $\mathbf{C}$ (lanes $1-3,8,9$, and 14), $\mathbf{D}$ (lanes 4, 5, 10, 11, and 15) or $\mathbf{E}$ (lanes 6, 7, 12, 13, and 16) incubated in the presence of the indicated $\mathrm{N}$-mustard (left) or after treatment of dilute $\mathrm{HCl}$ (right). Conditions: (Left) HEPES buffer $(50 \mathrm{mM}, \mathrm{pH} 7), \mathrm{NaCl}(100 \mathrm{mM})$, and $\mathrm{N}$-mustard $(1 \mathrm{mM}, 10 \%$ DMF) at $37{ }^{\circ} \mathrm{C}$ for $3 \mathrm{~h}$ (lanes $2,4,6,8,10,12$ ) or $3 \mathrm{~d}$ (lanes $3,5,7,9,11,13$ ). (Right) $\mathrm{HCl}(10 \mathrm{mM}), 37^{\circ} \mathrm{C}$ for $3 \mathrm{~h}$, then HEPES buffer $(50 \mathrm{mM}, \mathrm{pH} 7)$ and $\mathrm{NaCl}(100 \mathrm{mM})$ at $37^{\circ} \mathrm{C}$ for $3 \mathrm{~d}$. 
The Gates lab has published papers describing DNA interstrand cross-links involving the reaction of Ap-sites with opposing deoxyguanosine (dG) or deoxyadenine (dA) residues on the complimentary strand. ${ }^{49-51}$ We reported that dA-Ap derived crosslinks (Scheme 15) are formed in $5^{-}$-ApT sequences. ${ }^{51}$ This topic is discussed further in Chapters 3 and 4 . We hypothesize that cross-links resulting from the reaction between an abasic site and a dA residue. This results from initial G-alkylation followed by depurination to yield Ap-sites (Scheme 16, a $\rightarrow \mathbf{b} \rightarrow \mathbf{h} \rightarrow \mathbf{i}$ ). Scheme 15 describes a map of the all the possible reactions involved from N-mustard alkylation of $\mathrm{dG}$ residues of a duplex containing a central 5'-GNC sequence. Previous groups have reported crosslink formation by mechlorethamine within hours, ${ }^{13,48,52}$ prompting us to believe our longer incubation times allow ample depurination from $d G$ alkylation $(\mathbf{d} \rightarrow \mathbf{e}$ or $\mathbf{f})$. This would result in the absence of traditional $N$-mustard cross-links which may have formed early during the reaction.

To test this hypothesis, we incubated compound $\mathbf{5 6}$ and 87 with duplexes $\mathbf{C}, \mathbf{D}$, and $\mathbf{E}$ for a short 3-hour time period and analyzed by PAGE alongside incubations done for 3-days (Figure 11). Results show a dark band formed from reaction of mechlorethamine $\mathbf{8 7}$ (lane 8) for 3 hours for duplex $\mathbf{C}$, whereas the band disappeared for the longer incubation time (lane 9). Additionally this strong band was not seen for the same treatment of duplexes D or E, which were missing the central $5^{\circ}$ GNC sequence required for N-mustard cross-linking. This suggests that the dark band resulted from Gto-G cross-linking at the $5^{`}$-GNC sequence (e, Scheme 16) in duplex C. We also do not observe this product for $\mathbf{5 6}$, indicating that only mono-alkylation (b or $\mathbf{c}$ ) occurs before depurination (h or $\mathbf{k})$. Additionally, this fast forming product (e) possessed a faster 
mobility than the cross-linked product resulting from long incubation times (Lanes 3, 5, $7,9,11$, and 13).

We were able to generate the same slow forming band by incubation of duplexes $\mathrm{C}, \mathrm{D}$, and $\mathrm{E}$ in dilute acid for a short duration followed by the typical 3-day incubation after neutralization of the acid with buffer (Figure 11, lanes 14-16). In the absence of alkylating agent, we have shown that depurination by acid-treatment can generate the same slow migrating, slow forming band. This further supports our claim that these cross-links result from $\mathrm{dG}$ depurination, generating Ap-sites that form covalent attachments with the deoxyadenine residue (Scheme 15). This discovery has not been previously characterized, though evidence of such species is present in literature, as gels presented sometimes contain bands unaccounted for in their experiments. ${ }^{52-53}$

\section{Scheme 15}

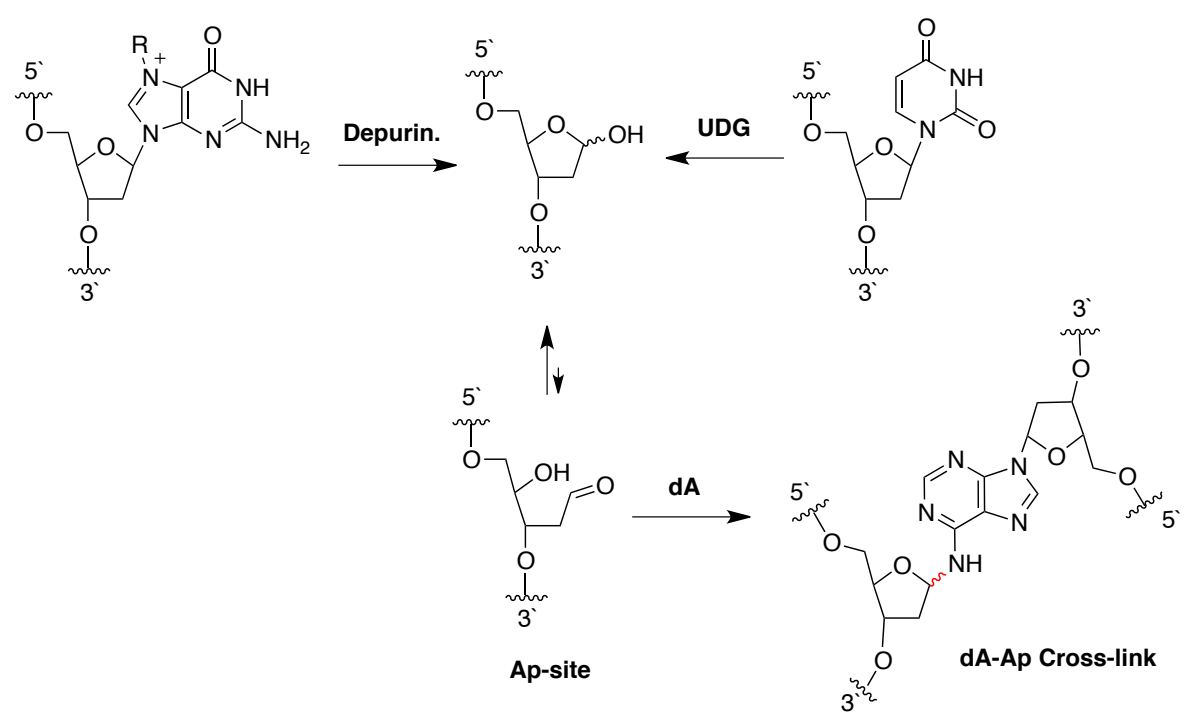




\section{Scheme 16}

\section{dA-Ap Cross-link}
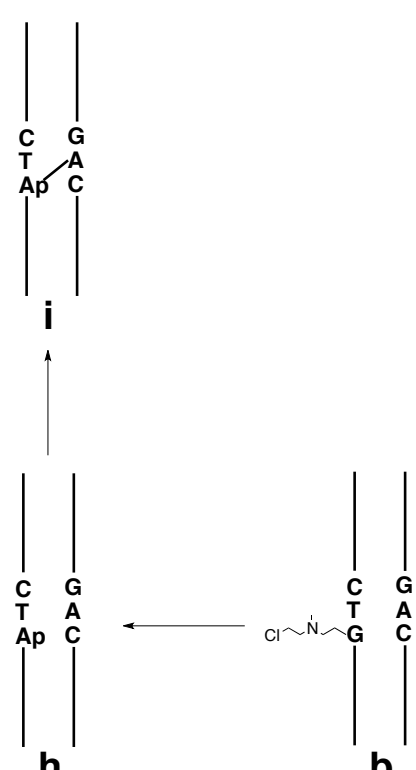

h
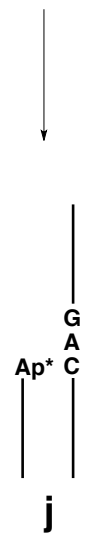

\section{$A p=$ Ap site}

$A p^{*}=$ Cleaved Ap Site $=$ SS break

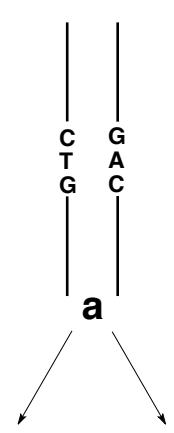<smiles>Nc1nc2c(ncn2[Tl])c(=O)[nH]1</smiles><smiles>Nc1ncnc2c1ncn2[Tl]</smiles>
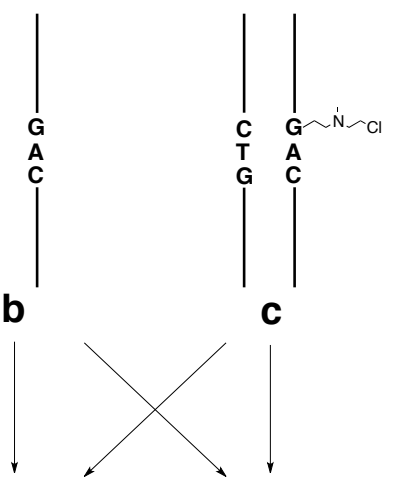

$\mathrm{N}$-mustard Cross-link
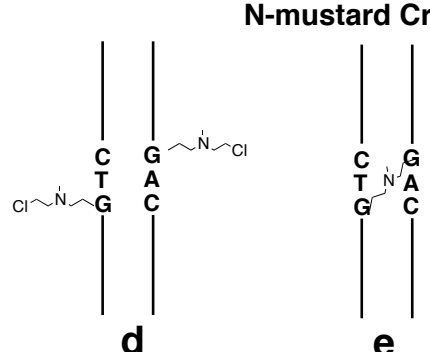

e

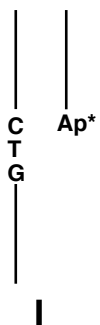

Scheme 16. Mechanistic route to all possible products resulting from N-mustard alkylated 5 ' GNC sequences. 
We confirmed this hypothesis by selectively incorporating Ap-sites (84) into our DNA duplex $\mathbf{C}$ template. Using deoxyuracil containing DNA duplexes (F and $\mathbf{G})$, we generated Ap-sites by treatment with uracil DNA glycosylase (UDG). This selectively incorporated an Ap-site in place of the deoxyguanine residue in the 5 GT sequence for duplex $\mathbf{C}^{49-51}$ Alkylation of duplex C or treatment with UDG generate Ap-sites capable of cross-linking with the opposing deoxyadenine residue in the resulting $5^{\prime}$-ApT sequence (Scheme 16). After UDG treatment, the Ap-containing duplexes were incubated in HEPES (50 mM, pH 7) and $\mathrm{NaCl}(100 \mathrm{mM})$ to form the dA-Ap cross-link (Figure 12, lanes 4 and 5). Analysis by 20\% denaturing PAGE showed a slow moving band indicative of a cross-link formed for both duplexes $\mathbf{F}$ and $\mathbf{G}$. Only UDG treated duplex $\mathbf{F}$ (lane 5) provided the same cross-link product as N-mustard alkylated duplex $\mathbf{C}$ (Figure 12, lanes 2 and 3). This means that an Ap-derived DNA interstrand cross-link has been formed at the indicated G1 (Figure 12, duplex C). UDG treated duplex G generated a slightly faster moving cross-link band not seen after alkylation of duplex $\mathbf{C}$. The difference in mobility resulted from attachment at a separate site. We are confident to conclude that DNA alkylating agents in general have the potential to form Ap-derived cross-links in duplex DNA along with their drug-derived cross-links that have been well characterized. 


\section{Figure 12}

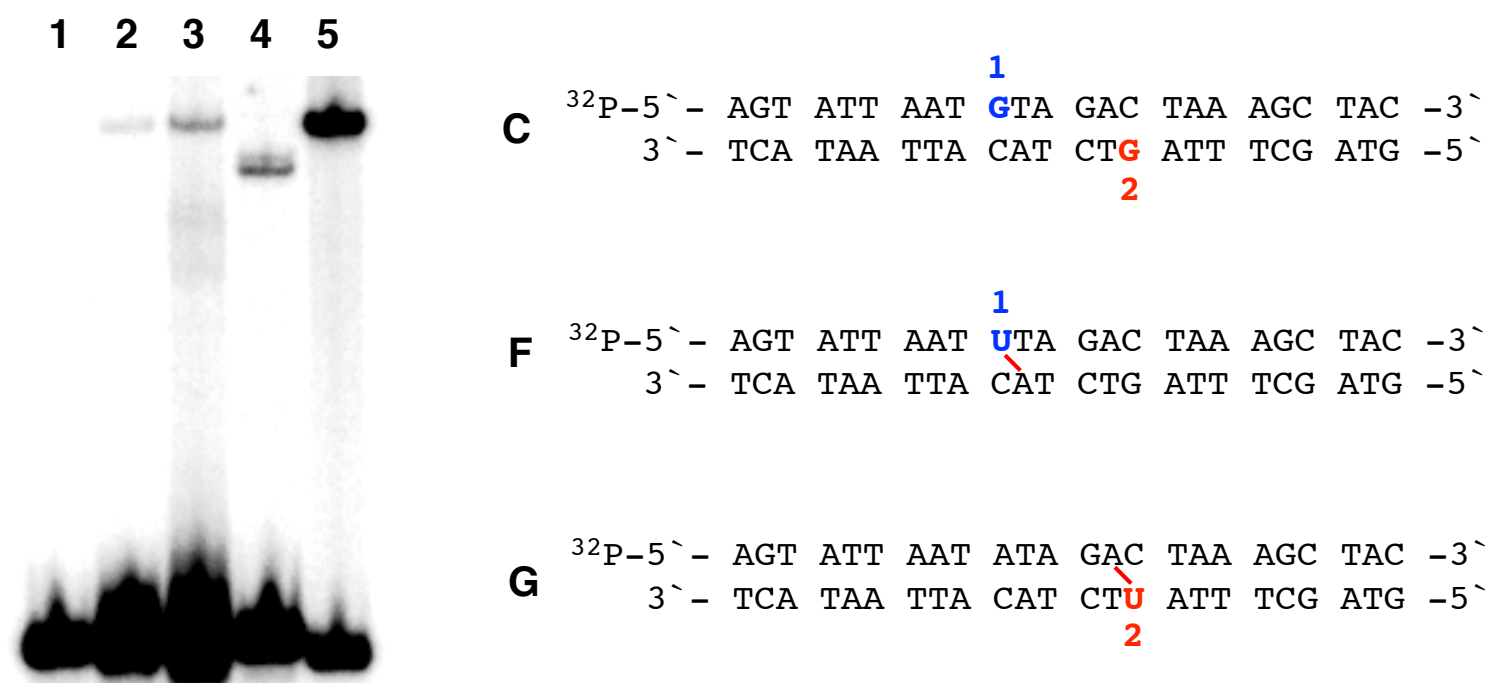

Figure 12. Identification of abasic site derived cross-link. $20 \%$ denaturing polyacrylamide gels of ${ }^{32} \mathrm{P}$ labeled duplex $\mathrm{C}$ (lanes 2 and 3 ) incubated in the presence of the indicated $\mathrm{N}$-mustard and ${ }^{32} \mathrm{P}$ labeled duplexes $\mathrm{G}$ (lane 4) and $\mathrm{F}$ (lane 5) after treatment with UDG. Conditions: Lanes 2 and 3: HEPES buffer (50 mM, pH 7), $\mathrm{NaCl}$ $(100 \mathrm{mM}), \mathrm{N}$-mustard $(1 \mathrm{mM}), 10 \% \mathrm{DMF}, 37{ }^{\circ} \mathrm{C}$ for 3 days. Lane 4 : Uracil DNA Glycosylase $(20 \mathrm{U} / \mathrm{mL})$ in UDG buffer $(1 \mathrm{X})$ at $37^{\circ} \mathrm{C}$ for $30 \mathrm{~min}$, then enzyme removal and EtOH precipitation, finally HEPES buffer $(50 \mathrm{mM}, \mathrm{pH} 7)$ and $\mathrm{NaCl}(100 \mathrm{mM})$ at 37 ${ }^{\circ} \mathrm{C}$ for $3 \mathrm{~d}$.

\subsection{Chapter 2 Summary}

In the work described here, we explored whether the hypoxia-selective enzymatic reduction of 1,2,4-benzotriazine 1,4-dioxides to the corresponding 1,2,4-benzotriazine 1oxide metabolites can be exploited for the selective generation of DNA-alkylating species in the oxygen-poor cells found in oxygen-poor tumor tissue. We found that the mono- $\mathrm{N}$ oxide mustard $\mathbf{5 6}$ is, in fact, 5-7 fold more reactive than the di- $N$-oxide mustard $\mathbf{5 7}$, as measured by the rates of hydrolysis. Hammett sigma and sigma-minus values measured for the 3-amino-1,2,4-benzotriazine 1-oxide and 3-amino-1,2,4-benzotriazine 1,4-dioxide "substituents" in $\mathbf{5 6}$ and $\mathbf{5 7}$, respectively, confirmed that removal of the 4-oxide causes a 
significant decrease in the electron-withdrawing effects exerted by the triazine ring system on substituents at the 6-postion of the benzo ring.

In contrast to the tirapazamine analogs $\mathbf{5 6}$ and 57, the reactivities of the mustard units in the desamino series $65,66,67$, and 68 were unaffected by the presence or absence of the 4-oxide group. It is interesting to consider why the reactivities of the mustard groups in the 3-desaminotirapazamine analogs are not "switched" by deoxygenation. First, it may be noteworthy that the $\mathrm{N}=\mathrm{N}(\mathrm{O})$ group in $\mathbf{5 6}$ and $\mathbf{5 7}$ is crossconjugated with the mustard nitrogen at the 6-position and the 3-amino group. Thus, in these tirapazamine analogs, the 3-amino group may serve to mitigate the electronwithdrawing properties of the $\mathrm{N}=\mathrm{N}(\mathrm{O})$ group. On the other hand, in analogs $\mathbf{6 5}$ and $\mathbf{6 6}$ that lack the 3-amino group, the $\mathrm{N}=\mathrm{N}(\mathrm{O})$ group may exert a strong electron-withdrawing (deactivating) effect on the mustard unit in the 6-position. This would prevent altogether the participation of the nitrogen's lone pair in aziridinium ion formation. The hydrolysis rates of 67 and 68 are higher than those of 65 and 66 , but are unaffected by the presence or absence of the 4-oxide unit. Evidently, the $\mathrm{N}=\mathrm{N}(\mathrm{O})$ unit attached "meta" to the mustard unit is less electron-withdrawing than in the "para" position. In this regard, the $\mathrm{N}=\mathrm{N}(\mathrm{O})$ group behaves in a manner similar to the nitro group. The observation that the reactivity of mustard unit in the 7-position is not affected by the presence or absence of the 4-oxide unit, may be rationalized by the fact that the nitrogen lone pair of the mustard substituent is not "through conjugated" with the 4-oxide unit.

The DNA alkylating function of the nitrogen mustard unit in the mono- $N$-oxide 56 is "switched on" compared to that the parent di-N-oxide 57. Under our assay conditions, the activated analog 56 generates approximately 30-fold greater yields of 
guanine alkylation than does 57. The mono- $N$-oxide 56 displays a striking and unexpected preference for reaction at guanine residues located in 5'-GT sequences. In contrast, typical mustards such as mechlorethamine (87) alkylate guanine residues with rather modest sequence selectivity (lane 5 of Figure $3 \mathrm{C}$ ). ${ }^{47}$ We speculate that the sequence specificity of $\mathbf{5 6}$ may arise via formation of Hoogsteen-type hydrogen bonds between the 3-amino-1,2,4-benzotriazine ring system and the adenine residue in the target 5'-GT/5'-AC sequence. Such an interaction could deliver the mustard unit of $\mathbf{5 6}$ to the N7-atom of the guanine residue in the major groove of the duplex (Figure 9). A similar scenario has been proposed to explain other DNA alkylating sequence specificities. $^{47}$ Finally, we provided evidence that the dialkylamino substituent on the 6position of the 3-amino-1,2,4-benzotriazine 1,4-dioxide ring in analogs $\mathbf{5 7}$ is compatible with the hypoxia-selective enzymatic deoxygenative metabolism required to deploy the activated mustards such as $\mathbf{5 6}$.

The compounds described here result from the combination of two well-studied anticancer drugs. The agent tirapazamine generates oxidative DNA damage selectively under hypoxic conditions ${ }^{1-2,54}$ and nitrogen mustards are clinically-used DNA-alkylating agents. ${ }^{46}$ This work provides evidence that the combination of these two anticancer drug motifs can yield new agents with the potential to deliver both DNA-alkylating and DNAoxidizing power selectively to hypoxic tumor tissue. More generally, our results provide evidence that the 1,2,4-benzotriazine 1,4-dioxide unit can serve as an oxygen-sensing prodrug platform for the selective release or activation of various bioactive agents in hypoxic tissue. 


\subsection{Experimental}

Materials and Methods: All chemicals were used as purchased from chemical suppliers. The compound 5-fluoro-2-nitroaniline was purchased from Ak Scientific. The compound 3-fluoro-4-nitrobenzoic acid was purchased from Oakwood Chemical. All other reagents were purchased from Sigma Aldrich or Fisher Scientific. For the kinetic measurements in the NMR, S500 select series NMR tubes from Norell were used. NMR spectra were recorded at $500 \mathrm{MHz}$ for ${ }^{1} \mathrm{H}-\mathrm{NMR}$ and $125 \mathrm{MHz}$ for ${ }^{13} \mathrm{C}-\mathrm{NMR}$. Oligonucleotides were obtained from Integrated DNA Technologies. T4 polynucleotide kinase was purchased from New England Biolabs. $\left[\gamma-{ }^{32} \mathrm{P}\right]-\mathrm{ATP}(6000 \mathrm{Ci} / \mathrm{mmol})$ was purchased from Perkin-Elmer.

Measurement of Mustard Hydrolysis Rates Using ${ }^{1}$ H-NMR. Solutions containing the 1,2,4-benzotriazine nitrogen mustards ( $1 \mathrm{mM}$ final concentration) were prepared in $\mathrm{CD}_{3} \mathrm{CN} / \mathrm{D}_{2} \mathrm{O}(1: 1)$ containing disodium maleate $(5 \mathrm{mM})$ as an internal standard. Solutions were placed in a capped S500 Norell NMR tube and warmed in a $50{ }^{\circ} \mathrm{C}$ water bath. At various time points the NMR tubes were removed from the heat bath, cooled in a room temperature water bath, and $1 \mathrm{H}-\mathrm{NMR}$ spectra obtained. Spectra were obtained using a Bruker DRX500 equipped with a $5 \mathrm{~mm}$ HCN cryo-probe. The probe temperature was $298 \mathrm{~K}$ during the experiment. Total number of scans acquired was 32 with repetition delay of $4.1719923 \mathrm{sec}$ to ensure that the integration of resonances in various compounds in the mixture was quantitatively accurate. The amount of unreacted mustard at each time point was assessed by measuring the integration of the $-\mathrm{CH}_{2}$ - resonances of the 
starting material in comparison to the $-\mathrm{CH}_{2}$ - peak of the internal standard at each time point. The pseudo-first-order rates for the hydrolysis reactions were obtained by a least squares fit to the equation $\ln \mathrm{A} / \mathrm{A}_{0}=-\mathrm{kt}$.

\section{Measurement of Mustard Hydrolysis Rates and Decomposition Products Using}

HPLC. Solutions of the mono- or di- $N$-oxide mustards $(250 \mu \mathrm{M})$ were prepared in sodium phosphate buffer $(25 \mathrm{mM}, \mathrm{pH} 7)$ containing $2.5 \% \mathrm{DMF}(\mathrm{v} / \mathrm{v})$. The samples were incubated at $50{ }^{\circ} \mathrm{C}$ for $24 \mathrm{~h}$. At various time-points aliquots were removed and frozen at $-20{ }^{\circ} \mathrm{C}$ for later analysis. The samples were then analyzed by HPLC using a Varian Microsorb-MV C-18 column (100 A sphere size, $5 \mu \mathrm{m}$ pore size, $250 \mathrm{~mm}$ length, and 2.6 mm i.d. eluted with a gradient mobile phase composed of solvent $\mathrm{A}\left(0.5 \% \mathrm{AcOH}\right.$ in $\left.\mathrm{H}_{2} \mathrm{O}\right)$ and solvent B (methanol). For compound 56 a gradient of $25-50 \%$ B over 5 min, followed by $50-100 \%$ B over $5 \mathrm{~min}$, followed by $100 \%$ B for $5 \mathrm{~min}$ was used. The mobile phase was returned to $25 \% \mathrm{~B}$ over $5 \mathrm{~min}$ and held at $25 \% \mathrm{~B}$ for 5 -min post-run. For compound 57 the mobile phase was held at 25\% B for 5 min following injection, before increasing to $50 \% \mathrm{~B}$ over $5 \mathrm{~min}$ and holding at $50 \% \mathrm{~B}$ for $4 \mathrm{~min}$. The mobile phase was then returned to $25 \% \mathrm{~B}$ over $1 \mathrm{~min}$ and held at $25 \% \mathrm{~B}$ for 5 -min post-run. The products were detected by monitoring absorbance at $280 \mathrm{~nm}$. The identity of the major hydrolysis products was confirmed by comparison to authentic synthetic standards.

$\mathbf{p K}_{\mathbf{a}}$ Determination of 80, 81, 82, and 83. UV/Vis spectra were taken for compounds 80, 81, 82, and $83(50 \mu \mathrm{M})$ in solutions with $\mathrm{pH}$ values from $0-9$ using $\mathrm{HCl}$ solutions and universal buffers prepared as in Britton and Robinson except containing 0.5\% DMF 
(v/v).[Britton, 1931 \#3396] Buffer $\mathrm{pH}$ was determined with via $\mathrm{pH}$ meter. Absorbance values were measured at $256 \mathrm{~nm}$ and $282 \mathrm{~nm}$ for $\mathbf{8 0}, 260 \mathrm{~nm}$ and $270 \mathrm{~nm}$ for $\mathbf{8 1}, 345 \mathrm{~nm}$ and $400 \mathrm{~nm}$ for 82, and $360 \mathrm{~nm}$ and $400 \mathrm{~nm}$ for compound 83. Changes in absorbance were plotted against $\mathrm{pH}$ and the $\mathrm{pK}_{\mathrm{a}}$ values were calculated from the midpoint for wavelengths monitored using least squares fitting. To confirm that $\mathrm{pK}_{\mathrm{a}}$ values measured reflected protonation of the 6-COOH or 6-OH substituents, $\mathrm{pH}$-absorbance measurements were performed with $\mathbf{1}$ and $\mathbf{4}$ to show that these control compounds displayed no significant changes in absorbance in the $\mathrm{pH}$ regions of interest.

Examination of the DNA-Alkylating Properties of 56 and 57. The 2'-

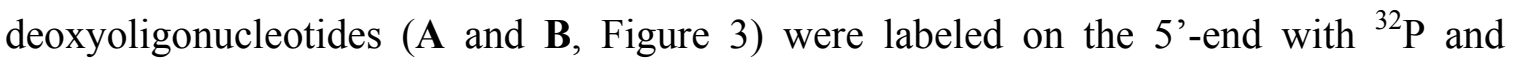
annealed to their complements using standard methods. ${ }^{42}$ DNA duplexes were mixed with the indicated compounds ( $1 \mathrm{mM}$ final concentrations), incubated at $37{ }^{\circ} \mathrm{C}$ for $3 \mathrm{~d}$ in HEPES buffer $(50 \mathrm{mM}, \mathrm{pH} 7)$ containing $\mathrm{NaCl}(100 \mathrm{mM})$ and DMF $(10 \% \mathrm{v} / \mathrm{v})$. The DNA was then ethanol precipitated, washed with $80 \%$ ethanol twice, and briefly dried in a SpeedVac concentrator (5 min at room temperature). The DNA was resuspended in piperidine (1 $\mathrm{M}$ in water) and heated to $95^{\circ} \mathrm{C}$ for $30 \mathrm{~min}$. The piperidine solution was removed under vacuum in a SpeedVac concentrator and the resulting residue resuspended in formamide loading buffer, ${ }^{42}$ warmed briefly, and loaded onto a $20 \%$ denaturing polyacrylamide gel. The gel was electrophoresed for $3 \mathrm{~h}$ at $1500 \mathrm{~V}$ to resolve the labeled DNA fragments. The labeled DNA fragments in the gel were visualized using a Personal Molecular Imager (BIORAD) with Quantity One software (v.4.6.5). 


\section{Hypoxia-Selective Enzymatic Reduction of N-Mustard Containing 1,2,4-}

Benzotriazine 1,4-Dioxides with Cytochrome P450. For experiments involving in vitro hypoxic metabolism, sodium phosphate buffer and HPLC-grade water were degassed by bubbling argon through the solutions for at least 30 min inside a glove bag filled with argon gas. Stock solutions of compounds $\mathbf{3 8}$ or $\mathbf{1}$ in DMF were degassed by three cycles of freeze-pump-thaw inside pyrex tubes. The tubes were then torch-sealed, scored, and transferred to the Argon-purged glove bag. The enzyme NADPH:cytochrome P450 reductase was used without degassing. The enzyme substrate NADPH was dissolved in degassed water inside the glove bag. In the glove bag, solutions containing sodium phosphate buffer (25 mM, pH 7), the di- $N$-oxide $38(100 \mu \mathrm{M})$, NADPH $(500 \mu \mathrm{M})$, and NADPH:cytochrome P450 reductase (1 unit/mL) and DMF $(1 \% \mathrm{v} / \mathrm{v})$ were incubated in a sealed microcentrifuge tube at room temperature protected from light for $24 \mathrm{~h}$. A similar reaction was prepared using non-degassed solutions and incubated open to air as a aerobic control. After $24 \mathrm{~h}$, the solutions were passed through Millipore (YM-3) centrifuge filters $(30 \mathrm{~min}, 7500 \mathrm{xg}$ ). The filtrate was analyzed by HPLC using a Varian Microsorb-MV C-18 column (100 Å sphere size, $5 \mu \mathrm{m}$ pore size, $250 \mathrm{~mm}$ length, and 2.6 mm i.d.). The column was eluted with a mobile phase composed of solvent A $(0.5 \%$ $\mathrm{AcOH}$ in $\mathrm{H}_{2} \mathrm{O}$ ) and solvent $\mathrm{B}$ (methanol). The column was eluted at a flow rate of 0.9 $\mathrm{mL} / \mathrm{min}$ for $2 \mathrm{~min}$ at $10 \% \mathrm{~B}$, a gradient of $10-50 \% \mathrm{~B}$ over $8 \mathrm{~min}, 50 \% \mathrm{~B}$ for $5 \mathrm{~min}$, then returned to $10 \% \mathrm{~B}$ over $5 \mathrm{~min}$ and held at $10 \% \mathrm{~B}$ for 5 min post-run. Compounds were detected by their absorbance at $420 \mathrm{~nm}$ and the identity of products 36 and $\mathbf{4}$ confirmed by comparison to authentic synthetic standards. 
Preparation of 3-amino-6-(bis(2-(tosyloxy)ethyl)amino)-1,2,4-benzotriazine 1-oxide

(54). Compound 36 (126 mg, $0.5 \mathrm{mmol})$ was suspended in a biphasic mixture of THF (2 $\mathrm{mL})$ and $\mathrm{NaOH}(1.5 \mathrm{~mL}$ of a $4 \mathrm{M}$ solution in water) and cooled in an ice bath. To this orange biphasic mixture was added dropwise an ice cold solution of $p$-toluenesulfonyl chloride (200 mg, 2.2 equiv) in THF ( $3 \mathrm{~mL})$. The resulting suspension was stirred vigorously with cooling in an ice bath for $5 \mathrm{~h}$. During this time the mixture turned yellow. The mixture was then poured into an ice-water slurry $(10 \mathrm{~mL})$ and stirred for 20 min to give a bright yellow powder. This solid was collected by vacuum filtration and washed with water and then diethyl ether, and then dried in a desiccator in to give $\mathbf{5 4}$ in 74\% yield. ${ }^{1} \mathrm{H}$ NMR (500 MHz, DMSO- $\left.d_{6}\right) \delta 7.73(\mathrm{~d}, J=9.7 \mathrm{~Hz}, 1 \mathrm{H}), 7.60(\mathrm{~d}, J=8.2$ Hz, $4 \mathrm{H}), 7.24$ (d, $J=8.1 \mathrm{~Hz}, 4 \mathrm{H}), 6.97$ (bs, 2 H), 6.63 (dd, $J=9.7,2.5 \mathrm{~Hz}, 1 \mathrm{H}), 6.15$ (d, $J=7.5 \mathrm{~Hz}, 1 \mathrm{H}), 4.13(\mathrm{t}, J=5.1 \mathrm{~Hz}, 4 \mathrm{H}), 3.64(\mathrm{t}, J=5.1 \mathrm{~Hz}, 4 \mathrm{H}), 2.25(\mathrm{~s}, 6 \mathrm{H}) ;{ }^{13} \mathrm{C} \mathrm{NMR}$ $\left(125 \mathrm{MHz}, \mathrm{DMSO}-d_{6}\right) \delta 160.6,151.4,150,4,144.9,131.6,129.9,127.4,122.5,120.6$, 113.7, 101.1, 67.29, 48.9, 20.9; HRMS (ESI) m/z calculated for $\mathrm{C}_{25} \mathrm{H}_{27} \mathrm{~N}_{5} \mathrm{O}_{7} \mathrm{~S}_{2}\left(\mathrm{M}+\mathrm{H}^{+}\right)$ 574.1425, found 574.1433. Crystals suitable for X-ray crystallography were prepared by slow evaporation of ethanol. The crystal structure and crystallographic data for $\mathbf{5 4}$ are shown in Crystal Structure 2 and the crystallographic data table respectively

Preparation of 3-amino-6-(bis(2-(tosyloxy)ethyl)amino)-1,2,4-benzotriazine 1,4dioxide (55). Compound 54 (501 $\mathrm{mg}, 0.9 \mathrm{mmol})$ was dissolved in THF (100 mL) and cooled with stirring in an ice bath. To this mixture was added $m$-CPBA (300 mg, 1.5 equiv, of a $77 \%$ maximum purity material) and the reaction stirred overnight in an ice bath. An additional portion of $m$-CPBA was added and the reaction stirred at room 
temperature for an additional $3 \mathrm{~d}$. The solution was concentrated under vacuum, poured into cold water, and the solid collected by vacuum filtration. The material was purified by column chromatography on silica gel eluted with a gradient of $1-3 \%$ methanol in $\mathrm{CH}_{2} \mathrm{Cl}_{2}$ to give $\mathbf{5 5}$ as a yellow solid in $37 \%$ yield: ${ }^{1} \mathrm{H}$ NMR (500 MHz, DMSO- $\left.d_{6}\right) 7.84$ (bs, $2 \mathrm{H}), 7.80(\mathrm{~d}, J=9.8 \mathrm{~Hz}, 1 \mathrm{H}), 7.60(\mathrm{~d}, J=8.2 \mathrm{~Hz}, 4 \mathrm{H}), 7.22(\mathrm{~d}, J=8.1 \mathrm{~Hz}, 4 \mathrm{H})$, $6.86(\mathrm{dd}, J=9.8,2.7 \mathrm{~Hz}, 1 \mathrm{H}), 6.65(\mathrm{~d}, J=2.7 \mathrm{~Hz}, 1 \mathrm{H}), 4.19(\mathrm{t}, J=5.0 \mathrm{~Hz}, 4 \mathrm{H}), 3.67$ (t, $J=4.9 \mathrm{~Hz}, 4 \mathrm{H}), 2.24(\mathrm{~s}, 6 \mathrm{H}) ;{ }^{13} \mathrm{C} \mathrm{NMR}\left(125 \mathrm{MHz}, \mathrm{DMSO}-d_{6}\right) \delta 151.6,151.5,144.9$, 139.3, 131.6, 129.9, 127.4, 123.0, 122.1, 115.6, 92.2, 67.1, 48.9, 20.8; HRMS (ESI) m/z calculated for $\mathrm{C}_{25} \mathrm{H}_{27} \mathrm{~N}_{5} \mathrm{O}_{8} \mathrm{~S}_{2}\left(\mathrm{M}+\mathrm{H}^{+}\right)$590.1374, found 590.1371.

\section{Synthesis of 3-amino-6-(bis(2-((methylsulfonyl)oxy)ethyl)amino)-1,2,4-benzotriazine}

1-oxide (56). Compound $36(500 \mathrm{mg}, 1.9 \mathrm{mmol})$ was dissolved in DMF (4.5 $\mathrm{mL})$, followed by the addition of triethylamine ( $800 \mu \mathrm{L}, 3$ equiv) and cooling in an ice bath. Methanesulfonyl chloride (370 $\mu \mathrm{L}, 2.5$ equiv) was added dropwise over $15 \mathrm{~min}$ as an ice cold solution in DMF $(0.5 \mathrm{~mL})$ and the resulting mixture stirred at room temperature for $2.5 \mathrm{~h}$. The solution was poured into $30 \mathrm{~mL}$ of cold water with stirring and refrigerated overnight at $4{ }^{\circ} \mathrm{C}$. The resulting orange precipitate was collected by vacuum filtration. The solid was washed with water and diethyl ether and dried in a desiccator to give $\mathbf{5 6}$ in $72 \%$ yield. ${ }^{1} \mathrm{H}$ NMR $\left(500 \mathrm{MHz}, \mathrm{DMSO}-d_{6}\right) \delta 7.94(\mathrm{~d}, J=9.6 \mathrm{~Hz}, 1 \mathrm{H}), 7.06(\mathrm{dd}, J=9.7$, $1.8 \mathrm{~Hz}, 2 \mathrm{H}), 6.98(\mathrm{bs}, 2 \mathrm{H}), 6.56(\mathrm{~s}, 1 \mathrm{H}), 4.38(\mathrm{t}, J=5.3 \mathrm{~Hz}, 4 \mathrm{H}), 3.90(\mathrm{t}, J=5.2 \mathrm{~Hz}, 4$ H), $3.17(\mathrm{~s}, 6 \mathrm{H}) ;{ }^{13} \mathrm{C}$ NMR $\left(125 \mathrm{MHz}, \mathrm{DMSO}-d_{6}\right) \delta 161.0,152.8,151.1,123.1,121.6$, 114.4, 101.6, 67.4, 49.7, 37.1; HRMS (ESI) $\mathrm{m} / \mathrm{z}$ calculated for $\mathrm{C}_{13} \mathrm{H}_{19} \mathrm{~N}_{5} \mathrm{O}_{7} \mathrm{~S}_{2}\left(\mathrm{M}+\mathrm{H}^{+}\right)$ 422.0799, found 422.0800. 


\section{Preparation of 3-amino-6-(bis(2-((methylsulfonyl)oxy)ethyl)amino)-1,2,4-} benzotriazine 1,4-dioxide (57). Compound $56(70 \mathrm{mg}, 0.17 \mathrm{mmol})$ and $\mathrm{NaHCO}_{3}(86$ $\mathrm{mg}, 6$ equiv) were suspended in methanol $(25 \mathrm{~mL})$. Oxone (245 mg, 1.2 equiv) was added, followed by water $(10 \mathrm{~mL})$. The mixture was stirred at $50{ }^{\circ} \mathrm{C}$ under a $\mathrm{N}_{2}$ atmosphere for $24 \mathrm{~h}$. Thin layer chromatographic analysis indicated that most of the reaction progress occurred within the first $5 \mathrm{~h}$. The reaction was cooled to room temperature and the white solid was removed by vacuum filtration and washed with $\mathrm{CH}_{2} \mathrm{Cl}_{2}(10 \mathrm{~mL})$. The filtrate was extracted with $\mathrm{CH}_{2} \mathrm{Cl}_{2}(2 \times 125 \mathrm{~mL})$, dried with anhydrous sodium sulfate, evaporated under reduced pressure, and the resulting residue subjected to column chromatography on silica gel eluted with a gradient of 1-5\% methanol in $\mathrm{CH}_{2} \mathrm{Cl}_{2}$ to give 57 as an orange solid in $15 \%$ yield: ${ }^{1} \mathrm{H}$ NMR $(500 \mathrm{MHz}$, DMSO-d $d_{6} \delta 8.01(\mathrm{~d}, J=9.8 \mathrm{~Hz}, 1 \mathrm{H}), 7.82(\mathrm{bs}, 2 \mathrm{H}), 7.28(\mathrm{dd}, J=9.9,2.7 \mathrm{~Hz}, 2 \mathrm{H})$, $7.09(\mathrm{~d}, J=2.7,1 \mathrm{H}), 4.43(\mathrm{t}, J=5.3 \mathrm{~Hz}, 4 \mathrm{H}), 3.97(\mathrm{t}, J=5.3 \mathrm{~Hz}, 4 \mathrm{H}), 3.19(\mathrm{~s}, 6 \mathrm{H}) ;{ }^{13} \mathrm{C}$ NMR $\left(125 \mathrm{MHz}, \mathrm{DMSO}-d_{6}\right) \delta 153.0,151.9,140.1,123.7,123.2,116.2,92.8,67.2,49.7$, 37.1; HRMS (ESI) m/z calculated for $\mathrm{C}_{13} \mathrm{H}_{19} \mathrm{~N}_{5} \mathrm{O}_{8} \mathrm{~S}_{2}\left(\mathrm{M}+\mathrm{H}^{+}\right)$438.0748, found 438.0746.

\section{Synthesis of 3-amino-5-tosyl-6-(bis(2-hydroxyethyl)amino)-1,2,4-benzotriazine 1-} oxide (58). Compound 38 (52 $\mathrm{mg}, 0.18 \mathrm{mmol})$ was suspended in a stirred solution of pyridine in an ice bath and tosyl chloride (172 mg, 5 equiv) was added. The mixture was stirred in an ice bath for $12 \mathrm{~h}$, poured into ice-cold water $(20 \mathrm{~mL})$ and extracted with methylene chloride $(5 \times 25 \mathrm{~mL})$. The combined organic fractions were washed with brine, dried over $\mathrm{Na}_{2} \mathrm{SO}_{4}$ and solvent by rotary evaporation. Column chromatography on 
silica gel eluted with $1 \%$ methanol in methylene chloride gave $\mathbf{5 8}$ in $10 \%$ yield: ${ }^{1} \mathrm{H}$ NMR $\left(500 \mathrm{MHz}, \mathrm{DMSO}-d_{6}\right) \delta 7.85(\mathrm{~d}, J=9.8 \mathrm{~Hz}, 1 \mathrm{H}), 7.75(\mathrm{~d}, J=8.2 \mathrm{~Hz}, 2 \mathrm{H}), 7.739(\mathrm{~d}, J=$ $8.2 \mathrm{~Hz}, 2 \mathrm{H}), 7.19$ (d, $J=9.8 \mathrm{~Hz}, 1 \mathrm{H}), 6.94$ (bs 2H), 4.65 (t, $J=5.1 \mathrm{~Hz}, 2 \mathrm{H}), 3.47-3.40$ (m, 8H); ${ }^{13} \mathrm{C}$ NMR (125 MHz, DMSO- $\left.d_{6}\right) \delta 160.1,148.2,145.9,145.5,132.6,129.5$, 128.8, 126.6, 123.6, 118.8, 118.7, 58.4, 54.3, 21.3; HRMS (ESI) m/z calculated for $\mathrm{C}_{7} \mathrm{H}_{5} \mathrm{FN}_{4} \mathrm{O} \quad\left(\mathrm{M}+\mathrm{H}^{+}\right)$436.1285, found 436.1293. Crystals suitable for X-ray crystallography were prepared by vapor diffusion with ethyl acetate and hexane. The crystal structure and crystallographic data for $\mathbf{5 8}$ are shown in Crystal Structure 1 and the crystallographic data table respectively.

\section{Synthesis of 3-amino-6-(bis(2-chloroethyl)amino)-1,2,4-benzotriazine 1-oxide (59).} Compound 54 (200 mg, $0.35 \mathrm{mmol})$ and $\mathrm{LiCl}(148 \mathrm{mg}, 10$ eq.) were dissolved in DMF $(1.5 \mathrm{~mL})$ and heated at $110{ }^{\circ} \mathrm{C}$ for $2 \mathrm{~h}$ under a $\mathrm{N}_{2}$ atmosphere before being cooled on ice and mixed with ice cold water $(20 \mathrm{~mL})$. The resulting yellow precipitate was collected by vacuum filtration, washed with water, diethyl ether, and then dried in a desiccator to give 59 in $94 \%$ yield. ${ }^{1} \mathrm{H}$ NMR $\left(500 \mathrm{MHz}, \mathrm{DMSO}-d_{6}\right) \delta 7.95(\mathrm{~d}, J=9.6 \mathrm{~Hz}, 1 \mathrm{H}), 7.04$ (dd, 9.7, 2.6 Hz, $1 \mathrm{H}), 6.98$ (bs, $2 \mathrm{H}), 6.48(\mathrm{~d}, J=2.5 \mathrm{~Hz}, 1 \mathrm{H}), 3.89(\mathrm{t}, J=6.6 \mathrm{~Hz}, 4 \mathrm{H})$, $3.80(\mathrm{t}, J=6.6 \mathrm{~Hz}, 4 \mathrm{H}) ;{ }^{13} \mathrm{C}$ NMR $\left(125 \mathrm{MHz}, \mathrm{DMSO}-d_{6}\right) \delta 160.7(\mathrm{~d}, J=253.90 \mathrm{~Hz})$, 152.1, 150.8, 122.8, 121.4, 113.9, 101.1, 51.8, 40.9; HRMS (ESI) m/z calculated for $\mathrm{C}_{11} \mathrm{H}_{13} \mathrm{Cl}_{2} \mathrm{~N}_{5} \mathrm{O}\left(\mathrm{M}+\mathrm{H}^{+}\right) 302.0570$, found 302.0576 .

Synthesis of 3-amino-6-(bis(2-bromoethyl)amino)-1,2,4-benzotriazine 1-oxide (60). Compound 54 (310 mg, $0.54 \mathrm{mmol})$ and $\mathrm{LiBr}$ (464 mg, 10 eq.) were dissolved in DMF 
$(2.25 \mathrm{~mL})$ and heated at $110{ }^{\circ} \mathrm{C}$ for $1.5 \mathrm{~h}$ under a $\mathrm{N}_{2}$ atmosphere before being cooled on ice and mixed with ice cold water $(20 \mathrm{~mL})$. The resulting yellow precipitate was collected by vacuum filtration, washed with water, diethyl ether, and then dried in a desiccator to give 60 in $93 \%$ yield: ${ }^{1} \mathrm{H}$ NMR (500 MHz, DMSO- $\left.d_{6}\right) \delta 7.95(\mathrm{~d}, J=9.7 \mathrm{~Hz}$, $1 \mathrm{H}), 7.02-6.99$ (comp, $3 \mathrm{H}), 6.44(\mathrm{~d}, J=2.6 \mathrm{~Hz}, 1 \mathrm{H}), 3.92(\mathrm{t}, J=7.2 \mathrm{~Hz}, 4 \mathrm{H}), 3.65(\mathrm{t}, J$ $=7.2 \mathrm{~Hz}, 4 \mathrm{H}) ;{ }^{13} \mathrm{C}$ NMR $\left(125 \mathrm{MHz}, \mathrm{DMSO}-d_{6}\right) \delta 160.7,151.7,150.8,122.8,121.5$, 113.8, 101.3, 51.6, 29.3; HRMS (ESI) $\mathrm{m} / \mathrm{z}$ calculated for $\mathrm{C}_{7} \mathrm{H}_{5} \mathrm{FN} \mathrm{F}_{4} \mathrm{O}\left(\mathrm{M}+\mathrm{H}^{+}\right)$302.0570, found 302.0576 .

\section{Synthesis of 3-amino-6-(bis(2-iodoethyl)amino)-1,2,4-benzotriazine 1-oxide (61).} Compound 54 (300 mg, $0.52 \mathrm{mmol})$ and potassium iodide $(869 \mathrm{mg}, 10$ eq.) were dissolved in DMF $(2.25 \mathrm{~mL})$ and heated at $110{ }^{\circ} \mathrm{C}$ for 30 min under a $\mathrm{N}_{2}$ atmosphere before being cooled on ice and mixed with ice cold water $(20 \mathrm{~mL})$. The resulting yellow precipitate was collected by vacuum filtration, washed with water, diethyl ether, and then dried in a dessicator to give 61 in $90 \%$ yield: ${ }^{1} \mathrm{H}$ NMR $\left(500 \mathrm{MHz}\right.$, DMSO- $\left.d_{6}\right) \delta 7.96(\mathrm{~d}, J$ $=9.6 \mathrm{~Hz}, 1 \mathrm{H}), 7.00(\mathrm{bs}, 2 \mathrm{H}), 6.95(\mathrm{dd}, 9.7,2.5 \mathrm{~Hz}, 1 \mathrm{H}), 6.35(\mathrm{~d}, J=2.5 \mathrm{~Hz}, 1 \mathrm{H}), 3.87$ (t, $J=7.7 \mathrm{~Hz}, 4 \mathrm{H}), 3.55(\mathrm{t}, J=7.7 \mathrm{~Hz}, 4 \mathrm{H}) ;{ }^{13} \mathrm{C}$ NMR $\left(125 \mathrm{MHz}\right.$, DMSO- $\left.d_{6}\right) \delta 160.7$, 151.2, 150.8, 122.8, 121.6, 113.6, 100.8, 52.4, 2.31; HRMS (ESI) m/z calculated for $\mathrm{C}_{7} \mathrm{H}_{5} \mathrm{FN}{ }_{4} \mathrm{O}\left(\mathrm{M}+\mathrm{H}^{+}\right)$302.0570, found 302.0576.

\section{Preparation of 3-amino-6-(bis(2-chloroethyl)amino)-1,2,4-benzotriazine 1,4-dioxide}

62. Compound 59 (50 mg, $0.17 \mathrm{mmol})$ and $\mathrm{NaHCO}_{3}(42 \mathrm{mg}, 3 \mathrm{eq})$ were suspended in methanol $(25 \mathrm{~mL})$. Oxone $(122 \mathrm{mg}, 1.2 \mathrm{eq})$ was added, followed by water $(10 \mathrm{~mL})$. The 
mixture was stirred at $50{ }^{\circ} \mathrm{C}$ under a $\mathrm{N}_{2}$ atmosphere. The reaction mixture was filtered while still warm and the solids washed with methanol $(5 \mathrm{~mL})$. The filtrate was cooled to room temperature, diluted with water $(50 \mathrm{~mL})$, and extracted methylene chloride $(3 \times 100$ $\mathrm{mL})$. Column chromatography on silica gel eluted with a gradient of $2-6 \%$ methanol in $\mathrm{CH}_{2} \mathrm{Cl}_{2}$ gave 62 as an orange solid in $30 \%$ yield: ${ }^{1} \mathrm{H}$ NMR (500 MHz, DMSO- $\left.d_{6}\right) \delta 8.01$ $(\mathrm{d}, J=9.8, \mathrm{~Hz}, 1 \mathrm{H}), 7.81$ (bs $2 \mathrm{H}), 7.27(\mathrm{dd}, J=9.8,2.7 \mathrm{~Hz}, 1 \mathrm{H}), 7.05$ (d, $J=2.7 \mathrm{~Hz}, 1$ H), $3.96(\mathrm{t}, J=6.7 \mathrm{~Hz}, 4 \mathrm{H}), 3.85(\mathrm{t} J=6.7 \mathrm{~Hz}, 4 \mathrm{H}) ;{ }^{13} \mathrm{C}$ NMR $\left(125 \mathrm{MHz}, \mathrm{DMSO}-d_{6}\right) \delta$ 152.3, 151.5, 139.7, 123.4, 123.0, 115.8, 92.2; HRMS (ESI) m/z calculated for $\mathrm{C}_{11} \mathrm{H}_{13} \mathrm{Cl}_{2} \mathrm{~N}_{5} \mathrm{O}_{2}\left(\mathrm{M}+\mathrm{H}^{+}\right)$318.0519, found 318.0519.

\section{Synthesis of compounds 6-(bis(2-(tosyloxy)ethyl)amino))-1,2,4-benzotriazine 1-oxide} and $\quad 7-($ bis(2-(tosyloxy)ethyl)amino)benzo[e][1,2,4]triazine 1-oxide $\quad(67)$ :

Compound 28 (200 mg) was dissolved in a biphasic mixture of THF (9 mL) and $\mathrm{NaOH}$ (2.4 $\mathrm{mL}$ of a $4 \mathrm{M}$ solution in water) and cooled in an ice bath. To this orange biphasic mixture was added dropwise an ice cold solution of $p$-toluenesulfonyl chloride (455 mg, 3 equiv) in THF (1.5 mL). The resulting mixture was stirred vigorously in an ice bath for 1.5 h. During this time the mixture turned yellow. The mixture was then poured into an ice-water slurry $(100 \mathrm{~mL})$ and stirred for $30 \mathrm{~min}$ to give a yellow precipitate. The solid was collected by vacuum filtration, then washed with water, diethyl ether, and dried in a desiccator to give $\mathbf{6 5}$ in 95\% yield: ${ }^{1} \mathrm{H}$ NMR (500 MHz, DMSO- $\left.d_{6}\right) \delta 8.87(\mathrm{~s}, 1 \mathrm{H}), 7.96$ $(\mathrm{d}, J=9.2 \mathrm{~Hz}, 1 \mathrm{H}), 7.57(\mathrm{~d}, J=8.3 \mathrm{~Hz}, 4 \mathrm{H}), 7.19(\mathrm{~d}, J=8.0,4 \mathrm{H}), 7.14(\mathrm{dd}, J=9.8,2.6$ $\mathrm{Hz}, 1 \mathrm{H}), 6.64(\mathrm{~d}, J=2.7 \mathrm{~Hz}, 1 \mathrm{H}), 4.18(\mathrm{t}, J=5.1 \mathrm{~Hz}, 4 \mathrm{H}), 3.71(\mathrm{t}, J=5.1 \mathrm{~Hz}, 4 \mathrm{H})$, $2.20(\mathrm{~s}, 6 \mathrm{H}) ;{ }^{13} \mathrm{C}$ NMR $\left(500 \mathrm{MHz}, \mathrm{DMSO}-d_{6}\right) \delta 154.8,152.1,149.2,145.2,131.9,130.2$, 
127.8，127.4，120.7，120.3，103.7，67.6，49.3，21.2; HRMS (ESI) m/z calculated for $\mathrm{C}_{25} \mathrm{H}_{26} \mathrm{~N}_{4} \mathrm{O}_{7} \mathrm{~S}_{2}\left(\mathrm{M}+\mathrm{H}^{+}\right)$559.1316, found 559.1320. Compound 67 was prepared in $80 \%$ yield from 33 using the same conditions: ${ }^{1} \mathrm{H}$ NMR $\left(500 \mathrm{MHz}, \mathrm{DMSO}-d_{6}\right) \delta 8.89(\mathrm{~s}, 1 \mathrm{H})$, $7.73(\mathrm{~d}, J=9.4 \mathrm{~Hz}, 1 \mathrm{H}), 7.56(\mathrm{~d}, J=8.2 \mathrm{~Hz}, 4 \mathrm{H}), 7.44$ (dd, $J=9.5,2.8,1 \mathrm{H}), 7.16(\mathrm{~d}, J$ $=8.1 \mathrm{~Hz}, 4 \mathrm{H}), 6.86(\mathrm{~d}, J=2.8 \mathrm{~Hz}, 1 \mathrm{H}), 4.19(\mathrm{t}, J=5.0 \mathrm{~Hz}, 4 \mathrm{H}), 3.69(\mathrm{t}, J=5.0 \mathrm{~Hz}, 4$ H), 2.17 (s, $6 \mathrm{H}) ;{ }^{13} \mathrm{C}$ NMR (125 MHz, DMSO- $\left.d_{6}\right) \delta$ 150.2, 148.6, 145.2, 140.7, 135.8, 132.0, 130.1, 129.5, 127.7, 125.0, 94.8, 67.5, 49.1, 21.2; HRMS (ESI) m/z calculated for $\mathrm{C}_{25} \mathrm{H}_{26} \mathrm{~N}_{4} \mathrm{O}_{7} \mathrm{~S}_{2}\left(\mathrm{M}+\mathrm{H}^{+}\right)$559.1316, found 559.1317.

\section{Preparation of 6-(bis(2-(tosyloxy)ethyl)amino))-1,2,4-benzotriazine 1,4-dioxide (66):} Compound 65 (20 mg, $0.04 \mathrm{mmol})$ and $\mathrm{NaHCO}_{3}(30 \mathrm{mg}, 10$ equiv) were suspended in methanol $(6.25 \mathrm{~mL})$. Oxone ( $245 \mathrm{mg}, 5$ equiv) was added, followed by water $(2.5 \mathrm{~mL})$ and the mixture was stirred at $50{ }^{\circ} \mathrm{C}$ under an atmosphere of nitrogen gas for $16 \mathrm{~h}$. The reaction was cooled to room temperature and extracted with methylene chloride $(5 \times 10$ $\mathrm{mL})$. The organic layers were combined, washed with brine, dried over anhydrous sodium sulfate. Column chromatography on silica gel eluted with $1 \% \mathrm{MeOH}$ in $\mathrm{CH}_{2} \mathrm{Cl}_{2}$ gave compound 66 in $10 \%$ yield with $50 \%$ recovery of starting materials: ${ }^{1} \mathrm{H}$ NMR (500 MHz, DMSO-d $\left.d_{6}\right) \delta 9.15(\mathrm{~s}, 1 \mathrm{H}), 7.96(\mathrm{~d}, J=9.8 \mathrm{~Hz}, 1 \mathrm{H}), 7.57(\mathrm{~d}, J=8.2 \mathrm{~Hz}, 4 \mathrm{H})$, 7.25-7.18 (m, $5 \mathrm{H}), 6.84(\mathrm{~d}, J=2.8 \mathrm{~Hz}, 1 \mathrm{H}), 4.21$ (t, $J=5.0 \mathrm{~Hz}, 4 \mathrm{H}), 3.70(\mathrm{t}, J=4.9 \mathrm{~Hz}$, $4 \mathrm{H}), 2.25$ (s, $6 \mathrm{H}) ;{ }^{13} \mathrm{C}$ NMR (125 MHz, DMSO- $\left.d_{6}\right) \delta 152.0,145.3,142.5,140.7,132.0$, 130.2, 127.8, 127.3, 122.4, 120.9, 84.6, 67.4, 49.1, 21.2; HRMS (ESI) m/z calculated for $\mathrm{C}_{25} \mathrm{H}_{26} \mathrm{~N}_{4} \mathrm{O}_{8} \mathrm{~S}_{2}\left(\mathrm{M}+\mathrm{H}^{+}\right)$575.1265, found 575.1263. 
Synthesis of 7-(bis(2-(tosyloxy)ethyl)amino)-1,2,4-benzotriazine 1,4-dioxide (68): A

procedure adapted from Pchalek and Hay was followed. ${ }^{55}$ Trifluoroacetic anhydride (300 $\mu \mathrm{L})$ and methylene chloride $(1.5 \mathrm{~mL})$ were mixed with stirring in an ice bath and $70 \%$ $\mathrm{H}_{2} \mathrm{O}_{2}(105 \mu \mathrm{L})$ was added dropwise. The mixture was stirred for $10 \mathrm{~min}$ and then allowed to warm to room temperature. This solution was cooled in an ice bath and slowly added to an ice cold solution of $67(110 \mathrm{mg}, 0.2 \mathrm{mmol})$ in methylene chloride (10 $\mathrm{mL}$ ). The reaction was stirred in an ice bath for $30 \mathrm{~min}$ before being diluted with methylene chloride (100 mL) and washed with cold water, cold $\mathrm{NaHCO}_{3}$ (saturated), and then brine. The organic layer was dried over anhydrous sodium sulfate and column chromatography on silica gel eluted with $0.5 \% \mathrm{MeOH}$ in $\mathrm{CH}_{2} \mathrm{Cl}_{2}$ gave 68 in $1 \%$ yield: ${ }^{1} \mathrm{H}$ NMR (500 MHz, DMSO-d $d_{6} \delta 9.06(\mathrm{~s}, 1 \mathrm{H}), 7.96(\mathrm{~d}, J=9.7 \mathrm{~Hz}, 1 \mathrm{H}), 7.57(\mathrm{~d}, J=8.3$ Hz, $4 \mathrm{H}), 7.41$ (dd, $J=9.7,2.7,1 \mathrm{H}), 7.22(\mathrm{~d}, J=8.0 \mathrm{~Hz}, 4 \mathrm{H}), 6.85$ (d, $J=2.6 \mathrm{~Hz}, 1 \mathrm{H})$, $4.19(\mathrm{t}, J=5.0 \mathrm{~Hz}, 4 \mathrm{H}), 3.67(\mathrm{t}, J=4.9 \mathrm{~Hz}, 4 \mathrm{H}), 2.25(\mathrm{~s}, 6 \mathrm{H}) ;{ }^{13} \mathrm{C} \mathrm{NMR}(125 \mathrm{MHz}$, DMSO- $\left.d_{6}\right) \delta 149.3,144.9,138.8,135.6,131.8,131.7,129.9,127.4,123.2,119.5,96.1$ 67.1, 48.6, 20.9; HRMS (ESI) $\mathrm{m} / \mathrm{z}$ calculated for $\mathrm{C}_{25} \mathrm{H}_{26} \mathrm{~N}_{4} \mathrm{O}_{8} \mathrm{~S}_{2}\left(\mathrm{M}+\mathrm{H}^{+}\right)$575.1265, found 575.1275 .

\section{Synthesis of 3-((4-(1-hydroxyethyl)phenyl)amino)-1,2,4-benzotriazine 1-oxide (70):}

A seal tube was charged with compound 5 (1.03 g, $5.6 \mathrm{mmol})$, 4-1'-hydroxyethylaniline (853 mg, 1.2 equiv), $\mathrm{K}_{3} \mathrm{PO}_{4}$ (4.8 g, 4 equiv), $\mathrm{Pd}(\mathrm{OAc})_{2}(63 \mathrm{mg}, 5 \%)$, SPhos (230 mg, $10 \%)$, tetrahydrofuran $(10 \mathrm{~mL})$ and Toluene $(50 \mathrm{~mL})$. The mixture was degassed by bubbling $\mathrm{N}_{2}$ through the suspension for 20 min then sealed. The reaction was stirred at $100{ }^{\circ} \mathrm{C}$ for $14 \mathrm{~h}$ (overnight) resulting in a bright orange precipitate. The reaction was 
cooled to room temperature and diluted with tetrahydrofuran $(40 \mathrm{~mL})$ before being filtered through celite. The celite was washed with a minimal amount of tetrahydrofuran and the filtrate was concentrated by rotary evaporation. The mixture was diluted with ethyl acetate $(200 \mathrm{~mL})$ and washed with $1 \mathrm{M} \mathrm{HCl}(3 \times 100 \mathrm{~mL}$, aq), then bicarbonate solution and brine. Purification was done by column chromatography on silica gel with $0.5 \% \mathrm{MeOH}$ in $\mathrm{CH}_{2} \mathrm{Cl}_{2}$ to afford 70 in $65 \%$ yield: $1 \mathrm{H}$ NMR (500 MHz, DMSO- $\left.d_{6}\right) \delta$ $10.19(\mathrm{~s}, 1 \mathrm{H}), 8.22(\mathrm{~d}, J=8.5 \mathrm{~Hz}, 1 \mathrm{H}), 7.87$ (ddd, $J=8.2,7.2,1.0 \mathrm{~Hz}, 1 \mathrm{H}), 7.77(\mathrm{~d}, J=$ $8.5 \mathrm{~Hz}, 2 \mathrm{H}), 7.73$ (d, $J=8.4 \mathrm{~Hz}, 1 \mathrm{H}), 7.46$ (appt, $J=81,7.4 \mathrm{~Hz}, 1 \mathrm{H}), 7.32$ (d, $J=8.5$ $\mathrm{Hz}, 2 \mathrm{H}), 5.08(\mathrm{~d}, J=4.2 \mathrm{~Hz}, 1 \mathrm{H}), 4.70(\mathrm{dt}, J=6.3,6.2 \mathrm{~Hz}, 1 \mathrm{H}), 1.33(\operatorname{appd}, J=6.4 \mathrm{~Hz}$, $3 \mathrm{H}) ;{ }^{13} \mathrm{C}$ NMR (125 MHz, DMSO- $\left.d_{6}\right) \delta 156.5,147.7,141.9,137.7,136.0,130.9,126.6$, 125.8, 125.6, 119.9, 119.3, 67.8, 25.9; HRMS (ESI) $\mathrm{m} / \mathrm{z}$ calculated for $\mathrm{C}_{15} \mathrm{H}_{14} \mathrm{~N}_{4} \mathrm{O}_{2}$ $\left(\mathrm{M}+\mathrm{H}^{+}\right)$283.1117, found 283.1194.

\section{Synthesis of 3-((4-(1-acetoxyethyl)phenyl)amino)-1,2,4-benzotriazine 1-oxide (71):}

Compound 70 (116 mg, $0.4 \mathrm{mmol})$ was dissolved in tetrahydrofuran $(2 \mathrm{~mL})$ and acetic acid $(2 \mathrm{~mL})$. Sodium acetate $(11 \mathrm{mg}, 10 \%$ equiv) was added and then the mixture was stirred under $\mathrm{N}_{2}$ atmosphere at $50{ }^{\circ} \mathrm{C}$ for $8 \mathrm{~h}$. The reaction was cooled to room temperature and poured into an ice-water slurry $(40 \mathrm{~mL})$ and stirred until the ice melts. The resulting precipitate was collected by vacuum filtration, washed with a minimal amount of cold water, and dried under vacuum. Compound 76 was collected as an orange solid in 70\% yield: $1 \mathrm{H}$ NMR (500 MHz, DMSO- $\left.d_{6}\right) \delta 10.27(\mathrm{~s}, 1 \mathrm{H}), 8.22(\mathrm{~d}, J=$ $7.8 \mathrm{~Hz}, 1 \mathrm{H}), 7.88$ (ddd, $J=8.3,7.2,1.2 \mathrm{~Hz}, 1 \mathrm{H}), 7.83$ (d, $J=8.6 \mathrm{~Hz}, 2 \mathrm{H}), 7.74$ (d, $J=$ $8.4 \mathrm{~Hz}, 1 \mathrm{H}), 7.48$ (appt, $J=8.3,1.0 \mathrm{~Hz}, 1 \mathrm{H}), 7.36$ (d, $J=8.6 \mathrm{~Hz}, 2 \mathrm{H}), 7.78$ (q, $J=6.6$ 
$\mathrm{Hz}, 1 \mathrm{H}), 2.04(\mathrm{~s}, J=6.7 \mathrm{~Hz}, 3 \mathrm{H}), 1.48(\mathrm{~d}, J=6.6 \mathrm{~Hz}, 3 \mathrm{H}) ;{ }^{13} \mathrm{C}$ NMR $(125 \mathrm{MHz}$, DMSO- $\left.d_{6}\right) \delta 169.7,156.4,147.6,138.8,136.1,135.9,131.0,126.6,126.5,126.0,119.9$, 119.4, 71.4, 21.9, 21.0; HRMS (ESI) m/z calculated for $\mathrm{C}_{17} \mathrm{H}_{16} \mathrm{~N}_{4} \mathrm{O}_{3}\left(\mathrm{M}+\mathrm{H}^{+}\right) 325.1295$, found 325.1299 .

\section{Synthesis of 3-((4-(1-acetoxyethyl)phenyl)amino)-1,2,4-benzotriazine 1,4-dioxide}

(72): Compound 71 (43 mg, $0.13 \mathrm{mmol})$ was dissolved in Acetone (1.5 mL) cooled to 0 ${ }^{\circ} \mathrm{C}$. To this solution was added dimethyl dioxirane $(4 \mathrm{~mL})$ (prepared as in Murray and Singh $)^{56}$. The reaction was stirred in a cold room $\left(4{ }^{\circ} \mathrm{C}\right)$ overnight and solvent removed by rotary evaporation. The crude solid was purified by column chromatography on silica gel with $0.5 \% \mathrm{MeOH}$ in $\mathrm{CH}_{2} \mathrm{Cl}_{2}$ to give 72 in $6 \%$ yield: ${ }^{1} \mathrm{HNMR}\left(500 \mathrm{MHz}\right.$, DMSO- $\left.d_{6}\right) \delta$ 10.25 (bs, $1 \mathrm{H}$ ), 8.27-8.24 (comp, $2 \mathrm{H}$ ), 8.00 (appt, $J=7.5,7.4 \mathrm{~Hz}, 1 \mathrm{H}$ ), 7.67-7.62 (comp, $3 \mathrm{H}), 7.39$ (d, $J=8.4 \mathrm{~Hz}, 2 \mathrm{H}), 5.79(\mathrm{q}, J=6.5 \mathrm{~Hz}, 1 \mathrm{H}), 2.05(\mathrm{~s}, 3 \mathrm{H}), 1.49(\mathrm{~d}, J$ $=6.6 \mathrm{~Hz}, 3 \mathrm{H}) ;{ }^{13} \mathrm{C}$ NMR $\left(125 \mathrm{MHz}, \mathrm{DMSO}-d_{6}\right) \delta 169.7,147.8,138.4,137.8,136.4$, $135.6,131.2,127.9,126.4,122.2,121.2,117.4,71.3,22.0,21.0 ; \mathrm{HRMS}(\mathrm{ESI}) \mathrm{m} / \mathrm{z}$ calculated for $\mathrm{C}_{17} \mathrm{H}_{16} \mathrm{~N}_{4} \mathrm{O}_{4}\left(\mathrm{M}+\mathrm{H}^{+}\right)$341.1245, found 341.1252.

Synthesis of 3-amino-6-chloro-1,2,4-benzotriazine 1-oxide (73): （adopted from Hay, M.P. et al. $)^{34}$ 5-chloro-2-nitroaniline $(5.6 \mathrm{~g}, 32 \mathrm{mmol})$ and cyanamide (15 g, 10 equiv) were heated together at $100{ }^{\circ} \mathrm{C}$ for 15 minutes until a melt is achieved. The mixture was cooled slightly and conc. $\mathrm{HCl}(20 \mathrm{~mL})$ was added dropwise while stirring over a 30 minute period. (CAUTION: A violent exothermic reaction may occur during or after $\mathrm{HCl}$ addition). After addition of acid was complete stirring was continued for an 
additional 10 minutes, adding more cyanamide to help stir if needed. The mixture was heated to $100^{\circ} \mathrm{C}$ for 3 hours and cooled to room temperature with continued stirring. $\mathrm{NaOH}(100 \mathrm{~mL}, 8 \mathrm{M})$ was added and the mixture stirred vigorously at $100^{\circ} \mathrm{C}$ for $2 \mathrm{~h}$. The orange suspension was cooled to room temperature, poured into $500 \mathrm{~mL} \mathrm{H}_{2} \mathrm{O}$, and filtered. The resulting precipitant was washed thoroughly with $\mathrm{H}_{2} \mathrm{O}$ and $\mathrm{Et}_{2} \mathrm{O}$ and dried in the oven overnight. Compound 73 was obtained as a bright yellow powder in $45 \%$ yield: ${ }^{1} \mathrm{H}$ NMR $\left(500 \mathrm{MHz}, \mathrm{DMSO}-d_{6}\right) \delta 8.13(\mathrm{~d}, J=9.4 \mathrm{~Hz}, 1 \mathrm{H}), 7.60(\mathrm{~d}, J=2.1 \mathrm{~Hz}, 1$ H), $7.53(\mathrm{bs}, 2 \mathrm{H}), 7.33(\mathrm{dd}, J=9.1,2.1 \mathrm{~Hz}, 1 \mathrm{H}) ;{ }^{13} \mathrm{C}$ NMR $\left(125 \mathrm{MHz}, \mathrm{DMSO}-d_{6}\right) \delta$ 160.8, 149.5, 140.4, 128.9, 124.8, 124.5, 122.1; HRMS (ESI) $\mathrm{m} / \mathrm{z}$ calculated for $\mathrm{C}_{7} \mathrm{H}_{5} \mathrm{ClN}_{4} \mathrm{O}\left(\mathrm{M}+\mathrm{H}^{+}\right)$197.0225, found 197.0228.

Synthesis of 6-chloro-1,2,4-benzotriazine 1-oxide (74): Using the general procedure of Boyd et al. ${ }^{29} 73$ (1.07 g, $\left.5 \mathrm{mmol}\right)$ was dissolved in anhydrous DMF (50 mL) and the mixture degassed by bubbling argon through the solution for $30 \mathrm{~min}$. To this mixture $t$ butyl nitrite $(3.5 \mathrm{~mL}, 5$ equiv, $90 \%$ ) was added by syringe and the mixture heated in a 60 ${ }^{\circ} \mathrm{C}$ oil bath for $2 \mathrm{~h}$ under an atmosphere of argon gas. The reaction was cooled and the solvent removed under vacuum. The resulting dark residue was taken up in ethyl acetate $(300 \mathrm{~mL})$ and mixed with brine $(150 \mathrm{~mL})$ and stirred vigorously. The phases were allowed to separate and the organic layer was washed with brine $(2 \times 150 \mathrm{~mL})$, dried over anhydrous sodium sulfate, and solvent removed by rotary evaporation. Column chromatography on silica gel eluted with a gradient of $0-10 \%$ ethyl acetate in $\mathrm{CH}_{2} \mathrm{Cl}_{2}$ gave 74 in 50\% yield: $1 \mathrm{H}$ NMR $\left(500 \mathrm{MHz}, \mathrm{DMSO}-d_{6}\right) \delta 9.21(\mathrm{~s}, 1 \mathrm{H}), 8.41(\mathrm{~d}, J=9.2$ $\mathrm{Hz}, 1 \mathrm{H}), 8.27(\mathrm{~d}, J=2.2 \mathrm{~Hz}, 1 \mathrm{H}), 7.92(\mathrm{dd}, J=9.2,2.2 \mathrm{~Hz}, 2 \mathrm{H}) ;{ }^{13} \mathrm{C}$ NMR $(125 \mathrm{MHz}$, 
DMSO- $\left.d_{6}\right) \delta 155.2,147.7,140.9,134.2,131.9,127.7,122.0 ;$ HRMS (ESI) m/z calculated for $\mathrm{C}_{7} \mathrm{H}_{4} \mathrm{ClN}_{3} \mathrm{O}_{1}$ 181.0043, found 181.0043

Synthesis of 6-((4-(1-hydroxyethyl)phenyl)amino)-1,2,4-benzotriazine 1-oxide (75): A seal tube was charged with compound 74 (379 $\mathrm{mg}, 2.1 \mathrm{mmol})$, 4-1`hydroxyethylaniline (340 mg, 1.2 equiv), $\mathrm{K}_{3} \mathrm{PO}_{4}$ (1.75 g, 4 equiv), $\mathrm{Pd}(\mathrm{OAc})_{2}(23 \mathrm{mg}$, 5\%), SPhos (85 mg, 10\%), Toluene (28 mL), and tetrahydrofuran (4.5 mL). The mixture was degassed by bubbling $\mathrm{N}_{2}$ through the suspension for $30 \mathrm{~min}$ then sealed. The reaction was stirred at $100{ }^{\circ} \mathrm{C}$ for $14 \mathrm{~h}$ (overnight) resulting in a bright orange precipitate. The reaction was cooled to room temperature and diluted with ethyl acetate $(300 \mathrm{~mL})$ before being filtered through celite. The celite was washed with a minimal amount of ethyl acetate and filtrate collected. The solvent was removed by rotary evaporation and Purification was done by column chromatography on silica gel with $1-2 \% \mathrm{MeOH}$ in $\mathrm{CH}_{2} \mathrm{Cl}_{2}$ to afford 75 in $85 \%$ yield: ${ }^{1} \mathrm{H}$ NMR $\left(500 \mathrm{MHz}, \mathrm{DMSO}-d_{6}\right) \delta 9.50(\mathrm{~s}, 1 \mathrm{H}), 8.83$ $(\mathrm{s}, 1 \mathrm{H}), 8.21(\mathrm{~d}, J=9.5 \mathrm{~Hz}, 1 \mathrm{H}), 7.45(\mathrm{dd}, J=9.5,2.5 \mathrm{~Hz}, 1 \mathrm{H}), 7.41(\mathrm{~d}, J=8.3 \mathrm{~Hz}, 2$ H), $7.28(\mathrm{~d}, J=8.4 \mathrm{~Hz}, 2 \mathrm{H}), 7.11(\mathrm{~d}, J=2.4 \mathrm{~Hz}, 1 \mathrm{H}), 5.16(\mathrm{~d}, J=4.3 \mathrm{~Hz}, 1 \mathrm{H}), 4.73$

$(\mathrm{dq}, J=6.4,6.3 \mathrm{~Hz}, 1 \mathrm{H}), 1.35(\mathrm{~d}, J=6.5 \mathrm{~Hz}, 3 \mathrm{H}) ;{ }^{13} \mathrm{C}$ NMR $\left(125 \mathrm{MHz}, \mathrm{DMSO}-d_{6}\right) \delta$ $155.0,151.8,150.2,144.0,138.2,128.7,127.0,123.7,121.8,121.7,103.1,68.1,26.2$ HRMS (ESI) m/z calculated for $\mathrm{C}_{15} \mathrm{H}_{14} \mathrm{~N}_{4} \mathrm{O}_{2}\left(\mathrm{M}+\mathrm{H}^{+}\right)$283.1119, found 283.1187 .

\section{Synthesis of 6-((4-(1-acetoxyethyl)phenyl)amino)-1,2,4-benzotriazine 1-oxide (76):}

Compound 75 (435 mg, $1.5 \mathrm{mmol})$ was dissolved in tetrahydrofuran (8 mL) and acetic acid $(8 \mathrm{~mL})$. Sodium acetate $(13 \mathrm{mg}, 10 \%$ equiv) was added and then the mixture was 
stirred under $\mathrm{N}_{2}$ atmosphere at $60{ }^{\circ} \mathrm{C}$ for $6 \mathrm{~h}$. The reaction was cooled to room temperature and diluted with $\mathrm{CH}_{2} \mathrm{Cl}_{2}(300 \mathrm{~mL})$. After the organic layer was washed with saturated sodium bicarbonate and then brine, the solution was dried over $\mathrm{Na}_{2} \mathrm{SO}_{4}$ and concentrated by rotary evaporation. Refrigeration overnight precipitated the product that was collected by vacuum filtration, washed with a minimal amount of diethyl ether, and dried under vacuum. Compound $\mathbf{7 6}$ was collected as an orange solid in $70 \%$ yield. If further purification is needed, it was done using column chromatography on silica gel with $20 \%$ ethyl acetate in $\mathrm{CH}_{2} \mathrm{Cl}_{2}:{ }^{1} \mathrm{H}$ NMR (500 MHz, DMSO- $\left.d_{6}\right) \delta 9.57(\mathrm{~s}, 1 \mathrm{H}), 8.85$ $(\mathrm{s}, 1 \mathrm{H}), 8.22(\mathrm{~d}, J=9.5 \mathrm{~Hz}, 1 \mathrm{H}), 7.47(\mathrm{dd}, J=9.5,2.4 \mathrm{~Hz}, 2 \mathrm{H}), 7.43(\mathrm{~d}, J=8.4 \mathrm{~Hz}, 1$ H), $7.32(\mathrm{~d}, J=8.5 \mathrm{~Hz}, 2 \mathrm{H}), 7.18(\mathrm{~d}, J=2.4 \mathrm{~Hz}, 1 \mathrm{H}), 5.81$ (q, $J=6.6 \mathrm{~Hz}, 1 \mathrm{H}), 2.05$ (s, $3 \mathrm{H}), 1.49(\mathrm{~d}, J=6.6 \mathrm{~Hz}, 3 \mathrm{H}) ;{ }^{13} \mathrm{C}$ NMR $\left(125 \mathrm{MHz}, \mathrm{DMSO}-d_{6}\right) \delta 169.7,154.7,150.9$, $149.7,139.1,137.3,128.5,127.4,123.4,121.5,121.1,103.3,71.3,21.9,21.0$; HRMS (ESI) $\mathrm{m} / \mathrm{z}$ calculated for $\mathrm{C}_{17} \mathrm{H}_{16} \mathrm{~N}_{4} \mathrm{O}_{3}\left(\mathrm{M}+\mathrm{H}^{+}\right)$325.1295, found 325.1299.

\section{Synthesis of 6-((4-(1-acetoxyethyl)phenyl)amino)-1,2,4-benzotriazine 1,4-dioxide} (77): Compound 76 (17 mg, $0.05 \mathrm{mmol})$ was dissolved in $\mathrm{CH}_{2} \mathrm{Cl}_{2}(3 \mathrm{~mL})$ and cooled to 0 ${ }^{\circ} \mathrm{C}$. To this mixture, a cold solution of MCPBA (17mg, 1.5 equiv) in $\mathrm{CH}_{2} \mathrm{Cl}_{2}$ was added and the resulting mixture was stirred at room temperature for $3 \mathrm{~d}$. The reaction was diluted with $\mathrm{CH}_{2} \mathrm{Cl}_{2}(30 \mathrm{~mL})$ and washed with cold $\mathrm{NH}_{4} \mathrm{OH}(3 \times 20 \mathrm{~mL})$ followed by brine. After drying with $\mathrm{Na}_{2} \mathrm{SO}_{4}$, purification was done using column chromotography on silica gel with $1-2 \% \mathrm{MeOH}$ in $\mathrm{CH}_{2} \mathrm{Cl}_{2}$ to yield 77 in $6 \%$ yield with $23 \%$ recovery of starting material (76): ${ }^{1} \mathrm{H}$ NMR (500 MHz, DMSO-d $) \delta 9.82(\mathrm{~s}, 1 \mathrm{H}), 9.09$ (s, $\left.1 \mathrm{H}\right), 8.19$ $(\mathrm{d}, J=9.5 \mathrm{~Hz}, 1 \mathrm{H}), 7.52(\mathrm{dd}, J=9.4,2.5 \mathrm{~Hz}, 1 \mathrm{H}), 7.49$ (d, $J=2.4 \mathrm{~Hz}, 1 \mathrm{H}), 7.47$ (d, $J=$ 
$8.4 \mathrm{~Hz}, 2 \mathrm{H}), 7.32$ (d, $J=8.4 \mathrm{~Hz}, 2 \mathrm{H}), 5.82$ (q, $J=6.6 \mathrm{~Hz}, 1 \mathrm{H}), 2.06$ (s, $3 \mathrm{H}), 1.50$ (d, $J$ $=6.6 \mathrm{~Hz}, 3 \mathrm{H}) ;{ }^{13} \mathrm{C}$ NMR $\left(125 \mathrm{MHz}, \mathrm{DMSO}-d_{6}\right) \delta 169.7,150.9,142.3,141.4,138.7$, $138.0,128.4,127.5,123.7,123.2,121.5,94.3,71.2,21.9,21.0 ;$ HRMS (ESI) m/z calculated for $\mathrm{C}_{17} \mathrm{H}_{16} \mathrm{~N}_{4} \mathrm{O}_{3}\left(\mathrm{M}+\mathrm{Na}^{+}\right)$363.1069, found 363.1072 .

\section{Synthesis of 3-amino-6-morpholino-1,2,4-benzotriazine 1-oxide (79): Compound 19} (503 mg, $2.8 \mathrm{mmol})$ and morpholine (0.72 mL, 3 equiv) were suspended in 1-methyl-2pyrrolidinone $(4 \mathrm{~mL})$ and heated to $100{ }^{\circ} \mathrm{C}$ overnight. The resulting orange suspension was cooled to room temperature and diluted with water $(40 \mathrm{~mL})$ and filtered. The precipitate was washed with water and diethyl ether and then dried in an oven overnight at $70{ }^{\circ} \mathrm{C}$. The orange-yellow powder was collected by vacuum filtration in $94 \%$ yield:

mp 245-250 ${ }^{\circ} \mathrm{C} \mathrm{dec} ;{ }^{1} \mathrm{H}$ NMR (500 MHz, DMSO- $\left.d_{6}\right) \delta 7.94(\mathrm{~d}, J=9.6 \mathrm{~Hz}, 1 \mathrm{H}), 7.16$ (dd, $J=9.7,2.5 \mathrm{~Hz}, 2 \mathrm{H}), 7.00$ (bs, $2 \mathrm{H}), 6.60(\mathrm{~d}, J=2.5,1 \mathrm{H}), 3.73(\mathrm{t}, J=4.7 \mathrm{~Hz}, 4 \mathrm{H})$, $3.38(\mathrm{t}, J=4.8 \mathrm{~Hz}, 4 \mathrm{H}) ;{ }^{13} \mathrm{C}$ NMR $\left(125 \mathrm{MHz}, \mathrm{DMSO}-d_{6}\right) \delta 160.7,155.3,150.8,123.3$, 120.9, 115.2, 103.0, 65.8, 46.8; HRMS (ESI) $\mathrm{m} / \mathrm{z}$ calculated for $\mathrm{C}_{11} \mathrm{H}_{15} \mathrm{~N}_{5} \mathrm{O}_{3}\left(\mathrm{M}+\mathrm{H}^{+}\right)$ 248.1142 , found 248.1142

Synthesis of 3-amino-6-carboxy-1,2,4-benzotriazine 1-oxide (80): Compound 80 was prepared using a modified method of Suzuki and Kawakami. ${ }^{38} \mathrm{NaOH}(528 \mathrm{mg}, 10$ equiv) was dissolved in hot ethanol $(30 \mathrm{~mL})$, guanidine hydrochloride (1.2 g, 10 equiv) added, and the resulting mixture stirred for $20 \mathrm{~min}$. The reaction was cooled to room temperature and filtered to remove the white precipitate. To the filtrate THF $(20 \mathrm{~mL})$ and 3-fluoro-4-nitrobenzoic acid (230 mg, $1.2 \mathrm{mmol}$ ) were added and the resulting 
heterogeneous mixture refluxed for $4 \mathrm{~h}$. Potassium tert-butoxide (150 mg, 10 equiv) were added and the mixture stirred at reflux for an additional $2 \mathrm{~h}$. After the reaction was complete, the THF was decanted off and water $(60 \mathrm{~mL})$ added with vigorous stirring. Acidification with $\mathrm{HCl}(1 \mathrm{M})$ resulted in precipitation of a yellow solid that was collected by vacuum filtration and washed with dilute $\mathrm{HCl}$, followed by minimal amounts of water and diethyl ether. The solid was then dried in an oven overnight at $70{ }^{\circ} \mathrm{C}$ to give $\mathbf{8 0}$ in 95\% yield: $\mathrm{mp}>280{ }^{\circ} \mathrm{C} ;{ }^{1} \mathrm{H}$ NMR $\left(500 \mathrm{MHz}\right.$, DMSO- $\left.d_{6}\right) \delta 13.63$ (bs, $\left.1 \mathrm{H}\right), 8.20(\mathrm{~d}, J=$ $8.9 \mathrm{~Hz}, 1 \mathrm{H}), 7.98(\mathrm{~d}, J=1.5 \mathrm{~Hz}, 1 \mathrm{H}), 7.74(\mathrm{dd}, J=2 \mathrm{~Hz}, 1.6 \mathrm{~Hz}, 1 \mathrm{H}), 7.52(\mathrm{~s}, 1 \mathrm{H}) ;{ }^{13} \mathrm{C}$ NMR (125 MHz, DMSO- $\left.d_{6}\right) \delta 166.1,160.6,148.6,137.1,131.7,127.4,123.6,120.7$; HRMS (ESI) m/z calculated for $\mathrm{C}_{8} \mathrm{H}_{6} \mathrm{~N}_{4} \mathrm{O}_{3}\left(\mathrm{M}+\mathrm{H}^{+}\right)$207.0513, found 207.0519.

Synthesis of 3-amino-6-carboxy-1,2,4-benzotriazine 1,4-dioxide (81): Compound 80 (40 mg, $0.2 \mathrm{mmol}$ ) was suspended in trifluoroacetic acid $(1 \mathrm{~mL})$ and $\mathrm{H}_{2} \mathrm{O}_{2}(70 \%, 0.8 \mathrm{~mL})$ and the mixture was stirred at $50{ }^{\circ} \mathrm{C}$ for $48 \mathrm{~h}$. After the reaction was complete (as judged by thin layer chromatography), the solvent was removed by rotary evaporation under reduced pressure and the resulting residue triturated with ethanol $(5 \mathrm{~mL})$. The resulting suspension was chilled and the red precipitate collected by vacuum filtration. The solid was washed with cold ethanol and dried under vacuum to provide compound $\mathbf{8 0}$ in $36 \%$ isolated yield: $\mathrm{mp} 260^{\circ} \mathrm{C}$ dec; $1 \mathrm{H}$ NMR (500 MHz, DMSO- $\left.d_{6}\right) \delta 13.84(\mathrm{bs}, 1 \mathrm{H}), 8.61(\mathrm{~s}$, $1 \mathrm{H}), 8.28(\mathrm{~d}, J=8.8 \mathrm{~Hz}, 1 \mathrm{H}), 8.19(\mathrm{bs}, 2 \mathrm{H}), 7.94(\mathrm{~d}, J=8.7 \mathrm{~Hz}, 1 \mathrm{H}) ;{ }^{13} \mathrm{C}$ NMR $(125$ MHz, DMSO- $\left.d_{6}\right) \delta 165.6,151.8,138.3,136.3,132.1,125.8,122.2,118.8 ;$ HRMS (ESI) $\mathrm{m} / \mathrm{z}$ calculated for $\mathrm{C}_{8} \mathrm{H}_{6} \mathrm{~N}_{4} \mathrm{O}_{4}\left(\mathrm{M}+\mathrm{H}^{+}\right)$223.0462, found 223.0467. 
Synthesis of 3-amino-6-hydroxy-1,2,4-benzotriazine 1-oxide (82): Using a procedure adapted from Cantrell et l. $^{41}$ compound 19 (504 mg, $\left.2.8 \mathrm{mmol}\right)$ was suspended in 1methyl-2-pyrrolidinone $(4 \mathrm{~mL})$ and an aqueous solution of $\mathrm{NaOH}(400 \mathrm{mg}$ in $20 \mathrm{~mL}, 4$ eq) was added. To this mixture, a solution of $\mathrm{H}_{2} \mathrm{O}_{2}(30 \%, 480 \mu \mathrm{L}, 2$ equiv) was added and the mixture stirred for $4 \mathrm{~h}$ at $60{ }^{\circ} \mathrm{C}$. The reaction was cooled to room temperature and filtered to remove undissolved starting material. $\mathrm{Na}_{2} \mathrm{~S}_{2} \mathrm{O}_{3}(700 \mathrm{mg})$ was added to decompose any remaining $\mathrm{H}_{2} \mathrm{O}_{2}$. The resulting solution was acidified with $\mathrm{HCl}(1 \mathrm{M})$, and the resulting precipitate collected by vacuum filtration. The solid was then washed with water and diethyl ether and dried in an oven overnight at $70{ }^{\circ} \mathrm{C}$ to give 82 in $50 \%$ yield: $\mathrm{mp} 210{ }^{\circ} \mathrm{C} \mathrm{dec} ;{ }^{1} \mathrm{H}$ NMR (500 MHz, DMSO- $\left.d_{6}\right) \delta 10.94(\mathrm{bs}, 1 \mathrm{H}), 8.00(\mathrm{~d}, J=9.3$ Hz, $1 \mathrm{H}), 7.13(\mathrm{bs}, 2 \mathrm{H}), 6.84(\mathrm{dd}, J=9.3 \mathrm{~Hz}, 1.9 \mathrm{~Hz}, 1 \mathrm{H})$, and $6.68(\mathrm{~d}, J=1.9 \mathrm{~Hz}, 1 \mathrm{H})$; ${ }^{13} \mathrm{C}$ NMR (125 MHz, DMSO- $\left.d_{6}\right) \delta 163.8,160.6,151.1,124.4,122.0,117.2,106.1$; HRMS (ESI) m/z calculated for $\mathrm{C}_{7} \mathrm{H}_{6} \mathrm{~N}_{4} \mathrm{O}_{2}\left(\mathrm{M}+\mathrm{H}^{+}\right)$179.0564, found 179.0566 .

\section{Synthesis of 3-amino-6-hydroxy-1,2,4-benzotriazine 1,4-dioxide (83): Compound 37} (160 mg, $0.83 \mathrm{mmol})$ was suspended in 1-methyl-2-pyrrolidinone (1.2 mL) and $\mathrm{NaOH}$ (120 mg, 4 equiv, in $6 \mathrm{~mL}$ of water) was added. To this mixture was added $\mathrm{H}_{2} \mathrm{O}_{2}(30 \%$, $144 \mu \mathrm{L}, 2$ equiv), followed by stirring for $1.5 \mathrm{~h}$ at $50{ }^{\circ} \mathrm{C}$. The reaction was cooled to room temperature and acidified with $\mathrm{HCl}(1 \mathrm{M})$. The resulting precipitate was collected by vacuum filtration and washed with water and diethyl ether. Drying under vacuum gave 83 as a dark red solid in 51\% yield: mp $202{ }^{\circ} \mathrm{C} \mathrm{dec} ;{ }^{1} \mathrm{H}$ NMR (500 MHz, DMSO- $\left.d_{6}\right)$ $\delta 11.51(\mathrm{bs}, 1 \mathrm{H}), 8.08(\mathrm{~d}, J=9.5 \mathrm{~Hz}, 1 \mathrm{H}), 7.92(\mathrm{bs}, 2 \mathrm{H}), 7.31(\mathrm{~d}, J=2.5 \mathrm{~Hz}, 1 \mathrm{H})$, and $7.04(\mathrm{dd}, J=9.5 \mathrm{~Hz}, 2.5 \mathrm{~Hz}, 1 \mathrm{H}) ;{ }^{13} \mathrm{C}$ NMR (125 MHz, DMSO- $\left.d_{6}\right) \delta 164.1,151.5$, 
140.1, 125.1, 123.7, 119.2, 98.0; HRMS (ESI) m/z calculated for $\mathrm{C}_{7} \mathrm{H}_{6} \mathrm{~N}_{4} \mathrm{O}_{3}\left(\mathrm{M}+\mathrm{H}^{+}\right)$

195.0513, found 195.0516.

\section{Crystal Structures}

\section{Crystal Structure 1}

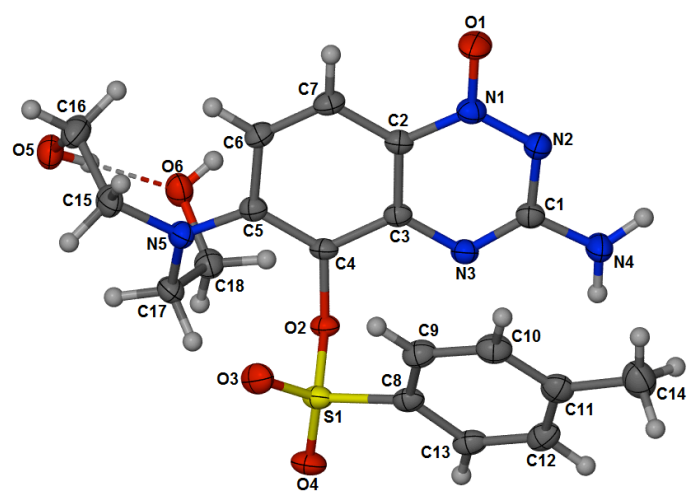

\section{Crystal Structure 2}
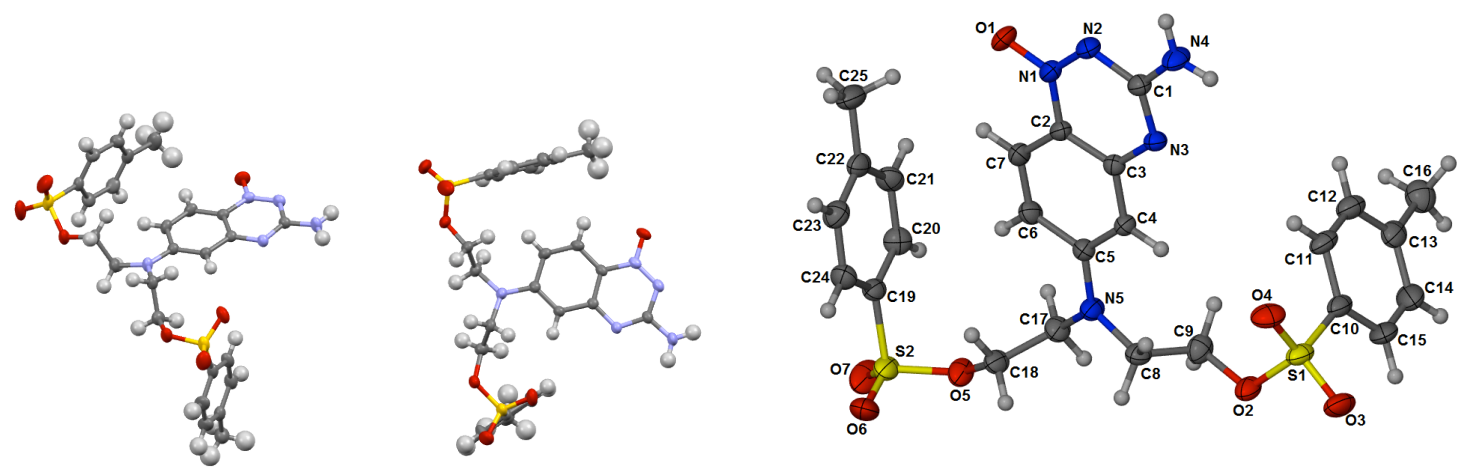

Crystal Structure 2. X-ray crystal structure of compound 54 (right). Different orientations (left) show possibility of intramolecular hydrophobic interactions between the tosylgroup and the benzoring. 
Crystallographic Data

Empirical formula

Formula weight

Temperature, $(\mathrm{K})$

W. length, $(\AA)$

Crystal system

Space group

a, $(\AA)$

$\mathrm{b},(\AA)$

$\mathrm{c},(\AA)$

$\alpha,(\operatorname{deg})$

$\beta,($ deg $)$

$\gamma,(\operatorname{deg})$

Volume, $\left(\AA^{3)}\right.$

$\mathrm{Z} /$ calculated density $\left(\mathrm{Mg} / \mathrm{m}^{3}\right)$

Absorption coefficient $\left(\mathrm{mm}^{-1}\right)$

Crystal size (mm)

Reflections collected/unique

Data/restraints/parameters

GOF

$\mathrm{R}$ indices (all data)
Crystal Structure 1

C18 H21 N5 O6 S
435.46
$173(2)$
0.71073

Monoclinic

P 21/c

$11.8137(17)$

$7.0470(10)$

24.199(4)

90

101.033

90

1977.4(5)

$4 / 1.463$

0.211

$0.50 \times 0.35 \times 0.10$

$22323 / 4574[\mathrm{R}(\mathrm{int})=$

$0.0261]$

4574 / 0 / 276

1.047

$\mathrm{R} 1=0.0413, \mathrm{wR} 2=$

0.0972
Crystal Structure 2

\author{
C25 H27 N5 O7 S2 \\ 573.64 \\ 173(2) \\ 0.71073
}

Monoclinic

P 21/c

$13.310(3)$

$8.7186(17)$

23.074(5)

90

105

90

2576.0(9)

$4 / 1.479$

0.263

$0.50 \times 0.25 \times 0.15$

$29329 / 5903[\mathrm{R}($ int $)=$ $0.0347]$

5903 / 0 / 354

1.040

$\mathrm{R} 1=0.0505, \mathrm{wR} 2=$ 0.1051 


\subsection{NMR Spectra for Compound Characterization} ${ }^{1}$ HNMR
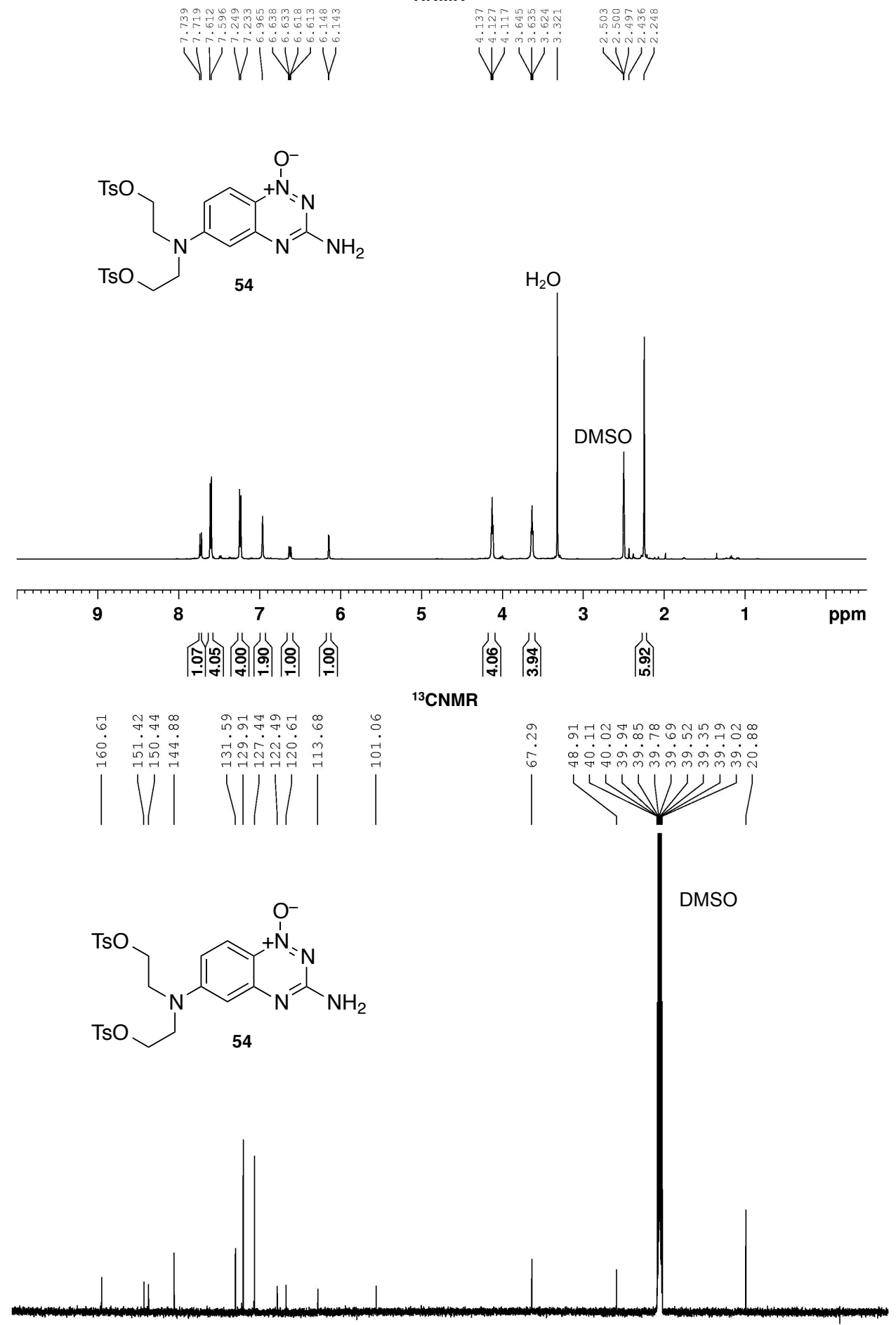

${ }^{13}$ CNMR
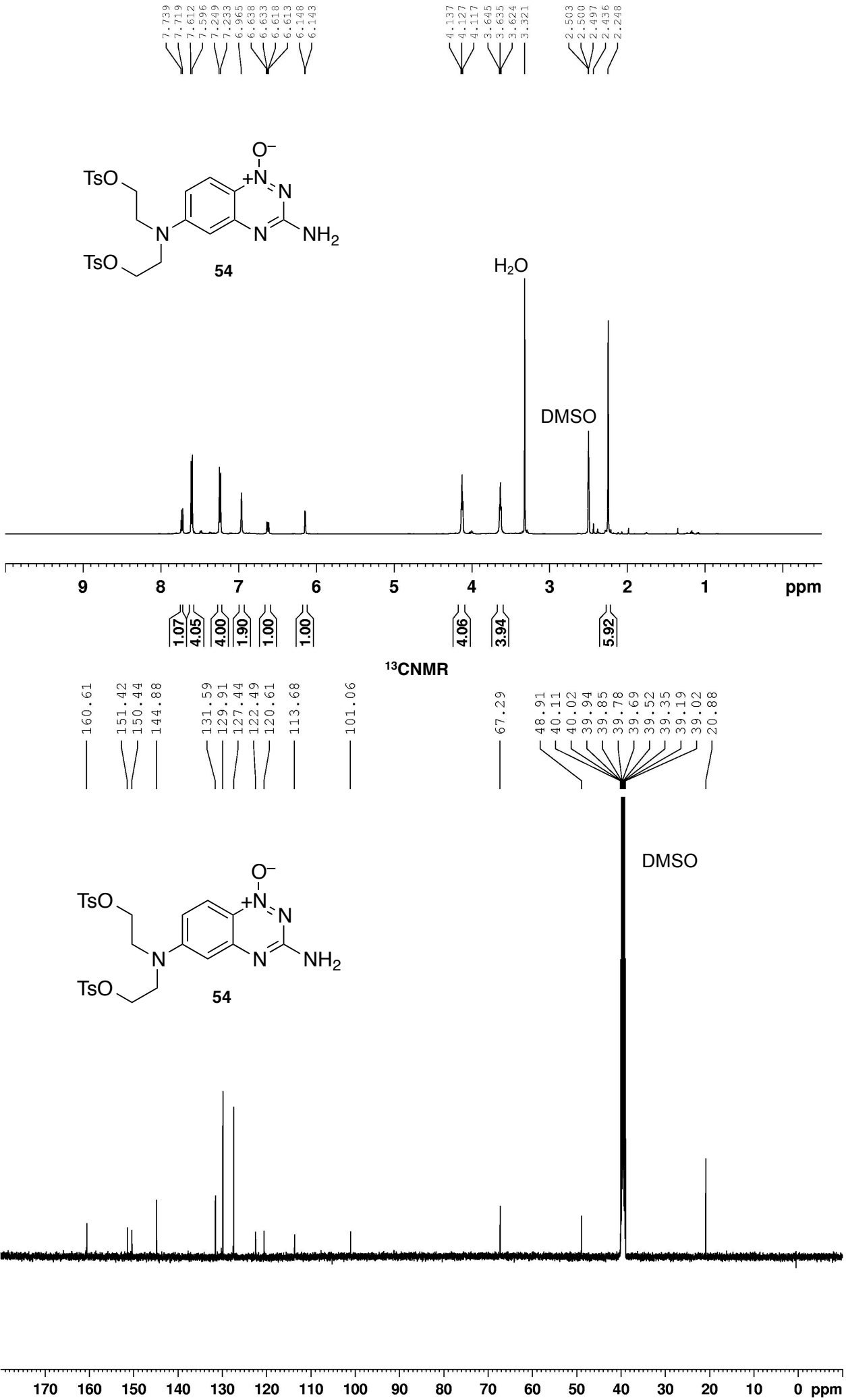
${ }^{1}$ HNMR
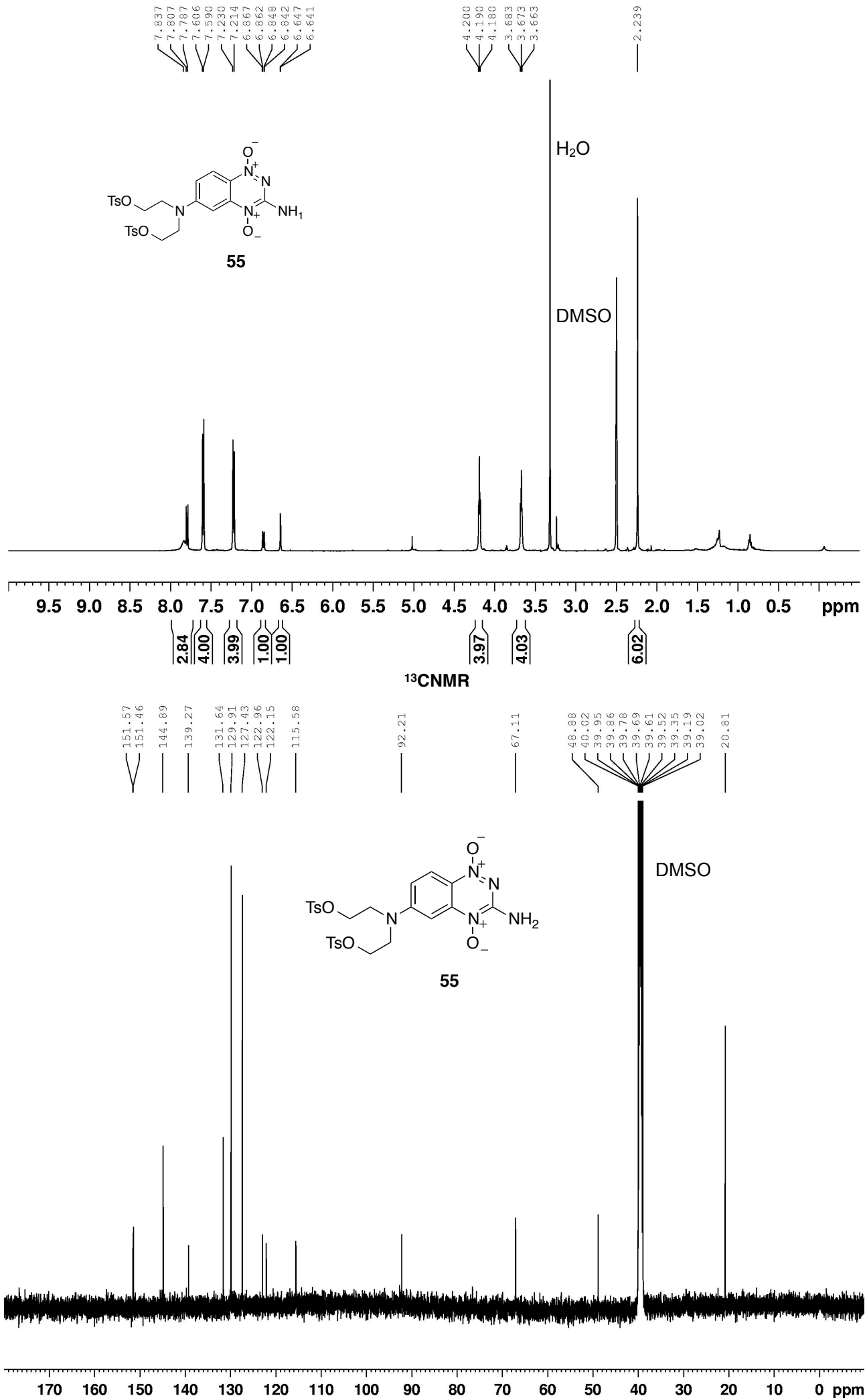
${ }^{1}$ HNMR
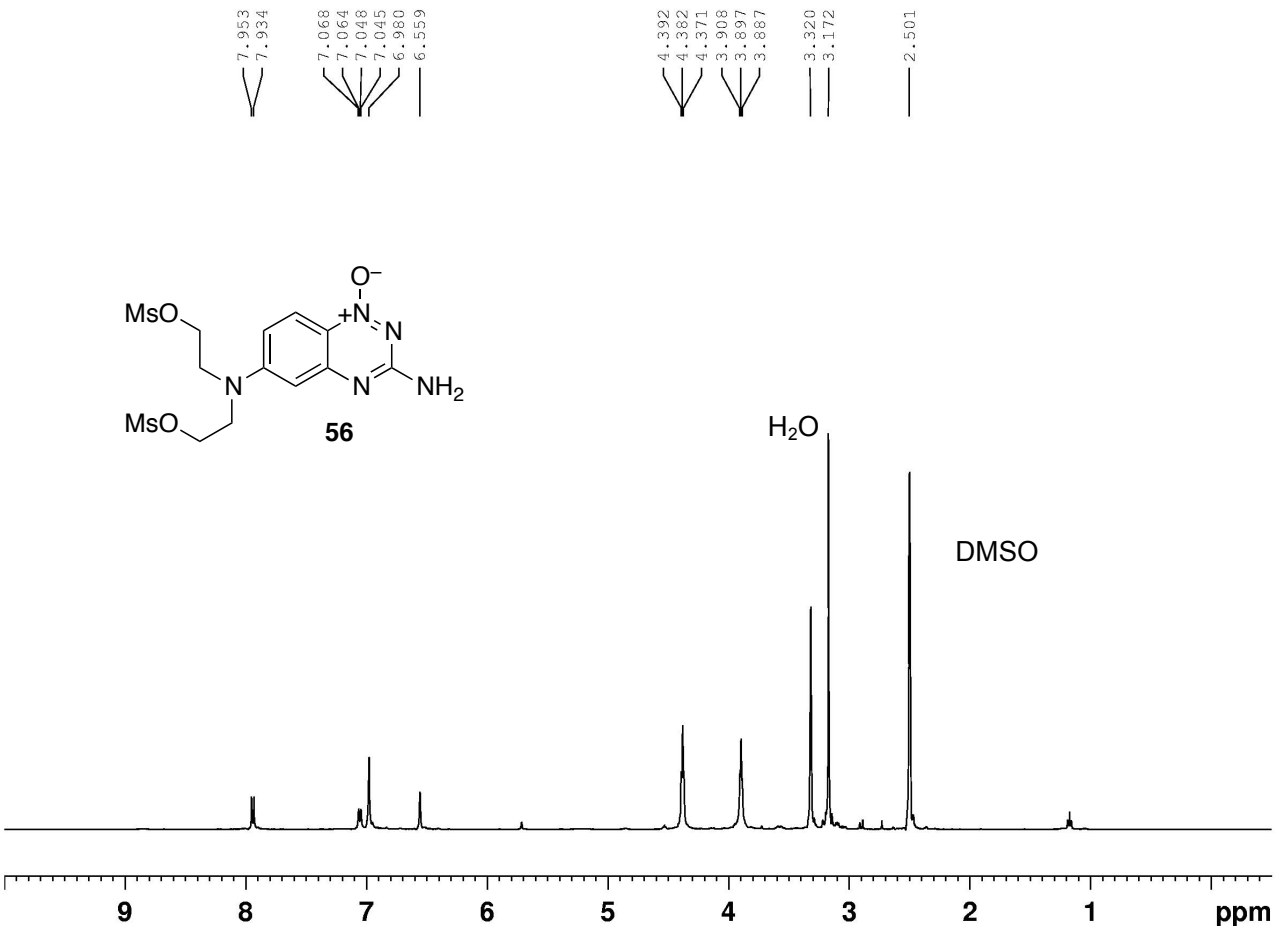

|용 |

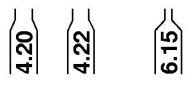

${ }^{13}$ CNMR

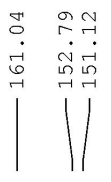
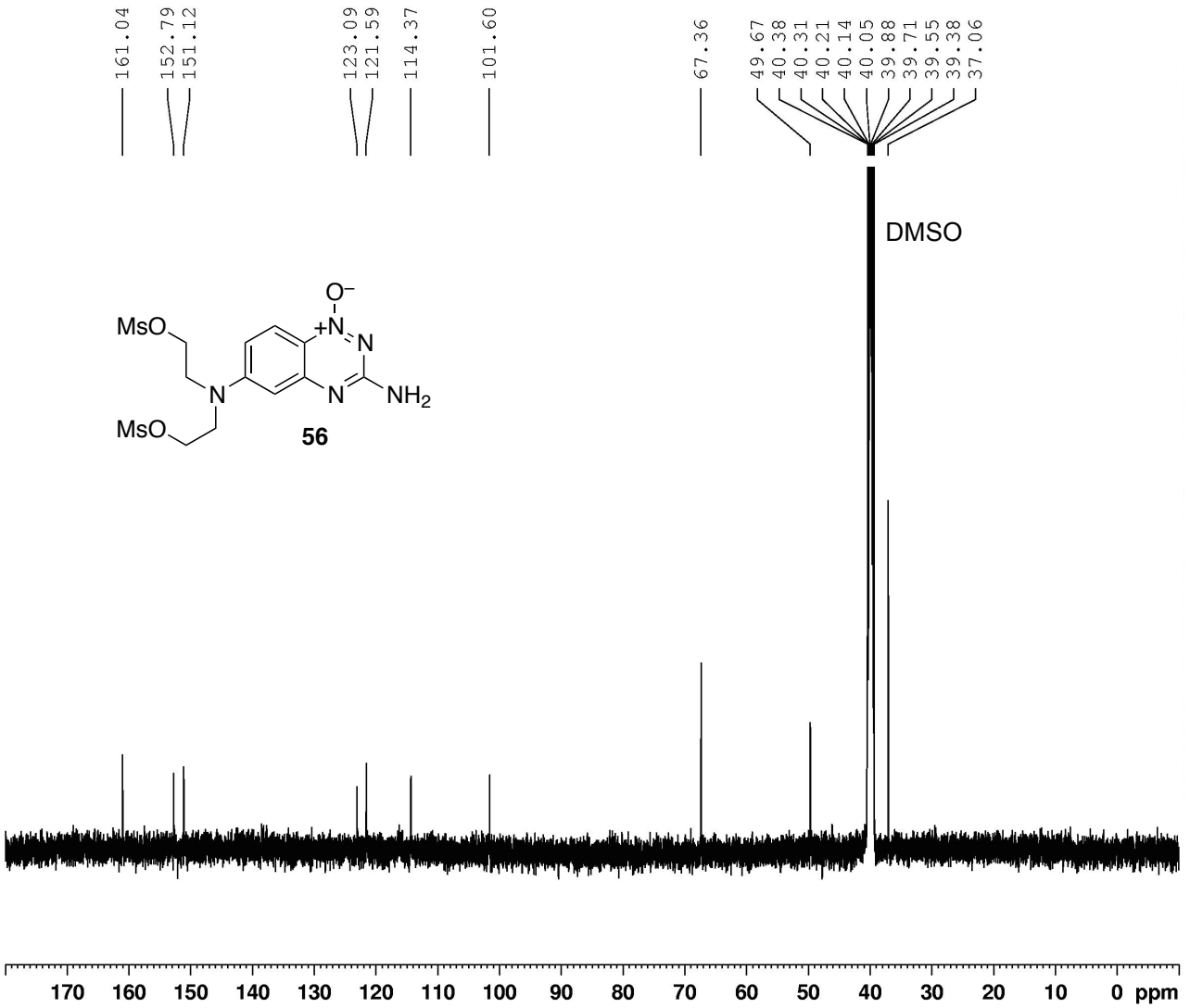


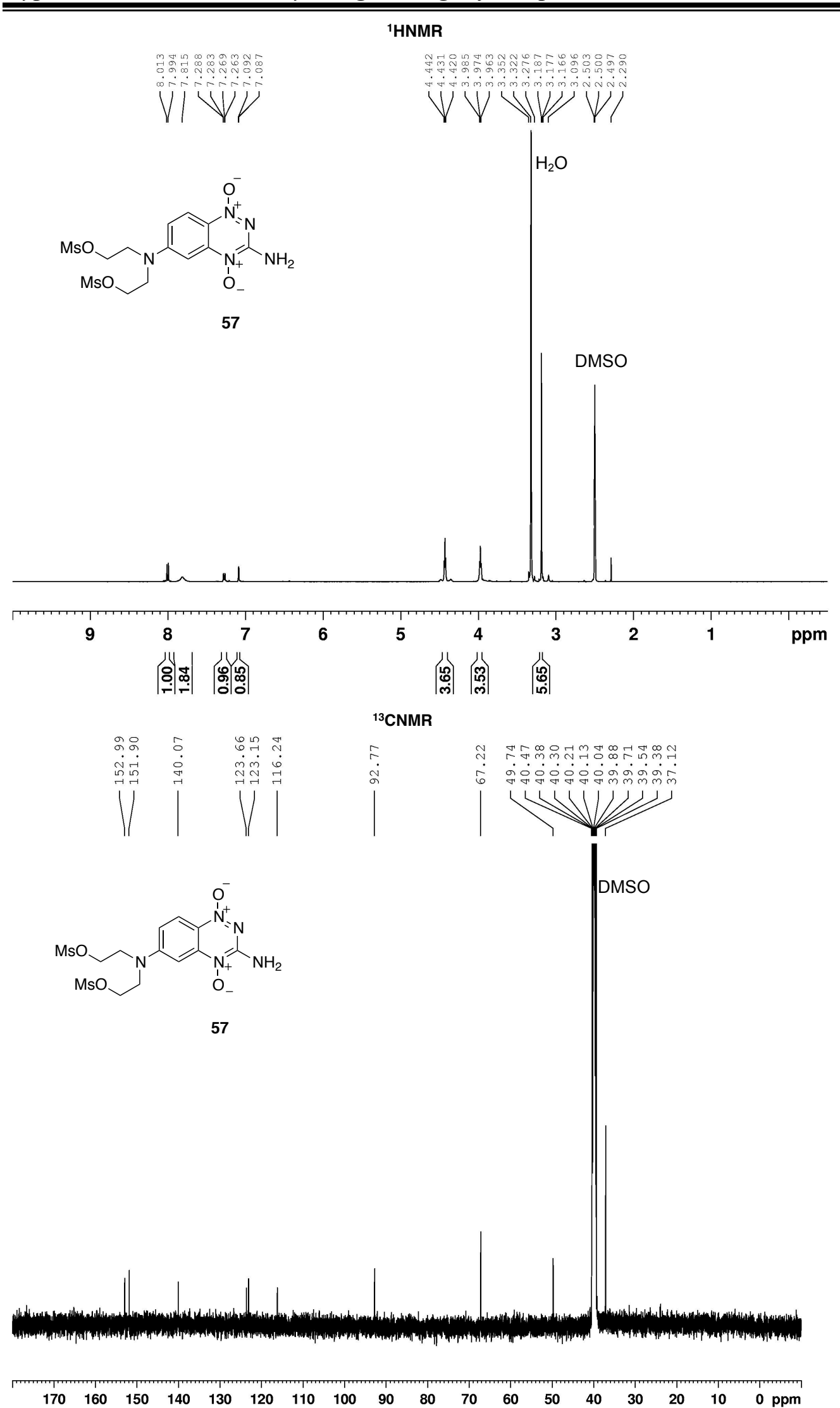



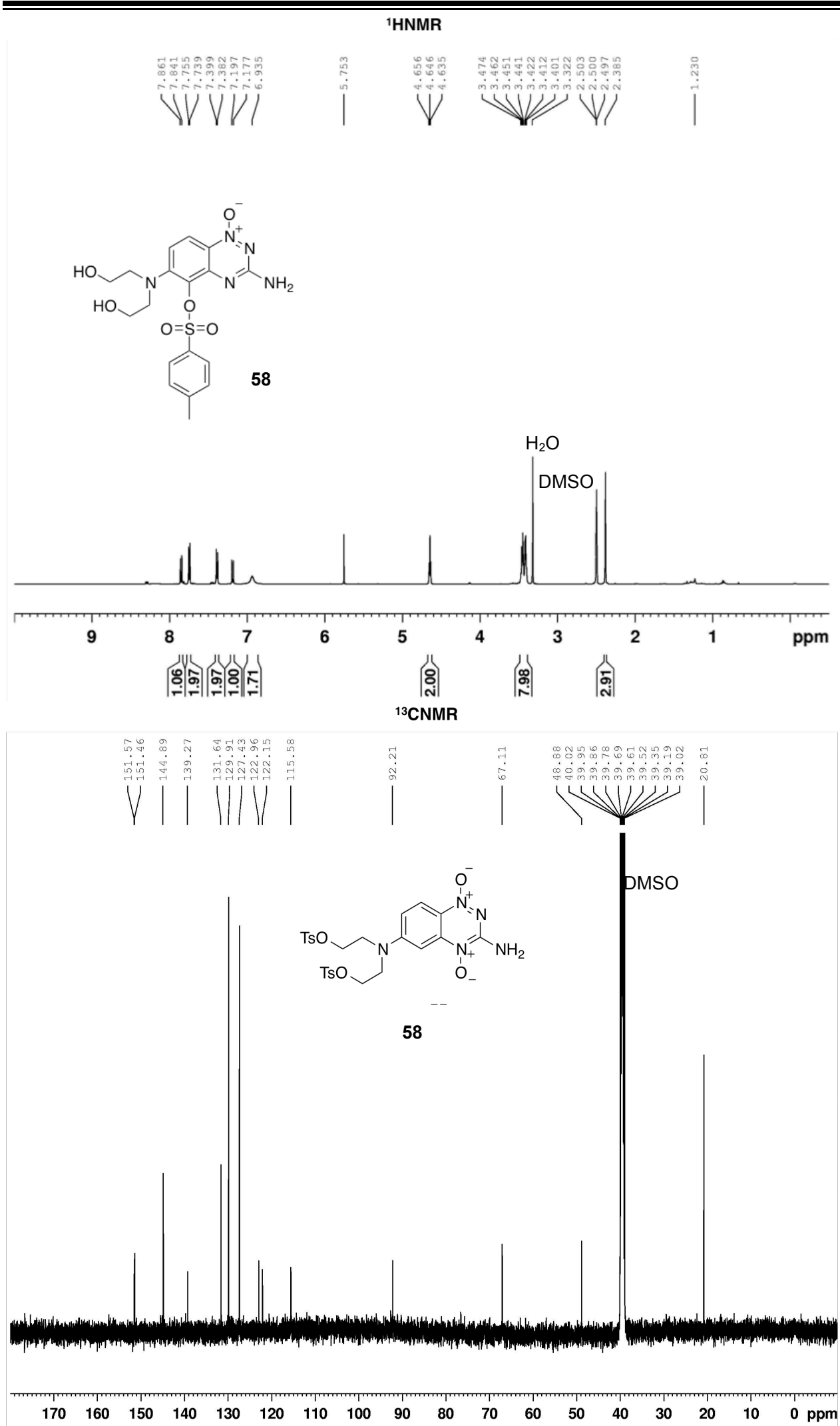


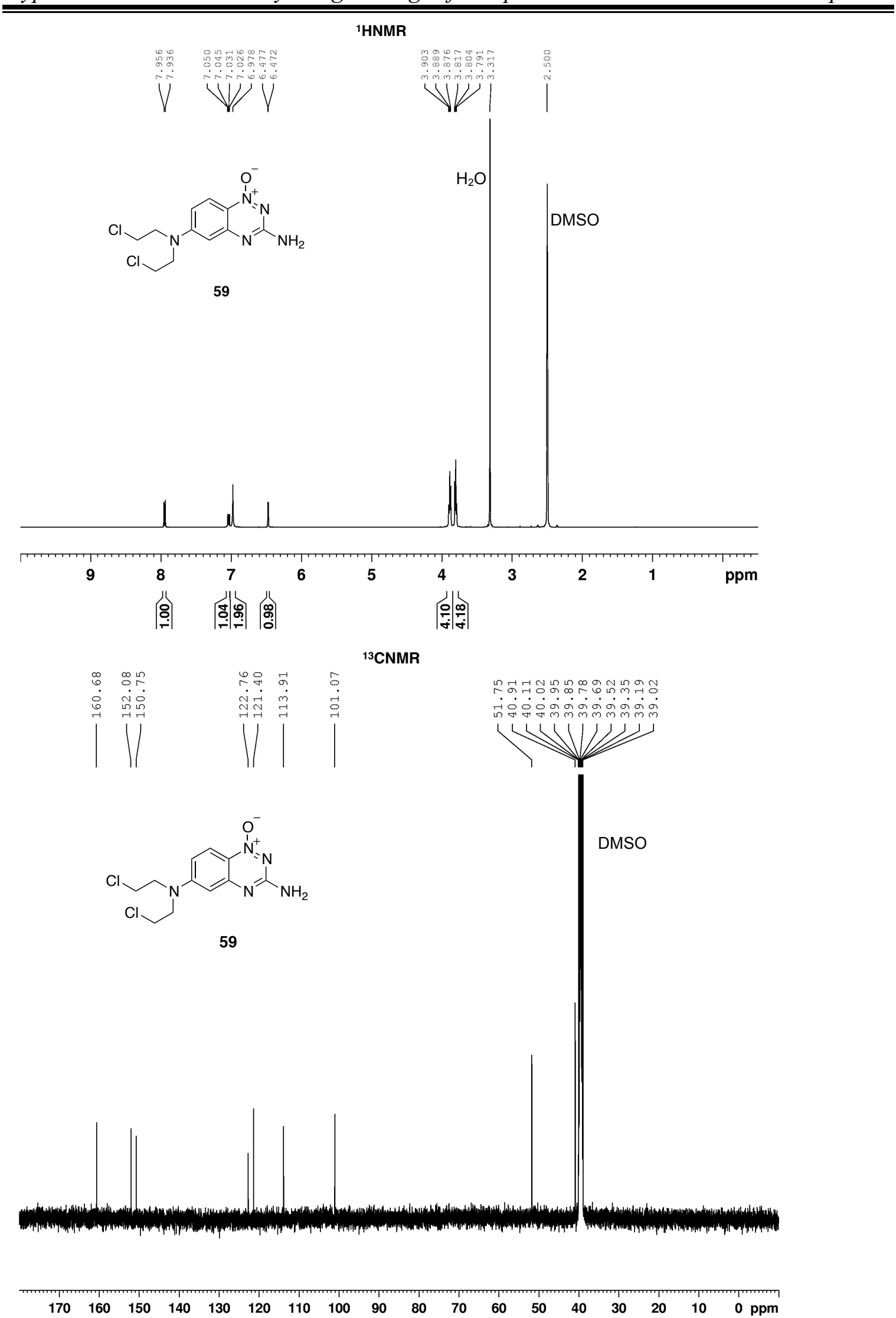


1HNMR
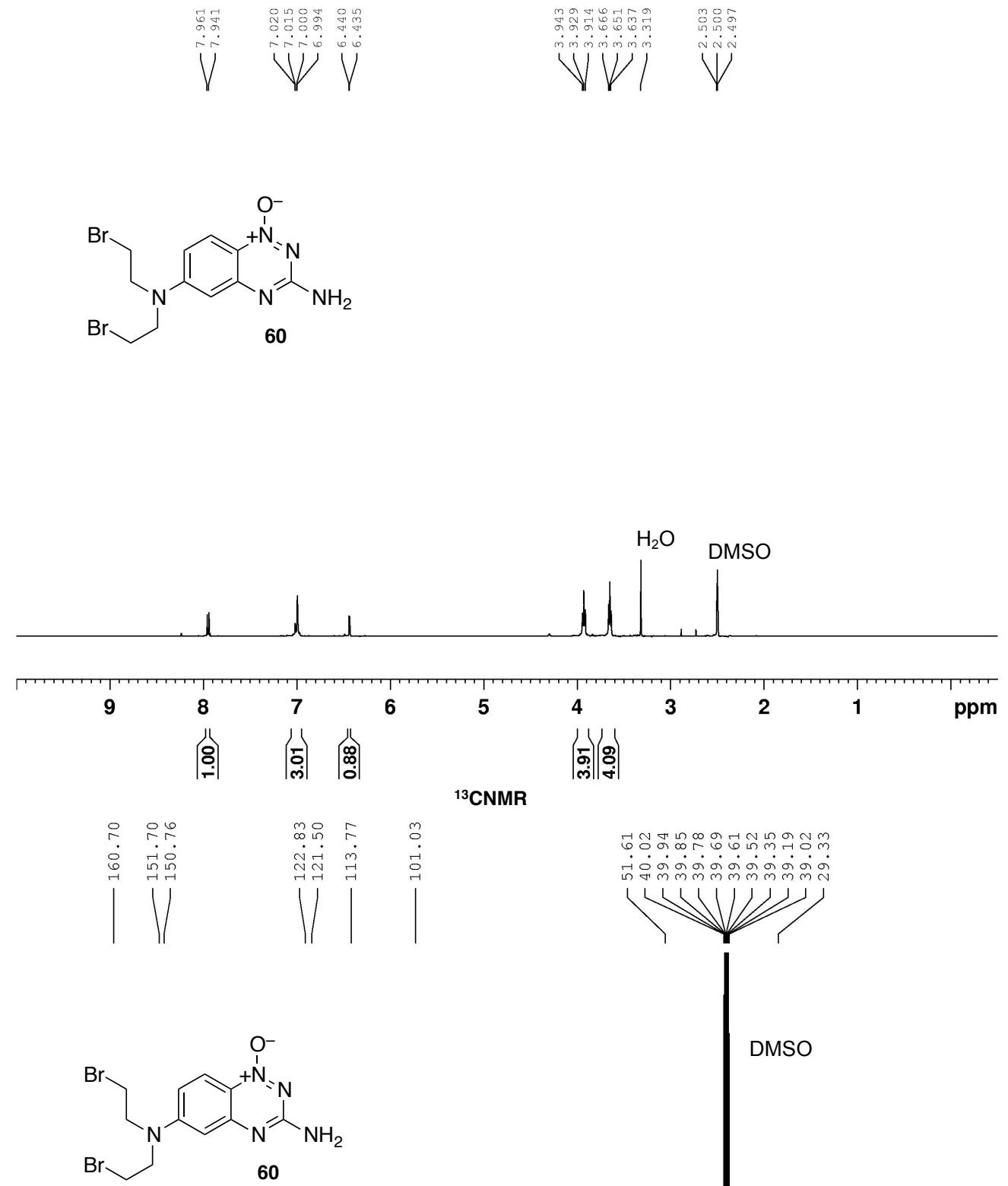

DMSO

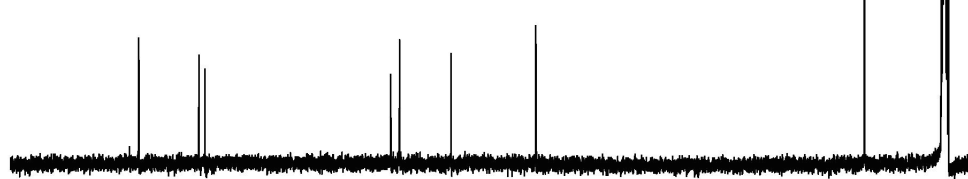

$\begin{array}{llllllllllllllllll}170 & 160 & 150 & 140 & 130 & 120 & 110 & 100 & 90 & 80 & 70 & 60 & 50 & 40 & 30 & 20 & 10 & 0\end{array}$ 
1HNMR
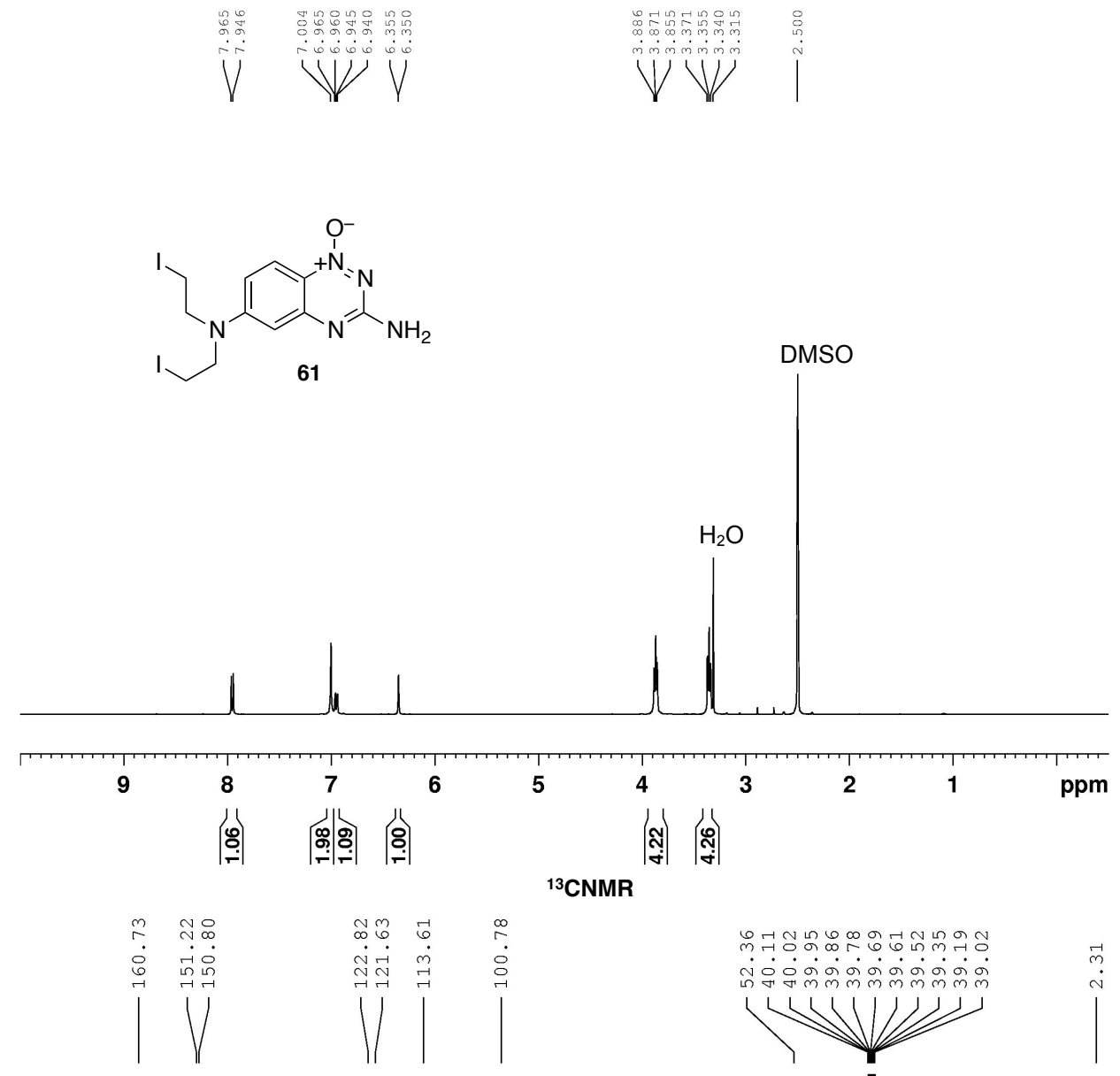

${ }^{13}$ CNMR

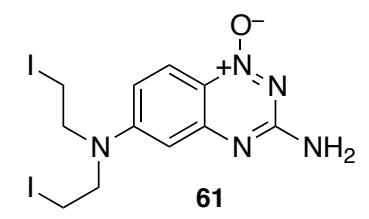

DMSO
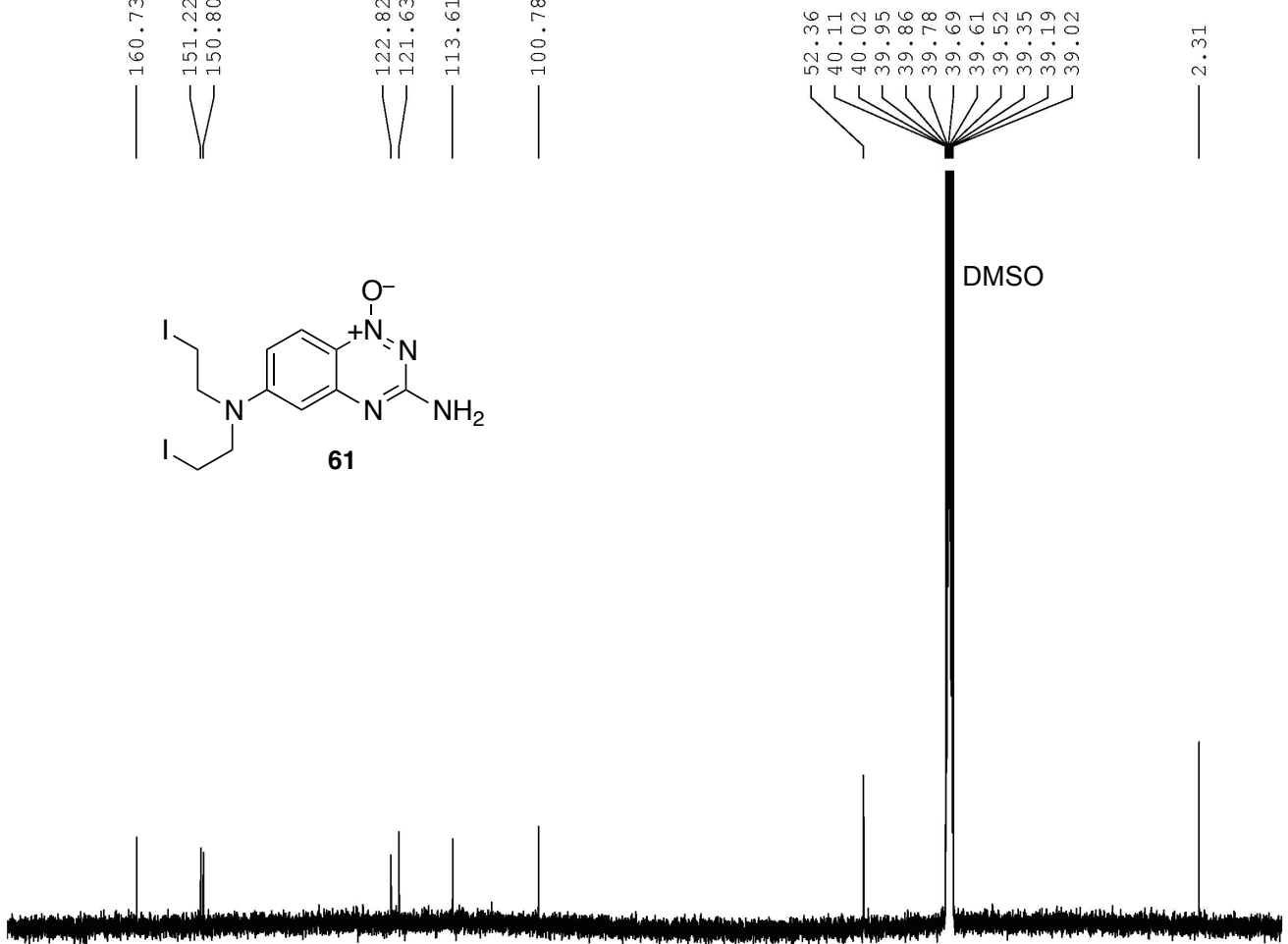

$\begin{array}{llllllllllllllllll}170 & 160 & 150 & 140 & 130 & 120 & 110 & 100 & 90 & 80 & 70 & 60 & 50 & 40 & 30 & 20 & 10 & 0\end{array}$ 
${ }^{1}$ HNMR
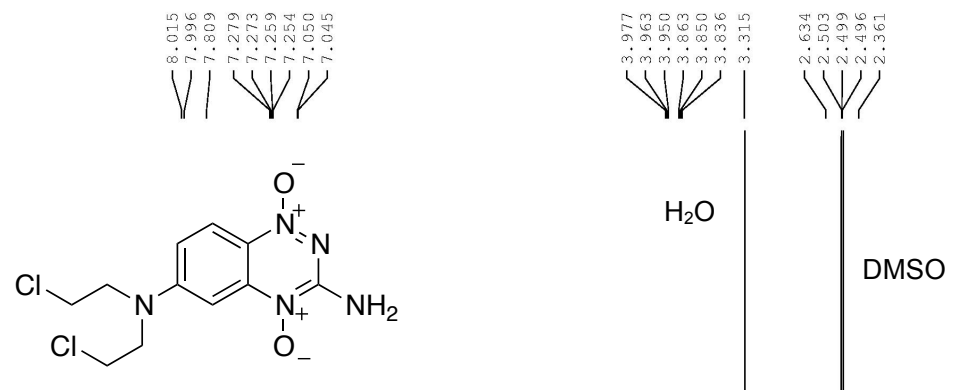

62

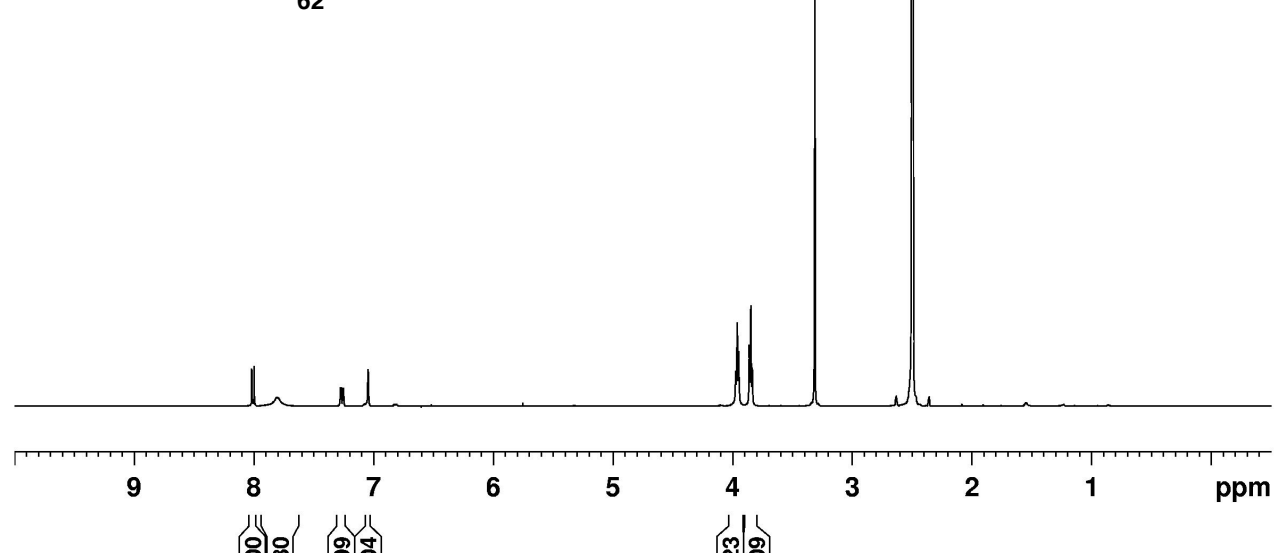

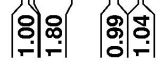

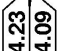

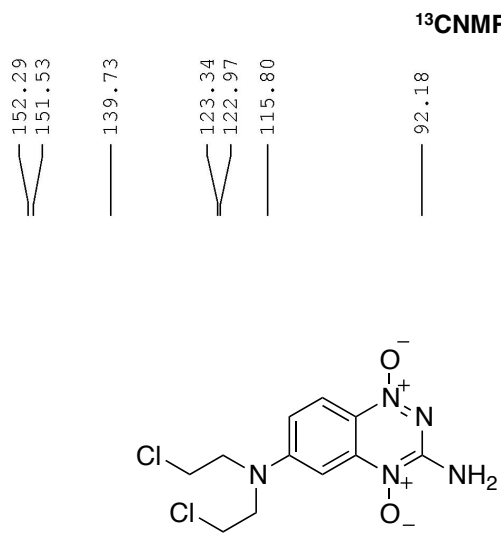

62

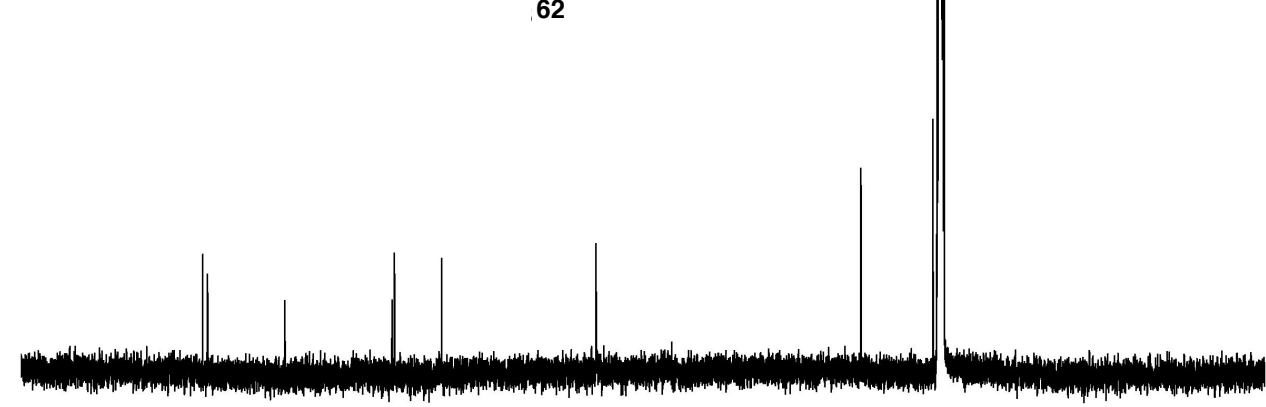

$\begin{array}{llllllllllllllllll}170 & 160 & 150 & 140 & 130 & 120 & 110 & 100 & 90 & 80 & 70 & 60 & 50 & 40 & 30 & 20 & 10 & 0\end{array}$ 
1HNMR
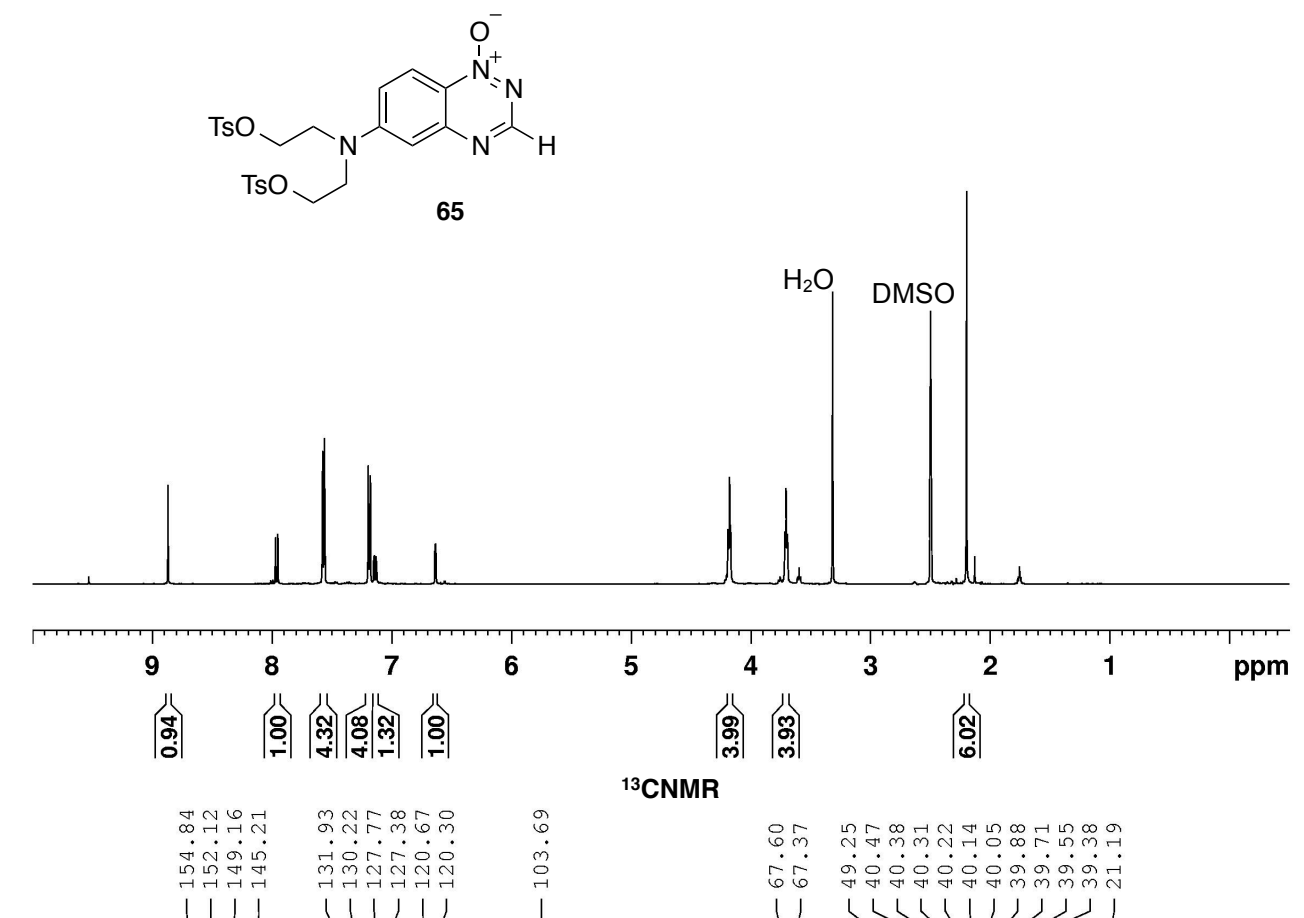

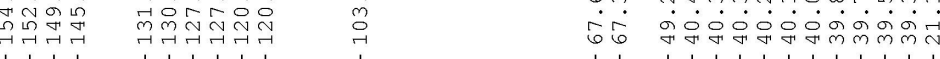

111111111

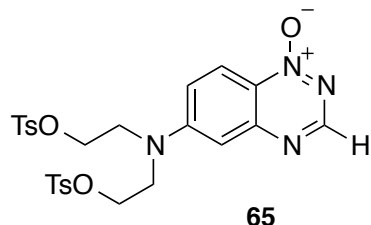

DMSO
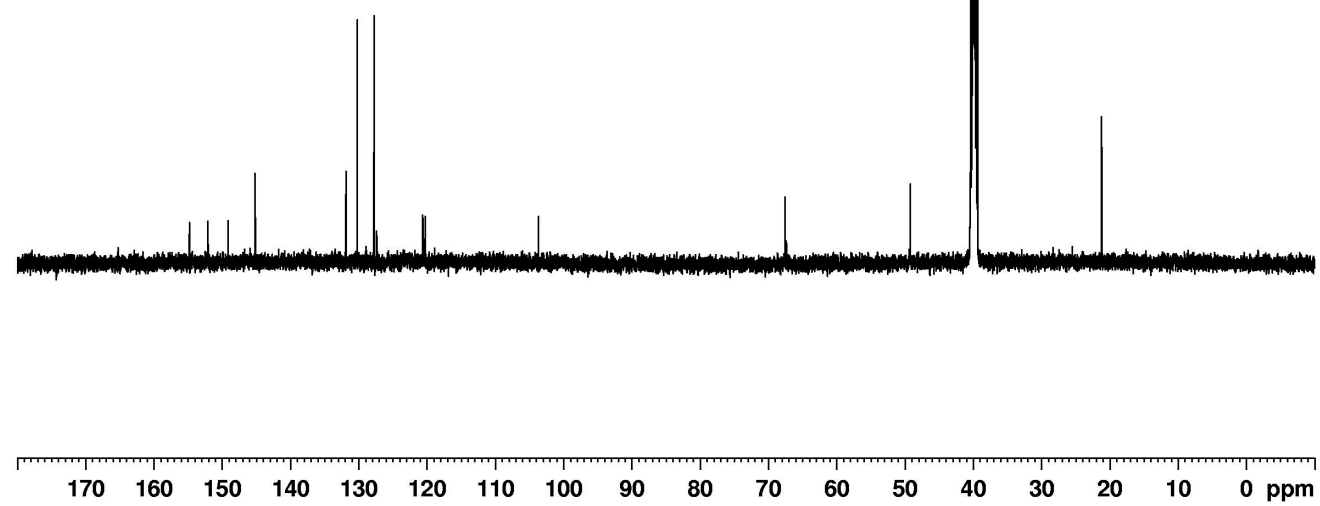
1HNMR
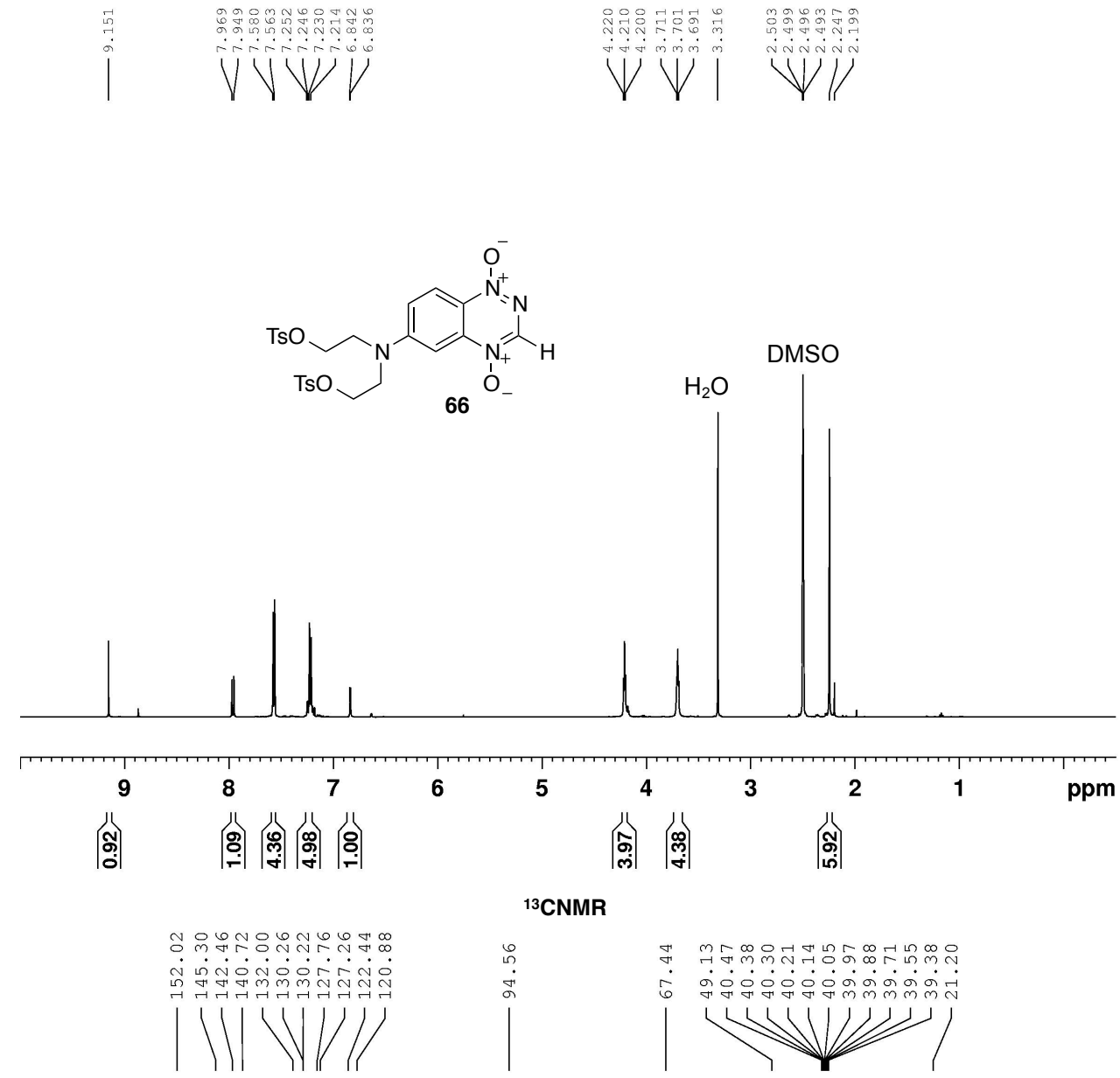

${ }^{13}$ CNMR
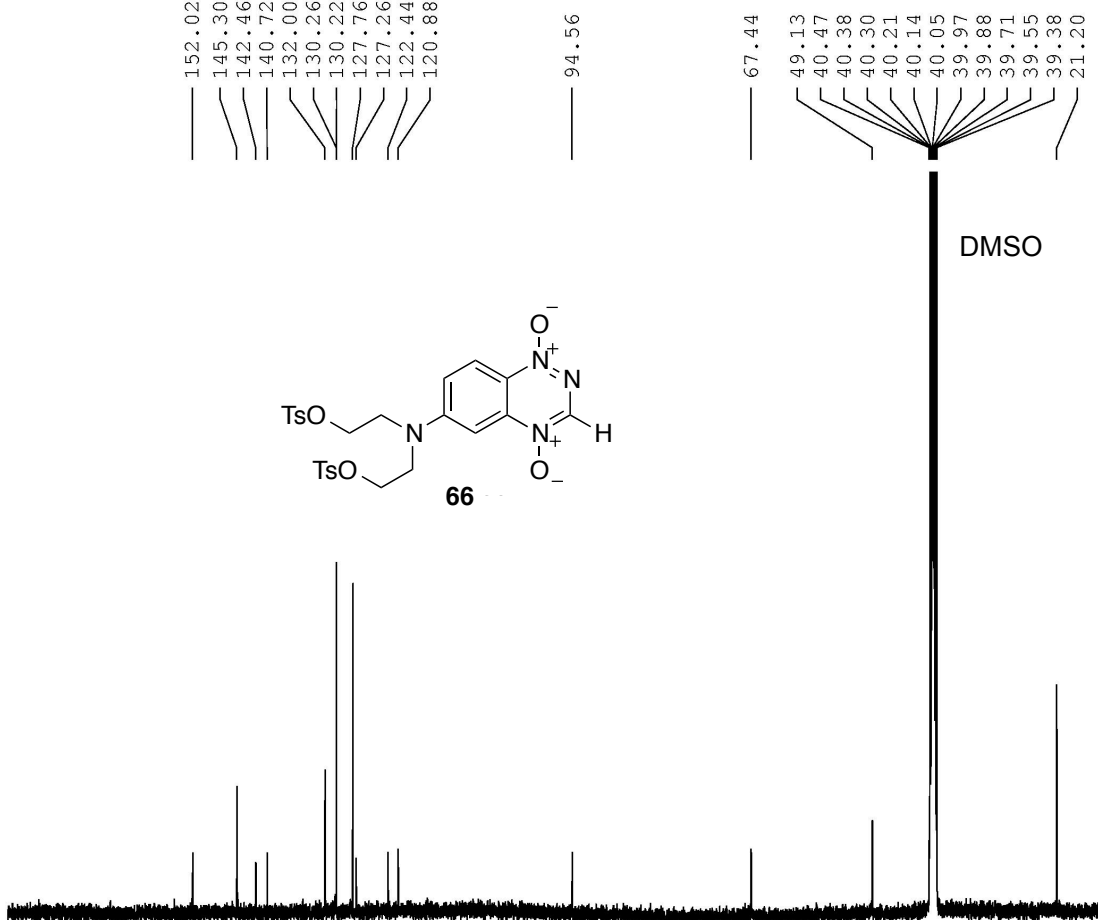

$170 \quad 160 \quad 150$
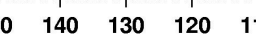

100

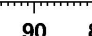

80

60

50

30

20

$0 \mathrm{ppm}$ 
1HNMR

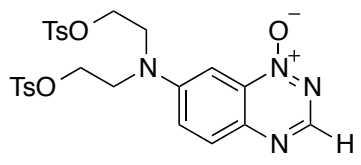

67
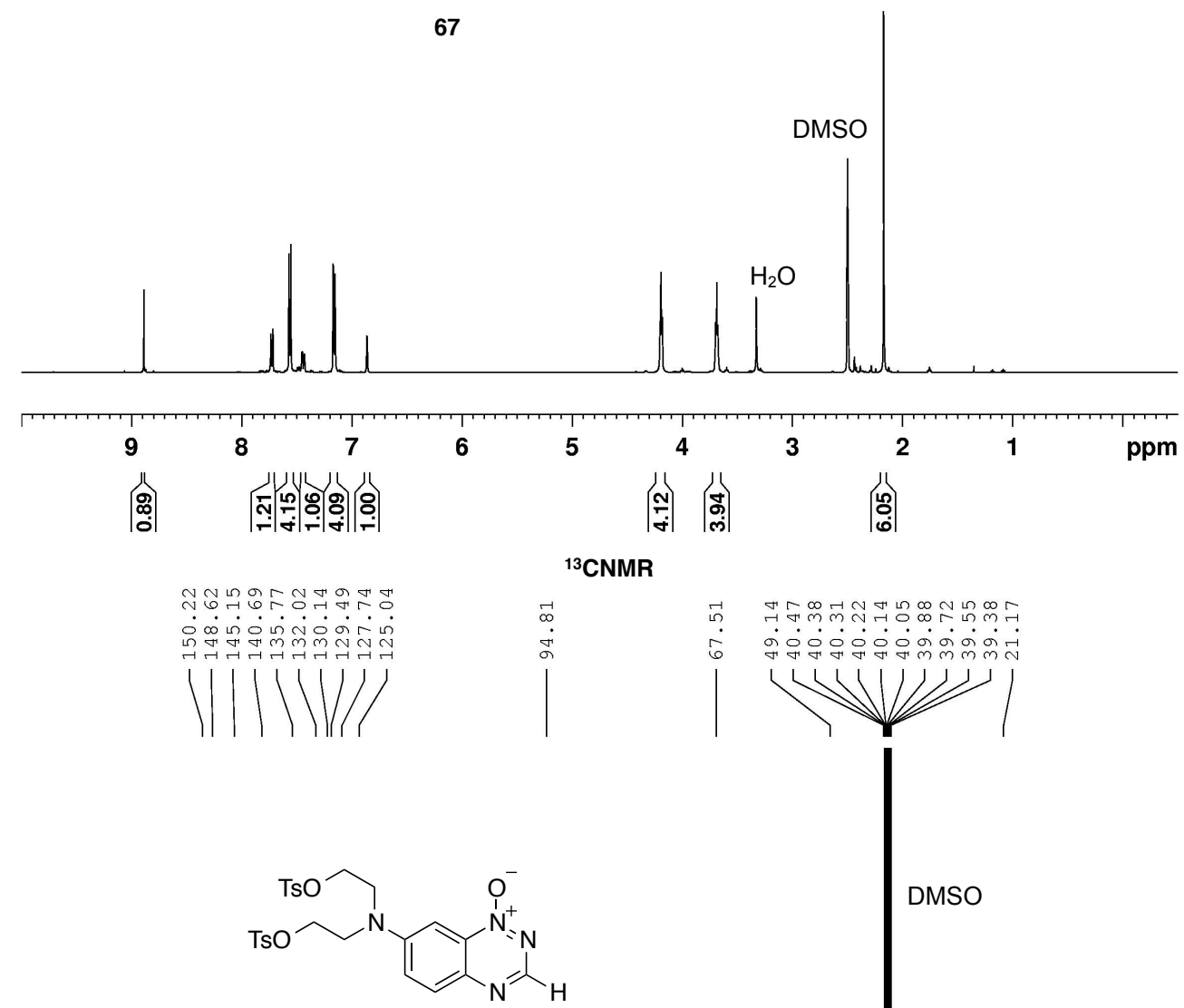

${ }^{13}$ CNMR

67

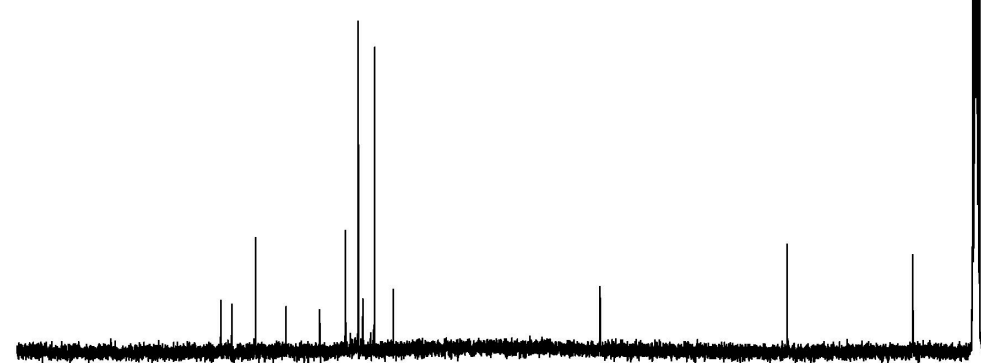

DMSO

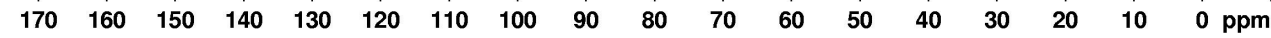


1HNMR
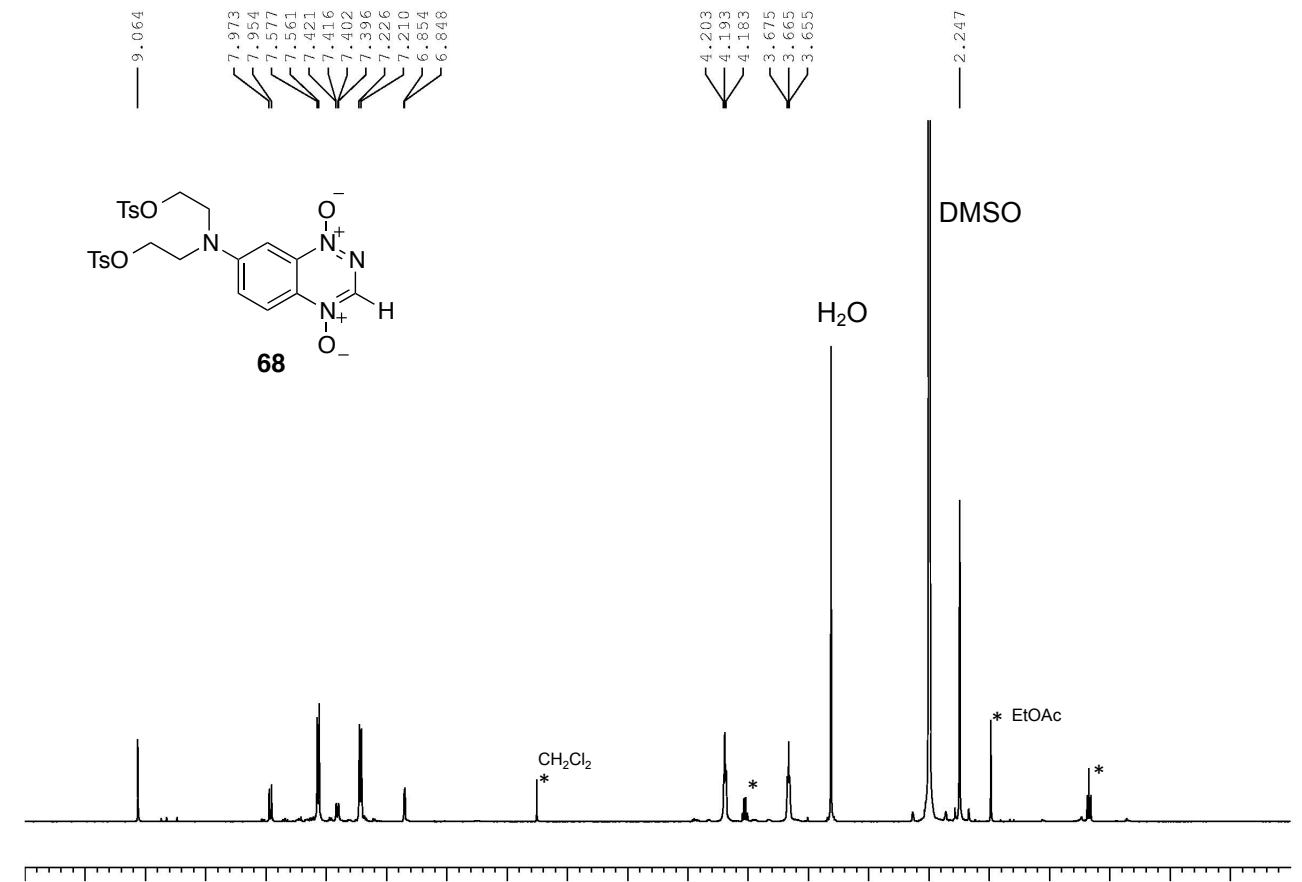

$\begin{array}{lllllllllllllllllllll}9.5 & 9.0 & 8.5 & 8.0 & 7.5 & 7.0 & 6.5 & 6.0 & 5.5 & 5.0 & 4.5 & 4.0 & 3.5 & 3.0 & 2.5 & 2.0 & 1.5 & 1.0 & 0.5 & \text { ppm }\end{array}$

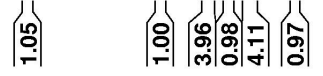

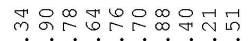

ơ

$1111 / 11$

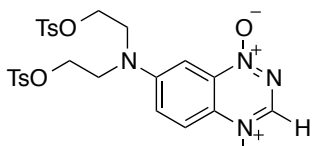

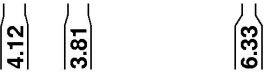

$68 \mathrm{O}$

DMSO
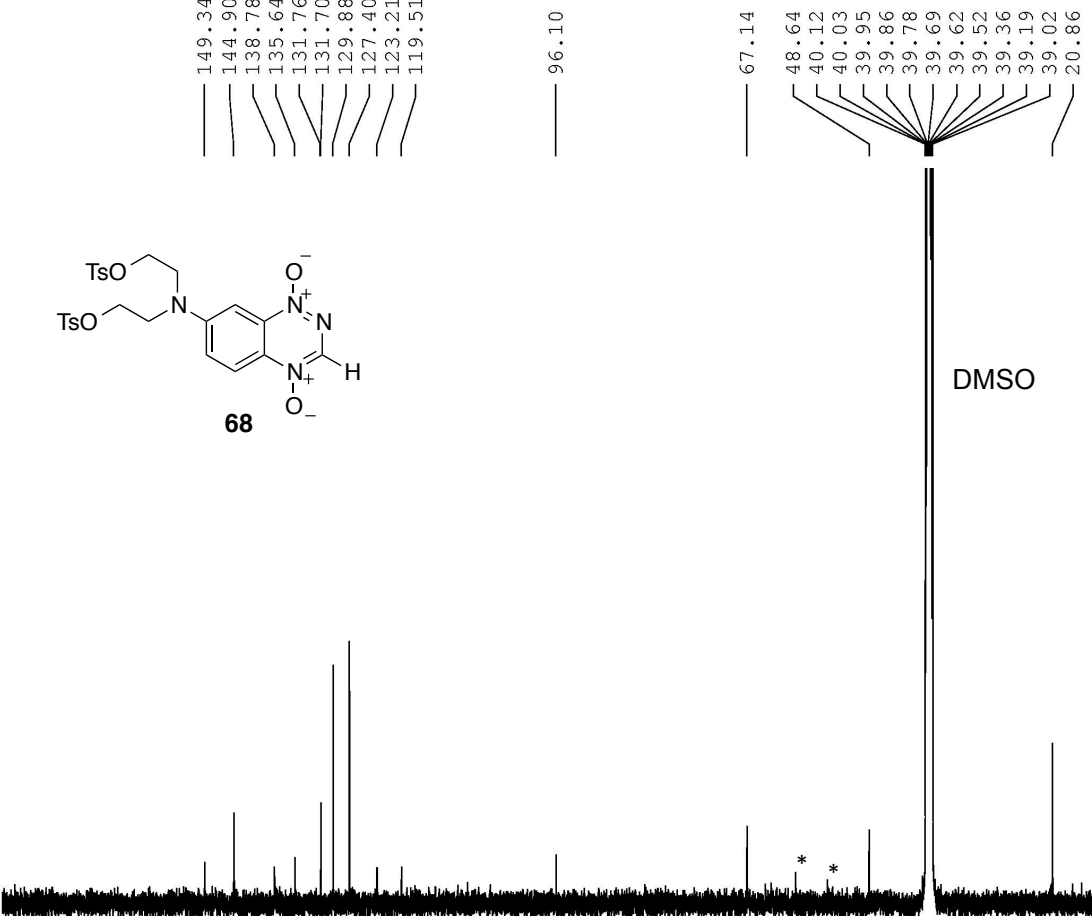

$\begin{array}{llllllllllllllllll}170 & 160 & 150 & 140 & 130 & 120 & 110 & 100 & 90 & 80 & 70 & 60 & 50 & 40 & 30 & 20 & 10 & 0\end{array}$ 

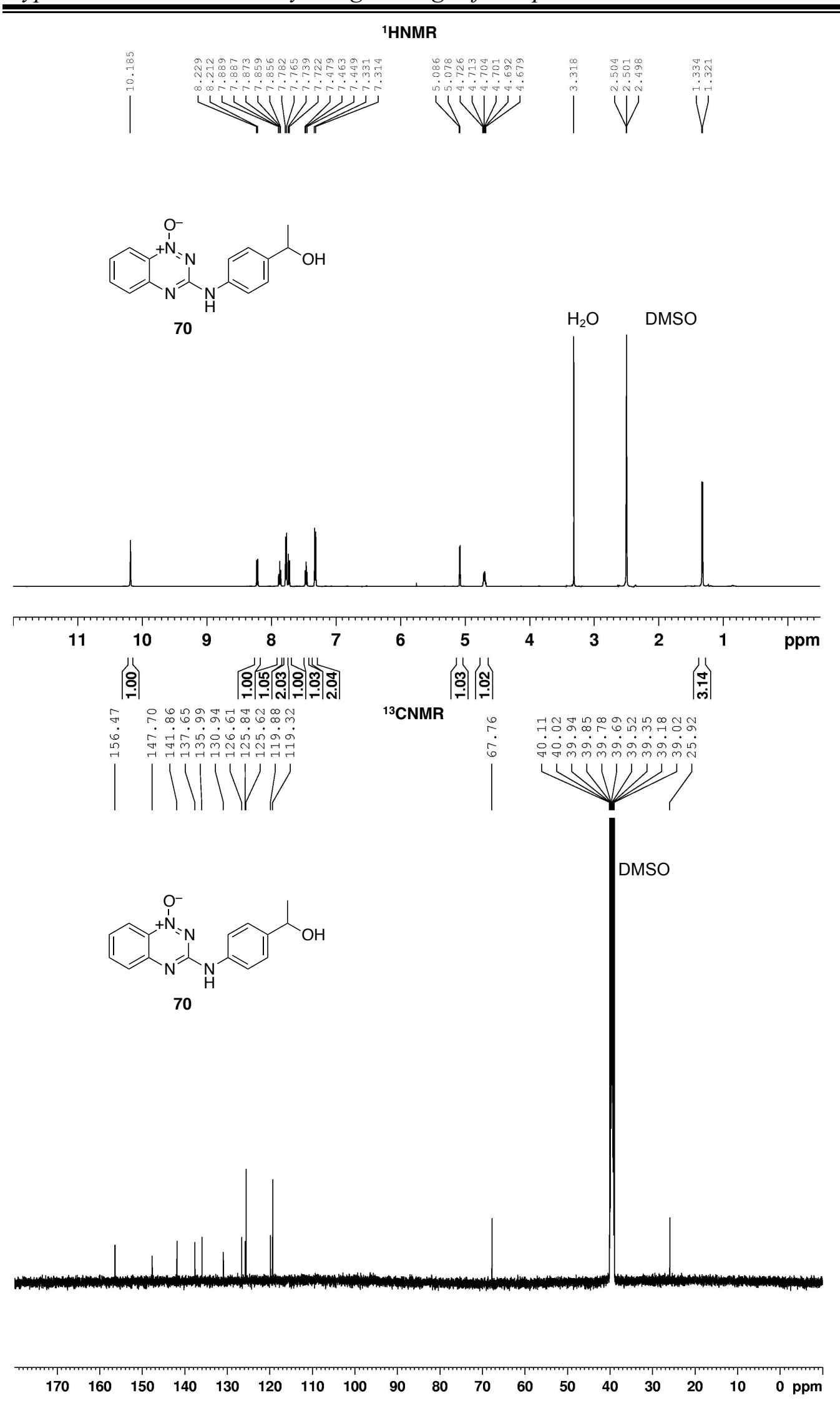
1HNMR
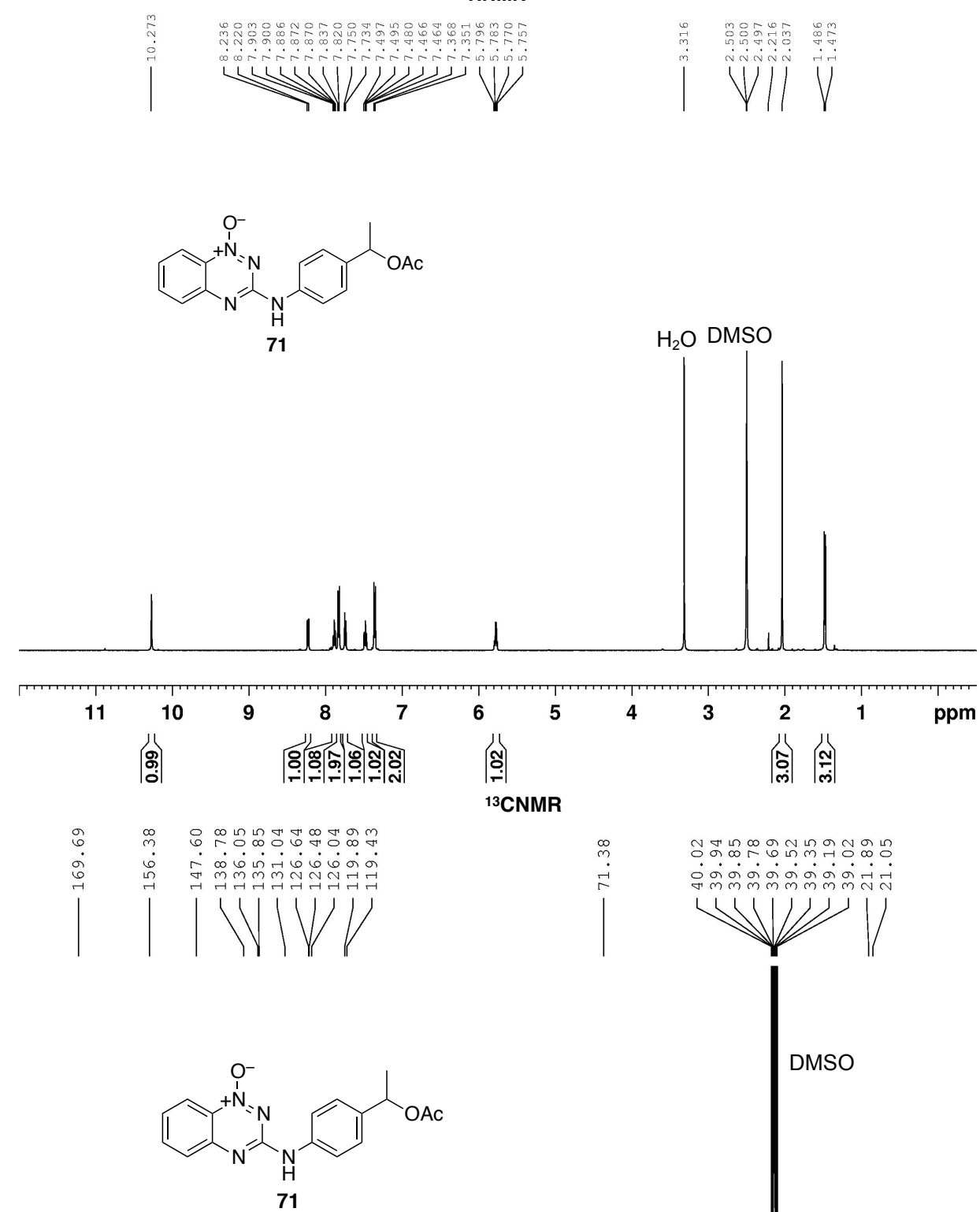

DMSO

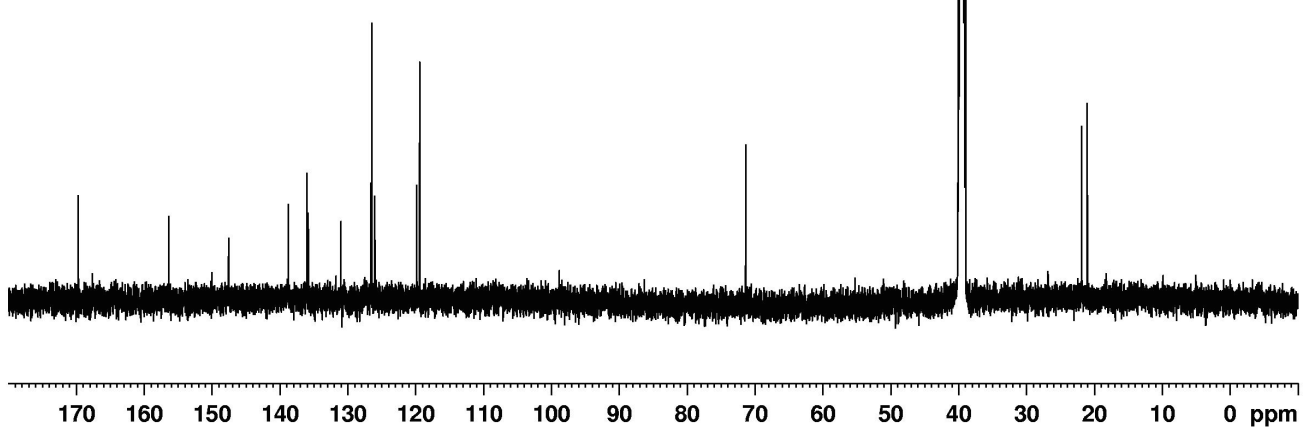



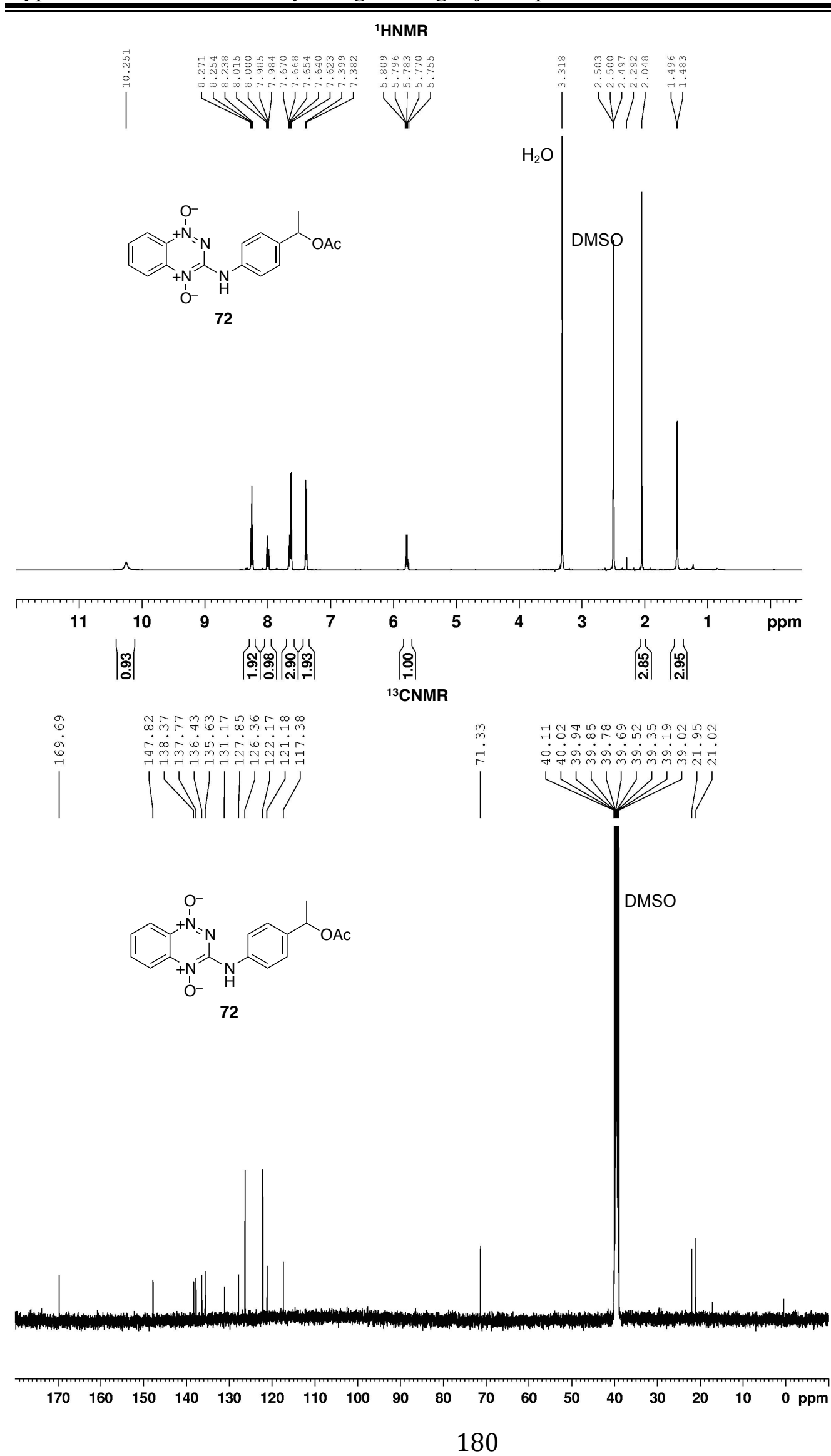


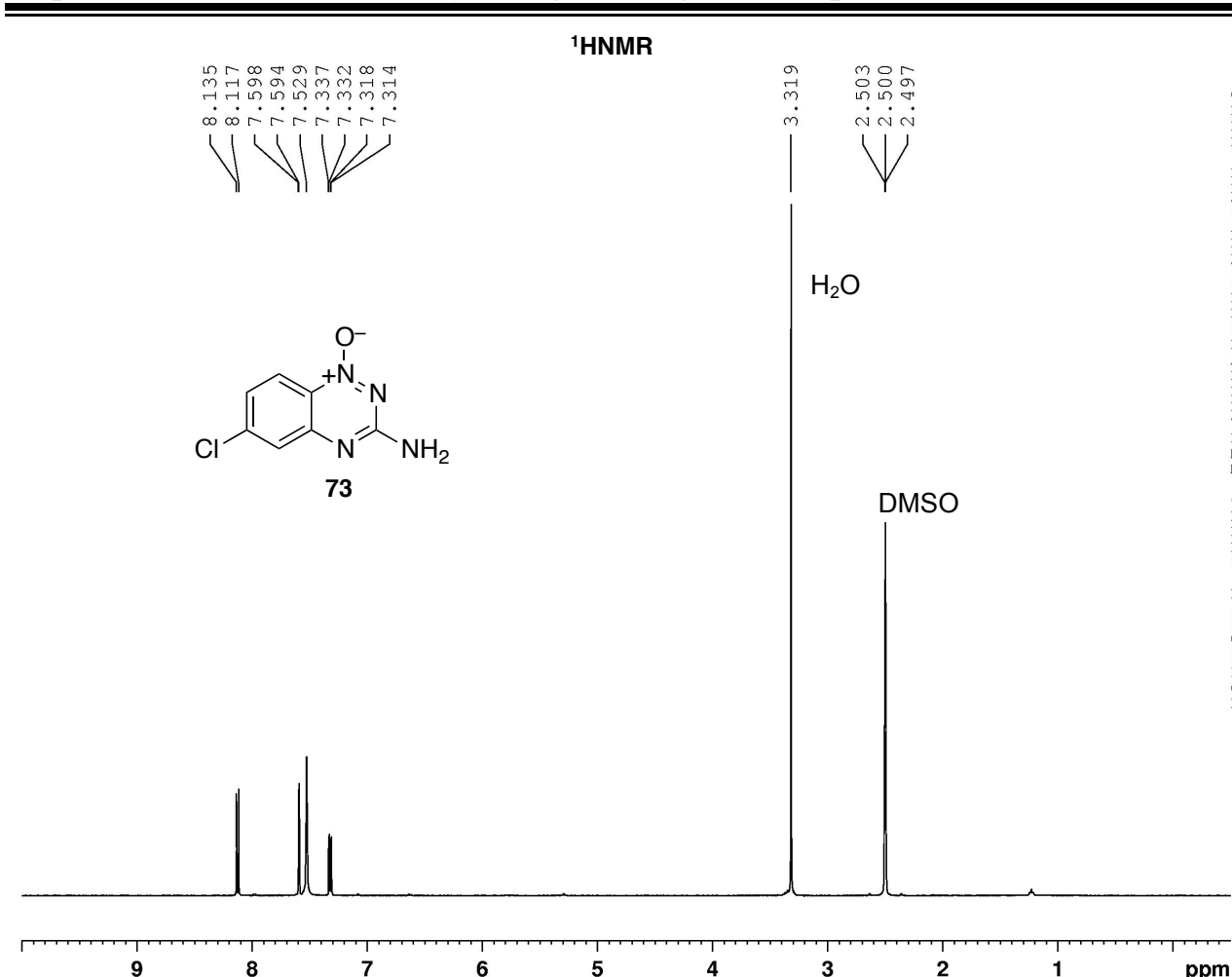

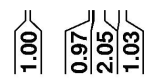
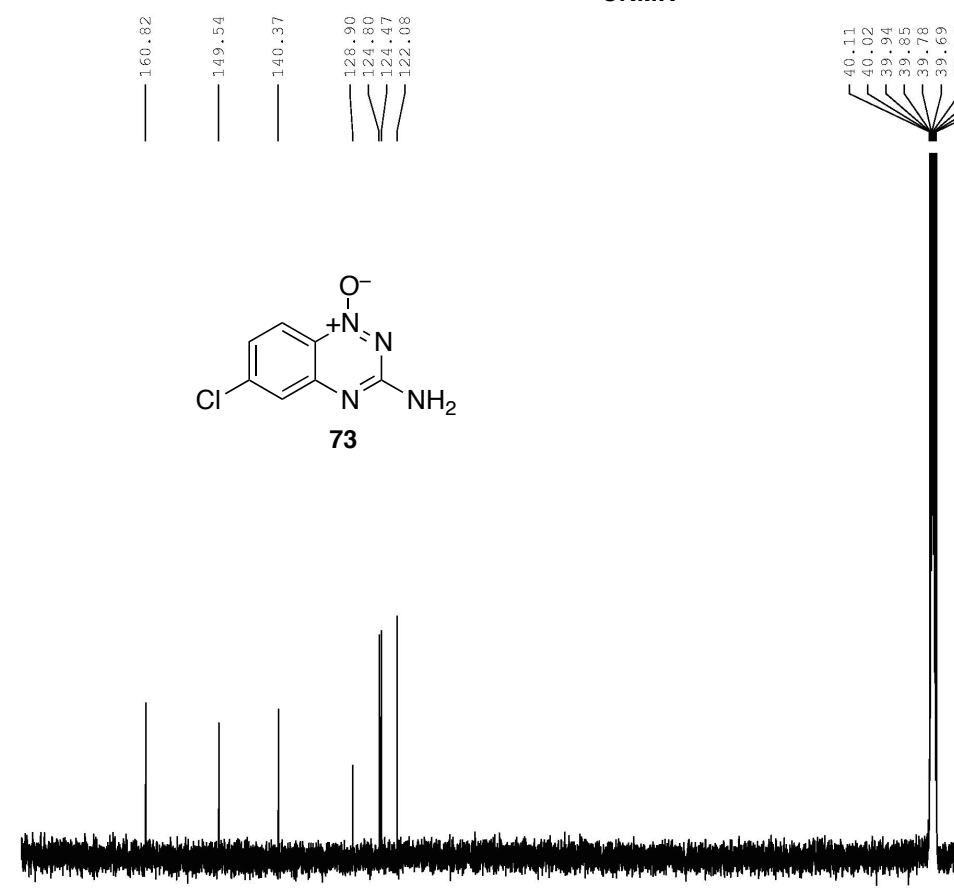

${ }^{13}$ CNMR

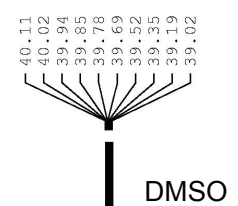

DMSO

$\begin{array}{llllllllllllllllll}170 & 160 & 150 & 140 & 130 & 120 & 110 & 100 & 90 & 80 & 70 & 60 & 50 & 40 & 30 & 20 & 10 & 0\end{array}$ 
1HNMR

|
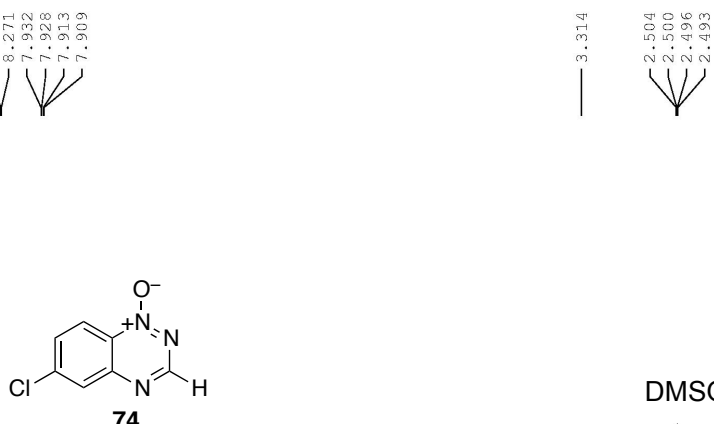

DMSO

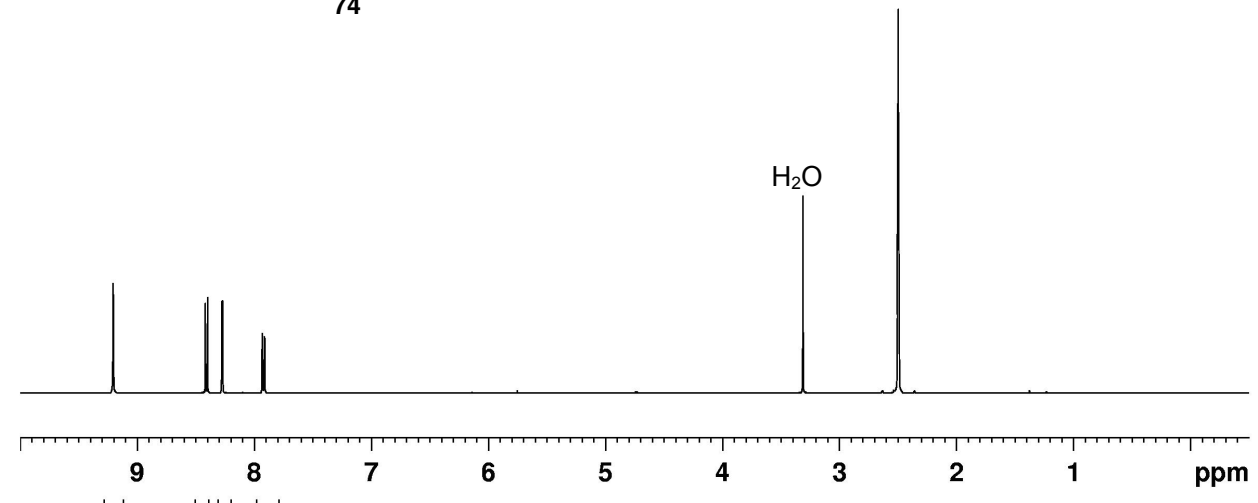

|ำ| |ํํํํำ|

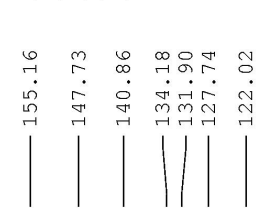

${ }^{13}$ CNMR

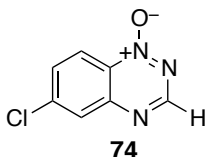

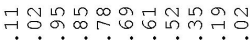

宊

WU1

DMSO

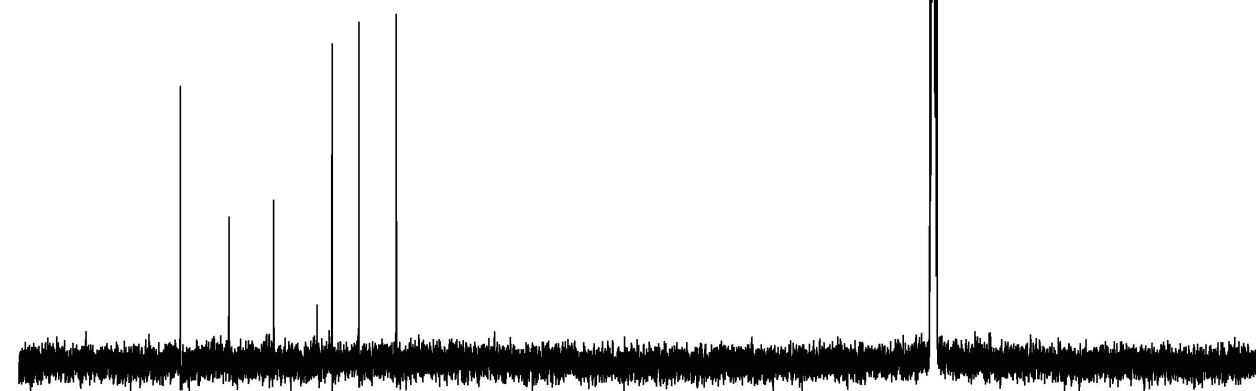

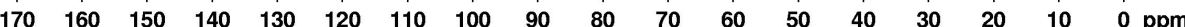




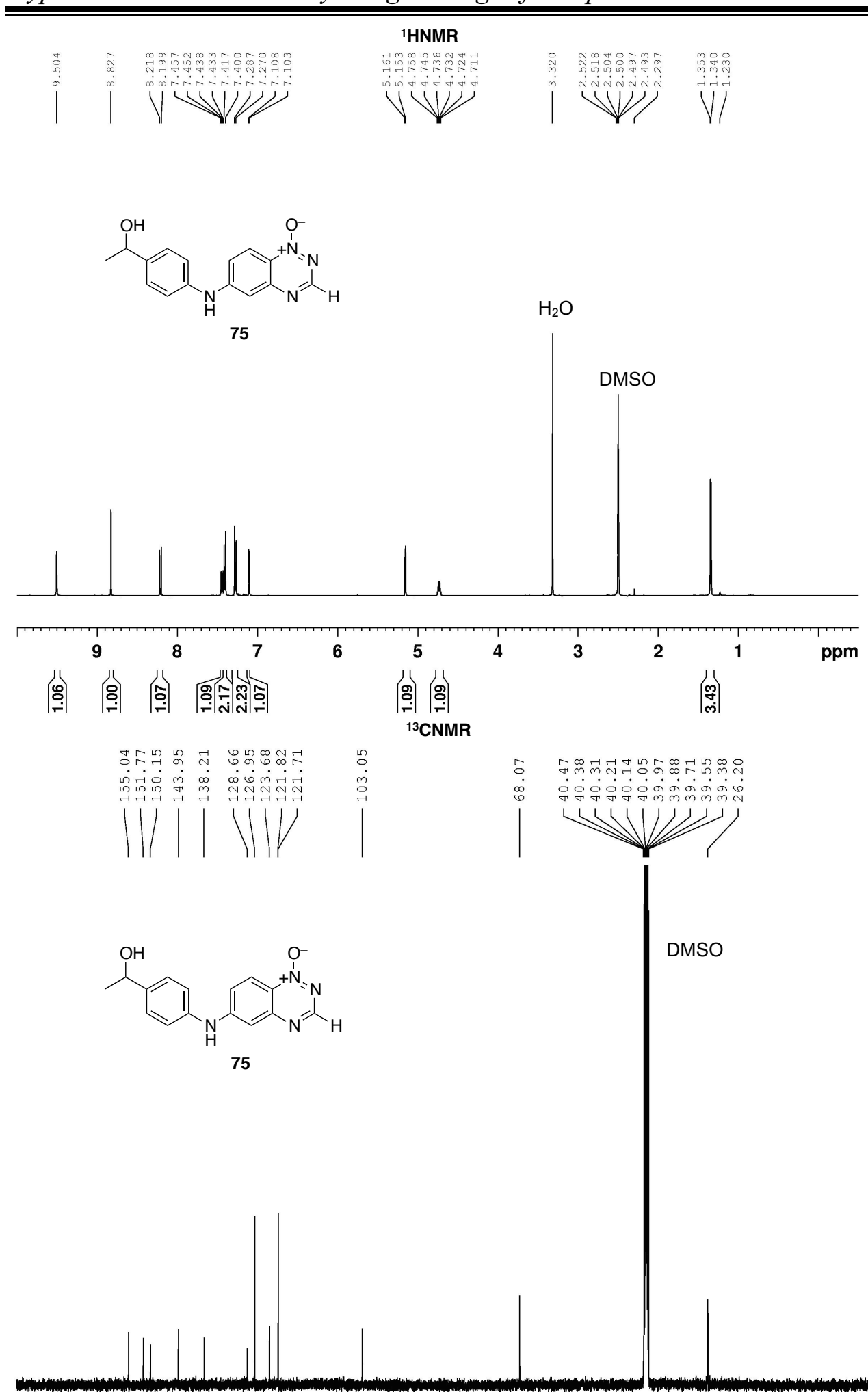

$\begin{array}{llllllllllllllllll}170 & 160 & 150 & 140 & 130 & 120 & 110 & 100 & 90 & 80 & 70 & 60 & 50 & 40 & 30 & 20 & 10 & 0\end{array}$ 
1HNMR

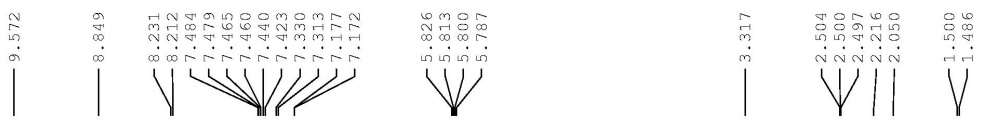<smiles></smiles>

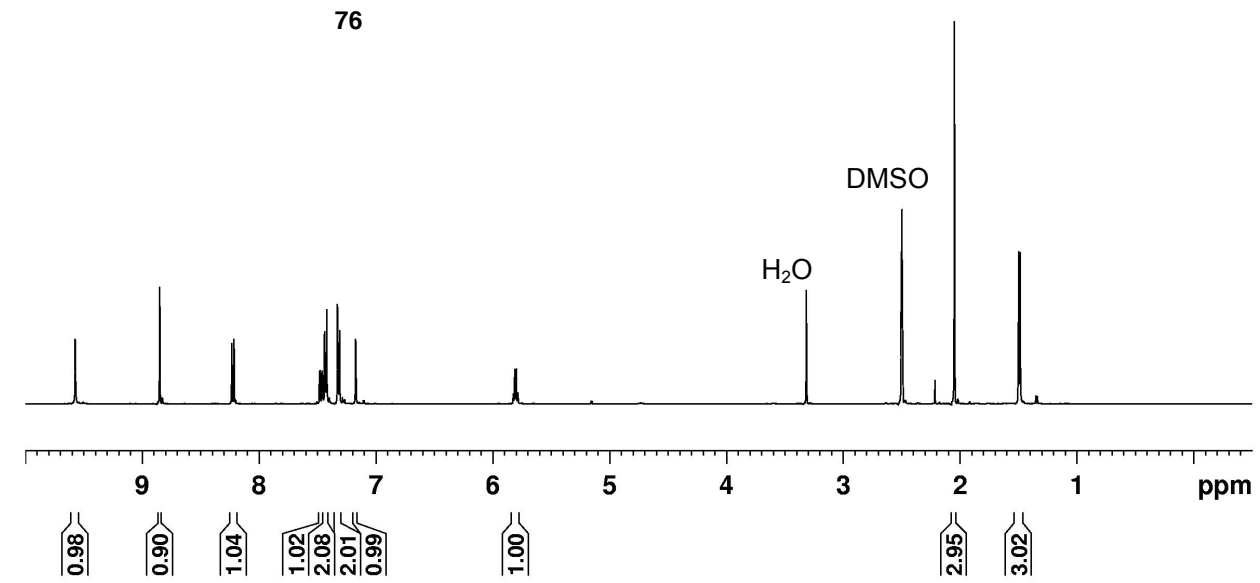

${ }^{13} \mathrm{CNMR}$

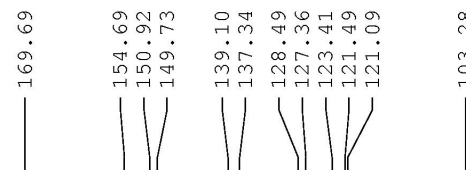<smiles></smiles>

DMSO

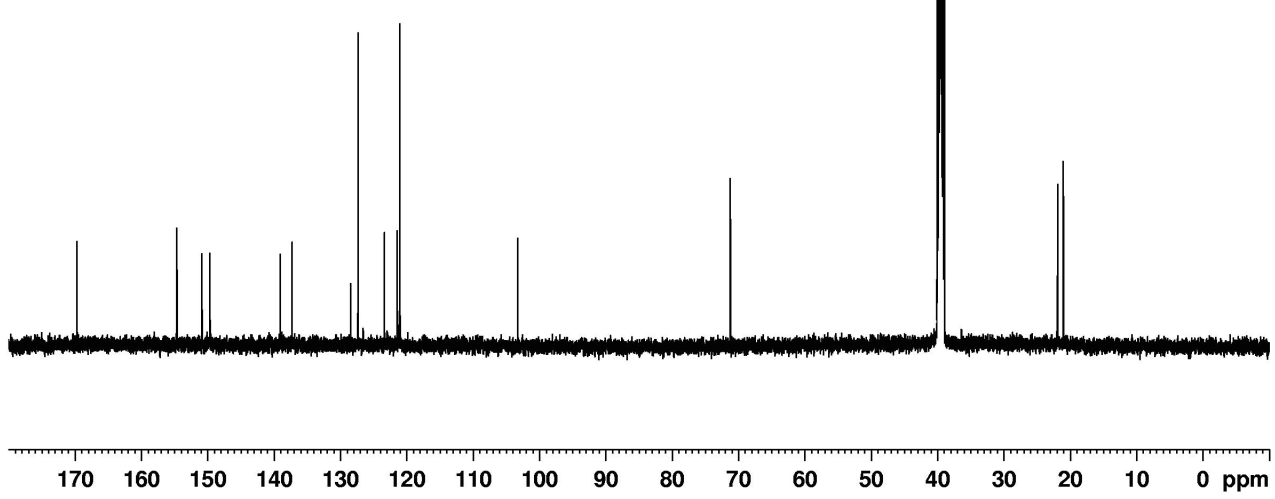




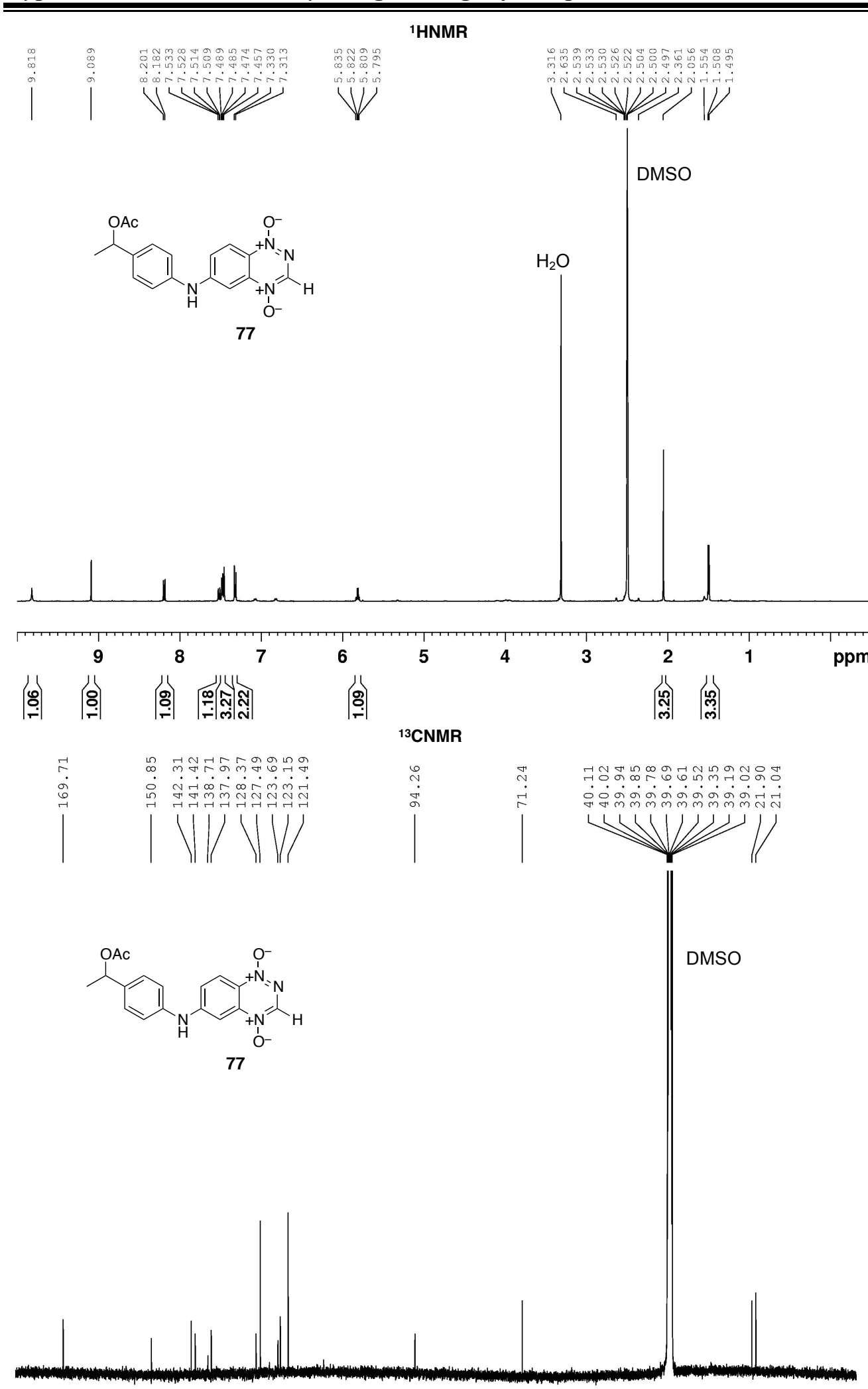

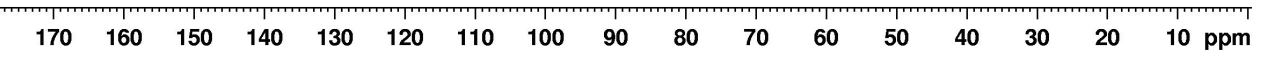



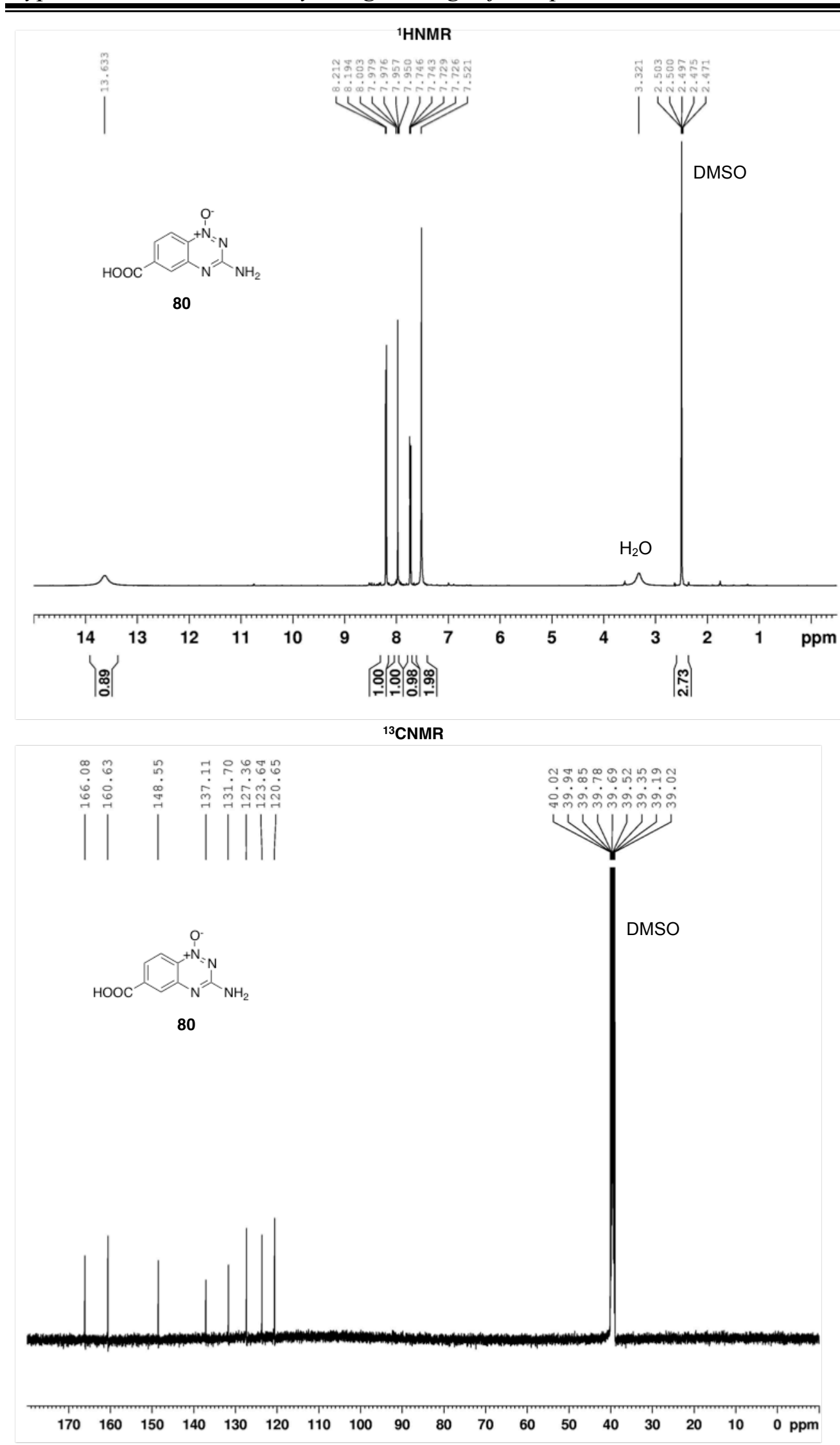
${ }^{1}$ HNMR
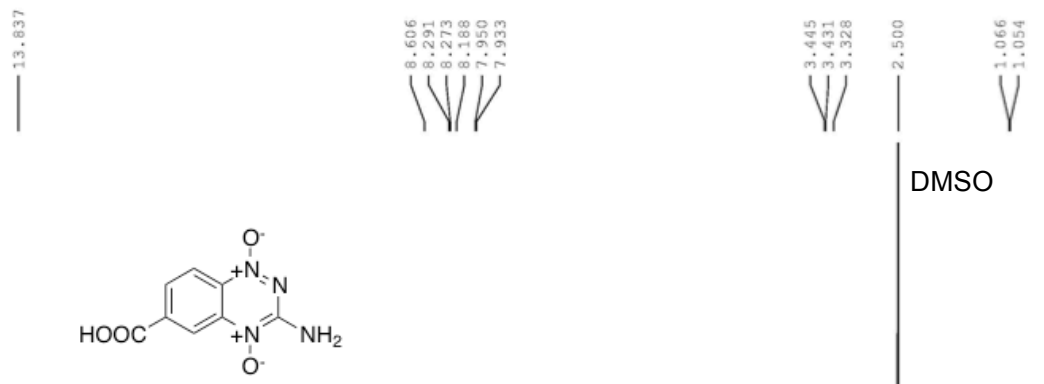

81
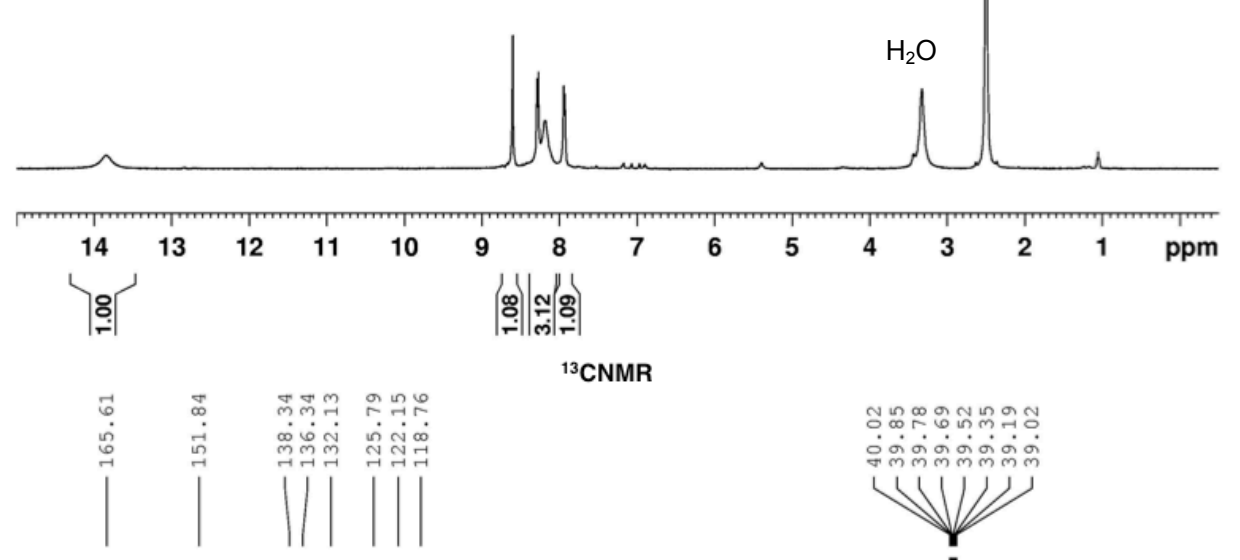

${ }^{13}$ CNMR

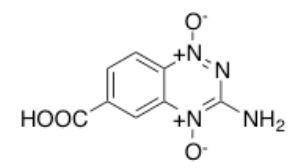

DMSO

81

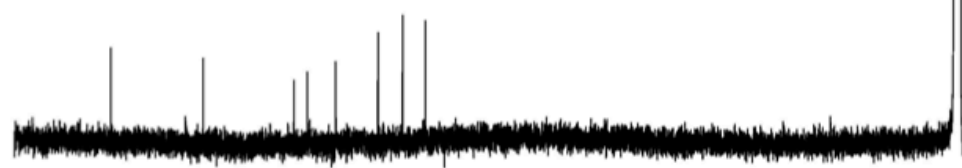

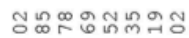

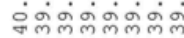

W.1

1

(1)

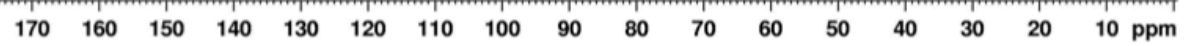




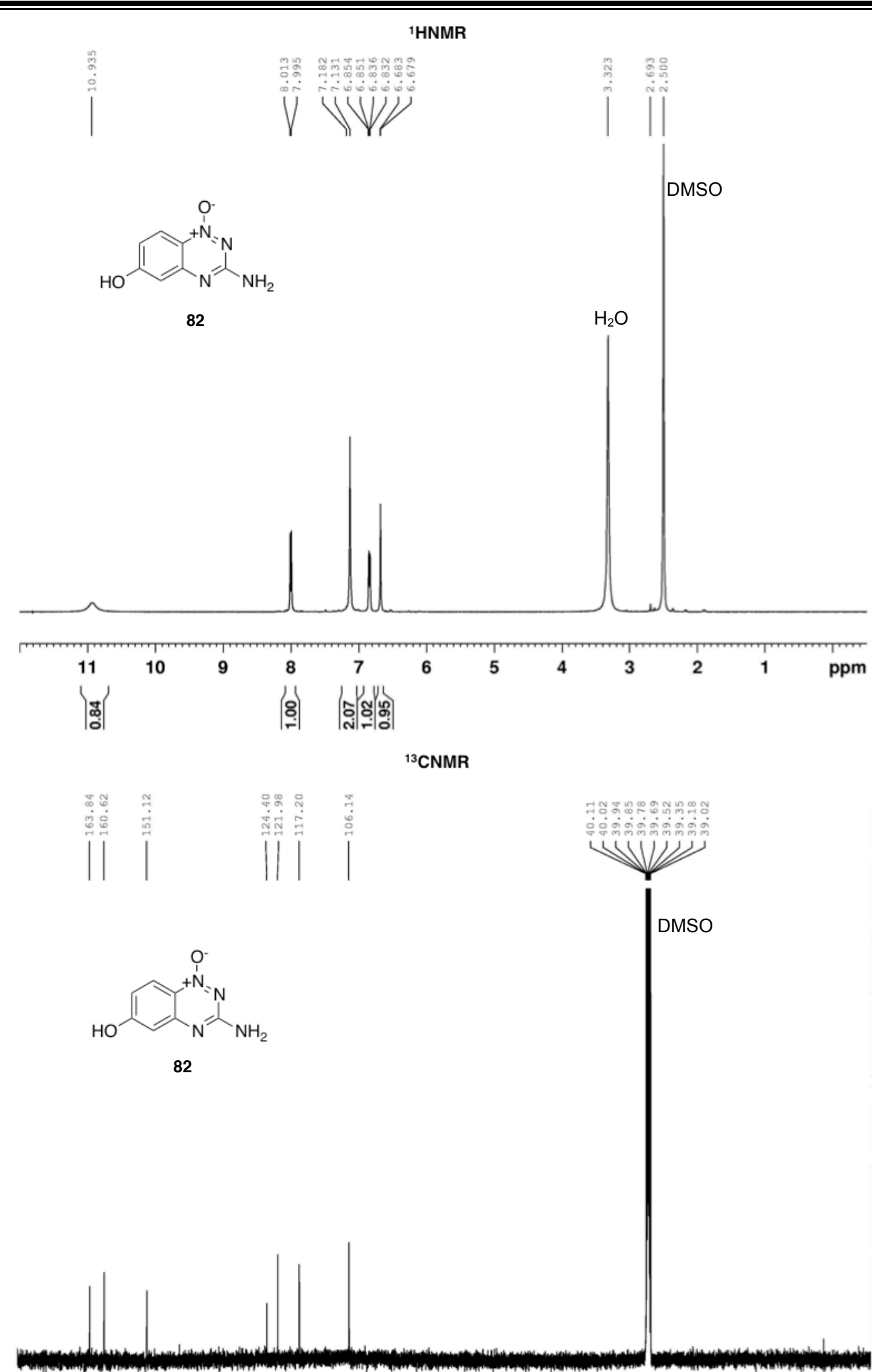

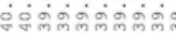

DMSO

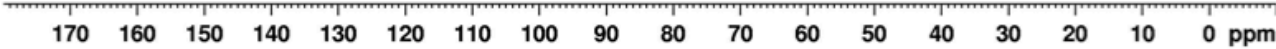



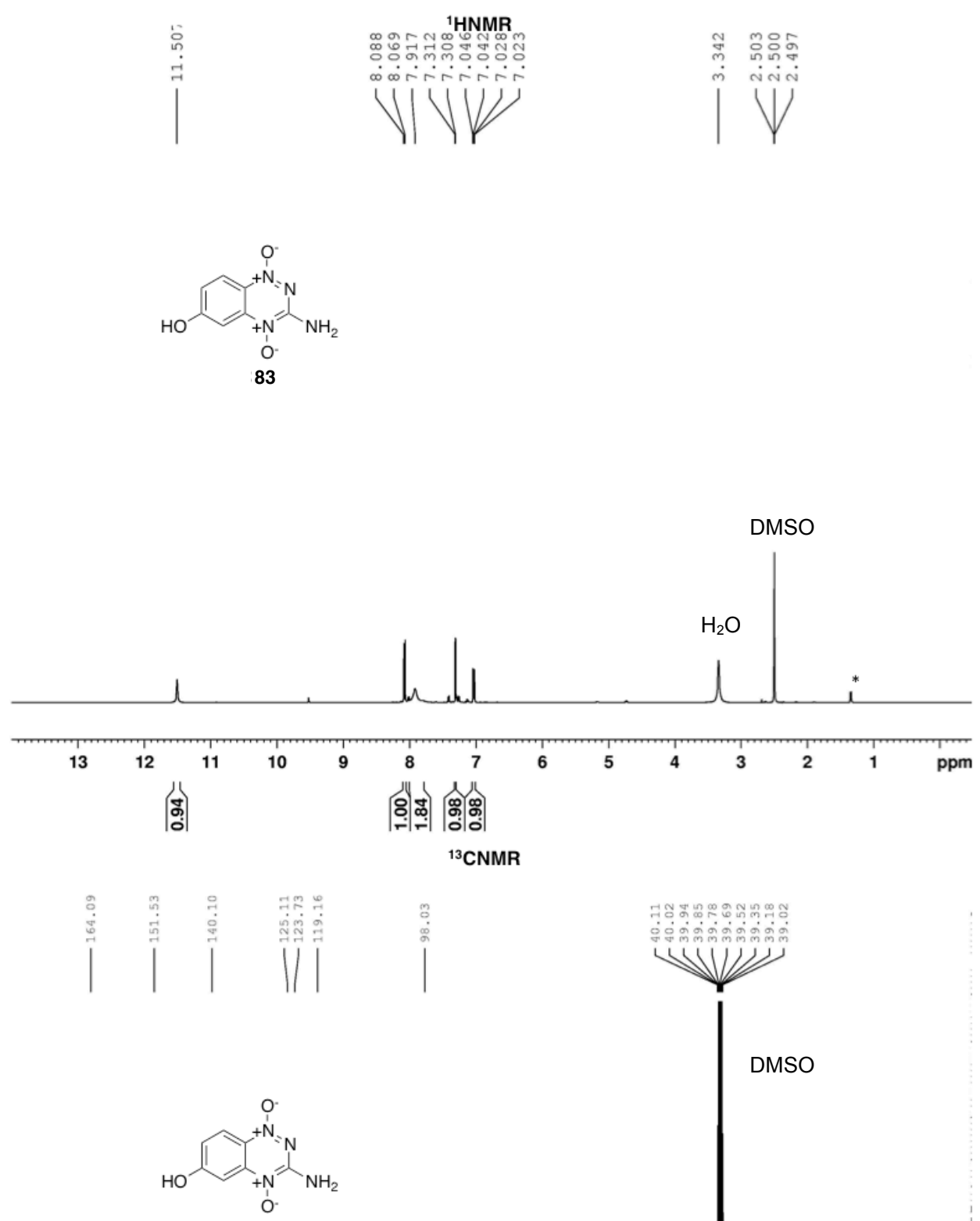

83

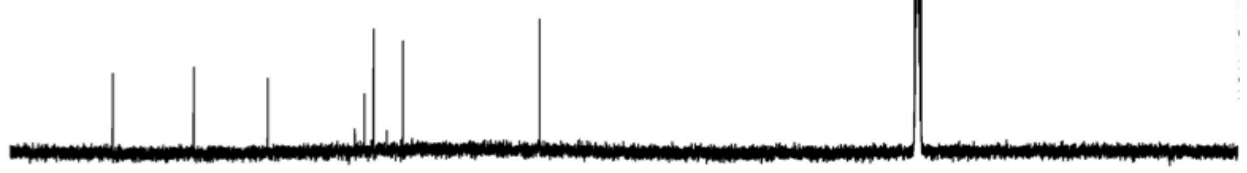

$\begin{array}{llllllllllllllllll}170 & 160 & 150 & 140 & 130 & 120 & 110 & 100 & 90 & 80 & 70 & 60 & 50 & 40 & 30 & 20 & 10 & 0\end{array}$ 


\section{References}

1. Brown, J. M. Br J Cancer 1993, 67 (6), 1163-70.

2. Chowdhury, G.; Junnotula, V.; Daniels, J. S.; Greenberg, M. M.; Gates, K. S. J. Am. Chem. Soc. 2007, 129 (42), 12870-7.

3. Mason, R. P.; Holtzman, J. L. Biochem. Biophys. Res. Commun. 1975, 67 (4), 1267-74.

4. Daniels, J. S.; Gates, K. S.; Tronche, C.; Greenberg, M. M. Chem. Res. Toxicol. 1998, $11(11), 1254-7$.

5. Peters, K. B.; Brown, J. M. Cancer Res 2002, 62 (18), 5248-53.

6. Wilson, W. R.; Hay, M. P. Nat Rev Cancer 2011, 11 (6), 393-410.

7. hicks, K. O. S., B.G.; Prujin, F. B.; and Wilson, W.R. Radiat. Res. 2004, 161 (6), 656-666.

8. Wilson, W. R.; Hicks, K. O.; Pullen, S. M.; Ferry, D. M.; Helsby, N. A.; Patterson, A. V. Radiat. Res. 2007, 167 (6), 625-36.

9. Hicks, K. O.; Siim, B. G.; Jaiswal, J. K.; Pruijn, F. B.; Fraser, A. M.; Patel, R.; Hogg, A.; Liyanage, H. D.; Dorie, M. J.; Brown, J. M.; Denny, W. A.; Hay, M. P.; Wilson, W. R. Clin Cancer Res 2010, 16 (20), 4946-57.

10. Atwell, G. J.; Yang, S.; Pruijn, F. B.; Pullen, S. M.; Hogg, A.; Patterson, A. V.; Wilson, W. R.; Denny, W. A. J. Med. Chem. 2007, 50 (6), 1197-212.

11. Chen, Y.; Hu, L. Med Res Rev 2009, 29 (1), 29-64.

12. Rooseboom, M.; Commandeur, J. N.; Vermeulen, N. P. Pharmacol Rev 2004, 56 (1), 53-102.

13. Fan, Y.-H.; Gold, B. J. Am. Chem. Soc. 1999, 121 (51), 11942-11946.

14. Rink, S. M.; Hopkins, P. B. Biochemistry 1995, 34 (4), 1439-45.

15. Everett, J. L.; Roberts, J. J.; Ross, W. C. J. J. Chem. Soc. 1953, (0), 2386.

16. Mulcahy, R. T.; Gipp, J. J.; Schmidt, J. P.; Joswig, C.; Borch, R. F. J. Med. Chem. 1994, 37 (11), 1610-1615.

17. Weiss, G. J.; Infante, J. R.; Chiorean, E. G.; Borad, M. J.; Bendell, J. C.; Molina, J. R.; Tibes, R.; Ramanathan, R. K.; Lewandowski, K.; Jones, S. F.; Lacouture, M. E.; Langmuir, V. K.; Lee, H.; Kroll, S.; Burris, H. A., 3rd Clin Cancer Res 2011, 17 (9), 2997-3004. 
18. Palmer, B. D.; Wilson, W. R.; Atwell, G. J.; Schultz, D.; Xu, X. Z.; Denny, W. A. J. Med. Chem. 1994, 37 (14), 2175-2184.

19. Zhang, J.; Tian, Q.; Chan, S. Y.; Duan, W.; Zhou, S. Drug Resist Updat 2005, 8 (5), 271-97.

20. Cullis, P. M.; Green, R. E.; Malone, M. E. J. Chem. Soc. Perkin Trans. 2 1995, (7), 1503-1511.

21. Pietra, A. A. a. S., Heterocyclic N-oxides. CRC Press: Boston, 1991.

22. J. M. Harris, F. L. S., P. von R. Schleyer, and C. J. Lancelot J. Am. Chem. Soc. 1969, $91,7508-7510$.

23. C. J. O'Connor, W. A. D., J. Y. Fan, G. L. Gravatt, B. A. Grigor, and D. J. Mclennan J. Chem. Soc. Perkin Trans. 2 1991, 1933-1939.

24. T. J. Bardos, N. D.-G., P. Hebborn, and D. J. Triggle J. Med. Chem. 1965, 8, 167174.

25. Fuchs, T.; Chowdhury, G.; Barnes, C. L.; Gates, K. S. J. Org. Chem. 2001, 66 (1), 107-114.

26. Jaramillo, P.; Domingo, L. R.; Pérez, P. Chem. Phys. Lett. 2006, 420 (1-3), 95-99.

27. Crossland, R. K.; Wells, W. E.; Shiner, V. J. J. Am. Chem. Soc. 1971, 93 (17), 4217-4219.

28. Bae, S. Y.; Winemiller, M. D. J. Org. Chem. 2013, 78 (13), 6457-70.

29. Boyd, M.; Hay, M. P.; Boyd, P. D. Magn. Reson. Chem. 2006, 44 (10), 948-54.

30. Verweij, J. a. P., H. M. Anti-Cancer Drugs 1190, 1, 5-13.

31. Walton, M. I.; Wolf, C. R.; Workman, P. Int J Radiat Oncol Biol Phys 1989, 16 (4), 983-6.

32. Walton, M. I.; Wolf, C. R.; Workman, P. Biochem. Pharmacol. 1992, 44 (2), 251259.

33. Fitzsimmons, S. A.; Lewis, A. D.; Riley, R. J.; Workman, P. Carcinogenesis 1994, $15(8), 1503-1510$.

34. Hay, M. P.; Gamage, S. A.; Kovacs, M. S.; Pruijn, F. B.; Anderson, R. F.; Patterson, A. V.; Wilson, W. R.; Brown, J. M.; Denny, W. A. J. Med. Chem. 2003, 46 (1), 169-82.

35. Bae, S. Y.; Winemiller, M. D. J. Org. Chem. 2013, 78, 6457-70. 
36. Mitoma, C.; Onodera, T.; Takegoshi, T.; Thomas, D. W. Xenobiotica 1977, 7 (4), 205-20.

37. Hansch, C.; Leo, A.; Taft, R. W. Chem. Rev. 1991, 91 (2), 165-195.

38. Suzuki, H.; Kawakami, T. Synthesis 1997, 1997 (08), 855-857.

39. Hammett, L. P. J. Am. Chem. Soc. 1937, 59 (1), 96-103.

40. O'Connor, C. J.; Denny, W. A.; Fan, J.-Y.; Gravatt, G. L.; Grigor, B. A.; McLennan, D. J. J. Chem. Soc. Perkin Trans.s 2 1991, (12), 1933.

41. $\quad$ Cantrell, W. R.; Bauta, W. E.; Engles, T. Tetrahedron Lett. 2006, 47 (25), 42494251.

42. Sambrook, J. F., E. F.; Maniatis, T., Molecular Cloning: A Lab Manual. Cold Spring Harbor Press: Cold Spring Harbor, NY, 1989.

43. Lindahl, T.; Andersson, A. Biochemistry 1972, 11 (19), 3618-3623.

44. Sugiyama, H.; Fujiwara, T.; Ura, A.; Tashiro, T.; Yamamoto, K.; Kawanishi, S.; Saito, I. Chem. Res. Toxicol. 1994, 7 (5), 673-83.

45. Wilde, J. A.; Bolton, P. H.; Mazumder, A.; Manoharan, M.; Gerlt, J. A. J. Am. Chem. Soc. 1989, 111 (5), 1894-1896.

46. Povirk, L. F.; Shuker, D. E. Mutat Res 1994, 318 (3), 205-26.

47. Kohn, K. W.; Hartley, J. A.; Mattes, W. B. Nucleic Acids Res. 1987, 15 (24), 10531-49.

48. Rink, S. M.; Solomon, M. S.; Taylor, M. J.; Rajur, S. B.; McLaughlin, L. W.; Hopkins, P. B. J. Am. Chem. Soc. 1993, 115 (7), 2551-2557.

49. Dutta, S.; Chowdhury, G.; Gates, K. S. J. Am. Chem. Soc. 2007, 129 (7), 1852-3.

50. Johnson, K. M.; Price, N. E.; Wang, J.; Fekry, M. I.; Dutta, S.; Seiner, D. R.; Wang, Y.; Gates, K. S. J. Am. Chem. Soc. 2013, 135 (3), 1015-25.

51. Price, N. E.; Johnson, K. M.; Wang, J.; Fekry, M. I.; Wang, Y.; Gates, K. S. J. Am. Chem. Soc. 2014, 136 (9), 3483-90.

52. Dong, Q. B., D.; Colvin, M. E.; Melius, C. F.; Ludeman, S. M.; Moravek, J. F.; Colvin, O. M.; Bigner, D. D.; Modrich, P.; and Friedman, H. S. Proc. Nat. Acad. Sci. 1995, 92 (26), 12170-12174.

53. Kuang, Y.; Balakrishnan, K.; Gandhi, V.; Peng, X. J. Am. Chem. Soc. 2011, 133 (48), 19278-81. 
54. Daniels, J. S.; Gates, K. S. J. Am. Chem. Soc. 1996, 118 (14), 3380-3385.

55. Pchalek, K.; Hay, M. P. J. Org. Chem. 2006, 71 (17), 6530-5.

56. Murray, R. W. a. S., M. Org. Synth. 1997, 74, 91. 


\title{
Chapter 3. DNA Interstrand Cross-Links Between an Abasic
}

\author{
Site and the Opposing Guanine Residue of 5'-CAp Sequences
}

\section{in Duplex DNA}

\subsection{Introduction}

Apurinic/apyrimidinic (Ap) sites are among the most common DNA lesions that form spontaneously in cells most often through a process termed depurination $(\mathbf{1}$, Scheme 1). ${ }^{1-2}$ Depurination results from the spontaneous hydrolytic cleavage of the glycosidic bond resulting in loss of the DNA base, leaving the deoxyribose sugar (Scheme 1). It is estimated about 10,000 Ap sites form per cell per day. ${ }^{3-5}$ Exogenous mutagens and anticancer drugs can increase this rate, resulting in greater abundance of Ap sites, which can be cytotoxic and mutagenic. ${ }^{6-7}$ DNA repair enzymes such as Uracil DNA Glycosylase (UDG) form Ap-sites (1) by removal misincorporated uracil residues. ${ }^{8}$ This like other base excision repair (BER) enzymes contribute to the generation of Ap-sites. 3, 6, 9-10 


\section{Scheme 1}
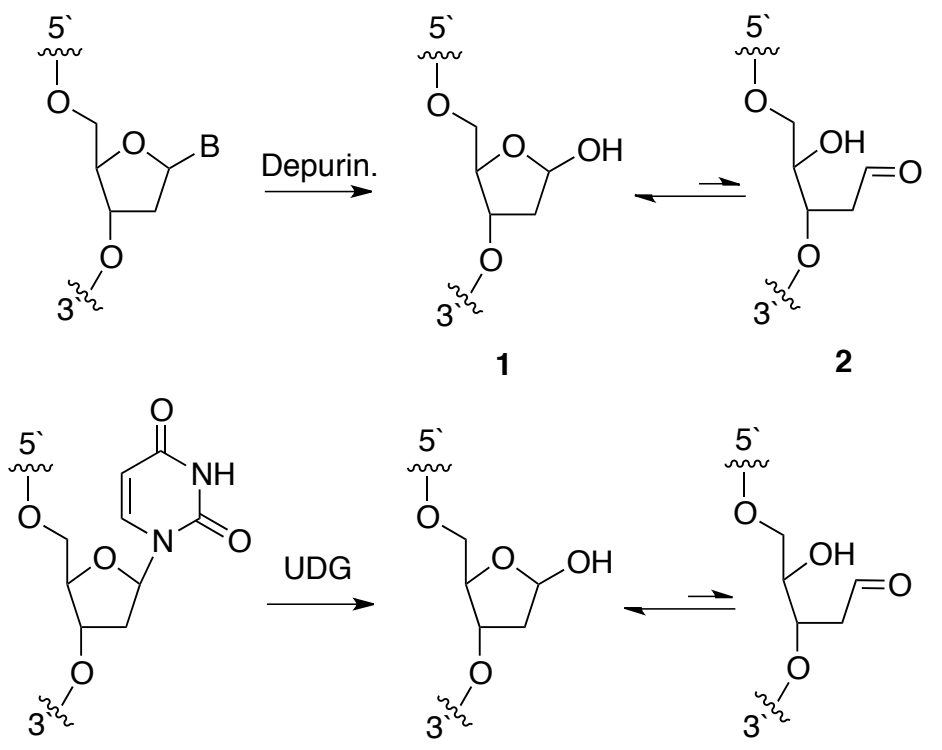

Ap sites are estimated to be in equilibrium as either a closed ring hemiacetal $(\sim 99 \%, \mathbf{1})$ or open chain aldehyde $(\sim 1 \%, 2) .{ }^{11}$ Aldehydes are known to be reactive functional groups towards nucleophilic attack. ${ }^{2}$ Imine formation involves a reversible reaction between a primary or secondary amine and an aldehyde or ketone (Scheme 2). Imines have been shown to occur between heterocyclic bases in DNA with various aldehyde-containing carcinogens such as acrolein or oxidation products from lipid peroxidation (Scheme 2). ${ }^{2}{ }^{12-13}$ Generally duplexes containing Ap-sites have significant structural diversity, but it is suggested that B-DNA structure is often retained. ${ }^{14-16} \mathrm{We}$ hypothesized that the DNA bases could form imine linkages with opposing Ap-sites.

We have studied and reported the formation of DNA interstrand cross-links between the aldehyde of an Ap-site and the exocyclic amine of an opposing guanine (dG) or adenine $(\mathrm{dA})$ residue in a DNA duplex via imine formation. ${ }^{17-19}$ Our early work employed conditions of reductive amination to capture the dG-Ap cross-link between in 5 -CApA sequences. ${ }^{17}$ This chapter will discuss the formation and stability of the 
(unreduced) dG-Ap cross-link formed under physiologically relevant conditions, and how the reduced dG-Ap cross-links were used to infer chemical structure. ${ }^{18}$

\section{Scheme 2}

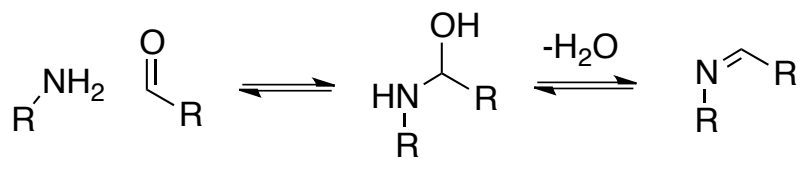

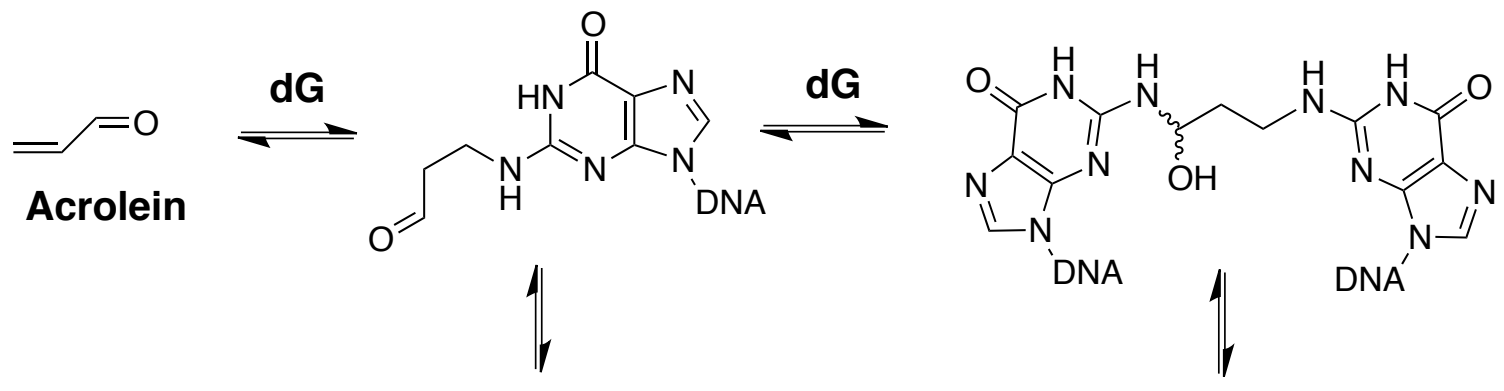<smiles>Nn1cnc2c(=O)n3c(nc21)NCC[C@H]3O</smiles><smiles>COn1cnc2c(=O)[nH]c(NC3CCNc4nc5c(ncn5OC)c(=O)n43)nc21</smiles>

\section{2 dG-Ap DNA Interstrand Cross-links Trapped by Reductive Amination}

Interstrand cross-links cause severe problems for cellular DNA repair systems. ${ }^{20}$

These lesions can block DNA transcriptions and replication, resulting in cell dysfunction, death, and aging. ${ }^{21-22}$ The deleterious nature of these cross-links suggests that small amounts of Ap-derived cross-links could be contributing to the observed biological significance of Ap-sites in Genomic DNA. This makes characterization of structure and biological importance for this lesion crucial.

Previous work involved capturing interstrand cross-links formed by the reaction of Ap-sites with deoxyguanosine residues using $\mathrm{NaCNBH}_{3}$. This mild reducing agent is 
commonly used for selective reduction of imines. Our experiments utilized uracilcontaining strands to selectively introduce Ap-sites into the duplex quickly with UDG (Scheme 1). This technique has proven useful for selectively generating Ap-sites at defined locations in all duplexes tested (Chapter 4). Further incubation of UDG treated uracil-containing DNA generated cross-links in $5^{\circ} \mathrm{CAp}$ sequences. We conducted several experiments to determine that the mechanism of cross-link generation involves imine formation between the exocyclic $-\mathrm{NH}_{2}$ of guanine residues and the aldehyde of abasicsites (Scheme 3).

\section{Scheme 3}

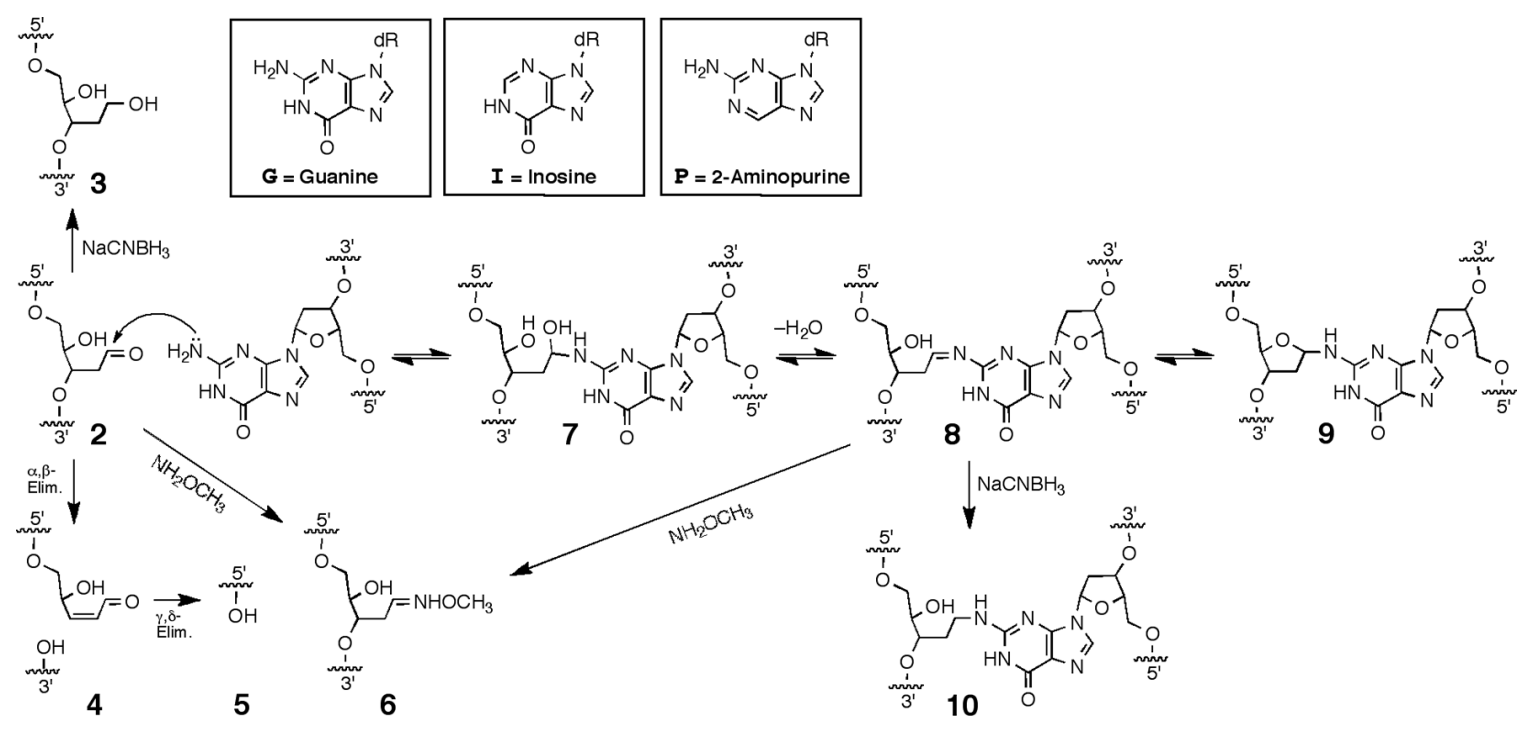

These conditions of reductive amination ${ }^{23}$ were designed to facilitate detection of the cross-link via irreversible reduction of the anticipated imine intermediate $\mathbf{8}$ to give a stable amine linkage (Scheme 1). ${ }^{24-26}$ In the current work, we examined cross-link formation in several 21-30 bp 2'-deoxyoligonucleotide duplexes, with the goal of 
characterizing the formation, structure, and properties of the dG-Ap cross-link formed at 5'-CAp sequences in duplex DNA.

${ }^{32}$ P-labeled oligonucleotides 15-mer base pairs long (duplex A Figure 1) were originally used to detect cross-links captured reductively with $\mathrm{NaCNBH}_{3}$ in $\mathrm{pH} 5.5$ buffer (MES, $50 \mathrm{mM}$ ) at $30{ }^{\circ} \mathrm{C}$ in low yields (2-3\%) over several days. ${ }^{17}$ Here we used duplexes of 21-30 base pairs in length (duplex B-G). The increase is length resulted in higher yields of reductively captured cross-links in significantly shorter incubation periods. We hypothesized the lower yields obtained with the 15-mer sequences resulted from partial dissociation of the Ap-containing duplexes upon incubation, preventing cross-link formation. Ap-sites have been shown to drastically affect the melting temperature of DNA duplexes. ${ }^{27}$ Using a longer more thermally stable duplex allowed for higher temperature incubations assisting in shorter incubation times.

We used gel mobility experiments to confirm the identity of the DNA interstrand cross-links. Duplexes $\mathbf{C}, \mathbf{D}$, or $\mathbf{E}$ were designed from duplex $\mathbf{B}$ containing 3 '-lengthened tails (5 base pairs) on either the Ap containing strand, complimentary strand, or both strands. After separation by PAGE, these tails produced gel-shifted bands. The lengthened ${ }^{32} \mathrm{P}$-labeled 26-mer strands would travel slower than the ${ }^{32} \mathrm{P}$-labled 21-mer strands because of the change in size. Additionally, any interstrand cross-links that form also travel slower than the corresponding single strand DNA, as it would contain both the 32P-labeled Ap-containing and unlabeled complimentary strands. 
Figure 1

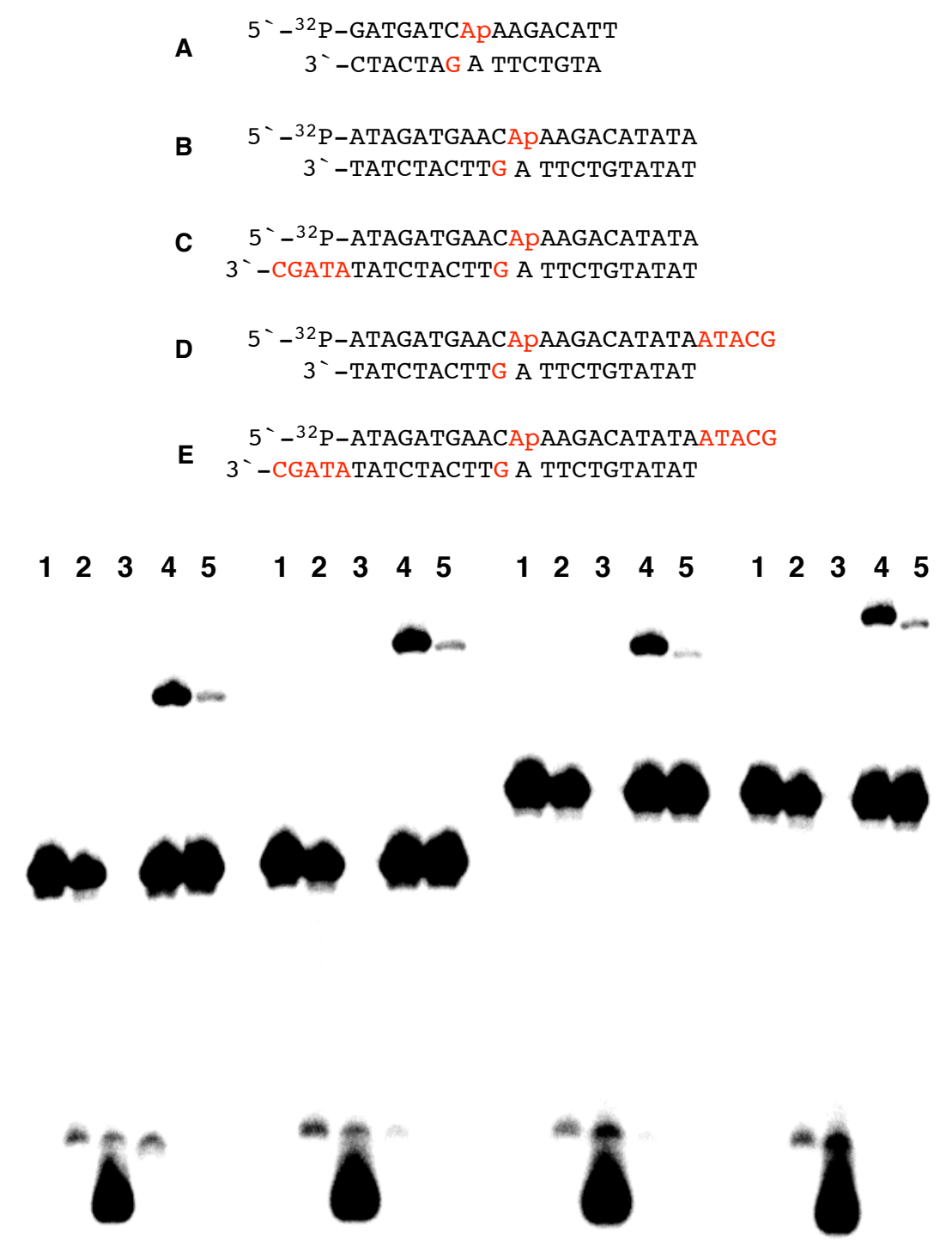

Figure 1. Interstrand cross-link formation in duplexes B-E under conditions of reductive amination. Duplex B, lanes 1-5, C, lanes 6-10, D, lanes 11-15, and E, lanes 16-20. The uracil-containing precursor 2'-deoxyoligonucleotides appear in lanes 1, 6, 11, and 16 . The abasic-site-containing duplexes without further incubation appear in lanes 2, 7, 12, and 17. The abasic-site-containing duplexes cleaved by treatment with piperidine ( $1 \mathrm{M}$, $95{ }^{\circ} \mathrm{C}$, for $25 \mathrm{~min}$ ) appear in lanes $3,8,13$, and 18). The cross-linking reactions involving incubation of the abasic-site-containing duplex in sodium acetate buffer (750 $\mathrm{mM}, \mathrm{pH}$ 5.2) and $\mathrm{NaCNBH}_{3}(250 \mathrm{mM})$ at $37{ }^{\circ} \mathrm{C}$ appear in lanes $4,9,14$, and 19 . The abasic-site-containing duplexes in sodium acetate buffer $\left(750 \mathrm{mM}\right.$, pH 5.2), $\mathrm{NaCNBH}_{3}$ $(250 \mathrm{mM})$, and methoxyamine hydrochloride $(2 \mathrm{mM})$ at $37^{\circ} \mathrm{C}$ appear in lanes $5,10,15$, and 20 . The ${ }^{32} \mathrm{P}$-labeled 2'-deoxyoligonucleotides were resolved on a sequencing gel and the radioactivity in each band quantitatively measured by phosphorimager analysis. 
We generated duplexes B-E (Figure 1), containing authentic Ap sites by treatment of the corresponding 2'-deoxyuridine-containing 2'-deoxyoligonucleotide duplexes with uracil DNA glycosylase (UDG) ${ }^{28-30}$ Prior to annealing and treatment with UDG, the uracil-containing strand of the duplexes B-E were $5{ }^{3}-{ }^{32} \mathrm{P}$-labeled using standard methods to allow detection of the products following separation on $20 \%$ denaturing polyacrylamide gels (PAGE). ${ }^{31}$

Incubation of 21-base pair duplex B in NaOAc buffer $(\mathrm{pH} 5.2,750 \mathrm{mM})$ with $\mathrm{NaCNBH}_{3}(250 \mathrm{mM})$ at $37{ }^{\circ} \mathrm{C}$ over a $24 \mathrm{~h}$ produced substantially greater cross-link yield $(\sim 20 \%)$. These cross-link reactions are analyzed by $20 \%$ denaturing PAGE as described in Chapter 2 and Figure 1 displays a representative gel of the results. Uracil-containing DNA (lanes 1, 6, 11, and 16, Figure 1) were treated with UDG (50 U/mL, 45-90 min, 37 $\left.{ }^{\circ} \mathrm{C}\right)$ (lanes 2, 7, 12, and 17, Figure 1) and incubated further with the aforementioned conditions with $\mathrm{NaOAc}$ and $\mathrm{NaCNBH}_{3}$ (lanes 4, 9, 14, and 19, Figure 1) to yield slower moving bands for each duplex. Piperidine cleavage (lanes 3, 8, 13, and 18, Figure 1) of Ap-containing DNA showed full uracil to Ap conversion. Inhibition by the aldehyde trapping agent methoxyamine $\left(\mathrm{CH}_{3} \mathrm{ONH}_{2} \bullet \mathrm{HCl}, 2 \mathrm{mM}\right.$, Scheme 3) (lanes 5, 10, 15, and 20, Figure 1) further provided evidence that the aldehyde is involved in the formation of the slow moving band indicative of cross-linked DNA.

Installment of the 5-base pair tails to each of the strands resulted in gel shifts of either the bands corresponding to single strand DNA, the slower moving cross-linked bands, or both depending on where the tail was attached. If the tail is attached to the complimentary strand (duplex $\mathbf{C}$, lanes 6-10) only the cross-linked band was gel shifted. When the tail is incorporated on the uracil/Ap-containing strand (duplex $\mathbf{D}$, lanes 11-15) the bands corresponding to full-length single strand DNA shifts as well as the band 
corresponding to cross-linked DNA. Finally, placing the tail on both strands (duplex E, lanes 16-20) of the duplex resulted in an even greater shift in the cross-linked DNA band. These results provide proof that the slower moving bands (lanes 4, 9, 14, and 19) contains both oligonucleotide strands (the ${ }^{32} \mathrm{P}$-labeled Ap-containing and complimentary strands) indicative of a DNA interstrand cross-link.

We tested to see if both the pH $5.2 \mathrm{NaOAc}$ buffer and $\mathrm{NaCNBH}_{3}$ for were required for significant detection of cross-link. We obtained highest crosslink yields when incubating Ap-containing duplex $\mathbf{B}$ in the combination of $\mathrm{NaOAc}$ buffer $(\mathrm{pH}$ 5.2, $750 \mathrm{mM})$ and $\mathrm{NaCNBH}_{3}(250 \mathrm{mM})$ at $37{ }^{\circ} \mathrm{C}$. The reaction conditions were optimized to achieve the highest yields of reduced cross-link. Additionally incubating duplex $\mathbf{B}$ with either pH 5.2 NaOAc buffer or $\mathrm{NaCNBH}_{3}$ alone did not yield significant reduced crosslink. Additionally, incubation of Ap-containing duplex $\mathbf{B}$ in neutral $\mathrm{pH} 7 \mathrm{NaOAc}$ buffer in the presence of $\mathrm{NaCNBH}_{3}$ did not yield significant cross-link as well. This is an interesting result, suggesting that the slightly acidic $\mathrm{pH}$ facilitates cross-link capture by $\mathrm{NaCNBH}_{3}$. It is known that imine formation is catalyzed by acid (and base), equilibrating faster at $\mathrm{pH}$ 's closer to 5 or lower. ${ }^{32-33}$

A time-course of formation for this presumably reduced dG-Ap cross-link was performed (Figure 2). We determine that under the reductive amination conditions, highest yields of the cross-link are obtained after 24 hours incubation ( 20\%), with an apparent half-time to completion of $\sim 4.5$ hours. Presumably competing reduction of the aldehyde by $\mathrm{NaCNBH}_{3}$ prevented higher yields from being obtained. 


\section{Figure 2}

A
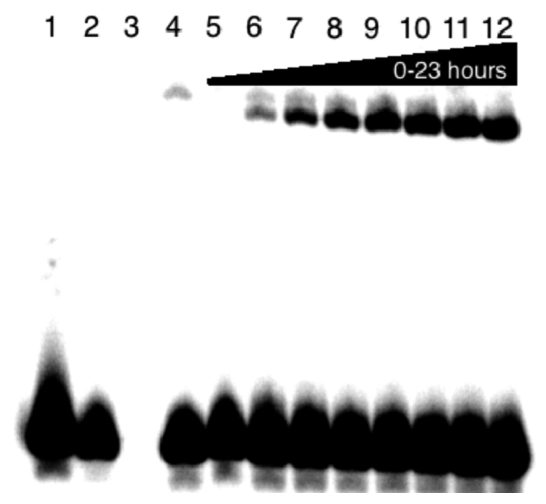

B

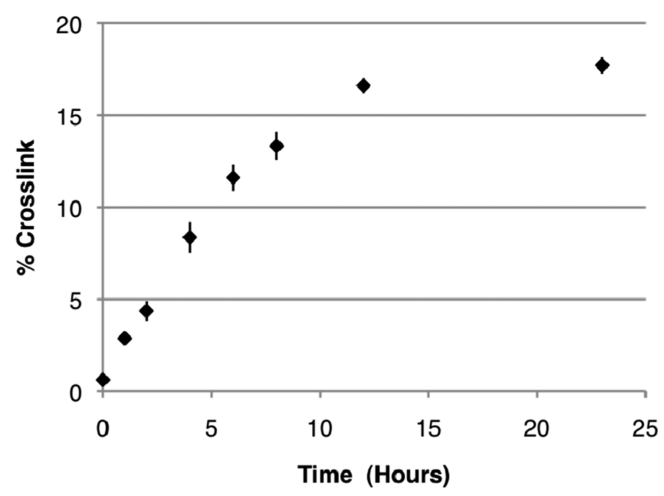

Figure 2. Time course for the formation of cross-linked duplex $\mathbf{B}$ under conditions of reductive amination. Duplex $\mathbf{B}$ was incubated in sodium acetate buffer $(750 \mathrm{mM}, \mathrm{pH}$ 5.2) and $\mathrm{NaCNBH}_{3}(250 \mathrm{mM})$ at $37^{\circ} \mathrm{C}$ and at $0,1,2,4,6,8,12$, and $23 \mathrm{~h}$ aliquots were removed from the reaction and frozen prior to sequencing gel analysis (lanes 5-12). The lower bands correspond to the full length labeled 2'-deoxyoligonucleotides and the upper band correspond to the cross-linked DNA. Lane 1 is the ${ }^{32} \mathrm{P}$-labeled uracil-containing precursor 2'-deoxyoligonucleotide, lane 2 is the ${ }^{32} \mathrm{P}$-labeled abasic-site-containing duplex without incubation, and lane 3 is the ${ }^{32} \mathrm{P}$-labeled abasic-site-containing duplexes cleaved by treatment with piperidine $\left(1 \mathrm{M}, 95{ }^{\circ} \mathrm{C}\right.$, for $\left.25 \mathrm{~min}\right)$. Lane 4 is the abasic-sitecontaining duplex incubated in HEPES buffer $(50 \mathrm{mM}, \mathrm{pH} 7)$ and $\mathrm{NaCl}(100 \mathrm{mM})$ for 24 $\mathrm{h}$ at $37^{\circ} \mathrm{C}$. The ${ }^{32} \mathrm{P}$-labeled 2'-deoxyoligonucleotides were resolved on a sequencing gel and the radioactivity in each band quantitatively measured by phosphorimager analysis. 
Figure 3

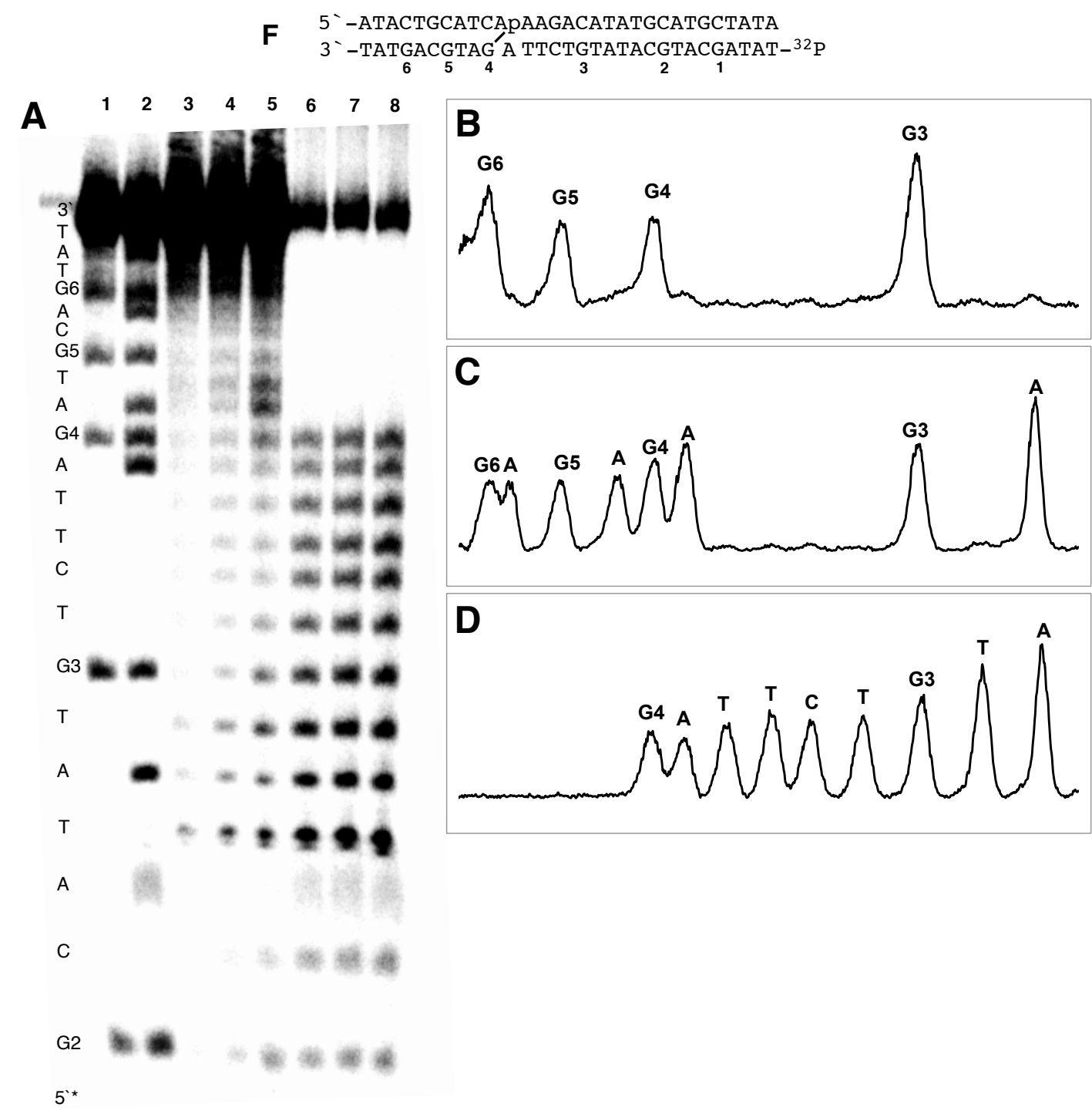

Figure 3. Hydroxyl radical footprinting of duplex $\mathbf{F}$ to locate the site of cross-link attachment. Lane 1 is a Maxam-Gilbert G-specific cleavage (sequencing) reaction of the labeled 2'-deoxyoligonucleotide strand in duplex $\mathbf{F}$. Lane 2 is an $A+G$ specific cleavage (sequencing) reaction of the labeled 2'-deoxyoligonucleotide strand in duplex $\mathbf{F}$. Lanes 3-5 the hydroxyl radical footprinting reaction of the labeled 2'-deoxyoligonucleotide strand in duplex F. Lanes 6-9 are the hydroxyl radical footprinting reaction of the slowmigrating, cross-link band generated by incubation of duplex $\mathbf{F}$ in sodium acetate buffer $\left(750 \mathrm{mM}, \mathrm{pH}\right.$ 5.2) and $\mathrm{NaCNBH}_{3}(250 \mathrm{mM})$ at $37{ }^{\circ} \mathrm{C}$. The ${ }^{32} \mathrm{P}$-labeled 2'deoxyoligonucleotides were resolved on a sequencing gel and visualized by phosphorimager analysis.(Panel A) and used to develop densitometry traces (Panels BD). Panel B is the trace of lane 1. Panel C is the trace of lane 2. Panel D is the trace of lane 4. 
To provide evidence that the cross-link obtained involved adduction of the deoxyguanine residue (Figure 1) onto the Ap-site, and not some other base of the DNA duplex we conducted two experiments to test this. One to identify that the guanine was the base attached to the Ap-site, and the second showing the attachment was at the exocyclic $\mathrm{N}^{2}$-amino group of guanine. The first experiment involved hydroxyl radical footprinting of the crosslink generated with duplex $\mathbf{F}$. Isolated cross-linked duplex $\mathbf{F}$ was subjected to cleavage by $\mathrm{H}_{2} \mathrm{O}_{2}$-iron-EDTA, ${ }^{34-35}$ and the resulting mixture of labeled DNA fragments as a "ladder" resolved on a sequencing gel. In this experiment, the presence of a cross-link results in an interruption of the "ladder" of DNA fragments at the site of cross-link attachment. Placement of the ${ }^{32} \mathrm{P}$-label on the opposing strand identifies which DNA base provided the attachment between both strands. Duplex $\mathbf{F}$ generated similar yields of crosslink to duplex B-E, and the longer duplex moved important bands out of a "salt-flare" zone for clearer results. Here, we observed a clear interruption in the fragment ladder at $\mathrm{G}_{4}$ of the labeled strand (Figure 3 and 4). This result provided specific evidence that the cross-link extends from the Ap site to the opposing guanine residue in the central 5'-CAp sequence of this duplex (Scheme 2).

Figure 4

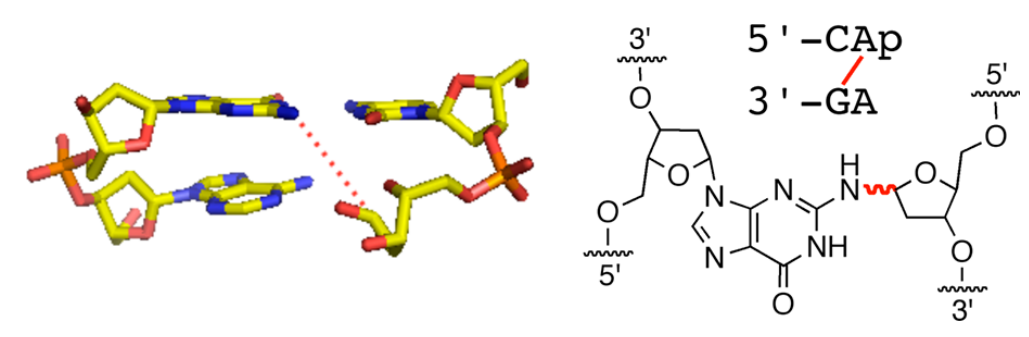

Figure 4. Molecular modeling of a 5'-CAp base paired sequence 
To show that the exocyclic amine of guanine (Figure 4) is the site of attachment, we substituted the guanine in the $5{ }^{`}$-CApA duplex B for a non-natural DNA base inosine (Figure 5, duplex G). This substitution results in the specific loss of the $\mathrm{N}^{2}$-amino group of guanine (structure shown in Figure 5). Incubation of duplex $\mathbf{G}$ in NaOAc buffer ( $\mathrm{pH}$ $5.2,750 \mathrm{mM}$ ) with $\mathrm{NaCNBH}_{3}(250 \mathrm{mM})$ at $37^{\circ} \mathrm{C}$ (Figure 5, lane 4) did not yield the same slow moving cross-link band as duplex $\mathbf{B}$ under the same conditions (lane 3). This result provided further evidence for the involvement of the guanine residue, specifically the N2amino group in cross-link formation at the 5'-CAp sequences in duplexes B-E.

\section{Figure 5}

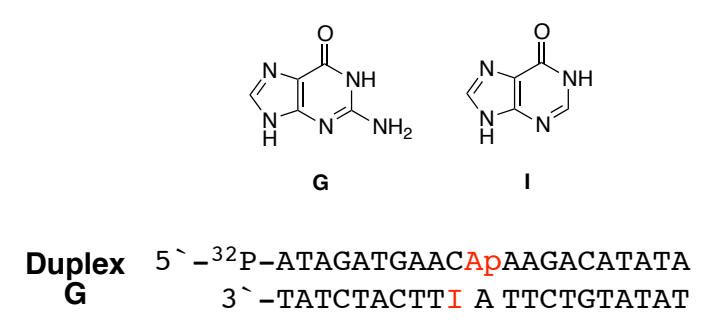

$\begin{array}{llll}1 & 2 & 3 & 4\end{array}$

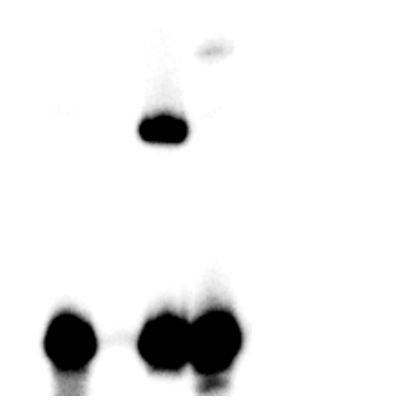

Figure 5. Cross-link formation was abrogated by replacement of the opposing guanine residue in the 5'-CAp sequence with an inosine residue. The lower bands correspond to the ${ }^{32}$ P-labeled full length labeled 2'-deoxyoligonucleotides and the upper band crosslinked 2'-deoxyoligonucleotides. Lane 1 is the abasic-site-containing duplex $\mathbf{B}$ without incubation. Lane 2 is the abasic-site-containing duplex $\mathbf{B}$ cleaved by treatment with piperidine $\left(1 \mathrm{M}, 95^{\circ} \mathrm{C}, 25 \mathrm{~min}\right)$. Lane 3 is duplex $\mathbf{B}$ incubated in sodium acetate buffer (750 mM, pH 5.2) and $\mathrm{NaCNBH}_{3}(250 \mathrm{mM})$ at $37^{\circ} \mathrm{C}$. Lane 4 is duplex $\mathbf{G}$ incubated in NaOAc buffer $(750 \mathrm{mM}, \mathrm{pH} 5.2)$ and methoxyamine $(250 \mathrm{mM})$ at $37^{\circ} \mathrm{C}$. The ${ }^{32} \mathrm{P}$-labeled 2 '-deoxyoligonucleotides were resolved on a sequencing gel and the radioactivity in each band quantitatively measured by phosphorimager analysis. The image shows the region of the gel where full-length oligonucleotide and cross-link migrate. 


\subsection{MALDI Mass Spectrometric Analysis of Reduced Cross-Link}

We prepared a cross-link of duplex $\mathbf{B}$ without the $5{ }^{3}{ }^{32} \mathrm{P}$ group on the Apcontaining strand, using our reductive amination conditions in $\mathrm{NaOAc}$ buffer $(\mathrm{pH} 5.2$, $750 \mathrm{mM})$ with $\mathrm{NaCNBH}_{3}(250 \mathrm{mM})$ at $37^{\circ} \mathrm{C}$. Preparative gel electrophoresis was used to separate the cross-linked material from the native single strands, and the DNA was visualized in the gel by UV-shadowing against a fluorescent TLC plate. The slowmoving, cross-linked band was excised and eluted from the gel, and further purified by desalting using a $\mathrm{C} 18$ cartridge, and precipitating in ethanol. MALDI-TOF mass spectrometric analysis (Figure 6) of the DNA obtained in this manner gave a strong signal that closely matched that expected for a reduced cross-link structure $\mathbf{1 0}$ such as in Scheme 3. We observed an $\mathrm{m} / \mathrm{z}$ for $[\mathrm{M}-\mathrm{H}]^{-}=12,720.8$ with a calculated $[\mathrm{M}-\mathrm{H}]^{-}$ $=12,721.5$. This equates to a relative mass error of $55 \mathrm{ppm}$.

\section{Figure 6}

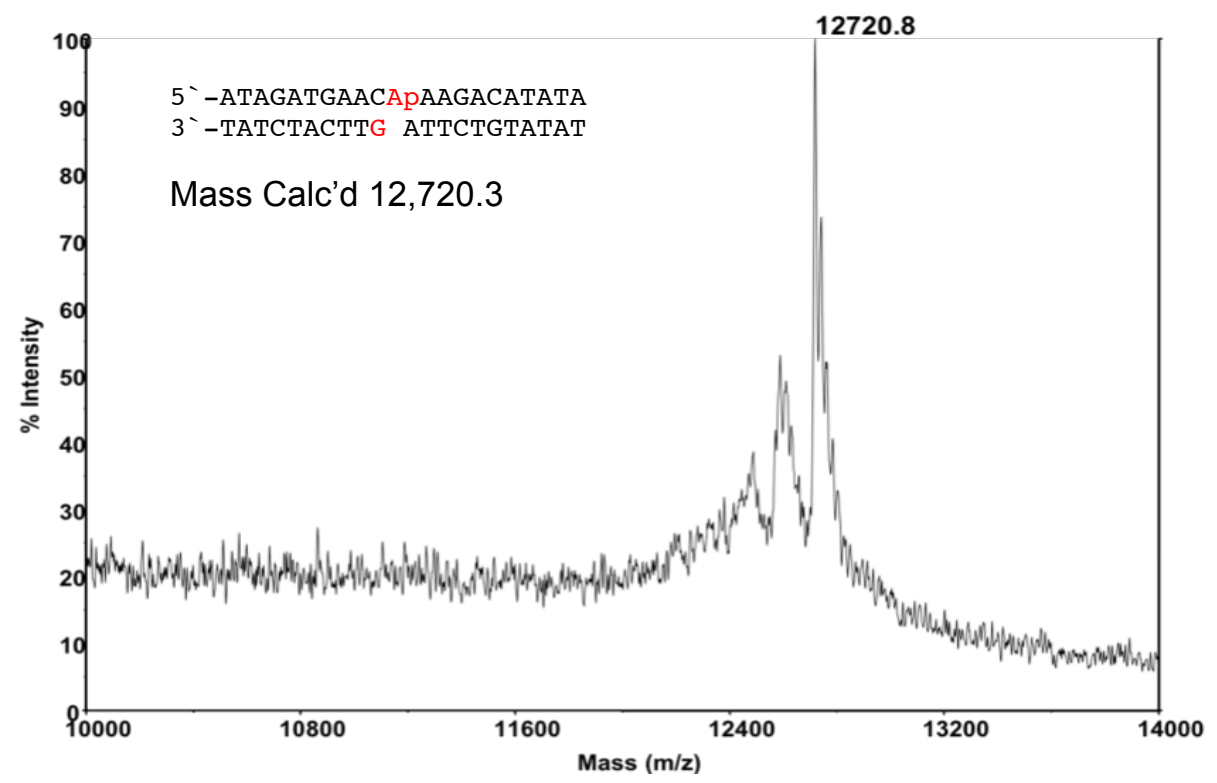

Figure 6. MALDI-MS of the $\mathrm{dG}$ cross-linked duplex $\mathbf{B}$ formed under reductive amination conditions using duplex B. 


\subsection{Cross-Linking of Ap-Containing DNA in Neutral Aqueous Solution}

We examined formation of dG-Ap cross-links in the absence of reducing agent under neutral, more biologically relevant conditions. So we incubated Ap-containing duplex $\mathbf{B}$ in HEPES buffer $(\mathrm{pH} 7,50 \mathrm{mM})$ and $\mathrm{NaCl}(100 \mathrm{mM})$ at $37^{\circ} \mathrm{C}$ and analyzed reaction on denaturing PAGE like before. Under these conditions, we saw a slowmigrating band of low yield $(\sim 2 \%)$ in the region where the previously characterized reduced cross-link duplex migrated (lane 5, Figure 7 and lane 4, Figure 2). Incubation in the presence of methoxyamine $\left(\mathrm{CH}_{3} \mathrm{ONH}_{2} \bullet \mathrm{HCl}, 2 \mathrm{mM}\right)$ inhibited the formation of this slow moving band (lane 4, Figure 7). Similarly to the previous section, incubation of duplex $\mathbf{G}$ containing the inosine residue in the $5{ }^{`}$-CApA sequence under neutral $\mathrm{pH}$ did not yield this slow moving band (lane 9). Together these results suggest that this slowmoving band was an unreduced dG-Ap interstrand cross-link, as the ability to form the reduced alkyl amine linkage is indicative of an unreduced imine cross-link. This native cross-link must be an intermediate captured under reductive amination conditions.

The native, unreduced cross-link could be resolved from the reduced cross-link using a $20 \%$ denaturing polyacrylamide gel when the products are run at least $12 \mathrm{~cm}$ from the well. Figure $\mathbf{8}$ shows a gel with clear separation of the unreduced cross-link (lanes 1 and 2) from the reduced cross-link (lanes 2 and 3). It is interesting to note how such a small change in structure could lead to a significant gel shift. As shown in Scheme 3, the unreduced cross-link would likely be stabilized in the closed-ring hemiaminal form $\mathbf{9}$, as opposed to an open ring imine species $\mathbf{8}$. On the other hand, reducing the imine intermediate (10) secures the linkage, and prevents cyclization of the deoxyribose sugar. This in turn gives the reduced cross-link more "reach" and flexibility 
to travel through the gel slightly faster. A comparison of the reduced and unreduced dG-

Ap linkage is discussed further in the next section.

\section{Figure 7}

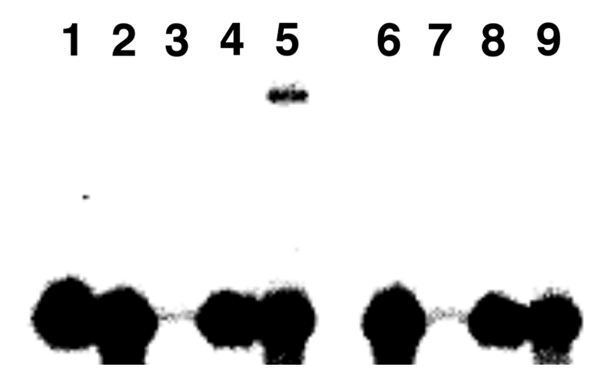

Figure 7. Detection of native (unreduced) dG-Ap cross-link duplex $\mathbf{B}$ and evidence that replacement of the opposing guanine residue in the 5'-CAp sequence of duplex $\mathbf{B}$ with inosine in duplex $\mathbf{G}$ abrogates cross-link formation. The lower bands correspond to the full-length ${ }^{32} \mathrm{P}$-labeled 2'-deoxyoligonucleotides and the upper band cross-linked DNA. Lane 1 is the uracil-containing precursor of duplex $\mathbf{B}$. Lane 2 is the abasic-sitecontaining duplex $\mathbf{B}$ without incubation. Lane 3 is the abasic-site-containing duplex $\mathbf{B}$ cleaved by treatment with piperidine $\left(1 \mathrm{M}, 95^{\circ} \mathrm{C}, 25 \mathrm{~min}\right)$. Lane 4 is duplex $\mathbf{B}$ incubated in with methoxyamine hydrochloride $(2 \mathrm{mM})$ in HEPES buffer $(50 \mathrm{mM}, \mathrm{pH} 7)$ containing $\mathrm{NaCl}(100 \mathrm{mM})$ at $37^{\circ} \mathrm{C}$. Lane 5 is duplex $\mathbf{B}$ incubated in HEPES buffer $(50 \mathrm{mM}, \mathrm{pH} 7)$ containing $\mathrm{NaCl}(100 \mathrm{mM})$ at $37{ }^{\circ} \mathrm{C}$. Lane 6 is the abasic-site-containing duplex $\mathbf{G}$ without incubation. Lane 7 is the abasic-site-containing duplex $\mathbf{G}$ cleaved by treatment with piperidine $\left(1 \mathrm{M}, 95{ }^{\circ} \mathrm{C}, 25 \mathrm{~min}\right)$. Lane 8 is duplex $\mathbf{G}$ incubated in with methoxyamine hydrochloride $(2 \mathrm{mM})$ in HEPES buffer $(50 \mathrm{mM}, \mathrm{pH}$ 7) containing $\mathrm{NaCl}$ $(100 \mathrm{mM})$ at $37^{\circ} \mathrm{C}$. Lane 9 is duplex $\mathbf{G}$ incubated in HEPES buffer $(50 \mathrm{mM}, \mathrm{pH} 7)$ containing $\mathrm{NaCl}(100 \mathrm{mM})$ at $37{ }^{\circ} \mathrm{C}$. The ${ }^{32} \mathrm{P}$-labeled 2'-deoxyoligonucleotides were resolved on a sequencing gel and the radioactivity in each band quantitatively measured by phosphorimager analysis. The image shows the region of the gel where full-length oligonucleotide and cross-link migrate. 


\section{Figure 8}

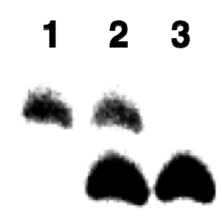

Figure 8. The reduced and unreduced dG-Ap cross-linked duplexes can be resolved by gel electrophoresis. Lane 1 is the native (unreduced) cross-link generated by incubation of duplex B in HEPES buffer $(50 \mathrm{mM}, \mathrm{pH} 7)$ containing $\mathrm{NaCl}(100 \mathrm{mM})$ at $37{ }^{\circ} \mathrm{C}$ for $3 \mathrm{~d}$. Lane 2 is a mixture of the native (Lane 1) and reduced (Lane 3) cross-links. Lane 3 is the reduced cross-link generated by incubation of duplex $\mathbf{B}$ in sodium acetate buffer (750 $\mathrm{mM}, \mathrm{pH}$ 5.2) and $\mathrm{NaCNBH}_{3}(250 \mathrm{mM})$ at $37{ }^{\circ} \mathrm{C}$ for $1 \mathrm{~d}$. The image shows the region of the gel where the cross-link migrates.

\subsection{Formation and Stability of the Native Unreduced dG-Ap Cross-Link}

Presumably the unreduced native cross-link would be reversible, as imine formation is described to exist in aqueous media as equilibrium mixtures of amine, aldehyde, hemiaminal and imine (Scheme 3). ${ }^{32-33,36}$ So unreduced cross-link reactions are described in terms of equilibrium yields. We expect this is a major contributor to why the unreduced cross-link yield is low. Incubation of duplex $\mathbf{B}$ in HEPES buffer $(\mathrm{pH} 7,50$ $\mathrm{mM})$ and $\mathrm{NaCl}(100 \mathrm{mM})$ revealed that the native (unreduced) dG-Ap cross-link formed quickly. A time course showed us that easily detectable amount of cross-link formed within the first $1 \mathrm{~h}$ of incubation at $37^{\circ} \mathrm{C}$, and often during the Ap-site generation by UDG from uracil-containing DNA duplex. In fact, incubation under the neutral conditions provided us with an apparent half-time to completion of the cross-linking reaction was less than $24 \mathrm{~h}$ (Figure 9). This rapid formation indicates that this cross-link should be biologically significant. Knowing the approximate rate of Ap-site formation in cells and number of DNA bases in the genome, this rapid cross-link formation indicates great biological significance towards cell proliferation. 


\section{Figure 9}

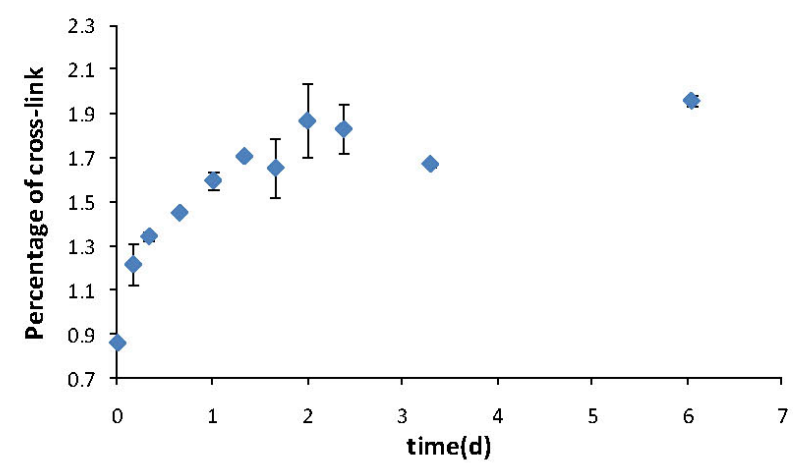

Figure 9. Time course for the formation of the native (unreduced) dG-Ap cross-link. Duplex B was incubated in HEPES buffer $(50 \mathrm{mM}$, pH 7) containing $\mathrm{NaCl}(100 \mathrm{mM})$ at $37^{\circ} \mathrm{C}$. At various times aliquots were removed and the DNA ethanol precipitated. The ${ }^{32} \mathrm{P}$-labeled 2'-deoxyoligonucleotides were resolved on a sequencing gel, the radioactivity in each band quantitatively measured by phosphorimager analysis, and the yield of slowmigrating (cross-linked DNA) band plotted versus time. Time $=0$ was defined as the end of the $1.5 \mathrm{~h}$ reaction of the uracil-containing $\mathbf{B}$ duplex with UDG to generate the Apcontaining duplex B. Detectable amounts of cross-link were already evident at this time.

We were interested to determine the viability of these cross-links for use in additional experiments. Following cross-link formation, the reaction mixtures were subjected to a variety of post-formation conditions. We exposed the cross-links reaction mixtures with heat, dilute piperidine, acidic or basic buffers, as well as various amines for 15 min each and the resulting mixtures analyzed by PAGE. The remaining yield of cross-link for each treatment were normalized against untreated control samples (Figure 10, panel A), run side-by-side in an analytical polyacrylamide gel. We found that the unreduced cross-link was by diminished slightly by $60{ }^{\circ} \mathrm{C}$ heat and significantly in $90{ }^{\circ} \mathrm{C}$. NaOAc buffer (pH 3, $25 \mathrm{mM}$ ) had no effect on cross-link yield, whereas phthalate buffer (pH 10, $25 \mathrm{mM}$ ) buffer increased overall cross-link yield slightly. Dilute piperidine (100 $\mathrm{mM}$ ) treatment at $60{ }^{\circ} \mathrm{C}$ decreased unreduced cross-link yield significantly as well. The reduced cross-link was not affected by these post-formation treatments, consistent with 
reduction of a reversible-imine linkage into a more robust alkyl-amine bond. The stability of the reduced cross-link makes it useful as a model for further studies in DNA repair and polymerization studies (provided in Chapter 4).

The unreduced cross-link was additionally treated with DMEDA, methoxyamine, and hydrazine $(20 \mathrm{mM})$ at room temperature. We expected cross-link yield to diminish for all three amine treatments, each acting as aldehyde trapping agents and reversing the equilibrium to give lower cross-link yields. Instead we find that both DMEDA and hydrazine increased the total cross-link while only methoxyamine decreased the yield slightly.

As we already described the formation of Ap-derived cross-links as an equilibrium reaction, it should hold that the decay would be as well. We wanted to see how fast "isolated" unreduced dG-Ap cross-links return to equilibrium yields. The low yield of the cross-link does not allow for easy isolation by gel purification. Additionally a series of purification steps most likely would result in substantial cross-link decay. So instead we used a different approach, instead of isolating the cross-link, we "removed" all un-reacted Ap-containing SS DNA. We did by treating the cross-link mixture after incubation with Apurinic Endonuclease 1 (APE1), an enzyme that selectively catalyzes single-strand breaks on Ap-containing DNA.37-38 After incubation with APE1, the resulting mixture was further incubated in HEPES $(50 \mathrm{mM}, \mathrm{pH} 7)$ and $\mathrm{NaCl}(100 \mathrm{mM})$ at $37{ }^{\circ} \mathrm{C}$ with aliquots taken at various time-points and separated on a $20 \%$ denaturing polyacrylamide gel. The time course shows the cross-link returns to equilibrium yield after $\sim 48$ hours, with a half-life of $14.7 \pm 0.9$ hours. This measurement tells us that the cross-link decays at a comparable rate to which it forms. This is consistent with an imine equilibrium, the formation and reversal thereof..$^{36,39}$ 
Figure 10
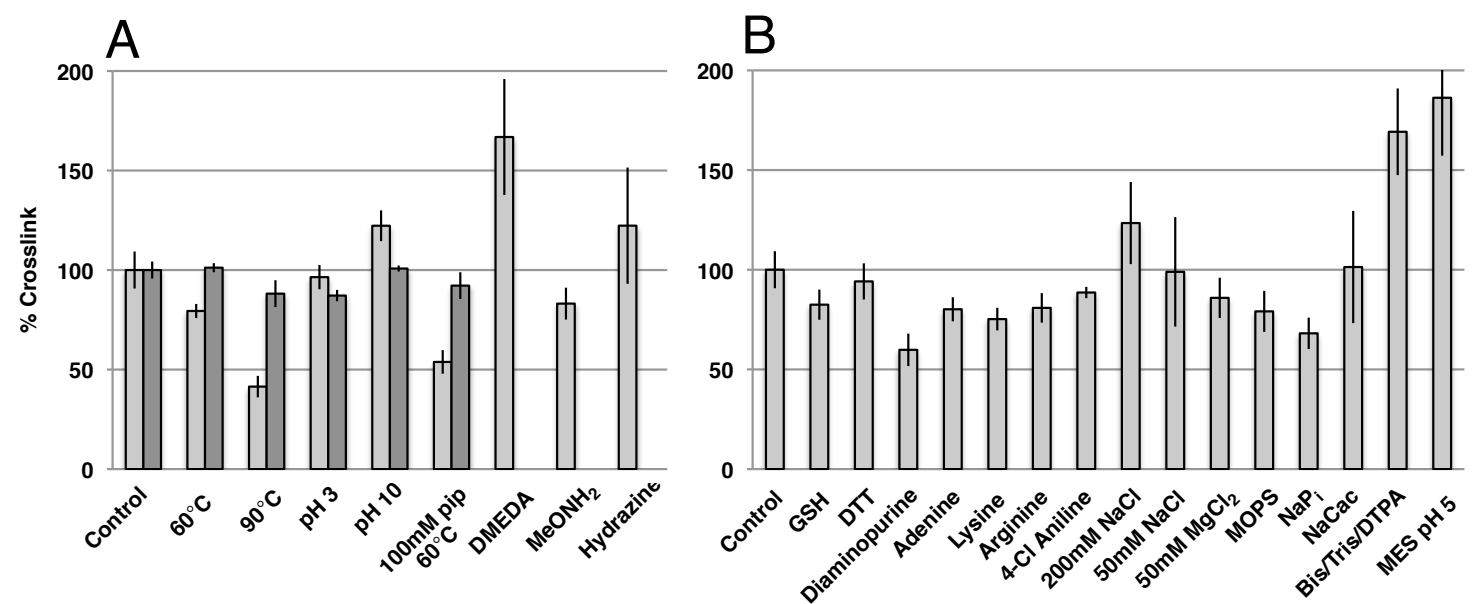

Figure 10. Stability of the reduced and native dG-Ap cross-link in duplex DNA against various post-formation conditions (panel A) and relative yield of the native (unreduced) cross-link formed under various reaction conditions (panel B). The light gray bars represent the relative yields of unreduced cross-link and the dark gray bars represent the relative yields of reduced cross-link. The yields of native (unreduced) cross-link obtained in reactions examining the formation and stability of native cross-link were normalized against a standard control cross-linking reaction involving incubation of duplex $\mathbf{B}$ in HEPES buffer $(50 \mathrm{mM}, \mathrm{pH} 7)$ containing $\mathrm{NaCl}(100 \mathrm{mM})$ at $37{ }^{\circ} \mathrm{C}$. Similarly, reactions examining the stability of the reduced cross-link were normalized against a standard control cross-linking reaction involving incubation of duplex $\mathbf{B}$ in sodium acetate buffer $(750 \mathrm{mM}, \mathrm{pH} 5.2)$ and $\mathrm{NaCNBH}_{3}(250 \mathrm{mM})$ at $37{ }^{\circ} \mathrm{C}$. Following formation of the cross-links, the reaction mixtures were subjected to the following workup conditions as shown from left to right in Panel A: $60{ }^{\circ} \mathrm{C}, 15 \mathrm{~min} ; 90{ }^{\circ} \mathrm{C}, 15 \mathrm{~min}, \mathrm{pH}$ adjusted to 3, $15 \mathrm{~min}$; $\mathrm{pH}$ adjusted to $10,15 \mathrm{~min} ; 100 \mathrm{mM}$ piperidine, $60^{\circ} \mathrm{C}, 15 \mathrm{~min}$; $N, N$-dimethylethylenediamine $(20 \mathrm{mM}, 15 \mathrm{~min})$; methoxyamine hydrochloride $(20 \mathrm{mM}$, $15 \mathrm{~min})$; and hydrazine sulfate $(20 \mathrm{mM}, 15 \mathrm{~min})$. Panel B. The formation of native cross-link was examined under various conditions. These experiments examine the effects of different conditions during the cross-linking reaction. Yields relative to a standard cross-linking reaction involving incubation of duplex $\mathbf{B}$ in HEPES buffer (50 $\mathrm{mM}, \mathrm{pH} 7)$ containing $\mathrm{NaCl}(100 \mathrm{mM})$ at $37{ }^{\circ} \mathrm{C}$ (labeled "Control"). The conditions shown from left to right in Panel B are: std reaction with glutathione $(1 \mathrm{mM})$; dithiothreitol $(1 \mathrm{mM})$, diaminopurine $(1 \mathrm{mM})$, adenine $(1 \mathrm{mM})$, lysine $(1 \mathrm{mM})$, arginine $(1 \mathrm{mM})$, or 4-chloroaniline $(1 \mathrm{mM})$. The reactions examining salt effects contained HEPES (50 mM, pH 7) and $\mathrm{NaCl}(200 \mathrm{mM}$ or $50 \mathrm{mM})$ or $\mathrm{MgCl}_{2}(50 \mathrm{mM})$. The reactions carried out in different buffers did not employ HEPES, rather contained $\mathrm{NaCl}(100 \mathrm{mM})$ and MOPS (50 mM, pH 7), sodium phosphate $(50 \mathrm{mM}, \mathrm{pH} 7)$, sodium cacodylate (50 $\mathrm{mM}, \mathrm{pH} 7)$, Bis-tris (25 mM, pH 7), DTPA (5 mM), sodium acetate (5 mM), or MES (50 $\mathrm{mM}, \mathrm{pH}$ 5.0). 
We felt it necessary to show that this cross-link could form under a variety of reaction conditions (buffers and salts), and in the presence of biologically relevant nucleophiles. Figure 10B summarizes the conditions used and nucleophiles included. Essentially we find that the dG-Ap cross-link will form in the presence of biologically relevant thiols such as GSH and amines like adenine and lysine. The cross-link yield was affected significantly by salt concentration and buffer identity. Higher salt concentrations tend to increase cross-link yields, consistent with increased DNA duplex flexibility from relieved charged repulsion of negatively charged phosphates. ${ }^{40-41}$ Additionally it seems that carboxylate-containing buffers (DTPA) lower $\mathrm{pH}$ buffers ( $\mathrm{pH}$ 5) also increase crosslink yield. Imine formation has been shown to be catalyzed by acetate. ${ }^{32}$

\subsection{Chapter 3 Summary}

The experiments described here examined the formation and properties of interstrand dG-Ap cross-links formed at 5'-CAp sequences in duplex DNA. Other groups have characterized related cross-links generated by oxidized Ap sites in DNA; ${ }^{42-44}$ however, it is important to emphasize that the structure and reactivity of the oxidized Ap sites are distinct from that of the "native" Ap site that is the focus of our work.

We found that incubation of DNA duplexes containing an abasic-site in a 5'-CAp sequence under physiologically-relevant conditions in the absence of reducing agents yields detectable amounts of a slow-moving cross-linked duplex within $1 \mathrm{~h}$, monitored by denaturing polyacrylamide gel electrophoresis. A slow-moving band on the gel was indicative of an interstrand cross-link resulting from the reaction of the Ap-aldehyde group with the opposing guanine residue. Formation of this product was inhibited by methoxyamine capping of the Ap site and by an inosine-for-guanine replacement at the 
5'-CAp site. We hypothesize that the equilibrium formation of the cyclic hemiaminal 9

is favored and makes this cross-link more stable than a typical imine or hemiaminal linkage. Cross-link formation was not highly sensitive to buffer identity, salt concentration, or the presence of the biological thiol glutathione $(1 \mathrm{mM})$.

Incubation of duplexes containing an 5'-CAp sequence in the presence of the reducing agent $\mathrm{NaCNBH}_{3}$ in pH 5.2 buffer generated good yields $(20 \%)$ of a slowmoving band on denaturing polyacrylamide gels. The results of MALDI-TOF mass spectrometry, and gel mobility experiments provided evidence that the slow-moving band generated under these conditions of reductive amination did contain both full-length strands of the starting duplex. The cross-link generated under reducing conditions was structurally distinct from the native cross-link, as it could be resolved from the native unreduced cross-link on denaturing gels. Methoxyamine capping, inosine-for-guanine replacement, and hydroxyl radical footprinting further provided evidence that cross-link formation involved attachment of the Ap-aldehyde group to the opposing guanine residue at the 5'-CAp sequences. The cross-link generated under reducing conditions was stable against all of the workup conditions examined here (Figure 10, panel A).

Overall, we provided evidence consistent with the chemical mechanism for crosslink formation at 5'-CAp sequences illustrated in Scheme 3, in which reaction of the Apaldehyde residue with the N2-amino group of the opposing guanine residue yields hemiaminal, imine, or cyclic hemiaminal linkages (structures 7-10). Under conditions of reductive amination $\left(\mathrm{NaCNBH}_{3} / \mathrm{pH}\right.$ 5.2), equilibrium amounts of the imine can be irreversibly converted to the amine linkage. Le Chatelier's principle tells us that the reduced cross-link has the potential to accumulate beyond the equilibrium levels of its structures 9 and 10. The system is complex and irreversible reduction of the cross-link 
likely must compete with reduction of the abasic aldehyde and decomposition of reducing agent in solution.

The yields of the reduced dG-Ap cross-link obtained in this more recent work were substantially greater than those reported..$^{45}$ The Ap-containing duplexes used here were longer than the 15 bp duplexes employed in the original studies and it is possible that partial melting of the duplexes in our early work limited cross-link yields. In addition, in the $21 \mathrm{bp}$ duplex used here, a thymine rather than an adenine residue rests on the 3'-side of the guanine residue involved in the cross-linking reaction and it is shown in Chapter 4 that the flanking bases affect the cross-link yield. Finally, the sodium acetate buffer used in the current reductive amination experiments may catalyze cross-link formation. ${ }^{46-48}$

We believe that the exocyclic $\mathrm{N}^{2}$-amino group of guanine is the nucleophile that reacts with the Ap aldehyde to generate the dG-Ap cross-link as postulated in Scheme 2. A wealth of precedents show that the $\mathrm{N}^{2}$-amino group of guanine residues in DNA can react with aldehyde groups in small molecules to form covalent adducts (Scheme 2). ${ }^{49-53}$ At the same time, it is important to recognize chemical precedents showing that intramolecular reactions of aldehydes with endocyclic nitrogens can yield covalent adducts. ${ }^{52,54}$ Thus, the exact chemical structure of the dG-Ap cross-links remains uncertain and efforts are underway to synthesize authentic standards of the putative crosslinked nucleoside analogs of $\mathbf{9}$ and $\mathbf{1 0}$ for use in structure elucidation.

Our observations of Ap-derived interstrand DNA-DNA cross-links could be relevant to the cytotoxic and mutagenic properties of Ap sites in DNA. The highly deleterious nature of cross-links suggests that even small amounts of Ap-derived crosslinks could make a significant contribution to the overall biological effects stemming 
from the generation of Ap sites in cellular DNA. Some of the cross-linked duplexes reported here may be useful substrates for the study of cross-link repair. Overall, our results provide a foundation for future investigations of the structure, occurrence, and biological consequences of Ap-derived cross-links in cellular DNA.

\subsection{Experimental}

Materials and Methods. Oligonucleotides were purchased from Integrated DNA Technologies. T4-Polynucleotide Kinase and Uracil DNA Glycosylase were from New England Biolabs (Ipswich, MA, USA). $\left[\gamma_{-}{ }^{32} \mathrm{P}\right]$-ATP $(6000 \mathrm{Ci} / \mathrm{mmol})$ was purchased from Perkin Elmer. C-18 sep-pak cartridges were purchased from Waters and BS Polyprep columns were obtained from BioRad. Quantification of radioactivity in polyacrylamide gels was carried out using a Personal Molecular Imager (BIORAD) with Quantity One software (v.4.6.5). All other reagents were purchased from Sigma-Aldrich.

\section{Representative procedure for cross-link formation under conditions of reductive}

amination. Single-stranded 2'-deoxyoligonucleotides were 5'-labeled using standard procedures. $^{31}$ Labeled DNA was annealed ${ }^{31}$ with its complimentary strand and treated with the enzyme UDG (50 units $/ \mathrm{mL}$, final concentration) at $37{ }^{\circ} \mathrm{C}$ for $1.5 \mathrm{~h}$ to generate Ap-sites. The enzyme was removed by phenol-chloroform extraction. ${ }^{31}$ In individual cross-linking reactions, the Ap-containing double-stranded DNA was incubated in sodium acetate buffer $(750 \mathrm{mM}, \mathrm{pH} 5.2)$ containing $\mathrm{NaCNBH}_{3}(250 \mathrm{mM})$ at $37^{\circ} \mathrm{C}$ for 24 $\mathrm{h}$ unless otherwise specified. The DNA was ethanol precipitated from the reaction mixture, ${ }^{31}$ resuspended in formamide loading buffer, ${ }^{31}$ loaded onto a $20 \%$ denaturing polyacrylamide gel, and the gel electrophoresed for $4 \mathrm{~h}$ at $1000 \mathrm{~V}$. The amount of 
radiolabeled DNA in each band on the gel was measured by phosphorimager analysis.

The time course for the formation of the native cross-link was carried out by incubating a solution containing labeled DNA (approximately 200,000 cpm), sodium acetate buffer (750 mM, pH 5.2) containing $\mathrm{NaCNBH}_{3}(250 \mathrm{mM})$ at $37^{\circ} \mathrm{C}$. At specified time points, aliquots $(20 \mu \mathrm{L})$ were removed and frozen at $-20{ }^{\circ} \mathrm{C}$, followed by ethanol precipitation and gel analysis as described above.

\section{Representative procedure for cross-link formation at $\mathrm{pH} 7$ in the absence of} reducing agent. Duplex DNA containing a ${ }^{32} \mathrm{P}$-labeled Ap-containing strand, prepared as described above, was incubated in a buffer composed of HEPES (50 mM, pH 7) containing $\mathrm{NaCl}(100 \mathrm{mM})$ at $37^{\circ} \mathrm{C}$ for $72 \mathrm{~h}$ unless otherwise specified. The DNA was ethanol precipitated, resuspended in formamide loading buffer, loaded onto a $20 \%$ denaturing polyacrylamide gel, and the gel electrophoresed for $4 \mathrm{~h}$ at $1000 \mathrm{~V}$. Control experiments involving direct loading of cross-linking reactions showed that ethanol precipitation does not markedly alter the yield of the slow-migrating, cross-link band. The amount of radiolabeled DNA in each band on the gel was measured by phosphorimager analysis.

Hydroxyl radical footprinting of cross-linked duplexes. We employed literature protocols to footprint the cross-linked duplexes. ${ }^{42,}{ }^{55}$ In these experiments, the strand opposing the Ap-containing oligonucleotide was 5'-labeled using standard procedures. ${ }^{31}$ Labeled DNA was annealed with the uracil-containing complement and treated with UDG to generate the abasic site as described above. The Ap-containing double-stranded DNA $(\sim 500,000 \mathrm{cpm})$ was incubated in sodium acetate buffer $(750 \mathrm{mM}, \mathrm{pH} 5.2)$ 
containing $\mathrm{NaCNBH}_{3}(250 \mathrm{mM})$ at $37{ }^{\circ} \mathrm{C}$ for $24 \mathrm{~h}$. The DNA was ethanol precipitated, suspended in formamide loading buffer, and separated on a $0.4 \mathrm{~mm}$ thick $20 \%$ denaturing polyacrylamide gel. The slow-migrating cross-linked duplex band was visualized using X-ray film, the band cut out of the gel, the gel slice crushed, and the gel pieces vortexed in elution buffer ( $\mathrm{NaCl} 200 \mathrm{mM}$; EDTA, $1 \mathrm{mM}$ ) at room temperature for at least $1 \mathrm{~h}$. The mixture was filtered through a poly-prep column to remove gel fragments and the filtrate desalted using a C18 Sep-pak (100 mg size). The resulting solution was evaporated using a Speed-Vac concentrator, the residue redissolved in water $(24 \mu \mathrm{L})$, split evenly into three microcentrifuge tubes, and diluted with $2 x$ oxidation buffer $(10 \mu \mathrm{L}$ of a solution composed of sodium phosphate, $20 \mathrm{mM}, \mathrm{pH} 7.2 ; \mathrm{NaCl}, 20 \mathrm{mM}$; sodium ascorbate, 2 $\left.\mathrm{mM} ; \mathrm{H}_{2} \mathrm{O}_{2}, 1 \mathrm{mM}\right)$. To this mixture was added a solution of iron-EDTA $(2 \mu \mathrm{L}$, EDTA, $\left.70 \mathrm{mM} ; \mathrm{Fe}\left(\mathrm{NH}_{4}\right)_{2}\left(\mathrm{SO}_{4}\right)_{2} \cdot 6 \mathrm{H}_{2} \mathrm{O}, 70 \mathrm{mM}\right)$ to start the reaction, the mixture vortexed briefly, and incubated at room temperature for 1,2, and $3 \mathrm{~min}$ before addition of thiourea stop solution (10 $\mu \mathrm{L}$ of a $100 \mathrm{mM}$ solution in water). Hydroxyl radical footprinting reactions, Maxam-Gilbert G, and Maxam-Gilbert A+G reactions were performed on the labeled single-strand to generate marker lanes. ${ }^{56}$ The resulting DNA fragments were analyzed using gel electrophoresis as described above.

Preparation of reduced cross-linked duplexes for mass spectrometric analysis. An unlabeled version of DNA duplex B, prepared as described above, was incubated in sodium acetate ( $750 \mathrm{mM}, \mathrm{pH} 5.2)$ and $\mathrm{NaCNBH}_{3}(250 \mathrm{mM})$ at $37{ }^{\circ} \mathrm{C}$ for $24 \mathrm{~h}$. The DNA was ethanol precipitated, resuspended in formamide loading buffer, and the DNA fragments separated on a $20 \%$ denaturing polyacrylamide gel. DNA bands were visualized with UV-shadowing. The reduced crosslink band was cut out of the gel, the 
gel slice crushed, and the solution vortexed in elution buffer $(\mathrm{NaCl}, 1 \mathrm{M}$; EDTA, 500

$\mathrm{mM}, \mathrm{pH} 8$ ) at room temperature for at least $1 \mathrm{~h}$. The solution was filtered through a Polyprep column, the filtrate desalted using a C18 Sep-pak (100 mg size), and the DNA ethanol precipitated. MALDI-TOF mass spectrometric analyses were carried out on an AB Sciex Voyager DE ${ }^{\mathrm{TM}}$ Pro mass spectrometer (Framingham, MA). The aqueous sample solution was combined in a $1 / 1 / 1(\mathrm{~V} / \mathrm{V} / \mathrm{V})$ ratio with triammonium citrate $(0.1 \mathrm{M}$, aq) and $2^{\prime}, 4^{\prime}, 6^{\prime}$-trihydroxyacetophenone $(0.1 \mathrm{M}$ in acetonitrile) for application to a polished stainless steel target for analysis. Negative ion spectra were acquired over a mass range of 5-14 $\mathrm{kDa}$ at a $25 \mathrm{kV}$ accelerating potential in the linear delayed-extraction mode using an oligonucleotide of known mass as an external calibrant. ${ }^{57-58}$ 


\section{References}

1. Gates, K. S.; Nooner, T.; Dutta, S. Chem. Res. Toxicol. 2004, 17 (7), 839-56.

2. Gates, K. S. Chem. Res. Toxicol. 2009, 22 (11), 1747-60.

3. Lindahl, T.; Nyberg, B. Biochemistry 1972, 11 (19), 3610-8.

4. $\quad$ Nakamura, J.; Swenberg, J. A. Cancer Res 1999, 59 (11), 2522-6.

5. Nakamura, J. W., V. E.; Upton, P. B.; Chiang, S.; Kow, T. W; and Swenber, J. A Cancer Research 1998, 58.

6. David, S. S.; Williams, S. D. Chem. Rev. 1998, 98 (3), 1221-1262.

7. Schaaper, R. M.; Loeb, L. A. Proc Natl Acad Sci U S A 1981, 78 (3), 1773-7.

8. Lindahl, T.; Ljungquist, S.; Siegert, W.; Nyberg, B.; Sperens, B. J. Biol. Chem. 1977, 252 (10), 3286-94.

9. Lindahl, T. Nature 1993, 362 (6422), 709-15.

10. Nilsen, H.; Rosewell, I.; Robins, P.; Skjelbred, C. F.; Andersen, S.; Slupphaug, G.; Daly, G.; Krokan, H. E.; Lindahl, T.; Barnes, D. E. Mol Cell 2000, 5 (6), 1059-65.

11. Wilde, J. A.; Bolton, P. H.; Mazumder, A.; Manoharan, M.; Gerlt, J. A. J. Am. Chem. Soc. 1989, 111 (5), 1894-1896.

12. Kozekov, I. D.; Nechev, L. V.; Sanchez, A.; Harris, C. M.; Lloyd, R. S.; Harris, T. M. Chem. Res. Toxicol. 2001, 14 (11), 1482-5.

13. Plastaras, J. P.; Riggins, J. N.; Otteneder, M.; Marnett, L. J. Chem. Res. Toxicol. 2000, 13 (12), 1235-1242.

14. Hoehn, S. T.; Turner, C. J.; Stubbe, J. Nucleic Acids Res. 2001, 29 (16), 3413-23.

15. Beger, R. D.; Bolton, P. H. J. Biol. Chem. 1998, 273 (25), 15565-73.

16. Chen, J.; Dupradeau, F. Y.; Case, D. A.; Turner, C. J.; Stubbe, J. Nucleic Acids Res. 2008, 36 (1), 253-62.

17. Dutta, S.; Chowdhury, G.; Gates, K. S. J. Am. Chem. Soc. 2007, 129 (7), 1852-3.

18. Johnson, K. M.; Price, N. E.; Wang, J.; Fekry, M. I.; Dutta, S.; Seiner, D. R.; Wang, Y.; Gates, K. S. J. Am. Chem. Soc. 2013, 135 (3), 1015-25.

19. Price, N. E.; Johnson, K. M.; Wang, J.; Fekry, M. I.; Wang, Y.; Gates, K. S. J. Am. Chem. Soc. 2014, 136 (9), 3483-90. 
20. Scharer, O. D. Chembiochem 2005, 6 (1), 27-32.

21. Muniandy, P. A.; Liu, J.; Majumdar, A.; Liu, S. T.; Seidman, M. M. Crit. Rev. Biochem. Mol. Biol. 2010, 45 (1), 23-49.

22. Greenberg, R. B.; Alberti, M.; Hearst, J. E.; Chua, M. A.; Saffran, W. A. J. Biol. Chem. 2001, 276 (34), 31551-60.

23. Borch, R. F.; Hassid, A. I. J. Org. Chem. 1972, 37, 1673-1674.

24. Manoharan, M.; Andrade, L. K.; Cook, P. D. Org. Lett. 1999, 1 (2), 311-314.

25. Dohno, C.; Okamoto, A.; Saito, I. J. Am. Chem. Soc. 2005, 127, 16681-16684.

26. Angelov, T.; Guainazzi, A.; Schärer, O. D. Org. Lett. 2009, 11 (3), 661-664.

27. Bertrand, J. R.; Vasseur, J. J.; Rayner, B.; Imbach, J. L.; Paoletti, J.; Paoletti, C.; Malvy, C. Nucleic Acids Res. 1989, 17 (24), 10307-19.

28. Varshney, U.; van de Sande, J. H. Biochemistry 1991, 30, 4055-4061.

29. Eftedal, I.; Guddal, P. H.; Slupphaug, G.; Volden, G.; Krokan, H. E. Nucleic Acids Res. 1993, 11 (9), 2095-2101.

30. Nilsen, H.; Yazdankhah, S. P.; Eftedal, I.; Krokan, H. E. FEBS Lett. 1995, 362, 205-209.

31. Sambrook, J.; Fritsch, E. F.; Maniatis, T., Molecular Cloning: A Lab Manual. Cold Spring Harbor Press: Cold Spring Harbor, NY, 1989.

32. Kallen, R. G.; Jencks, W. P. J. Biol. Chem. 1966, 241 (24), 5851-63.

33. Carey, F. A.; Sundberg, R. J., Advanced Organic Chemistry - Part A: Structure and Mechanisms (5th Edition). Springer - Verlag.

34. Sczepanski, J. T.; Jacobs, A. C.; Majumdar, A.; Greenberg, M. M. J. Am. Chem. Soc. 2009, 131 (31), 11132-9.

35. Luce, R. A.; Hopkins, P. B., Chemical cross-linking of drugs to DNA. In Methods in Enzymology, Jonathan B. Chaires, M. J. W., Ed. Academic Press: 2001; Vol. Volume 340, pp 396-412.

36. Layer, R. W. Chem. Rev. 1963, 63 (5), 489-510.

37. Wilson, D. M., 3rd; Barsky, D. Mutat Res 2001, 485 (4), 283-307.

38. Myles, G. M.; Sancar, A. Chem. Res. Toxicol. 1989, 2 (4), 197-226.

39. Osowska, K.; Miljanic, O. S. Angew. Chem. Int. Ed. Engl. 2011, 50 (36), 8345-9. 
40. Savelyev, A. Phys. Chem. Chem. Phys. 2012, 14 (7), 2250-4.

41. Sim, A. Y.; Lipfert, J.; Herschlag, D.; Doniach, S. Physical Review E: Statistical, Nonlinear, and Soft Matter Physics 2012, 86 (2), 021901/1-021901/5.

42. Sczepanski, J. T.; Jacobs, A. C.; Majumdar, A.; Greenberg, M. M. J. Am. Chem. Soc. 2009, 131, 11132-11139.

43. Regulus, P.; Duroux, B.; Bayle, P.-A.; Favier, A.; Cadet, J.; Ravanat, J.-L. Proc. Nat. Acad. Sci. USA 2007, 104 (Aug 28), 14032-14037.

44. Sczepanski, J. T.; Jacobs, A. C.; Greenberg, M. M. J. Am. Chem. Soc. 2008, 130, 9646-9647.

45. Dutta, S.; Chowdhury, G.; Gates, K. S. J. Am. Chem. Soc. 2007, 129, 1852-1853.

46. Kallen, R. G.; Jencks, W. P. J. Biol. Chem. 1966, 241 (24), 5851-5863.

47. Bomann, M. D.; Guch, I. C.; DiMare, M. J. Org. Chem. 1995, 60, 5995-5996.

48. Abdel-Magid, A., F. ; Carson, K. G.; Harris, B. D.; Maryanoff, C. A.; Shah, R. D. J. Org. Chem. 1996, 61, 3849-3862.

49. Wang, M.; McIntee, E. J.; Cheng, G.; Shi, Y.; Villalta, P. W.; Hecht, S. S. Chem. Res. Toxicol. 2000, 13 (11), 1149-1157.

50. Riggins, J. N.; Daniels, J. S.; Rouzer, C. A.; Marnett, L. J. J. Am. Chem. Soc. 2004, 126 (6), 8237-8243.

51. Chaw, Y. F. M.; Crane, L. E.; Lange, P.; Shapiro, R. Biochemistry 1980, 19, 5525-5531.

52. Stone, M. P.; Cho, Y. J.; Huang, H.; Kim, H. Y.; Kozekov, I. D.; Kozekova, A.; Wang, H.; Minko, I. G.; Lloyd, R. S.; Harris, T. M.; Rizzo, C. J. Acc. Chem. Res. 2008, $41,793-804$.

53. Kozekov, I. D.; Nechev, L. V.; Moseley, M. S.; Harris, C. M.; Rizzo, C. J.; Stone, M. P.; Harris, T. M. J. o. t. A. C. S., 125(1), 50-61 J. Am. Chem. Soc. 2003, 125 (1), 5061.

54. Zhang, X.-a.; Song, D.; Lippard, S. J. J. Org. Chem. 2008, 73, 734-737.

55. Luce, R. A.; Hopkins, P. B. Methods Enzymol. 2001, 340, 396-412.

56. Maxam, A. M.; Gilbert, W. Methods Enzymol. 1980, 65, 499-560.

57. Lavanant, H.; Lange, C. Rapid Commun. Mass. Spec. 2002, 16, 1928-1933. 
DNA Interstrand Cross-Links Between an Abasic Site and the Opposing Guanine Residue of 5 '-CAp Sequences in Duplex DNA Chapter 3

58. Koomen, J. M.; Russell, W. K.; Tichy, S. E.; Russell, D. H. J. Mass Spectrom. 2002, $37(357-371)$. 


\section{Chapter 4. Ap-Derived DNA Interstrand Cross-Links are} Sequence Dependent

\subsection{Introduction}

DNA insterstrand cross-links are a deleterious type of DNA damage in cells. Their bioactivity results from prevention of strand separation, required for both DNA transcription and replication. ${ }^{1}$ DNA repair processes, such as nucleotide excision repair (NER) are needed to fix these biologically important DNA lesions. NER is thought to be the mechanism of interstrand cross-link repair. ${ }^{1-3}$ We discussed the biological significance of Ap sites DNA in Chapter 3, and presented evidence for DNA interstrand cross-links resulting from the reaction of an Ap-site with an opposing deoxyguanine (dG) residue. However we did not present evidence of other DNA bases forming covalent adducts with Ap-sites in DNA. Here we will discuss the effects of changing the local DNA sequence surrounding an Ap-site, and present a new high yielding Ap-derived 
crosslink formed under neutral conditions resulting from adduction of an Ap-site with deoxyadenine (dA).

\subsection{Structure of Ap-Derived DNA Interstrand Cross-Link Changes Depending on}

\section{the Sequence}

In the previous Chapter, we utilized sequences where a $\mathrm{dG}$ residue generated cross-links via imine formation. ${ }^{4-5}$ However, understanding there are many $\left(4^{3}=64\right)$ possibilities of Watson-Crick base paired combinations in a $5^{`}$-NApN sequence, where $\mathrm{N}$ is any nucleobase, we realized it would be important to examine as many Ap-site containing DNA sequences as possible. Starting with single base pair substitutions, we designed three sequences similar to duplex $\mathbf{B}$ that varies the flanking base on the 3 ' side of the Ap-site (duplexes H-J, Figure 1). Incubating the $5{ }^{32} \mathrm{P}$-labeled Ap-containing strands for duplexes $\mathbf{B}, \mathbf{H}, \mathbf{I}$, and $\mathbf{J}$ in HEPES buffer (pH 7, $50 \mathrm{mM}$ ) with $\mathrm{NaCl}(100$ $\mathrm{mM}$ ) at $37{ }^{\circ} \mathrm{C}$ yielded striking results. Upon analysis by $20 \%$ denaturing PAGE, we saw significantly different cross-link yields were obtained for each sequence, indicated by the slower moving band in lanes 4, 9, 14, and 19. Where duplex $\mathbf{H}$ and $\mathbf{J}$ resulted in virtually no cross-link at all, we see a substantial increase in cross-link yield for duplex I ( $60 \%$, lane 14, Figure 1) when compared to duplex B $(\sim 2 \%$, lane 4 , Figure 1). This result suggests two possibilities. The first being that the change in local DNA structure surrounding the Ap-site allowed for easier attachment of the deoxyguanine residue with

the Ap-site on the ${ }^{32} \mathrm{P}$-labeled strand. The second possibility being that the cross-linking site has changed. Described throughout this chapter, we examined 38 Ap-containing 
sequences where both sequence and site of cross-link attachment are major contributors

to the varied yields $(\sim 1-96 \%)$ of DNA cross-links.

\section{Figure 1}

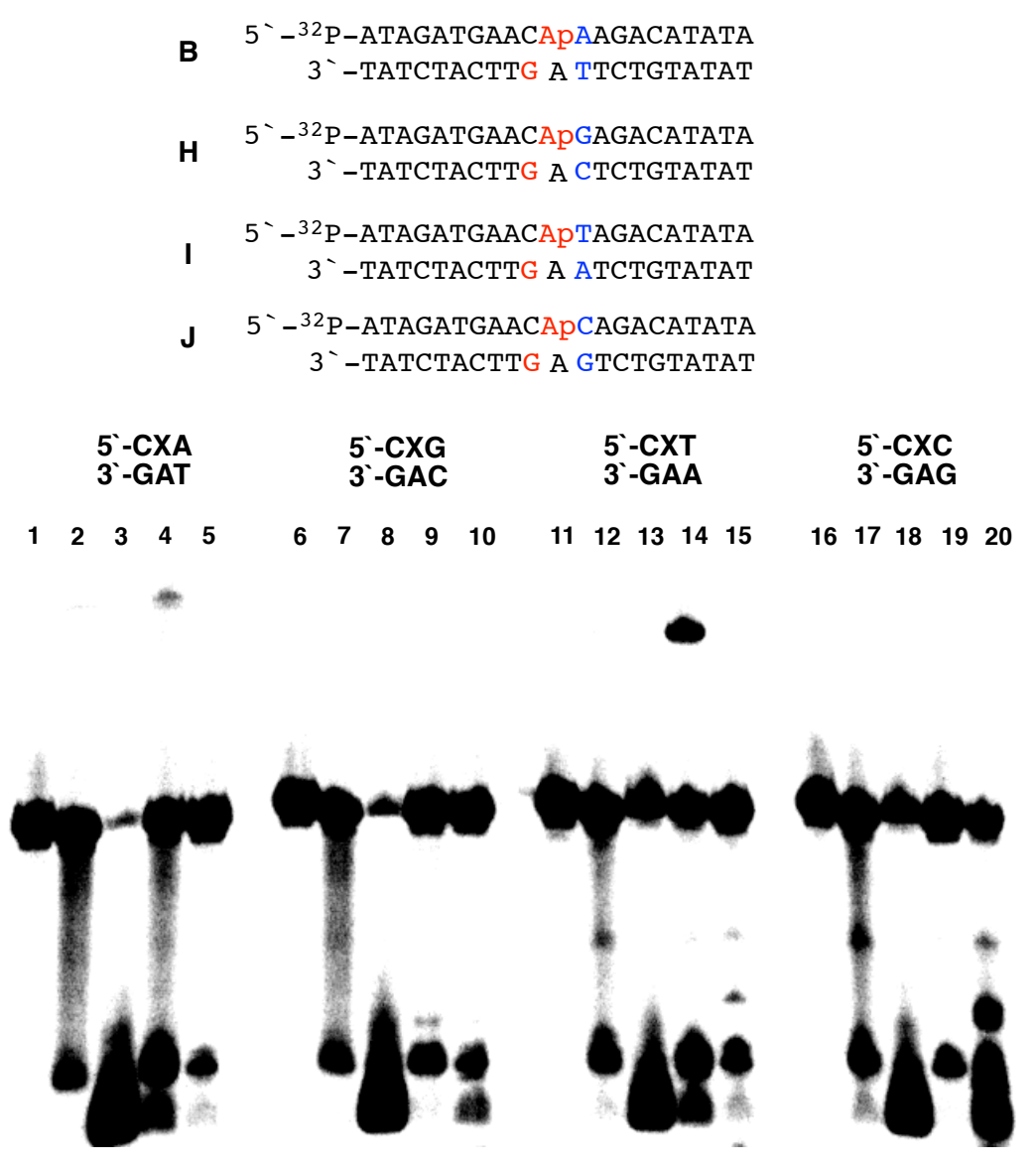

Figure 1. Interstrand cross-link formation in ${ }^{32} \mathrm{P}$-labeled 2 '-deoxyoligonucleotides duplexes $\mathbf{B}, \mathbf{H}, \mathbf{I}$, and $\mathbf{J}$ under native ( $\mathrm{pH} 7$ ) conditions. Duplex $\mathbf{B}$, lanes 1-5, $\mathbf{H}$, lanes 610, I, lanes 11-15, and $\mathbf{J}$, lanes 16-20. The uracil-containing duplex appear in lanes 1,6 , 11, and 16. The Ap-containing duplexes without incubation appear in lanes 2, 7, 12, and 17. The Ap-containing duplexes cleaved by treatment with piperidine $\left(1 \mathrm{M}, 95^{\circ} \mathrm{C}\right.$, for 25 min) appear in lanes $3,8,13$, and 18). The cross-linking reactions involving incubation of the Ap-containing duplex in HEPES buffer $(50 \mathrm{mM}, \mathrm{pH} 7)$ and $\mathrm{NaCl}(100 \mathrm{mM})$ at 37 ${ }^{\circ} \mathrm{C}$ for $3 \mathrm{~d}$ appear in lanes 4, 9, 14, and 19. The Ap-containing duplexes in HEPES buffer (50 mM, pH 7), $\mathrm{NaCl}(100 \mathrm{mM})$, and methoxyamine hydrochloride $(2 \mathrm{mM})$ at $37^{\circ} \mathrm{C}$ for 3 $\mathrm{d}$ appear in lanes 5, 10, 15, and 20. The were resolved on a sequencing gel and the radioactivity in each band quantitatively measured by phosphorimager analysis. 
We examined various Ap-containing DNA structures obtained from the PDB database that were generated using $2 \mathrm{D}-\mathrm{NMR}^{6-8}$ In general, a DNA duplex containing a single Ap-site is modeled to retain B-form DNA structure. ${ }^{6-8}$ But upon closer examination, we see that the Ap-site orientation within the duplex can vary wildly. The structures of different Ap-containing duplexes can develop "kinks" in the DNA, or they can completely collapse around the Ap-site to relieve the missing base pair stacking (Figure 2) ${ }^{6-8}$ The important thing to remember is that the DNA double helix is not a static structure. We developed an Ap-containing model of duplex I (Figure 3) generated from the PDB file 2HPX. ${ }^{9}$ Here we removed a thymine residue to construct an Ap-site opposing the adenine residue to model duplex I. It is important to note that the N2-amino group of the guanine is located in the minor groove, whereas the N6-amino group of adenine is located in the major groove. While located in two distinct positions, the exocyclic amines are pointed in the direction of the Ap-site. Minor twists of the DNA bases would provide optimal positioning for nucleophilic attack of the Ap-aldehyde of the $\mathrm{dG}$ or $\mathrm{dA}$ residue. 


\section{Figure 2}

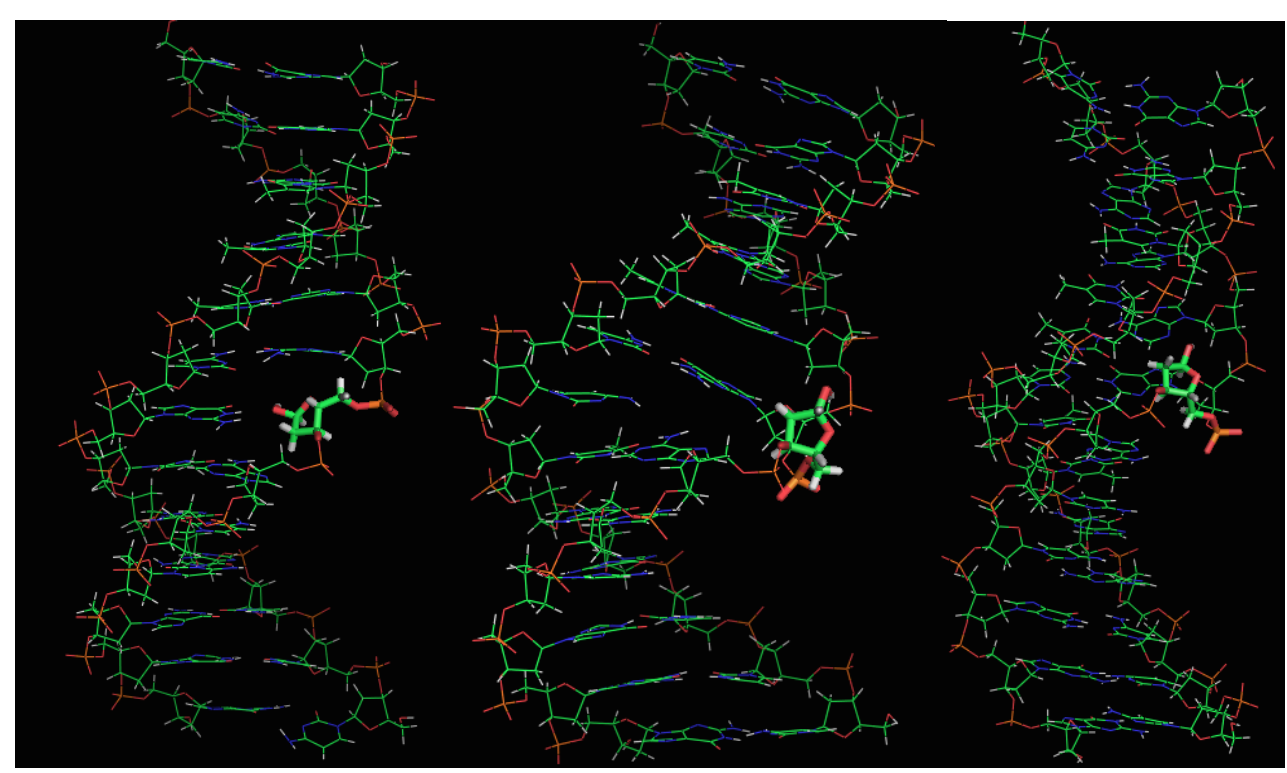

Figure 2. Ap-containing DNA molecular models obtained from the RCSB protein databank. PDB files obtained have matching sequences except the directly opposing base: 2O7W (left, dG), 2082 (middle, dC), and 2O7Y (right, dT). The DNA duplex is depicted as wire frames with the Ap-site indicated as bolded sticks.

\section{Figure 3}

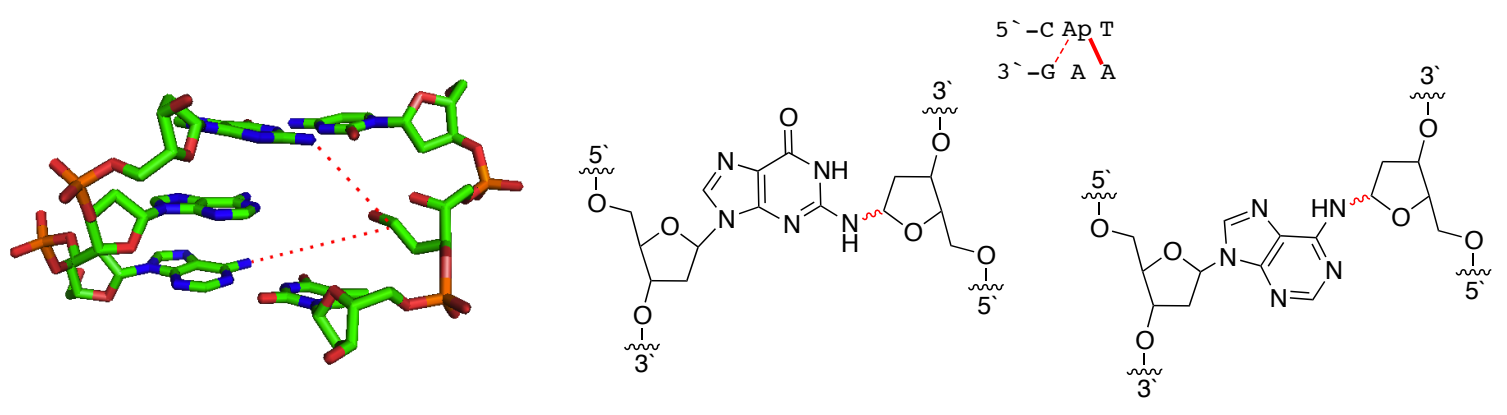

Figure 3. Abasic site containing molecular model with opposing dG and dA residues.

We measured the distance between the exocyclic nitrogen atoms of each base to the aldehyde carbon of the Ap-site (Figure 3). We see that the N2-amino group of guanine was $\sim 3.3 \AA$ closer to the Ap site than the N6-amino group of adenine. For this reason one 
may not initially suspect a cross-link would form between either exocyclic amino group and the Ap-aldehyde. Though in aqueous solutions DNA is fluid and flexible, dependent on the ionic strength of the solution. ${ }^{10}$ This flexibility may explain why Ap-sites are capable of forming cross-links. It is important to remember the directly opposing adenine residue (in between the dG and $\mathrm{dA}$ in duplex I) did not form detectable cross-links. While this base positioned closer to the Ap-site than the $3^{\prime}-\mathrm{dA}$ or $5{ }^{\prime}-\mathrm{dG}$, the exocyclic amine is not positioned well for an appropriate nucleophilic attack on the Ap-aldehyde.

If DNA sequence can directly affect position of Ap-sites in DNA duplexes, ${ }^{6-9}$ then that could have a pronounced effect on how the Ap-site can cross-link. The results in Figure 1 obligated us to determine the site of attachment for the high yielding cross-link of duplex I. We performed DNA footprinting reactions as described in Chapter 3. Figure 4 displays the hydroxyl radical footprinting of duplex $\mathbf{K}$, a longer DNA sequence containing the core 5'-CApT sequence. After incubation of Ap-containing duplex $\mathbf{K}$ in HEPES buffer $(50 \mathrm{mM}, \mathrm{pH} 7)$ with $\mathrm{NaCl}(100 \mathrm{mM})$ at $37^{\circ} \mathrm{C}$, the resulting cross-link was purified by $20 \%$ denaturing PAGE and subjected to $\bullet \mathrm{OH}$ cleavage. From the gel, we can see a clear interruption of the ladder in lanes 6-8 containing the cross-link treated with the $\mathrm{H}_{2} \mathrm{O}_{2}$-iron-EDTA complex. The labeled adenines from duplex $\mathbf{K}$ were listed above their corresponding peaks in the histograms, showing us that A6 (in red) was indeed the adenine cross-linked to the Ap-site. We published these results in the Journal of the American Chemical Society, accepted at the beginning of 2014. This chapter discusses the formation of this high yielding dA-Ap cross-link, as well as how variation in local sequence affects the Ap-derived cross-links in general. 
Figure 4

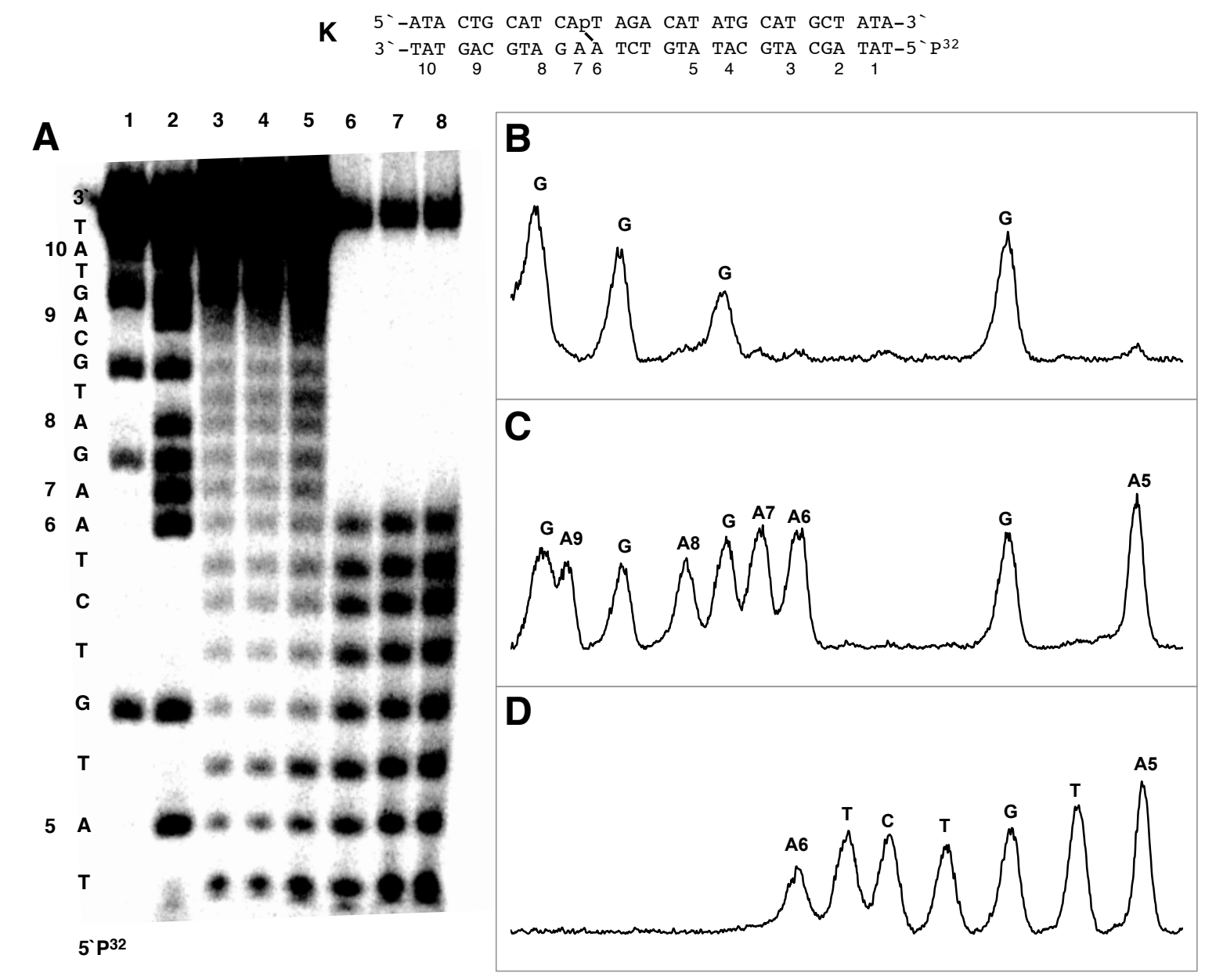

Figure 4. Hydroxyl radical footprinting of duplex $\mathbf{K}$ to locate the site of cross-link attachment. Lane 1 is a Maxam-Gilbert G-specific cleavage (sequencing) reaction of the labeled 2'-deoxyoligonucleotide strand in duplex $\mathbf{K}$. Lane 2 is an $A+G$ specific cleavage (sequencing) reaction of the labeled 2'-deoxyoligonucleotide strand in duplex $\mathbf{K}$. Lanes 3-5 the hydroxyl radical footprinting reaction of the labeled 2'-deoxyoligonucleotide strand in duplex K. Lanes 6-9 are the hydroxyl radical footprinting reaction of the slowmigrating, cross-link band generated by incubation of duplex $\mathbf{K}$ in HEPES buffer (50 $\mathrm{mM}, \mathrm{pH} 7)$ and $\mathrm{NaCl}(100 \mathrm{mM})$ at $37{ }^{\circ} \mathrm{C}$. ${ }^{32} \mathrm{P}$-labeled 2'-deoxyoligonucleotides were resolved on a polyacrylamide gel visualized by phosphorimager analysis (Panel A) and used to develop densitometry traces (Panels B-D). Panel B is the trace of lane 1. Panel C is the trace of lane 2. Panel D is the trace of lane 8 . 


\subsection{Formation and Stability of the High Yielding dA-Ap}

It is astounding that duplex $\mathbf{I}$ generated such a high yielding cross-link. This would allow easy and efficient preparation of an Ap-site derived cross-link for further experimentation. Performing a time-course reaction under neutral conditions shows us that the cross-link can form in yields of up to $\sim 78 \%$ after incubating for $5 \mathrm{~d}$ (Figure 5), the majority of which is formed in under $3 \mathrm{~d}$. With a half-time to completion calculated to be $16.3 \pm 0.7 \% \mathrm{~h}$, we see significantly more cross-link formed in 1 hour $(\sim 5 \%)$ for duplex I, than in 3 days for duplex $\mathbf{B}(\sim 2 \%)$. This means that deoxyadenine residues opposing an Ap-site in the $3^{\prime}$-direction cross-links more efficiently than guanine opposing an Ap-site in the 5-direction (Figure 3). Additionally, purification of the crosslink by PAGE followed by further incubation under the same conditions resulted in only $\sim 20 \%$ loss of cross-link from imine equilibration. This suggesting a more stable linkage than the previously described low-yielding dG-Ap cross-link, consistent with a higher yielding cross-link equilibrium. 


\section{Figure 5}

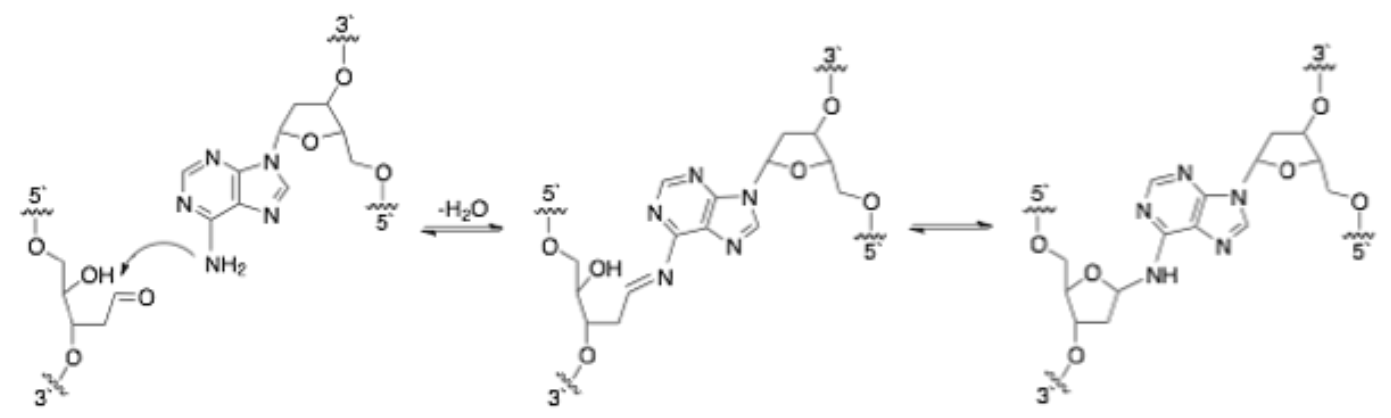

I $5{ }^{32}$ P-ATAGATGAacAptagacatata
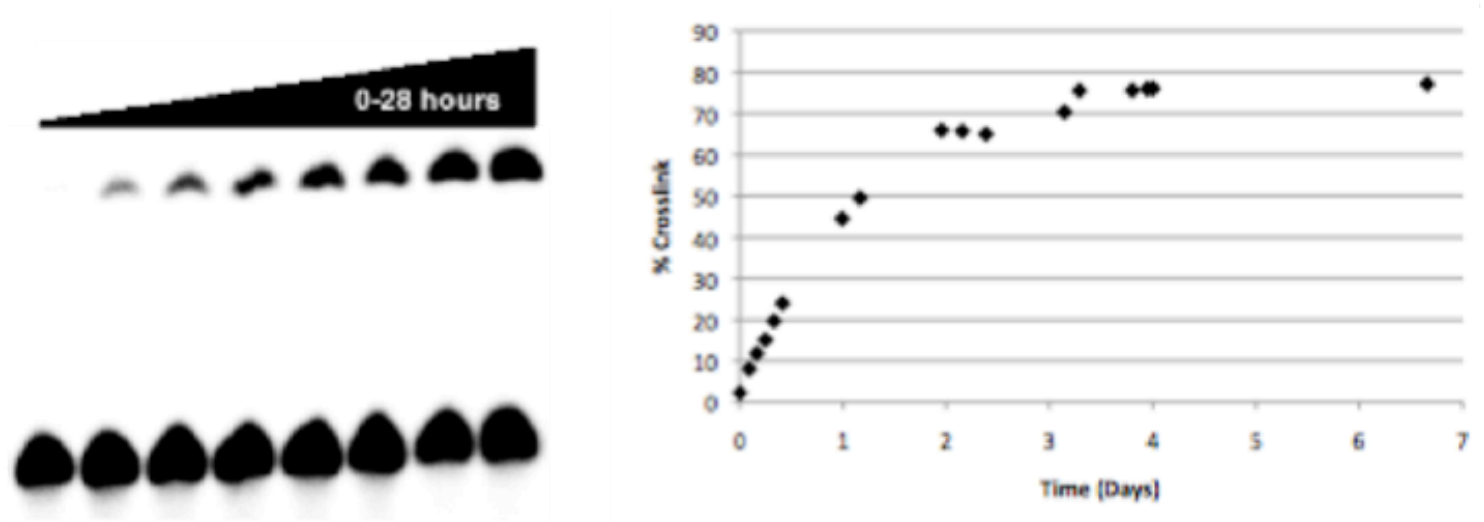

Figure 5. Time course for the formation of cross-link in duplex $\mathbf{I}$. The abasic-sitecontaining duplex was incubated in HEPES buffer $(50 \mathrm{mM}, \mathrm{pH} 7.0)$ and $\mathrm{NaCl}(100 \mathrm{mM})$ at $37{ }^{\circ} \mathrm{C}$ and aliquots were removed from the reaction and frozen prior to sequencing gel analysis. The lower bands correspond to the full length labeled 2'-deoxyoligonucleotides and the upper band cross-linked DNA. The ${ }^{32} \mathrm{P}$-labeled $2^{\prime}$-deoxyoligonucleotides were resolved on a polyacrylamide gel and the radioactivity in each band quantitatively measured by phosphorimager analysis. The left panel shows a representative gel depicting the first $28 \mathrm{~h}$ of the cross-linking reaction. The right panel shows results from obtained from full time course experiments.

The enormous difference in yield between duplexes $\mathbf{I}$ and $\mathbf{B}$ is most likely attributed to the higher nucleophilicity of the N6-amine on adenine compared to the N2amine on guanine (unpublished results by Catalino, M.). In our follow-up paper discussing the dG-crosslink in $2012,{ }^{5}$ we used the non-native nucleotide 2-aminopurine (P) to test this hypothesis (duplex $\mathbf{L}$, figure 6). 2-aminopurine is a structural isomer of 
adenine, in that the N6-amine is essentially migrated to the N2-position. This amine migration results in a "more nucleophilic guanine," and that is precisely what we saw in our experiments. This is similar to the inosine (I, Figure 6) experiments described in Chapter 3, using a non-native nucleotide substitution. But instead of preventing imine formation as with inosine, we expected to see increased yields of cross-link using 2aminopurine. Yields of up to $\sim 20 \%$ were obtained when incubating an Ap-containing duplex that replaced the guanine-cytosine base pair with the 2-aminopurine-thymine base pair under native conditions. This is a similar yield obtained when incubating duplex $\mathbf{B}$ under the reductive amination conditions (Chapter 3).

\section{Figure 6}
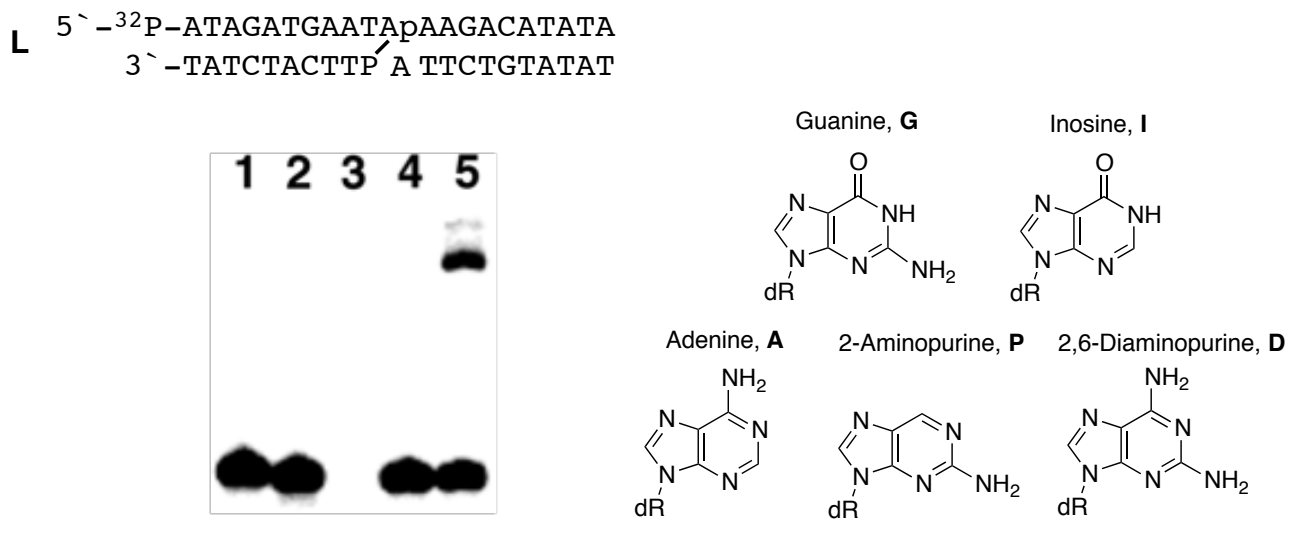

Figure 6. Evidence for cross-link formation in 2-aminopurine-containing $(\mathbf{P}){ }^{32} \mathrm{P}$-labeled duplex $\mathbf{L}$. The lower band corresponds to full-length labeled single strand DNA and the upper band cross-linked DNA. Lane 1 is the uracil-containing precursor of duplex $\mathbf{L}$. Lane 2 is the abasic-site-containing duplex $\mathbf{L}$ without incubation. Lane 3 is the abasicsite-containing duplex $\mathbf{L}$ cleaved by treatment with piperidine $\left(1 \mathrm{M}, 95{ }^{\circ} \mathrm{C}, 25 \mathrm{~min}\right)$. Lane 4 is duplex $\mathbf{L}$ incubated with methoxyamine hydrochloride $(2 \mathrm{mM})$ in HEPES buffer $\left(50 \mathrm{mM}, \mathrm{pH}\right.$ 7) containing $\mathrm{NaCl}(100 \mathrm{mM})$ at $37^{\circ} \mathrm{C}$ for $72 \mathrm{~h}$. Lane 5 is duplex $\mathbf{L}$ incubated in HEPES buffer $(50 \mathrm{mM}, \mathrm{pH} 7)$ containing $\mathrm{NaCl}(100 \mathrm{mM})$ at $37^{\circ} \mathrm{C}$ for $72 \mathrm{~h}$. The reaction mixtures were resolved on a sequencing gel and the radioactivity in each band quantitatively measured by phosphorimager analysis.

The same substitution with 2-aminopurine was incorporated into duplex I as well.

Here we wanted to see if 2-aminopurine in the $5{ }^{`}$-direction from the Ap-site would 
compete with the adenine in the 3 -direction from the Ap-site for cross-link formation (duplex M). Incubation of this 2-aminopurine-containing duplex in HEPES buffer (50 $\mathrm{mM}, \mathrm{pH} 7)$ with $\mathrm{NaCl}(100 \mathrm{mM})$ at $37^{\circ} \mathrm{C}$ for $3 \mathrm{~d}$ provided two bands of slowed mobility. This indicates the presence of two structurally different cross-links as we expected (Figure 7). The yields obtained were $8.2 \%$ and $10.7 \%$. This result shows that two DNA bases of isomeric structure formed cross-links in comparable yields, suggesting adenine and 2-aminopurine form Ap-derived cross-links to a similar degree. It is interesting that the sum of both yields do not equate to the $60-80 \%$ typically obtained in duplex I, but as discussed before that may be attributed to differences in DNA sequence structure.6-8

Figure 7

$$
\begin{array}{r}
\text { M } 5 \text {-32P-ATAGATGAATAPTAGACATATA } \\
\text { 3-TATCTACTTP A ATCTGTATAT }
\end{array}
$$

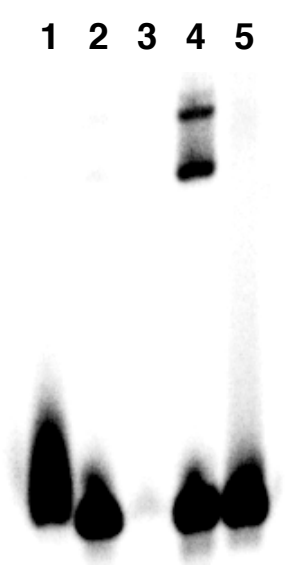

Figure 7. Evidence for cross-link formation in 2-aminopurine-containing duplex $\mathbf{M}$. Lane 1 is the uracil-containing precursor of 2'-deoxyoligonucleotide duplex M. Lane 2 is the abasic-site-containing 2'-deoxyoligonucleotide duplex $\mathbf{M}$ without incubation. Lane 3 is the abasic-site-containing 2'-deoxyoligonucleotide duplex $\mathbf{M}$ cleaved by treatment with piperidine ( $\left.1 \mathrm{M}, 95{ }^{\circ} \mathrm{C}, 25 \mathrm{~min}\right)$. Lane 4 is duplex $\mathbf{M}$ incubated in HEPES buffer $(50 \mathrm{mM}, \mathrm{pH} 7)$ containing $\mathrm{NaCl}(100 \mathrm{mM})$ at $37{ }^{\circ} \mathrm{C}$ for $72 \mathrm{~h}$. Lane 5 is duplex $\mathbf{M}$ incubated with methoxyamine hydrochloride $(2 \mathrm{mM})$ in HEPES buffer $(50 \mathrm{mM}, \mathrm{pH}$ 7) containing $\mathrm{NaCl}(100 \mathrm{mM})$ at $37{ }^{\circ} \mathrm{C}$ for $72 \mathrm{~h}$. The reaction mixtures were resolved on a sequencing gel and the radioactivity in each band quantitatively measured by phosphorimager analysis. 
We tested the stability of this high yielding dA-Ap cross-link using postformation work-up conditions employed in Chapter 3. Figure 8 displays the results. After 15-minute treatments, changes in $\mathrm{pH}$ did not affect cross-link yield, and dilute piperidine $(100 \mathrm{mM})$ treatment at $60{ }^{\circ} \mathrm{C}$ halved the yield. We saw that $90{ }^{\circ} \mathrm{C}$ heat will dissociate the cross-link almost completely, but most interesting was that $60{ }^{\circ} \mathrm{C}$ heat alone only gave us a minor decrease in remaining cross-link. This potentially owes to a greater stability of the dA-cross-link in duplex $\mathbf{I}$ over the dG cross-link in duplex $\mathbf{B}$, evident of substantially greater cross-link equilibrium yield. An Ap-containing duplex that favor's cross-link formation, should therefore be harder to reverse. 


\section{Figure 8}

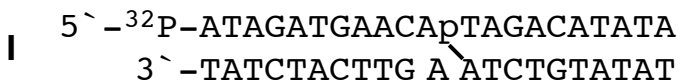

A

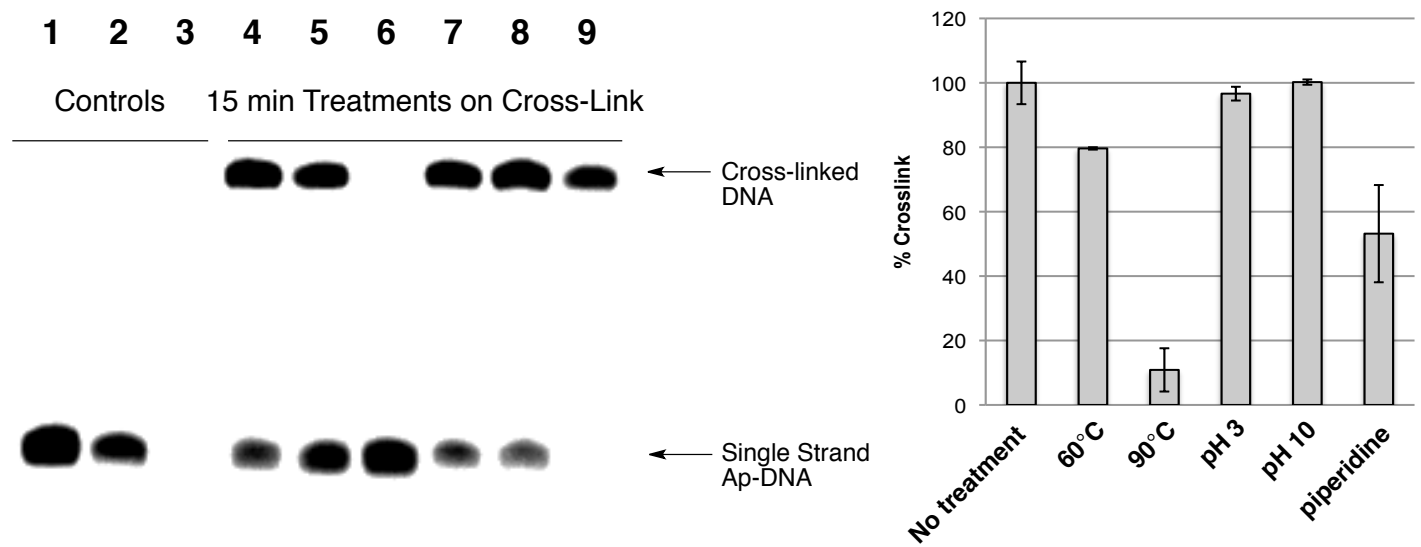

Figure 8. Stability of the cross-linked duplex I when subjected to various post-formation work-up conditions. Panel A displays the remaining amount of cross-linked DNA after various treatments compared with untreated cross-link. Lane 1 is the uracil-containing precursor of 2'-deoxyoligonucleotide duplex I. Lane 2 is the abasic-site-containing 2'deoxyoligonucleotide duplex $\mathbf{I}$ without incubation. Lane 3 is the abasic-site-containing 2'-deoxyoligonucleotide duplex I cleaved by treatment with piperidine $\left(1 \mathrm{M}, 95{ }^{\circ} \mathrm{C}, 25\right.$ min). Lane 4 is duplex $\mathbf{I}$ incubated in HEPES buffer $(50 \mathrm{mM}, \mathrm{pH}$ 7) containing $\mathrm{NaCl}$ $(100 \mathrm{mM})$ at $37^{\circ} \mathrm{C}$, ethanol precipitated and stored in water for $15 \mathrm{~min}$. Lanes 5-9 show cross-linked DNA generated as described for lane 4 except subjected to various work-up conditions: lane $5,60{ }^{\circ} \mathrm{C}, 15 \mathrm{~min}$; lane $6,90{ }^{\circ} \mathrm{C}, 15 \mathrm{~min}$; lane $7, \mathrm{pH}$ adjusted to 3,15 min; lane $8, \mathrm{pH}$ adjusted to $10,15 \mathrm{~min}$; lane $9,100 \mathrm{mM}$ piperidine, $60^{\circ} \mathrm{C}, 15 \mathrm{~min}$. Panel $\mathrm{B}$ is a bar graph with a quantitative illustration of the data from the gels. The yields of the cross-linked DNA obtained remaining after various work-ups were normalized against the amount of cross-link present in the sample that was similarly precipitated, but not subjected to any work-up (lane 4).

Incubation of duplex $\mathbf{I}$ in the presence of various additives directly affected the equilibrium yield of cross-links (Figure 9). The Ap-derived cross-link formed in the presence of biologically relevant thiol $(1 \mathrm{mM})$, and actually observed a slight increase in yield in the presence of GSH. Aromatic and aliphatic amines $(1 \mathrm{mM})$ significantly inhibited cross-link formation, most likely through competing imine formation. Various known DNA intercalators ethidium bromide, daunomycin, and proflavine $(1 \mathrm{mM})$ were 
also examined. These agents inhibited cross-link formation. We postulated that the intercalation between bases physically blocks cross-link formation and rigidifies the DNA duplex through the added aromatic stacking interactions as well. This would result in a less flexible duplex, and thus make it harder for the $\mathrm{N}_{6}$-amine of adenine to "reach" the electrophilic aldehyde. As seen in Chapter 3, the aldehyde trapping agent methoxyamine also inhibited cross-link formation.

Figure 9

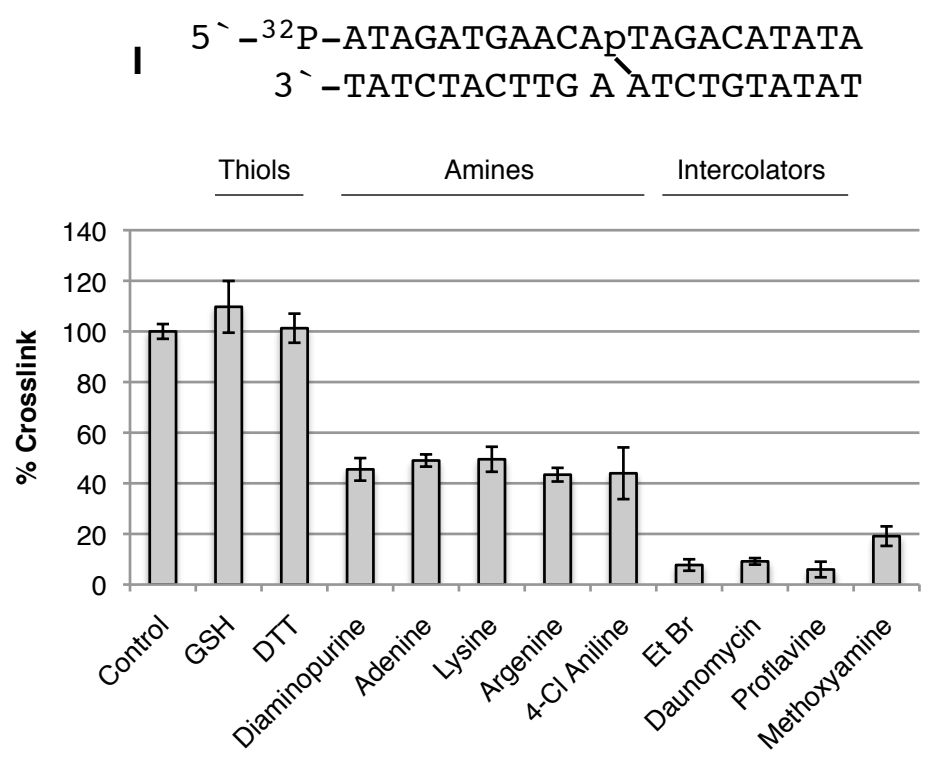

Figure 9. Formation of native dA-Ap cross-link examined in the presence of various nucleophiles. Yields relative to a standard cross-linking reaction (Control, no additive) involving incubation of duplex I in HEPES buffer $(50 \mathrm{mM}, \mathrm{pH}$ 7) containing $\mathrm{NaCl}(100$ $\mathrm{mM})$ and the listed additive $(1 \mathrm{mM})$ at $37{ }^{\circ} \mathrm{C}$ for $72 \mathrm{~h}$.

We were curious whether incubating duplex I under the reductive amination conditions employed in Chapter 3 would provide improved yields of a stable reduced cross-link (structure 4, Figure 10). Unfortunately through several attempts we could not reduce the cross-link generated by connection between the deoxyadenine and Ap-site. In 
fact, incubation of duplex I under the reductive amination conditions yielded a pair of bands with distinct gel mobility. Figure 10 shows two sets of data for duplexes $\mathbf{B}$ and $\mathbf{I}$ run side by side, both incubated under the neutral conditions and reductive amination conditions. Based upon gel mobility, lane 4 shows that duplex I generated a band that was also formed under neutral conditions (structure 3, lane 3). Additionally, a slightly slower moving band with the same mobility as the reduced dG cross-link resulting from incubation of duplex B under reductive amination conditions was also seen (structure 2, lane 2). This tells us that the dG-Ap cross-link (Figure 10, structure 1) is reduced (Figure 10, structure 2) selectively under our conditions, and that duplex I has the potential to still form dG-Ap cross-links as well as dA-Ap cross-links. We assume that since the dAAp cross-link (Figure 10, structure 3 ) yield is so high, that it predominates over the dGAp cross-link making it difficult to detect. 
Figure 10

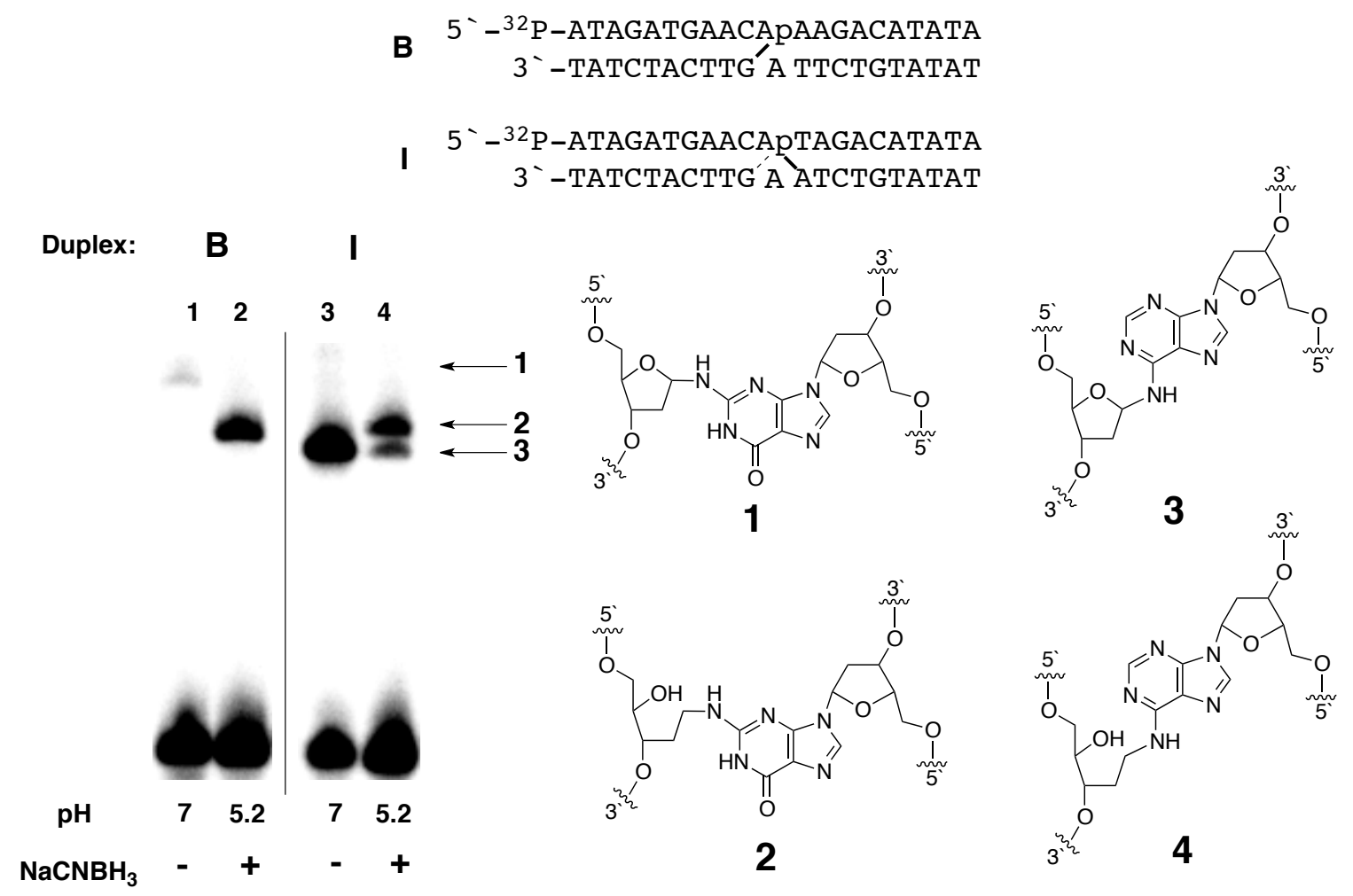

Figure 10. Generation of reduced dG-Ap cross-link in duplex I. Lane 1 is duplex $\mathbf{B}$ incubated in HEPES buffer $(50 \mathrm{mM}, \mathrm{pH} 7)$ containing $\mathrm{NaCl}(100 \mathrm{mM})$ at $37{ }^{\circ} \mathrm{C}$ for $72 \mathrm{~h}$. Lane 2 is duplex $\mathbf{B}$ incubated in sodium acetate buffer $(750 \mathrm{mM}, \mathrm{pH} 5.2)$ containing $\mathrm{NaCNBH}_{3}(250 \mathrm{mM})$ at $37{ }^{\circ} \mathrm{C}$ for $24 \mathrm{~h}$. Lane 3 is duplex $\mathbf{I}$ incubated in HEPES buffer $(50 \mathrm{mM}, \mathrm{pH} 7)$ containing $\mathrm{NaCl}(100 \mathrm{mM})$ at $37{ }^{\circ} \mathrm{C}$ for $72 \mathrm{~h}$. Lane 4 is duplex I incubated in sodium acetate buffer $\left(750 \mathrm{mM}, \mathrm{pH}\right.$ 5.2) containing $\mathrm{NaCNBH}_{3}(250 \mathrm{mM})$ at $37{ }^{\circ} \mathrm{C}$ for $24 \mathrm{~h}$. Reactions were ethanol precipitated before being resolved on a sequencing gel.

We were curious why the dA-Ap cross-link characterized does not seem to undergo reduction under the reductive conditions employed in these studies. We speculate that imine formation between adenine residues behaves differently than with guanosine, preventing reduction of any the imine that may (or may not) form in solution.

Nanospray QTOF MS of a cross-link generated from dupex I-2 under native (nonreductive) conditions (Figure 11) yielded a mass of $7162.3 \mathrm{Da}$ (calc. mass: 7162.8). This duplex is a shortened version of duplex $\mathbf{I}$. The mass obtained is consistent with structure 240 
3 (Figure 10), following a similar mechanism of formation described in Chapter 3,

Scheme 3. We are unsure why we cannot stabilize the dA-Ap cross-link by reduction, but it is possible the imine intermediate is trapped by ring closure too quickly, preventing hydride reduction. While chemically interesting, we did not pursue this further for our studies.

\section{Figure 11}

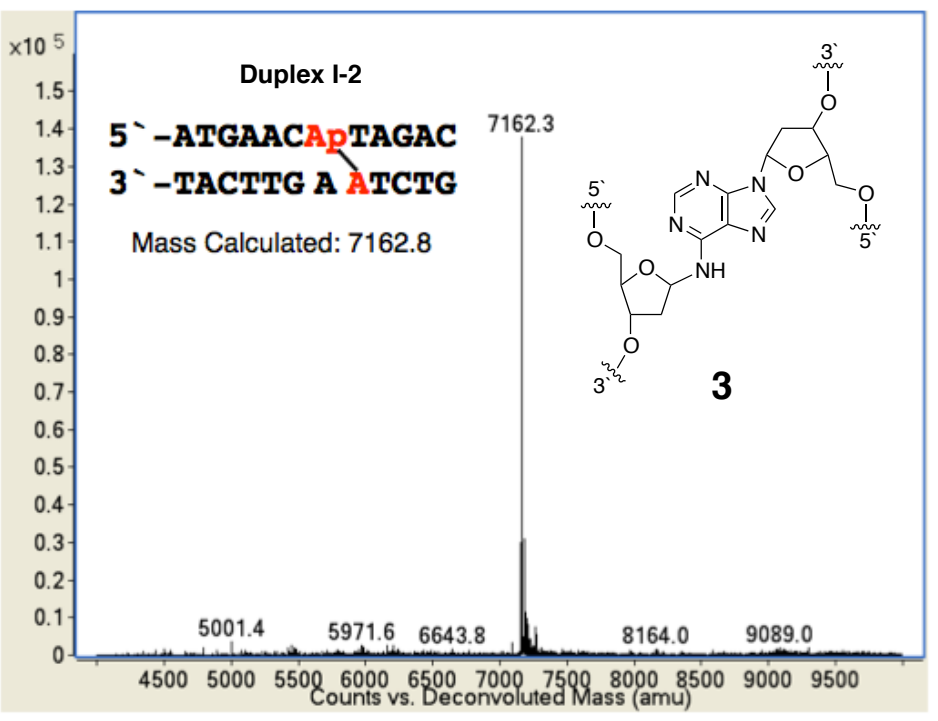

Figure 11. Nanospray QTOF MS of a cross-linked duplex containing the same core sequence found in duplex I (I-2) prepared by incubating in HEPES $(50 \mathrm{mM}, \mathrm{pH} 7)$ and $\mathrm{NaCl}(100 \mathrm{mM})$ at $37^{\circ} \mathrm{C}$ for $3 \mathrm{~d}$ and isolated from a $20 \%$ denaturing polyacrylamide gel.

\subsection{Sequence effects of Ap-Derived DNA Interstrand Cross-Links}

Discovery of the high yielding dA-Ap cross-link prompted us to examine a variety of Ap-containing DNA sequences to determine how DNA sequence affects crosslink yield. We surveyed a wide variety of sequences (38) by preparing duplexes with 5'${ }^{32}$ P-labeled Ap-containing DNA duplexes to compare the cross-link yields of each sequence after incubation. We tested sequences expected to form dA-Ap cross-links as well as dG-Ap cross-links (reduced and unreduced). Ap-containing duplexes were 
incubated in HEPES buffer $(50 \mathrm{mM}, \mathrm{pH} 7)$ with $\mathrm{NaCl}(100 \mathrm{mM})$ at $37{ }^{\circ} \mathrm{C}$ for $3 \mathrm{~d}$ or NaOAc buffer $\left(750 \mathrm{mM}, \mathrm{pH}\right.$ 5.2) with $\mathrm{NaCNBH}_{3}(250 \mathrm{mM})$ for $1 \mathrm{~d}$. Following incubation, the reactions were ethanol precipitated and analyzed by $20 \%$ denaturing polyacrylamide gel electrophoresis as before. Table 1 and 2 summarizes the equilibrium yields of all cross-links obtained, under the biologically relevant neutral conditions or chemically stabilized reductive amination conditions.

Quickly skimming through Tables 1 and 2, one can see that cross-link yields vary greatly, despite the fact that the sequence variations are subtle. It may be useful to compare the yields listed for each sequence to entries a (Table 1) and aa (Table 2), as those correspond to duplexes I and $\mathbf{B}$ respectively. We obtained cross-link yields varied between $0.2-95.5 \%$. Generally dA-Ap cross-linking duplexes containing 5'-ApT sequences (entries a-q) generated high yielding cross-links under the native $\mathrm{pH} 7$ conditions. Base pair changes in both the $5^{\prime}$-direction and $3^{\prime}$-direction of the crosslinking sites greatly affected the dA-Ap cross-link yields (b-j) and reduced dG-Ap crosslink yields (bb-ii). The unreduced dG-Ap cross-links were not affected as significantly in regards to overall cross-link yield. The use of non-natural bases inosine (I), 2aminopurine (P), and 2,6-diaminopurine (D) (Figure 6) provided expected results on cross-link formation: inosine prevented cross-links from forming, while 2-aminopurine and 2,6-diaminopurine increased cross-link yields, as well as resulting in multiple crosslinks (Tables 1 and 2).

Other than non-natural nucleobases, base pair mismatches generally had the largest impact on relative cross-link yield (entries $\mathbf{k - 0}$ and $\mathbf{j j}$-mm). Entries containing AA mismatches near the cross-linking dA residue ( $3^{`}$-direction, entries $\mathbf{m - o}$ ) produced high 
yields of dA-Ap cross-link, while mismatches on the opposite side (5'-direction, entries $\mathbf{k}$ an I) significantly decreased cross-link yield. Entry jj, which does not contain a dA residue in the dA-Ap cross-linking position on the opposing strand in the $3^{\prime}$-side of the Ap-site, surprisingly produced a high yield of cross-link under the neutral $\mathrm{pH} 7$ incubation conditions. This is interesting because a dG residue capable of cross-linking still resides in the sequence, though we have not yet observed such a high dG cross-link yield formed under native conditions. We set out to footprint this reaction to determine if the A-C mismatch resulted in a higher yielding dG-Ap cross-link, or if some other nucleobase forged an attachment with the Ap-site in this sequence.

Table 1. Survey of Various dA-Ap Cross-Linking DNA Sequences.

\begin{tabular}{|c|c|c|c|c|c|c|c|}
\hline Entry & Sequence & Neutral & Red. Am. & Entry & Sequence & Neutral & Red. Am. \\
\hline a & $\begin{array}{lll}5 & -\mathrm{CXT} & \text { A } \\
3^{-} & -\mathrm{GAA} & \mathrm{T}\end{array}$ & $74.7 \pm 1.6$ & $\begin{array}{l}10.9 \pm 0.2 \\
5.3 \pm 0.5\end{array}$ & $\mathrm{k}$ & $\begin{array}{ll}5-\bar{A} \mathrm{AT} & \bar{A} \\
3^{-}-\mathrm{GAA} & \mathrm{T}\end{array}$ & $4.6 \pm 0.1$ & \\
\hline b & $\begin{array}{lll}5 & -\mathrm{CXT} & \mathrm{A} \\
3^{-}-\mathrm{GCA} & \mathrm{T}\end{array}$ & $60.0 \pm 2.3$ & & 1 & $\begin{array}{ll}5-\mathrm{GXT} & \mathrm{A} \\
3^{-}-\mathrm{GAA} & \mathrm{T}\end{array}$ & $2.1 \pm 0.1$ & \\
\hline C & $\begin{array}{lll}5 & -\mathrm{CXT} & \text { A } \\
3 & -\mathrm{GTA} & \mathrm{T}\end{array}$ & $50.3 \pm 2.6$ & & $\mathrm{~m}$ & $\begin{array}{lll}5 & -\mathrm{CXA} & \mathrm{A} \\
3^{-}-\mathrm{GAA} & \mathrm{T}\end{array}$ & $88.3 \pm 0.6$ & \\
\hline d & $\begin{array}{lll}5 & -\mathrm{CXT} & \mathrm{A} \\
3-\mathrm{GGA} & \mathrm{T}\end{array}$ & $39.8 \pm 2.7$ & ---------- & $\mathrm{n}$ & $\begin{array}{lll}5-\mathrm{CXT} & \mathrm{A} \\
3^{-}-\mathrm{GAA} & \mathrm{A}\end{array}$ & $68.7 \pm 2.8$ & ---- \\
\hline e & $\begin{array}{ll}5-\mathrm{AXT} & \mathrm{A} \\
3-\mathrm{TAA} & \mathrm{T}\end{array}$ & $35.0 \pm 0.3$ & & 0 & $\begin{array}{lll}5 & -\mathrm{CXA} & \text { A } \\
3^{-}-\mathrm{GAA} & \mathrm{A}\end{array}$ & $82.9 \pm 0.7$ & \\
\hline$f$ & $\begin{array}{ll}5-\mathrm{GXT} & \mathrm{A} \\
3^{-}-\mathrm{CAA} & \mathrm{T}\end{array}$ & $18.2 \pm 0.2$ & & $\mathrm{p}$ & $\begin{array}{lll}5-T X T & \text { A } \\
3-\text { - AAA } & \text { T }\end{array}$ & $\begin{array}{l}8.2 \pm 0.2 \\
10.7 \pm 0.2\end{array}$ & \\
\hline g & $\begin{array}{lll}5-\mathrm{TXT} & \mathrm{A} \\
3-\mathrm{AAA} & \mathrm{T}\end{array}$ & $8.6 \pm 0.1$ & & $q$ & $\begin{array}{ll}5-C X T & A \\
3^{-}-i A A & T\end{array}$ & $63.3 \pm 5.1$ & \\
\hline $\mathrm{h}$ & $\begin{array}{lll}5 & -\mathrm{CXT} & \mathrm{T} \\
3 & -\mathrm{GAA} & \mathrm{A}\end{array}$ & $17.6 \pm 0.4$ & & $r$ & $\begin{array}{llll}5 & -\mathrm{T} & \mathrm{GXT} & \mathrm{G} \\
3^{-}-\mathrm{A} & \mathrm{CAP} & \mathrm{C}\end{array}$ & $2.3 \pm 0.0$ & $\begin{array}{l}1.3 \pm 0.1 \\
5.1 \pm 0.4\end{array}$ \\
\hline$i$ & $\begin{array}{lll}5 & -\mathrm{CXT} & \mathrm{G} \\
3 & -\mathrm{GAA} & \mathrm{C}\end{array}$ & $63.2 \pm 4.1$ & & $\mathrm{~s}$ & $\begin{array}{llll}5^{-} & -\mathrm{T} & \mathrm{GXT} & \mathrm{G} \\
3^{-} & -\mathrm{A} & \mathrm{CAD} & \mathrm{C}\end{array}$ & $\begin{array}{l}3.8 \pm 0.1 \\
22.2 \pm 0.3\end{array}$ & $\begin{array}{l}3.4 \pm 0.3 \\
7.2 \pm 1.4\end{array}$ \\
\hline$j$ & $\begin{array}{lll}5-\mathrm{CXT} & \mathrm{C} \\
3-\mathrm{GAA} & \mathrm{G} \\
\end{array}$ & $17.4 \pm 0.9$ & & & $=A p-s i t$ & & \\
\hline
\end{tabular}

Table 1. Ap-containing duplexes were incubated in HEPES buffer $(50 \mathrm{mM}, \mathrm{pH} 7)$ with $\mathrm{NaCl}(100 \mathrm{mM})$ at $37{ }^{\circ} \mathrm{C}$ for $3 \mathrm{~d}$ or $\mathrm{NaOAc}$ buffer $\left(750 \mathrm{mM}, \mathrm{pH}\right.$ 5.2) with $\mathrm{NaCNBH}_{3}$ $(250 \mathrm{mM})$ for $1 \mathrm{~d}$. Reactions were resolved on a sequencing gel and quantified by autoradiography. Yields listed as $\%$ of total ${ }^{32} \mathrm{P}$-labeled DNA in the reaction. Bases marked in red indicates sequence changes made based off entry $\mathbf{a}$. 
Table 2. Survey of Various dG-Ap Cross-linking DNA Sequences.

\begin{tabular}{|c|c|c|c|c|c|c|c|}
\hline Entry & Sequence & Neutral & Red. Am. & Entry & Sequence & Neutral & Red. Am. \\
\hline aa & $\begin{array}{lll}5 & -\mathrm{A} & \mathrm{CXA} \\
3^{-} & -\mathrm{T} & \mathrm{GAT}\end{array}$ & $3.0 \pm 0.4$ & $23.3 \pm 0.3$ & $\mathrm{kk}$ & $\begin{array}{lll}5 & -\mathrm{A} & \mathrm{CXA} \\
3^{-} & -\mathrm{T} & \mathrm{GAG}\end{array}$ & $3.8 \pm 0.8$ & $35.1 \pm 2.0$ \\
\hline $\mathrm{bb}$ & $\begin{array}{lll}5 & -\mathrm{A} & \mathrm{CXA} \\
3^{-} & -\mathrm{T} & \mathrm{GGT}\end{array}$ & $1.0 \pm 0.1$ & $38.6 \pm 0.5$ & 11 & $\begin{array}{lll}5 & -\mathrm{A} & \mathrm{CXT} \\
3 & -\mathrm{T} & \mathrm{GAT}\end{array}$ & $3.4 \pm 0.3$ & $18.5 \pm 1.5$ \\
\hline $\mathrm{CC}$ & $\begin{array}{lll}5 & -\mathrm{A} & \text { CXA } \\
3^{-} & -\mathrm{T} & \mathrm{GTT}\end{array}$ & $0.2 \pm 0.0$ & $13.1 \pm 0.7$ & $\mathrm{~mm}$ & $\begin{array}{lll}5 & -A & \text { CXT } \\
3 & -T & G A G\end{array}$ & $6.4 \pm 1.3$ & $21.7 \pm 0.3$ \\
\hline dd & $\begin{array}{lll}5 & -\mathrm{A} & \mathrm{CXA} \\
3^{-} & -\mathrm{T} & \mathrm{GCT}\end{array}$ & $0.4 \pm 0.0$ & $40.4 \pm 1.3$ & $\mathrm{nn}$ & $\begin{array}{lll}5-A & \text { CXA } \\
3^{-}-T & \text { iAT }\end{array}$ & none seen & none seen \\
\hline ee & $\begin{array}{lll}5 & -\mathrm{A} & \mathrm{CXG} \\
3^{-} & -\mathrm{T} & \mathrm{GAC}\end{array}$ & $1.4 \pm 0.2$ & $13.8 \pm 0.2$ & ০o & $\begin{array}{lll}5 & -\mathrm{A} & \mathrm{CXA} \\
3^{-}-\mathrm{T} & \text { iGT }\end{array}$ & $0.61 \pm 0.02$ & $0.33 \pm 0.01$ \\
\hline $\mathrm{ff}$ & $\begin{array}{lll}5 & -\mathrm{A} & \mathrm{CXC} \\
3 & -\mathrm{T} & \mathrm{GAG}\end{array}$ & $1.1 \pm 0.1$ & $13.0 \pm 0.3$ & $\mathrm{pp}$ & $\begin{array}{lll}5-\mathrm{A} & \mathrm{CXA} \\
3-\mathrm{T} & \mathrm{GiT}\end{array}$ & $0.73 \pm 0.07$ & $23.0 \pm 0.1$ \\
\hline gg & $\begin{array}{ll}5-T & \text { CXA } \\
3-A & \text { GAT }\end{array}$ & $1.7 \pm 0.0$ & $8.7 \pm 0.3$ & qq & $\begin{array}{lll}5-A & \text { TXA } \\
3^{-}-\mathrm{T} & \text { PAT }\end{array}$ & $29.1 \pm 0.7$ & $89.1 \pm 0.2$ \\
\hline $\mathrm{hh}$ & $\begin{array}{ll}5-G & \text { CXA } \\
3^{-}-C & \text { GAT }\end{array}$ & $1.3 \pm 0.2$ & $18.7 \pm 1.3$ & $r r$ & $\begin{array}{lll}5-\mathrm{A} & \text { TXA } \\
3 & -\mathrm{T} & \text { DAT }\end{array}$ & $5.7 \pm 0.7$ & $95.5 \pm 0.5$ \\
\hline ii & $\begin{array}{ll}5-C & C X A \\
3^{-}-G & G A T\end{array}$ & $1.0 \pm 0.1$ & $15.4 \pm 0.3$ & ss & $\begin{array}{lll}5-A & { }^{\mathrm{me}} \mathrm{C} & \text { XA } \\
3^{-}-\mathrm{T} & \mathrm{G}^{\mathrm{me}} \mathrm{CT}\end{array}$ & $0.6 \pm 0.1$ & $54.3 \pm 5.7$ \\
\hline jj & $\begin{array}{lll}5 & -\mathrm{A} & \mathrm{CXA} \\
3^{-} & -\mathrm{T} & \mathrm{GAC}\end{array}$ & $24.3 \pm 5.3$ & $36.4 \pm 0.3$ & & $i$ & & \\
\hline
\end{tabular}

Table 2. Ap-containing duplexes were incubated in HEPES buffer $(50 \mathrm{mM}, \mathrm{pH} 7)$ with $\mathrm{NaCl}(100 \mathrm{mM})$ at $37{ }^{\circ} \mathrm{C}$ for $3 \mathrm{~d}$ or $\mathrm{NaOAc}$ buffer $\left(750 \mathrm{mM}, \mathrm{pH}\right.$ 5.2) with $\mathrm{NaCNBH}_{3}$ $(250 \mathrm{mM})$ for $1 \mathrm{~d}$. Reactions were resolved on a sequencing gel and quantified by autoradiography. Yields listed as \% of total ${ }^{32} \mathrm{P}$-labeled DNA in the reaction. Bases marked in red indicate sequences changes made based off entry $\mathbf{a a}$. 
Figure 12

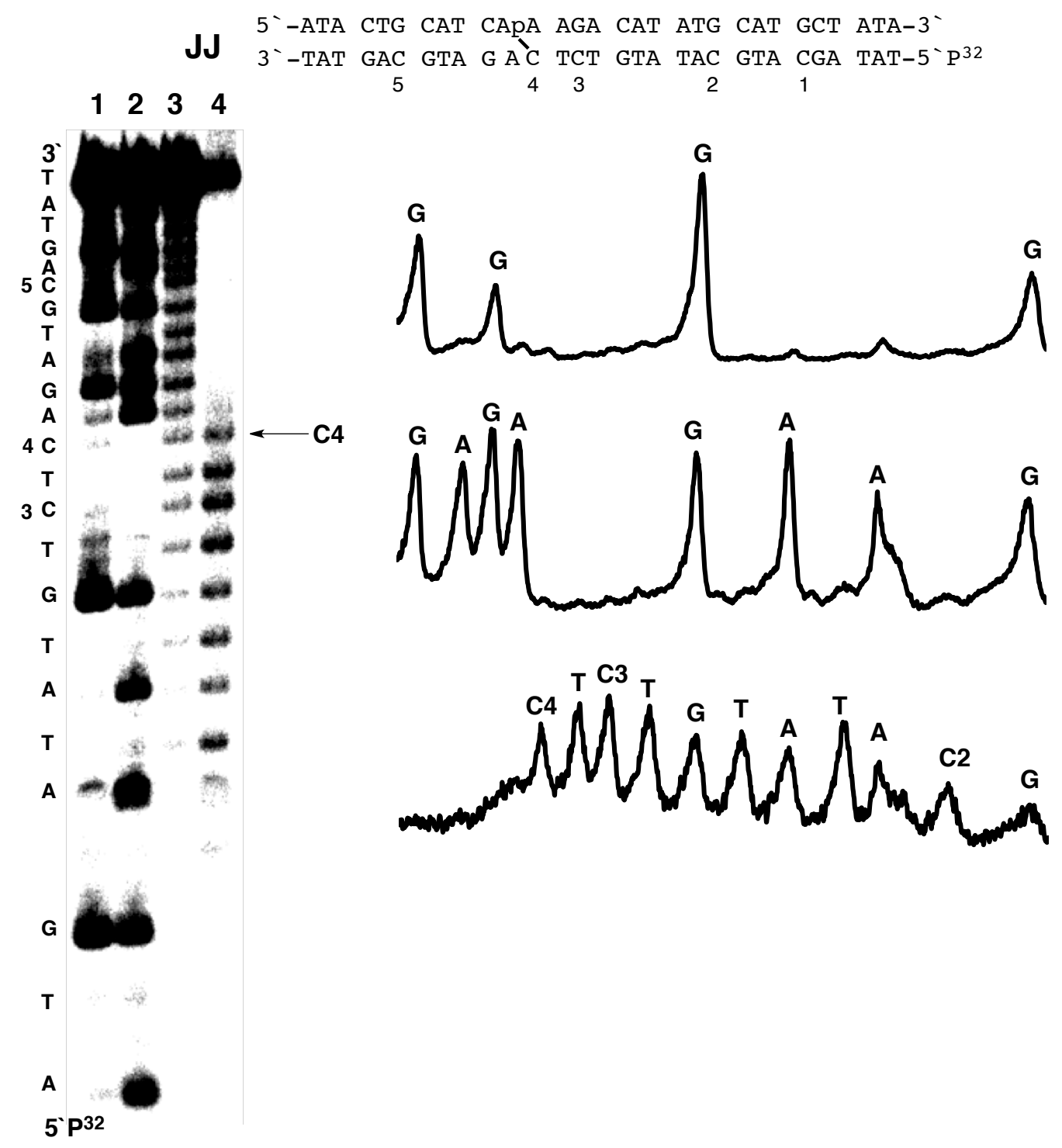

Figure 12. Hydroxyl radical footprinting of ${ }^{32} \mathrm{P}$-labeled 2'-deoxyoligonucleotide duplex JJ to locate the site of cross-link attachment. Lane 1 is a Maxam-Gilbert G-specific cleavage (sequencing) reaction of the ${ }^{32} \mathrm{P}$-labeled strand in duplex $\mathbf{J J}$. Lane 2 is an $\mathrm{A}+\mathrm{G}$ specific cleavage (sequencing) reaction of the ${ }^{32} \mathrm{P}$-labeled strand in duplex $\mathbf{J J}$. Lane 3 is the hydroxyl radical footprinting reaction of the ${ }^{32} \mathrm{P}$-labeled strand in duplex JJ. Lane 4 is the hydroxyl radical footprinting reaction of the ${ }^{32} \mathrm{P}$-labeled slow-migrating cross-link band generated by incubation of duplex $\mathbf{J J}$ in HEPES buffer $(\mathrm{pH} 7,50 \mathrm{mM})$ and $\mathrm{NaCl}$ $(100 \mathrm{mM})$ at $37{ }^{\circ} \mathrm{C}$ for $3 \mathrm{~d}$. ${ }^{32} \mathrm{P}$-labeled 2'-deoxyoligonucleotides were resolved on a polyacrylamide gel visualized by phosphorimager analysis (Panel A) and used to develop densitometry traces (Panels B-D). Panel B is the trace of lane 1. Panel C is the trace of lane 2. Panel $\mathrm{D}$ is the trace of lane 4 . 
We performed hydroxyl radical footprinting on the duplex for entry $\mathbf{j j}$ in Table 1 (duplex JJ, Figure 12) to determine the site of attachment. We concluded that duplex $\mathbf{J J}$ yielded a cross-link between the deoxycytidine residue and the Ap-site. As shown by the break in the ladder (lane 4), the band does not match with a dG or dA residue (lanes 1 and 2). Presumably the distorted structure resulting from the A-C mismatch $3^{`}$-from the Apsite resulted in a favorable interaction between the deoxycytidine $(\mathrm{dC})$ residue and the Ap-site. This is the first direct evidence we have obtained for a linkage between an Apsite and a $\mathrm{dC}$ residue.

\subsection{Native dA-Ap and Reduced dG-Ap Cross-Links Stalls Polymerase Ф29}

With such a large assortment of cross-linking sequences, the potential biological significance of these Ap-site derived cross-links appears to be substantial. It is therefore important to understand how these DNA lesions behave during DNA transcription and replication. ${ }^{1,11}$ We already discussed in Chapter 3 that DNA interstrand cross-links prevent strand separation, blocking DNA and RNA polymerases from performing their function. ${ }^{12}$

We used a simple model where Phi29 polymerase (\$29) is utilized to assess the capabilities of these cross-links to block primer extension reactions. ${ }^{13-14} \Phi 29$ polymerase is an enzyme isolated from the Bacteriophage $\Phi 29$. The protein exhibits effective polymerase activity, with strand displacement properties as well. ${ }^{13-14}$ This allows us to model DNA replication using double stranded DNA without the need for a helicase protein. We tested for polymerase stalling by each the native dA-Ap cross-link (structure 3, Figure 6) and reduced dG-Ap cross-link (structure 2, Figure 6) by incubating DNA 
duplexes resembling duplex I and B with $\Phi 29$. We incubated unlabeled Ap-containing duplexes (PA and PG, Figure 13) containing the central base pair sequences seen in duplexes I and $\mathbf{B}$ under neutral $\left(\mathrm{pH}\right.$ 7) or reductive amination ( $\left.\mathrm{pH} 5.2, \mathrm{NaCNBH}_{3}\right)$ conditions previously described. The resulting cross-links generated were purified by denaturing PAGE, eluted from the gel, desalted, and annealed with a $5{ }^{3}{ }^{32} \mathrm{P}$-labeled 15 mer primer (Figure 13, PA-3 and PG-3). Control duplexes missing the cross-link (PA-2 and PG-2) or the uracil-containing strand (PA-1 and PG-1) but still containing the $5{ }^{3}{ }^{32} \mathrm{P}-$ labeled 15-mer primer were prepared as well. Figure 14 display the results of $\Phi 29$ extension for the dA-Ap cross-link and reduced dG-cross-link.

\section{Figure 13}

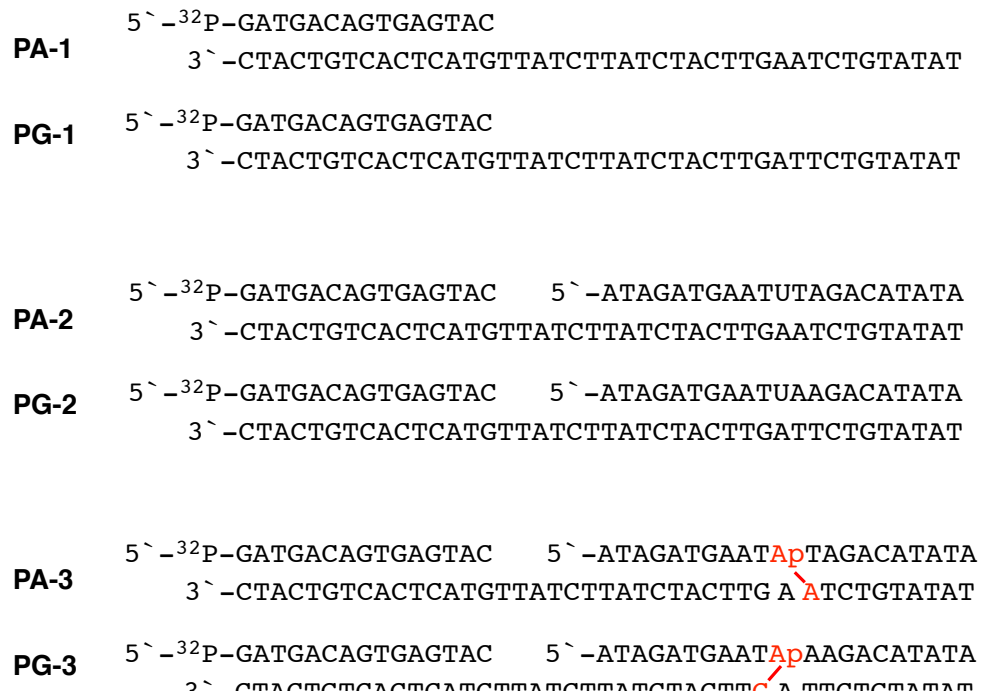

Figure 13. Sequences used for primer extension reactions containing either the native dA-Ap cross-link (PA) or the reduced dG-Ap cross-link (PG). Three duplexes each were extended with $\Phi 29$ : 1-primer hybridized to the template strand, 2- primer hybridized to the template strand annealed to the uracil containing strand, and 3- primer hybridized to the cross-linked template. 


\section{Figure 14}

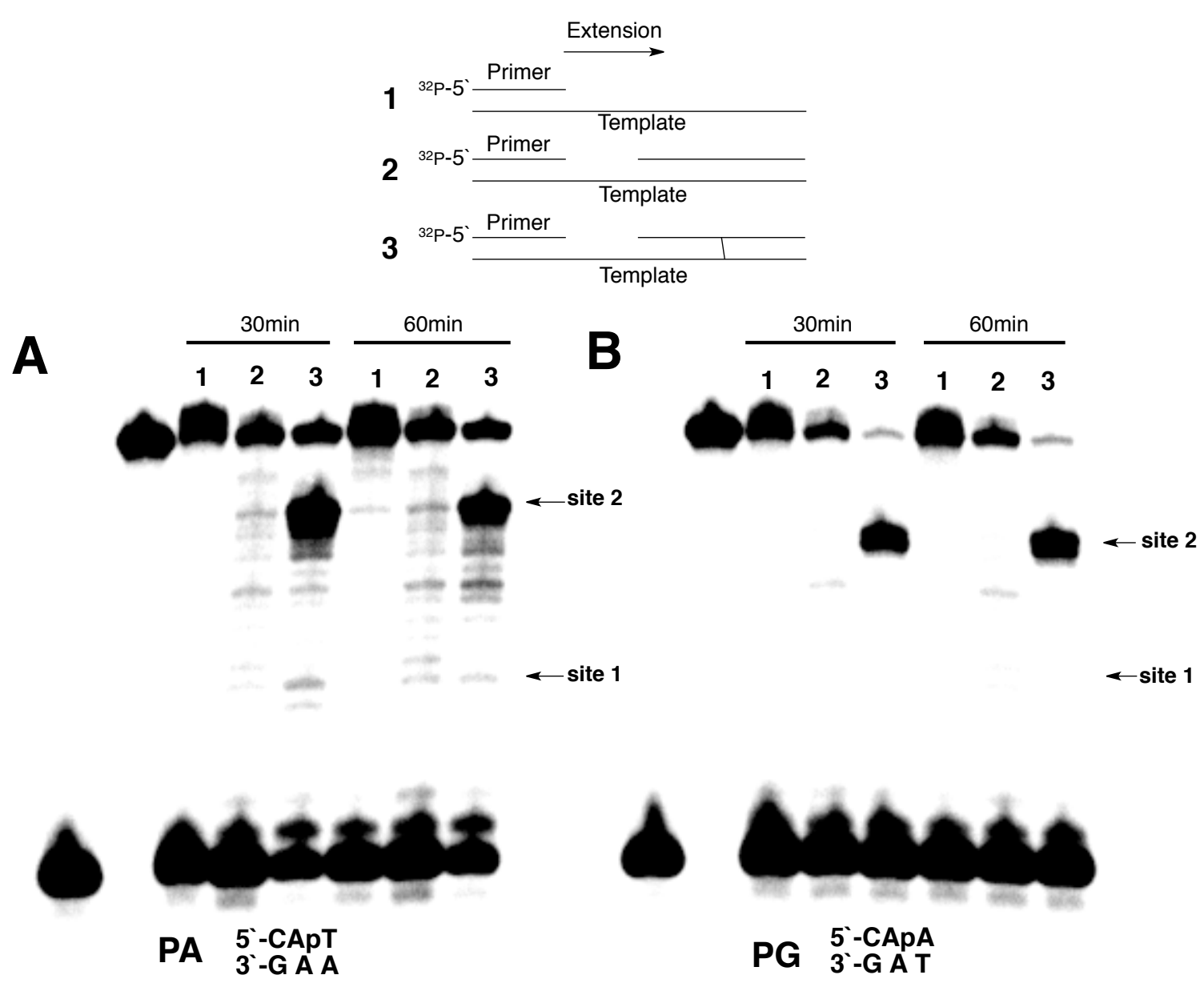

Figure 14. Phi29 primer extension of duplexes PA (Panel A) and PG (Panel B) using templates 1, 2, and 3. The lower bands corresponds to non-extended primer (15-mer) and the upper bands corresponds to fully extended primer (42-mer) as marked by ${ }^{32} \mathrm{P}$-labled standards. Lanes marked as 1, 2, or 3 contain primer extension reactions incubated in NEB buffer $(1 \mathrm{X})$ with primer annealed template $(0.4 \mathrm{\rho mol} / \mu \mathrm{L}$ final conc.), DNTPs $(200$ $\mu \mathrm{M})$, BSA $(200 \mu \mathrm{g} / \mathrm{mL})$ and $\Phi 29(400 \mathrm{U} / \mathrm{mL})$ absent of the uracil containing strand (lane 1), annealed to the uracil-containing strand (lane 2), or cross-linked to the Ap-containing strand (lane 3) at $37{ }^{\circ} \mathrm{C}$ for the indicated time. Reactions were quenched with EDTA (10 $\mathrm{mM}, \mathrm{pH} 7$ ) and ethanol precipitated before being separated on a sequencing gel.

Incubation of primer annealed duplexes with $\Phi 29$ in the presence of a mixture of deoxyribonucleotide triphosphates (dNTPs, $200 \mathrm{mM}$ ) at $37{ }^{\circ} \mathrm{C}$ yielded extended ${ }^{32} \mathrm{P}$ labeled products. After the reactions were quenched and analyzed by PAGE, lanes 2 and 
3 left a light ladder of uncompleted extended primers, primarily in the range of where annealed DNA duplexes begin (site 1, Figure 14). Here we see the start of bands forming that correspond to initial stalling at the beginning of strand displacement. Primer extension of cross-linked duplexes PA-3 and PG-3 results in a dark band where the cross-linking site would be just short of the fully extended products (lane 3, site 2, Figure 14). This indicates significant stalling of the primer extension reaction occurred. As expected, the cross-link inhibited the primer extension reaction from finishing. This provided first evidence that Ap-derived cross-links could block strand separation by helicase enzymes, required for DNA transcription and replication to occur. ${ }^{12}$

We see quantifiable amounts of fully extended product for cross-link containing reactions. This is not surprising as the dA-Ap cross-link (Figure 13, duplex PA-3) was already characterized as reversible, meaning there most likely was a small amount of reversed cross-link at the start of the primer extension reaction resulting in fully extended primer product. And although PA would produce a reversible cross-link, significant amounts of stalled extension product were still obtained (Figure 14, lane 3). We were surprised to see a similar result, though not as significant, for the reduced dG-Ap crosslink. Theoretically an irreversible cross-link (Chapter 3) would completely prevent strand separation, thereby preventing completion of the primer extension reaction. It is possible that the fully extended product could result from polymerase bypass, ${ }^{15}$ involving extension past the lesion. To investigate, a sample of the prepared reduced dG-Ap crosslink stock (duplex PG-3) was 5'-labeled and analyzed by PAGE. Results indicated a portion $(\sim 5 \%)$ of the purified cross-link for PG-3 was contaminated with uncross-linked 
single-strand DNA. This can account for the small amount of fully extended primer seen in lane 3 for duplex PG.

\subsection{Chapter 4 Summary}

In this chapter we characterized cross-link formation between an Ap-site and a deoxyadenine residue on the opposing strand of a DNA duplex. We characterized these cross-links specifically as higher yielding reversible DNA adducts. The results were consistent with cross-link generation via reversible imine formation, involving attack of the exocyclic amino group of adenine or guanine (or cytosine) on the aldehyde of an Apsite. This likely proceeds via hemiaminal (2, Scheme 1) formation followed by dehydration (3, Scheme 1) and ring closure (4, Scheme 1), supported by mass spectrometry analysis. It is also possible that the cross-link could exist partially as enamine 5, supplying some evidence as to why we do not observe stabilization by reduction with hydride. Literature precedent supports hemiaminal structure 4 as being the predominant form. ${ }^{16-17}$ This is also supported by the significant stability of the crosslink, allowing for isolation from a gel. Combined with the results discussed in Chapter 3, we have identified that both $\mathrm{dG}$ and $\mathrm{dA}$ can adduct with Ap-sites to form two distinct cross-links. Defining $5^{`}-\mathrm{CAp} / 5^{`}-\mathrm{A} \underline{\mathrm{G}}$ and $5^{`}-\mathrm{ApT} / 5^{`}-\underline{\mathrm{A} A}$ core sequences as optimal locations for Ap-derived cross-links to form, where the underlined bases are involved in Ap-adduction. ${ }^{18}$ 


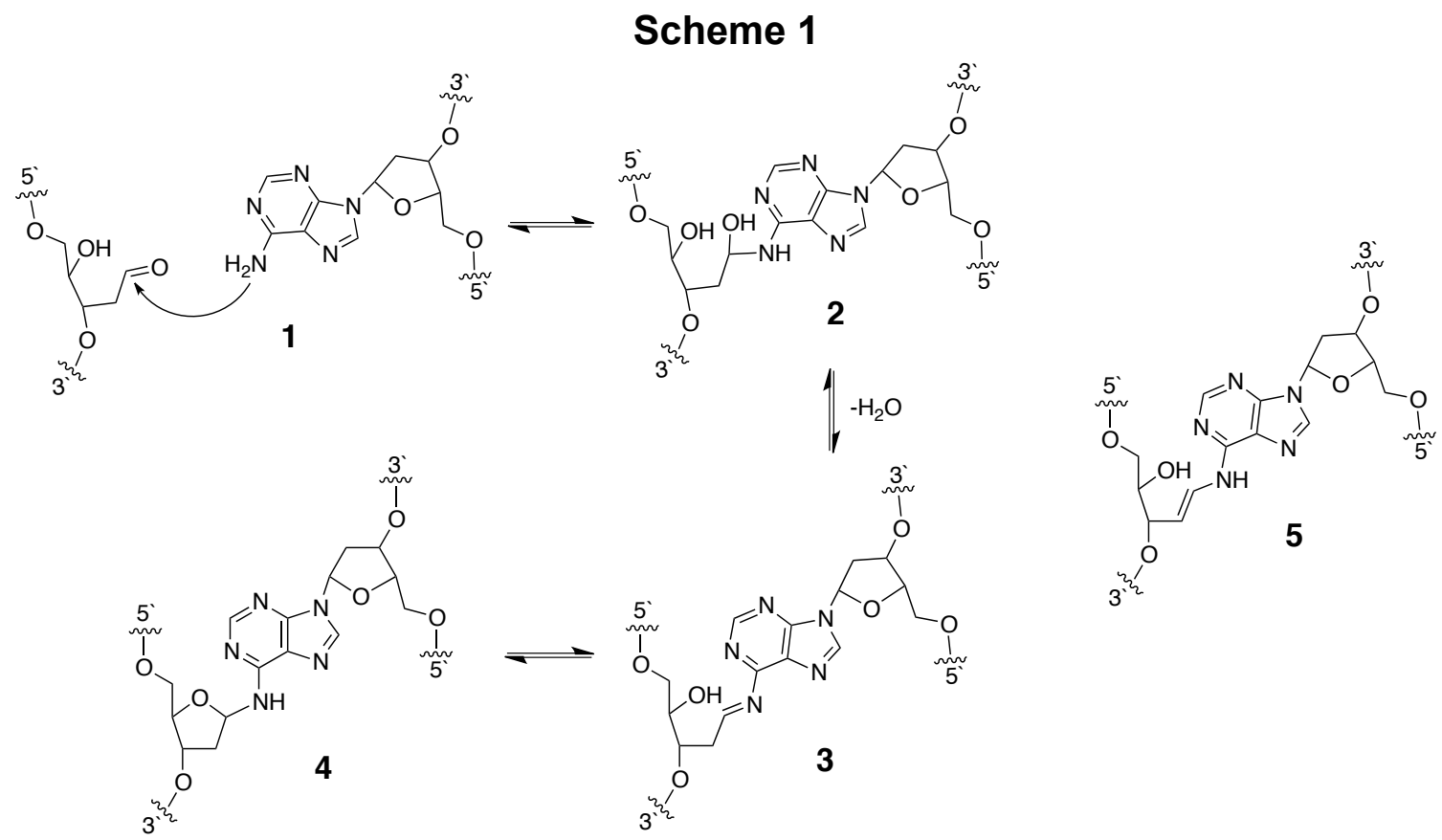

We see a distinct preference for dA-Ap over dG-Ap crosslink formation. We believe this results from the lower inherent nucelophilicity of dG. This is supported by substitution of dG for 2-aminopurine (P) in duplex $\mathbf{M}$ resulting in a second cross-link product, most likely with the 2-aminopurine residue. We cannot rule out base positioning as having significant effect towards imine formation of the Ap-site, as seen by the varied yields in cross-link formation dependent on DNA sequence (Tables 1 and 2). Observing cross-link formation for so many unique sequences further supports biological significance of the lesion. And even though Ap-sites are only estimated to exist as an aldehyde at $\sim 1 \%$ abundance, the human genome is $\sim 3.2 \times 10^{9}$ base pairs in size, ${ }^{19}$ with estimated steady state levels of Ap-sites are approximately 1 lesion per $10^{5}$ nucelotides. ${ }^{20}$ Making the possibility of Ap-derived cross-links more prevalent, particularly for some of the higher yielding Ap-containing cross-link sequences. 
We know that DNA repair processes initiated by APE1 are efficient in processing Ap-sites, and that this would compete with cross-link formation. Additionally Ap-sites spontaneously cleave if not repaired, resulting in single strand breaks. ${ }^{21}$ Therefore not all Ap-sites would engage in DNA cross-linking. But given the chance, an Ap-derived DNA interstrand cross-link could present significant challenges to replication, transcriptions and repair. Upon initial inspection, Ap-derived cross-links appear to inhibit $\Phi 29$ polymerase activity. We see distinct primer extension stalling (if not complete inhibition) at the cross-link site as shown in Figure 14, similar to other known DNA interstrand cross-links. ${ }^{15}$

In summary, Ap-derived DNA interstrand cross-links have potential significance, with observed native cross-link yields of anywhere between $\sim 1-80 \%$. With a large variety of possible cross-linking sequences, these lesions could explain why complicated repair pathways such as NER are utilized in eukaryotic cells, repairing lesions formed endogenously on genomic DNA for cell survival. ${ }^{1-3}$ Finally, one example of literature providing evidence for the existence of Ap-derived interstrand cross-links was from examination of ancient DNA. It has been theorized that difficulty in sequencing and amplification of ancient DNA is the result of cross-links, in addition to oxidative damage, Ap-sites, and strand breaks. ${ }^{22}$ Studies are still needed to provide hard evidence of Apderived cross-links generated in cells utilizing LC-MS analysis of enzymatically digested DNA and small molecule synthetic standards, a project currently underway in the Gates research group. 


\subsection{Experimental}

Materials and Methods. Oligonucleotides were purchased from Integrated DNA Technologies. All enzymes were purchased from New England Biolabs (Ipswich, MA, USA). $\left[\gamma_{-}{ }^{32} \mathrm{P}\right]$-ATP $(6000 \mathrm{Ci} / \mathrm{mmol})$ was purchased from Perkin Elmer. C-18 sep-pak cartridges were from Waters. BS Polyprep columns were purchased from BioRad. Quantification of radioactivity in polyacrylamide gels was carried out using a Personal Molecular Imager (BIORAD) with Quantity One software (v.4.6.5). All other reagents were purchased from Sigma-Aldrich.

Representative procedure for cross-link formation. Single-stranded uracil containing 2'-deoxyoligonucleotides were 5'-labeled using standard procedures. Labeled DNA was annealed $^{23}$ with its complimentary strand and treated with the enzyme UDG (50 units $/ \mathrm{mL}$, final concentration) to generate Ap sites. UDG enzyme was removed by phenol-chloroform extraction. ${ }^{23}$ Individual DNA duplexes were incubated in a buffer composed of HEPES $(50 \mathrm{mM}, \mathrm{pH} 7)$ containing $\mathrm{NaCl}(100 \mathrm{mM})$ at $37^{\circ} \mathrm{C}$ for $72 \mathrm{~h}$. The DNA was ethanol precipitated, ${ }^{23}$ resuspended in formamide loading buffer, ${ }^{23}$ loaded onto a $20 \%$ denaturing polyacrylamide gel, and the gel electrophoresed for $4 \mathrm{~h}$ at $1000 \mathrm{~V}$. Direct loading of cross-linking reactions (without ethanol precipitation) showed that ethanol precipitation does not alter the yield of the slow-migrating, cross-link band. The amount of radiolabeled DNA in each band on the gel was measured by phosphorimager analysis. The time course for the formation of the Ap site cross-link was carried out by incubating a solution containing labeled DNA (approximately 300,000 cpm), in HEPES 
$(50 \mathrm{mM}, \mathrm{pH} 7)$ and $\mathrm{NaCl}(100 \mathrm{mM})$ at $37^{\circ} \mathrm{C}$. At specified time points, aliquots $(10 \mu \mathrm{L})$

were removed and frozen at $-20{ }^{\circ} \mathrm{C}$, after all time points were collected samples were loaded directly on the gel and analyzed as described above.

Hydroxyl radical footprinting of cross-linked duplexes. Standard literature protocols were used in the footprinting of the cross-linked duplexes. ${ }^{24-25}$ In these experiments, the strand opposing the uracil-containing oligonucleotide was 5'-labeled using standard procedures. ${ }^{23}$ Labeled DNA was annealed with the uracil-containing complement and treated with UDG to generate the abasic site as described above. The Ap-containing double-stranded DNA $(\sim 500,000 \mathrm{cpm})$ was incubated in HEPES $(50 \mathrm{mM}, \mathrm{pH} 7)$ and $\mathrm{NaCl}(100 \mathrm{mM})$ at $37{ }^{\circ} \mathrm{C}$ for $120 \mathrm{~h}$. The DNA was ethanol precipitated, suspended in formamide loading buffer, and the 2'-deoxyoligonucleotides resolved on a $0.4 \mathrm{~mm}$ thick $20 \%$ denaturing polyacrylamide gel. The slow-migrating cross-linked duplex band was visualized using X-ray film, the band cut out of the gel, the gel slice crushed, and the gel pieces vortexed in elution buffer $(\mathrm{NaCl} 200 \mathrm{mM}$; EDTA, $1 \mathrm{mM})$ at room temperature for at least $1 \mathrm{~h}$. The mixture was filtered through a poly-prep column to remove gel fragments and the filtrate desalted using a C18 Sep-pak (100 mg size). The resulting solution was evaporated using a Speed-Vac concentrator, the residue redissolved in water (24 $\mu \mathrm{L}$ ), split evenly into three microcentrifuge tubes, and diluted with $2 \mathrm{x}$ oxidation buffer $(10 \mu \mathrm{L}$ of a solution composed of sodium phosphate, $20 \mathrm{mM}, \mathrm{pH} 7.2 ; \mathrm{NaCl}, 20$ $\mathrm{mM}$; sodium ascorbate, $2 \mathrm{mM} ; \mathrm{H}_{2} \mathrm{O}_{2}, 1 \mathrm{mM}$ ). To this mixture was added a solution of iron-EDTA ( $2 \mu \mathrm{L}$, EDTA, $70 \mathrm{mM}$; $\left.\mathrm{Fe}\left(\mathrm{NH}_{4}\right)_{2}\left(\mathrm{SO}_{4}\right)_{2} \bullet 6 \mathrm{H}_{2} \mathrm{O}, 70 \mathrm{mM}\right)$ to start the reaction, the mixture vortexed briefly, and incubated at room temperature for 1,2 , and $3 \mathrm{~min}$ 
before addition of thiourea stop solution (10 $\mu \mathrm{L}$ of a $100 \mathrm{mM}$ solution in water).

Hydroxyl radical footprinting reactions, Maxam-Gilbert G, and Maxam-Gilbert $A+G$ reactions were performed on the labeled single-strand to generate marker lanes. ${ }^{26}$ The resulting DNA fragments were analyzed using gel electrophoresis as described above.

Static Nanospray QTOF MS. The oligonucleotide sample was analyzed in a $40 \mathrm{mM}$ dimethylbutylammonium acetate ( $\mathrm{pH}$ 7.1) buffer. Negative ion MS spectra was taken for mass range of 280-3200 Da on an Agilent6520A QTOF MS with Chip Cube source (G4240A). Monoisotopic neutral masses were calculated from the multiply charged ion spectrum present in the 500-2000 Da mass range. Sample introduction was done with New Objective Econo12 N uncoated borosilicate glass emitters. Negative ion spectrum was acquired at a capillary potential sufficient to initiate spray of the sample. The nitrogen gas was heated to $290^{\circ} \mathrm{C}$ and introduced at a flow rate of $4 \mathrm{~L} / \mathrm{min}$. The Fragmentor, Skimmer, and Octapole1 RF Vpp potentials were set to $200 \mathrm{~V}, 65 \mathrm{~V}$, and $750 \mathrm{~V}$, respectively. External Calibration was done with the Agilent ESI-Low calibration tuning mixture (cat. no. G1969-85000) and data analysis was performed with Agilent Mass Hunter Workstation Qualitative Analysis software v B.02.00, Build 2.0.197.0 with Bioconfirm Software (2008). Peptide isotope model was assumed and peak set height threshold for extraction was set to $\geq 500$ counts. Deconvolution was done with a $0.1 \mathrm{Da}$ step size with a result of 20 iterations of the algorithm calculation 


\section{References}

1. Scharer, O. D. Chembiochem 2005, 6 (1), 27-32.

2. Hoy, C. A.; Thompson, L. H.; Mooney, C. L.; Salazar, E. P. Cancer Res 1985, 45 (4), 1737-43.

3. Osawa, T. D., D.; and hartley, J. A. Cell Death and Dis 2001, 2, e187.

4. Dutta, S.; Chowdhury, G.; Gates, K. S. J. Am. Chem. Soc. 2007, 129 (7), 1852-3.

5. Johnson, K. M.; Price, N. E.; Wang, J.; Fekry, M. I.; Dutta, S.; Seiner, D. R.; Wang, Y.; Gates, K. S. J. Am. Chem. Soc. 2013, 135 (3), 1015-25.

6. Hoehn, S. T.; Turner, C. J.; Stubbe, J. Nucleic Acids Res. 2001, 29 (16), 3413-23.

7. Beger, R. D.; Bolton, P. H. J. Biol. Chem. 1998, 273 (25), 15565-73.

8. Chen, J.; Dupradeau, F. Y.; Case, D. A.; Turner, C. J.; Stubbe, J. Nucleic Acids Res. 2008, 36 (1), 253-62.

9. Chen, J.; Dupradeau, F. Y.; Case, D. A.; Turner, C. J.; Stubbe, J. Biochemistry 2007, 46 (11), 3096-107.

10. Savelyev, A. Phys. Chem. Chem. Phys. 2012, 14 (7), 2250-4.

11. Muniandy, P. A.; Liu, J.; Majumdar, A.; Liu, S. T.; Seidman, M. M. Crit. Rev. Biochem. Mol. Biol. 2010, 45 (1), 23-49.

12. Stivers, J. T.; Jiang, Y. L. Chem. Rev. 2003, 103 (7), 2729-59.

13. Esteban, J. A.; Salas, M.; Blanco, L. J. Biol. Chem. 1993, 268 (4), 2719-26.

14. Rodriguez, I.; Lazaro, J. M.; Blanco, L.; Kamtekar, S.; Berman, A. J.; Wang, J.; Steitz, T. A.; Salas, M.; de Vega, M. Proc Natl Acad Sci U S A 2005, 102 (18), 6407-12.

15. Ho, T. V.; Guainazzi, A.; Derkunt, S. B.; Enoiu, M.; Scharer, O. D. Nucleic Acids Res. 2011, 39 (17), 7455-64.

16. Holton, S.; Runquist, O. J. Org. Chem. 1961, 26 (12), 5193-5195.

17. Cordes, E. H.; Jencks, W. P. J. Am. Chem. Soc. 1963, 85 (18), 2843-2848.

18. Price, N. E.; Johnson, K. M.; Wang, J.; Fekry, M. I.; Wang, Y.; Gates, K. S. J. Am. Chem. Soc. 2014, 136 (9), 3483-90.

19. De Bont, R.; van Larebeke, N. Mutagenesis 2004, 19 (3), 169-85.

20. Nakamura, J.; Swenberg, J. A. Cancer Res 1999, 59 (11), 2522-6. 
21. Sugiyama, H.; Fujiwara, T.; Ura, A.; Tashiro, T.; Yamamoto, K.; Kawanishi, S.; Saito, I. Chem. Res. Toxicol. 1994, 7 (5), 673-83.

22. Mitchell, D.; Willerslev, E.; Hansen, A. Mutat Res 2005, 571 (1-2), 265-76.

23. Sambrook, J.; Fritsch, E. F.; Maniatis, T., Molecular Cloning: A Lab Manual. Cold Spring Harbor Press: Cold Spring Harbor, NY, 1989.

24. Sczepanski, J. T.; Jacobs, A. C.; Majumdar, A.; Greenberg, M. M. J. Am. Chem. Soc. 2009, 131, 11132-11139.

25. Luce, R. A.; Hopkins, P. B. Methods Enzymol. 2001, 340, 396-412.

26. Maxam, A. M.; Gilbert, W. Methods Enzymol. 1980, 65, 499-560. 


\section{Chapter 5. DNA Interstrand Cross-Links Derived From Single Strand Breaks in the DNA Duplex.}

\subsection{Introduction}

As discussed in Chapter 3, Ap sites (1, Scheme 1) resulting from hydrolysis of the glycosidic bond are among the most common form of DNA damage. ${ }^{1} \mathrm{C} 4$ '-Oxidized Apsites have also been shown to be generated by radiation or bleomycin (C4-AP, Scheme 2) via $\mathrm{C}^{\prime}$-hydrogen abstraction from the deoxyribose sugar, followed by oxidation. ${ }^{2}$ Additionally, several other oxidized Ap-sites have been identified. ${ }^{3}$ The C4 '-oxidized Ap sites have been shown to cross-link with lysine and deoxyadenine residues (structures $\mathbf{1 0}$ and 11, Scheme 3). ${ }^{4}$ 


\section{Scheme 1}

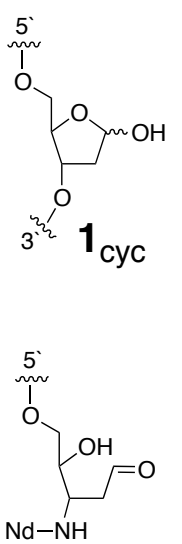

$6_{\text {open }}$

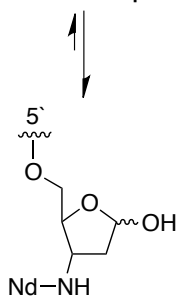

$6_{\mathrm{cyc}}$
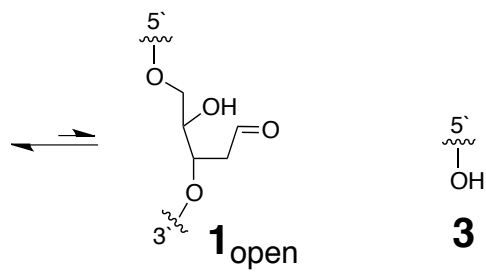

3
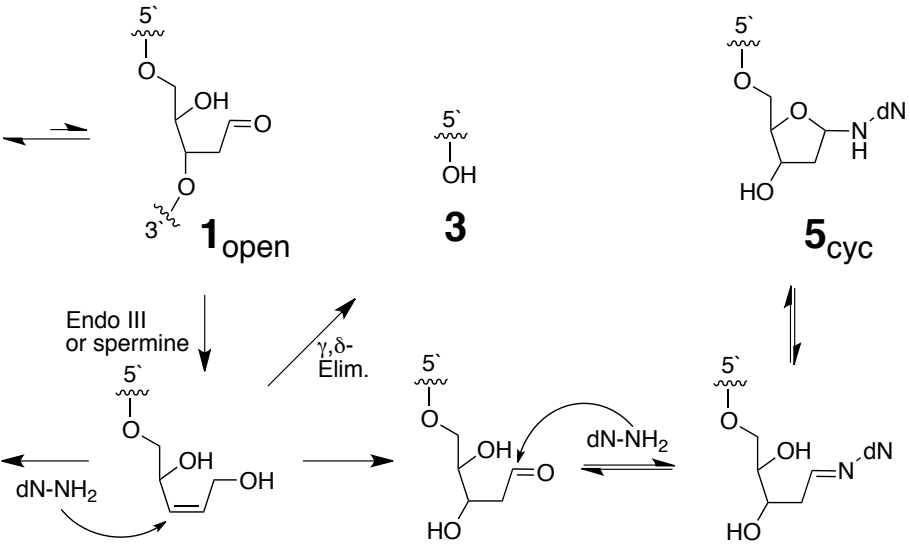

4

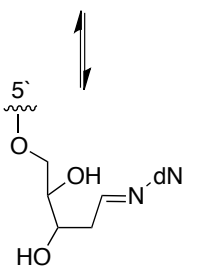

$5_{\text {open }}$

One common reaction of $\mathrm{C}^{`}{ }^{-}$-oxidized Ap sites is $\alpha, \beta$-cleavage to give structure 9 by elimination of the $3^{3}$-phosphate group. ${ }^{5}$ The elimination product 9 exists as an equilibrium mixture of ring closed $\left(\boldsymbol{9}_{\mathrm{cyc}}\right)$ form and ring opened $\alpha, \beta$-unsaturated aldehydes $\left(\mathbf{9}_{\text {open }}\right)$. In general, $\alpha, \beta$-unsaturated aldehydes are reactive electrophiles, readily reacting with various nucleophiles at the $\beta$-carbon via conjugate addition reactions (Scheme 3). For example, acrolein, a simple $\alpha, \beta$-unsaturated aldehyde, has been studied for its toxicological effects as it is a common environmental pollutant from many sources (cooking, smoking, plastics). ${ }^{6-7}$ Acrolein has been shown to readily form adducts with both enzymes and DNA bases, ${ }^{8-10}$ and can cause DNA-DNA inter- and intrastrand crosslinks between two deoxyguanosine residues in a $5{ }^{`}$-CG sequence (Chapter 3 , Scheme 2). ${ }^{9}$ 


\section{Scheme 2}
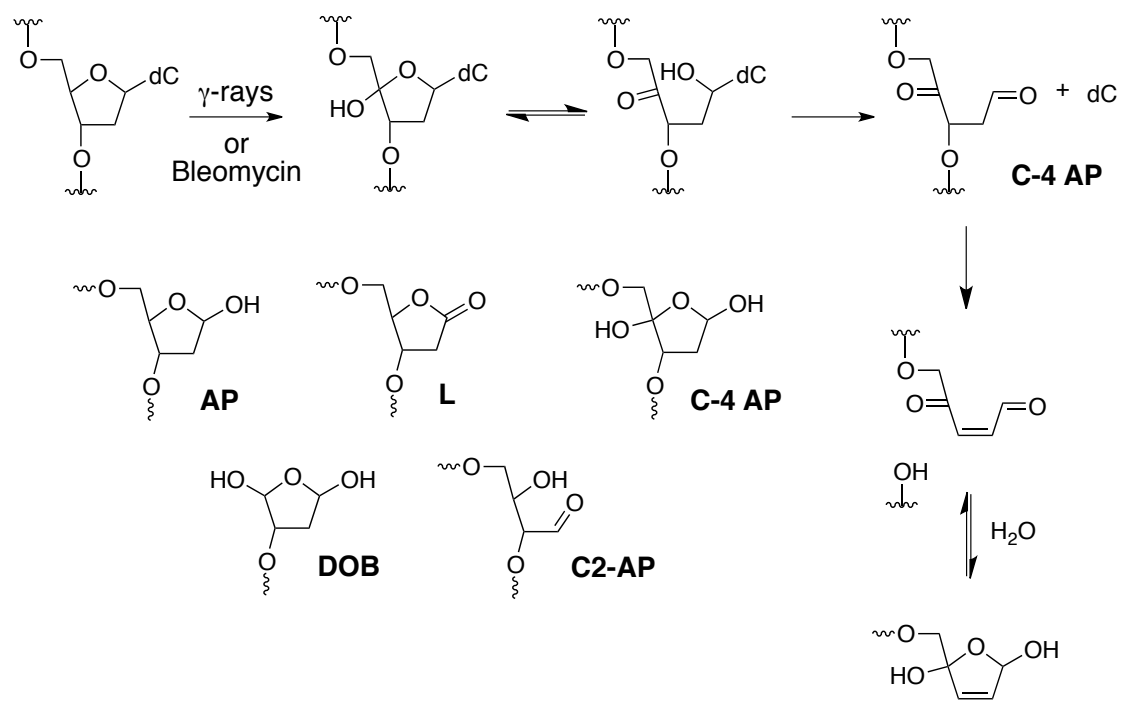

9

\section{Scheme 3}

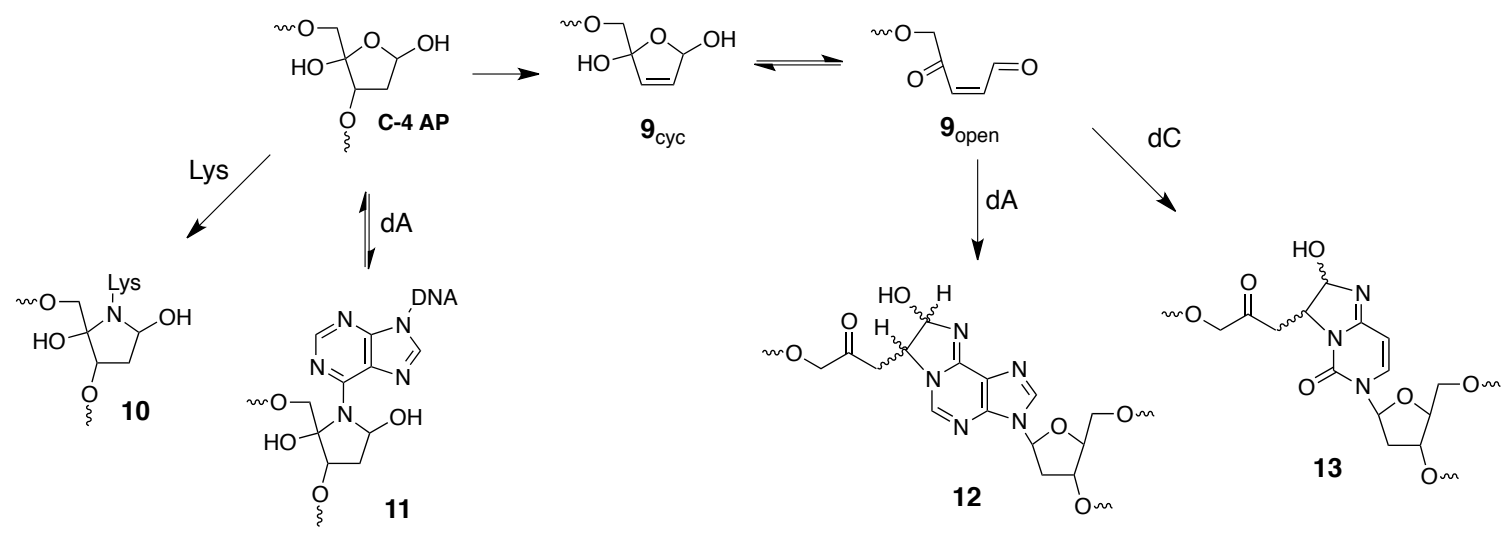

Similarly, the $\alpha, \beta$-unsaturated oxidized Ap-site 9 has been shown to be highly reactive in DNA, ${ }^{3-4}$ forming cross-link adducts with an opposing deoxyadenine (12) or deoxycytosine (13) residue in the DNA duplex through conjugate addition and imine formation (Scheme 3). ${ }^{2,4}$ DNA cross-links of this type are especially deleterious to cells, as failed repair by NER can result in double-strand breaks. ${ }^{4}$ 
While cross-links generated from the C4-oxidized $\alpha, \beta$-unsaturated Ap site (9) have been well characterized, ${ }^{2-4}$ cross-links have yet to be indentified from native $\alpha, \beta$ unsaturated Ap sites (2). It is known that the $\alpha, \beta$-elimination of the $3^{`}$-phosphate from the Ap-site occurs readily. ${ }^{11}$ This process is assisted by heat and Schiff-Base formation via lysines or secondary amines (Scheme 1)., ${ }^{3,5,12}$ Some repair enzymes like UV endonuclease V, 8-oxoguanine glycosylase, and endonuclease III contain lyase activity that generates $2 .{ }^{13-18}$ With several sources of these lesions and substantial literature precedent suggesting their high degree of reactivity, $\mathbf{2}$ could potentially be a severe threat to the function of cellular DNA.

We were interested in studying the formation of what we will term "low molecular weight" (LMW) cross-links, derived from reaction of $\mathbf{2}$ with a nucleobase on the opposing strand of a DNA duplex. This chapter will describe two different methods for generating 2 in ${ }^{32} \mathrm{P}-5$-labeled oligonucleotides and characterization of the crosslinked products. Initially we utilized endonuclease III (Scheme 4), an enzyme reported to selectively cleave Ap-sites via $\beta$-elimination (2). ${ }^{19-20}$ Interestingly we found that Endo III is an inefficient reagent for generating $\alpha, \beta$-unsaturated Ap-sites (2) as it also catalyzes hydration of the $\alpha, \beta$-unsaturated Ap-site to yield a $3^{\prime}$-deoxyribose phosphate (4), resulting in a mixture of single-strand break products in our experiments (approximately 40:60 ratio for $\mathbf{2}$ and 4$).{ }^{18}$ This led us to use spermine (14) as a Schiff-Base catalyst to generated 2. We use a combination of PAGE and mass spectrometry experiments to analyze products formed upon incubating 2 and 4 in a DNA duplex under biologically relevant conditions. Additionally we used thiols 15 (thioglycolate), 16 (glutathione), and 17 ( $\beta$-mercaptoethanol) to assist in structure determination. 


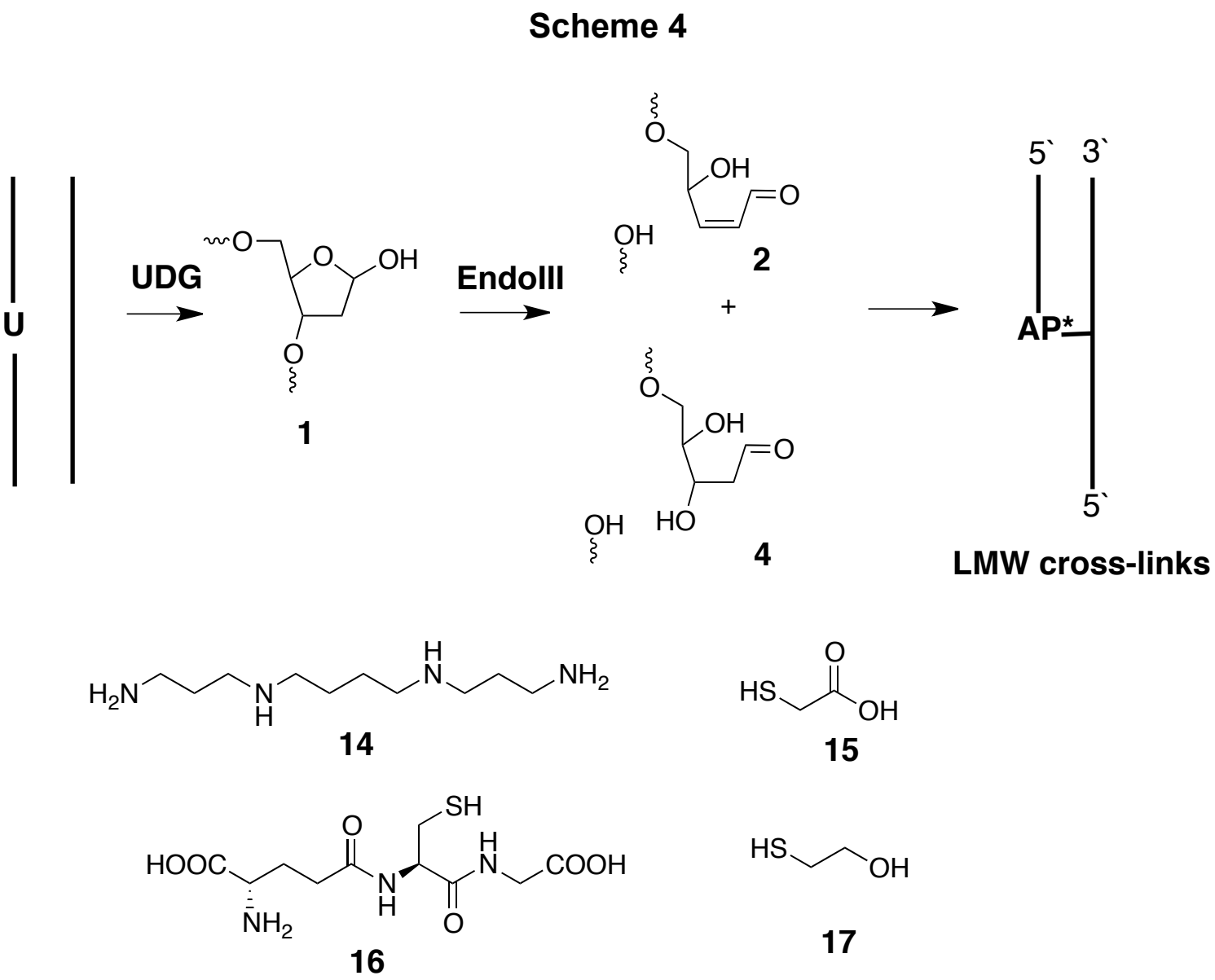

\subsection{Generating Low Molecular Weight Cross-Links with Endonuclease III}

We initially employed endonuclease III to generate 2. This enzyme has been used previously for the conversion of the C4-Ap to $9 .^{21}$ We treated deoxyuridine containing ${ }^{32} \mathrm{P}-5$-labeled DNA duplexes with UDG (Scheme 4) to generate an Ap-site (1). We used sequences that mimic duplexes described in earlier chapters (Duplex I, Chapter 4) designed to place a dA-residue with the N6-amino group in close proximity of the $\alpha, \beta$ eliminated abasic site. Elimination of the 3 -phosphate was catalyzed by incubation of UDG treated duplex N (1) with Endo III in HEPES buffer $(50 \mathrm{mM}, \mathrm{pH}$ 8) and $\mathrm{NaCl}(100$ 
$\mathrm{mM})$ at $37{ }^{\circ} \mathrm{C}$ for 30 minutes to give predominantly $\mathbf{4}$ with small amounts of $\mathbf{2}$. Control cross-linking reactions (Chapters 3 and 4) were done by incubating Ap-containing (1) duplex $\mathbf{N}$ in HEPES buffer (50 mM, pH 7) and $\mathrm{NaCl}(100 \mathrm{mM})$ at $37{ }^{\circ} \mathrm{C}$ for $5 \mathrm{~d}$. LMW cross-link formation was done by incubating $\alpha, \beta$-eliminated Ap-containing duplex $\mathbf{N}$ containing under matching conditions. The reaction mixtures were analyzed by $20 \%$ denaturing PAGE to give a mixture of slow moving bands relative to un-reacted singlestranded DNA (Figure 1). The bands with slowest mobility was identified as the previously described Ap-dA cross-link ( 71\% yield) via gel mobility (Figure 1, lane 5) formed after incubation of 1 (Chapters 3 and 4). ${ }^{22}$ The slightly faster moving band, suggestive of a LMW cross-link $(\sim 35 \%)$, was mainly present in the reaction mixture incubated at $37{ }^{\circ} \mathrm{C}$ at $\mathrm{pH} 7$ after pretreatment with EndoIII (lane 6). This reaction resulted in significantly lower yields of the dA-AP cross-link (Chapter 4), as EndoIII processed the majority of the abasic DNA. Low yields of this LMW cross-link were also seen in lanes 4 and $5(\sim 5 \%)$ from DNA not treated with EndoIII. Most likely this occurred from spontaneous $\alpha, \beta$-elimination of $\mathbf{1}$ (without EndoIII treatment). 


\section{Figure 1}

\section{Duplex N}

5-32P-ATG CAT GCT ATA ATA CTG GAT CUT AGA CAT

3-TAC GTA CGA TAT TAT GAC CTA GAA TCT GTA

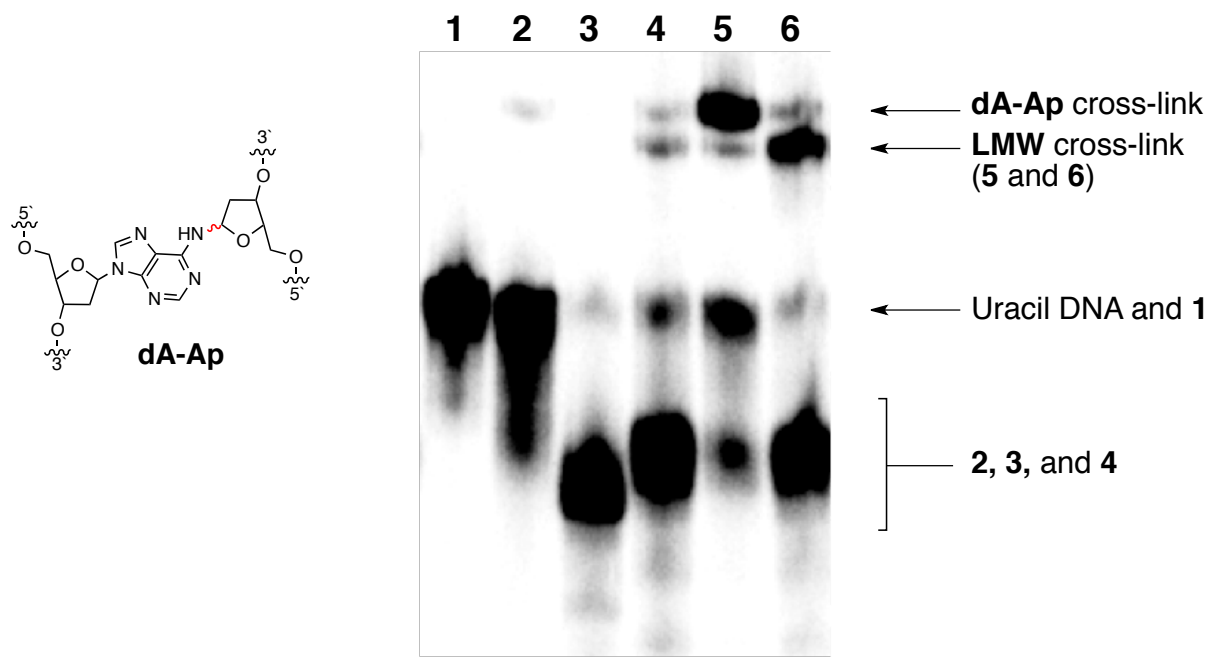

Figure 1. Interstrand cross-link formation in ${ }^{32} \mathrm{P}$-labeled 2'-deoxyoligonucleotide duplex $\mathbf{N}$. Lanes 1 is the uracil-containing duplex. Lane 2 is the UDG-treated (1) duplex without further incubation. Lane 3 is the UDG-treated duplex subjected to piperidine work-up $\left(1 \mathrm{M}, 95^{\circ} \mathrm{C}, 25 \mathrm{~min}\right)$ to cleave the Ap site. Lane 4 is the UDG/EndoIII-treated duplex (2) without further incubation. Lane 5 is the cross-linking reactions involving incubation of the Ap-containing duplexes (1) in HEPES buffer $(50 \mathrm{mM}, \mathrm{pH} 7)$ containing $\mathrm{NaCl}(100 \mathrm{mM})$ at $37^{\circ} \mathrm{C}$. Lane 6 is the cross-linking reactions involving incubation of 2 in HEPES buffer $(50 \mathrm{mM}, \mathrm{pH} 7)$ containing $\mathrm{NaCl}(100 \mathrm{mM})$ at $37{ }^{\circ} \mathrm{C}$. The ${ }^{32} \mathrm{P}$-labeled 2 '-deoxyoligonucleotides were resolved by electrophoresis on a $20 \%$ denaturing polyacrylamide gel and the radioactivity in each band quantitatively measured by phosphorimager analysis.

To avoid uncatalyzed cleavage of $\mathbf{1}$, we utilized longer duplexes to ensure neither the labeled nor $\alpha, \beta$-cleaved fragment would melt off after $\beta$-elimination of Ap-containing DNA (1, Duplex $\mathbf{O})$. Duplex $\mathbf{O}$ was treated with UDG and EndoIII as before and further incubated in HEPES (50 mM, pH 7) and $\mathrm{NaCl}(100 \mathrm{mM})$ at $37{ }^{\circ} \mathrm{C}$ for $1 \mathrm{~d}$ before being analyzed by $20 \%$ denaturing PAGE. The results are presented in Figure 2. Incubation 
after treatment with only UDG selectively provided the dA-Ap cross-link ( $44 \%$, Lane

2). While incubation after treatment with both UDG and EndoIII provided the LMW cross-link ( $20 \%$, Lane 4). Additionally, cross-link formed in the presence of thiol $(\sim 17 \%$, lane 5), but was blocked in the presence of methoxyamine (lane 6$)$.

Figure 2

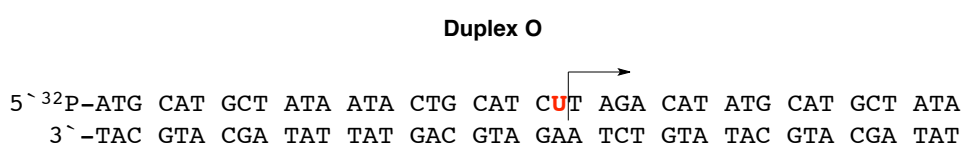

$\begin{array}{llllll}1 & 2 & 3 & 4 & 5 & 6\end{array}$
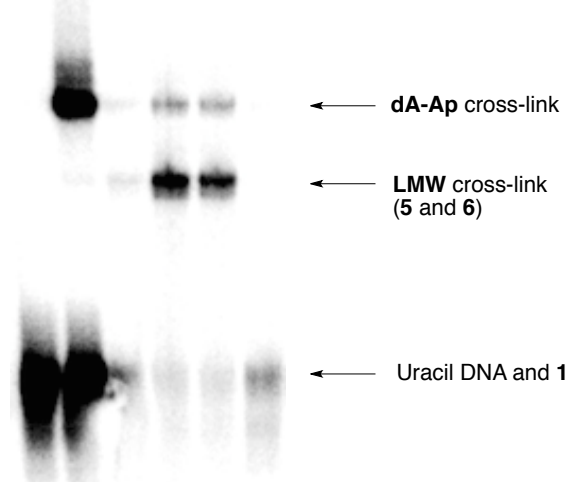

Figure 2. Interstrand cross-link formation in ${ }^{32} \mathrm{P}$-labeled 2'-deoxyoligonucleotide duplex O. Lane 1 is the UDG-treated duplex (1) without further incubation. Lane 2 contains the cross-linking reactions involving incubation of 1 in HEPES buffer $(50 \mathrm{mM}, \mathrm{pH}$ 7) containing $\mathrm{NaCl}(100 \mathrm{mM})$ at $37{ }^{\circ} \mathrm{C}$. Lane 3 contains the UDG and EndoIII-treated duplex (2) without further incubation. Lane 4 contains the cross-linking reactions involving incubation of 2 in HEPES buffer $(50 \mathrm{mM}, \mathrm{pH} 7)$ containing $\mathrm{NaCl}(100 \mathrm{mM})$ at $37{ }^{\circ} \mathrm{C}$. Lane 5 is the same with thioglycolate $(15,1 \mathrm{mM})$ at $37{ }^{\circ} \mathrm{C}$. Lane 6 is the same with methoxyamine $(2 \mathrm{mM})$ at $37^{\circ} \mathrm{C}$. The ${ }^{32} \mathrm{P}$-labeled $2^{\prime}$-deoxyoligonucleotides were resolved by electrophoresis on a $20 \%$ denaturing polyacrylamide gel and the radioactivity in each band quantitatively measured by phosphorimager analysis. 
These LMW cross-links were all obtained in relatively high equilibrium yields ( $25-30 \%)$ within 1 day incubation at $37^{\circ} \mathrm{C}$ in $\mathrm{NaCl}(100 \mathrm{mM})$ and HEPES $(50 \mathrm{mM}, \mathrm{pH}$

7) (Figure 3A). This is much faster rate of formation than the dA-Ap derived cross-links described in Chapter 4, which typically required incubations of 2-5 days to reach equilibrium yield. ${ }^{22-23}$ Intuitively this makes sense, as the newly formed $\alpha, \beta$-cleaved Apsites should have superior flexibility when not tethered by the 3 '-phosphate ( 2 and $\mathbf{4}$, Scheme 1) and thus would react faster with opposing bases. Additionally, the purified LMW cross-links dissociated much quicker as well, returning to equilibrium yields in less than 24 hours at $37^{\circ} \mathrm{C}$ in $\mathrm{NaCl}(100 \mathrm{mM})$ and HEPES (50 mM, pH 7) buffer (Figure 3B). The incomplete yield and reversibility of these products suggest that imine formation is involved in the attachment, as imines are reversible in aqueous solutions. ${ }^{24-26}$ Although we cannot rule out that purification involves denaturing conditions, causing inefficient re-hybridization and decreased stabilization.

\section{Figure 3}

A
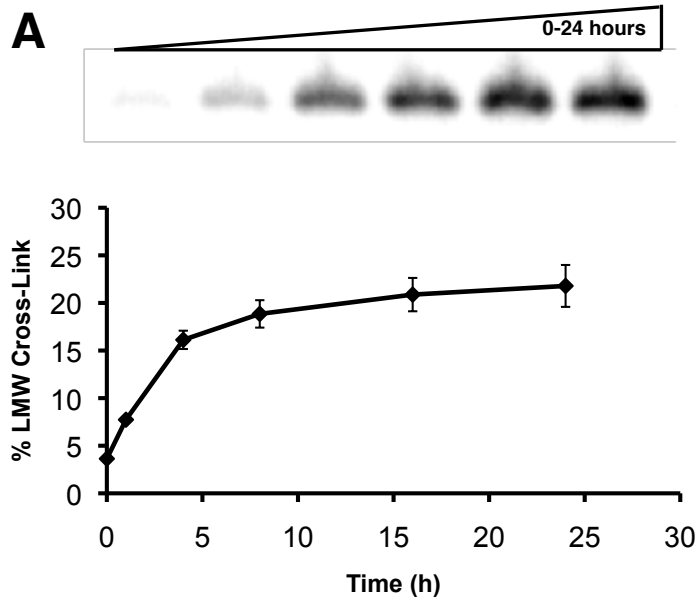

B
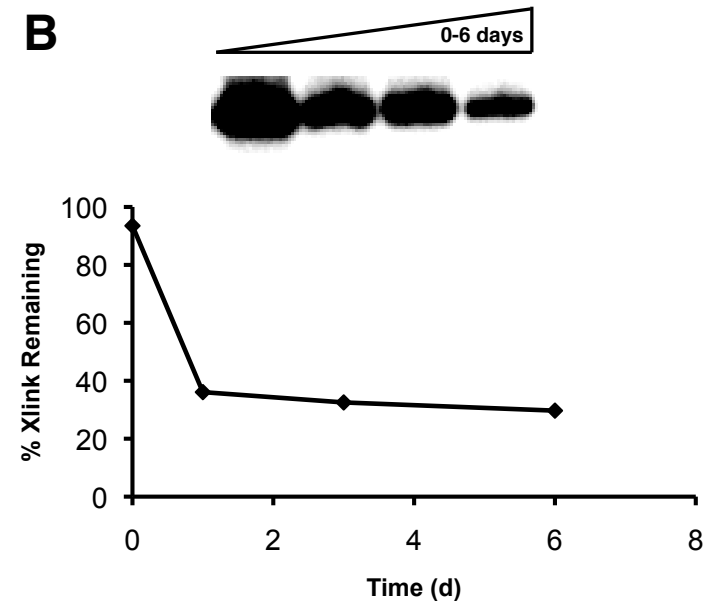

Figure 3. Time course showing formation (Panel A) and Decomposition (Panel B) of LMW cross-link of duplex $\mathbf{O}$ in HEPES buffer $(50 \mathrm{mM}, \mathrm{pH} 7)$ and $\mathrm{NaCl}(100 \mathrm{mM})$ at 37 ${ }^{\circ} \mathrm{C}$. 
To expand the scope of this cross-linking reaction, we examined which nucleobases were capable of forming LMW cross-links. We prepared duplexes P-S (below), each possessing only a specific nucleobase directly opposing and flanking in the 5 - and $3{ }^{\prime}$ - direction of the $\alpha, \beta$-eliminated Ap-site ( 2 and $\left.\mathbf{4}\right)$. This was to ensure that any cross-link seen from reaction of the Ap-site, resulted from reaction of that specific base $(\mathrm{dA}, \mathrm{dT}, \mathrm{dG}$, or $\mathrm{dC}) .{ }^{32} \mathrm{P}$-labeled uracil containing DNA was treated with UDG and EndoIII as before and allowed to incubate further in HEPES buffer (pH 7). After 24 hours, the reaction products were analyzed with PAGE and the results shown in Table 1. Only duplexes $\mathbf{P}, \mathbf{R}$ and $\mathbf{S}$ generated LMW cross-links. Duplex $\mathbf{P}$ gave the highest yield $(\sim 11 \%)$ of the three while duplexes $\mathbf{R}$ and $\mathbf{S}$ produced only modest yields $(\sim 3-4 \%)$. Additionally, no cross-link was seen for duplex $\mathbf{Q}$ as expected since deoxythymine residues do not contain exocyclic amines for cross-link formation. While no structural characteristics can be confirmed, these results show that most bases have the potential to form LMW cross-links but suggest $\mathrm{dA}$ is superior. We discuss in a later section the effect of LMW cross-link formation using spermine instead.

\section{Duplex}

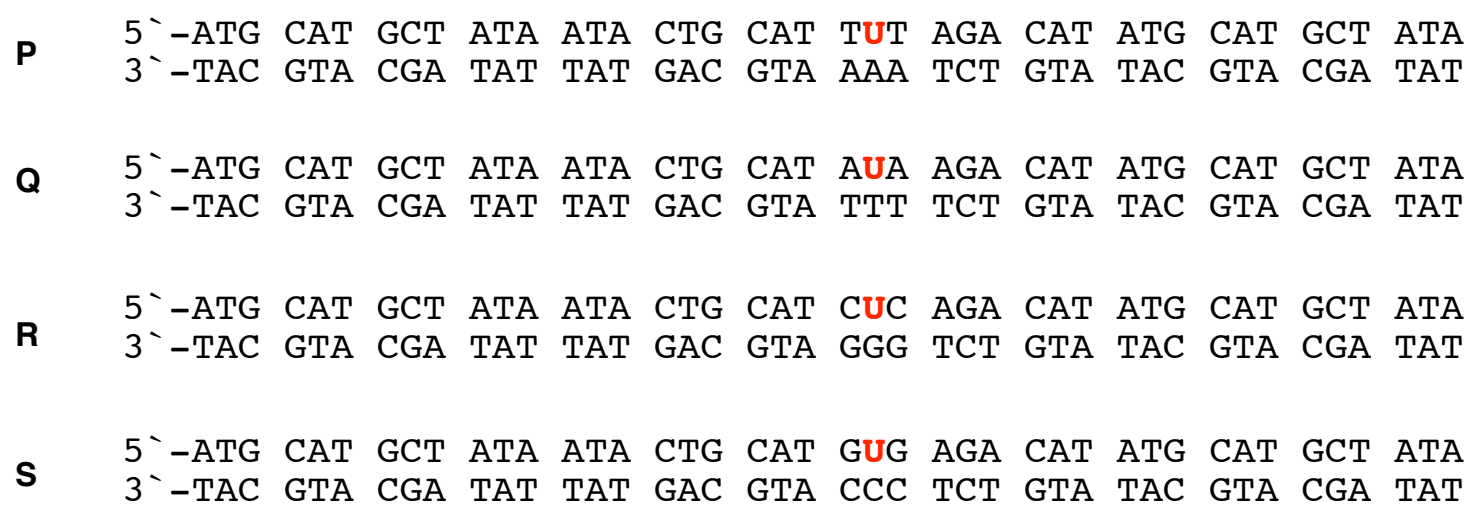


TABLE 1. Sequence Dependent Formation of LMW Cross-Links From $\alpha, \beta$-Unsaturated Ap-Sites

\begin{tabular}{|c|c|c|c|}
\hline \multirow[b]{2}{*}{ Duplex } & \multicolumn{2}{|c|}{ \% LMW Cross-Link } & \multirow[b]{2}{*}{ Structure } \\
\hline & Endo III & Spermine & \\
\hline $\mathbf{P}$ & $11.2 \pm 0.2$ & $10.4 \pm 2.5$ & $\begin{array}{l}5^{-} \text {-TAp* } \\
3^{-} \text {-A A A }\end{array}$ \\
\hline $\mathbf{Q}$ & none & $1.7 \pm 0.2$ & $\begin{array}{l}5-\text { - } A \text { Ap* } \\
3 \text { - T T T }\end{array}$ \\
\hline $\mathbf{R}$ & $2.8 \pm 0.2$ & $39.7 \pm 2.6$ & $\begin{array}{l}5 \text {-CAp* } \\
3 \text { - - G G G }\end{array}$ \\
\hline $\mathbf{s}$ & $3.7 \pm 0.4$ & $1.5 \pm 0.3$ & $\begin{array}{l}5^{-} \text {-GAp* } \\
3^{-}-\mathrm{C} \mathrm{C} \mathrm{C}\end{array}$ \\
\hline
\end{tabular}

Ap $^{*}=$ structure 2 or 4

\subsection{Structure Elucidation of the Endonuclease III-Generated Cross-Links by} Hydroxyl Radical Footprinting and Gel Shift Assay

Observation of cross-link bands with faster mobility than dA-Ap cross-links (dependent upon EndoIII treatment) is consistent with formation of LMW cross-links. We next set out to better characterize the structure and location of this LMW cross-link. It was important to locate the site of attachment, so we performed hydroxyl radical footprinting reactions as described in Chapter 3 for sequence $\mathbf{O}$. After analysis with PAGE, results show that the site of attachment is at $\mathbf{A 9}$ (Figure 4). This cross-link site of attachment resembles that of the dA-Ap cross-links discussed in Chapter 4 from which the duplex $\mathbf{O}$ sequence was based. 
Figure 4

\section{Duplex 0}

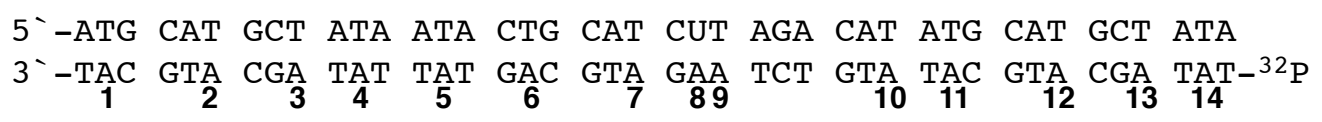

A

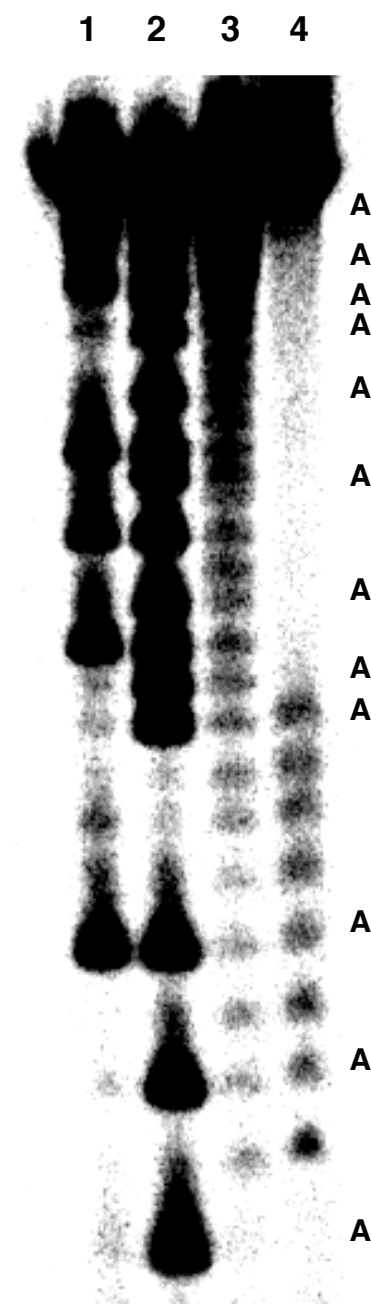

B

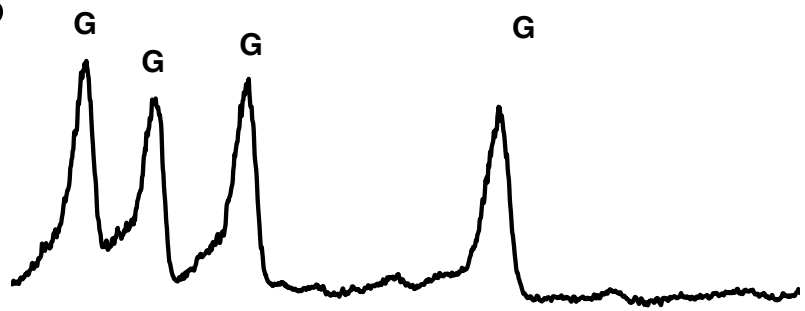

A5

A6

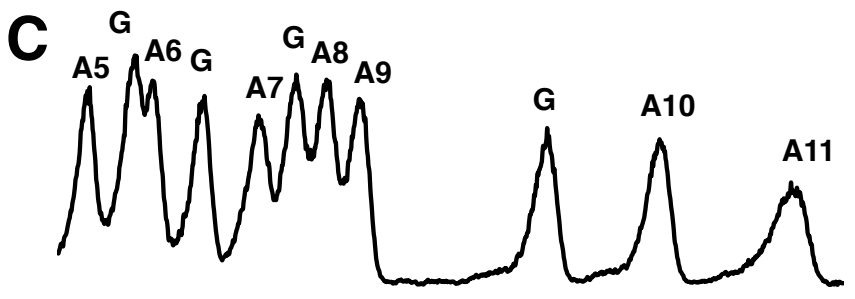

A9

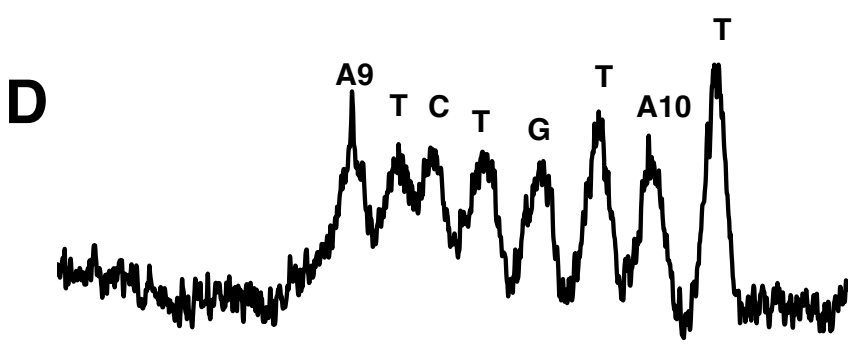

Figure 4. Hydroxyl radical footprinting of duplex $\mathbf{O}$ to locate the site of attachment for Endo III generated LMW cross-link (Panel A). Panel A: Lane 1 is a Maxam-Gilbert Gspecific cleavage (sequencing) reaction of the labeled strand. Lane 2 is an $A+G$ specific cleavage (sequencing) reaction of the labeled strand. Lane 3 is the hydroxyl radical footprinting reaction of the single stranded non-uracil containing oligonucleotide. Lane 4 is the hydroxyl radical footprinting reaction of the PAGE purified cross-link generated by incubation of UDG and EndoIII treated duplex $\mathbf{O}$ in HEPES buffer $(50 \mathrm{mM}, \mathrm{pH} 7)$ containing $\mathrm{NaCl}(100 \mathrm{mM})$ at $37{ }^{\circ} \mathrm{C}$. ${ }^{32} \mathrm{P}$-labeled 2'-deoxyoligonucleotides were resolved on a polyacrylamide gel visualized by phosphorimager analysis (Panel A) and used to develop densitometry traces (Panels B-D). Panel B is the trace of lane 1. Panel C is the trace of lane 2. Panel D is the trace of lane 3. 
To determine approximately the amount at which Ap-containing DNA (1) were converted to $\mathbf{2}$ and $\mathbf{4}$, we performed the LMW cross-link reactions in the presence of thiols to capture the $\alpha, \beta$-unsaturated aldehydes (2) present to form 7 (Scheme 1). It is known that thiols react quickly with $\alpha, \beta$-unsaturated aldehydes. ${ }^{27}$ If the major site of cross-link formation was at the $\beta$-carbon, then thiols were expected to diminish or quench cross-link formation. Furthermore, a gel shift assay was used to "visualize" conjugate additions of thiols to the $\alpha, \beta$-unsaturated Ap-sites (2). ${ }^{28}$ DNA fragments adducted by thioglycolate (15) can produce significant changes to their gel mobility. ${ }^{28}$ Consequently, all thiol adducted $\alpha, \beta$-unsaturated aldehydes (7) or LMW cross-linked (8) would be observed as a gel shifted (faster moving) band relative to the non-thiol-adducted DNA because of the additional negative charge. 


\section{Figure 5}

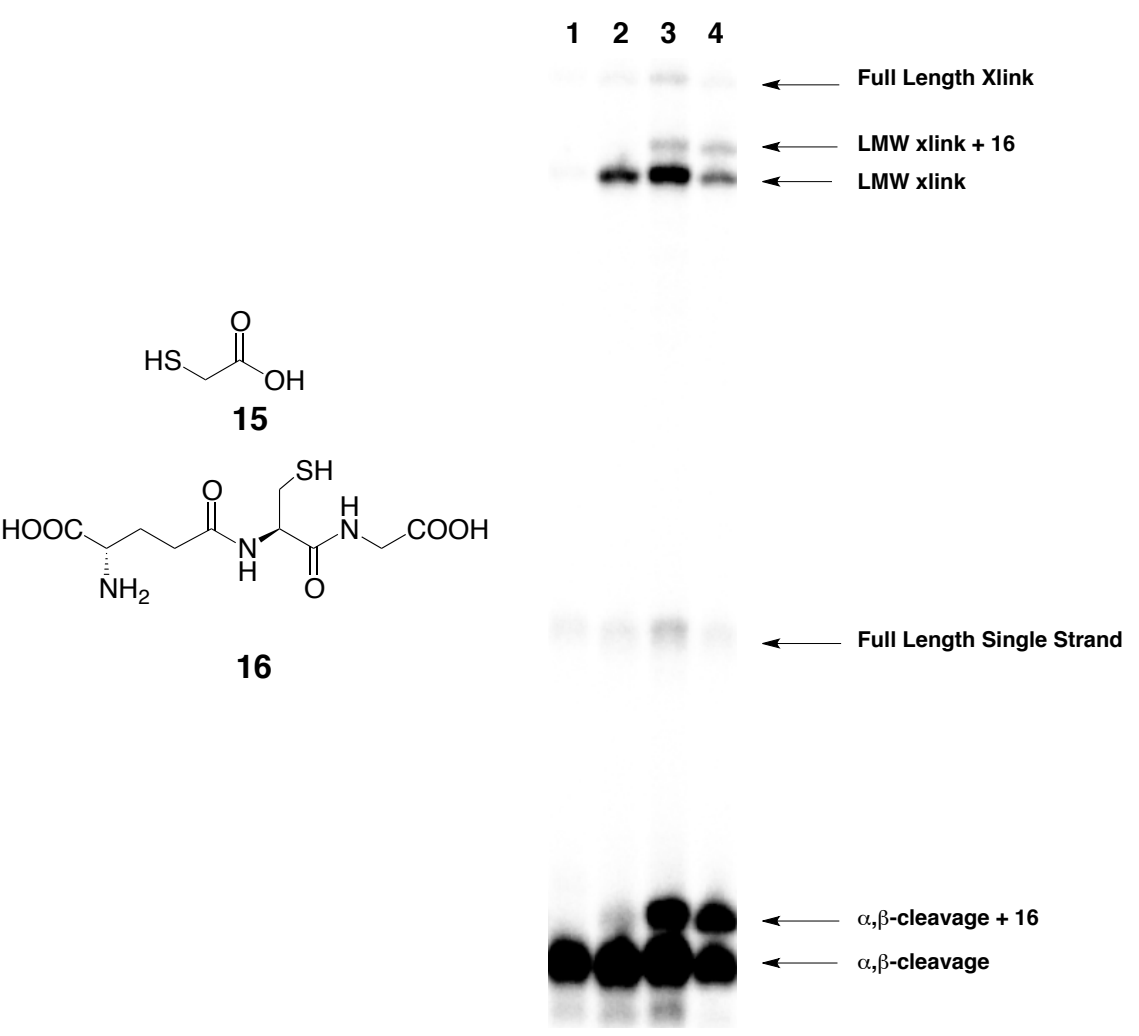

Figure 5. Thiol induced gel shift assay of LMW cross-link generated from UDG and EndoIII treated duplex $\mathbf{N}$. $\alpha, \beta$-Eliminated DNA from treatment with EndoIII was incubated in HEPES buffer $(50 \mathrm{mM}, \mathrm{pH} 8)$ containing $\mathrm{NaCl}(100 \mathrm{mM})$ at $37{ }^{\circ} \mathrm{C}$ for $24 \mathrm{~h}$ in the presence (or absence) or glutathione (16,1 mM). Lane 1 is enzyme treated DNA (no inc), Lane 2 is enzyme treated DNA with incubation, Lane 3 is a mixture of reactions co-loaded with samples included in Lanes 2 and 4, and Lane 4 is enzyme treated DNA incubated in the presence of thiol $\mathbf{1 6 .}$

For this assay, we first followed a procedure described by Bailly and Verly. ${ }^{28} \mathrm{We}$ incubated $\alpha, \beta$-eliminated Ap-DNA with thioglycolate (15) in HEPES buffer $(50 \mathrm{mM}, \mathrm{pH}$ 8) and $\mathrm{NaCl}(100 \mathrm{mM})$. After analysis by PAGE, no observable gel shift was seen. Examining Verly's work more closely revealed their gel shifted DNA involved 8-mer 2deoxyoligonucleotides $(\sim 3 \mathrm{kDa})$ with a terminal $\alpha, \beta$-unsaturated Ap-site (2). Oligonucleotides of this length are much smaller in size and mass than the duplexes 
employed in this study $(>16 \mathrm{kDa})$, therefore a single negative charge produced by thioglycolate would have less of an effect on gel mobility than in Verly's work. ${ }^{28}$

So instead we decided to use a much larger thiol, utilizing its size to slow the mobility of any $\alpha, \beta$-eliminated Ap-DNA. Glutathione (GSH, 16, Scheme 4) is a large thiol present in high abundance in cells, with a molecular mass of $307.32 \mathrm{~g} / \mathrm{mol}$. While GSH contains two negatively charged carboxyl groups, it is much larger than any single nucleoside within DNA and should produce a noticeable gel shift from its additional mass and inherent bulkiness. This was actually observed in experiments described in Chapters 3 and 4 when Ap-derived cross-link formation was tested in the presence of various additives. $\alpha, \beta$-eliminated Ap-DNA that formed during incubation produced gelshifted bands in the presence of GSH (slowed mobility).

EndoIII-treated, Ap-containing duplex $\mathbf{N}$ incubated in the presence of GSH (16, 1 $\mathrm{mM}$ ) produced a gel shift for the LMW cross-link (8) as well as the uncross-linked cleaved DNA (7) (Figure 5, lanes 3 and 4). Only a fraction of each band resulted in a gel shift, indicating only partial adduction by thiol. Quantification of the bands in Figure 5 tells us that a mixture of $\mathbf{2}$ and $\mathbf{4}$ was obtained after EndoIII treatment of $\mathbf{1}$. About 40$50 \%$ of the EndoIII treated Ap-DNA was gel shifted when incubated in the presence of GSH. Furthermore, a similar portion of the LMW cross-link was also gel shifted from the presence of GSH $(\sim 30 \%)$. This result is consistent with a mixture of cleaved APcontaining DNA (2 and 4). Any $\alpha, \beta$-unsaturated Ap-sites (2) would be adducted by thiol giving a gel-shifted band corresponding to a $3{ }^{\prime}-\mathrm{GSH}$ adduct of the Ap-site (7, Scheme 1). The $3{ }^{`}$-thiol adducted Ap-site (7) was able to cross-link; presumably by imine formation resulting in a GSH adducted LMW cross-link (8). Formation of this product was not 
dependent on whether thiol was present during or after treatment with EndoIII (data not shown). Finally, any 3`-deoxyribose phosphate (4) DNA present would not be adducted by thiol as the $\alpha, \beta$-unsaturation was hydrated. For this reason we would not observe a gel shifted band for both the $3{ }^{`}$-deoxyribose phosphate (4) and $3^{`}$-deoxyribose phosphate LMW cross-link (5).

\subsection{Mass Spectrometric Analysis of Low Molecular Weight Cross-link Generated by}

\section{Endonuclease III}

We were curious why we did not see a complete gel shift in the DNA upon thiol treatment. So we used mass spectrometry to get the molecular mass of the EndoIIIgenerated, cross-linked product, with and without thiol. LMW cross-links were prepared as before using duplex N-2 (Figure 6). Purification was done by preparative PAGE and analysis by Nanospray-QTOF MS provided the spectra in Figure 6. We observed a neutral mass of 16115.53 Da for the non thiol-adducted cross-link of duplex N-2 (Figure 6). This mass is 18 mass units $\left(+\mathrm{H}_{2} \mathrm{O}\right)$ higher than the mass expected for structure $\mathbf{1 8}$ (calc'd 16097.42 Da) that would form through an imine intermediate from 2. Initially this would suggest that conjugate addition was the preferred method of cross-link formation (Scheme 5, structure 19, calc'd 16115.44 Da). But as suggested before a mixture of LMW cross-links most likely was obtained providing the isobaric structure 22 (calc'd 16115.44 Da).

We also observed smaller masses identified as each of the single strand DNA dissociated from the LMW cross-link isolated with neutral masses of 9244.04 Da and 6889.54 $\mathrm{Da}$. These masses correspond to the full-length complimentary bottom strand 
(Figure 6, calc'd 9244.00 Da) and the 3'-deoxyribose-containing top strand (4, calc'd 6889.46 Da). These results are consistent with dissociation of LMW cross-link with structure 22, formed by the reaction between the aldehyde of structure 4 and the exocyclic $-\mathrm{NH}_{2}$ of deoxyadenine on the opposing strand.

\section{Scheme 5}

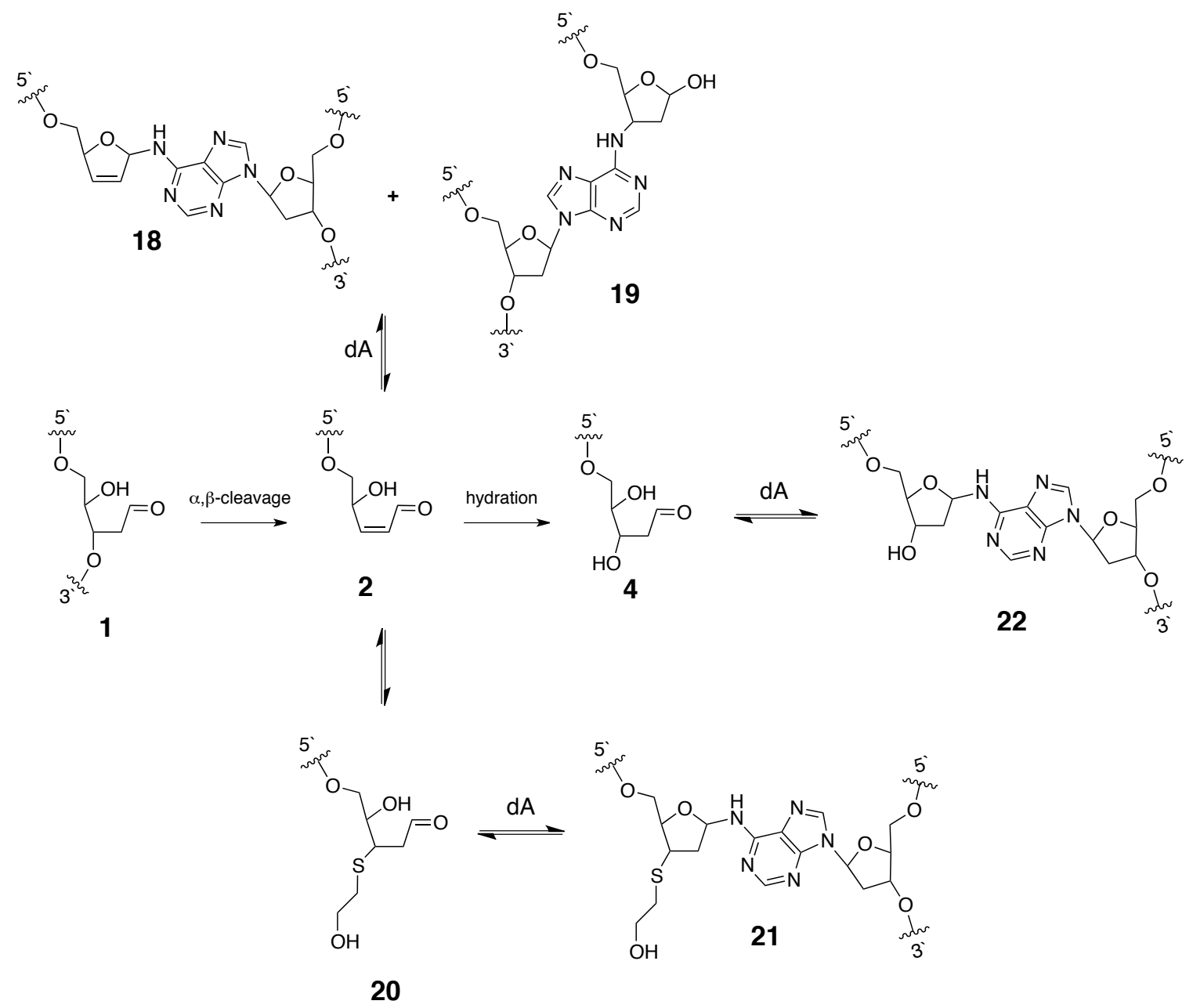


Figure 6

Duplex N-2 5 -ATG CAT GCT ATA ATA CTG CAT CUT AGA CAT-3

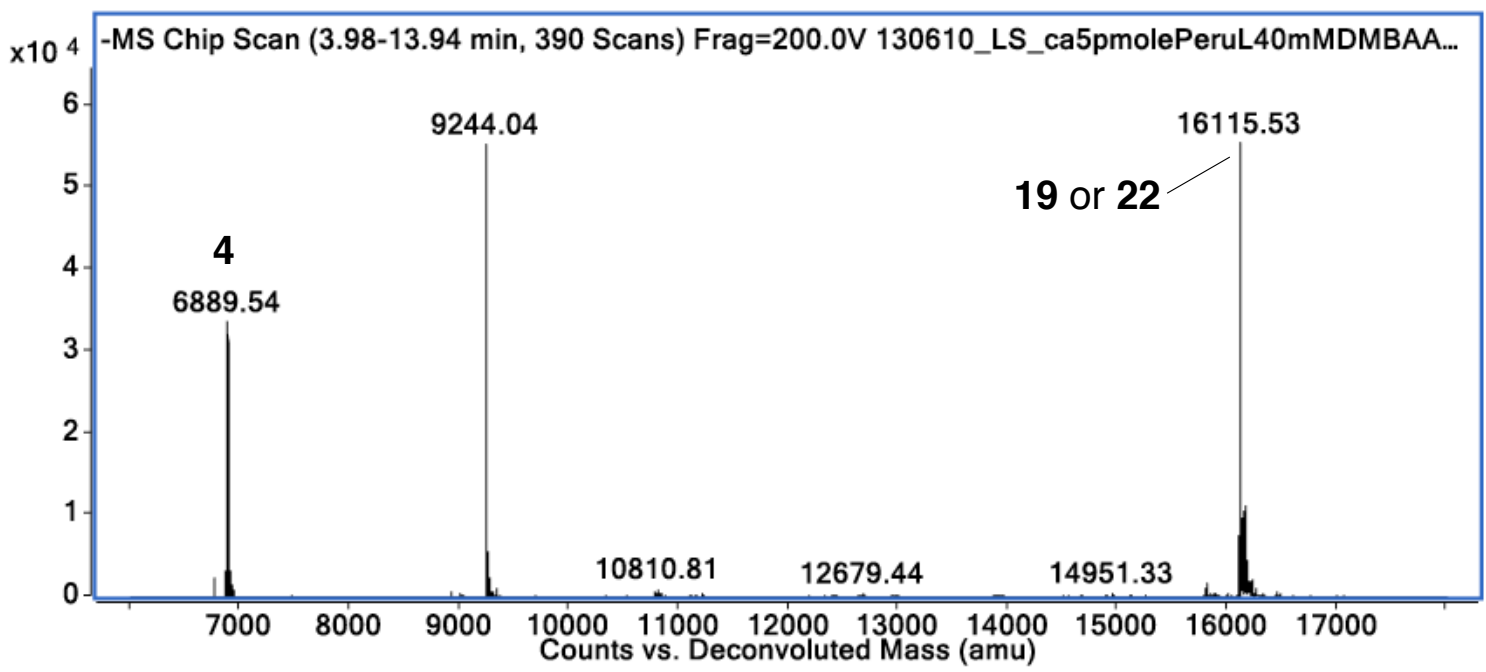

Figure 6. Nanospray QTOF MS of LMW cross-link generated by treating duplex N2 with UDG and Endo III and isolated from a $20 \%$ denaturing polyacrylamide gel.

\section{Figure 7}

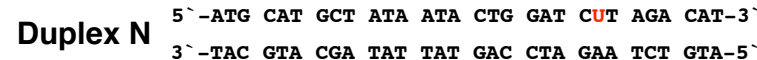

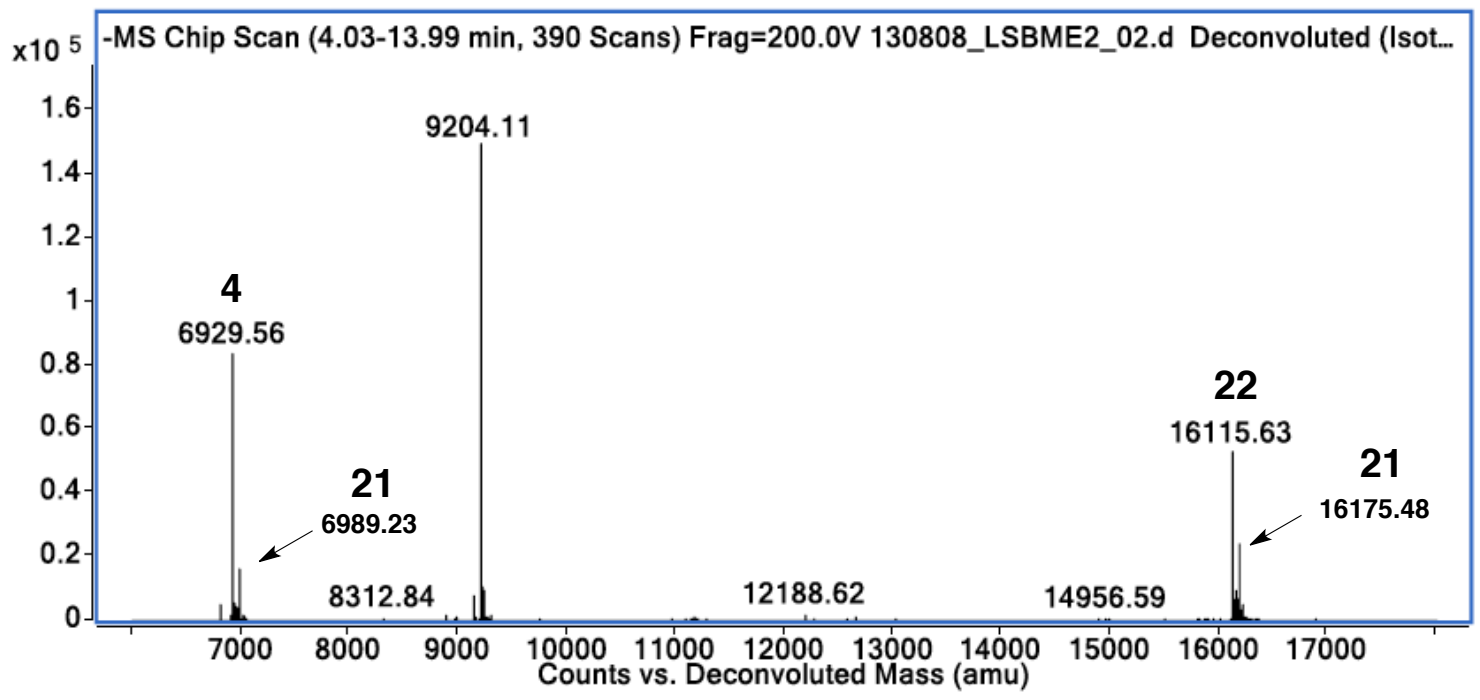

Figure 7. Nanospray QTOF MS of LMW cross-link (formed in the presence of $\beta$ mercaptoethanol, 17) generated by treating duplex $\mathbf{N}$ with UDG and Endo III and isolated from a $20 \%$ denaturing polyacrylamide gel. 
We derivatized the LMW cross-links by thiol adduction to provide additional evidence that EndoIII treated AP DNA generated a mixture of products ( 2 and $\mathbf{4}$, Scheme 1). We used $\beta$-mercaptoethanol (17) for this experiment as it is a much smaller thiol and less bulky, therefore more nucleophilic for conjugate addition. LMW cross-links were prepared as before using UDG and EndoIII treated duplex $\mathbf{N}$ incubated in the presence of 17 (1 mM) (Duplex $\mathbf{N}$ differs in only 1 base pair, changing the masses of each singlestranded DNA, but is isobaric with duplex $\mathbf{N}-2$ ). LMW cross-link was isolated from a preparative polyacrylamide gel and was analyzed by Nanospray-QTOF MS to provide Figure 7. We observed a neutral mass of 16115.63 Da corresponding to the non thioladducted LMW cross-link of duplex N (22, Scheme 5) (calc'd 16115.44 Da).

Again we observed smaller masses identified as each of the single strand DNA dissociated from the LMW cross-link isolated with neutral masses of 9204.11 Da and 6929.56 Da. These correspond to the full-length complimentary bottom strand (Figure 6, calc'd $9203.97 \mathrm{Da}$ ) and the Ap-containing top strand (calc'd 6929.48 Da). This is again consistent with the structure 4 (Scheme 5). Upon closer inspection of the spectrum, we see minor peaks at $\mathrm{m} / \mathrm{z} 16175.48 \mathrm{Da}$ and 6989.23 $\mathrm{Da}$ corresponding to thiol (17) adducted cross-link of duplex $\mathbf{N}(\mathbf{1 4}$, calc'd $16175.55 \mathrm{Da})$ and the dissociated $\beta$-ME adducted Ap-cleaved top strand (13, calc'd 6989.60 Da). These less abundant but heavier masses would result from removal of $\mathrm{H}_{2} \mathrm{O}(18 \mathrm{Da})$ from the 16115.63 and $6929.56 \mathrm{Da}$ masses and addition of $17(78.13 \mathrm{Da})$. These results are consistent with Endo III generated LMW cross-link primarily results from structure $\mathbf{4}$. Only small amounts of $\mathbf{2 0}$ and 21 were observed, consistent with only small amounts of $\mathbf{2}$ present during the crosslink reaction after enzyme treatment. EndoIII cleaved DNA containing a $33^{\prime}-\mathrm{OH}$ cap (4) 
would only react with an opposing $\mathrm{dA}$ by imine formation and prevent conjugate addition from occuring. The thiol adducted products would arise from small amounts of 2 released from the enzyme before hydration occurred at the $\alpha, \beta$-unsaturation.

As mentioned before, recent publications report that EndoIII primarily generates 3 -deoxyribose phosphate products $(4$, Scheme 1$){ }^{18}$ It is also possible that the $\alpha, \beta$ unsaturated Ap-sites (2) hydrate after cross-link formation, as Schiff Bases can assist in reactions involving $\alpha, \beta$-unsaturated aldehydes. ${ }^{29}$ But it is more likely it that Endo III lyase activity is the primary source of $4 .^{30}$ Additionally, the amount of thiol adduction determined by gel shift was independent of whether GSH $(1 \mathrm{mM})$ was present during the EndoIII treatment or after. Combined these results suggest that a mixture of predominantly 3'-OH capped Ap-sites (4) with lower amounts of $\alpha, \beta$-unsaturated Apsites (2) were obtained after EndoIII treatment.

\subsection{Generating Low Molecular Weight Cross-Links with Spermine}

While catalyzing $\alpha, \beta$-cleavage of Ap-sites is an efficient process enzymatically, significant hydration product is clearly obtained in the process. ${ }^{18}$ For this reason we decided to generate the $\alpha, \beta$-unsaturated Ap-sites (2) by a chemical method instead. Spermine $($ Scheme $4, \mathbf{1 4})$ has been shown to efficiently and selectively catalyze the $\beta$ elimination of Ap-sites (1) to yield $\alpha, \beta$-unsaturated products with little $\gamma, \zeta$-cleavage and no significant hydration at the $3{ }^{`}$-carbon $(4$, Scheme 5$) .{ }^{31-32}$ Uracil containing $5{ }^{\prime}-{ }^{32} \mathrm{P}-$ labeled duplex $\mathrm{N}$ was treated with UDG in the presence of spermine (1-10 $\mathrm{mM})$ in HEPES buffer $(50 \mathrm{mM}, \mathrm{pH} 8)$ and $\mathrm{NaCl}(100 \mathrm{mM})$ to generate the $\alpha, \beta$-unsaturated $\mathrm{Ap}$ sites (2). After enzyme removal and ethanol precipitation, further incubation in HEPES 
$(50 \mathrm{mM}, \mathrm{pH} 8)$ and $\mathrm{NaCl}(100 \mathrm{mM})$ at $37{ }^{\circ} \mathrm{C}$ produced high yields $(\sim 63 \%)$ of LMW cross-link product within 24 hours (lane 4, Figure 8A) and the presence of thiols significantly reduce LMW cross-link yields (Lanes 5 and 6). Similar incubations under pH 7 conditions instead provided yields of $\sim 30 \%$. Performing the same incubation on duplex $\mathbf{O}$ at $\mathrm{pH} 8$ provided slightly lower yields ( $\sim 35-40 \%$, lane 3, Figure $8 \mathrm{~B})$ with no significant difference when incubating at $\mathrm{pH} 7(\sim 35 \%)$. The substantial change in yield for two duplexes with an identical core is most likely due to changes in flexibility after $\alpha, \beta$-cleavage. Remember, duplex $\mathbf{N}$ was designed so the $\beta$-eliminated strand would melt off the duplex after elimination of the $3{ }^{\prime}$-phosphate, whereas duplex $\mathbf{O}$ would remain hybridized as a double helix (Scheme 6).

\section{Scheme 6}

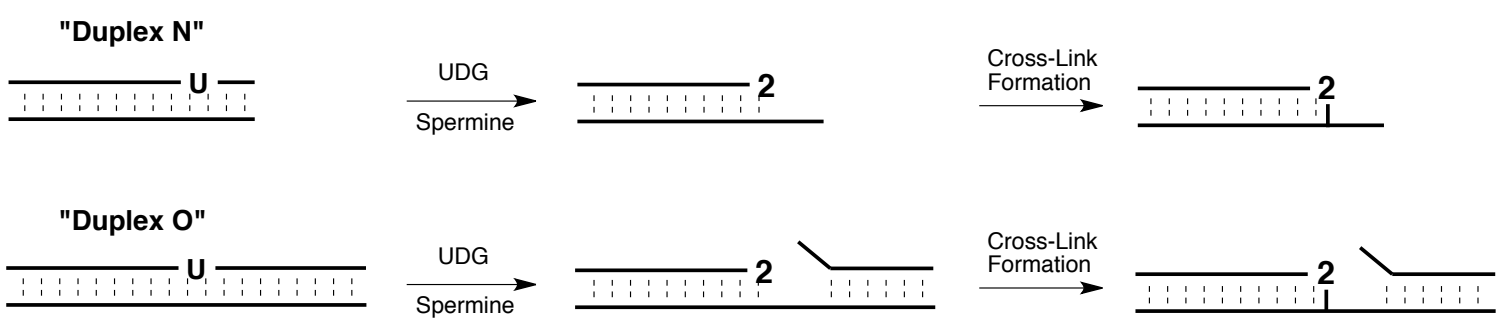

We noticed that cross-link yield seems to be $\mathrm{pH}$ dependent, as we generally see higher yields obtained when using slightly basic $\mathrm{pH} 8$ buffer, rather than neutral $\mathrm{pH} 7$ buffer (Table 2) after spermine treatment. The higher LMW cross-link yield resulting from slightly basic buffer $\mathrm{pH}$ is only observed for $\alpha, \beta$-unsaturated Ap-sites generated with spermine (2). These results are consistent with a conjugate addition mechanism in aqueous media, as basic conditions would increase the rate of addition. Additionally, LMW cross-link yields were not as sensitive to $\mathrm{pH}$ when treating Ap-containing DNA with EndoIII. We have shown EndoIII primarily generates 4, which would only form imine-type cross-links (Scheme 4). Finally, significant thiol adduction onto cleaved Ap- 
DNA was observed, indicated by changes in gel mobility (Figure 8, lanes 5 and 6). Thiol also significantly decreased the LMW cross-link yield. Thiol adduction (7, Scheme 1) would inhibit cross-link formation by conjugate addition, leaving only imine formation to $\operatorname{occur}(\mathbf{8}$, Scheme 1).

Table $2 \mathrm{pH}$ Dependent Formation of LMW Cross-Links From $\alpha, \beta$-Unsaturated Ap-Sites

$\%$ LMW Cross-Link

\begin{tabular}{cccc}
\cline { 3 - 4 } Duplex & pH & Endo III & Spermine \\
\hline $\mathrm{N}$ & $\mathbf{7}$ & $29.3 \pm 2.4$ & $29.7 \pm 2.2$ \\
& 8 & $17.8 \pm 1.6$ & $63.0 \pm 2.2$ \\
$\mathbf{0}$ & $\mathbf{7}$ & $22.4 \pm 1.1$ & $35.0 \pm 2.7$ \\
& 8 & $23.6 \pm 3.9$ & 39.7 \\
\hline
\end{tabular}


Figure 8

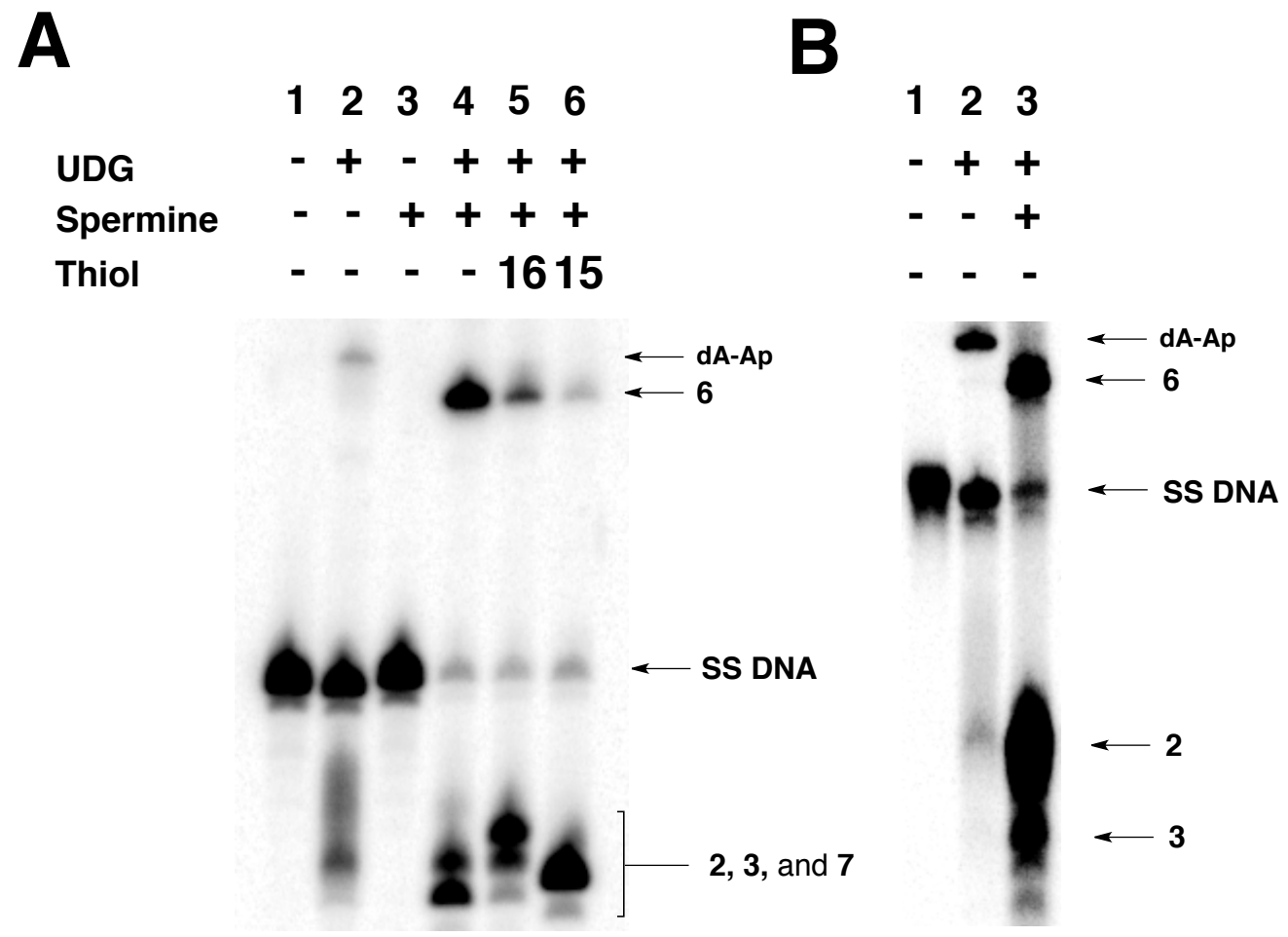<smiles>NC(=O)CCC(=O)N[C@@H](CS)C(=O)NCC(=O)O</smiles>

16<smiles>O=C(O)CS</smiles>

15

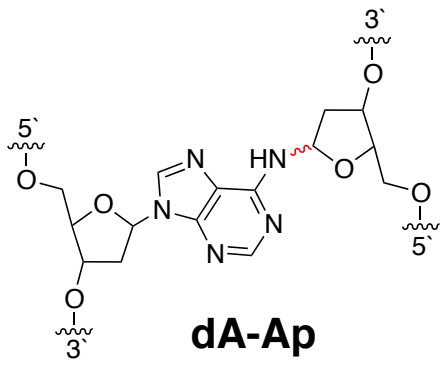

Figure 8. Interstrand cross-link formation from ${ }^{32} \mathrm{P}$-labeled duplexes $\mathbf{N}$ and duplex $\mathbf{O}$ resolved by electrophoresis on $20 \%$ denaturing polyacrylamide gels. Panel A Duplex N incubated in HEPES buffer $(50 \mathrm{mM}, \mathrm{pH} 8)$ containing $\mathrm{NaCl}(100 \mathrm{mM})$ at $37{ }^{\circ} \mathrm{C}$ for $24 \mathrm{~h}$ with the indicated reagent: Lane 1 is duplex $\mathbf{N}$ alone. Lane is 2 duplex $\mathbf{N}$ with UDG. Lane 3 is duplex $\mathbf{N}$ with spermine $(1 \mathrm{mM})$. Lane 4 is duplex $\mathbf{N}$ with UDG and spermine $(1 \mathrm{mM})$. Lane 5 is duplex $\mathbf{N}$ with UDG and spermine $(1 \mathrm{mM})$ in the presence of GSH (1 $\mathrm{mM})$. Lane 6 is duplex $\mathbf{N}$ with UDG and spermine $(1 \mathrm{mM})$ in the presence of sodium thioglycolate $(1 \mathrm{mM})$. Panel B Duplex $\mathbf{O}$ incubated in HEPES buffer $(50 \mathrm{mM}$, pH 7) containing $\mathrm{NaCl}(100 \mathrm{mM})$ at $37^{\circ} \mathrm{C}$ for $24 \mathrm{~h}$ AFTER the indicated treatment: Lane 1 is duplex $\mathbf{O}$ with no treatment. Lane is 2 duplex $\mathbf{O}$ pretreated with UDG. Lane 3 is duplex $\mathbf{O}$ pretreated with UDG and spermine $(1 \mathrm{mM})$. 
Ap-containing duplexes P-S incubated in HEPES (50 mM, pH 7) and $\mathrm{NaCl}(100$ $\mathrm{mM})$ at $37^{\circ} \mathrm{C}$ for $3 \mathrm{~d}$ after being treated with spermine $(1 \mathrm{mM})$ produced different results than when treated with EndoIII. $\alpha, \beta$-Unsaturated Ap-containing (2) duplex $\mathbf{P}$ significantly decreased in cross-link yield while duplexes $\mathbf{Q}$ and $\mathbf{S}$ gave no additional cross-link or none at all for the spermine treated duplexes when compared to the EndoIII treated duplexes (Table 1). Surprisingly, we observed a substantial increase in LMW cross-link yield for duplex $\mathbf{R}(\sim 40 \%)$ following spermine treatment when compared to Endo III treatment $(\sim 2 \%)$. These results lead us to believe $\mathrm{dG}$ residues are excellent candidates for conjugate addition of $\alpha, \beta$-unsaturated Ap-sites (2). Deoxyguanosine residues are previously reported to adduct and cross-link with $\alpha, \beta$-unsaturated aldehydes (Chapter 3, Scheme 2). ${ }^{10}$ We show in the next section evidence that these new high yielding LMW cross-link are formed by conjugate addition of both adenine (duplex $\mathbf{N}$ ) and guanine (Duplex $\mathbf{R}$ ) residues on the $\alpha, \beta$-unsaturated Ap-site (structure 6, Scheme 1).

\subsection{Site of Attachment for Cross-Links Generated by Spermine Treated Ap-DNA}

Hydroxyl radical footprinting was performed for duplex $\mathbf{O}$ (Figure 9) and $\mathbf{R}$ (Figure 10) after UDG and spermine treatment as described in the previous section. Footprinting of duplex $\mathbf{O}$ produced a break in the ladder (lane 4) at $\mathbf{A 9}$, meaning this is the major site of attachment, with no cross-link indicated at the $\mathrm{dG}$ residue. A minor band is observable at $\mathbf{A 8}$, indicating a small amount of cross-link at the adenine directly opposing the $\alpha, \beta$-unsaturated Ap-site (2). DNA footprinting of duplex $\mathbf{R}$ did not provide a single site of attachment (Figure 9). The histogram plotting ${ }^{32} \mathrm{P}$-intensity over distance traveled by DNA fragments does not show a clean break for lane 4 (Figure 10, Panel D). 
As seen in the gel, the increasing signal intensities for G 5-7 indicates that multiple cross-

links were formed. This means that duplex $\mathbf{R}$ generated a mixture of dG cross-links at G5, G6, and G7, each with similar mobility in denaturing PAGE, as they were isolated from the same band in the gel used to purify the LMW cross-links.

\section{Figure 9}

\section{Duplex 0}

5-ATG CAT GCT ATA ATA CTG CAT CUT AGA CAT ATG CAT GCT ATA

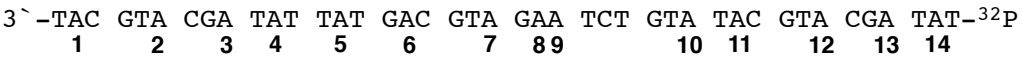

\section{A}

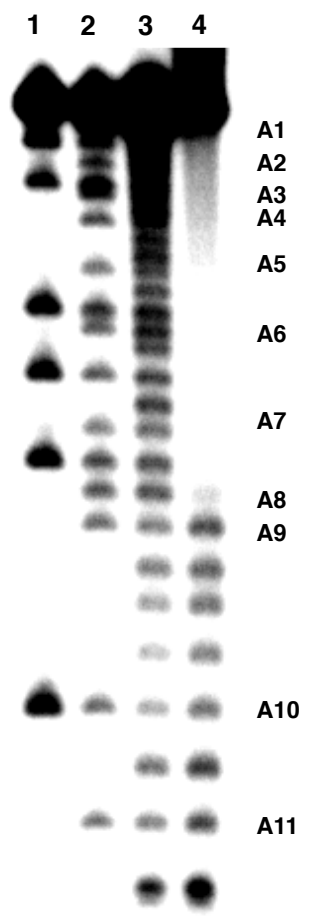

B $\quad$ G $\quad$ G $\quad$ G
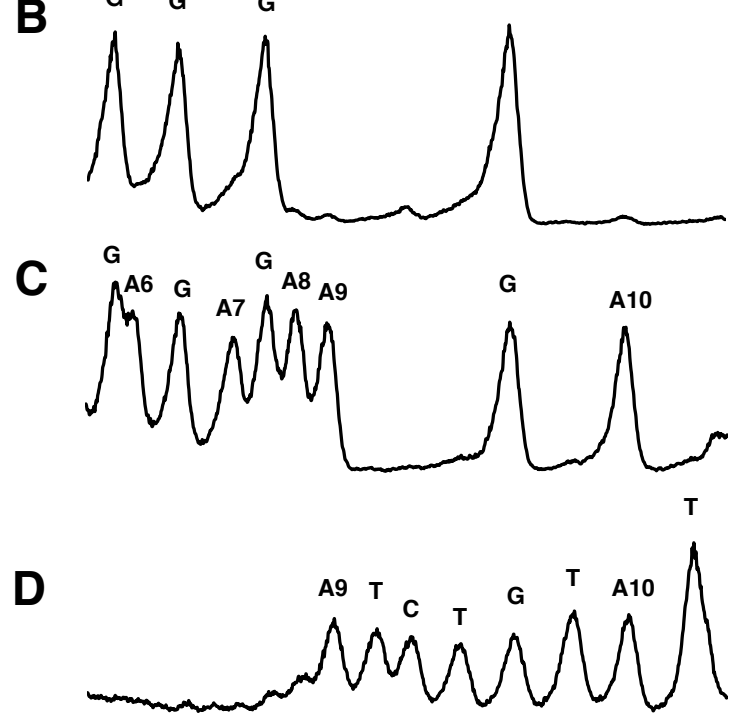

Figure 9. Hydroxyl radical footprinting of duplex $\mathbf{O}$ to locate the site of attachment for spermine generated LMW cross-link. Lane 1 is a Maxam-Gilbert G-specific cleavage (sequencing) reaction of the labeled strand. Lane 2 is an $A+G$ specific cleavage (sequencing) reaction of the labeled strand. Lane 3 is the hydroxyl radical footprinting reaction of the single stranded non-uracil containing oligonucleotide. Lane 4 is the hydroxyl radical footprinting reaction of the PAGE purified cross-link generated by incubation of UDG and spermine with duplex $\mathbf{O}$ in HEPES buffer $(50 \mathrm{mM}, \mathrm{pH} 8)$ containing $\mathrm{NaCl}(100 \mathrm{mM})$ at $37{ }^{\circ} \mathrm{C} .{ }^{32} \mathrm{P}$-labeled $2^{\prime}$-deoxyoligonucleotides were resolved on a polyacrylamide gel visualized by phosphorimager analysis (Panel A) and used to develop densitometry traces (Panels B-D). Panel B is the trace of lane 1. Panel C is the trace of lane 2. Panel D is the trace of lane 3. 
Figure 10

Duplex R

5-Atg CAT GCT ATA ATA CTG CAT CUC AGA CAT ATg CAT GCt AtA

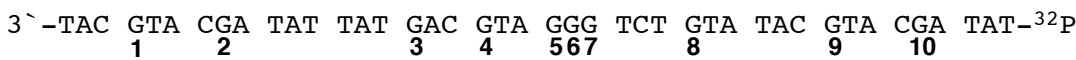

A

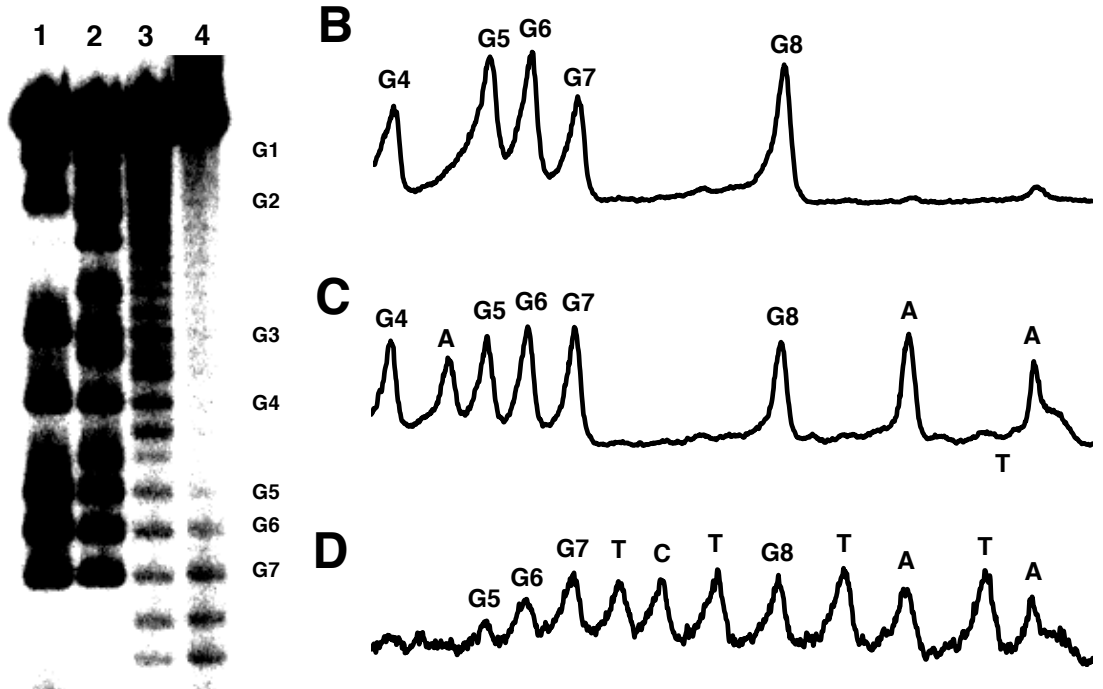

Figure 10. Hydroxyl radical footprinting of duplex $\mathbf{R}$ to locate the site of attachment for spermine generated LMW cross-link. Lane 1 is a Maxam-Gilbert G-specific cleavage (sequencing) reaction of the labeled strand. Lane 2 is an $A+G$ specific cleavage (sequencing) reaction of the labeled strand. Lane 3 is the hydroxyl radical footprinting reaction of the single stranded non-uracil containing oligonucleotide. Lane 4 is the hydroxyl radical footprinting reaction of the PAGE purified cross-link generated by incubation of UDG and spermine with duplex $\mathbf{R}$ in HEPES buffer $(50 \mathrm{mM}, \mathrm{pH} 8)$ containing $\mathrm{NaCl}(100 \mathrm{mM})$ at $37{ }^{\circ} \mathrm{C} .{ }^{32} \mathrm{P}$-labeled 2'-deoxyoligonucleotides were resolved on a polyacrylamide gel visualized by phosphorimager analysis (Panel A) and used to develop densitometry traces (Panels B-D). Panel B is the trace of lane 1. Panel C is the trace of lane 2. Panel D is the trace of lane 3. 


\subsection{Mass Spectrometric Analysis of Low Molecular Weight Cross-link Generated}

\section{by Spermine}

We used mass spectrometry to analyze LMW cross-link prepared by incubating uracil containing duplex $\mathbf{N}$ with UDG in the presence of spermine (10 mM). The LMW cross-link was separated from uncross-linked DNA on a $20 \%$ denaturing polyacrylamide gel, excised from the gel, and analyzed by Nanospray QTOF MS. We obtained a single peak with a neutral mass of $16115.73 \mathrm{Da}$, consistent with a conjugate addition of the opposing dA onto the $\alpha, \beta$-unsaturated abasic site (Figure 11, structure 19, calc'd 16115.44 Da). Moreover, no significant dissociation peaks were observed.

Figure 11

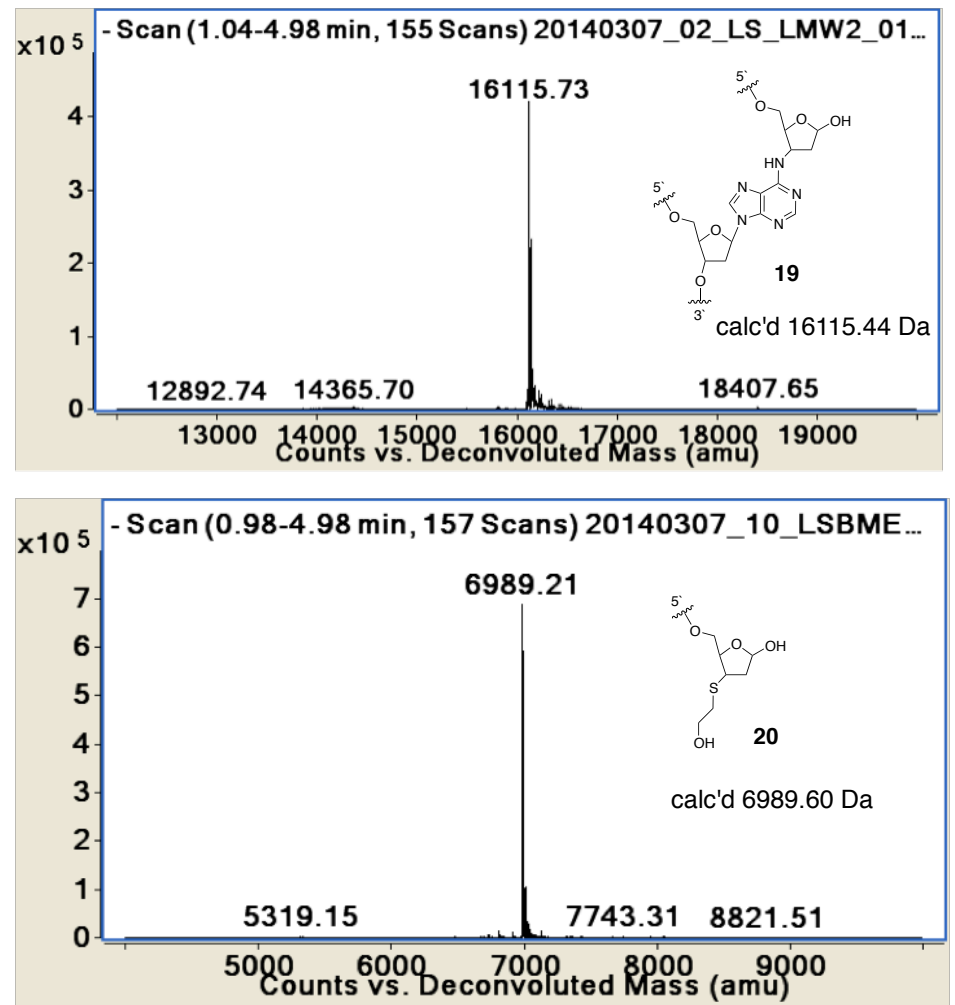

Figure 11. Nanospray QTOF MS of LMW cross-link generated by treating duplex $\mathbf{N}$ with UDG and Endo III isolated from a $20 \%$ denaturing polyacrylamide gel. 
We also incubated duplex $\mathbf{N}$ under the same conditions in the presence of $\beta$ mercaptoethanol $(1 \mathrm{mM})$. While no cross-link was obtained in this reaction, the single stranded cleaved DNA recovered from this reaction produced a single neutral mass of 6989.21 Da. This matches the mass of a 3`- $\beta$-mercaptoethanol adducted Ap-containing top strand of duplex $\mathbf{N}$ (structure 20, calc'd 6989.60 Da). From this we can conclude full thiol adduction at the 3 -carbon was observed, preventing cross-link formation. Additionally no evidence of hydration at the $\alpha, \beta$-unsaturation was observed.

Overall our results provide evidence supporting our hypothesis that these LMW cross-links form via conjugate addition of an opposing base with the $\alpha, \beta$-unsaturated Apsite. We saw earlier that incubation of the uracil-containing duplex $\mathbf{N}$ with UDG and spermine in the presence of GSH or thioglycolate resulted in significant decrease of the LMW cross-link yield (Figure 8, lanes 5 and 6). Thiols inhibited cross-link formation. Consistent with a conjugate addition mechanism, this suggests that the $3^{`}$-opposing dA residue A9 (Figure 9) and thiol competed for addition onto 2 (Scheme 1). This competition is supported by literature reported on inhibition of cross-link formation of C4 '-oxidized Ap-sites with DNA bases by dithiothreitol (DTT). ${ }^{4}$ It was suggested that conjugate addition of DTT prevented addition by the DNA bases required for cross-link formation. ${ }^{4}$ It is unclear why we do not see a mixture of cross-linked products with differing gel mobility after treatment with GSH, as seen before for the EndoIII treated duplex (Figure 5). It is possible spermine competed for Schiff-Base formation, resulting in no interstrand cross-links by imine attachment after thiol addition at the $3{ }^{`}$-carbon. 


\subsection{Chapter 5 Summary}

We have described interstrand cross-links resulting from the reaction of a cleaved Ap-site resulting from a single strand break at the $3^{`}$-carbon with an opposing base in DNA duplexes. Two known methods for generating $\alpha, \beta$-unsaturated Ap-sites (to varying degrees) were utilized in this study. Treating Ap-containing DNA (1) with either EndoIII or spermine catalyzes the elimination of the $3^{\prime}$-phosphate of an Ap-site. Using modifications of literature methods, ${ }^{22-23,33}$ we generated Ap-sites with UDG and further treated them with either cleaving agent. Yields of cross-link varied greatly depending on the reagent used, resulting from differences in chemical structure of the cleaved Ap-site products. We have provided evidence for Ap-site structures with gel mobility and mass spectrometry experiments. It has been determined that cross-links formed by reaction of an Ap-site treated with EndoIII generating primarily 4 will occur via imine formation (5) with smaller amounts of conjugate addition product (6) resulting from the release of $\mathbf{2}$ (Scheme 1). We have supplied evidence that spermine cleaved Ap-sites primarily gave conjugate addition products (6). Additionally the presence of thiol inhibits formation of LMW cross-links by conjugated addition (7, Scheme 1), but does not completely prevent it (Figure 8).

Hydroxyl radical footprinting allowed us to identify that $\alpha, \beta$-unsaturated Ap-sites (via spermine cleavage) cross-link with both deoxyadenine as well as deoxyguanine. Duplex $\mathbf{R}$ yielded a mixture of attachments with the various opposing dG residues from the $\alpha, \beta$-unsaturated Ap-site (Figure 10. And while duplex $\mathbf{O}$ contains a guanine residue 
near the $\alpha, \beta$-unsaturated Ap-site, only a single major attachment with $\mathrm{dA}$ residue A9

(Figure 9) was observed.

Mass spectrometry experiments for the spermine generated LMW cross-link (Figure 11) provided a neutral mass consistent with structure 19 (Scheme 5, calc'd 16115.44 Da). Incubation of the ${ }^{32}$-P-labeled $\alpha, \beta$-unsaturated Ap-containing (2) DNA provided a single observable cross-link band on the gel (Figure 8), indicating a single cross-linked product. It is possible that the isolated LMW cross-link actually exists as cyclized structures $\mathbf{2 3}$ or $\mathbf{2 4}$ (Scheme 7). These attachments would have been forged by subsequent conjugate addition and hemiaminal formation of the exocyclic N6-nitrogen and endocyclic N1-nitrogen of adenine. We could not discern between them using mass spectrometry as they are isobaric. Structures like these have been previously proposed for the C4-oxidized cross-links. ${ }^{4}$ Only a single product cross-linkband was observed throughout our experiments, indicating a single major product was obtained. Though the gel mobilities of each structure may be too similar to separate them effectively on a $20 \%$ denaturing polyacrylamide gel. Further characterization is needed. Overall we have presented evidence for the formation of a previously uncharacterized cross-link resulting from $\alpha, \beta$-unsaturated Ap-sites in duplex DNA.

\section{Scheme 7}

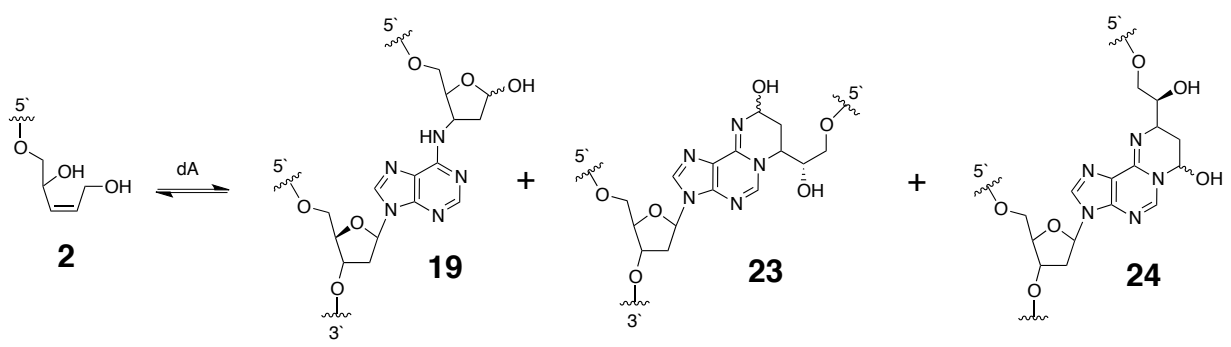




\subsection{Experimental}

Materials and Methods. Oligonucleotides were purchased from Integrated DNA Technologies. All enzymes were purchased from New England Biolabs (Ipswich, MA, USA). $\left[\gamma_{-}{ }^{32} \mathrm{P}\right]$-ATP $(6000 \mathrm{Ci} / \mathrm{mmol})$ was purchased from Perkin Elmer. C-18 sep-pak cartridges were from Waters. BS Polyprep columns were purchased from BioRad. Zeba Spin Desalting Columns (7K MWCO, $0.5 \mathrm{~mL}$ ) were purchased from Thermo Scientific. Quantification of radioactivity in polyacrylamide gels was carried out using a Personal Molecular Imager (BIORAD) with Quantity One software (v.4.6.5). All other reagents were purchased from Sigma-Aldrich.

Representative procedure for cross-link formation using Endonucelase III. Singlestranded uracil containing 2'-deoxyoligonucleotides were 5'-labeled using standard procedures. ${ }^{34}$ Labeled DNA was annealed with its complimentary strand and added to an enzyme cocktail containing Uracil DNA Glycosylase (200 units/mL, final concentration), Endonuclease III (Nth) (200 units/mL), and BSA (1X) to generate $\alpha, \beta$-Unsaturated ApSites. NOTE: Buffer exchange of enzymes must be done prior to DNA treatment to remove DTT included in storage buffer. Enzymes were passed through a Zeba spin column exchanged with HEPES buffer (50 mM, pH 8) and $\mathrm{NaCl}(100 \mathrm{mM})$. After addition of DNA to enzyme, the mixture was incubated at $37{ }^{\circ} \mathrm{C}$ for $30 \mathrm{~min}$. Enzymes were removed by phenol-chloroform extraction and then the aqueous layer was ethanol precipitated. ${ }^{34}$ DNA duplexes were then incubated further in HEPES buffer $(50 \mathrm{mM}, \mathrm{pH}$ 7 or 8) containing $\mathrm{NaCl}(100 \mathrm{mM})$ at $37{ }^{\circ} \mathrm{C}$ for $24 \mathrm{~h}$. The DNA was ethanol precipitated, ${ }^{34}$ resuspended in formamide loading buffer, ${ }^{34}$ loaded onto a $20 \%$ denaturing 
polyacrylamide gel, and the gel electrophoresed for $4 \mathrm{~h}$ at $1000 \mathrm{~V}$. The amount of radiolabeled DNA in each band on the gel was measured by phosphorimager analysis. The time course for the formation of the Ap site cross-link was carried out by incubating a solution containing labeled DNA (approximately 300,000 cpm), in HEPES (50 mM, pH 7) and $\mathrm{NaCl}(100 \mathrm{mM})$ at $37{ }^{\circ} \mathrm{C}$. At specified time points, aliquots $(1 \mu \mathrm{L})$ were removed and frozen at $-20{ }^{\circ} \mathrm{C}$, after all time points were collected samples were loaded directly on the gel and analyzed as described above.

Representative procedure for cross-link formation using Spermine. Single-stranded uracil containing 2'-deoxyoligonucleotides were 5'-labeled using standard procedures. ${ }^{34}$ Labeled DNA was annealed with its complimentary strand and added Uracil DNA Glycosylase (200 units $/ \mathrm{mL}$, final concentration) and spermine $(1 \mathrm{mM})$ and the mixture was incubated at $37{ }^{\circ} \mathrm{C}$ for $30 \mathrm{~min}$ to generate $\alpha, \beta$-Unsaturated Ap-Sites. Enzyme was removed by phenol-chloroform extraction and then the aqueous layer was ethanol precipitated. ${ }^{34}$ DNA duplexes were then incubated like above and analyzed by $20 \%$ denaturing polyacrylamide gel.

Hydroxyl Radical Footprinting. DNA footprinting reactions were done as in Chapter 3 and 4, preparing the cross-link using the conditions above.

Static Nanospray QTOF MS. The oligonucleotide sample was analyzed in a $40 \mathrm{mM}$ dimethylbutylammonium acetate $(\mathrm{pH}$ 7.1) buffer by static nanospray QTOF MS (negative ion detection) on an Agilent 6520A mass spectrometer equipped with a Chip 
Cube source (G4240A). Spectra were calibrated internally using the ion at $\mathrm{m} / \mathrm{z}$ 1279.99666473 which was the $[\mathrm{M}-\mathrm{H}]^{-}$for the acetate adduct with the reference standard Hexakis $\left(1 \mathrm{H}, 1 \mathrm{H}, 4 \mathrm{H}\right.$-hexafluorobutyloxy)phosphazine $\left(\mathrm{C}_{24} \mathrm{H}_{18} \mathrm{O}_{6} \mathrm{~N}_{3} \mathrm{P}_{3} \mathrm{~F}_{36}, 1221.990637\right.$ Da), introduced into the instrument source separately from the samples. An oligodeoxynucleotide standard (IDT, Neutral Average mass: 12379.12 Da) was also analyzed as a check on the calibration. Samples were introduced into the instrument with New Objective Econo12 N uncoated emitters. Negative ion MS spectra were acquired in the extended dynamic range (2-GHz) mode over the range of $100-3200 \mathrm{Da}$ at a rate of 1.5 seconds per spectrum Monoisotopic neutral masses were calculated from the multiply charged ion spectrum present in the 500-2000 Da mass range. Sample introduction was done with New Objective Econo12 N uncoated borosilicate glass emitters. Negative ion spectrum was acquired at a capillary potential sufficient to initiate spray of the sample. The nitrogen gas was heated to $290^{\circ} \mathrm{C}$ and introduced at a flow rate of $4 \mathrm{~L} / \mathrm{min}$. The Fragmentor, Skimmer, and Octapole1 RF Vpp potentials were set to $200 \mathrm{~V}, 65 \mathrm{~V}$, and $750 \mathrm{~V}$, respectively. External Calibration was done with the Agilent ESI-Low calibration tuning mixture (cat. no. G1969-85000) and data analysis was performed with Agilent Mass Hunter Workstation Qualitative Analysis software v B.02.00, Build 2.0.197.0 with Bioconfirm Software (2008). Peptide isotope model was assumed and peak set height threshold for extraction was set to $\geq 500$ counts. Deconvolution was done with a $0.1 \mathrm{Da}$ step size with a result of 20 iterations of the algorithm calculation 


\section{Thesis Summary}

In summary, this thesis presents research completed towards designing new uses for the 3-amino-1,2,4-benzotriazine 1,4-dioxide (Tirapazamine, 1) core in regards to hypoxia selective probes and DNA alkylating drug candidates. The well-described di-Noxide system shows promise for generating many structurally diverse compounds with tuneable reactivity and function. Several scaffolds and synthetic methods have been developed for generation of numerous benzotriazine-containing compounds potentially useful for development of fluorescent probes for cellular hypoxia or drugs for anti-cancer chemotherapy. We also presented work important for understanding processes involving cross-links that could form from the biologically important abasic site in duplex DNA. Showing that the abasic site aldehyde while in low abundance can react with DNA bases to form significant amounts of DNA interstrand cross-links. We have provided evidence that while common anti-cancer drugs and alkylating agents commonly produce Ap-sites through depurination, they indirectly are capable of causing Ap-site derived cross-links as well. Cross-links resulting from generation of native Ap-sites and $\alpha, \beta$-unsaturated Apsite can have profound biological consequences and are important targets for study. 


\section{References}

1. $\quad$ Lindahl, T.; Nyberg, B. Biochemistry 1972, 11 (19), 3610-8.

2. Regulus, P.; Duroux, B.; Bayle, P. A.; Favier, A.; Cadet, J.; Ravanat, J. L. Proc Natl Acad Sci U S A 2007, 104 (35), 14032-7.

3. Greenberg, M. M. Acc. Chem. Res. 2014, 47 (2), 646-55.

4. Sczepanski, J. T.; Jacobs, A. C.; Majumdar, A.; Greenberg, M. M. J. Am. Chem. Soc. 2009, 131 (31), 11132-9.

5. $\quad$ Sugiyama, H.; Fujiwara, T.; Ura, A.; Tashiro, T.; Yamamoto, K.; Kawanishi, S.; Saito, I. Chem. Res. Toxicol. 1994, 7 (5), 673-83.

6. $\quad$ Lijinsky, W.; Reuber, M. D. Toxicol Ind Health 1987, 3 (3), 337-45.

7. Bannasch, P.; Booman, G.; Feron, V. J.; Fishbeing, L.; Garner, M. J.; Hayashi, J.; Hemminki, K.; Henschler, D.; van der Hoeven, J. C. M.; Hogstedt, C.; Kavlock, R. J.; Meinhardt, T.; Obe, G.; O'Brien, P. J.; Patel, J. M.; Rosenkranz, H. S.; Solovyev, Y. N.; Waters, M. D.; Sieber, S. M.; McCaleb, K. E.; Clary, J.; Grasso, P., Allyl Compounds, Aldehydes, Epoxides and Peroxides. World Health Organization, International Agency for Research on Cancer: Lyon, France, 1985; Vol. 36, p 131-161.

8. Seiner, D. R.; LaButti, J. N.; Gates, K. S. Chem. Res. Toxicol. 2007, 20 (9), 131520.

9. Sanchez, A. M.; Kozekov, I. D.; Harris, T. M.; Lloyd, R. S. Chem. Res. Toxicol. 2005, 18 (11), 1683-90.

10. Chung, F.-L.; Young, R.; Hecht, S. S. Cancer Research 1984, 44 (3), 990-995.

11. Lindahl, T.; Andersson, A. Biochemistry 1972, 11 (19), 3618-3623.

12. Sczepanski, J. T.; Zhou, C.; Greenberg, M. M. Biochemistry 2013, 52 (12), 215764.

13. Manoharan, M.; Mazumder, A.; Ransom, S. C.; Gerlt, J. A.; Bolton, P. H. J. Am. Chem. Soc. 1988, 110 (8), 2690-2691.

14. McCullough, A. K.; Dodson, M. L.; Lloyd, R. S. Annu. Rev. Biochem 1999, 68, 255-85.

15. Vidal, A. E.; Hickson, I. D.; Boiteux, S.; Radicella, J. P. Nucleic Acids Res. 2001, $29(6), 1285-92$.

16. Hill, J. W.; Hazra, T. K.; Izumi, T.; Mitra, S. Nucleic Acids Res. 2001, 29 (2), 430-8. 
17. Mazumder, A.; Gerlt, J. A.; Absalon, M. J.; Stubbe, J.; Cunningham, R. P.; Withka, J.; Bolton, P. H. Biochemistry 1991, 30 (4), 1119-1126.

18. Darwanto, A.; Farrel, A.; Rogstad, D. K.; Sowers, L. C. Anal. Biochem. 2009, 394 (1), 13-23.

19. Hatahet, Z.; Kow, Y. W.; Purmal, A. A.; Cunningham, R. P.; Wallace, S. S. J. Biol. Chem. 1994, 269 (29), 18814-18820.

20. Sancar, A.; Sancar, G. B. Annu. Rev. Biochem 1988, 57 (1), $29-67$.

21. Sczepanski, J. T.; Jacobs, A. C.; Greenberg, M. M. J. Am. Chem. Soc. 2008, 130 (30), 9646-7.

22. Price, N. E.; Johnson, K. M.; Wang, J.; Fekry, M. I.; Wang, Y.; Gates, K. S. J. Am. Chem. Soc. 2014, 136 (9), 3483-90.

23. Johnson, K. M.; Price, N. E.; Wang, J.; Fekry, M. I.; Dutta, S.; Seiner, D. R.; Wang, Y.; Gates, K. S. J. Am. Chem. Soc. 2013, 135 (3), 1015-25.

24. Osowska, K.; Miljanic, O. S. Angew. Chem. Int. Ed. Engl. 2011, 50 (36), 8345-9.

25. Toth, G. P., I.: and Messmer, A Tetrahedron Lett. 1974, 9, 735-738.

26. Carey, F. A. a. S., R., Condensation Reaction of Aldehydes and Ketons with Nitrogen Nucleophiles. In Advanced Organic Chemistry, Fifth ed.; Springer: New York, 2007; Vol. Part A: Sructure and Mechanisms, pp 645-653.

27. Parsons, Z. D.; Gates, K. S. Biochemistry 2013, 52 (37), 6412-23.

28. Bailly, V.; Verly, W. G. Nucleic Acids Res. 1988, 16 (20), 9489-96.

29. Northrup, A. B.; MacMillan, D. W. J. Am. Chem. Soc. 2002, 124 (11), 2458-60.

30. Greenberg, M. M.; Weledji, Y. N.; Kim, J.; Bales, B. C. Biochemistry 2004, 43 (25), 8178-83.

31. Bailly, V.; Verly, W. G. Biochem. J 1988, 253 (2), 553-9.

32. Bailly, V.; Derydt, M.; Verly, W. G. Biochem. J 1989, 261 (3), 707-13.

33. Dutta, S.; Chowdhury, G.; Gates, K. S. J. Am. Chem. Soc. 2007, 129 (7), 1852-3.

34. Sambrook, J. F., E. F.; Maniatis, T., Molecular Cloning: A Lab Manual. Cold Spring Harbor Press: Cold Spring Harbor, NY, 1989. 


\section{Vita}

Kevin Johnson, youngest son of two, was born to Karan and Richard Johnson in San Dimas, California and grew up in Walnut for the first eight years of his life. His family moved to Blue Springs, Missouri, where he continued his childhood. After graduating from Blue Springs High School in May 2005, he went on to Truman State University in Kirksville, Missouri, where he was recruited to compete in varsity swimming at the collegiate level. While at Truman State, he studied Chemistry, working under Professor Anne Moody developing an undergraduate lab for use in the organic teaching labs. In May 2009, Kevin graduated from Truman State University with a B.S. in Chemistry. From there he went to the University of Missouri, where he was accepted into the $\mathrm{PhD}$ program for Chemistry. In Spring of 2010 he joined Professor Gates research lab to start his research towards completion of the $\mathrm{PhD}$ degree. After graduating with a $\mathrm{PhD}$ in Chemistry in July 2014, went on to the University of Vanderbilt in Nashville, TN where he accepted a post-doctoral position working for Professor Guengerich studying Biochemistry. 